\title{
SITE CHARACTERIZATION PLAN CONCEPTUAL DESIGN REPORT FOR A HIGH-LEVEL NUCLEAR WASTE REPOSITORY IN SALT, VERTICAL EMPLACEMENT MODE
}

\author{
Volume 1
}

\section{DECEMBER 1987}

PREPARED FOR THE

U.S. DEPARTMENT OF ENERGY

OFFICE OF CIVILIAN RADIOACTIVE WASTE MANAGEMENT

SALT REPOSITORY PROJECT OFFICE

BY

FLUOR TECHNOLOGY, INC.

IN CONJUNCTION WITH

MORRISON-KNUDSEN ENGINEERS, INC.

SCIENCE APPLICATIONS INTEANATIONAL CORPORATION ENGINEERED SYSTEMS \& DEVELOPMENT CORPORATION WOODWARD-CLYDE CONSULTANTS

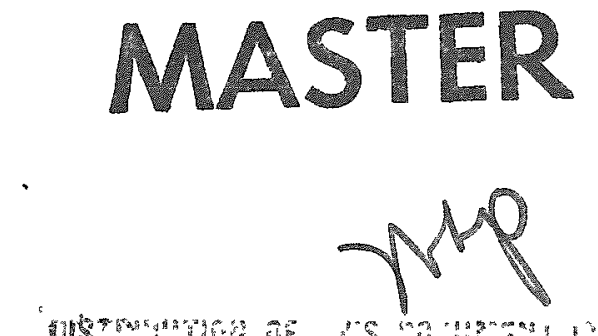




\section{DISCLAIMER}

This report was prepared as an account of work sponsored by an agency of the United States Government. Neither the United States Government nor any agency Thereof, nor any of their employees, makes any warranty, express or implied, or assumes any legal liability or responsibility for the accuracy, completeness, or usefulness of any information, apparatus, product, or process disclosed, or represents that its use would not infringe privately owned rights. Reference herein to any specific commercial product, process, or service by trade name, trademark, manufacturer, or otherwise does not necessarily constitute or imply its endorsement, recommendation, or favoring by the United States Government or any agency thereof. The views and opinions of authors expressed herein do not necessarily state or reflect those of the United States Government or any agency thereof. 


\section{DISCLAIMER}

Portions of this document may be illegible in electronic image products. Images are produced from the best available original document. 


\section{BIBLIOGRAPHIC DATA}

Fluor Technology, Inc., 1987. Site Characterization Plan Conceptual Design Report for a HighLevel Nuclear Waste Repository in Salt, Vertical Emplacement Mode, 2 Vols., DOE/CH/46656-15, prepared for the U.S. Department of Energy, Salt Repository Project Office, Hereford, TX.

\section{NOTICE}

This report was prepared as an account of work sponsored by an agency of the United States Government. Neither the United States Government nor any agency thereof, nor any of their employees, makes any warranty, expressed or implied, or assumes any legal liability or responsibility for the accuracy, completeness, or usefulness of any information, apparatus, product, or process disclosed, or represents that its use would not infringe privately owned rights. Reference herein to any specific commercial product, process, or service by trade name, trademark, manufacturer, or otherwise, does not necessarily constitute or imply its endorsement, recommendation, or favoring by the United States Government or any agency thereof. The views and opinions of authors expressed herein do not necessarily state or reflect those of the United States Government or any agency thereof. 


\title{
SITE CHARACTERIZATION PLAN CONCEPTUAL DESIGN REPORT FOR A HIGH-LEVEL NUCLEAR WASTE REPOSITORY IN SALT, VERTICAL EMPLACEMENT MODE
}

\author{
Volume 1
}

DECEMBER 1987

\begin{abstract}
PREPARED FOR THE
U.S. DEPARTMENT OF ENERGY

OFFICE OF CIVILIAN RADIOACTIVE WASTE MANAGEMENT

SALT REPOSITORY PROJECT OFFICE
\end{abstract}

BY

\section{FLUOR TECHNOLOGY, INC.}

IN CONJUNCTION WITH

MORRISON-KNUDSEN ENGINEERS, INC.

SCIENCE APPLICATIONS INTERNATIONAL CORPORATION

ENGINEERED SYSTEMS \& DEVELOPMENT CORPORATION

WOODWARD-CLYDE CONSULTANTS

This report was prepared by Fluor Technology, Inc., under Contract No. DE-ACO2-83WM46656 with the U.S. Department of Energy. 
This Conceptual Design Report describes the conceptual design of a highlevel nuclear waste repository in salt at a proposed site in Deaf Smith County, Texas. Waste receipt, processing, packaging, and other surface facility operations are described. Operations in the shafts and underground are described, including waste hoisting, transfer, and vertical emplacement. This report specifically addresses the vertical emplacement mode, the reference design for the repository. Waste retrieval capability is described. The report includes a description of the layout of the surface, shafts, and underground. Major equipment items are identified. The report includes plans for decommissioning and sealing of the facility. The report discusses how the repository will satisfy performance objectives. Chapters are included on basis for design, design analyses, and data requirements for completion of future design efforts. 
FOREWORD

The National Waste Terminal Storage (NWTS) program was established in 1976 by the U.S. Department of Energy's (DOE) predecessor, the Energy Research and Development Administration. In September 1983, this program became the Civilian Radioactive Waste Management (CRWM) Program. Its purpose is to develop technology and provide facilities for safe, environmentally acceptable, permanent disposal of high-level waste (HLW). HLW includes wastes from both commercial and defense sources, such as spent (used) fuel from nuclear power reactors, accumulations of wastes from production of nuclear weapons, and solidified wastes from fuel reprocessing. The Nuclear Waste Policy Act of 1982 (NWPA) is the principal federal statute governing disposal of high-level nuclear waste.

The information in this report pertains to the conceptual design studies of the Salt Repository Project of the Office of Geologic Repositories in the CRWM Program.

Fluor Technology, Inc., is the prime contractor to DOE for conceptual design of a high-level nuclear waste repository in salt. Fluor's contract began in October 1983, and an assortment of design studies were carried out between then and 1985. In 1985, the Fluor team began a conceptual design effort to support the site characterization plan. Between January and August 1986, certain additional design studies were conducted. This Conceptual Design Report (SCP-CDR) is a principal work product of those design efforts.

At the direction of the Salt Repository Project Office, the Fluor team prepared separate conceptual design reports describing the reference case vertical emplacement design and the passive alternate case horizontal emplacement design. This Conceptual Design Report ( $S C P-C D R$ ) presents the reference case. 
TABLE OF CONTENTS

Volume 1

EXECUTIVE SUMMARY $\ldots \ldots \ldots \ldots \ldots \ldots \ldots \ldots \ldots \ldots \ldots \ldots \ldots \ldots \ldots \ldots \ldots \ldots$

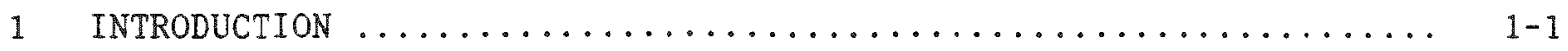

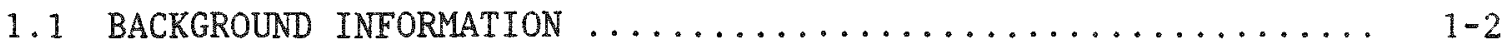

1.2 DOE'S PHASED APPROACH TO REPOSITORY DESIGN ............ 1-4

1.3 GENERAL INFORMATION RELEVANT TO THE SCP CONCEPTUAL DESIGN ... 1-6

1.4 TWO-PHASE CONCEPT FOR REPOSITORY CONSTRUCTION AND OPERATION ............................ 1-9

2 BASIS FOR SCP SALT REPOSITORY CONCEPTUAL DESIGN $\ldots \ldots \ldots \ldots \ldots \ldots$

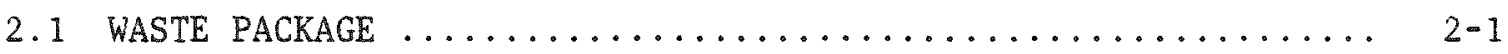

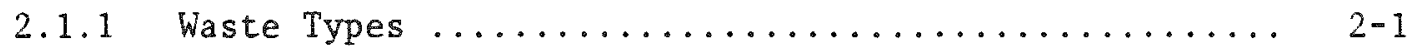

2.1.2 Waste Container Data .................. 2-2

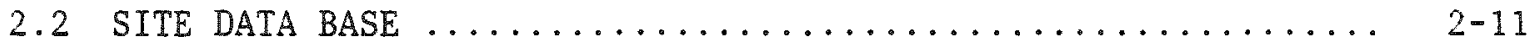

2.2.1 Surface Data Base ................... 2-12

2.2.2 Underground Data Base - Formations Above
Repository Horizon ...................... 2-24

2.2.3 Underground Data Base - Repository Horizon ....... 2-46

2.2.4 Active and Potential Geologic and Hydrologic $2-60$

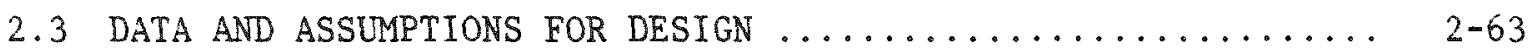

2.3.1 Bases for Design - Surface Structures ........... 2-64

2.3.2 Bases for Design - Shafts .................. 2-74

2.3.3 Bases for Design - Underground .............. 2-95

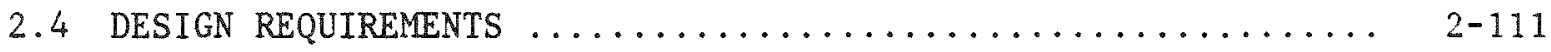

2.4.1 Program Requirements .................... 2-111

2.4.2 General Design Guidelines ................ 2-114

2.4 .3 Major Design Assumptions ................. 2-115

2.4.4 Definition of Repository Scope ............... 2-119

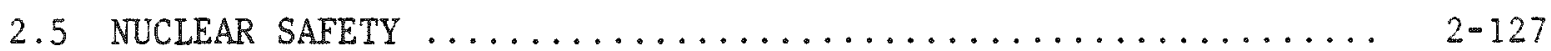

2.5.1 Radiation Exposure Limits .................. 2-127

2.5.2 Radionuclide Concentrations ................. 2-128

2.5.3 Radioactivity Source Terms ................. 2-131

2.5 .4 Nuclear Criticality Safety ............... $2-132$ 
TABLE OF CONTENTS

(Continued)

Page

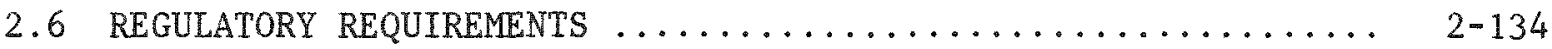

2.6.1 General Regulatory Requirements .............. 2-134

2.6.2 Nuclear Waste Policy Act (NWPA) .............. 2-134

2.6.3 Federal Siting Guidelines and Licensing $2-136$

Regulations ................................ $2-136$

2.6.4 EPA Environmental Standards ................. 2-138

2.6 .5 Mission Plan .......................... 2-139

2.6.6 Other Federal Laws, Regulations, and Executive

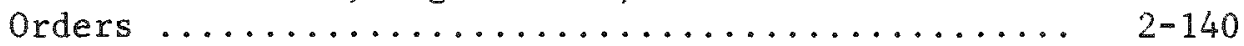

2.6 .7 DOE Orders .............................. 2-144

2.6.8 Industrial Codes and Standards .............. 2-144

2.6.9 State and Local Regulations ............... 2-147

2.7 STRUCTURES, SYSTEMS, AND COMPONENTS IMPORTANT TO

SAFETY, AND IMPORTANT TO WASTE ISOLATION $\ldots \ldots \ldots \ldots \ldots \ldots .2$ 2-150

3 SALT REPOSITORY OPERATIONS AND FUNCTIONS $\ldots \ldots \ldots \ldots \ldots \ldots \ldots \ldots \ldots$

3.1 WASTE HANDLING AND EMPLACEMENT $\ldots \ldots \ldots \ldots \ldots \ldots \ldots \ldots \ldots \ldots \ldots \ldots \ldots .1$

3.1.1 Functional Flow Description ............... 3-1

3.1 .2 Mechanical Flow Description ................. 3-2

3.1.3 Waste Handling Building 1 - Phase I ........... 3-27

3.1.4 Waste Handling Building 1 - Phase II .......... 3-35

3.2 WASTE RETRIEVAL ............................. $3-45$

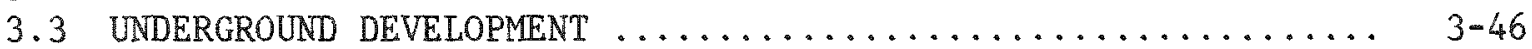

3.3.1 Excavation Method ..................... 3-46

3.3.2 Mined-Salt Handling System ................. 3-52

3.3 .3 Development Sequence ................... 3-53

3.3 .4 Impacts of MSHA Regulations ................ 3-55

3.3.5 Ground Control Methods ..................... 3-56

3.3.6 Equipment Needing Development ............. 3-56

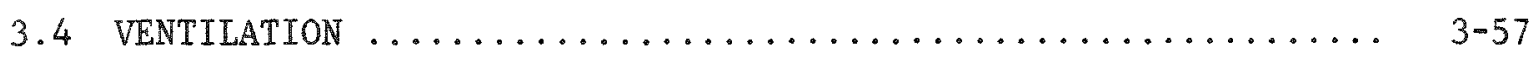

3.4.1 General Underground Descriptions .............. 3-57

3.4.2 Underground Development Ventilation System ........ 3-68

3.4.3 Emplacement Ventilation System .............. 3-84

4 SALT REPOSITORY DESIGN DESCRIPTION $\ldots \ldots \ldots \ldots \ldots \ldots \ldots \ldots \ldots \ldots$

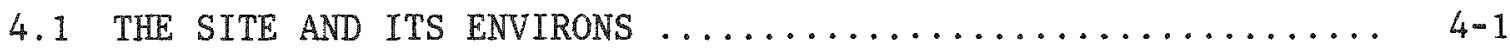


TABLE OF CONTENTS

(Continued)

Page

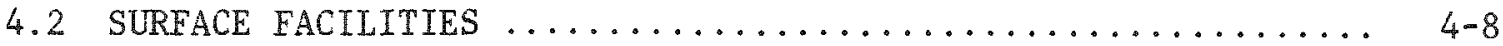

4.2.1 Facility Layout Description ................ 4-8

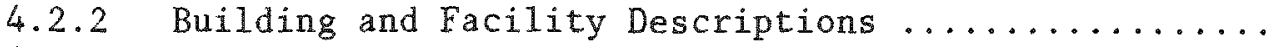

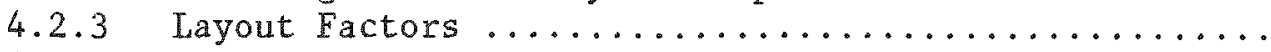

4.2.4 Waste Handling Building Layout Considerations .......

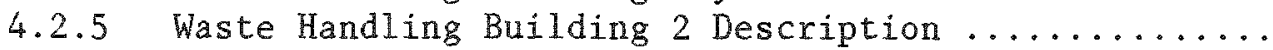

4.2 .6

Waste Handling Building 1 Description

$4-15$

$4-31$

$4-35$

$4-47$

$4-63$

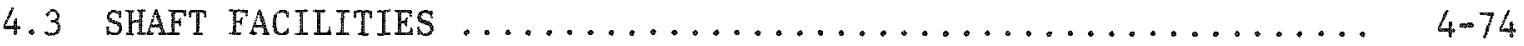

4.3 .1 Shaft Requirements ..................... 4-74

4.3.2 Shaft Linings and Operational Seals ........... 4-79

4.3 .3 Hoisting Systems ........................ $4-99$

4.3 .4 Shaft Equipment ....................... $4-112$

4.3.5 Shaft Construction Methods ................ 4-115

4.4 UNDERGROUND FACILITIES ........................ 4 . 119

4.4.1 Design of Underground Facilities ............ 4-119

4.4 .2 Underground Layout ..................... 4-134

4.5 SUBSURFACE REPOSITORY OPERATIONS ................. 4-160

4.5.1 Support Activities ................... 4-160

4.5.2 Repository Emplacement Sequence ............. 4-165

4.5.3 Panel Emplacement Sequence ............... 4-171

4.5.4 Emplacement 0perations ..................... 4-172

4.5.5 Entry Backfilling and Entry Stopping ........... 4-192

4.6 STRUCTURES, SYSTEMS AND COMPONENTS IMPORTANT TO SAFETY,

AND IMPORTANT TO WASTE ISOLATION $\ldots \ldots \ldots \ldots \ldots \ldots \ldots \ldots \ldots$ 4-196

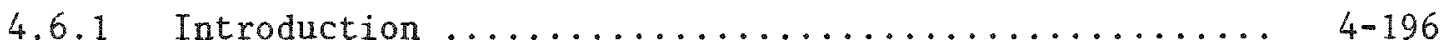

4.6.2 Q-List Methodology .................... 4-198

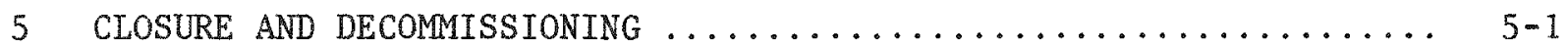

5.1 CLOSURE OF THE UNDERGROUND FACILITY .............. 5-2

5.1.1 Major Elements Requiring Barriers .............. 5-3

5.1 .2 Removal of Operating Equipment .............. 5-10

5.1 .3 Construction of Bulkheads .................. 5-11

5.1 .4 Installation of Backfill ................. $5-22$

5.1 .5 Further Research Needs .................. 5-27 
TABLE OF CONTENTS

(Continued)

Page

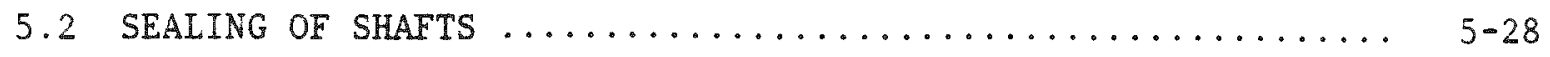

5.2.1 Shaft Sealing System Components ............. 5-28

5.2 .2 Bulkhead Connection to Shaft Liner ............ 5-41

5.2 .3 Shaft Seal System Interaction with Aquifers ....... 5-45

5.2.4 Shaft Seal System Response to Seismic Load ........ 5-46

5.2 .5 Further Research Needs .................. 5-46

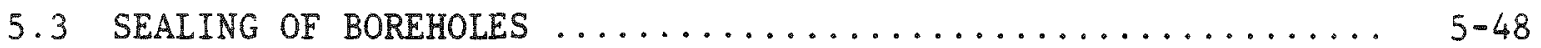

5.3 .1 Sealing Criteria .................... 5-48

5.3.2 Description of Sealing System for Deep Boreholes .... 5-53

5.3 .3 Response to Seismic Loads ................. 5-58

5.3 .4 Future Résearch Needs .................. 5-59

5.4 DECONTAMINATION AND DECOMMISSIONING OF SURFACE FACILITIES .. 5-60

5.4 .1 Decommissioning Activities ................ 5-60

5.4.2 Decommissioning Design Considerations ......... 5-61

5.4 .3 Postclosure Activities .................... 5-64

Volume 2

6 PERFORMANCE OBJECTIVES $\ldots \ldots \ldots \ldots \ldots \ldots \ldots \ldots \ldots \ldots \ldots \ldots \ldots \ldots \ldots \ldots \ldots \ldots \ldots$

6.1 CONTROL OF RADIOACTIVE RELEASES DURING NORMAL OPERATIONS ... 6-1

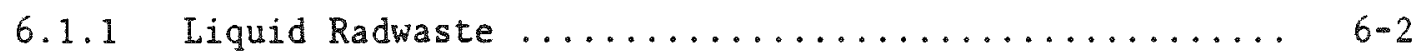

6.1 .2 Solid Radwaste ............................... $6-10$

6.1 .3 Radioactive Gaseous Effluents ................ 6-17

6.1 .4 Site Monitoring ...................... $6-47$

6.2 CONTROL OF RELEASES UNDER ACCIDENT CONDITIONS ........... 6-49

6.2.1 Design-Basis Accident Analysis Methodology ....... 6-50

6.2 .2 Design-Basis Accidents .................... 6-54

6.2 .3 Design of Preventive and Mitigative Features ....... $6-72$

6.2.4 Q-List Support Calculations for Subsurface

Preclosure Events ..................... $6-78$

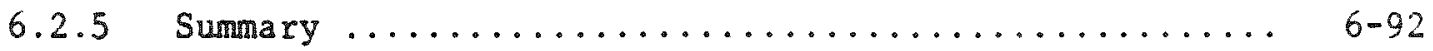

6.3 WASTE RETRIEVAL $\ldots \ldots \ldots \ldots \ldots \ldots \ldots \ldots \ldots \ldots \ldots \ldots \ldots \ldots \ldots \ldots \ldots$

6.3 .1 Reasons for Retrieval ..................... 6-93

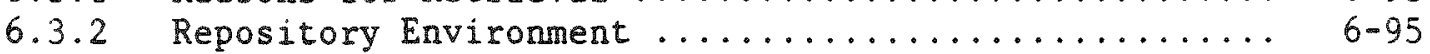

6.3 .3 Waste Retrieval operations ................... 6-100

6.3 .4 Operational Considerations .................. 6-127

6.3 .5 Demonstration Program ....................... 6-132 
TABLE OF CONTENTS

(Continued)

Page

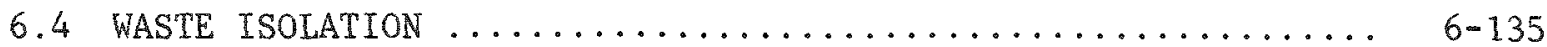

6.4 .1 Subsurface Stability ................... 6-135

6.4 .2 Underground Layout ..................... 6-137

6.4 .3 Rock Excavation ....................... 6-140

6.4 .4 Thermal and Thermomechanical Response .......... 6-142

6.4 .5 Shaft and Borehole Seals .................. 6-152

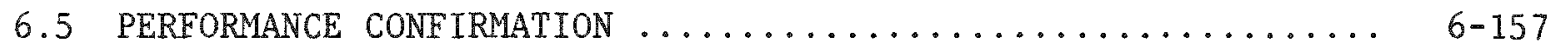

6.5.1 Program Plan ........................... 6-157

6.5.2 Computer Code Development and Verification ........ 6-164

6.5 .3 Performance Confirmation Facilities ............ 6-165

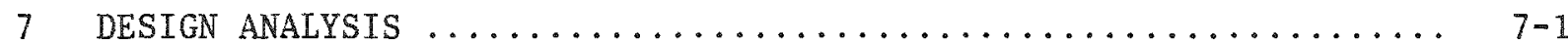

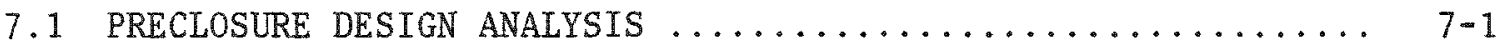

7.1.1 Approach to the Analysis ................ 7-1

7.1 .2 Surface Elements .............................. 7-4

7.1 .3 Shafts and Underground Elements ............ 7-15

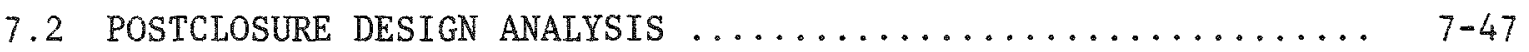

7.2.1 Approach to the Analysis ................ 7-47

7.2 .2 Near-Repository Effects ................. 7-48

7.2.3 Far-Field Rock Mass Effects ................ 7-50

7.2 .4 Repository Sealing System ............... 7-50

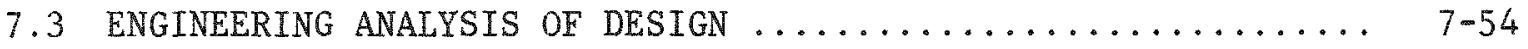

7.3.1 Site Characteristics Affecting Design ......... 7-54

7.3.2 Effects of Construction Techniques ............. 7-59

7.3 .3 The Effect of the ESF .................... 7-60

7.4 STRUCTURES, SYSTEMS, AND COMPONENTS IMPORTANT TO SAFETY,

AND IMPORTANT TO WASTE ISOLATION $\ldots \ldots \ldots \ldots \ldots \ldots \ldots \ldots \ldots$ 7-64

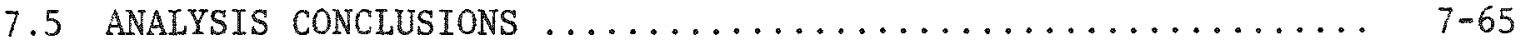

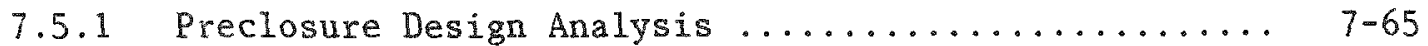

7.5 .2 Postclosure Design Analysis ................ 7-70 
TABLE OF CONTENTS

(Continued)

Page

8 DESIGN ISSUES AND DATA NEEDS $\ldots \ldots \ldots \ldots \ldots \ldots \ldots \ldots \ldots \ldots \ldots \ldots \ldots \ldots \ldots$

8.1 INTRODUCTION $\ldots \ldots \ldots \ldots \ldots \ldots \ldots \ldots \ldots \ldots \ldots \ldots \ldots \ldots \ldots \ldots \ldots \ldots \ldots$

8.1.1 Design Information Needs to be Resolved by the

Site Characterization Program ............. 8-2

8.1.2 Design Information Needs to be Resolved by

Ongoing Work by Other Contractors and Technology

Development Programs ................. 8-15

8.2 SURFACE FACILITIES $\ldots \ldots \ldots \ldots \ldots \ldots \ldots \ldots \ldots \ldots \ldots \ldots \ldots \ldots \ldots \ldots \ldots .17$

8.2.1 Site Preparation ..................... 8-17

8.2 .2 Design of Civil Features ................... 8-19

8.2 .3 Design of Structural Features ................ 8-20

8.2.4 Surface Facilities Layout .................. 8-21

8.2 .5 Waste Handling Buildings $\ldots \ldots \ldots \ldots \ldots \ldots \ldots \ldots . \ldots \ldots$ 8 $8 \ldots \ldots \ldots$

8.2 .6 Offsites Systems....................... $8-32$

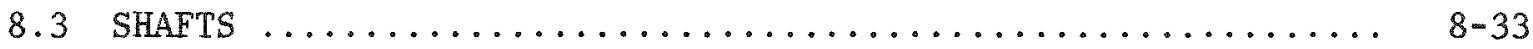

8.3.1 Design Information Required .............. 8-33

8.3.2 Resolved Information Needs ................ 8-35

8.3.3 Unresolved Information Needs ................ 8-37

8.4 UNDERGROUND $\ldots \ldots \ldots \ldots \ldots \ldots \ldots \ldots \ldots \ldots \ldots \ldots \ldots \ldots \ldots \ldots \ldots \ldots$

8.4.1 Repository Horizon Selection ................. 8-40

8.4.2 Dimensions of Entries and Pillars ........... 8-42

8.4 .3 Ground Control ........................ 8-43

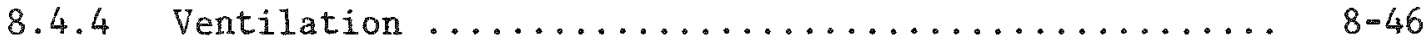

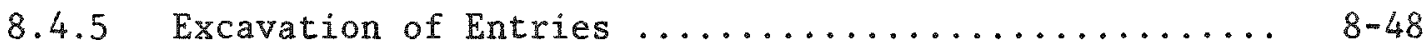

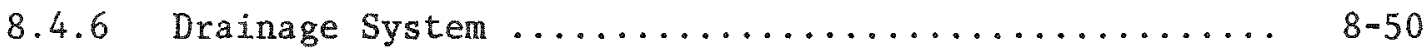

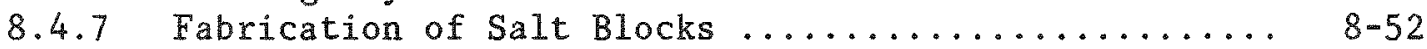

8.4.8 Dimension of Emplacement Holes ............... 8-53

8.4.9 Spacing of Emplacement Holes .............. 8-54

8.4.10 Excavation of Emplacement Holes and Counterbores ... 8-55

8.4.11 Emplacement of Disposal Containers ............. 8-55

8.4 .12 Installation of Backfill ................... 8-56

8.4.13 Underground Emplacement Equipment ............ 8-58

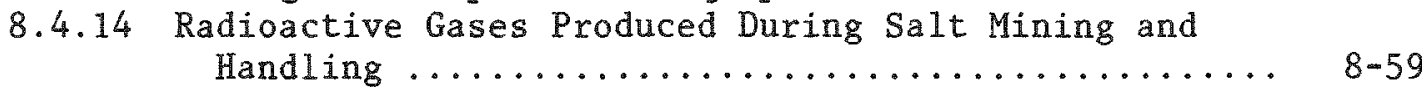


TABLE OF CONTENTS

(Continued)

Page

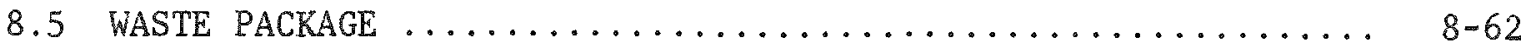

8.5.1 Information Which the A/E Contractor Will Provide for Waste Package Design ............... 8-62

8.5.2 Information Which the Waste Package Design and Development Contractor Will Provide for Design of the Repository .................. 8-63

8.6 RETRIEVAL ................................. $8-64$

8.6.1 Design Information Required ............... 8-64

8.6.2 Resolved Information Needs ................ 8-65

8.6.3 Unresolved Information Needs ................ 8-66

8.7 SEAL SYSTEM FOR PERMANENT CLOSURE $\ldots \ldots \ldots \ldots \ldots \ldots \ldots \ldots \ldots$ 8-68

8.7.1 Crushed Salt Backfill Performance .............. 8-68

8.7.2 Crushed Salt Backfill Installation ............. 8-70

8.7.3 Earthen Material Backfill Performance ............. 8-72

8.7.4 Earthen Material Backfill Installation ............ 8-74

8.7.5 Salt Block Bulkhead Performance ............. 8-77

8.7.6 Salt Block Bulkhead Installation .............. 8-79

8.7.7 Concrete Bulkhead Performance .............. 8-81

8.7.8 Concrete Bulkhead Installation .............. 8-83

8.7.9 Drilled Cutoff Curtain ................... 8-86

8.7.10 In Situ Decommissioning Conditions ........... 8-88

8.7.11 Borehole Grouting ..................... 8-91

9 QUALITY ASSURANCE ............................ 9-1

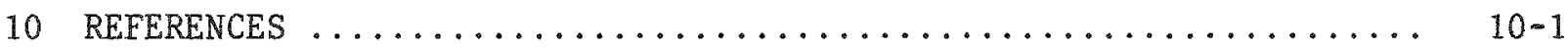

10.1 GENERAL REFERENCES ........................ 10-1

10.2 FEDERAL LAWS AND EXECUTIVE ORDERS .............. 10-19

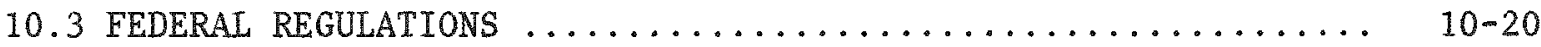

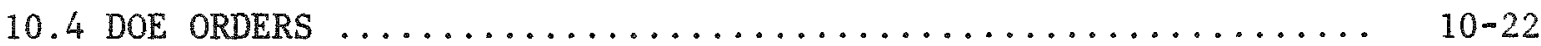

10.5 TEXAS STATE LAWS, REGULATIONS, AND CODES ........... 10-23

LIST OF ACRONYMS, ABBREVIATIONS AND SYMBOLS $\ldots \ldots \ldots \ldots \ldots \ldots \ldots \ldots$

LIST OF ELEMENTS $\ldots \ldots \ldots \ldots \ldots \ldots \ldots \ldots \ldots \ldots \ldots \ldots \ldots$

GLOSSARY OF TERMS $\ldots \ldots \ldots \ldots \ldots \ldots \ldots \ldots \ldots \ldots \ldots \ldots \ldots \ldots \ldots \ldots \ldots \ldots \ldots$ 
TABLE OF CONTENTS

(Continued)

Page

APPENDIX A: INTERIM REPOSITORY SUBSYSTEM DESIGN REQUIREMENTS

FOR HIGH-LEVEL NUCLEAR WASTE REPOSITORY IN SALT $\ldots . . \quad A-1$

APPENDIX B: TELEPHONE CONVERSATION BETWEEN JOE O'BRIEN, NUS, AND JUDITH MOODY, ONWI $\ldots \ldots \ldots \ldots \ldots \ldots \ldots \ldots \ldots \ldots$ B-1

APPENDIX C: LABORATORY LIQUID PERMEABILITY MEASUREMENTS ON

ROCK CORE SAMPLES $\ldots \ldots \ldots \ldots \ldots \ldots \ldots \ldots \ldots \ldots \ldots \ldots, c-1$

APPENDIX D: UNIAXIAL/TRIAXIAL STRENGTH TEST DATA OF PERMIAN

ROCK UNITS ......................... D-1

APPENDIX E: UNCONFINED COMPRESSIVE STRENGTH OF CYCLE 4 SALT $\ldots . . \quad$ E-1

APPENDIX $\mathrm{F}: \quad$ PUMPING TEST DATA, J. FREIMEL NO. 1 WELL (PD-9) $\ldots \ldots$ F-1

APPENDIX G: HYDRODYNAMIC INVESTIGATIONS IN THE TEXAS

PANHANDLE AREA . ...................... G-1

APPENDIX H: $\quad$ SUMMARY OF CHEMICAL AND ISOTOPIC DATA FOR

GROUNDWATERS IN THE PALO DURO BASIN, TEXAS $\ldots \ldots \ldots . . .$. 


\section{LIST OF TABLES}

Volume 1

Page

S-1 Estimated Quantities and Types of Emplaced Waste Packages ....

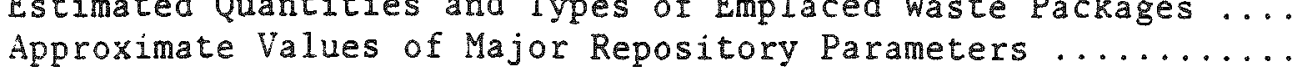

Repository Shaft Functions and Sizes $\ldots \ldots \ldots \ldots \ldots \ldots \ldots \ldots$

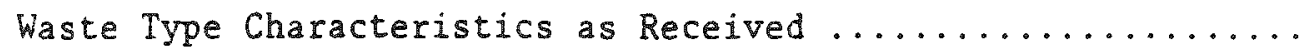

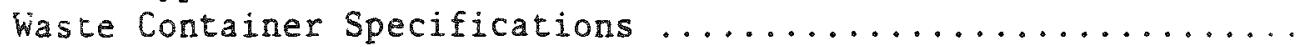

Representative Hydrochemistry of Formation waters ...........

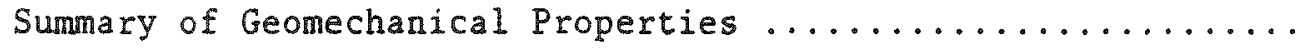

$2.2-5$

$2.2-6$

$2.2-7$

$2.2-8$

Summary of In Situ Stress Test Results, Holtzclaw Well .......

Range of Thermal Property Measurements, J. Friemel Well ......

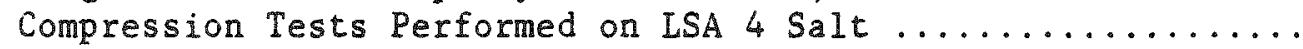

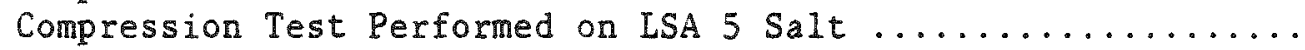

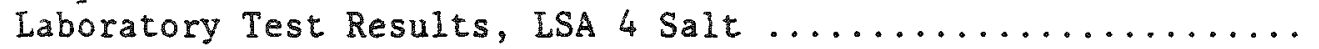

2.3-2 Estimated Ground Surface and Formation Top Elevation and

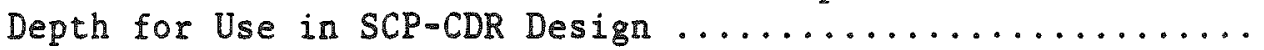

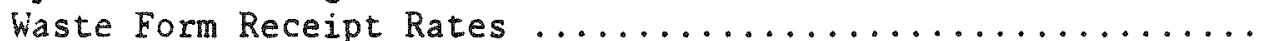

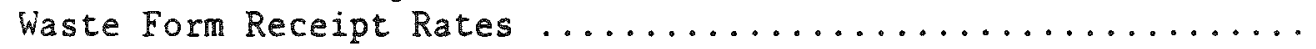

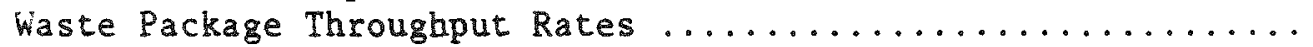

Shipping Cask Receipt Rates - WHB1 ................ 2-125

Shipping Cask Receipt Rates - WHB2 ................. 2-126

2.5-6 Sumary of Radionuclide Inventory Data for Reference

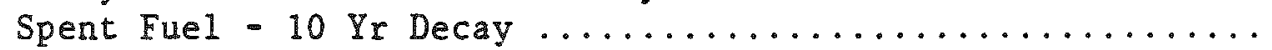

2.5-2 Summary of Radionuclide Inventory Data for 60,000 MWD/MTU

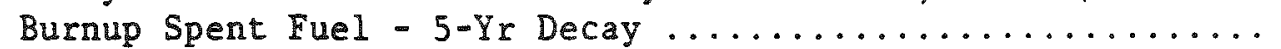

2.6-1 List of Most Important Federal Laws, Regulations, and Executive Orders Affecting Repository Design ........... 2-141

2.6-2 List of Most Important DOE Orders Affecting Repository Design ...................................... 2-145

2.6-3 List of State Laws and Regulations Affecting Design ....... 2-148

3.1-1 List of Major Waste Handling Equipment for WhB 2, Receiving Yard, Waste Shaft, and Underground .......... 3-15

$3.1-2$ List of Major Waste Handling Equipment for WHB

3.4-1 Underground Development Ventilation Air Quantity

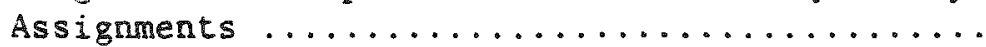

3.4-2 Waste Emplacement Ventilation Air System Quantity Assignments ............................ 3-91 
Transfer Cask Design Specifications haft Functions, Dimensions, Airflows, and Hoisting

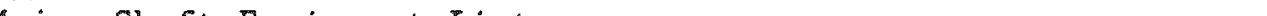

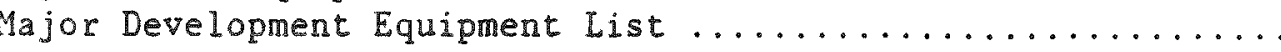

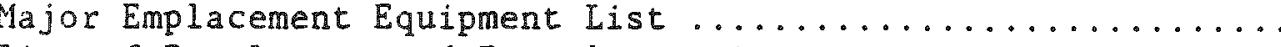

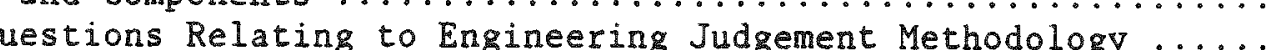

sic Components in a Seal System for an Underground

ummary of Materials, Specifications, and Construction Methods for Sealing the Underground Facility ........... 5-15

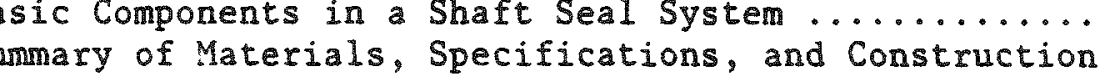

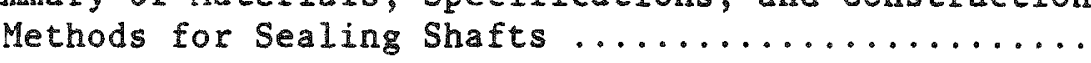

to Sealing

umma ry

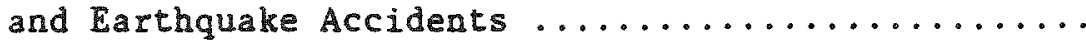


LIST OF TABLES

(Continued)

$\underline{\text { Page }}$

7.1-4 Range of Hydraulic Conductivities (k) of Formations and Steady-State Water Inflow in a 33-ft Diameter Excavated

Shaft ............................... 7-34

7.1-5 Key Thermal and Mechanical Parameters of LSA 4 Salt ....... 7-37

7.1-6 Summary of Sensitivity of Maximum Entry Wal1 Temperatures ... 7-42

7.1-7 Summary of Sensitivity of Maximum Salt Temperatures at Waste Package Interface ...................... 7-43

7.1-8 Summary of Sensitivity of Entry Closure at 2 Years After Retrieval Begins .......................... 7-46

8.1-1 Repository Design Data Needs $\ldots \ldots \ldots \ldots \ldots \ldots \ldots \ldots \ldots \ldots \ldots . \ldots$ 


\section{IIST OF FIGURES}

Volume 1

Page

$S-1$

$\mathrm{S}-2$

$\mathrm{S}-3$

$S-4$

$S-5$

$S-6$

$S-7$

$S-8$

2. $1-1$

2.1-2

2. $1-3$

2. $2-1$

$2.2-2$

2. 2-3

$2.2-4$

$2 \cdot 2-5$

$2 \cdot 2-6$

$2 \cdot 2-7$

$2.2-8$

2. $3-1$

$2 \cdot 3-2$

$2 \cdot 3-3$

$2 \cdot 3-4$

$2.3-$

$2 \cdot 3-6$

$2.3-7$

$2.3-8$

$2.3-9$

2. 6-1

$3 \cdot 1-1$

$3 \cdot 1-2$

$3 \cdot 1-3$

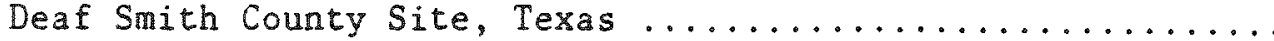

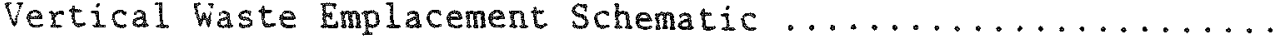

Estimated Stratigraphy at Representative Shaft Location .....

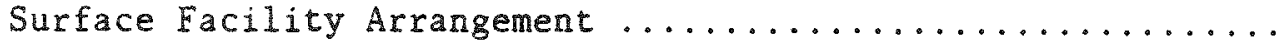

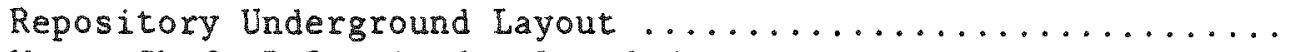

Waste Shaft B Longitudinal and Horizontal Sections .........

Schematic of Backfill and Decommissioning Seals in the

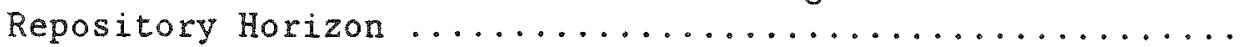

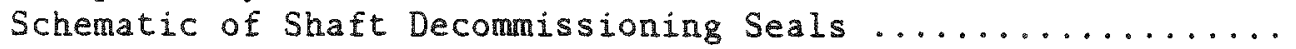

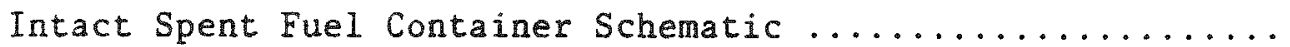

Consolidated Spent Fuel Container Schematic ..............

Defense High-Level Waste Container Schematic ...............

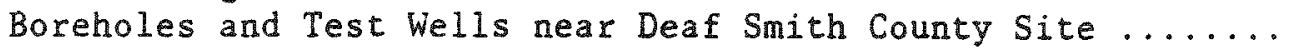

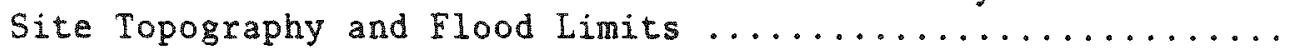

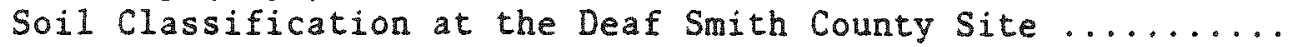

Generalized Hydrostratigraphic Column for the Deaf

Smith Region.

Section A-A' North-South Cross Section Queen/Grayburg

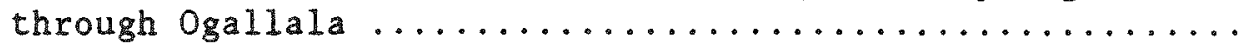

Section A-A' North-South Cross Section Wichita through

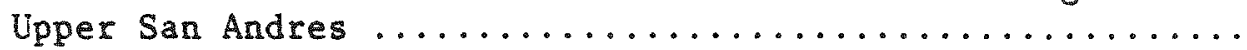

Section B-B' Compound Cross Section Lower San Andres Unit 4 Salt

Thermal Conductivity Measurements of Salt

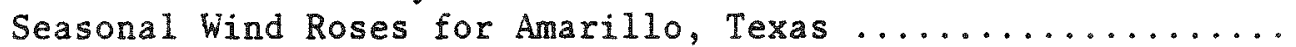

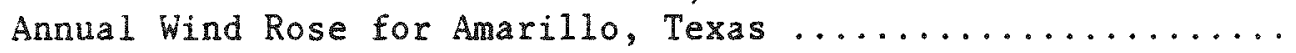

Estimated Stratigraphy at Representative Shaft Location .....

SCP Conceptual Design Hydrogeologic Parameters

Ogallala Aquifer through LSA Unit $4 \ldots \ldots \ldots \ldots \ldots \ldots$

Hypothetical Detailed LSA Unit 4 Salt Stratigraphy

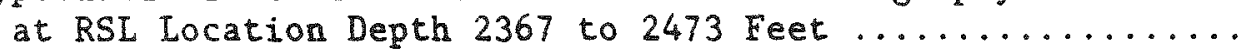

Hypothetical Detailed LSA Unit 4 Salt Stratigraphy

at RSL Location Depth 2431 to 2528 Feet ..............

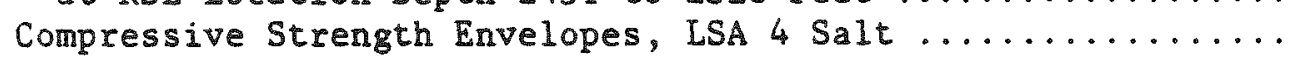

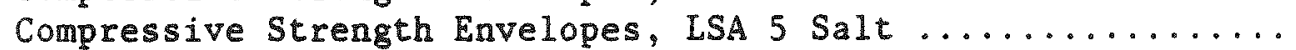

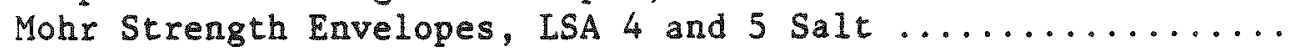

Hierarchy of Law, Regulations and Program Guidance ..........

Functional Flow Diagram Waste Handling/Emplacement wHB 2

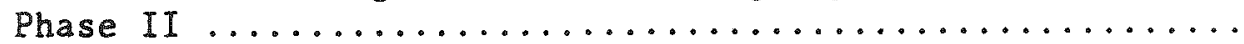

Functional Flow Diagram Waste Handling/Emplacement WHB 1

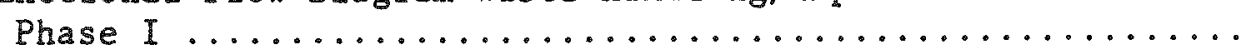

Functional Flow Diagram Waste Handling/Emplacement WHB 1 Phase II
$S-4$

$S-6$

$S-7$

$S-15$

$S-19$

$S-23$

$S-27$

$\mathrm{S}-28$

$2-6$

2-8

2-9

2-13

2-15

2-19

$2-22$

$2-25$

2-27

$2-31$

$2-61$

2-66

$2-67$

2-77

$2-81$

$2-97$

2-99

2-103

2-104

2-106

$2-135$

$3-3$

$3-5$

3-7 


\section{LIST OF FIGURES \\ (Continued)}

\begin{tabular}{|c|c|c|}
\hline $1-4$ & $\begin{array}{l}\text { Mechanical Flow Diagram Waste Handling/Emplacement WHB } 2, \\
\text { Phase II } \ldots \ldots \ldots \ldots \ldots \ldots \ldots \ldots \ldots \ldots \ldots \ldots \ldots \ldots \ldots\end{array}$ & $3-9$ \\
\hline $1-5$ & Mechanical Flow Diagram Waste Handling/Enplacement WHB 1 , & \\
\hline $.1-6$ & $\begin{array}{c}\text { Phase } I \ldots \ldots \ldots \ldots \ldots \ldots \ldots \ldots \ldots \ldots \ldots \ldots \ldots \ldots \ldots \ldots \ldots \ldots \\
\text { Mechanical Flow Diagram Waste Handiing/Emplacement wHB } 1 \text {, }\end{array}$ & $3-29$ \\
\hline & 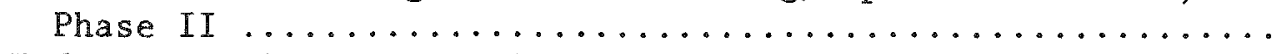 & $3-39$ \\
\hline $.3-1$ & Underground Development Sequence $\ldots \ldots \ldots \ldots \ldots \ldots$ & $3-47$ \\
\hline $3.3-2$ & Emplacement Entry Excavation Sequence $\ldots \ldots \ldots \ldots \ldots$ & $3-50$ \\
\hline$\cdot 3-3$ & Underground Development Excavation Conceptual Flow & \\
\hline & 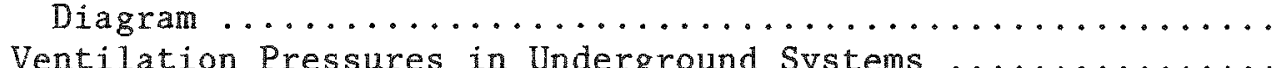 & $3-51$ \\
\hline $.4-1$ & Ventilation Pressures in Underground Systems ....... & -59 \\
\hline $3.4-2$ & Ventilation Control Devices $\ldots \ldots \ldots \ldots \ldots \ldots \ldots \ldots$ & $3-63$ \\
\hline $3.4-3$ & Underground Airflow Paths - Year $9 \ldots \ldots \ldots \ldots \ldots \ldots$ & $3-69$ \\
\hline $3.4-4$ & Underground Airflow Paths - Year $15 \ldots \ldots \ldots \ldots \ldots$ & $3-71$ \\
\hline $3.4-5$ & 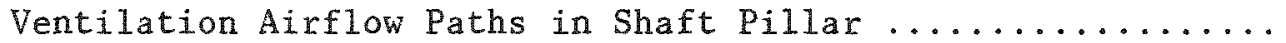 & $3-75$ \\
\hline $3.4-6$ & Panel Ventilation During Development $\ldots \ldots \ldots \ldots \ldots \ldots \ldots$ & $3-77$ \\
\hline $3.4-7$ & Ventilation of Main and Submain Entries During & \\
\hline & opment $\ldots \ldots \ldots \ldots \ldots \ldots \ldots \ldots \ldots \ldots$ & -81 \\
\hline $.4-8$ & Ventilation Detail of Panel Mining Operations ...... & .83 \\
\hline $3.4-9$ & Panel Ventilation During Emplacement Operations ..... & -87 \\
\hline$+.1-1$ & egiona1 Transportation and Utility Map & $4-5$ \\
\hline $4.2-1$ & $\ldots \ldots \ldots \ldots \ldots \ldots \ldots \ldots \ldots \ldots$ & $4-9$ \\
\hline +. $2-2$ & Surface Facility Arrangement & $4-13$ \\
\hline $.2-3$ & Cell Operations Flow Schematic & -37 \\
\hline $4.2-4$ & WHB 2 Building Perspective $\ldots \ldots \ldots \ldots \ldots \ldots \ldots$ & -49 \\
\hline$+.2-5$ & WHB 2 General Arrangement & -51 \\
\hline$+.2-6$ & Disassembly/Canistering and Overpack Cell Arrangement & -55 \\
\hline $4.2-7$ & $\ldots \ldots \ldots \ldots \ldots \ldots \ldots \ldots \ldots$ & -57 \\
\hline .2 & Waste Shaft Loading Area-Layout and Elevations .. & 65 \\
\hline 4.2 & WHB 1 General Arrangement $\ldots \ldots \ldots \ldots \ldots \ldots \ldots \ldots$ & $4-69$ \\
\hline 4.3 & $\begin{array}{l}\text { Typical Longitudinal Shaft Lining Section Showing } \\
\text { Relationship to Geology and Hydrogeology ...... }\end{array}$ & -81 \\
\hline $4.3-2$ & 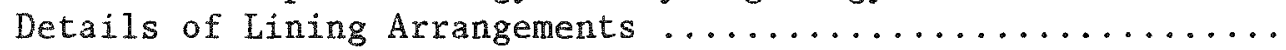 & $4-83$ \\
\hline 4.3 & Details of Lining Arrangements & -85 \\
\hline 4.3 & Perspectives of Various haft Lining Components & -87 \\
\hline 4.3 & Perspectives of Various shaft Lining Components & $4-89$ \\
\hline & Waste Shaft B Hoisting System and Cage General & \\
\hline & em & 2 \\
\hline & Mined Salt/Exhaust Shaft D Sections and Hoisting System & \\
\hline $4.3-8$ & Service/Intake Shaft E Sections and Hoisting System & \\
\hline & & 1 \\
\hline & Waste Shaft B Longitudinal and Horizontal Sections & $4-109$ \\
\hline & $\begin{array}{l}\text { tilation Shafts } A, F \text { and } G \text { General } \\
\ldots \ldots \ldots \ldots \ldots \ldots \ldots \ldots \ldots \ldots \ldots\end{array}$ & \\
\hline & Layout of Exploratory Shaft Facility & $4-120$ \\
\hline & $\begin{array}{l}\text { Stratigraphy and Discont } \\
\text { Emplacement Horizon. }\end{array}$ & 3 \\
\hline
\end{tabular}




\section{IIST OF FIGURES}

(Continued)

Page

$4 \cdot 4-3$

$4.4-4$

$4.4-5$

$4.4=0$

$4 \cdot 4-7$

$4.4-8$

$4.4-9$

$4.4-10$

$4.4-11$

$4.4-12$

$4.4-13$

4. 5-1

$4.5-2$

$4.5-3$

$4.5-4$

$4.5-5$

$4.5-6$

$4.5-7$

4.5-8

$4.5-9$

Shaft Pillar Arrangement

$4-125$

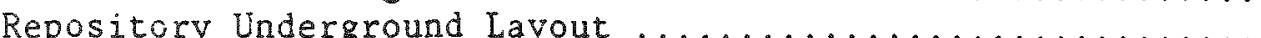

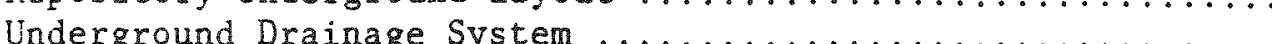

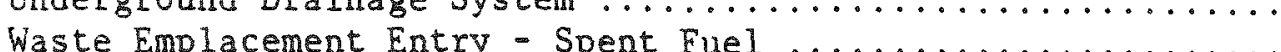

Waste Emplacement Entry - DHLW, WVHLw, FAH $\ldots \ldots \ldots \ldots \ldots \ldots$

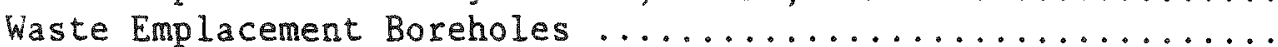

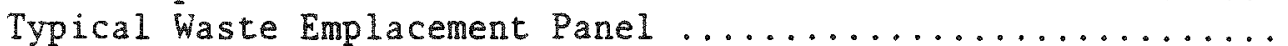

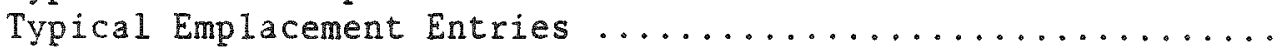

Mined-Salt Handling Systern Process Flow Diagram ............

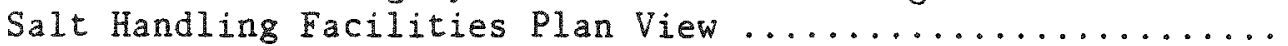

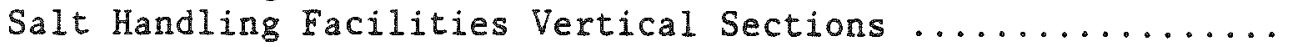

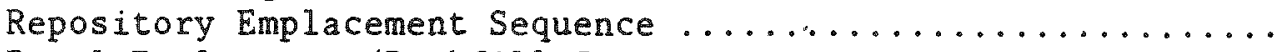

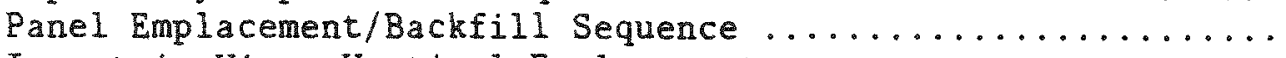

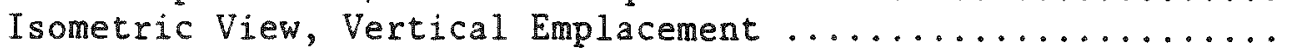

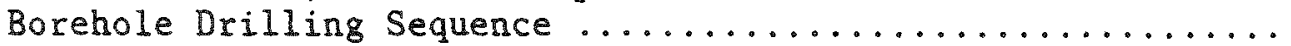

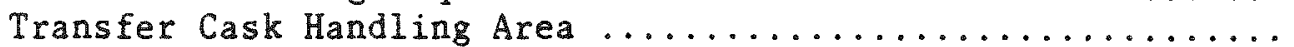

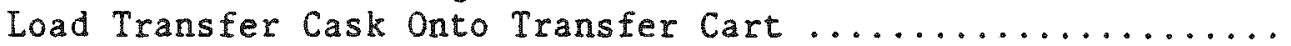

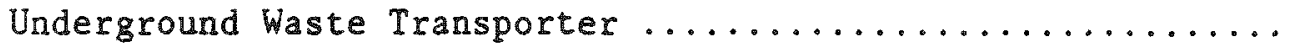

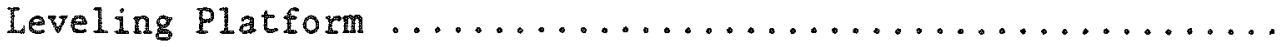

Transfer Cask Moved from Underground Waste Transporter

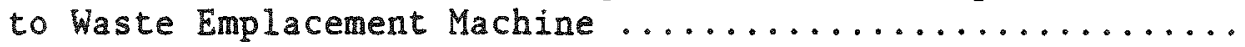

$4.5-10$

Emplacement Machine with Transfer Cask in Vertical

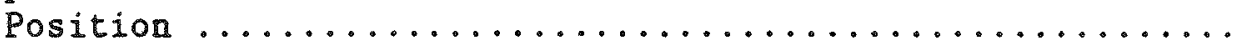

$4.5-11$

$4.5-12$

$4.5-13$

$4.5-14$

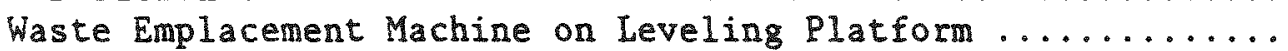

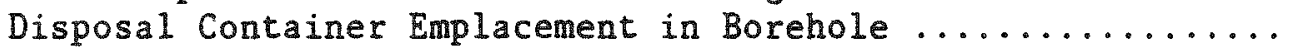

Emplacement Borehole Backfill Machine ...................

Entry Backfilling and Entry Stopping Conceptual Flow

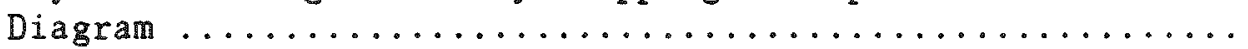

$4-129$

$4-135$

$4-139$

4-141

$4-143$

$4-145$

$4-147$

$4-151$

$4-155$

4-157

$4-167$

$4-169$

$4-173$

4-175

$4-177$

$4-178$

$4-181$

$4-184$

$4-185$

$4-186$

4-187

4-189

4-191

4-193

5.1-1

General Sealing Areas Within Underground Facility ..........

$5-5$

5. $1-2$ General Seals Schematic for Main and Submain Entries ........

5.1-3

5.1-4

5. 1-5

5. 2-1

$5.2-2$

5. 2-3

5. $2-4$

5. 3-1

5. $3-2$

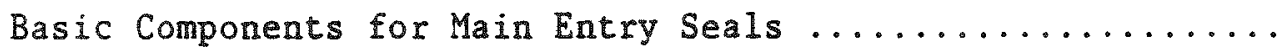

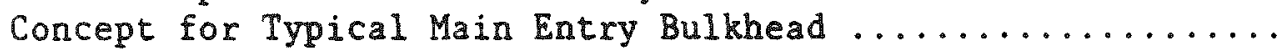

Construction Sequence for Main Entry Bulkhead ..............

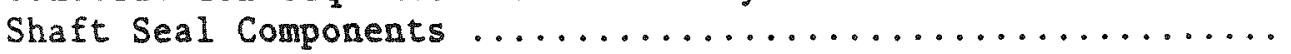

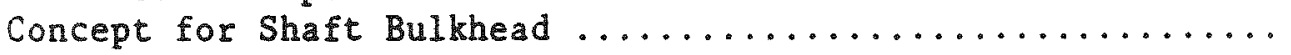

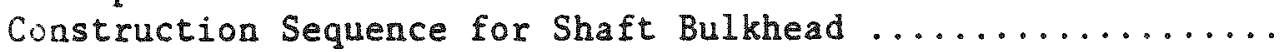

Operational Liners Integrated with Shaft Keyways ...........

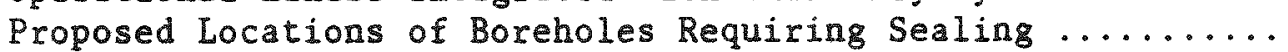

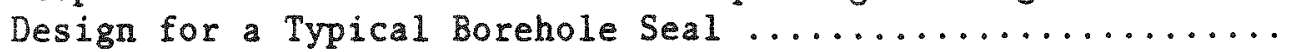

5-8

5-12

$5-13$

$5-18$

$5-29$

$5-33$

$5-38$

$5-44$

$5-49$

5-54

Volume 2

6.1-1 Liquid Radwaste Handling System WHB 1 and $2 \ldots \ldots \ldots \ldots$ 


\section{LIST OF FIGURES}

(Continued)

\begin{tabular}{|c|c|c|}
\hline & & ge \\
\hline $6.1-7$ & WHB 2 Ventilation Zones - Level 2 & $6-31$ \\
\hline & Air Flow Diagram WHB 1 and 2 Radwaste Facilities .......... & \\
\hline & Air Flow Diagram WHB 1 - Phase I and II Operations ........ & 37 \\
\hline & Air Flow Diagram WHB 2 - Phase II Operations $\ldots \ldots \ldots \ldots \ldots$ & 39 \\
\hline & 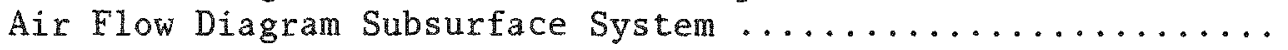 & 42 \\
\hline & Logic Network for DBA Analysis $\ldots \ldots \ldots \ldots \ldots \ldots \ldots$ & $6-52$ \\
\hline & $\begin{array}{l}\text { nderground Waste Transporter Collision and Fire } \\
\text { Functional Event Tree } \ldots \ldots \ldots \ldots \ldots \ldots \ldots \ldots \ldots \ldots \ldots\end{array}$ & $0-80$ \\
\hline $2-3$ & xplosion Functional Event Tree $\ldots \ldots \ldots \ldots \ldots \ldots \ldots \ldots$ & -81 \\
\hline & nal Event Tree. & 82 \\
\hline 6.2 & uake Functional Event Tree & 83 \\
\hline & onal Flow Diagram Waste Retrieval & 103 \\
\hline & nical Flow Diagram Waste Retrieval. & 107 \\
\hline & nine $\ldots \ldots \ldots \ldots \ldots \ldots$ & 11 \\
\hline & ling Plug Removal from Retrieval Hole ......... & 113 \\
\hline 6.3 & $\begin{array}{l}\text { c Manipulator System - Exposing the Top End of the } \\
\text { osal Container for the Overcoring Operation } \ldots \ldots \ldots\end{array}$ & $6-114$ \\
\hline 6.3 & $\begin{array}{l}\text { Remotely Controlled Overcoring Mach } \\
\text { Vehicle } \ldots \ldots \ldots \ldots \ldots \ldots \ldots \ldots \ldots\end{array}$ & \\
\hline $\begin{array}{l}6.3-7 \\
6.3-8\end{array}$ & $\begin{array}{l}\text { oring } \ldots \ldots \ldots \ldots \ldots \ldots \ldots \ldots \ldots \\
\text { em - Preparing the Disposal }\end{array}$ & 7 \\
\hline & $\ldots \ldots \ldots \ldots \ldots$ & -118 \\
\hline 6.3 & $\begin{array}{l}\text { ainer into the Retrieval Tra } \\
\ldots \ldots \ldots \ldots \ldots \ldots \ldots \ldots \ldots \ldots \ldots \ldots \ldots \ldots\end{array}$ & 9 \\
\hline 6.3 & $\begin{array}{l}\text { ic Breached Disposal Cont } \\
\ldots \ldots \ldots \ldots \ldots \ldots \ldots \ldots \ldots \ldots \ldots \ldots\end{array}$ & 122 \\
\hline 6.3 & 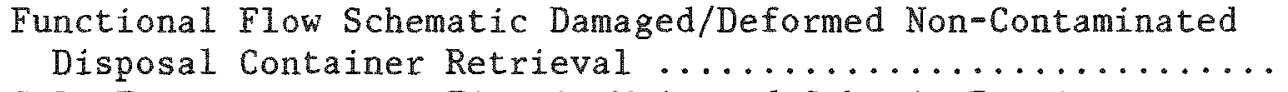 & -124 \\
\hline-1 & alt Temperature vs. Time in Main and Submain Entries & -14 \\
\hline $6.4-2$ & It Temperature at Waste Package Interface & -148 \\
\hline 3 & Average Temperature vs. Time in Emplacement Entry & $6-150$ \\
\hline & $\begin{array}{l}\text { Temperature Contours }\left({ }^{\circ} \mathrm{F}\right) \text { at } 40 \text { Years (At Peak Entry } \\
\text { Temperatures) } \ldots \ldots \ldots \ldots \ldots \ldots \ldots \ldots \ldots \ldots \ldots \ldots \ldots \ldots \ldots \ldots \ldots\end{array}$ & -15 \\
\hline & Entry Closure for Vertical Emplacement & $6-15$ \\
\hline 6 & $\begin{array}{l}\text { Deviatoric Stress Along Entry Pillar at Elevated } \\
\text { Temperatures } \ldots \ldots \ldots \ldots \ldots \ldots \ldots \ldots \ldots \ldots \ldots \ldots \ldots \ldots\end{array}$ & 20 \\
\hline & Performance Confirmation Flow Schen & $6-16$ \\
\hline & 01 & -40 \\
\hline & om Temperature to Thermal & $7-41$ \\
\hline & ensitivi & -44 \\
\hline & Scale Tem & -49 \\
\hline & -Scale Dis & -51 \\
\hline & Repository-Scale Differential Stre & $7-52$ \\
\hline & $\begin{array}{l}\text { Lateral Cont } \\
\text { County } \ldots\end{array}$ & $7-57$ \\
\hline
\end{tabular}




\section{LIST OF FIGURES}

(Continued)

8.1-1 Example Data Needs Form ..................... 8-16

9.1-1 Project Organization ............................ 9-3

9.1-2 Quality Assurance Program Hierarchy ................. 9-6 
EXECUTIVE SUMMARY

In response to the requirements of Section 113 of the Nuclear Waste Policy Act of 1982 (NWPA), the U.S. Department of Energy (DOE) is issuing a Site Characterization Plan (SCP) describing the characterization activities to be conducted at the candidate site for a high-level nuclear waste repository in salt. This SCP Conceptual Design Report (CDR) has been prepared to support development of SCP Chapter 6, Conceptual Design of a Repository. The results of this conceptual design effort indicate that a repository can be built at the Deaf Smith County site in Texas.

Current repository design concepts presented in this report reflect both prior repository design feasibility studies and newly established guidelines with respect to underground ventilation (i.e., compliance with gassy mine criteria), the vertical waste emplacement mode, and areal heat loading. In addition, design of the facilities has incorporated some of the results of recent studies involving the two-phase repository construction concept and the impact of the exploratory shaft facility (ESF) on the repository. The existence of the monitored retrievable storage (MRS) facility was not assumed, but some of the results of DOE's Repository/MRS studies were used (e.g., disassembly equipment concepts).

The purpose of this Executive Summary is to provide a management-level view of the salt repository CDR, summarizing its most significant parts. The CDR has been organized to present the basis for the design followed by descriptions of the primary operations and the physical layout of the surface, shafts, and underground facilities. After a description of the plans and designs for closure and decommissioning, the evaluations of the primary performance objectives are discussed. The report concludes with analyses and specification of future design activities, and a section identifying remaining design issues and data needed to complete License Application Design for the repository. 


\section{S.1 OVERALL REPOSTTORY FUNCTION AND PURPOSE}

The high-level nuclear waste repository will be designed to safely dispose of and isolate for 10,000 years three basic types of waste: spent fuel (SF) from commercial power reactors, defense high-level waste (DHLW), and high-level waste from the West Valley Demonstration Facility (WVHLW) in New York. To accomplish this requirement, the repository will receive, consolidate, package, and dispose of the waste. Waste will be emplaced in a stable geologic salt formation approximately $2,500 \mathrm{ft}$ below ground level. The first waste is expected to be received by January 31, 1998. The repository is expected to operate for about 25 yrs and emplace the equivalent of 70,000 metric tons of uranium (MTU). Underground entries in disposal areas will be backfilled as soon as possible after waste emplacement.

In the event waste must be retrieved after it has been emplaced, the repository has been designed so as not to preclude such retrieval.

After completion of emplacement and performance confirmation operations (up to 50 yrs following initial emplacement), the repository will be decommissioned. The decommissioning process will include backfilling remaining underground entries, sealing entries and repository shafts, decontaminating and dismantling all surface facilities, and erecting permanent markers at the surface.

To protect the public, workers, and the environment, the repository will be licensed by the U.S. Nuclear Regulatory Commission (NRC). All design, site characterization, construction, operation, and decommissioning will be conducted subject to an appropriate quality assurance program.

\section{S.2 BASIS FOR CONCEPTUAL DESIGN}

This section outlines the primary design bases and assumptions used in preparation of the conceptual design. 
1. Baseline. The repository conceptual design is based on the 1985 Mission Plan which defines repository milestones, the waste acceptance schedule, the basic system configuration, and the phased operational concept.

2. Site. The repository site consists of a nine-square-mile area located in Deaf Smith County, Texas. Figure S-1 identifies the general location of this site.

3. Waste receipts. The repository will receive a total of 70,000 MTU equivalent of waste in certified shipping casks. This waste will consist of:

a. Spent fuel from commercial light water reactors. This will include primarily pressurized-water reactor (PWR) and boilingwater reactor (BWR) spent fuel in the form of intact assemblies and boxes of reactor consolidated spent fuel rods.

b. DHLW in stainless steel canisters.

c. WVHLW in stainless steel canisters.

4. Waste packaging. The repository will seal spent fuel inside thin-walled steel canisters. These in turn, will be sealed inside thick-walled carbon steel disposal containers. WVHLW and DHLW canisters will also be sealed inside thick-walled carbon steel disposal containers. Estimates of the quantities of disposal containers to be prepared and emplaced are given in Table S-1 


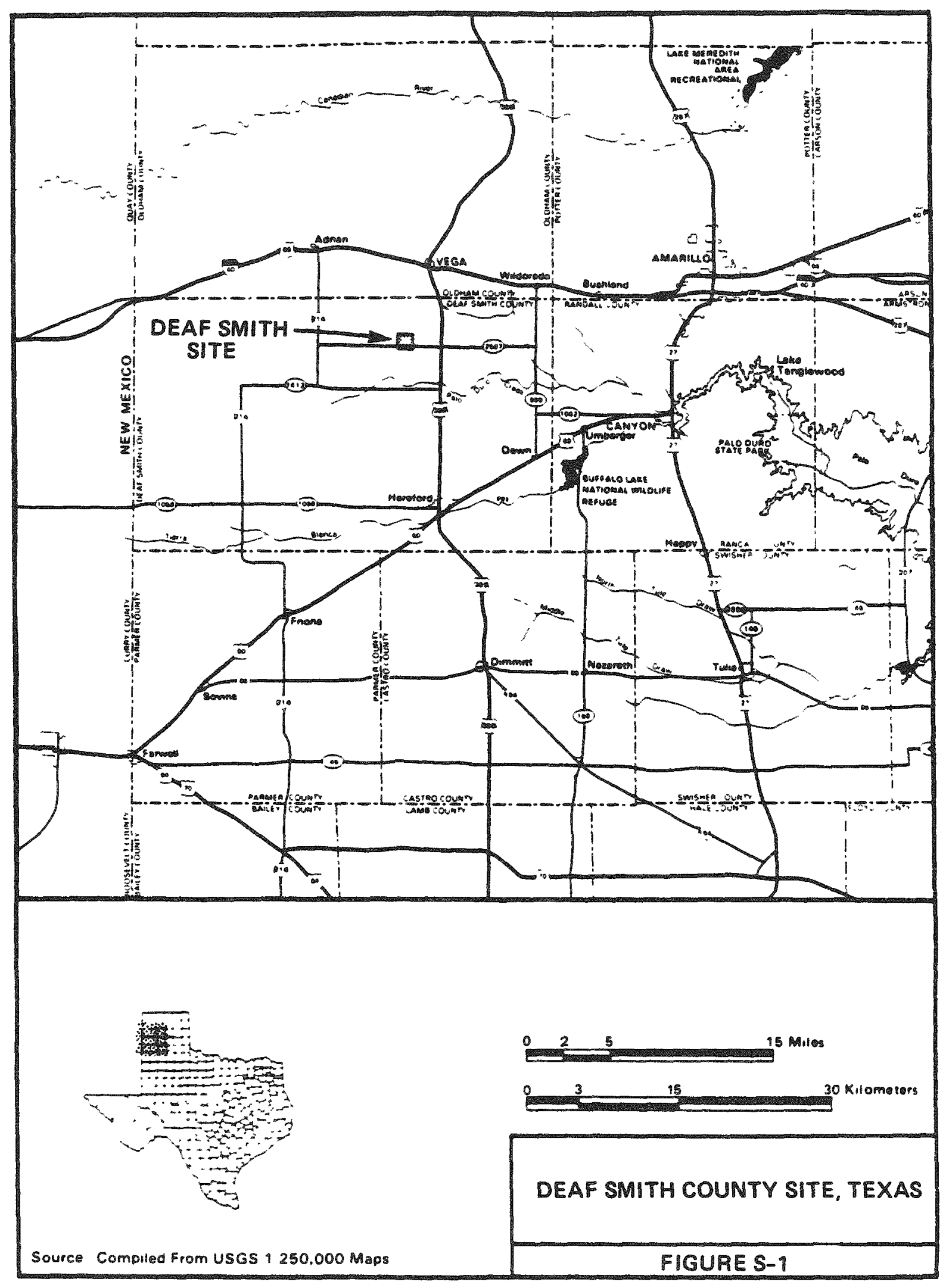


rable S-1. Estimated Quantities and Types of Emplaced Waste Containers

\begin{tabular}{lccc}
\hline Waste Type & $\begin{array}{c}\text { Total } \\
\text { Containers }\end{array}$ & $\begin{array}{c}\text { Metric Tons } \\
\text { Uranium } \\
\text { Equivalent }\end{array}$ & $\begin{array}{c}\text { Percent } \\
\text { Total } \\
\text { Containers }\end{array}$ \\
PWR Spent Fuel & 8,966 & 39,670 & 25 \\
BWR Spent Fuel & 5,339 & 22,330 & 15 \\
DHLW & 14,700 & 7,350 & 41 \\
WVHLW & 300 & 650 & 1 \\
Fuel Assembly Hardware & 6,702 & 0 & 18 \\
$\quad$ (FAH) (a) & $\mathbf{3 6 , 0 0 7}$ & 70,000 & 100 \\
Totals & & &
\end{tabular}

(a) Fuel assembly hardware consists of all nonfuel pin components of spent fuel assemblies, including end fittings, grids, etc.

5. Waste emplacement. High-level nuclear waste will be emplaced in an underground facility. This facility will be similar to a mine, but it will be specially designed and constructed for use as a repository. Two emplacement alternatives, the reference case vertical emplacement mode and the passive alternate case horizontal emplacement mode, were evaluated during the design process. This Conceptual Design Report ( $\mathrm{SCP}-\mathrm{CDR}$ ) presents the vertical emplacement design. Figure $\mathrm{S}-2$ illustrates a typical vertical emplacement of a disposal container.

6. Repository horizon. The underground facility at the repository will be located at a depth of approximately 2,500 ft in a salt stratum called the Lower San Andres Formation Unit 4 (LSA 4). Figure S-3 identifies the estimated stratigraphy at the repository site from the ground surface to the repository horizon. 


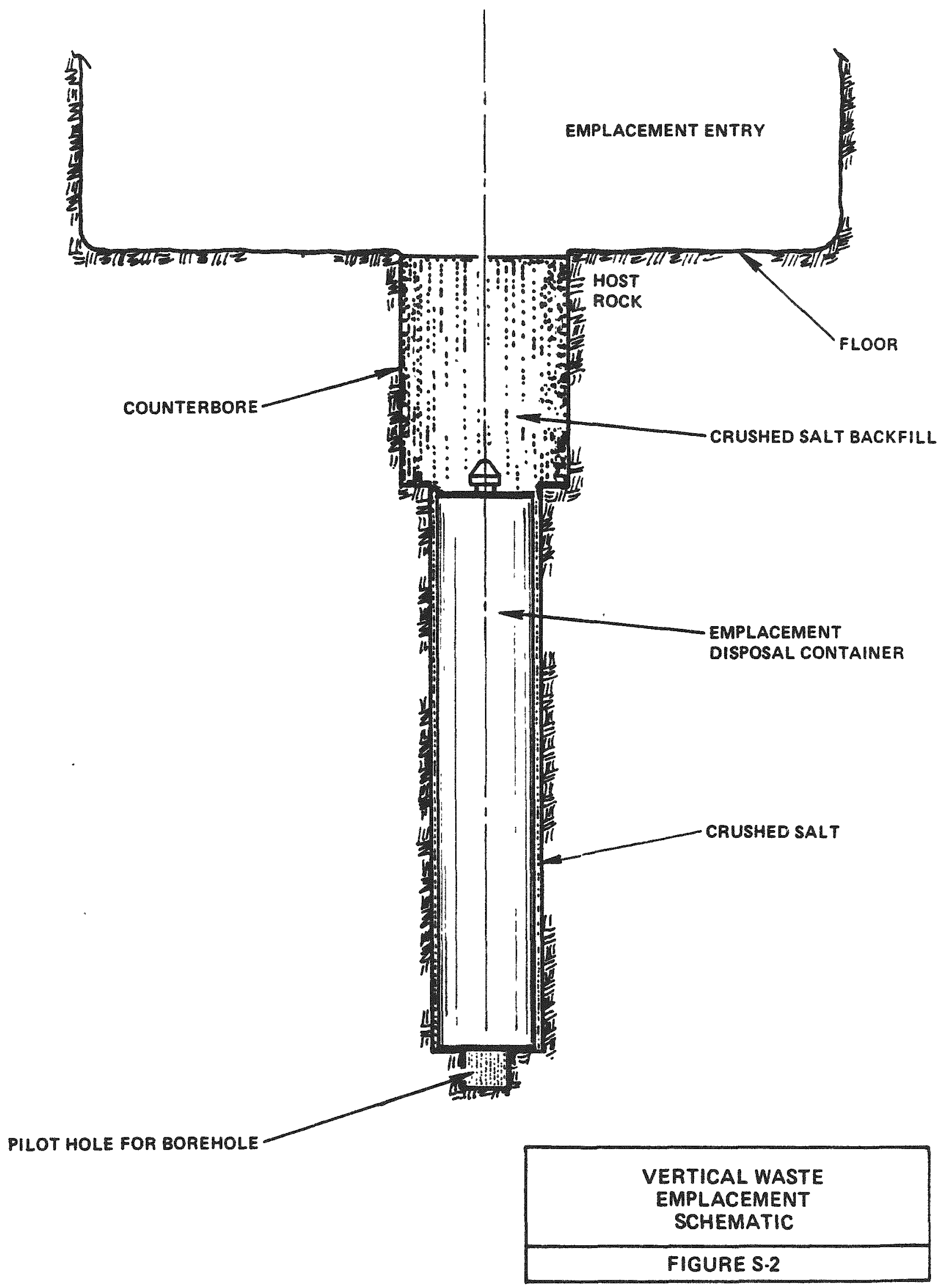




\begin{tabular}{|c|c|c|c|c|}
\hline $\begin{array}{l}\text { FORMATION } \\
\text { AND (THICKNESS) } \\
\end{array}$ & $\begin{array}{c}\text { DEPTH } \\
\text { (FI) }\end{array}$ & GRAPHIC & $\begin{array}{c}E L E V \\
(F, M S L)\end{array}$ & GENERAL DESLBIPTION \\
\hline & 4 & & 4030 & (Ground Surlace) \\
\hline $\begin{array}{l}\text { BLACKWATER ORAW } \\
\text { AND TOPSOIL } \\
\end{array}$ & 65 & $0-1$ & 3965 & $\begin{array}{l}\text { Loess (silt) and some sand, density increases } \\
\text { downward. Topsoil } 3 \text { It. thick. }\end{array}$ \\
\hline $\begin{array}{l}\text { OGALLALA } \\
\text { (272) } \\
\text { Static Water Level }\end{array}$ & 337 & $\frac{a}{4}$ & 3693 & $\begin{array}{l}\text { Mostly fine-to-coarse sand with silt, } \\
\text { minor clay lgenerally coarser w/depth; } \\
\text { cementation generally increases w/depth) } \\
\text { - fluvial deposition-channel and over bank } \\
\text { deposits-zero to } 10 \text { feet of hard caliche } \\
\text { denear the top. Gravel and sand unit may } \\
\text { occur at base. }\end{array}$ \\
\hline \multirow{3}{*}{$\begin{array}{l}\text { DOCKUM } \\
(621)\end{array}$} & \multirow[b]{3}{*}{958} & & \multirow[b]{3}{*}{3072} & $\begin{array}{l}\text { Upper part is mostly sitstone with lenses } \\
\text { of claystone and sandstone- pootly } \\
\text { consolidated. Identified engineering } \\
\text { properties categories are numbers } 1 \text { and } 2 .\end{array}$ \\
\hline & & & & $\begin{array}{l}\text { Middle part is mostly sandstone with some } \\
\text { siltstone and minar claystone - poorly } \\
\text { consoldated Identified engineering propertites } \\
\text { categaries are numbers } 1,2 \text { and } 3 \text {. }\end{array}$ \\
\hline & & & & $\begin{array}{l}\text { Lower part is mostly siltstone with some } \\
\text { sandsione and claystone; contained some } \\
\text { conglomerate in J. Friemel-poosly } \\
\text { consolidated. Identified engineering propertres } \\
\text { categories are numbers } 1,2,3 \text { and } 4 \text {. }\end{array}$ \\
\hline $\begin{array}{l}\text { DEWEY LAKE } \\
\text { (74) }\end{array}$ & 1032 & 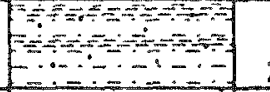 & 2998 & Interbedded siltstone and claystone. \\
\hline ALLBATES (32) & 1064 & $3 x^{3} x^{2} x^{2}+5 i=4$ & 2966 & $\begin{array}{l}\text { Dolomite with silstone ingerbed. Local anhydrite } \\
\text { and gyp sum may be associated with dolomite. }\end{array}$ \\
\hline SALADO (67) & 1131 & a & 2899 & Mostly sillstone interbedded anhydrite. \\
\hline YATES $(65)$ & 1196 & $=-1=$ & 2834 & Interbedded siltstone and claystone. \\
\hline $\begin{array}{l}\text { UPPER } \\
\text { SEVEN RIVERS } \\
\text { (129) }\end{array}$ & 1325 & 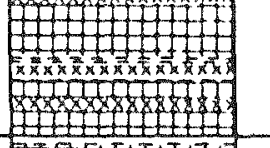 & 2705 & $\begin{array}{l}\text { Mostly salt, interbedded anhydrite and } \\
\text { claystone. }\end{array}$ \\
\hline $\begin{array}{l}\text { LOWER } \\
\text { SEVEN AIVERS } \\
\text { (194) }\end{array}$ & 1519 & 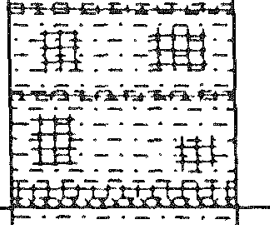 & 2591 & $\begin{array}{l}\text { Mostiy saity siltsione with interbeds of } \\
\text { siltstone, claystone, salt and anhydrite. }\end{array}$ \\
\hline $\begin{array}{l}\text { QUEENi } \\
\text { GRAYBURG } \\
(180)\end{array}$ & 1699 & $=$ & 2331 & $\begin{array}{l}\text { Interbedded silistone, sandstone and claystone. } \\
\text { Mostly sandstone in central portion. }\end{array}$ \\
\hline $\begin{array}{l}\text { UPPER } \\
\text { SAN ANDRES II } \\
\text { (306) }\end{array}$ & 2005 & 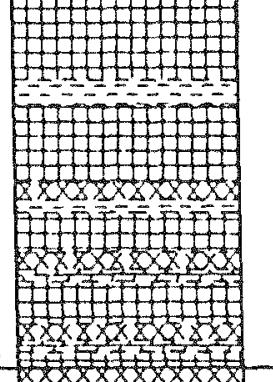 & 2025 & $\begin{array}{l}\text { Mostly sals with numerous thm ciay seams and } \\
\text { admixtures of silt and clay, interbedded with } \\
\text { anhydrite and dolomite; minor siltsione. } \\
\text { claystone and sandstone. }\end{array}$ \\
\hline $\begin{array}{l}\text { UPPER } \\
\text { SAN ANDRES I } \\
(168)\end{array}$ & 2173 & 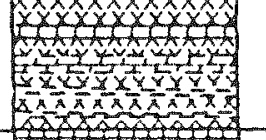 & 1357 & $\begin{array}{l}\text { Mosily anhydrite with } 10-15 \% \text { interbeds of } \\
\text { dolomite and occasional interbeds of shale. }\end{array}$ \\
\hline $\begin{array}{l}\text { LOWER } \\
\text { SAN ANDRES } \\
\text { UNIT } 5 \\
\text { (194) }\end{array}$ & 2285 & 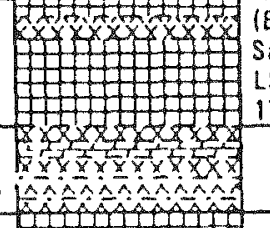 & $\begin{array}{l}\text { (8ase of } \\
\text { Salt in } \\
\text { LSA 5) } \\
1745 \\
1863 \\
\end{array}$ & $\begin{array}{l}\text { Upper part mosily salt, interbedded anhydrtite } \\
\text { and siltstone, salt contains clay seams and } \\
\text { admixtures of sith and clay. Lower part mosely } \\
\text { anhydrite, interbedded dolomite and } \\
\text { siltstone. }\end{array}$ \\
\hline $\begin{array}{l}\text { LOWER } \\
\text { SAN ANDRES } \\
\text { UNIT } 4 \\
\text { STEO: }\end{array}$ & (1) & 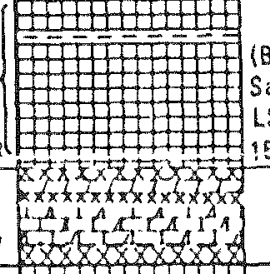 & $\begin{array}{l}(\text { Base of } \\
\text { Salt in } \\
\text { LSA } 4) \\
15 n ?-2\end{array}$ & $\begin{array}{l}\text { Upper part is salt contraning inudstone seamis, } \\
\text { minor claystone. Lower part mossly dolomite, } \\
\text { dolomitic limestone and anhydrite: mines } \\
\text { shale, salt and siltstone. }\end{array}$ \\
\hline $\begin{array}{l}\text { LOWER SAN } \\
\text { ANDRES UNIT } 3 \\
\text { (120) }\end{array}$ & & ए+ & 1293 & $\begin{array}{l}\text { Interbedded salt, salty mudstone, and salty } \\
\text { anhydrite with dolomite at the base. }\end{array}$ \\
\hline $\begin{array}{l}\text { LOWER SAN } \\
\text { ANDRES UNIT } 2 \\
\text { IIII }\end{array}$ & & 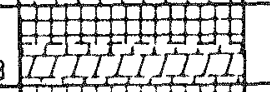 & 1222 & Salt and dolomite. \\
\hline GLORIETA & & 世井地形 & & Interbedded salt, salty mudstone, and siltstone. \\
\hline
\end{tabular}

LEGEND:

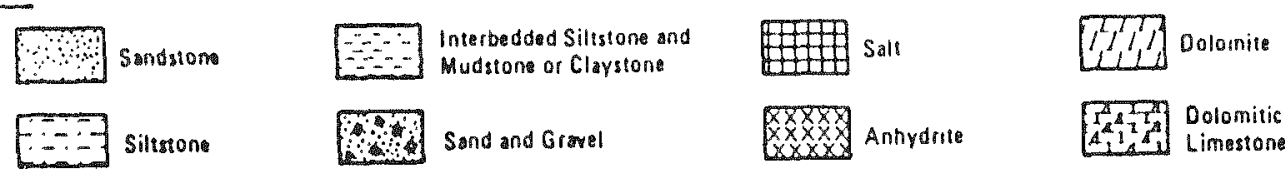

MSL = Mean Sea Lovat

$R O D=$ Rock Qualiey Designation

Engineering Propertiss Categorles

1. Mudstona/Siltztone (Unslabbed)

Sandstone/Conglomerate in water bearing unit

. Very, very soft mudstone 
$$
\text { . }
$$ 
7. Laws, regulations and DOE orders. The repository design must conform with applicable federal laws and regulations as implemented through DOE orders and repository program guidance documents. Of particular concern are federal regulations promulgated by the Nuclear Regulatory Commission and the Environmental Protection Agency. Repository guidance requires that the design comply with Texas state laws and regulations and local ordinances that are not inconsistent with federal law. This conceptual design meets the requirements of laws, regulations, and orders listed in Section 2.6, Regulatory Requirements, of this report.

\section{S.3 REPOSITORY DESCRIPTION}

Table $\mathrm{S}-2$ is a fact sheet which gives approximate values for design parameters.

\section{S.3.1 Waste Handling Operations}

The basic functions of the repository include the following:

1. Waste receipt. This will consist of receiving and inspecting shipping casks, unloading waste shipments from the casks, and related activities.

2. Temporary waste storage. Lag storage will be provided between the waste receipt and emplacement steps.

3. Fuel assembly consolidation. Most of the spent fuel assemblies (SFA) will be disassembled, and the rods will be consolidated prior to packaging.

4. Packaging. Spent fuel will be sealed inside steel canisters which will then be sealed inside thick-walled steel disposal containers. Fuel assembly hardware will be packaged in a similar manner. WVHLW and DHLW will be received in stainless steel canisters and then sealed inside thick-walled steel disposal containers. The packaging function will also include inspection and decontamination. 
Table S-2. Approximate values for major repository parameters(a)

(Page 1 of 3 )

Parameter

Approximate value

\section{SURFACE FACILITIES}

$\begin{array}{lc}\text { Surface area, MGDS(b) site } & 5,760 \text { acres }\left(9 \mathrm{mi}^{2}\right) \\ \text { Surface facility area } & 700 \text { acres }\left(1 \mathrm{mi}^{2}\right) \\ \text { Length of main roads, on site } & 9 \mathrm{mi} \\ \text { Length of secondary and patrol roads } & 6 \mathrm{mi} \\ \text { Length of railroad trackage, on site } & 9 \mathrm{mi} \\ \text { Length of access road, off site } & 1 \mathrm{mi} \text { (new) } \\ \text { Length of railroad corridor, off site } & 11 \mathrm{mi} \text { (improved) } \\ \text { Number of buildings } & 23 \mathrm{mi} \text { (new) } \\ \text { Number of Waste Handling Buildings } & \text { About } 60 \\ \text { Size of Waste Handling Buildings } & 2\end{array}$

SHAFT FACILITIES

Number of shafts

Finished inside diameters of shafts

Shaft functions

Shaft ventilation flow rates

Hoist types

Conveyance types

Hoist rope safety factors

Lining design

Lining materials

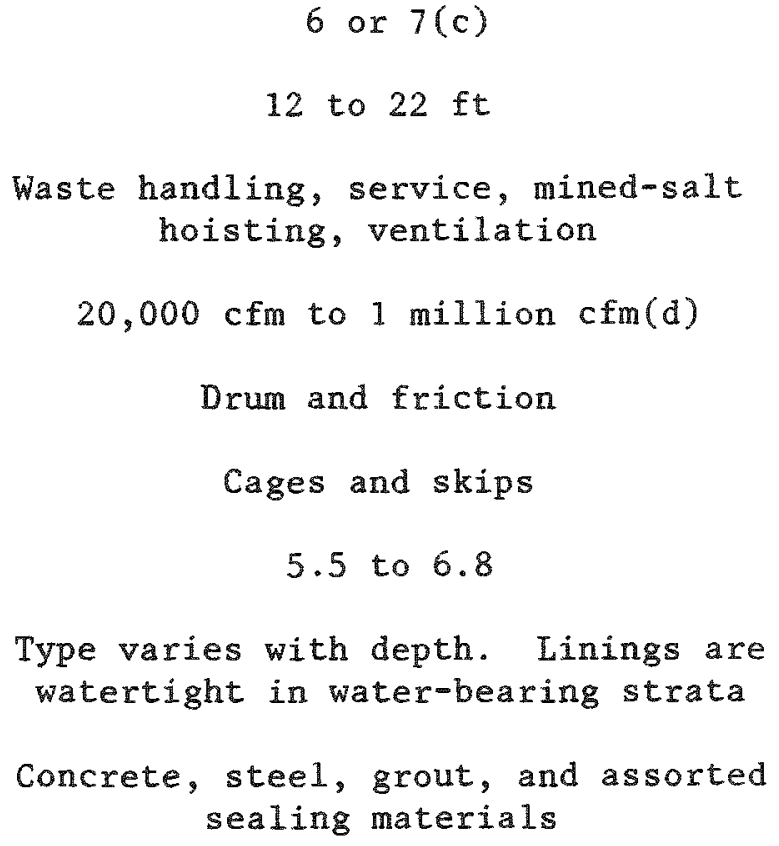


Table S-2. Approximate values for major repository parameters(a)

(Page 2 of 3 )

\begin{tabular}{|c|c|}
\hline Parameter & Approximate value \\
\hline \multicolumn{2}{|c|}{ SUBSURFACE FACILITIES } \\
\hline Depth below surface & $1 / 2 \mathrm{mi}(2,600 \mathrm{ft})$ \\
\hline Area & 4,000 acres $\left(6 \mathrm{mi}^{2}\right)$ \\
\hline Total length of mined opening & Over $200 \mathrm{mi}$ \\
\hline Ventilation systems & $\begin{array}{c}\text { One for mine development, and one for } \\
\text { waste emplacement }\end{array}$ \\
\hline Radius of shaft pillar area & $1,200 \mathrm{ft}$ \\
\hline Areal heat loading & $\begin{array}{c}\text { Up to } 40 \mathrm{~kW} / \text { acre in spent fuel areas } \\
\text { Up to } 18 \mathrm{~kW} / \text { acre in low-heat waste areas } \\
\text { Zero in other areas }\end{array}$ \\
\hline Number of emplacement panels & 9 \\
\hline Sizes of entries & 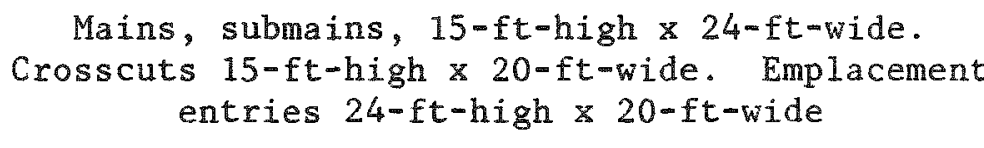 \\
\hline Emplacement entry spacing & $120 \mathrm{ft}$ or $170 \mathrm{ft}$ \\
\hline Location of emplacement holes & $\begin{array}{c}\text { Centerline of floor of waste emplacement } \\
\text { entries. }\end{array}$ \\
\hline Emplacement hole spacing & $9 \mathrm{ft}$ to $44 \mathrm{ft}$ \\
\hline Size of emplacement holes & $\begin{array}{l}\text { 18- to } 23-\mathrm{ft} \text { deep } \\
\text { 3- to 3.5- ft diameter borehole with } 5-\mathrm{ft}- \\
\text { diameter counterbore at top }\end{array}$ \\
\hline Backfill material & Crushed salt and salt bricks \\
\hline
\end{tabular}


Table S-2. Approximate values for major repository parameters(a)

$$
\text { (Page } 3 \text { of } 3 \text { ) }
$$

(a) This table includes approximate values for size, length, and other parameters that describe the Conceptual Design. Because these numbers are rounded off, the values in this table may not be identical to the values that appear in detailed portions of the SCP-CDR.

(b) MGDS - Mined Geologic Disposal System.

(c) The base design includes construction of six shafts: four repository shafts and two ESF shafts. It is assumed that these six shafts will be used for repository operations. If the two ESF shafts are not used for repository operations, then a seventh shaft will be constructed and used for repository operations.

(d) The waste shaft will have a downcast air movement of $20,000 \mathrm{cfm}$ for contamination control. It does not ventilate the underground. Airflows of up to a million $\mathrm{cfm}$ in individual shafts will be needed for ventilation of the subsurface.

If the ESs are used for ventilation, a similar volume would be split between the two shafts. 
5. Transportation to underground. Disposal containers will be transported to the underground area on a dedicated waste hoist in a dedicated waste shaft.

6. Underground transportation. Disposal containers will be transported from the bottom of the waste shaft to prepared boreholes in emplacement entries.

7. Waste emplacement. Disposal containers will be emplaced in boreholes, the annulus will be filled with packing material, and then the borehole will be plugged with shielding material. Once all boreholes in an entry are filled, the entry will be backfilled with crushed salt.

8. Preparation of shipping casks for return. Empty shipping casks will be inspected, cleaned if necessary, and prepared for return to nuclear waste generators.

\section{S.3.2 Surface Facilities}

Repository surface facilities will be located in the north-central section of the site. Between 10 and 15 percent of the site area will be required for surface facilities. Figure $\mathrm{S}-4$ illustrates the arrangement of these facilities. Most of the remaining surface of the nine-square-mile site will remain in its present condition.

Five general types of facilities will be at the surface:

1. Waste handling facilities - Buildings and facilities directly involved in the handling and packaging of nuclear waste. Spent fuel will be consolidated and packaged in the larger of the two Waste Handing Buildings (WHBs). The smaller WHB will handle and package unconsolidated spent fuel for the first five years, after which it will handle WVHW and DHLW.

2. Underground support facilities - Buildings and facilities required to support underground mine development and waste emplacement operations. 



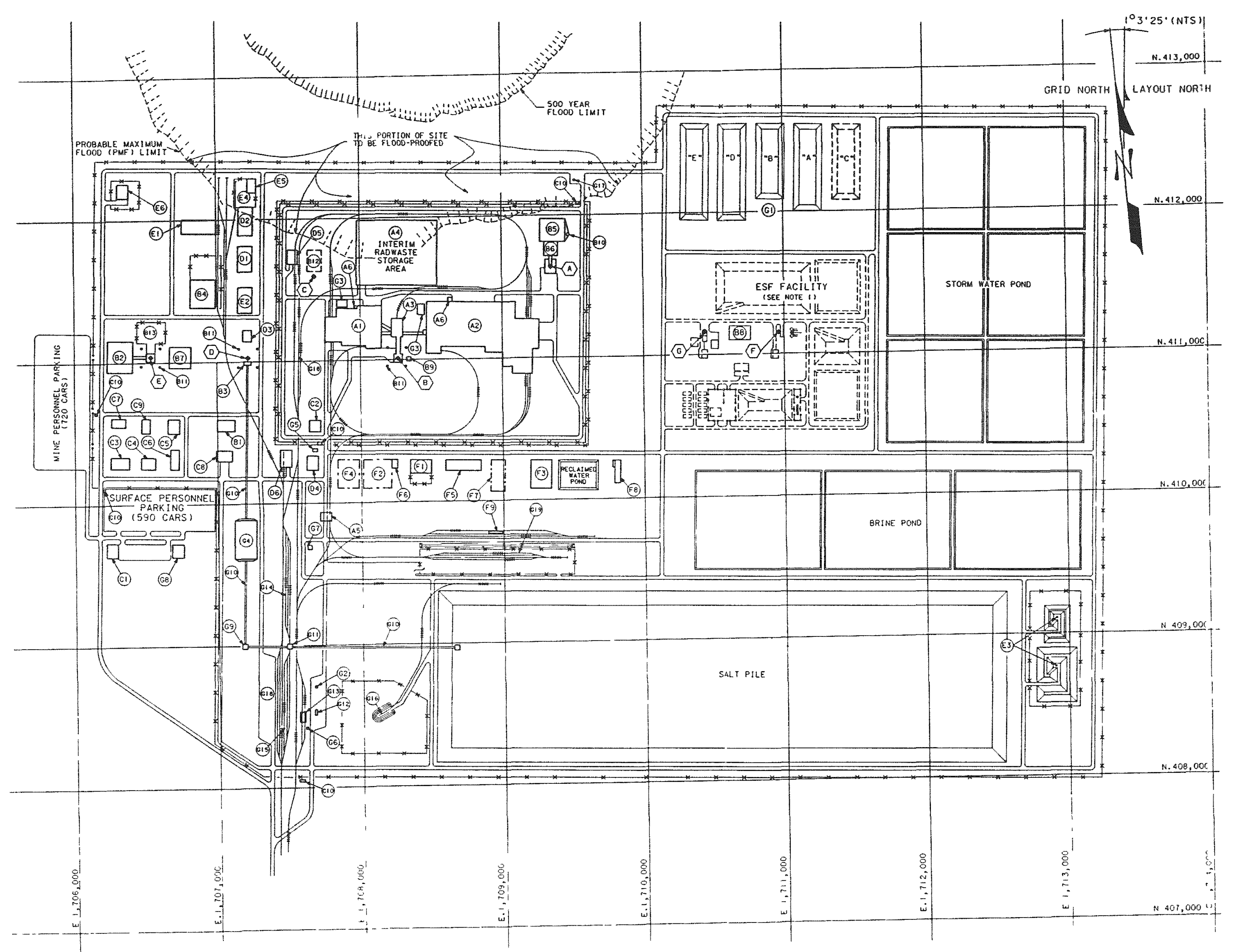

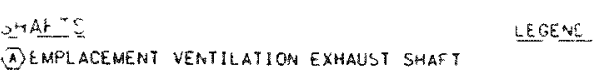
(ब) WASTE SHAET OMINED SALT I EXKALSST SHAFT

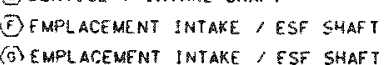

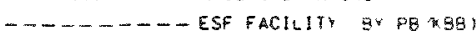

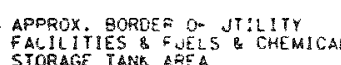

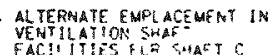

\section{and}

worts

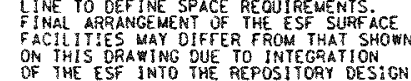

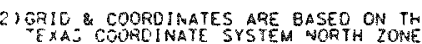

at waste HanoL LinG BuILOTOMG

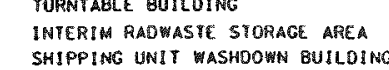

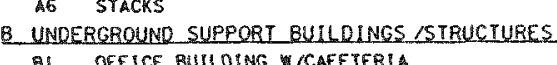

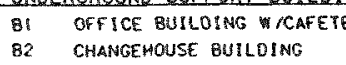

gs Salt ats

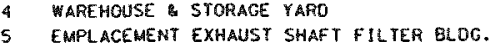

6 EmPlacement Exhaust Shaft fan bloc.

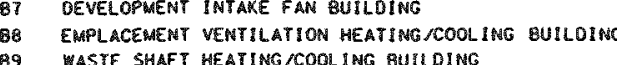

10 strack Shaf hearings

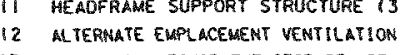

C2 CENTRAL SECURTSY BULIOHAG

ENGINEERING OFFICE BUILOING

G6 HELLTH PHYSICS LABORATORY

C8 FIRE STAT:ON

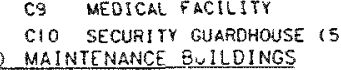

D2 FABRICATIOAR SHOP

03. WOBLLE EOUPHENT MAINTENANCE SHO

I5 CASK REPALA QUULLING

STORAGE/WAREHUUSE BUILOINGS

STOPAGE/MAREHYUSE BULL

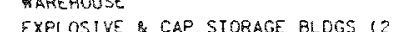

ET STORAGE MARO

E6 HAZZDOOUS MATERTALS STOPAGE BUTLUING

tinger

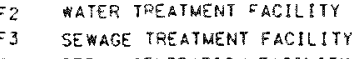

F5
FOMPRESSOR CHILLR BUILOING
FG UTHLITY CONTROL BULLOING

fr fuels \& chenical storabe tank area

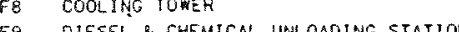

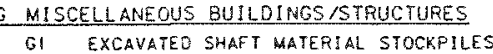

62 ScAlEHOUSE

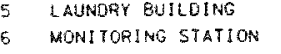

SALT CONEEVRR TRANSFER TOWEA

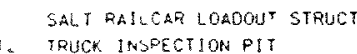

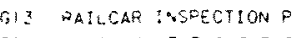

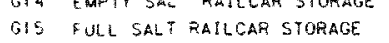

Git SHMPFING UNIT PACIF ECATION AREA

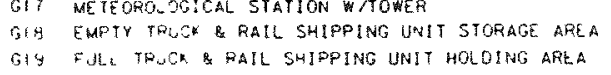

\begin{tabular}{|c|}
\hline $\begin{array}{c}\text { SURFACE FACILITY } \\
\text { ARRANGEMENT }\end{array}$ \\
\hline FIGURE S-4 \\
\hline
\end{tabular}


$$
\text { . }
$$ 
3. Onsite utility facilities - Buildings and facilities required to supply emergency utility services to the repository.

4. Administration, maintenance storage, and miscellaneous facilities Buildings and facilities required to maintain operations and support. the overall repository staff and operating personnel.

5. Ponds and storage areas - Areas required to handle and treat site runoff water and provide space for onsite storage of excavated material to be used as repository backfill. Excess salt will be transferred off the repository site.

\section{S.3.3 Shafts}

Repository shafts will provide the connecting links between all surface facilities and the underground. It is expected that six shafts will be constructed. Shafts $F$ and $G$ will be the original exploratory shafts, which are expected to be converted to supply ventilation for emplacement areas during repository operations. If shafts $F$ and $G$ are not used for repository ventilation, alternate Shaft $C$ (a seventh shaft) will be constructed to supply emplacement intake ventilation. Locations for these shafts are identified on Figures $S-4$ and S-5. Primaryo functions and sizes of the shafts are shown in Table S-3. Figure S-6 shows a section view of a shaft.

Important elements of shaft design will be two types of seals. Operational seals will keep groundwater from penetrating the shaft liners. This will keep water from entering the repository during construction and operation. Decommissioning seals will be installed to keep the repository dry after it is permanently closed.

\section{S.3.4 Underground}

The nuclear waste will be disposed of at a location approximately 2,500 ft below the surface in a geologically stable bedded salt deposit. The underground area and facilities that will be required are indicated in Figure $5-5$. 


Table S-3. Repository Shaft Functions and Sizes

\begin{tabular}{clc}
\hline Shaft & \multicolumn{1}{c}{ Function } & $\begin{array}{c}\text { Finished } \\
\text { Diameter, ft }\end{array}$ \\
\hline A & $\begin{array}{l}\text { Emplacement exhaust shaft - ventilation } \\
\text { exhaust for the underground emplacement areas }\end{array}$ & 18 \\
B & $\begin{array}{l}\text { Waste shaft - dedicated waste handling shaft } \\
\text { for transfer of waste between the surface and }\end{array}$ & 18 \\
underground & $\begin{array}{l}\text { Emplacement intake shaft - alternate emplacement } \\
\text { ventilation intake shaft will be constructed if } \\
\text { shafts F and G are not used for emplacement } \\
\text { ventilation }\end{array}$ & 18 \\
C & $\begin{array}{l}\text { Mined salt/exhaust shaft - ventilation } \\
\text { exhaust and salt transfer shaft for } \\
\text { underground development }\end{array}$ \\
Service/intake shaft - ventilation intake \\
and service shaft for underground development \\
E
\end{tabular}





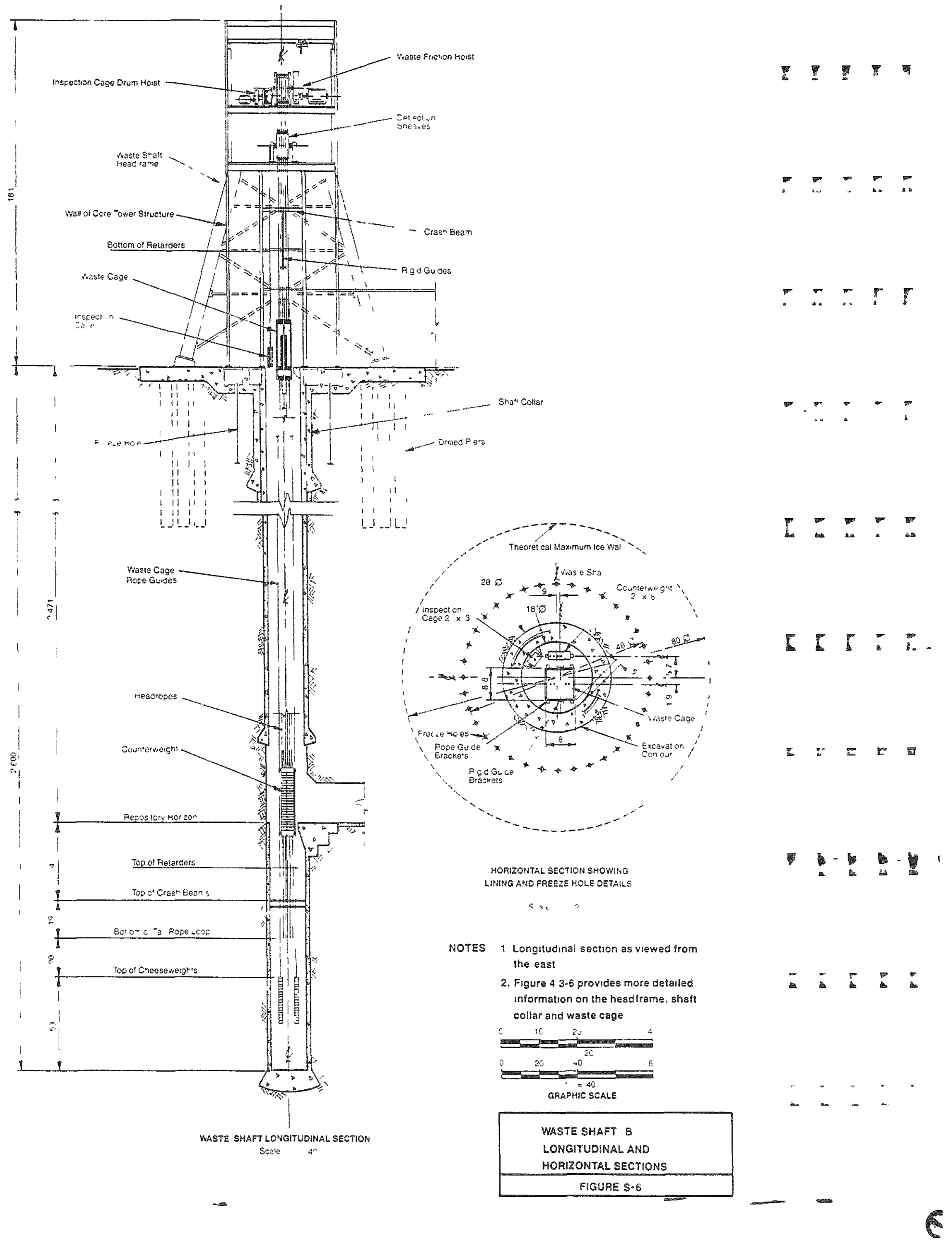



The areal extent of the underground facilities will be about 4,000 acres (about six square miles). These facilities will consist of the following:

1. Shaft pillar area - An area established around the shafts to protect them from ground subsidence caused by underground excavation. Shafts will be located approximately $1,200 \mathrm{ft}$ from the nearest waste emplacement area. Located in the shaft pillar are the ESF and a number of underground support facilities such as a mechanical shop.

2. Waste emplacement panels - Nine underground areas where the nuclear waste will be emplaced. Each panel will include over 70 entries (rooms) in which waste will be emplaced. The underground will include over $100 \mathrm{mi}$ of entries for emplacement of the 70,000 MTU of waste. These entries will be backfilled with salt as soon as possible after waste emplacement.

3. Development areas - Areas where future emplacement entries are being mined. Development operations will be conducted concurrently with emplacement operations; however, the two zones will be physically separated at all times and operated on separate ventilation systems.

4. Performance confirmation areas - Areas in the underground where intensive monitoring and testing of host rock and the emplaced nuclear waste packages will occur. During repository operation, the portions of the ESF at the working horizon will be used for some of the performance confirmation testing. Portions of the emplacement areas will also be dedicated to performance confirmation.

5. Other underground entries - Underground passageways for transportation and ventilation purposes.

\section{S.4 CLOSURE AND DECOMMTSSTONING}

After all waste has been emplaced and performance confirmation has been completed successfully, the DOE will close the repository. The decommissioning process will involve removing operating equipment, backfilling all open 
underground entries, constructing bulkhead seals at critical points in the underground, backfilling all shafts, and constructing bulkhead seals in all shafts. Figure S-7 depicts typical locations for repository decommissioning seals. Figure S-8 depicts typical decommissioning seals for shafts.

Surface facilities will be decontaminated and dismantled. The site condition will be returned as close as possible to its original state. Permanent surface markers will be erected to identify boundaries and notify future generations of the presence of the underground repository.

\section{S.5 PERFORMANCE OBJECTIVES}

A part of the conceptual design process included evaluating the design to assure conformance with regulatory requirements for limiting radioactive releases to the public and environment.

\section{S.5.1 Normal Operations}

Under normal operations repository facilities will monitor, control, and limit radioactive releases to the public. The design will include processes for containment, collection, and treatment of onsite generated liquid, solid, and gaseous radwaste. All onsite generated low-level radwaste will be treated and solidified in a grout matrix. It is expected that about 1.2 million cu $\mathrm{ft}$ of such radwaste will be processed during the $25 \mathrm{yr}$ operation of the repository. Solidified radwaste will be packaged in 55 gallon drums. It will be temporarily stored in a repository surface facility and then shipped offsite.

\section{S.5.2 Abnormal Operations}

Repository operations were analyzed to identify abnormal events that could lead to a release of radioactive material during the preclosure period. As a result of this analysis, a list of potential design basis accidents (DBAs) was prepared. Prevention and mitigation of these potential DBAs were considered in designing repository systems so that potential releases to the public and environment will be within prescribed limits. 


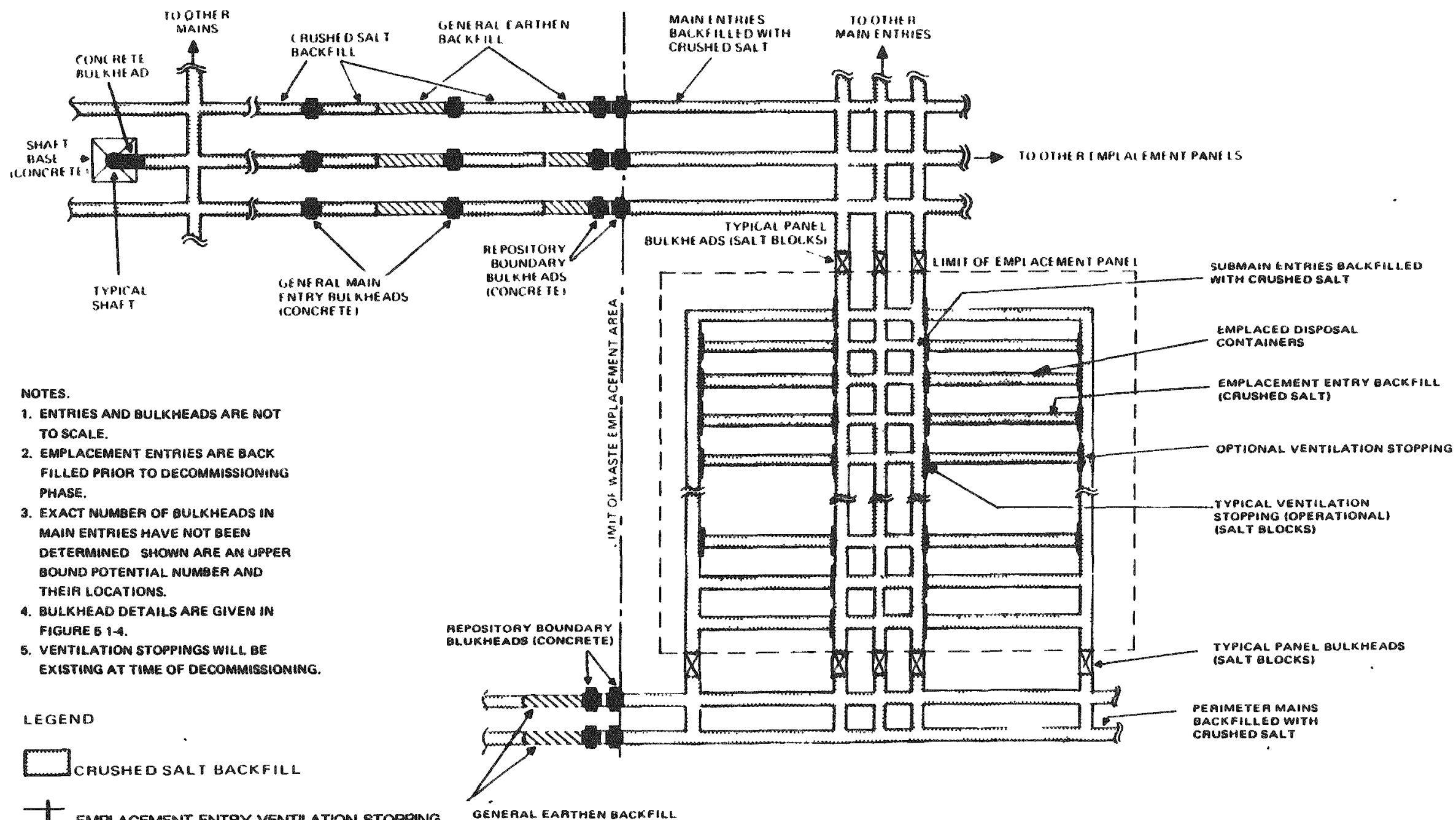

F emplacement entar ventulation stopping

SCHEMATIC OF BACKFILL AND

DECOMMISSIONING SEALS IN

I panel bulkheads

THE REPOSITORY HORIZON

FIGURE S-7 


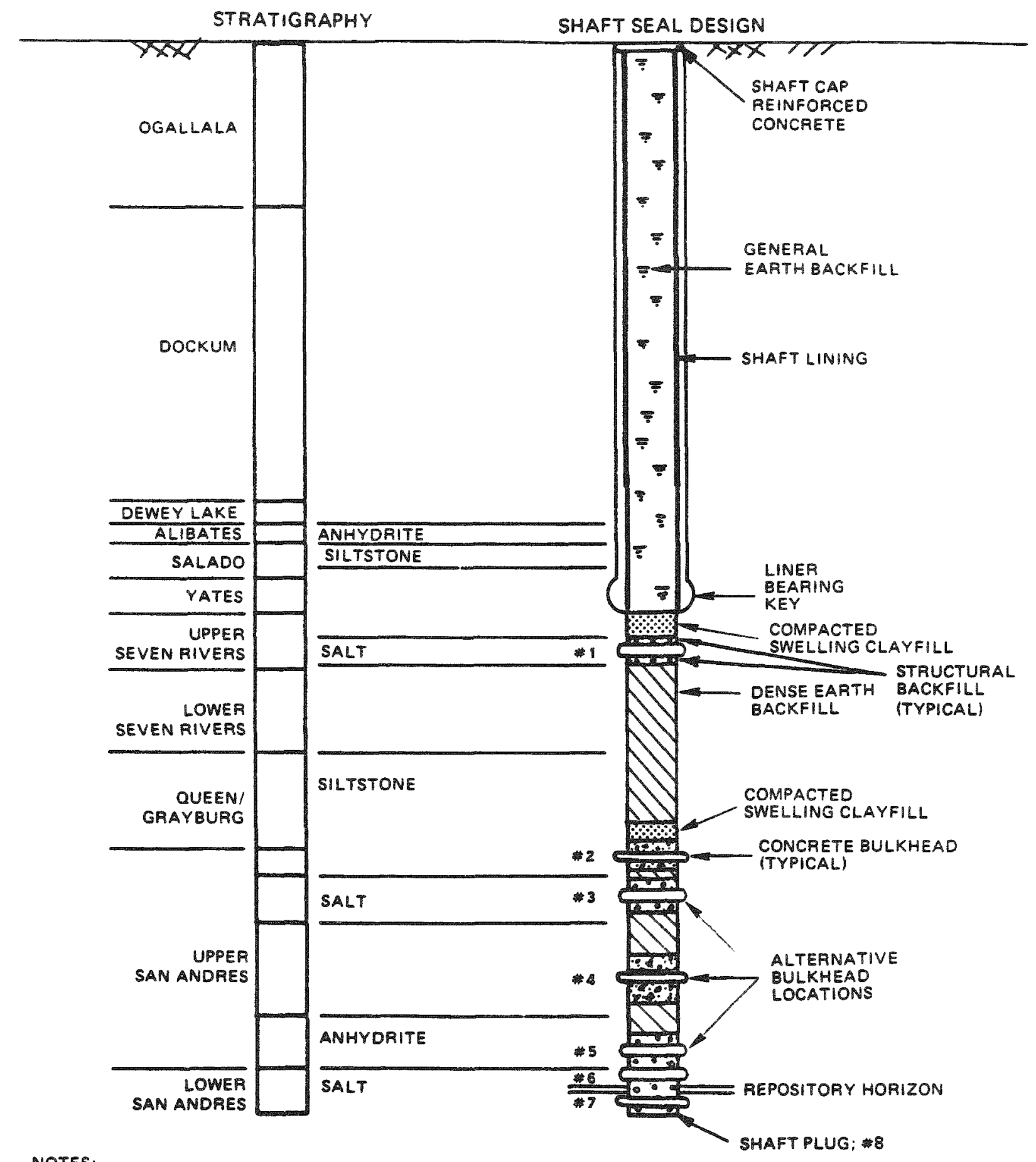

NOTES:

1. BULKHEAD LOCATIONS TO BE DETERMINED ACCORDING TO ACTUAL STRATIGRAPHY.

2. EXACT NUMBER AND LOCATIONS OF BULKHEADS HAVE NOT BEEN DETERMINED. SHOWN ARE AN UPPER BOUND POTENTIAL NUMBER AND THEIR LOCATION.

3 INER AND BULKHEADS ARE NOT TO SCALE.

4 LINER SECTIONS IN SALT STRATA MAY BE REMOVED UPON DECOMMISSIONING.

SCHEMATIC OF SHAFT DECOMMISSIONING SEALS

FIGURE S-8 


\section{S.5.3 Retrieval}

The Nuclear Waste Policy Act of 1982 (NWPA) specifies that the design of the repository shall not preclude retrieval of the waste in order to protect the health and safety of the public, protect the environment, or recover the resources contained in the spent fuel. Therefore, the current design includes the capability to retrieve waste. If retrieval were required, it is probable that all emplacement operations would be halted. The design would permit repository facilities to be modified if necessary to allow retrieval of all or part of the waste which had previously been emplaced. The basic steps in the waste retrieval process would be as follows:

1. Re-excavate backfilled emplacement entries.

2. Locate and re-excavate nuclear waste containers.

3. Retrieve and transport the waste to the surface facilities.

4. Process and handle the waste to make it ready for re-emplacement or shipment offsite.

5. Re-emplace the waste or ship it offsite.

Pursuant to provisions of the NWPA, the design will accommodate exercising the retrieval option for a period of 50 yrs from the start of emplacement.

\section{S.5.4 Performance Confirmation}

A performance confirmation program will determine if the repository is performing as designed. Dedicated areas of the underground will be established for storage and for monitoring waste packages. The purpose of these performance confirmation areas will be to gather information concerning the performance of the rock mass and waste packages. A formalized testing program will be established to confirm performance consistent with repository design and regulatory requirements. As part of this program, waste packages will be periodically removed from the performance confirmation area and transported to 
the surface facilities or offsite for examination. Performance of the repository will also be monitored in the underground emplacement areas. Geologic monitoring will take place from the ESF stage until closure. Equipment and facilities to accomplish these activities have been included in the repository design.

\section{S.6 DESIGN ANALYSIS}

The repository design presented in the $S C P-C D R$ is the end result of a series of evaluations and analyses performed since October, 1983. Primary areas of analysis have involved the following:

1. Preclosure design analyses, including surface, shafts, and underground.

2. Postclosure design allysis.

3. Engineering analysis of the design.

4. Structures, systems, and components important to safety, and engineered and natural barriers important to waste isolation.

All analyses were based on current levels of knowledge and design concepts .

\section{S.7 DESIGN ISSUES AND DATA NEEDS}

As a result of the SCP-CDR effort, issues have been identified for further evaluation. Data needs have been defined for advanced design phases. This information will be useful in planning the Advanced Conceptual Design, License Application Design, and Final Procurement and Construction Design. It will also aid the Salt Repository Project (SRP) in developing test plans for site characterization activities. 


\section{INTRODUCTION}

This Conceptual Design Report (CDR) describes the Site Characterization Plan (SCP) conceptual design of a repository in salt for the permanent disposal of high-level nuclear waste at a proposed site in Deaf Smith County, Texas. This chapter presents the following information:

1. Background information, past design efforts, and a brief description of these design efforts.

2. An explanation of the U.S. Department of Energy's (DOE) decision to divide the design of the repository into phases.

3. General information relevant to the SCP conceptual design, which is the subject of this report, including:

a. Scope for the SCP conceptual design.

b. Summary of the regulatory standards with which the CDR complies.

c. Organization of the CDR.

d. Intended use of the CDR.

4. An explanation of the phased concept for repository construction and operation. 


\subsection{BACKGROUND INEORMATION}

This CDR has been prepared by the Architect/Engineer (A/E Contractor) for design of the salt repository. The $A / E$ Contractor consists of Fluor Technology, Inc., which acts as Project Manager, and four subcontractors: Morrison-Knudsen Engineers, Inc., Science Applications International Corporation, Woodward-Clyde Consultants, and Engineered Systems Development Corporation. This team is referred to in this report as the $A / E$ Contractor. The $A / E$ Contractor's work is overseen by the SRPO.

The material in this CDR primarily reflects the results of a conceptual design effort conducted during calendar year 1985 . The CDR also reflects some additional design changes made up to August, 1986. This design effort drew heavily from prior studies and designs performed by the A/E Contractor and other entities prior to 1985 . Of particular significance are the following:

1. The designs for the Exploratory Shaft Facility (ESF) were developed by Parsons Brinkerhoff/PB-KBB, the ESF Design Contractor. Parsons Brinkerhoff/PB-KBB is a contractor to DOE's Salt Repository Project Office. The ESF Title I design layout was used. The layout will change on the basis of the completed ESF Title II Design.

2. The design concepts for waste packages were derived from designs developed by Westinghouse Electric Corporation, a subcontractor to Battelle Project Management Division's Office of Nuclear Waste Isolation (ONWI). ONWI is a contractor to the SRPO. The Westinghouse waste package designs have been further modified by ONWI.

3. The designs for postclosure seals were developed by IT/D'Appolonia, an ONWI subcontractor. Their effort was referred to as a schematic design.

4. The design for a fuel rod consolidation machine was developed as part of the design for a Monitored Retrievable Storage (MRS) facility. That design effort was conducted by a DOE contractor team led by Ralph M. Parsons Company. 
5. Prior to embarking on an integrated conceptual design effort in 1985 , the $\mathrm{A} / \mathrm{E}$ Contractor spent approximately two years working on a large number of topical studies. These studies involved evaluations of the two-phase construction concept, integration of the ESF and repository designs, selection of waste handling methods, and other subjects. Each study aimed at developing the technical basis for a particular element of repository design. The conceptual design described in this CDR is based in part on the knowledge accumulated during the course of these studies.

6. The $\mathrm{A} / \mathrm{E}$ Contractor made some use of the results of design work carried out by engineering firms who worked on repository design in earlier years. The design work conducted prior to 1983 by Stearns-Catalytic, Kaiser, and Bechtel provided useful information for the $A / E$ Contractor.

7. The A/E Contractor also made some use of the results of research work conducted by the Office of Waste Isolation (e.g., OWI, 1978) and Project Salt Vault (Bradshaw and McClain, 1971). 


\subsection{DOE'S PHASED APPROACH TO REPOSITORY DESIGN}

Salt is one of the three rock types under consideration by DoE for the first repository. At the Deaf Smith County site, the waste emplacement area of the repository will be located in bedded salt deposits approximately $2,500 \mathrm{ft}$ below the surface. This CDR describes most of the major elements that would be included in a salt repository. From this stage, the design process will move forward to increasingly detailed levels. Because the nature of the design process is evolutionary, the design of some items shown in the CDR is expected to change before they are built.

A typical conceptual design effort is intended to examine alternatives and determine which ones appear to be the most suitable. However, the conceptual design described in this CDR was developed with a slightly different purpose in mind. Specifically, the design was developed to be responsive to an annotated outline which was intended to yield comparable repository designs in the salt, tuff, and basalt media. In addition, the purpose of the CDR design effort was to develop a workable design approach. One of the goals was to identify design issues and data needs to be resolved prior to filing a license application. Site characterization planning and technology development planning will be based, in part, on the need for design information.

In the future, the design effort will exhibit two principal characteristics: the design alternatives will be sorted, and the design will become increasingly detailed. Future design phases are expected to include the following:

1. Advanced Conceptual Design - (ACD) A phase during which design alternatives are evaluated and preferred alternatives are selected.

2. License Application Design - (LAD) A design phase during which license application materials will be prepared and critical design issues resolved. The License Application Design (LAD) phase will start the detailed design process by beginning the development of detailed construction drawings and specifications. During this phase, the emphasis will be on those aspects of repository design required for inclusion in the license application and its supporting 
documents (i.e., the Environmental Impact Statement (EIS), Safety Analysis Report (SAR), and Site Selection Report). Design details will be developed to the point where minimum changes in the design of licensed facilities, systems, structures, components, or engineered barriers are likely to occur during the following design phases.

3. Final Procurement and Construction Package Design - A design phase which completes the detailed design process initiated during license application design. For structures, systems, and components important to safety and engineered barriers important to waste isolation, the detailed design activity that was initiated during LAD will be carried to completion. For repository facilities which are not important to safety or waste isolation, the detailed design process will be initiated and carried to conclusion.

4. Construction Support - A design phase during which the A/E Contractor will provide construction support by engineering of design changes when they are needed (Title III design). 


\subsection{GENERAL INFORMATION RELEVANT TO THE SCP CONCEPTUAL DESTGN}

This section describes the scope of the CDR, its organization, and its intended uses. The design reflected in the CDR will comply with all applicable federal regulatory standards. These are described in more detail in Section 2.6 of this CDR.

The CDR is organized in nine chapters:

1. The first two chapters include an introduction and basis for the design.

2. Chapters 3 and 4 describe the function and design of the repository. Because the primary purpose of the CDR is to describe the conceptual design of the repository, Chapters 3 and 4 are considered the most important parts of the report.

3. Chapter 5 describes the plans for closing the repository after operation is completed.

4. Chapter 6 addresses how the repository will satisfy performance objectives. These are requirements included in federal regulations.

5. Chapter 7 explains, in summary fashion, the analytical bases for the important elements of the design. More detailed and complete design analyses will be conducted in future design phases. The CDR is not intended to present a detailed discussion of the design analyses that underlie all elements of the conceptual design.

6. Chapter 8 of the CDR discusses information needed for future design efforts and the plans for development of this information.

7. Chapter 9 explains the quality assurance program which was adhered to during development of the conceptual design. 
This CDR is intended to satisfy several needs:

1. It is intended to respond to the Staff Technical Position on Design Information Requirements for the Site Characterization Plan (SCP), a document published in draft form by the U.S. Nuclear Regulatory Commission (NRC) in early 1985, and published in final form in December 1985 (NRC, 1985). It was published by the NRC to articulate the sort of design information which would be of interest during their review of the SCP. The SCP must be published by DOE prior to sinking the ESF at a salt site, and $\mathrm{NRC}$ is required by law to review DOE's plan for site characterization.

2. The CDR is intended to provide a basis of information for Chapter 6 of the SCP. Chapter 6 of the SCP is a description of the conceptual design of the salt repository. DOE is required by law and regulations to include a conceptual design description in the SCP. The $A / E$ Contractor is responsible for preparation of Chapter 6 of the SCP.

3. This CDR has also been written to provide a description of the conceptual design to persons in the technical community. The CDR has been prepared for a target reader who is assumed to be technically trained but not necessarily an expert on any subject discussed in the report.

4. The CDR is not intended to be an exhaustive, detailed reference work. When DOE made the decision to prepare and publish a CDR, two ground rules were established. First, the CDR was to be written pursuant to a baselined annotated outline developed by engineering personnel representing the Salt, Tuff and Basalt Repository Programs. This was done to ensure that a common approach among all projects would be followed to permit CDR's to be evaluated on a consistent basis. The outline was modified slightly in an effort to make it specific to the salt repository. The second ground rule was that strict limits were 
placed on the number of pages of text. It was determined that a document which includes no more than 450 pages of single spaced text should be adequate to satisfy the three purposes listed above. It was assumed that the reader who requires more information could refer to other sources.

5. The CDR primarily reflects the design efforts of chemical, nuclear, structural, environmental, mechanical, and mining engineers. The design process has not evolved far enough to allow significant participation by design experts in fields such as electrical, instrumentation, and fire protection engineering; however, future design phases will include significant contributions in these areas. 


\subsection{TWO-PHASE CONCEPT FOR REPOSITORY CONSTRUCTION AND OPERATION}

The Nuclear Waste Policy Act (NWPA) requires DOE to begin receiving spent fuel from electric utilities no later than January, 1998. In 1984, DoE became concerned that a delay in the schedule for repository site selection, licensing, or construction might make it impossible to have a full-sized repository operating by January, 1998. DOE developed a contingency plan to ensure that the 1998 deadline is achieved. This plan consists of building the repository in two phases with construction of both phases beginning around 1993 Phase I construction will end in 1998, while Phase II construction will end two or three years later. Included in Phase I will be the construction of a small waste handling building (WHB 1) which will handle 400 metric tons of equivalent uranium (MTU) per year of spent fuel during its first five years of operation. This waste will be in the form of unconsolidated spent fuel rods. Later, WHB 1 will handle defense high-level waste (DHLW) and West Valley high-level waste (WHLW). WHB 1 will be a simple facility which will not carry out complex operations such as consolidation of spent fuel rods. Phase II will include construction of a larger, more complex waste handling building (WHB 2). This building will handle 3,000 MTU per year of spent fuel. It will carry out complex operations such as fuel rod consolidation. DOE's two-phase concept allowed construction of this large building to be removed as a constraint to achieving the 1998 waste receipt schedule. 



\section{BASIS EOR SCP SALT REPOSITORY CONCEPTUAL DESTGN}

This chapter presents design assumptions and referenceable data values used by the Architect Engineer (A/E Contractor) as the design bases for the Site Characterization Plan (SCP) conceptual design. The design bases include: (1) technical design data and assumptions; (2) site constraints, assumptions, and data; and (3) reference geologic and geotechnical data. Regulatory requirements that will be imposed on repository design and construction are identified as part of these tasks.

\subsection{WASTE PACKAGE}

Waste type and package data have been compiled as a basis for the SCP conceptual design. The primary reference sources for these data are:

1. Waste Types. U.S. Department of Energy (DOE) Generic Requirements for a Mined Geologic Disposal System (GRMGDS, DOE, 1985a)

2. Waste Packages. Based on reference concepts prepared for the Office of Nuclear Waste Isolation (ONWI) (Westinghouse Electric Corporation, 1986). However, certain modifications were made in applying these base concepts to this repository design.

\subsubsection{Waste Types}

Appendix B.1 of the GRMGDS (DOE, 1985a) is explicit on the types of wastes to be disposed of in the salt repository. It identifies the following wastes types:

1. Spent fuel from commercial light water nuclear reactors. Both intact spent fuel and consolidated spent fuel forms will be prepared for disposal. Spent fuel received at the repository will be of the pressurized-water reactor (PWR) and boiling-water reactor (BWR) types.

2. Defense high-level waste (DHLW). Existing and future defense related high-level waste (HLW) will be received at the repository. These reprocessing wastes will be solidified and canistered at the Defense 
Waste Processing Facility (DWPF). See Section 2.1.2 for canister descriptions and source reference.

3. Existing commercial high-level waste (CHLW). It is assumed that only the existing waste from the West Valley Demonstration Facility in New York State will be accepted at the repository. It is also assumed that this waste will be in the same form as defense wastes produced at the DWPF and that it will be similarly packaged. In this design report, this waste is referred to as West Valley high-level waste (WVHLW).

The SCP conceptual design is based on the receipt of these three waste types. Handling requirements at the repository will be determined by the characteristics of these waste types (e.g., radiation levels, thermal output, physical dimensions) and by the form in which they are received (e.g., intact spent fuel assemblies, consolidated rods). The characteristics of the design basis waste types as received are given in Table 2.1-1. These characteristics, including those of the DHLW, have been compiled from ONWI-517 (Westinghouse Electric Corporation, 1986) and from the Repository Subsystem Design Requirements (RSDR). See Appendix A.

In addition to the waste types received for disposal, fuel assembly hardware (FAH) waste will be generated at the repository as a result of disassembly and rod consolidation. This waste is wasidered to be part of the spent fuel and will therefore be disposed of in the repository. Specific characteristics of FAH are not well defined at this time. The characteristics of EAH will be defined during advanced conceptual design (ACD).

\section{1 .2 Waste Container Data}

Waste received at the repository will be prepared for disposal prior to being transferred to the underground. This preparation will include operations on the waste itself (e.g., spent fuel consolidation) and the sealing of the 
Table 2.1-1. Waste Type Characteristics as Received

\begin{tabular}{llll}
\hline Waste Type & PWR & BWR & DHLW/WVHLW \\
\hline
\end{tabular}

SPENT FUEL

Spent Fuel Assembly (SFA)

$\begin{array}{lcc}\text { Form } & \begin{array}{c}\text { Intact } \\ \text { Assemblies }\end{array} & \begin{array}{c}\text { Intact } \\ \text { Assemblies }\end{array} \\ \text { Weight, tons } & 0.76 & 0.34 \\ \text { Uranium content, MTU } & 0.46 & 0.18 \\ \text { Radiation levels, mrem/hr } & \text { (a) } & \text { (a) } \\ \text { Heat load, watts (b) } & 550 & 180\end{array}$

Reactor Consolidated Spent

Fuel (RCSE)

Form

Assemblies per Box

Weight, tons

Uranium content, MTU

Radiation levels, mrem/hr

Heat load, watts (b)

$\begin{array}{cc}\text { Boxed Rods } & \text { Boxed Rods } \\ 2 & 2 \\ 1.44 & 0.62 \\ 0.92 & 0.36 \\ \text { N/A(e) } & \text { N/A } \\ 1,100 & 360\end{array}$

DHLW

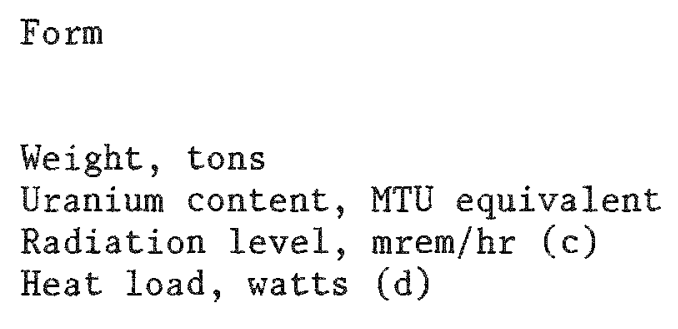
Borosilicate glass in canister
2.1
0.5
$2.6 \times 10^{7}$
423

WVHLW

Form
Borosilicate glass in canister
$\mathrm{N} / \mathrm{A}$
2.17
$\leqq 2.6 \times 10^{7}$
225

Weight, tons

Uranium content, MTU equivalent

Radiation level, mrem/hr (c)

Heat load, watts (d)

Source: Appendix A and Westinghouse Electric Corporation, 1986
(a) Data given for packaged fuel assemblies, see Table 2.1-2.
(b) Based on 10-year decayed spent fuel.
(c) At surface of canister.
(d) Maximum thermal power at receipt.
(e) N/A: not avaialble 
waste in containers. The containers will be thick-walled steel vessels designed to provide long-term containment ( 300 years to 1,000 years) of the waste as required by 10CFR60. The intent of the regulations is to demonstrate that by meeting the waste package containment requirement, a sufficient contribution to the 10,000 year isolation requirement has been made. The containers will be designed to withstand lithostatic pressures expected at the repository depth so that these pressures are unlikely to deform and breach them. They will also be designed to include an allowance for corrosion.

Upon arrival at the repository, spent fuel will first be placed in thinwalled canisters to facilitate handling and waste retrieval. The canisters will then be inserted into containers in preparation for final disposal. DHLW and WVHLW, in the form of borosilicate glass, will be received in canisters. These canisters will then be inserted into containers. The containers and the material sealed in them will make up the disposal containers. The operations required to assemble disposal containers at the repository are described in detail in Section 3.1. When the disposal containers are emplaced in the repository, they are termed waste packages. For purposes of this report, a waste package is the waste form enclosed by the canister which is in turn enclosed by the disposal container and emplaced in the repository with any surrounding absorbent or other packing material.

The configurations of the waste containers handled at the repository will depend on the types of waste and the phase of repository operations. During Phase I, only spent fuel assemblies (SFAs) and reactor consolidated spent fuel (RCSF) boxes will be received. These assemblies and boxes will be packaged intact. The intact spent fuel container design will be used for PWR and BWR assemblies, and RCSF boxes. The intact spent fuel container used in Phase $I$ is described in Table 2.1-2, and a schematic is presented in Figure 2.1-1. This design is adapted from ONWI-517 (Westinghouse Electric Corporation, 1986).

Since intact BWR spent fuel containers will be only a small fraction of the total waste containers to be emplaced in Phase I, the length of the intact spent fuel container is designed to accommodate PWR spent fuel which is the shorter of the two fuel types. The intact spent fuel canisters will therefore 
Table 2.1-2. Waste Container Specifications

\begin{tabular}{|c|c|c|c|c|}
\hline & $\begin{array}{c}\mathrm{CO}-1 \\
\text { Intact Spent Fuel } \\
\text { Container }\end{array}$ & $\begin{array}{l}\qquad \mathrm{co-2} \\
\text { Consolidated } \\
\text { PWR Container }\end{array}$ & $\begin{array}{l}\text { CO-3 } \\
\text { Consoljdated } \\
\text { BWR Container }\end{array}$ & $\begin{array}{c}\text { CO-4 } \\
\text { DHLW/WVIILW } \\
\text { Container }\end{array}$ \\
\hline PHASE & I, II & II & II & II \\
\hline \multicolumn{5}{|l|}{ WASTE FORMS CONTAINED } \\
\hline $\begin{array}{l}\text { Units per Container//Heat } \\
\text { Load per Container (a) }\end{array}$ & $\begin{array}{c}4 \text { PWR SFA//2.2 kW } \\
\text { or } 9 \text { BWR SFA//1.62 } \mathrm{kW} \\
\text { or } 4 \text { PWR RCSF boxes (c)//4.4 kW } \\
\text { or } 9 \text { BWR RCSF boxes (c)//3.24 kW }\end{array}$ & $\begin{array}{l}\text { 12 PWR } / / 6.6 \mathrm{~kW} \\
\text { or FAH }(\mathrm{b}) / / \mathrm{L} 0\end{array}$ & $30 \mathrm{BWR} / / 5.4 \mathrm{~kW}$ & $\begin{array}{l}1 \text { DHLW Canister } / / 0.423 \mathrm{~kW} \\
\text { or } 1 \text { WVHLW Canister } / / 0.225 \mathrm{~kW}\end{array}$ \\
\hline \multicolumn{5}{|l|}{ WASTE CANISTER DATA } \\
\hline $\begin{array}{l}\text { Canister Material } \\
\text { Canister Outside Diameter, in } \\
\text { Canister Length, ft (d) } \\
\text { Maximun Gross Weight, tons }\end{array}$ & $\begin{array}{c}\text { Carbon Stee1 } \\
26.5 \\
13.9 \\
6.6\end{array}$ & $\begin{array}{c}\text { Carbon Steel } \\
24.4 \\
13.1 \\
9.3\end{array}$ & $\begin{array}{c}\text { Carbon Steel } \\
24.4 \\
14.3 \\
9.7\end{array}$ & $\begin{array}{c}\text { Stainless Steel } \\
24 \\
9.8 \\
2.1\end{array}$ \\
\hline Surface Radiation Level, mrem/hr & $<3.0 \times 10^{7}$ & $3.0 \times 10^{7}(\mathrm{PWR})$ & $<3.0 \times 10^{7}$ & $2.6 \times 10^{7}$ \\
\hline \multicolumn{5}{|l|}{ DISPOSAL CONTAINER DATA } \\
\hline $\begin{array}{l}\text { Container Material } \\
\text { Container Outside Diameter, in } \\
\text { Container Length, ft (d) } \\
\text { Wall Thickness, in } \\
\text { Head Thickness, in } \\
\text { Maximum Gross Weight, tons }\end{array}$ & $\begin{array}{c}\text { Carbon Steel } \\
37.3 \\
15.9 \\
5.0 \\
7.8 \\
21.5\end{array}$ & $\begin{array}{c}\text { Carbon Steel } \\
34.8 \\
14.8 \\
4.7 \\
7.2 \\
21.8\end{array}$ & $\begin{array}{c}\text { Carbon Stee1 } \\
34.8 \\
15.9 \\
4.7 \\
7.2 \\
23.0\end{array}$ & $\begin{array}{c}\text { Carbon Steel } \\
33.4 \\
11.1 \\
4.2 \\
6.6 \\
10.1\end{array}$ \\
\hline Surface Radiation Leve1, mrem/hr & $<1.9 \times 10^{5}$ & $1.9 \times 10^{5}$ (PWR) & $<1.9 \times 10^{5}$ & $3.3 \times 10^{5}$ \\
\hline
\end{tabular}

Note: These designs were adapted from Westinghouse Electric Corporation (1986).

(a) Corresponds to spent fuel 10 years after reactor discharge.

(b) FAH capacity is 18 PWR or 45 BWR assembly equivalent per container. Also, container capacity for end fittings only (not all fuel assembly hardware) will be 90 BWR assembly equivalent.

(c) RCSF box contains reactor consolidated spent fuel rods from 2 SFAs.

(d) Pintle lengths are not included (does not apply to DHLW/WVHLW canisters). 


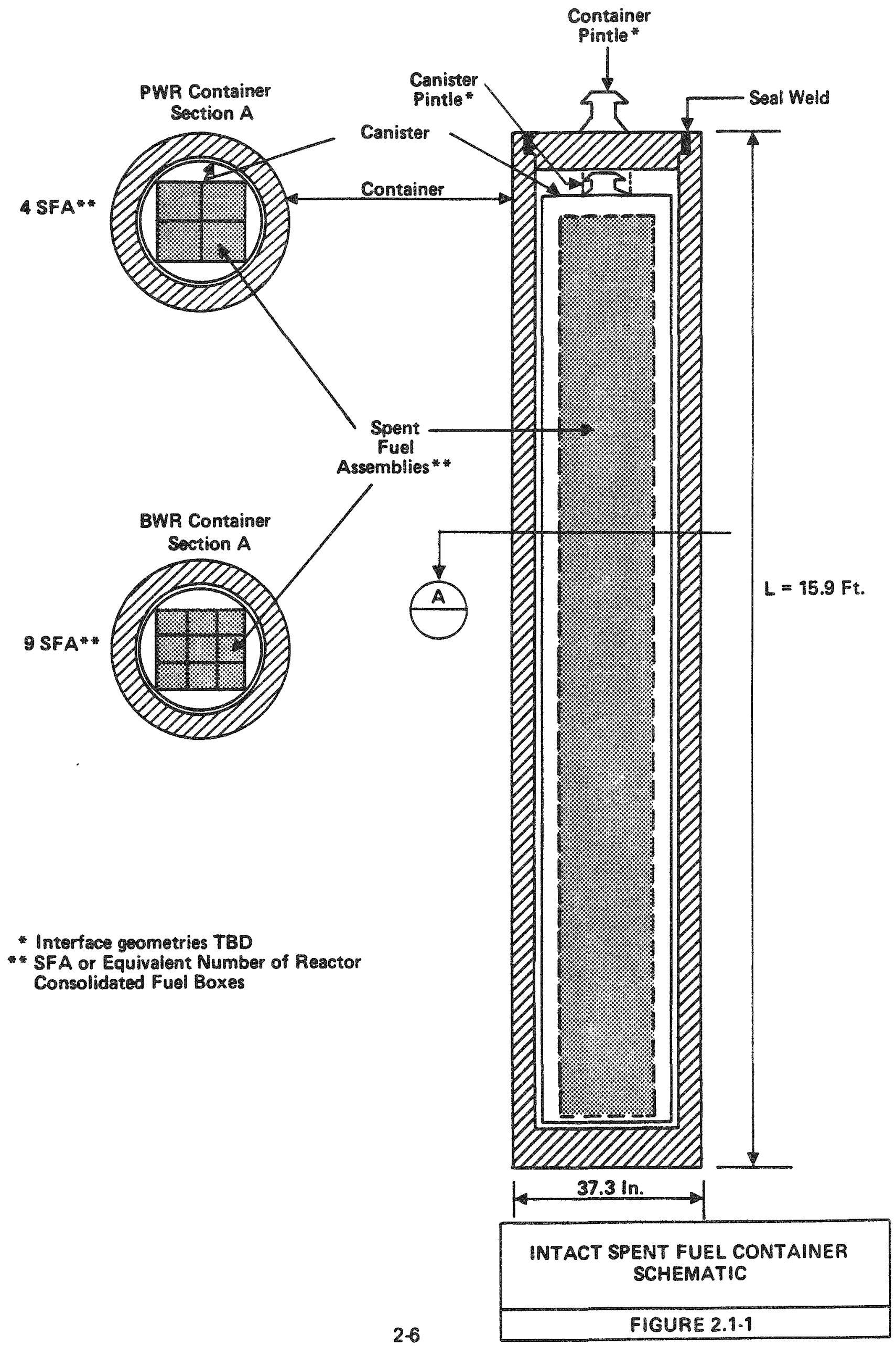


be about one foot shorter than most full length BWR SFAs. Consequently, most BWR SFAs in Phase I will be shortened by removing part of one or both end fittings prior to canistering. These operations will be accomplished in the special function area of Waste Handling Building No. 1 (WHB 1).

During Phase II operations, SFAs will be the primary waste form received. Only a small number of RCSF boxes will remain after Phase $I$, and these will be received during the first five years of Phase II. In addition, during Phase II, the repository will receive DHLW and WHLW canisters. Waste containers have been designed for these Phase II waste types as well as for the FAH generated during spent fuel consolidation. Consolidated PWR fuel rod canisters and FAH waste canisters will use a common container design (Table 2.1-2, consolidated PWR container), but consolidated BWR fuel rod canisters will use a longer container design (Table 2.1-2, consolidated BWR container). Figure 2.1-2 provides a schematic view of a consolidated spent fuel container. If a fuel assembly cannot be disassembled during Phase II, a Phase I type intact spent fuel container will be used. In these cases, some BWR SFAs will be sent to the special function cell and shortened as in Phase $I$. Canisters of DHLW and WHLW will use the container design described in Table 2.1-2 and depicted in Figure 2.1-3. The Phase II container design was adapted from ONWI-517 (Westinghouse Electric Corporation, 1986).

The spent fuel container heat loads specified in the design basis correspond to a standard burnup and a 10-year decay period after reactor discharge. In addition, the projected throughput of disposal containers (Section 2.4.4) is based on the receipt of standard burnup 10-year decayed spent fuel. It is possible, however, that 5-year decayed fuel will be received at the repository. This waste will have a heat load about $30 \%$ higher than 10-year decayed fuel. The 5-year decayed fuel will be packaged and emplaced similarly to the 10-year decayed fuel. However, to maintain the overall waste container heat load at the levels of the 10-year decayed fuel, less of the 5 -year decayed fuel will be packaged in each container. Quantities will be determined case-by-case. Extended burnup fuel (e.g., 60,000 megawatt-days/ metric ton uranium) will also have higher levels of decay heat than base case fuel. As with 5-year decayed fuel, it may therefore be necessary to reduce the amount of the fuel in each container. 


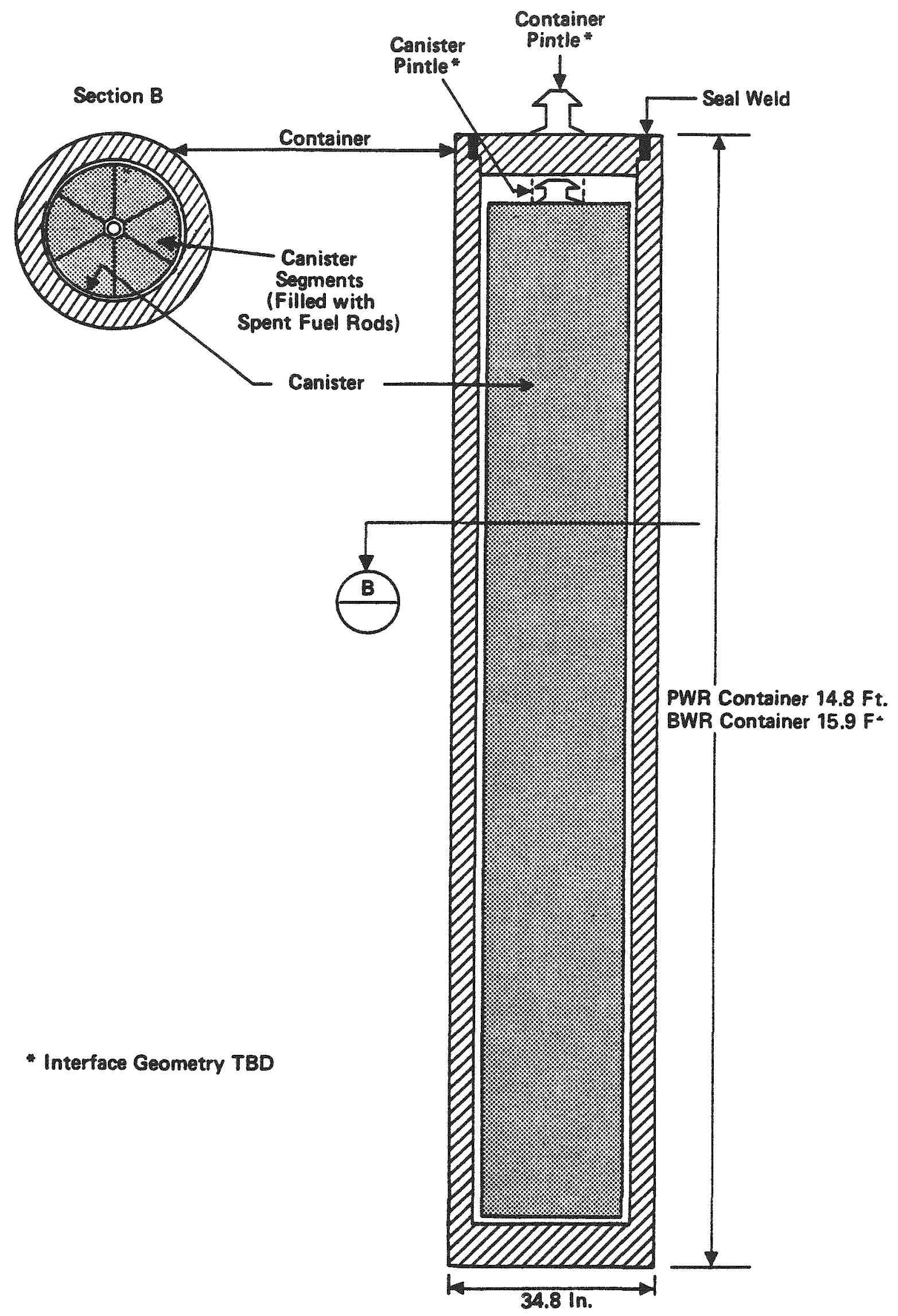

\begin{tabular}{|c|c|}
\hline & $\begin{array}{c}\text { CONSOLIDATED } \\
\text { SPENT FUEL CONTAINER } \\
\text { SCHEMATIC }\end{array}$ \\
\hline FIGURE 2.1.2 \\
\hline
\end{tabular}




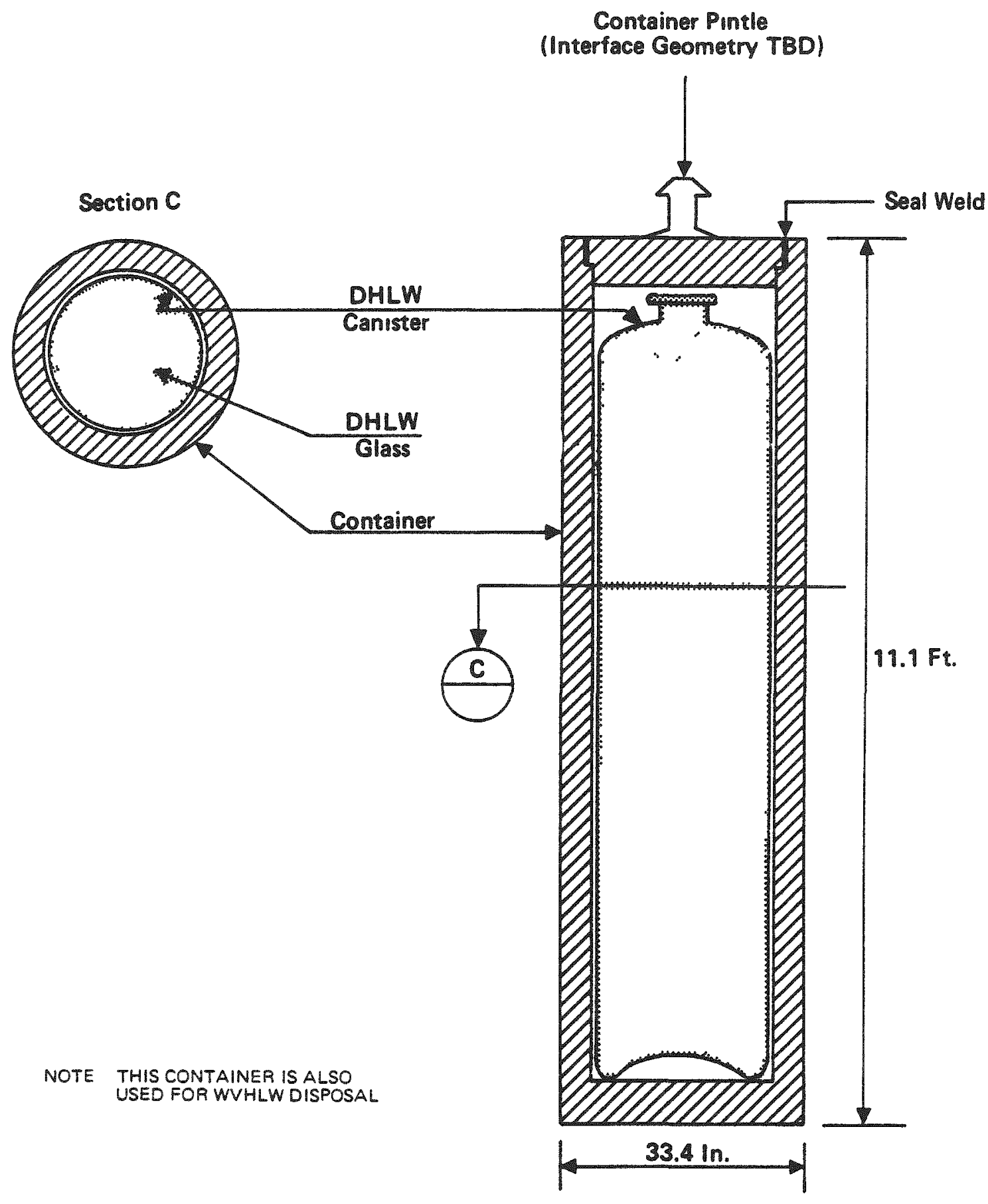


The container heat loads for DHLW and WVHLW forms are specified in Appendix $B$ of the GRMGDS. No significant deviations from the reference heat loads (Table 2.1-1) are expected for these waste forms. 


\subsection{SITE DATA BASE}

This section describes the existing data applicable to the conceptual design of a repository at the Deaf Smith County, Texas site, including a description and/or a range of measured data in each technical discipline category. When sufficient data exists, this section presents the number of measurements available, the maximum and minimum values, and the mean value. In many cases, however, only minimal data are available, in which case the data are presented in the format in which they were found. Although the resulting data base is necessarily incomplete, as very little site-specific data exists, it serves to illustrate representative values for properties of interest without interpretation.

This section is not intended to present the design values used in the conceptual design report. The description of design values is deferred to Section 2.3, which generally includes both a listing of design values and a discussion of, or a reference for, their derivation. It is helpful to remember that the purpose of Section 2.2 is to present an objective compilation of actual measured data (the Site Data Base) relevant to the conceptual design of a repository at the Deaf Smith site, rather than the design values which are presented in Section 2.3. Moreover, some of the design values presented in Section 2.3 are estimates based on engineering judgement for which no actual data exist, and therefore, cannot be directly correlated with the compilation of actual data in this section.

Most of the site data base was compiled from the Synthetic Geotechnical Design Reference Data for the Deaf Smith Site (DOE, 1986b, SGDRD). However, data was also compiled from several other sources including (1) the published literature [e.g., U.S. Geological Survey (USGS) topographic maps], (2) published Salt Repository Program Office (SRPO) documents (e.g., Deaf Smith location meteorology and air quality characterization reports, pumping tests and fluid sampling reports for SRPO test wells drilled in the proposed site region, and rock mechanics laboratory test reports), and (3) information contained in Chapter 3, The Site, of the Environmental Assessment for the Deaf Smith County Site (DOE, 1986a, EA). Data in these sources was generally developed from regional Texas Panhandle data rather than from site-specific investigations. 
For example, to date, no underground geologic information and no climatological data have been collected from within the nine-square-mile proposed site.

Instead, conditions within the site boundary were interpreted based on boreholes located from $2 \mathrm{mi}$ to more than $80 \mathrm{mi}$ away, and on regional (Amari1lo) weather data. A plan showing the site in relation to various deep boreholes drilled for the salt repository program is shown on Figure 2.2-1.

In the data base, data are presented under three broad divisions:

1. Surface or near-surface data related to planned repository structures at the ground surface (e.g., the WHBs) or near the ground surface (e.g., the shaft collar). These data are presented in Section 2.2.1.

2. Underground data related to design of the shafts. This information is presented in Section 2.2.2.

3. Underground data pertaining to design of the entries, pillars, and other elements of the underground layout. This data is presented in Section 2.2.3.

Within each of these divisions, the data are separated by discipline topics such as natural phenomena, stratigraphy, hydrogeology, and geomechanical parameters.

\subsubsection{Surface Data Base}

\subsubsection{Surface Topographic and Geomorphic Data}

The Deaf Smith County site is located in the north central part of Deaf Smith County, in the Southern High Plains of the Texas Panhandle. The High Plains area is comprised of nearly flat, relatively undissected tableland. In the vicinity of the site, the land surface slopes gently to the east. Elevations on the site range from 4,062 ft above mean sea level (MSL) on the west side to $3,983 \mathrm{ft}$ above MSL on the east side. Figure 2.2-2 illustrates the topography of the site (Litton Aero Service, 1985). 


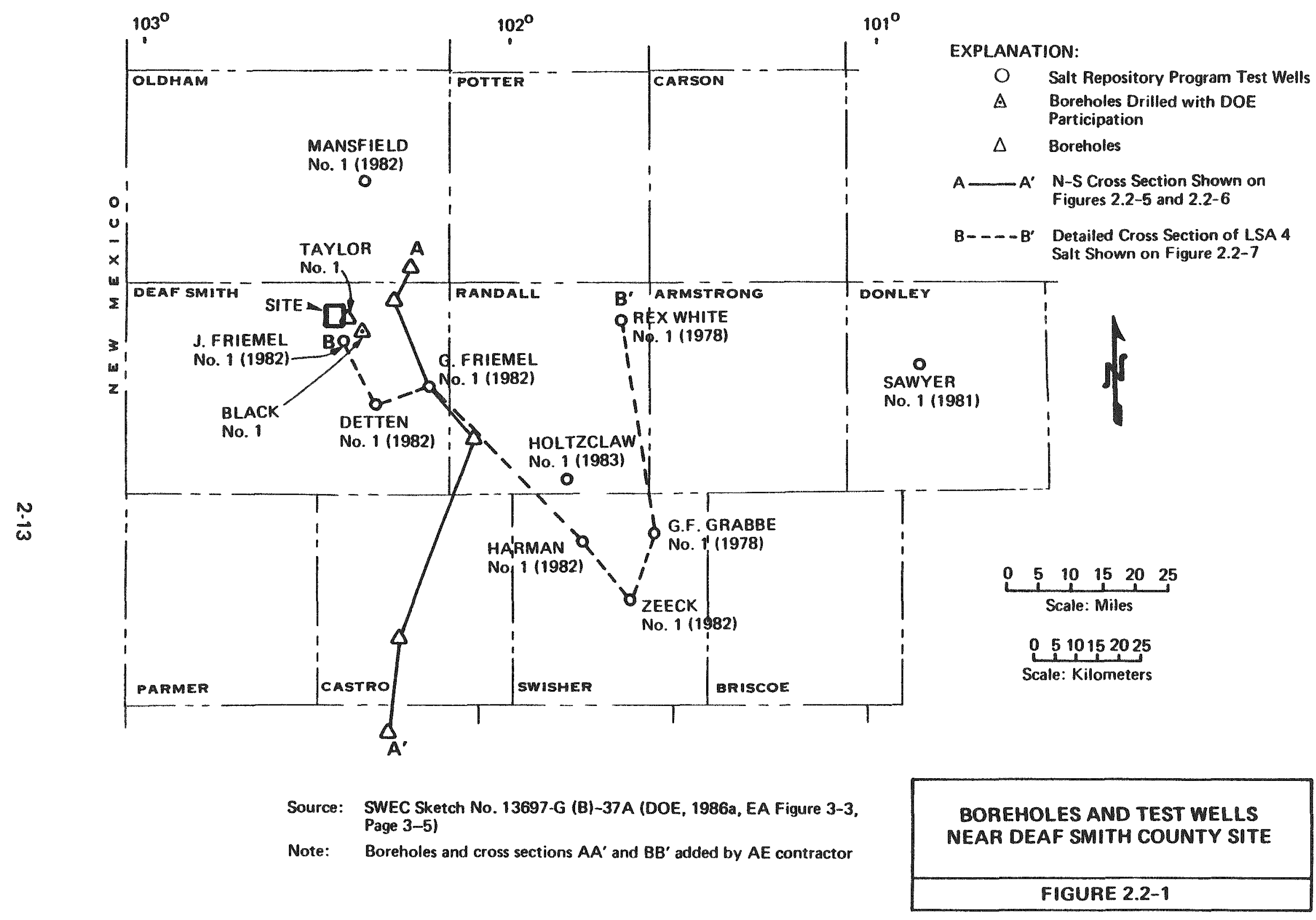



NOTES.

1 Topographic map information $v$ as provided by Litton Areo Service Litton is a contractor to Parsons Brinkerhoff ( $\mathrm{PB}-\mathrm{KBB}$ ), the exploratory shaft contractor for the Salt Repository Project office The flood limit information was added to the map by fluor

2 Flood limits were derived from flooding studhes of proposed repository locations in the Palo Juro Basin of the Texas Panhandle, April 1985 (NUS, 1985)

3 Grid is based on Texas Coordinc te System, North Zone

LEGEND

EXISTING BUILDING AND STRUCTURES

PAVEO ROAD

EXISTING GAS LINE

- existing gas lin 

The site is bordered on the north by an unnamed draw which is a tributary to the main branch of the North Palo Duro Creek $3 \mathrm{mi}$ east of the site. This draw is about $25 \mathrm{ft}$ to $35 \mathrm{ft}$ below the surrounding terrain, and runoff in the northern part of the site drains into it. This topographic/geomorphic feature is of some concern to the SCP conceptual design because a portion of the currently proposed surface facility layout is expected to be located within an area subject to its probable maximum flood (PMF). (See Figures 2.2-2 and 4.2-1.) As explained in Section 4.2 (Surface Facilities) those facilities located within this PMF area will be founded on engineered fill compacted and raised to above the PMF elevation.

As shown in Figure 2.2-2, there are two playas within the site boundary. Although surface drainage is generally eastward across the site, much runoff drains into these playas. The origin of the playas is unresolved and subject to considerable debate in the technical community. Playas have generally been attributed to one or more of the following: (1) wind erosion, (2) collapse due to dissolution of caliche, gypsum, or salt in near-surface underlying formations, or (3) subsidence due to downward piping of fines during heavy rainfall recharge of underlying aquifers (DOE, 1986a, EA, pp. 3-7 to 3-9). To preclude the mitigation that would be necessary for construction on collapsible soils, surface facilities, roads, railroads, and utility corridors should be located away from these playas.

Three scales of topographic maps are available for the site region and site area. These are (1) 1:250,000-scale regional topographic maps for the Tucumcari, New Mexico and Texas; Amarillo, Texas; Clovis, New Mexico; and Plainview, Texas quadrangles (USGS, 1973-1977); (2) 1:24,000-scale area topographic maps for Simms NE, Vega South, Overstreet Lake, and Ford, Texas (USGS, 1966); and ( 3 ) $1: 2,400$ scale ( 1 in $=200 \mathrm{ft}$ ) topographic maps of the nine-square-mile site (Litton Aero Service, 1985).

\subsubsection{Near-Surface Soil and Rock Stratigraphy}

No shallow borehole information is available from within the site. The only known estimates of near-surface soil and rock stratigraphy are provided by (1) reports by the Soil Conservation Service (SCS) (Geiger, et al., 1968) and 
the Bureau of Economic Geology, University of Texas at Austin (TBEG) (Seni, 1980); and (2) rough estimates of the outcrop elevation of hard caliche (caprock) near the site. Near-surface soil and rock conditions will be investigated during site characterization (see Section 8.2).

Soils present in the site vicinity consist of a 0 to $7 \mathrm{ft}$ thick topsoil sequence, generally classified as Pullman and/or Ulysses series clay loam (Geiger, et al., 1968). These clay loams extend over $90 \%$ of the site area (Figure 2.2-3). Their index properties are presented in Table 2.2-1. These surface soils usually overlie the Blackwater Draw Loess which is estimated to be about $62 \mathrm{ft}$ thick, and which is composed of silt with very minor clay. The soil and/or the upper loess may contain some soft caliche (Geiger, et al., 1968). The Blackwater Draw Loess is underlain by the Ogallala Formation which is composed of fluvial sand, gravel, silt, minor clay, and caliche. The first occurrence of hard caliche, or caprock, is expected to be at the top of the Ogallala Formation (Seni, 1980).

Table 2.2-1. Index Properties of Surface Soil (Geiger, et al., 1968)

\begin{tabular}{ll}
\hline Soil & \multicolumn{1}{c}{ Index Properties } \\
\hline & Low plasticity clay \\
& Liquid limit average $42 \%$ \\
Pullman Clay Loam & Plasticity index average 24\% \\
(SCS classification & High shrink/swell potential \\
PmA or PmB) & Minimum $75 \%$ to $80 \%$ passing No. 200 sieve \\
& AASHTO classification A-7 \\
& \\
& Low plasticity clay \\
& Liquid 1imit average $37 \%$ \\
Ulysses Clay Loam & Plasticity index average 19\% \\
(SCS classification & Moderate shrink/swel1 potential \\
UsA or UsB) & Minimum 50\% to 55\% passing No. 200 sieve \\
& AASHTO classification A-4 to A-6 \\
\hline
\end{tabular}




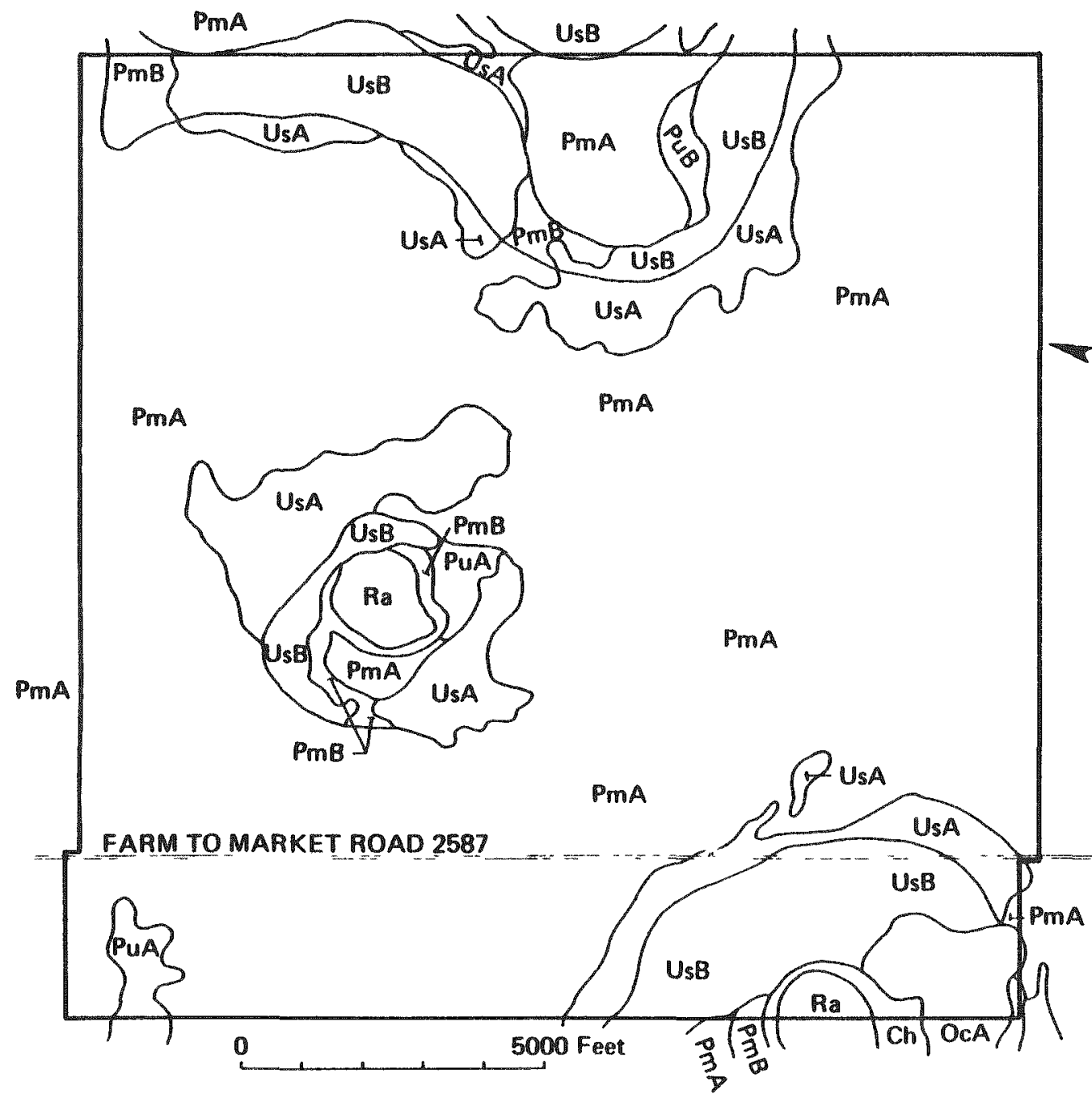

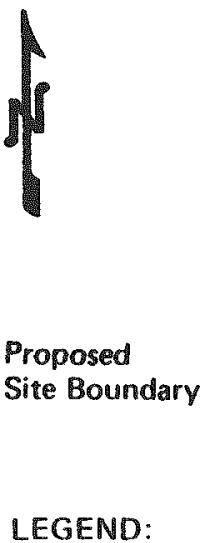

PrnA = Pullman Clay Loam

PmB = Pullman Clay Loam

UsA $=$ Ulysses Clay Loam

UsB = Ulysses Clay Loam

PuA = Pullman-Ulysses Complex

PuB = Pullman-Ulysses Complex

$\mathrm{Ra}=$ Pandall Clay

$\mathrm{Ch}=$ Church Clay

OcA = Olton Clay Loam

From: Soil Conservation Report by Geiger, al. 1968.

SOLL CLASSIFICATION AT THE DEAF SMITH COUNTY SITE

FIGURE 2.2-3 
The Ogallala Formation is expected to have significant variations in lithologic conditions across the site including unconsolidated sand, silt, and some clay combined with local gravel and local partially- to well-cemented caliche layers. As many as three hard caliche layers may be present within the Formation (Knowles, et al., 1984), and it may become coarser and more cemented with increasing depth.

It is not considered necessary at this stage to prepare a surface stratigraphic map to any more detail than shown in Figure 2.2-3, although surficial soil stratigraphy is probably more complex around the playas and draws than in other areas. When shallow foundation investigation boreholes are drilled, cross sections can be drawn for use in the design of building foundations. Future core samples, laboratory testing, and more detailed mapping of caprock outcrops near the site will be used to describe the engineering geology and geomechanical properties of shallow rock and soil units.

\subsubsection{Seismicity}

Seismicity compilations and evaluations have been made for the region around Deaf Smith County (DOE, 1986a, EA, p. 3-76). Evaluations of historical seismicity have generated epicenter maps for the Texas Panhandle region (DOE 1986a, EA, Fig. 3-37). This regional seismographic coverage, though limited, helps identify the locations of the larger earthquakes in this area. A microearthquake network in the site area has also detected a few very small earthquakes (DOE, 1986a, EA, p. 3-81).

Interpretations of these seismic data, combined with structural geologic evaluations, have led to the conclusion that a magnitude $\mathrm{M}_{\mathrm{bLg}} 5.3$ earthquake is the expected maximum event for the zone including the Palo Duro Basin. A mean peak acceleration of $0.14 \mathrm{~g}$ would result at the epicenter of an event of this size (Nuttli and Hermann, 1978 and 1981; DOE, 1986a, EA, p. 3-82). A meanvalue peak acceleration of $0.14 \mathrm{~g}$ at the site can also be associated with a magnitude $\mathrm{M}_{\mathrm{bLg}} 6.3$ earthquake $35 \mathrm{mi}$ northeast of the site along the Amarillo Uplift (Nuttli and Herrmann, 1978 and 1981; DOE, 1986a, EA, p. 3-82). The maximum earthquake is considered to be an infrequent event with an annual 
probability of occurrence on the order of $10^{-4}$ to $10^{-3}$ (DOE, 1986a, EA, p. $3-82)$.

\subsubsection{General Hydrogeologic Setting}

The site is located in the semiarid to subhumid region of the Texas Panhandle where the hydrogeologic systems are a part of the Palo Duro structural basin. The hydrostratigraphic units (HSU), originally defined by Bassett, et a1., (1981) and recently described by Bair, et al., (1985), consist of three systems (Figure 2.2-4):

- HSU A - Shallow freshwater aquifer system (Ogallala - Dockun)

- HSU B - Intermediate shale and evaporite aquitard system (Dewey Lake - Wichita)

- HSU C - Deep-basin limestone and dolomite brine flow system (Wolfcamp and deeper units)

The Ogallala Formation an"' "he middle part of the Dockum Group are the primary aquifers, and wells have been drilled into them for domestic and irrigation purposes. The Ogallala Formation is recharged from precipitation and from underflow from New Mexico. The Dockum is recharged by percolation from the Ogallala and by infiltration in the Pecos and Canadian River valleys. The deeper systems are recharged at the Canadian River to the north and the Pecos River to the west. Natural discharge occurs at the Prairie Dog Town Fork of the Red River to the east of the site.

The phreatic surface in the Ogallala Formation was measured in Well Number 07-61-224 on January 24, 1985. (See Appendix B.) The water level stood at $265 \mathrm{ft}$ below ground surface at an elevation of $3,748 \mathrm{ft}$ above MSL. A review of the published literature (DOE, 1986a, EA, pp. 3-155 to 3-157; DOE, 1986b; Knowles, et a1., 1984) indicates that groundwater depths range from approximately $230 \mathrm{ft}$ to $290 \mathrm{ft}$, depending on the ground surface elevation. It is possible that local perched water tables may exist above zones of relatively impervious strata in the surficial deposits and in the Ogallala Formation. The 


\begin{tabular}{|c|c|c|c|}
\hline ERA & SYSTEM & ROCK UNIT & $\begin{array}{c}\text { HYDROSTRATIGRAPHIC } \\
\text { UNIT (HSU) }\end{array}$ \\
\hline \multirow{2}{*}{ 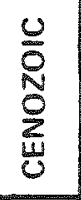 } & QUATEANARY & RECENT FLUVIALAEOLIAN \& LACUSTRINE OEPOSITS & \multirow{3}{*}{$\begin{array}{c}\text { FRESHWATER } \\
\text { FLOW SYSTEM } \\
\text { HSUA }\end{array}$} \\
\hline & TERTIARY & OGALLALA FORMATION & \\
\hline $\begin{array}{l}\frac{U}{O} \\
\mathbb{N} \\
0 \\
\stackrel{H}{\Sigma} \\
\stackrel{u}{\Sigma}\end{array}$ & TRIASSIC & DOCKUM GROUP & \\
\hline \multirow{19}{*}{ 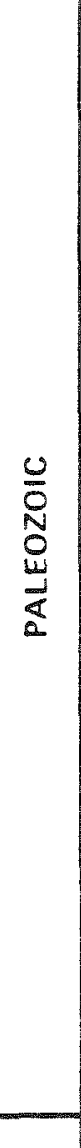 } & \multirow{14}{*}{ PERMIAN } & DEWEY LAKE FOAMATION & \multirow{13}{*}{$\begin{array}{c}\text { SHALE AND } \\
\text { EVAPORITE } \\
\text { AQUITARD } \\
\text { HSU B }\end{array}$} \\
\hline & & ALIBATES FORMATION & \\
\hline & & SALADO FORMATION & \\
\hline & & YATES FOAMATION & \\
\hline & & $\therefore$ EVEN RIVERS FORMATION & \\
\hline & & QUEEN-GRAYBURG FORMATION & \\
\hline & & SAN ANDRES FORMATION & \\
\hline & & GLORIETA FORMATION & \\
\hline & & UPPEA CLEAR FORK FORMATION & \\
\hline & & TUBB FORMATION & \\
\hline & & LOWER CLEAR FORK FORMATION & \\
\hline & & RED CAVE FORMATION & \\
\hline & & WICHITA GROUP & \\
\hline & & WOLFCAMP SERIES & \multirow{5}{*}{$\begin{array}{l}\text { DEEP-BASIN } \\
\text { BRINE } \\
\text { FLOW SYSTEM } \\
\text { HSUC }\end{array}$} \\
\hline & PENNSYLVANIAN & \multirow{4}{*}{ VARIOUS FORMATIONS } & \\
\hline & MISSISSIPPIAN & & \\
\hline & ORDOVICIAN & & \\
\hline & CAMBRIAN & & \\
\hline & PRECAMBRIAN & YARIOUS FORMATIONS & \\
\hline
\end{tabular}

Source: Modified from DOE, 1986a, EA, p. 3-138

GENERALIZED

HYDROSTRATIGRAPHIC COLUMN

FOR THE DEAF SMITH REGION

FIGURE $2.2-4$ 
many windmills noted on the SCS and USGS maps may draw limited amounts of water (estimate less than $5 \mathrm{gpm}$ ) from these shallow, perched water sources. The yield from these sources is probably relatively minor.

The hydrologic and geochemical properties of water in the ogallala aquifer are presented in Section 2.2.2.2.

\subsubsection{Surface Hydrology}

Surface flooding potential near the site has been studied by NUS Corporation (1985). Typically, the most severe floods (flash floods) are associated with intense local thunderstorms. The extent of flood limits for the 100-yr, 500-yr, and PMF was estimated based on the entire drainage area of the draw along the north site boundary. Flood hydrographs were produced according to the method used by the SCS for ungaged watersheds. The computations were made with the HEC-1 Flood Hydrograph Package of computer programs as developed by the U.S. Army Corps of Engineers (1981a). The flood analyses did not consider water storage in playas.

Water surface elevations were computed with the HEC-2 Water surface Profiles program, also developed by the U.S. Army Corps of Engineers (1981b). The flood limits for the 100-yr, 500-yr, and PMF floods are shown in Figure 2.2-2. The 50-yr flood limit is assumed to have a flood elevation less than $1 \mathrm{ft}$ below that of the 100-yr flood. Areas lying within the 100-yr flood limit are legally defined as flood plains.

\subsubsection{Geomechanical Properties}

No site-specific data are available for the geomechanical properties of the near-surface soil and rock strata. Some index properties of surface soils, based on an SCS report (Geiger, et al., 1968) are presented in Table 2.2-1 of Section 2.2.1.2. 


\subsubsection{Archaeology and Historic Resources}

A preliminary assessment of cultural resources has been conducted for the site and its vicinity (NUS, 1984a). This assessment consisted of a literature search and archival review which provided an analysis and evaluation of recorded sites. To date, no archaeological sites have been recorded at the site or in the vicinity. Areas with the greatest potential for containing unrecorded historic sites are located near water sources.

No recorded historic resources or national historic trails are located on the site or within its vicinity. However, the potential for historic resources within the area is high. Settlement occurred in the upland plains as a consequence of the development of irrigation technology. Therefore, potential historic sites are not restricted to available surface water sources and may be located throughout the site vicinity. Historic sites that may occur within the site include Comanchero and Cibolero trails located north of Palo Duro Creek, Patores occupational sites along stream drainages, and evidence of ranching and farming activities. Also, a trail from the historic period may be located in the southern two-thirds of the site.

\subsubsection{Underground Data Base - Formations Above Repository Horizon}

\subsubsection{Stratigraphy and Geology above Repository Horizon}

Ten deep test wells have been drilled as a part of the Salt Repository Program (SRP) in the Texas Panhandle. The locations of these wells are shown in Figure 2.2-1. Also shown in this figure are the wildcat hydrocarbon exploration wells that have been used to construct stratigraphic cross sections or that are close to the site boundaries.

Many hydrocarbon exploration wells in addition to those shown in Figure 2.2-1 have been drilled in the panhandle area. These wells are shown in the EA (DOE, 1986a, p. 3-116). Two cross sections derived from SRP and wildcat wells are shown in plan in Figure 2.2-1. Section $A-A^{\prime}$ (Figures 2.2-5 and 2.2-6) includes all formations from the ground surface to the Permian Witchita Formation, which is considerably below the ISA 4 salt horizon. 


\begin{tabular}{|c|c|c|c|c|c|c|c|}
\hline 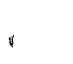 & E & a: & 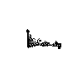 & a. & 19 & an & 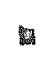 \\
\hline$\because:$ & $\Delta$ & B: & L. & $\therefore$ & L. & b. & 4 \\
\hline : & 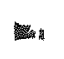 & $B$ & b. & $\therefore$ & $B$ & $\omega$ & $\omega$ \\
\hline$\therefore$ & $m$ & (b) & b: & a: & $\|$ & $\omega$ & 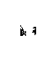 \\
\hline$\therefore$ & 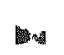 & $\Delta$ & \&. & $B$ & mu & H & $u$ \\
\hline
\end{tabular}

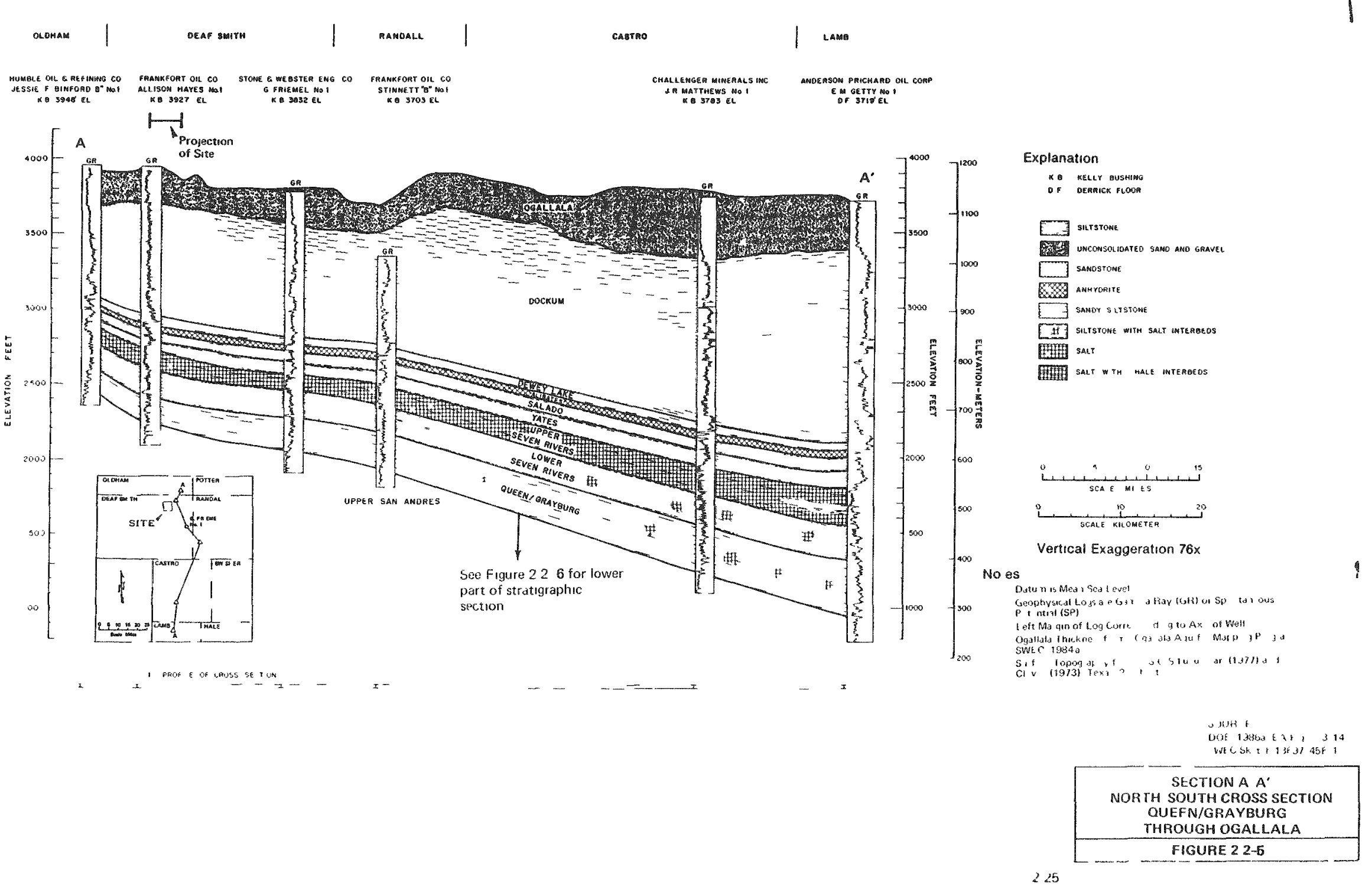




Figure 2.2-5 shows formations from the Queen/Grayburg Formation through the surface, and Figure 2.2-6 shows formations from the Witchita Formation through the Upper San Andres Formation (DOE, 1986a, EA, pp. 3-23 and 3-21). The other section, $B-B^{\prime}$, shown in Figure $2.2-7$, is a detailed cross section of LSA 4 illustrating the continuity of subunits within LSA 4 as interpreted by TBEG geologists (Hovorka, et al., 1985).

A brief description of the general stratigraphy above the Glorieta Formation in the Texas Panhandle area (depicted along Cross Section $\mathrm{A}-\mathrm{A}^{\prime}$ ) is provided below. This description is based on the discussion in the EA, Section 3.2.3. It is recognized that minor differences in lithology exist between this general description of the Panhandle area and the estimated site stratigraphy at a representative shaft area location (see Section 2.3 ). The estimated site stratigraphy is based on specific core data from the J. Friemel borehole.

The San Andres Formation in the Panhandle area is an evaporite sequence with minor carbonates and clastic rocks. From bottom to top, the various San Andres units generally consist of limestone, dolomite, nodular anhydrite, laminated anhydrite, bedded halite, and chaotic mixtures of halite and mudstone (Hovorka, 1983, p. 1). These units are generally separated by transgressive shale. Lower and upper divisions of the San Andres Formation have been established by the TBEG (Presley, 1980), and five subdivisions of the Lower San Andres have been established based on depositional cycles. The lower part of Unit 4 is composed mostly of dolomitic limestone and microcrystalline dolomite. Above these carbonates is a sequence of the cleanest and thickest San Andres salt recognized in the basin, which is the proposed repository orizon (DOE, 1986a, EA, p. 3-19). Unit 5 and the Upper San Andres similarly consist of a lower sequence of anhydrite with some dolomite, overlain by salt having interbeds of shale, siltstone, anhydrite, or dolomite.

The Queen/Grayburg Formation in the Panhandle area is primarily reddishbrown fine sandstone, siltstone, and mudstone with thinly bedded layers of salt and anhydrite throughout (DOE, 1986a, EA, p. 3-25). The Lower Seven Rivers Formation is composed of salty siltstone, having interbeds of siltstone, claystone, salt, and anhydrite. The Upper Seven Rivers Formation consists of a lower section of siltstone with interbeds of anhydrite and salt, and an upper 

San Andres Formation Unit 4 Halite

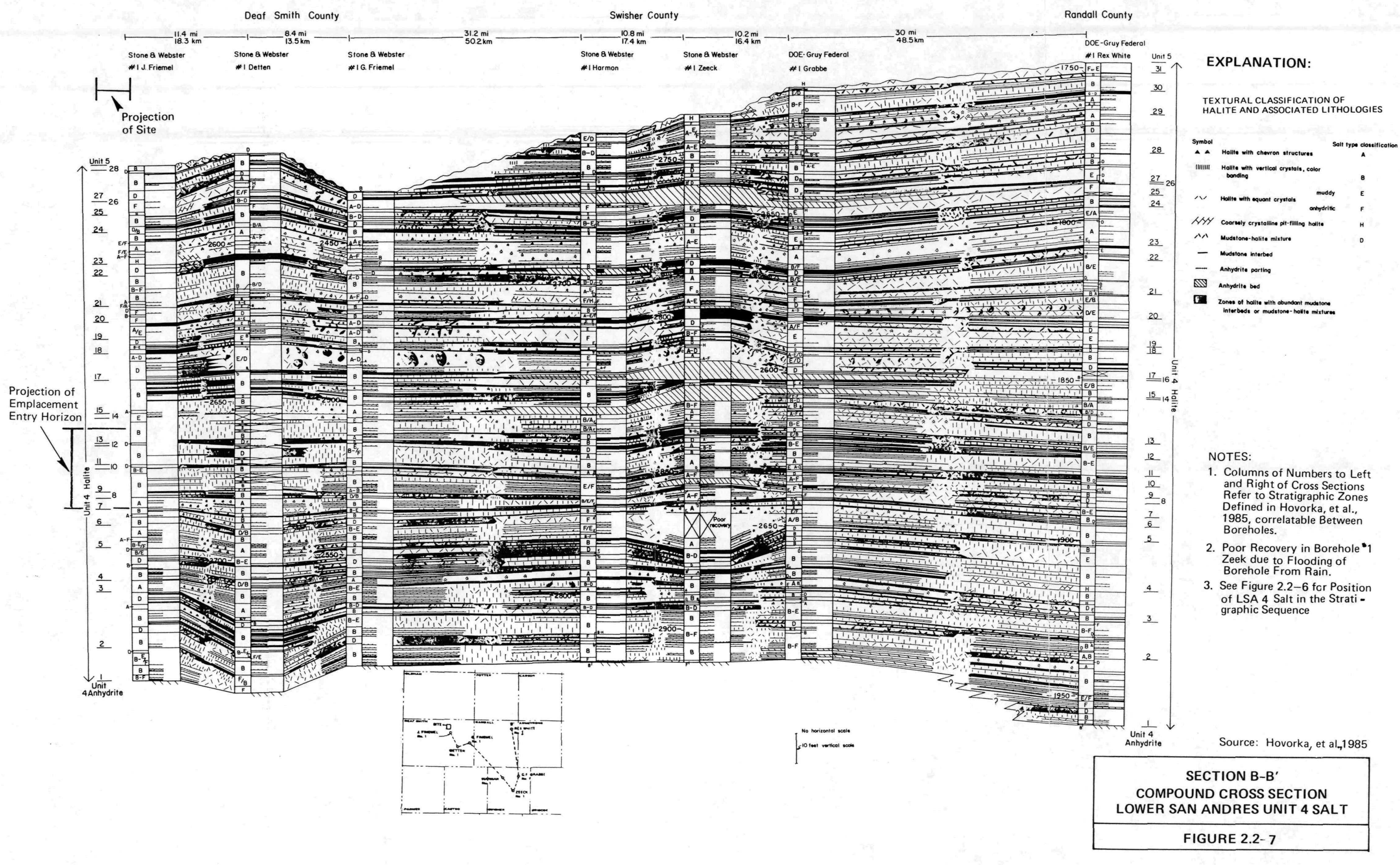


$0 \quad 0$ 
section of predominantly massive salt with interbeds of mudstone and anhydrite. Within the northern part of the Panhandle area (including the site) this formation contains the uppermost Permian salt bed. The Yates Formation is a thin interval of siltstone and claystone; to the south it contains thinly interbedded anhydrite and salt. The northern part of the Salado (SaladoTansil1) Formation consists of interbedded anhydrite and silty shale. The Alibates Formation, a thin and persistent marker bed across the basin, is composed of a lower anhydrite and dolomite unit, a middle siltstone unit, and an upper anhydrite and dolomite unit. In the J. Friemel well, dolomite is the dominant lithology. The youngest Permian unit is the Dewey Lake Formation, a relatively thin interval composed of fluvial siltstone and claystone.

The Upper Triassic Dockum Group consists mainly of terrigenous clastics deposited in a complex fluvial-lacustrine basin (DOE, 1986a, EA, p. 3-25). Complex interfingering of conglomeritic sandstone with finer-grained sediments complicates stratigraphic correlation in the Dockum Group. Some intervals of the Dockum are unconsolidated. In some areas of the Palo Duro Basin, sandstone of the middle part of the Dockum (correlated with the permeable Santa Rosa sandstones in New Mexico) produce water suitable for livestock and irrigation. Triassic Dockum Group deposits in the site area are unconformably overlain by the Ogallala Formation of Neogene Age. The Ogallala consists of mostly fineto-coarse sand, gravel, and silt with some clay and caliche. It is unconsolidated except where caliche has been deposited in less-than-1-ft to 10-ft-thick layers near the top of the formation.

Several general observations about the regional geologic structure can be made. The regional dip direction is south. The dip magnitude generally increases with depth from $12 \mathrm{ft} / \mathrm{mi}$ in the Alibates Formation to $30 \mathrm{ft} / \mathrm{mi}$ in the Lower San Andres. The thickness of most formations between the Dockum and Glorieta decreases across the site in a northeast or northwest direction; net thickness change of any formation across the site below the Dockum is probably less than $50 \mathrm{ft}$. These estimated thickness variations are based on preliminary isopach maps using data from (1) the engineering design borehole (EDBH) estimated stratigraphy (DOE, 1986a, EA, 3-3, pp. 3-34 to 3-37) and (2) the J. Friemel, Black, Taylor, G. Friemel, and Detten boreholes. Lithologic variations within formations across the site area are expected to be relatively minor based on 
the regional cross sections presented in Figures $2.2-5$ and 2.2-6. All interpretations and estimations should be re-evaluated as site-specific borehole and geologic information becomes available.

\subsubsection{Hydrogeology and Geochemistry - Strata Above Repository Horizon}

For the various types of rock in formations above LSA 4, available hydrogeologic data describes field hydraulic conductivity, laboratory permeability, effective porosity, temperature of groundwater, and potentiometric surface. The symbols and units for these properties are listed in Table 2.2-2 together with the measured or calculated values and their respective references.

The values for the various hydrogeologic parameters were obtained or calculated from primary well data and from data presented in Chapter 3 of the EA (DOE, 1986a). The hydraulic conductivity and permeability values for the Ogallala and Dockum aquifers were obtained from pump tests and laboratory permeability testing of core samples. Most of the permeability, porosity, and ambient water temperature data for deeper formations were obtained from drillstem test (DST) data, borehole pumping tests, and laboratory permeability testing of core samples. The potentiometric surface, apart from measurements made in observation wells penetrating the Ogallala and Dockum aquifers, was calculated using downhole pressure data from DSTs or pumping tests with correction factors for brine density. The borehole location plan, Figure 2.2-1, gives the location of deep SRP holes used for DSTs and pumping tests.

Ranges of values and sources of information for various types of rock are summarized for the various hydrogeologic and geochemical properties in Table 2.2-2. Table 2.2-3 summarizes hydrochemical information on various formation waters, including major anion and cation concentrations, total dissolved solids (TDS), and $\mathrm{pH}$. These tables summarize the range of readily available data from the literature, especially the values and citations referenced in the EA (DOE, 1986a). They do not represent an exhaustive search of all available literature. The primary permeability unit is the millidarcy $(\mathrm{mD})$, and the primary hydraulic conductivity unit is the Meinzer Unit, in gallons per day per square foot (gpd/ft ${ }^{2}$ ). 
Table 2.2-2. Sumary of Desf Saich County Site Hydrogeological Properties (Sheet 1 of 2)

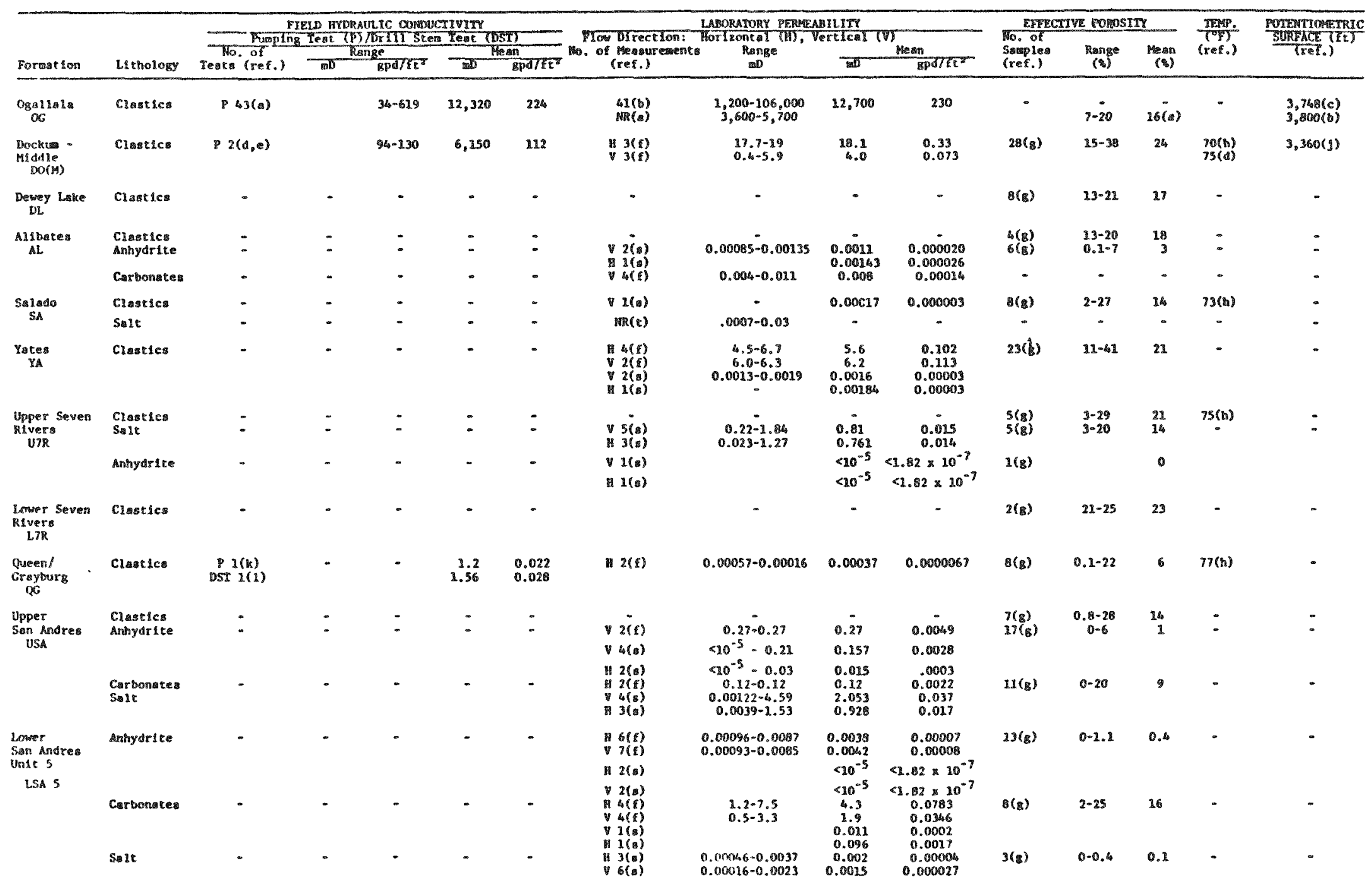



Table 2.2-2. (Sheet 2 of 2)

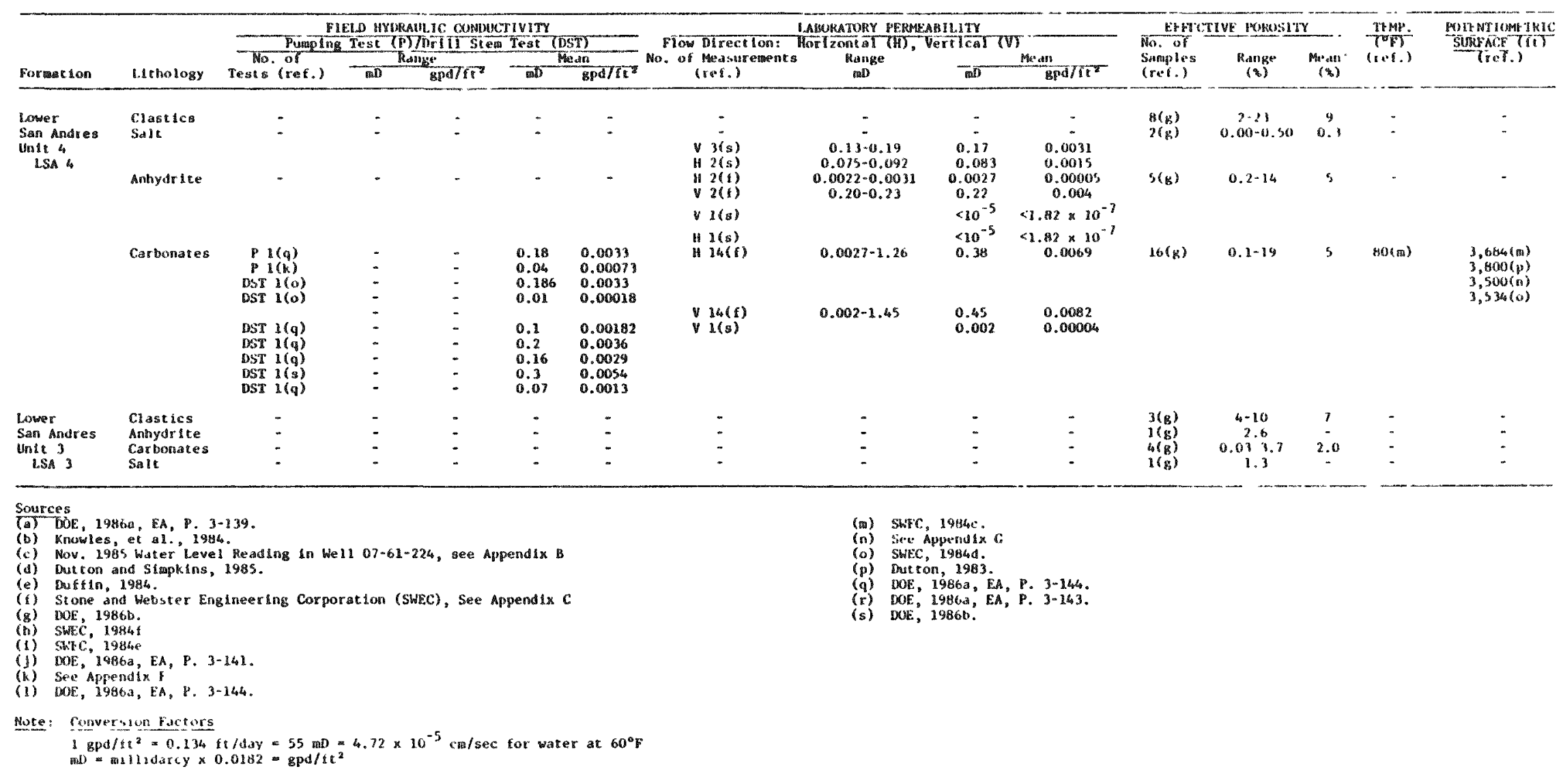



Table 2.2-3. Representative Hydrochemistry of Formation Waters

\begin{tabular}{|c|c|c|c|c|c|c|c|c|c|}
\hline $\begin{array}{l}\text { Formation and we } 11 \\
\text { Identification }\end{array}$ & $\mathrm{Na}$ & K & $\mathrm{Mg}$ & $\begin{array}{l}\text { Major Ion } \\
\text { Ca } \\
\text { A11 concen }\end{array}$ & $\begin{array}{l}\text { ncentrat } \\
\text { C1 } \\
\text { ations e }\end{array}$ & $\begin{array}{l}\operatorname{TDS}_{,} \text {a } \\
\mathrm{SO}_{4} \\
t \mathrm{pH} \text { in }\end{array}$ & $\mathrm{HCO}_{3}$ & TDS & $\mathrm{pH}$ \\
\hline \multicolumn{10}{|l|}{ OGALLALA } \\
\hline $\begin{array}{l}\text { We } 11 \text { 10-07-802 (a) } \\
\text { (Dawn } 20 \mathrm{mi} \mathrm{SE} \text { of site) }\end{array}$ & 37 & NR & 48 & 56 & 45 & 89 & 299 & 499 & 7.9 \\
\hline $\begin{array}{l}\text { We11 10-14-404 (a) } \\
\text { (Three miles SE of Hereford) }\end{array}$ & 28 & NR & 45 & 47 & 32 & 59 & 305 & 422 & 7.7 \\
\hline Average (b) & 39 & 2 & 29 & 45 & 23 & 41 & 294 & 379 & 7.9 \\
\hline \multicolumn{10}{|l|}{ DOCKUM } \\
\hline We11 07-52-902 (c) & 236 & 3 & 5 & 9 & 62 & 110 & 401 & 645 & 8.4 \\
\hline We11 10-14-107 (c) & 313 & 2.0 & 1 & 4 & 56 & 240 & 449 & 858 & 8.5 \\
\hline $\begin{array}{l}\text { We11 10-13-503 (c) } \\
\text { (highest IDS we11) }\end{array}$ & 909 & 3.0 & 1 & 6 & 508 & 356 & 999 & 2,307 & 8.4 \\
\hline Average (b) & 373 & NR & 3.4 & 7.6 & 111 & 217 & 523 & 987 & 8.5 \\
\hline \multicolumn{10}{|l|}{ QUEEN/GRAYBURG } \\
\hline $\begin{array}{l}\text { J. Frieme1 (d) } \\
\text { (wellhead) }\end{array}$ & 73,000 & 1,080 & 13,800 & 17,500 & 182,000 & 230 & NR & 288,000 & 6.6 \\
\hline $\begin{array}{l}\text { J. Frieme1 (d) } \\
\text { (Downhole) }\end{array}$ & 76,800 & 1,170 & 16,900 & 22,200 & 190,000 & 380 & NR & 309,000 & NR \\
\hline \multicolumn{10}{|l|}{ SAN ANDRES Dolomites } \\
\hline $\begin{array}{l}\text { J. Frieme } 1 \text { (d) } \\
\text { (Downhole) }\end{array}$ & 21,000 & 3,900 & 18,200 & 98,000 & 256,000 & 81 & NR & 399,730 & 6.1 \\
\hline J. Friemel (e) & 21,270 & 3,700 & 17,400 & 87,780 & 250,200 & 34 & 415 & NR & 6.6 \\
\hline $\begin{array}{l}\text { Zeeck (d) } \\
\quad \text { (Downhole) }\end{array}$ & 67,000 & 3,300 & 7,900 & 46,500 & 208,000 & 100 & NR & 334,000 & 7.1 \\
\hline
\end{tabular}

$\mathrm{NR}=$ No Records

TDS = Total Dissolved Solids

*Geochemistry used in design (DOE, 1986b). See text, Section 2.3.2.2, for explanation.

Sources

(a) SWEC, 1983a

(b) DOE, 1986a, EA, p. 3-162.

(c) Duffin, 1984 .

(d) See Appendix $\mathrm{H}$.

(e) Dutton and Orr, 1986. 
The hydraulic conductivity of the Ogallala ranges from about $35 \mathrm{gpd} / \mathrm{ft}^{2}$ to about $620 \mathrm{gpd} / \mathrm{ft}^{2}$, based upon analysis of pumping tests from 43 wells (DOE, $1986 \mathrm{a}, \mathrm{EA}, \mathrm{p} .3-139$ ). The ground water movement in the Ogallala is towards the southeast at an average velocity of about $115 \mathrm{ft} / \mathrm{yr}$. In the Dockum Group the most permeable horizon is in the middle part of the formation, with static water levels at about $610 \mathrm{ft}$ below ground level in the vicinity of the shafts. The general ground water flow is towards the south to southeast at an average velocity of $98 \mathrm{ft} / \mathrm{yr}$. Although there is a net downward potential from the Ogallala Formation and Dockum Group toward the deeper Pennsylvanian aquifers, a lateral component of flow may exist in the San Andres Formation (Gustavson, 1982).

The potentiometric surface elevations in the LSA 4 dolomites is $3,684 \mathrm{ft}$ above MSL, as calculated from the Detten Well Drill Stem tests. Two potentiometric surface maps give the levels as about $3,500 \mathrm{ft}$ and $3,800 \mathrm{ft}$ above MSL (see Table 2.2-2).

Chemically, the Ogallala aquifer is composed of sodium and calcium bicarbonate water with hardness of about 300 milligrams/liter (mg/1), and TDS concentration of about $380 \mathrm{mg} / 1$. The Dockum has predominantly sodium bicarbonate waters with TDS concentration around $1,000 \mathrm{mg} / 1$. The Queen/Grayburg brines have TDS concentration of about $309,000 \mathrm{mg} / 1$ and the San Andres Dolomite brines have TDS concentration of about $400,000 \mathrm{mg} / 1$. The major cation-anion concentrations is reported in Table 2.2-3.

\subsubsection{Geomechanical Properties and In Situ Stress - Strata Above Repository Horizon}

The available geomechanical property data required for repository conceptual design was compiled for formations above, and including, the Glorieta. Uniaxial compressive strength, indirect tensile strength, static Young's modulus, static Poisson's ratio, and wet density are summarized in Table 2.2-4. All data concerning these properties was compiled from the "interpreted ranges" presented in the SGDRD (DOE, 1986b). These ranges are representative of each property on the basis of sample compositions, testing conditions (e.g., stress- or strain-rate control) or other testing variables. The SGDRD includes a 


\begin{tabular}{|c|c|c|c|c|c|c|c|c|c|c|c|c|c|c|c|c|}
\hline \multirow[b]{2}{*}{ FORMATION } & \multirow[b]{2}{*}{ LITHOLOGY } & \multicolumn{3}{|c|}{$\begin{array}{c}\text { UNIAXIAL COMPRESSIVE STRENGTH } \\
\mathrm{psi}\end{array}$} & \multicolumn{3}{|c|}{$\begin{array}{l}\text { INDIRECT TENSILE STRENGTH } \\
\mathrm{ps1}\end{array}$} & \multicolumn{3}{|c|}{$\begin{array}{l}\text { STATIC YOUNG'S MODULUS } \\
\times 10^{6} \mathrm{psi}\end{array}$} & \multicolumn{3}{|c|}{ STATIC POISSON'S RATIO } & \multicolumn{3}{|c|}{$\begin{array}{c}\text { WET DENSITY } \\
\text { PCf }\end{array}$} \\
\hline & & Samples & Range & Mean & Samples & Range & Mean & Samples & Range & Mean & Samples & Range & Mean & Samples & Range & Mean \\
\hline Dockum & Clastics & 1 & 1,100 & 1,100 & 1 & 44 & 44 & 6 & $0.15-2.86$ & 1.33 & 6 & $0.17-0.40$ & 0.22 & 14 & $112-145$ & 135 \\
\hline \multirow[t]{2}{*}{ Dewey Lake } & Clastics & & & & 1 & 57 & 57 & 3 & $0.22-1.61$ & 0.72 & 2 & $0.18-0.37$ & 0.28 & 6 & $139-153$ & 143 \\
\hline & Clastics & 2 & $2,930-3,200$ & 3,065 & 2 & $110-186$ & 148 & 8 & $0.73-1.64$ & 1.24 & 8 & $0.10-0.26$ & 0.19 & 11 & $138-155$ & 148 \\
\hline \multirow[t]{2}{*}{ Alibates } & Carbonates & 2 & $6,161-8,900$ & 7,530 & & & & 2 & $2.46-5.46$ & 3.96 & 2 & $0.13-0.35$ & 0.24 & 2 & $137-143$ & 140 \\
\hline & Anhydrites & 8 & $4,205-19,100$ & 9,480 & 3 & $493-1,083$ & 797 & 6 & $5.88-13.64$ & 10.69 & 6 & $0.26-0.42$ & 0.32 & 13 & $145-184$ & 176 \\
\hline \multirow[t]{2}{*}{ Salado } & Clastics & 3 & $3,915-4,930$ & 4,350 & 2 & $35-88$ & 62 & & $1.04-2.67$ & 1.78 & 5 & $0.17-0.28$ & 0.21 & 9 & $132-162$ & 150 \\
\hline & Anhydrites & 2 & $13,600-17,750$ & 15,675 & & & & 2 & $6.07-9.01$ & 7.54 & 2 & $0.14-0.37$ & 0.26 & 4 & $182-185$ & 183 \\
\hline Yates & Clastics & 13 & $950-7,105$ & 4,050 & 4 & $133-213$ & 169 & 9 & $0.21-2.48$ & 1.22 & 9 & $0.07-0.40$ & 0.23 & 12 & $136-162$ & 149 \\
\hline Upper & Clastics & 2 & $1,050-2,010$ & 1,530 & & & & 4 & $0.81-2.75$ & 1.79 & 4 & $0.17-0.33$ & 0.26 & 5 & $121-152$ & 143 \\
\hline Seven & Anhydrites & 2 & 11,520 & 11,520 & & & & 1 & 9.09 & 9.09 & 1 & 0.14 & 0.14 & 2 & $175-183$ & 179 \\
\hline Rivers & Salts & 14 & $734-5,200$ & 1,911 & 4 & $145-242$ & 185 & 14 & $1.00-7.09$ & 3.62 & 14 & $0.15-0.35$ & 0.23 & 18 & $129-154$ & 136 \\
\hline \multicolumn{17}{|l|}{ Lower } \\
\hline \multicolumn{17}{|l|}{ Rivers } \\
\hline \multirow{4}{*}{$\begin{array}{l}\text { Queen/ } \\
\text { Grayburg }\end{array}$} & Clastics & 3 & $2,720-8,140$ & 5,410 & 3 & $52-942$ & 429 & 13 & $1.26-5.92$ & 3.54 & 13 & $0.14-0.45$ & 0.27 & 20 & $145-161$ & 152 \\
\hline & Anhydrites & 2 & $14,718-15,375$ & 15,047 & & & & 2 & $6.64-6.88$ & 6.76 & 2 & 0.15 & 0.15 & 2 & $181-183$ & 182 \\
\hline & Salts & 2 & $2,110-2,660$ & 2,385 & & & & 2 & $2.00-3.55$ & 2.78 & 2 & $0.16-0.27$ & 0.22 & 2 & $136-151$ & 144 \\
\hline & Clastics & 4 & $1,500-12,760$ & 8,416 & & & & 2 & $1.47-6.08$ & 3.78 & 2 & $0.06-0.22$ & 0.14 & 4 & $141-163$ & 151 \\
\hline Upper & Carbonates & 8 & $4,350-14,935$ & 10,036 & 3 & $282-405$ & 341 & 11 & $2.67-8.57$ & 4.80 & 10 & $0.11-0.38$ & 0.22 & 16 & $138-176$ & 159 \\
\hline \multirow[t]{2}{*}{ San Andres } & Anhydrites & 20 & $7,000-25,738$ & 16,722 & 14 & $589-1,453$ & 1,146 & 15 & $6.17-18.94$ & 10.50 & 14 & $0.17-0.43$ & 0.30 & 29 & $160-198$ & 182 \\
\hline & Salts & 17 & $2,175-4,930$ & 3,090 & 13 & $174-348$ & 245 & 35 & $2.78-5.38$ & 3.91 & 25 & $0.12-0.39$ & 0.26 & 19 & $135-142$ & 137 \\
\hline Lower & Carbonates & 12 & $5,075-14,790$ & 9,652 & 2 & $344-\quad 487$ & 416 & 7 & $3.04-5.17$ & 3.94 & 7 & $0.19-0.41$ & 0.28 & 12 & $136-170$ & 153 \\
\hline \multirow{3}{*}{$\begin{array}{l}\text { San Andres } \\
\text { Unit } 5\end{array}$} & Anhydrites & 11 & $13,500-19,865$ & 16,270 & 8 & $249-1,392$ & 976 & 15 & $6.98-16.23$ & 11.202 & 14 & $0.22-0.35$ & 0.30 & 24 & $173-185$ & 182 \\
\hline & Salts & & See Table $2.2-10$ & & & Table $2.2-1$ & & & ee Table $2.2-1$ & & & Table $2.2-1$ & & 18 & $131-138$ & 135 \\
\hline & Clastics & & & & & & & 1 & 2.38 & 2.38 & 1 & 0.20 & 0.20 & 3 & $149-165$ & 159 \\
\hline \multirow{4}{*}{$\begin{array}{l}\text { Lower } \\
\text { San Andres } \\
\text { Unit } 4\end{array}$} & Carbonates & 21 & $7,540-35,380$ & 14,354 & 7 & $753-1,626$ & 1,067 & 21 & $3.33-10.00$ & 6.54 & 21 & $0.15-0.39$ & 0.27 & 27 & $150-169$ & 160 \\
\hline & Anhydrites & 1 & 10,260 & 10,260 & 2 & $756-1,131$ & 944 & 3 & $11.16-12.25$ & 11.87 & 3 & $0.26-0.32$ & 0.30 & 6 & $176-184$ & 181 \\
\hline & Salts & & See Table $2.2-9$ & & & e Table 2.2 & & & See Table 2.2 - & & & e Table $2.2-$ & & 22 & $131-140$ & 135 \\
\hline & Clastics & 2 & $7,687-8,742$ & 8,215 & & & & 2 & $4.48-7.00$ & 5.74 & 2 & $0.20-0.22$ & 0.21 & 3 & $149-161$ & 157 \\
\hline \multirow{3}{*}{$\begin{array}{l}\text { Lower } \\
\text { San Andres } \\
\text { Unit } 3\end{array}$} & Carbonates & 6 & $13,137-21,750$ & 17,318 & 1 & 1,105 & 1,105 & 5 & $3.33-10.04$ & 6.88 & 5 & $0.20-0.29$ & 0.25 & 7 & $157-169$ & 163 \\
\hline & Anhydrites & & & & 1 & 106 & 106 & & & & & & & 2 & $171-181$ & 176 \\
\hline & Salts & 1 & 3,300 & 3,300 & & & & 1 & 3.29 & 3.29 & 1 & 0.17 & 0.17 & 1 & 140 & 140 \\
\hline Glorieta & Clastics & 6 & $3,882-6,685$ & 5,542 & & & & 2 & $3.86-6.90$ & 5.38 & 2 & $0.20-0.27$ & 0.24 & 2 & 153-155 & 154 \\
\hline
\end{tabular}

Source: Synthetic Geotechnical Design Reference Data for the Deaf Smith Site (DOE, 1986b)
* Note: No test results available for the Lower San Andres Unit 2 

discussion of the interpreted range for each property or parameter presented. The values in Table 2.2-4 are grouped according to the names of the overall stratigraphic formations and the lithologic classifications within each formation. For each formation and lithologic group, the table presents the number of test results or measurements that comprise the population sample for a given property, the range of test results or measurements obtained, and the mean value for that property.

Data on triaxial compression were obtained from the SGDRD (DOE, 1986b) whereas direct shear testing data were obtained from laboratory test reports prepared by Stone and Webster Engineering Corporation (SWEC, 1984g, h; 1985a, b; 1987a). The approaches used to interpret the test results and to develop triaxial compressive strength and direct shear strength parameters for design purposes are described in Section 2.3.2.3.

Stone and Webster (SWEC) conducted five in situ stress tests in the Holtzclaw well using the hydraulic fracturing technique (Borjeson and Lamb, 1987). Results of these tests are presented in Table 2.2-5. One test was conducted in the LSA 4 salt, one in the LSA 5 salt, and three in nonsalt strata. Four of the tests were considered successful. Section 2.2.3.3.4 contains a discussion of the interpretation of somewhat high minimum horizontal stresses presented in Table 2.2-5 for the LSA 4 and LSA 5 salt strata. Chapter 3 of the EA (DOE, 1986a) discusses other sources of information regarding regional in situ stress fields within Texas and adjacent states.

\subsubsection{Thermal Properties - Strata Above Repository Horizon}

Data on the thermal properties of rocks that overlie the host salt stratum are required for thermal and thermomechanical analyses of the far-field or repository scale effects generated from emplaced waste. Ranges of results of thermal tests reported by Durham, et al., (1987) for nonsalt rocks are summarized in Table 2.2-6. Conductivity, thermal diffusivity, and coefficient of thermal expansion were measured. According to the measurements reported in Table 2.2-6, these properties generally showed negative temperature dependence, and only 
Table 2.2-5. Summary of In Situ Stress Test Results, Holtzclaw We11 (a)

\begin{tabular}{|c|c|c|c|c|c|c|c|c|}
\hline $\begin{array}{l}\text { Formation } \\
\text { (Rock Type) }\end{array}$ & $\begin{array}{l}\operatorname{Depth}(e) \\
(\mathrm{ft})\end{array}$ & $\frac{\text { Vertical stress }}{(\text { psi) }}$ & $\frac{\text { Horizonta }}{\text { Min (psi) }}$ & $\frac{1 \text { Stress }}{\operatorname{Max}(p s i)}$ & $\begin{array}{l}\sigma_{\mathrm{v}} / \text { Depth } \\
\text { (psi/ft) }\end{array}$ & $\begin{array}{c}\sigma_{\text {HMin }} / \text { Depth } \\
(\text { psi/ft })\end{array}$ & $\begin{array}{c}\sigma_{\text {Hax }} / \text { Depth } \\
(\text { psi/ft })\end{array}$ & $\sigma_{\text {HMax }} / \sigma_{\text {Min }}$ \\
\hline $\begin{array}{l}\text { Queen/Grayburg } \\
\text { (siltstone) }\end{array}$ & $1,850-1,858.5$ & $1,835(\mathrm{~b})$ & $1,1,10$ & 1,260 & 0.99 & 0.60 & 0.68 & 1.14 \\
\hline $\begin{array}{l}\text { Upper San Andres } \\
\text { (Anhydrite) }\end{array}$ & $2,330-2,338.5$ & $2,335(b)$ & (d) & (d) & 1.00 & - & - & -- \\
\hline LSA 5 (Salt) & $2,430-2,438.5$ & $\begin{array}{l}2,445(b) \\
2,780(c)\end{array}$ & 2,915 & (d) & $\begin{array}{l}1.00 \\
1.14\end{array}$ & 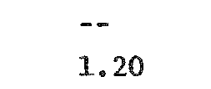 & - & -- \\
\hline $\operatorname{LSA} 4(\operatorname{SaIt})$ & $2,581-2,589.5$ & $\begin{array}{l}2,600(b) \\
2,950(c)\end{array}$ & 3,500 & (d) & $\begin{array}{l}1.01 \\
1.14\end{array}$ & 1.36 & -- & -- \\
\hline LSA 4 (Limestone) & $2,790-2,798.5$ & $2,810(b)$ & 1,940 & 2,650 & 1.01 & 0.69 & 0.95 & 1.37 \\
\hline
\end{tabular}

(a) Borjeson and Lamb, 1987.

(b) Weight of overburden by integrating Lithodensity Log.

(c) Calculated from hydraulic fracture data.

(d) Not determinable from the data obtained. Refer to Borjeson and Lamb, 1987.

(e) Depth of pressurized interval.

$$
\begin{aligned}
& \sigma_{\mathrm{v}}=\text { vertical stress } \\
& \sigma_{\text {HMin }}=\text { minimum horizontal stress } \\
& \sigma_{\text {HMax }}=\text { maximum horizontal stress }
\end{aligned}
$$


Table 2.2-6. Range of Thermal Property Measurements, J. Frienel Well

\begin{tabular}{|c|c|c|c|c|c|}
\hline Sample Description & $\begin{array}{c}\text { Thermal (a) } \\
\text { Conductivity } \\
(\mathrm{w} / \mathrm{m}-\mathrm{K})\end{array}$ & $\begin{array}{l}\text { Thermal(b) } \\
\text { Diffusivity } \\
\left(10^{-6} \mathrm{~m}^{2} / \mathrm{s}\right)\end{array}$ & $\begin{array}{c}\text { Assumed (c) } \\
\text { Rock Density } \\
\left(\mathrm{kg} / \mathrm{m}^{3}\right)\end{array}$ & $\begin{array}{c}\text { Calculated(d) } \\
\text { Specific } \\
\text { Heat } \\
(\mathrm{J} / \mathrm{kgK})\end{array}$ & $\begin{array}{c}\text { Coefficient(e) } \\
\text { of Thermal } \\
\text { Expansion } \\
\left(10^{-6} / \mathbb{K}\right)\end{array}$ \\
\hline
\end{tabular}

\begin{tabular}{|c|c|c|c|c|c|}
\hline $\begin{array}{l}\text { Anhydrite; } \\
\text { Upper San Andres Fm; } \\
2282 \mathrm{ft} \text { depth } \\
\text { from J. Friemel }\end{array}$ & $\begin{array}{l}4.63 \text { at } 100^{\circ} \mathrm{C}(7) * \\
5.41 \text { at } 29^{\circ} \mathrm{C}(6) *\end{array}$ & $\begin{array}{l}1.77 \text { at } 89^{\circ} \mathrm{C}(6) * \\
2.18 \text { at } 35^{\circ} \mathrm{C}(4) *\end{array}$ & 2,920 & $\begin{array}{l}920 \text { at } 89^{\circ} \mathrm{C}(5) * \\
840 \text { at } 35^{\circ} \mathrm{C}(5) *\end{array}$ & $\begin{array}{l}16.2 \text { at } 35^{\circ} \mathrm{C} \text { and } 3 \mathrm{MPa} \\
4.0 \text { at } 100^{\circ} \mathrm{C} \text { and } 3 \mathrm{MPa} \\
6.2 \text { at } 35^{\circ} \mathrm{C} \text { and } 30 \mathrm{MPa} \\
6.2 \text { at } 100^{\circ} \mathrm{C} \text { and } 30 \mathrm{MPa}\end{array}$ \\
\hline $\begin{array}{l}\text { Dolonite; } \\
\text { LSA } 5 \\
2500 \text { ft depth } \\
\text { from J. Friemel }\end{array}$ & $\begin{array}{l}2.33 \text { at } 100^{\circ} \mathrm{C}(6) * \\
2.63 \text { at } 29^{\circ} \mathrm{C}(5) *\end{array}$ & $\begin{array}{l}1.11 \text { at } 89^{\circ} \mathrm{C}(6) * \\
1.31 \text { at } 35^{\circ} \mathrm{C}(4) *\end{array}$ & 2,450 & $\begin{array}{l}870 \text { at } 89^{\circ} \mathrm{C}(5) * \\
820 \text { at } 35^{\circ} \mathrm{C}(5) *\end{array}$ & $\begin{array}{l}10.0 \text { at } 35^{\circ} \mathrm{C} \text { and } 3 \mathrm{MPa} \\
12.0 \text { at } 100^{\circ} \mathrm{C} \text { and } 3 \mathrm{MPa} \\
5.0 \text { at } 35^{\circ} \mathrm{C} \text { and } 30 \mathrm{MPa} \\
4.0 \text { at } 100^{\circ} \mathrm{C} \text { and } 30 \mathrm{MPa}\end{array}$ \\
\hline $\begin{array}{l}\text { Anhydrite; } \\
\text { Upper San Andres Fm; } \\
2289 \text { ft depth } \\
\text { from J. Friemel }\end{array}$ & $\begin{array}{l}4.11 \text { at } 100^{\circ} \mathrm{C}(6) * \\
5.39 \text { at } 29^{\circ} \mathrm{C}(6) *\end{array}$ & $\begin{array}{l}1.87 \text { at } 89^{\circ} \mathrm{C}(6) * \\
2.36 \text { at } 35^{\circ} \mathrm{C}(4) *\end{array}$ & 2,920 & $\begin{array}{l}790 \text { at } 89^{\circ} \mathrm{C}(5) * \\
770 \text { at } 35^{\circ} \mathrm{C}(5) *\end{array}$ & $\begin{array}{l}15.3 \text { at } 35^{\circ} \mathrm{C} \text { and } 3 \mathrm{MPa} \\
12.4 \text { at } 100^{\circ} \mathrm{C} \text { and } 3 \mathrm{MPa} \\
9.2 \text { at } 35^{\circ} \mathrm{C} \text { and } 30 \mathrm{MPa} \\
5.1 \text { at } 100^{\circ} \mathrm{C} \text { and } 30 \mathrm{MPa}\end{array}$ \\
\hline $\begin{array}{l}\text { Dolomite; } \\
\text { LSA } 4 ; \\
2748 \mathrm{ft} \text { depth } \\
\text { from J. Frieme1 }\end{array}$ & $\begin{array}{l}3.09 \text { at } 100^{\circ} \mathrm{C}(6) * \\
3.37 \text { at } 29^{\circ} \mathrm{C}(5)\end{array}$ & $\begin{array}{l}1.13 \text { at } 89^{\circ} \mathrm{C}(6) * \\
1.43 \text { at } 35^{\circ} \mathrm{C}(4) *\end{array}$ & 2,560 & $\begin{array}{c}1,080 \text { at } 89^{\circ} \mathrm{C}(5) * \\
920 \text { at } 35^{\circ} \mathrm{C}(5) *\end{array}$ & $\begin{array}{l}8 . \text { at } 35^{\circ} \mathrm{C} \text { and } 3 \mathrm{MPa} \\
12.8 \text { at } 100^{\circ} \mathrm{C} \text { and } 3 \mathrm{MPa} \\
2.1 \text { at } 35^{\circ} \mathrm{C} \text { and } 30 \mathrm{MPa} \\
7.9 \text { at } 100^{\circ} \mathrm{C} \text { and } 30 \mathrm{MPa}\end{array}$ \\
\hline
\end{tabular}

(a) Thermal conductivity values from Durham, et a1. (1987) Figure 15. Measurements conducted at temperature indicated.

(b) Thermal diffusivity values from Durhan, et al. (1987) Figure 16. Measurements conducted at temperature indicated.

(c) Rock density taken from Table $2.2-4$ and converted using $1,000 \mathrm{~kg} / \mathrm{m}^{3}=62.4$ pounds per cubic foot (pcf).

(d) Specific heat calculated by $A / E$ Contractor using range of thermal conductivity and thermal diffusivity measurements between $35^{\circ} \mathrm{C}$ and $89^{\circ} \mathrm{C}$ and the assumed value for rock density.

(e) Coefficient of thermal expansion values from Durham, et a1. (1987) Figure 11 . Measurements conducted at temperatures and confining pressures indicated.

* Numbers in parentheses denote the number of tests at each data point. 
coefficient of thermal expansion showed any dependence on confining pressure between 3 and $30 \mathrm{MPa}$. Table $2.2-6$ also presents the assumed density of tested rock samples (obtained from Table 2.2-4) and values of specific heat. The latter values were calculated based on the range of measurements of thermal conductivity and thermal diffusivity, and the assumed values for rock density.

The results in Table $2.2-6$ are limited to somewhat deep samples of anhydrite or dolomite within $300 \mathrm{ft}$ of the host salt stratum, LSA 4. Results of tests for salt lithologies are discussed in Section 2.2.3.4. Thermal testing of other lithologies overlying LSA 4 (such as siltstone, mudstone, claystone, and sandstone) have not been reported. The values reported in this section serve primarily to confirm values used in previous thermal analyses. Design thermal parameters used in the SCP-CDR for strata above ISA 4 are discussed in Section 2.3.2.5.

\subsubsection{Underground Data Base - Repository Horizon}

\subsubsection{Stratigraphy and Geology of Repository Horizon}

Overall, the LSA 4 unit consists of a lower sequence of microcrystalline dolomite, dolomitic limestone, and anhydrite, plus an upper sequence of fairly clean bedded salt. For purposes of the conceptual design, it was assumed that the repository underground facilities will be located within the bedded salt sequence (DOE, 1986a, EA, p. 3-19). As described in Section 2.2.2.1, three boreholes penetrating the ISA 4 salt were drilled in Deaf Smith County. These boreholes are located to the southeast of the proposed site. Seven other boreholes were drilled in nearby counties to the north, east, and southeast of Deaf Smith County. The locations of these ten boreholes are shown in plan in Figure 2.2-1. No boreholes have been drilled through the ISA 4 stratum to the west of the proposed site.

Detailed information documenting the depth, thickness, dip, and stratigraphy of the LSA 4 salt was obtained from Chapter 3 of the EA and from Hovorka, et a1., (1985). Figure 2.2-7 shows a detailed cross section of the LSA 4 salt corresponding to the Section $B-B^{\prime}$ location shown in Figure 2.2-1. Section $B-B^{\prime}$, obtained from Hovorka, et al., (1985) shows a fairly consistent thickness of 
the LSA 4 stratum across more than 100 miles. Within this region, the formation consists of a $150 \mathrm{ft}$ to $200 \mathrm{ft}$ thick stratum of sequential interbeds of salt and thin mudstone seams.

In the J. Friemel well, the SRP borehole located closest to the proposed site, the stratum is approximately $160 \mathrm{ft}$ thick and consists of halite, anhydrite, mudstone, and minor occurrences of other constituents. Halite is the dominant component at about $87 \%$ by volume; anhydrite is the next most prevalent component at about $4 \%$ by volume. Mudstone and other constituents, including dolomite and anhydrite, comprise the remaining $9 \%$ by volume. About half of the mudstone is disseminated within the salt and about half occurs as discrete mudstone beds. Hovorka, et al., (1985) identified 91 discrete mudstone beds in the J. Friemel core with an average thickness of 1.2 in and a maximum thick: ss of $18.5 \mathrm{in}$. Details of the LSA 4 stratum are discussed further in Sections 2.3.3.1, Stratigraphy and Geology Considered in Underground Design; 4.4, Underground Facility; and 7.3.1, Site Characteristics Affecting Design.

\subsubsection{Hydrogeology and Geochemistry of Repository Horizon}

Hydrogeologic data for the salt and dolomite of LSA 4 are summarized in Table 2.2-2. Results of hydraulic conductivity and permeability tests performed on salt were obtained from a literature review of permeability values for similar lithologies, laboratory gas permeability tests, and from field tests conducted in Permian salts in New Mexico. Hydraulic conductivity and permeability data for dolomites of the LSA 4 are based on drill-stem tests and pumping tests performed in deep exploratory holes.

Three values of potentiometric surface elevation are reported in the literature. They range from 3,500 to 3,800 ft above MSL (Table 2.2-2).

Geochemically, the LSA 4 contains small amounts of brine as fluid inclusions, water bound in hydrated minerals and clays and intergranular water in halite, and as pore water in mudstones and dolomites. Based upon the analysis of 50 samples of halite brines from various wells, the significant parameter appears to be a high concentration of magnesium (with a mean of $49,400 \mathrm{ppm}$ ), suggesting a long-time isolation from external waters (DOE, 1986a, EA, p. 3-108). The 
LSA 4 dolomite contains a brine that has a TDS concentration of about 400,000 ppm with major cations, as indicated in Table 2.2-3.

\subsubsection{Geomechanical Properties and In Situ Stress of Repository Horizon}

Geomechanical properties, obtained through laboratory testing of salt rock samples, are used to describe the strength, deformation, and creep characteristics of rock at the repository horizon. For purposes of this section, two strata, the ISA 4 and LSA 5 salts, were investigated. The assumed host stratum for the repository is the LSA 4 salt (DOE, 1986a, EA, p. 3-19). Results from LSA 5 salt were also investigated to provide a check as to the reasonableness of test results available for the LSA 4 salt. Laboratory test results were obtained from several sources. The test results and sources of the data are summarized in this section of the report. Interpretations and methods used to develop design geomechanical parameters from these data are discussed in Section 2.3.3.3.

\subsection{Compressive Strength. Two testing laboratories performed} uniaxial (unconfined) and triaxial (confined) compression tests on samples obtained from the two salt strata. RE/SPEC Inc. (RST) (under subcontract to Battelle-ONWI) and Applied Research Associates (ARA) (under subcontract to SWEC) conducted tests covering a range of temperatures and confining pressures. Summaries of the numbers and types of tests performed are shown in Tables $2.2-7$ and $2.2-8$, respectively.

ARA performed tests at room temperature only. RSI performed tests at five different temperatures for LSA 4 samples, and at four different temperatures for LSA 5 samples. However, as can be seen in the tables, often only one or two tests were performed for a given combination of confining pressure and temperature. Overall, RSI perfokued 23 compression tests on LSA 4 salt and 14 compression tests on LSA 5 salt; ARA performed 15 compression tests on LSA 4 salt and 13 compression tests on LSA 5 salt. The actual test results for the LSA 4 and LSA 5 salts, as well as the well names, sample depths, testing laboratories, and data references, are shown in Tables $2.2-9$ and $2.2-10$, respectively. The small number of compression test results that are available to form a representative data base creates a significant uncertainty in 
Table 2.2-7. Compression Tests Performed on LSA 4 Salt

\begin{tabular}{|c|c|c|c|c|c|c|c|c|c|c|}
\hline \multicolumn{11}{|c|}{ Confining Pressure psi } \\
\hline & 0 & 362.5 & 725 & 1000 & 1450 & 2000 & 2175 & 3000 & 3626 & \\
\hline $\begin{array}{c}\text { Test } \\
\text { Temperature }\end{array}$ & & & Number & of Tests & Perfo & rmed ( & $I-A R A)$ & & & Subtotal \\
\hline $68^{\circ} \mathrm{F}$ & $9-0$ & $1-0$ & $1-0$ & & $1=0$ & & $1-0$ & & & $13-0$ \\
\hline $75^{\circ} \mathrm{F}$ & $1-4$ & & $1-1$ & $0-1$ & $1-1$ & $0-4$ & $1-1$ & $0-2$ & $0-1$ & $4-15$ \\
\hline $122^{\circ} \mathrm{F}$ & $4-0$ & & & & & & & & & $4-0$ \\
\hline $212^{\circ} \mathrm{F}$ & & & & & $1-0$ & & & & & $1-0$ \\
\hline $392^{\circ} \mathrm{F}$ & & & & & $1-0$ & & & & & $1-0$ \\
\hline Totals & $14-4$ & $1-0$ & $2-1$ & $0-1$ & $4-1$ & $0-4$ & $2-1$ & $0-2$ & $0-1$ & $23-15$ \\
\hline
\end{tabular}

Note: 9-0 signifies 9 tests by RSI and zero tests by ARA.

Table 2.2-8. Compression Tests Performed on LSA 5 Salt

\begin{tabular}{|c|c|c|c|c|c|c|c|c|c|c|}
\hline \multicolumn{11}{|c|}{ Confining Pressure psi } \\
\hline & 0 & 362.5 & 725 & 1000 & 1450 & 2000 & 2175 & 3000 & -- & \\
\hline $\begin{array}{c}\text { Test } \\
\text { Temperature }\end{array}$ & \multicolumn{9}{|c|}{ Number of Tests Performed (RST-ARA) } & Subtotal \\
\hline $68^{\circ} \mathrm{F}$ & $2-0$ & $1-0$ & $1-0$ & & $1-0$ & & $1-0$ & & & $6-0$ \\
\hline $75^{\circ} \mathrm{F}$ & $1-5$ & & $1-0$ & $0-3$ & $1-0$ & $0-3$ & $1-0$ & $0-2$ & & $4-13$ \\
\hline $212^{\circ} \mathrm{F}$ & & & & & $2-0$ & & & & & $2-0$ \\
\hline $392^{\circ} \mathrm{F}$ & & & & & $2-0$ & & & & & $2-0$ \\
\hline Totals & $3-5$ & $1-0$ & $2-0$ & $0-3$ & $6=0$ & $0-3$ & $2-0$ & $0-2$ & - & $14-13$ \\
\hline
\end{tabular}

Note: 2-0 signifies 2 tests by RSI and zero tests by ARA. 
Table 2.2-9. Laboratory Test Results, ISA 4 Salt (Sheet 1 of 4 )

\begin{tabular}{|c|c|c|c|c|c|c|c|c|c|}
\hline We11 & $\begin{array}{l}\text { Sample } \\
\text { Depth } \\
\text { (ft) }\end{array}$ & $\begin{array}{l}\text { Testing(a) } \\
\text { Laboratory }\end{array}$ & $\begin{array}{l}\text { Sample(b) } \\
\text { Temperature } \\
\left({ }^{\circ} \mathrm{F}\right)\end{array}$ & $\begin{array}{l}\text { Confining } \\
\text { Pressure } \\
\text { (psi) }\end{array}$ & $\begin{array}{l}\text { Fallure } \\
\text { Strength } \\
\text { (psi) }\end{array}$ & $\begin{array}{l}\text { Static } \\
\text { Young's } \\
\text { Modu1us } 6 \text { ) } \\
\left(\text { psi. } \times 10^{6}\right)\end{array}$ & $\begin{array}{c}\text { Static } \\
\text { Poisson" } \mathrm{S} \\
\text { Ratio }\end{array}$ & $\begin{array}{l}\text { Indirect }(c) \\
\text { Tensile } \\
\text { Strength } \\
\text { (psi) }\end{array}$ & Reference \\
\hline Grabbe & $2,527.00$ & RSI & 75 & 0 & $3,204.5$ & 2.7550 & - & - & DOE, $1986 \mathrm{~b}$ \\
\hline Grabbe & $2,528.00$ & RST & 75 & $1,450.0$ & $8,888.5$ & 4.2195 & 0.32 & - & DOE, $1986 \mathrm{~b}$ \\
\hline Grabbe & $2,580.00$ & RSI & 75 & $2,175.0$ & $7,250.0$ & 3.6105 & 0.38 & - & DOF, $1986 \mathrm{~b}$ \\
\hline Grabbe & $2,581.00$ & RSI & 75 & 725.0 & $6,684.5$ & 3.9585 & 0.41 & - & DOE, $1986 \mathrm{~b}$ \\
\hline Grabbe & $2,582.01$ & RSI & 75 & - & - & - & - & 159.5 & DOE, $1986 \mathrm{~b}$ \\
\hline J. Friemel & $2,630.00$ & RST & 68 & 0 & $3,929.5$ & 3.7120 & - & - & $\mathrm{DOE}, 1986 \mathrm{~b}$ \\
\hline J. Frieme I & $2,604.00$ & RSI & 68 & 0 & $3,813.5$ & 3.3205 & - & - & DOE, $1986 \mathrm{~b}$ \\
\hline J. Frieme1 & $2,665.00$ & RSI & 68 & 0 & $4,045.5$ & 3.6540 & - & - & DOE, $1986 \mathrm{~b}$ \\
\hline J. Frieme1 & $2,685.00$ & RSI & 68 & 0 & $4,959.0$ & 4.0165 & - & - & DOE, $1986 \mathrm{~b}$ \\
\hline Zeeck & $2,811.00$ & RSI & 68 & $2,175.0$ & $9,280.0$ & 4.1035 & 0.28 & - & $\mathrm{DOE}, 1986 \mathrm{~b}$ \\
\hline Zeeck & $2,811.01$ & RSI. & 68 & - & - & - & - & 290.0 & DOE, $1986 \mathrm{~b}$ \\
\hline Zeeck & $2,814.00$ & RSI & 68 & $1,450.0$ & $8,845.0$ & 4.2195 & 0.33 & - & DOE, 1986b \\
\hline Zeeck & $2,814.01$ & $\mathrm{RSI}$ & 68 & - & - & - & - & 246.5 & DOE, $1986 \mathrm{~b}$ \\
\hline Zeeck & $2,814.02$ & RSI & 68 & - & - & - & - & 159.5 & DOE, $1986 \mathrm{~b}$ \\
\hline zeeck & $2,861.00$ & RSI & 68 & 725.0 & $7,830.0$ & 4.2050 & 0.30 & - & DOE, $1986 \mathrm{~b}$ \\
\hline Zeeck & $2,890.00$ & RSI & 68 & 0 & $4,930.0$ & 3.9150 & - & - & $\mathrm{DOE}, 1986 \mathrm{~b}$ \\
\hline Zeeck & $2,890.00$ & RST & 68 & - & - & - & - & 174.0 & Appendix D \\
\hline Zeeck & $2,894.00$ & RSI & 68 & 362.5 & $5,655.0$ & 3.8425 & 0.27 & - & DOE, $1986 \mathrm{~b}$ \\
\hline
\end{tabular}


Table 2.2-9 (Sheet 2 of 4 )

\begin{tabular}{|c|c|c|c|c|c|c|c|c|c|}
\hline We11 & $\begin{array}{l}\text { Sample } \\
\text { Depth } \\
\text { (ft) }\end{array}$ & $\begin{array}{l}\text { Testing(a) } \\
\text { Laboratory }\end{array}$ & $\begin{array}{l}\text { Sample (b) } \\
\text { Temperature } \\
\left({ }^{\circ} \mathrm{F}\right)\end{array}$ & $\begin{array}{l}\text { Confining } \\
\text { Pressure } \\
\text { (psi) }\end{array}$ & $\begin{array}{l}\text { Failure } \\
\text { Strength } \\
\text { (psi) }\end{array}$ & $\begin{array}{c}\text { Static } \\
\text { Young's } \\
\text { Modu1us } \\
\left(\text { psi. } \times 10^{6}\right)\end{array}$ & $\begin{array}{l}\text { Static } \\
\text { Poisson's } \\
\text { Ratio }\end{array}$ & $\begin{array}{l}\text { Indirect(c) } \\
\text { Tensile } \\
\text { Strength } \\
\text { (psi) }\end{array}$ & Reference \\
\hline Zeeck & $2,901.00$ & RSI & 68 & 0 & $3,915.0$ & 3.9295 & - & - & DOE, $1986 \mathrm{~b}$ \\
\hline Zeeck & $2,901.01$ & RSI & 68 & 0 & $3,915.0$ & 1.8560 & - & - & DOE, $1986 \mathrm{~b}$ \\
\hline Zeeck & $2,901.30$ & RSI & 68 & - & - & - & - & 246.5 & Appendix D \\
\hline Zeeck & $2,907.00$ & RSI & 68 & 0 & $5,220.0$ & 3.9585 & - & - & DOE, $1986 \mathrm{~b}$ \\
\hline Zeeck & $2,907.01$ & RSI & 68 & 0 & $4,495.0$ & 4.2485 & - & - & DOE, $1986 \mathrm{~b}$ \\
\hline J. Friemel & $2,606.00$ & RSI & 122 & 0 & $4,205.0$ & 3.5235 & - & - & Appendix $E$ \\
\hline J. Frienel & $2,632.00$ & RSI & 122 & 0 & $3,755.5$ & 3.0160 & - & - & Appendix $\mathbf{E}$ \\
\hline J. Frieme1 & $2,662.00$ & RSI & 122 & 0 & 4.451 .5 & 3.7845 & - & - & Appendix $E$ \\
\hline J. Frieme1 & $2,688.00$ & RSI & 122 & 0 & $3,842.5$ & 3.3060 & - & - & Appendix E \\
\hline Grabbe & $2,581.00$ & RSI & 212 & $1,450.0$ & $5,234.5$ & 3.1900 & 0.33 & - & Appendix D \\
\hline Rexwhite & $1,877.50$ & RSI & 392 & $1,450.0$ & $2,682.5$ & 3.2190 & 0.30 & - & Appendix D \\
\hline Rexwhite & $1,878.00$ & RSI & 75 & - & - & - & - & 348.0 & Appendix D \\
\hline Detten & $2,664.20$ & ARA & 75 & 0 & $2,575.0$ & 4.9200 & 0.31 & - & DOE, $1986 \mathrm{~b}$ \\
\hline Detten & $2,673.10$ & ARA & 75 & $2,000.0$ & $5,253.0$ & 4.1500 & 0.26 & - & DOE, $1986 \mathrm{~b}$ \\
\hline G. Friemel & $2,528.30$ & ARA & 75 & 0 & $4,222.0$ & 2.5700 & 0.43 & - & DOE, $1986 \mathrm{~b}$ \\
\hline J. Frieme1 & $2,567.70$ & ARA & 75 & 725.2 & $3,315.0$ & 4.4000 & 0.14 & - & DOE, $1986 \mathrm{~b}$ \\
\hline J. Friemel & $2,607.10$ & ARA & 75 & $3,626.0$ & $3,585.0$ & 4.2400 & 0.14 & - & DOE, $1986 \mathrm{~b}$ \\
\hline
\end{tabular}


Table 2.2-9 (Sheet 3 of 4)

\begin{tabular}{|c|c|c|c|c|c|c|c|c|c|}
\hline We11 & $\begin{array}{l}\text { Sample } \\
\text { Depth } \\
\text { (ft })\end{array}$ & $\begin{array}{l}\text { Testing(a) } \\
\text { Laboratory }\end{array}$ & $\begin{array}{l}\text { Sample (b) } \\
\text { Temperature } \\
\text { (०F) }\end{array}$ & $\begin{array}{l}\text { Confining } \\
\text { Pressure } \\
\text { (psi) }\end{array}$ & $\begin{array}{l}\text { Failure } \\
\text { Strength } \\
\text { (psi) }\end{array}$ & $\begin{array}{c}\text { Static } \\
\text { Young's } \\
\text { Modulus } \\
\left(\text { psi } \times 10^{6}\right)\end{array}$ & $\begin{array}{l}\text { Static } \\
\text { Poisson's } \\
\text { Ratio }\end{array}$ & $\begin{array}{l}\text { Indirect(c) } \\
\text { Tensile } \\
\text { Strength } \\
\text { (psi) }\end{array}$ & Reference \\
\hline J. Frieme1 & $2,642.00$ & ARA & 75 & $2,176.0$ & $4,190.0$ & 4.3500 & 0.14 & - & $\mathrm{DOE}, 1986 \mathrm{~b}$ \\
\hline J. Frieme1 & $2,704.20$ & ARA & 75 & $1,450.0$ & $3,780.0$ & 4.0300 & 0.26 & - & DOE, $1986 \mathrm{~b}$ \\
\hline Harman & $2,656.90$ & ARA & 75 & $3,000.0$ & $3,900.0$ & 3.7000 & 0.28 & - & DOE, $1986 \mathrm{~b}$ \\
\hline Harman & $2,661.80$ & ARA & 75 & $2,000.0$ & $3,470.0$ & 3.4500 & 0.30 & - & DOE, $1986 \mathrm{~b}$ \\
\hline Harman & $2,678.00$ & ARA & 75 & $1,000.0$ & $3,300.0$ & 5.1000 & 0.21 & - & DOE, $1986 \mathrm{~b}$ \\
\hline Harman & $2,691.20$ & ARA & 75 & $3,000.0$ & $3,060.0$ & 5.7500 & 0.28 & - & $\mathrm{DOE}, 1986 \mathrm{~b}$ \\
\hline Harman & $2,703.50$ & ARA & 75 & 0 & $2,350.0$ & 4.1700 & 0.26 & - & DOE, $1986 \mathrm{~b}$ \\
\hline HoItzclaw & $2,591.60$ & ARA & 75 & $2,000.0$ & $2,800.0$ & 4.3900 & 0.21 & - & DOE, $1986 \mathrm{~b}$ \\
\hline Holtzclaw & $2,607.20$ & ARA & 75 & $2,000.0$ & $3,200.0$ & 3.4200 & 0.21 & - & DOE, $1986 b$ \\
\hline Holtzclaw & $2,633.20$ & ARA & 75 & 0 & $3,750.0$ & 4.9500 & 0.28 & - & DOE, $1986 \mathrm{~b}$ \\
\hline Detten & $2,665.01$ & SWEC & 75 & - & - & - & - & 222.0 & DOE, $1986 \mathrm{~b}$ \\
\hline Detten & $2,668.41$ & SWEC & 75 & - & - & - & - & 209.0 & DOE, $1986 \mathrm{~b}$ \\
\hline Holtzclaw & $2,578.60$ & SWEC & 75 & - & - & - & - & 252.0 & DOE, $1986 \mathrm{~b}$ \\
\hline Holtzclaw & $2,583.80$ & SWEC & 75 & - & - & - & - & 205.0 & DOE, $1986 \mathrm{~b}$ \\
\hline Holtzclaw & $2,587.90$ & SWEC & 75 & - & - & - & - & 224.0 & DOE, $1986 \mathrm{~b}$ \\
\hline Holtzclaw & $2,618.40$ & SWEC & 75 & - & - & - & - & 200.0 & DOE, $1986 \mathrm{~b}$ \\
\hline Holtzclaw & $2,653.20$ & SWEC & 75 & - & - & - & - & 234.0 & DOE, $1986 \mathrm{~b}$ \\
\hline
\end{tabular}


Table $2.2-9$ (Sheet 4 of 4 )

\begin{tabular}{|c|c|c|c|c|c|c|c|c|c|}
\hline We 11 & $\begin{array}{l}\text { Sample } \\
\text { Depth } \\
\text { (ft) }\end{array}$ & $\begin{array}{l}\text { Testing(a) } \\
\text { Laboratory }\end{array}$ & $\begin{array}{l}\text { Sample(b) } \\
\text { Temperature } \\
\text { (०F) }\end{array}$ & $\begin{array}{l}\text { Confining } \\
\text { Pressure } \\
\text { (psi) }\end{array}$ & $\begin{array}{l}\text { Failure } \\
\text { Strength } \\
\text { (psi) }\end{array}$ & $\begin{array}{c}\text { Static } \\
\text { Young's } \\
\text { Modulus } 6) \\
\left(\text { psi } \times 10^{6}\right)\end{array}$ & $\begin{array}{l}\text { Static } \\
\text { Poisson's } \\
\text { Ratio }\end{array}$ & $\begin{array}{l}\text { Indirect }(c) \\
\text { Tensile } \\
\text { Strength } \\
\text { (psi) }\end{array}$ & Reference \\
\hline J. Frieme 1 & $2,638.30$ & SWEC & 75 & - & - & - & - & 265.0 & DOE, $1986 \mathrm{~b}$ \\
\hline J. Frieme1 & $2,671.30$ & SWEC & 75 & - & - & - & - & 295.0 & $\mathrm{DOE}, 1986 \mathrm{~b}$ \\
\hline
\end{tabular}

(a) Testing Laboratory

ARA - Applied Research Assoc., Inc. Tests conducted at constant strain rate of $10^{-6} / \mathrm{s}$

RSI - RE/SPEC Inc. Compression tests conducted at constant stress rate of $0.025 \mathrm{MPa} / \mathrm{S}$. Tensile test rate variable.

SWEC - Stone \& Webster Engineering Corporation. Tensile test rate variable.

(b) AII ARA and SWEC tests were conducted at room temperature. The temperature of $75^{\circ}$ is assumed,

(c) Indirect tensile strength measured by the Brazilian test method. 
Table 2.2-10. Laboratory Test Results, ISA 5 Salt (Sheet 1 of 3)

\begin{tabular}{|c|c|c|c|c|c|c|c|c|c|}
\hline & $\underset{(\mathrm{ft})}{\text { Sample }}$ & Testing(a) & $\underset{\left({ }^{\circ} \mathrm{F}\right)}{\text { Sample(b) }}$ & $\begin{array}{c}\text { Confining } \\
\text { (psi) }\end{array}$ & $\begin{array}{c}\text { Failure } \\
\text { (psi) }\end{array}$ & $\begin{array}{c}\text { Static } \\
\text { Young } \\
\left(\operatorname{psi}^{\prime} \mathrm{x}^{6}\right)\end{array}$ & $\begin{array}{l}\text { Static } \\
\text { Poisson's }\end{array}$ & $\begin{array}{l}\text { Indirect(c) } \\
\text { Tensile } \\
\text { (psi) }\end{array}$ & \\
\hline Mansfield & $1,463.00$ & RSI & 75 & - & - & - & - & 217.5 & DOE, $1986 \mathrm{~b}$ \\
\hline Mansfield & $1,464.00$ & RSI & 75 & - & - & - & - & 188.5 & $\mathrm{DOE}, 1986 \mathrm{~b}$ \\
\hline Mansfield & $1,466.00$ & RSI & 75 & 725.0 & $7,322.5$ & 4.1325 & 0.34 & - & DOE, $1986 \mathrm{~b}$ \\
\hline Mansfield & $1,474.00$ & RSI & 75 & 0 & $3,509.0$ & 3.5090 & - & - & DOE, $1986 \mathrm{~b}$ \\
\hline Mansfield & $1,474.01$ & RSI & 75 & - & - & - & - & 290.0 & DOE, $1986 \mathrm{~b}$ \\
\hline Mansfield & $1,478.00$ & RSI & 75 & $2,175.0$ & $9,062.5$ & 4.8430 & 0.35 & - & DOE, $1986 \mathrm{~b}$ \\
\hline Mansfield & $1,479.00$ & RSI & 75 & $1,450.0$ & $7,989.5$ & 4.3065 & 0.34 & - & DOE, $1986 \mathrm{~b}$ \\
\hline Detten & $2,414.00$ & RSI & 68 & 725.0 & $8,410.0$ & 4.2195 & 0.24 & - & DOE, $1986 \mathrm{~b}$ \\
\hline Detten & $2,414.01$ & RSI & 68 & - & - & - & - & 275.5 & DOR, $1986 \mathrm{~b}$ \\
\hline Detten & $2,446.00$ & RST & 68 & 0 & $4,930.0$ & 3.9875 & - & - & DOE, $1986 \mathrm{~b}$ \\
\hline Detten & $2,446.10$ & RSI & 68 & 0 & $5,365.0$ & 4.0165 & - & - & $\mathrm{DOE}, 1.986 \mathrm{~b}$ \\
\hline Detten & $2,450.00$ & RST & 68 & $2,175.0$ & $9,425.0$ & 4.5095 & 0.26 & - & DOE, $1986 \mathrm{~b}$ \\
\hline Detten & $2,450.01$ & RSI & 68 & - & - & - & - & 261.0 & DOE, $1986 \mathrm{~b}$ \\
\hline Detten & $2,464.0$ & RSI & 68 & 362.5 & $5,220.0$ &.$\quad .55$ & 0.26 & - & DOE, $1986 \mathrm{~b}$ \\
\hline Detten & $2,466.0$ & RSI & 68 & $1,450.0$ & $8,555.0$ & 4.3790 & 0.26 & - & DOE, $1986 \mathrm{~b}$ \\
\hline Detten & $2,451.0$ & RST & 212 & $1,450.0$ & $5,365.0$ & 4.3355 & 0.41 & - & $\begin{array}{l}\text { Senseny et a1., } \\
(1985), \text { p. } 76\end{array}$ \\
\hline Detten & $2,451.01$ & RSI & 68 & - & - & - & - & 145.0 & DOE, $1986 \mathrm{~b}$ \\
\hline Detten & $2,456.0$ & RSI & 392 & $1,450.0$ & $2,900.0$ & 3.8860 & 0.42 & - & $\begin{array}{l}\text { Senseny et a1., } \\
(1985), \text { p. } 76\end{array}$ \\
\hline
\end{tabular}


Table 2.2-10 (Sheet 2 of 3 )

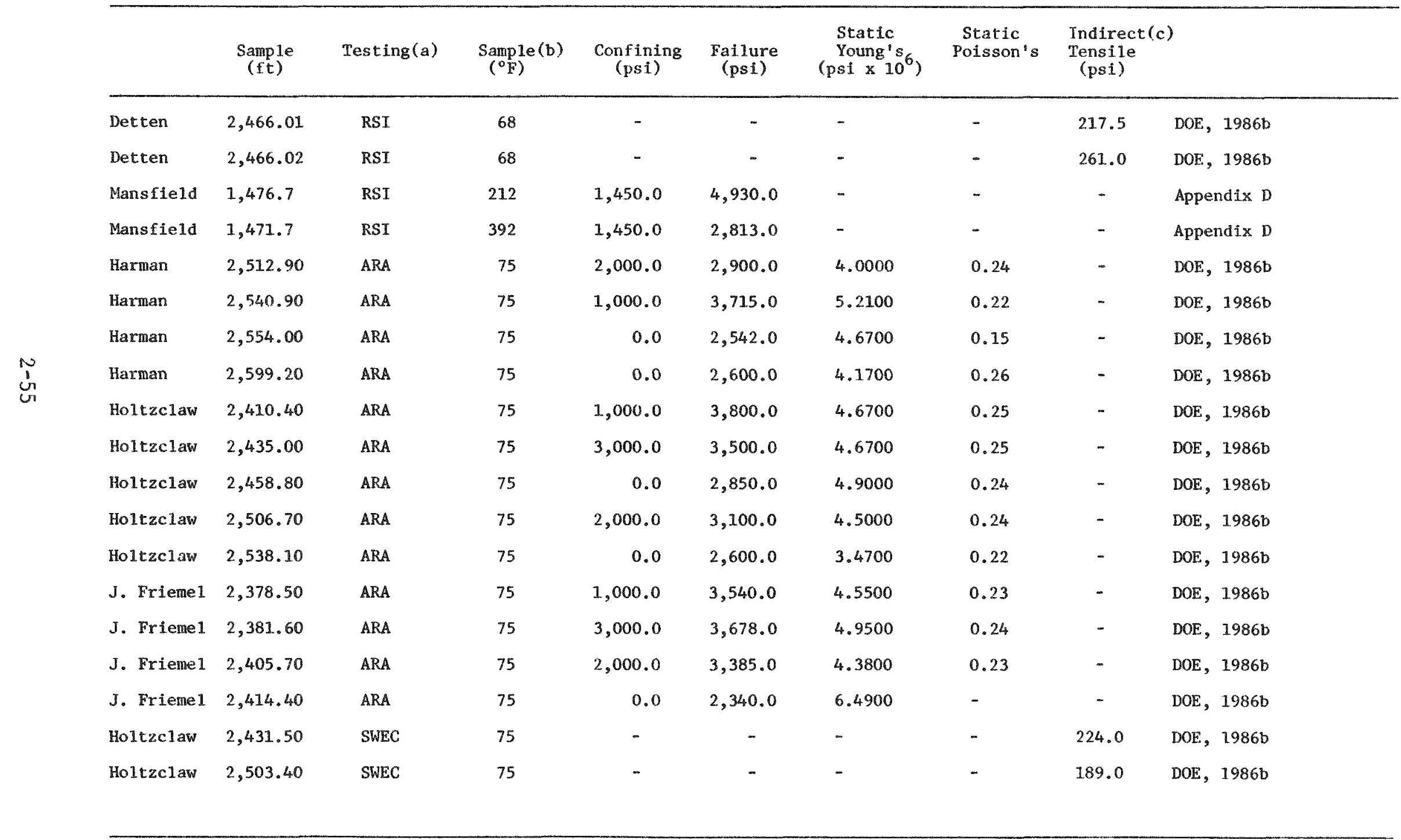


Table $2,2-10$ (Sheet 3 of 3 )

\begin{tabular}{|c|c|c|c|c|c|c|c|c|c|}
\hline & $\begin{array}{c}\text { Sample } \\
(\mathrm{ft})\end{array}$ & Testing(a) & $\underset{\left({ }^{\circ} \mathrm{F}\right)}{\operatorname{Sample}(\mathrm{b})}$ & $\begin{array}{l}\text { Confining } \\
\text { (psi) }\end{array}$ & $\begin{array}{l}\text { Fallure } \\
\text { (psi) }\end{array}$ & $\begin{array}{c}\text { Static } \\
\text { Young's } \\
\left(\text { psi } \times 10^{6}\right)\end{array}$ & $\begin{array}{c}\text { Static } \\
\text { Poisson's }\end{array}$ & $\begin{array}{l}\text { Indirect(c) } \\
\text { Tensile } \\
\text { (psi) }\end{array}$ & \\
\hline Holtzclaw & $2,511.40$ & SWEC & 75 & - & - & - & - & 273.0 & DOE, $1986 \mathrm{~b}$ \\
\hline J. Frieme1 & $2,456.50$ & SWEC & 75 & - & - & - & - & 140.0 & DOE, 1986b \\
\hline
\end{tabular}

(a) Testing Laboratory

ARA - Applied Research Assoc., Inc. Tests conducted at a constant strain rate of $10^{-6} / \mathrm{S}$.

RSI - RE/SPEC, Inc. Compression tests conducted a constant stress rate of $0.025 \mathrm{MPa} / \mathrm{S}$. Tensile test-rate variable.

SWEC - Stone \& Webster Engineering Corporation. Tensile test-rate variable.

(b) AII ARA and SWEC tests were conducted at room temperature. The temperature of $75^{\circ}$ is assumed.

(c) Indirect tensile strength measured by the Brazilian test method. 
uncertainty in selecting appropriate design strength values. This required a fairly conservative selection of design values.

\subsection{Other Quasi-Static Properties. Tables $2.2-9$ and 2.2-10 also} summarize values of static Young's modulus, static Poisson's ratio, and indirect tensile strength. The latter was determined by the Brazilian test method. The Young's modulus and Poisson's ratio will be determined by dynamic methods in future designs. None were available, nor were any used, for the conceptual design.

2.2.3.3.3 Creep Parameters. Salt exhibits significant time dependent (or creep) deformation, especially at elevated temperatures. For the purposes of this conceptual design report, an exponential-time creep law was assumed to be an acceptable representation of the transient (or primary) and steady-state (or secondary) creep deformation of salt. The results of creep tests using the exponential-time creep law are presented in three different references. One reference, Pfeifle, et al., (1983), provides the results of three creep tests each for the LSA 4 and ISA 5 salts, including stress differentials up to $10 \mathrm{MPa}$ and temperatures up to $200^{\circ} \mathrm{C}$, and presents creep law coefficients based on each set of tests. A second reference, Senseny, et al., (1986), reports the results of 12 additional tests for LSA 4 salt, including stress differentials up to $15 \mathrm{MPa}$ and temperatures up to $200^{\circ} \mathrm{C}$, and provides a new set of creep coefficients for those 12 tests. Similarly, Senseny, et al., (1985) reports the results of 12 additional tests for the LSA 5 salt, including stress differentials to $15 \mathrm{MPa}$ and temperatures up to $200^{\circ} \mathrm{C}$, and provides a new set of coefficients based on those tests. The creep parameters reported for the LSA 4 and LSA 5 strata are shown in Table 2.2-11. Interpretations of these data are presented in Section 2.3.3.3.3.

There are uncertainties about the time-dependent deformational behavior of salt strata at the Deaf Smith County site. Constitutive relations in the form of mathematical equations have been developed by fitting creep deformation data collected in the laboratory with theoretical equations. However, few creep tests have been conducted to date, and the predictions about the creep behavior of salt strata in situ, that is, in an underground mine, have not 
Table 2.2-11. Creep Coefficients for LSA 4 and LSA 5 Salt

\begin{tabular}{|c|c|c|c|c|c|c|c|c|}
\hline \multirow{3}{*}{$\begin{array}{l}\text { Salt } \\
\text { Stratum }\end{array}$} & \multicolumn{3}{|c|}{ Steady-State Creep(a) } & \multicolumn{4}{|c|}{ Transient Creep(b) } & \multirow{2}{*}{ Reference } \\
\hline & A & $\mathrm{n}$ & $Q / R$ & $\dot{\varepsilon}_{\mathrm{ss}}^{*}$ & & $\varepsilon_{\mathrm{a}}$ & B & \\
\hline & $\mathrm{MPa}^{-\mathrm{n}} \cdot \mathrm{s}^{-1}$ & - & ${ }^{\circ} \mathrm{K}$ & $\mathrm{S}^{-1}$ & & - & - & Conments \\
\hline LSA 4 & $4.66 \times 10^{-3}$ & 4.60 & 8,660 & $5.0 \times 10^{-8}$ & 3.97 & $\times 10^{-2}$ & 82 & $\begin{array}{l}\text { Pfeifle, et al., Based on } 3 \text { tests. } \\
\text { (1983) p. } 42\end{array}$ \\
\hline LSA 4 & $6.50 \times 10^{-3}$ & 5.50 & 9,770 & $1.6 \times 10^{-8}$ & 6.80 & $\times 10^{-2}$ & 88 & $\begin{array}{l}\text { Senseny, et a1., Based on } 12 \text { tests. } \\
(1986) \text { p.22(c) }\end{array}$ \\
\hline LSA 5 & $1.93 \times 10^{-4}$ & 4.15 & 7,154 & $5.0 \times 10^{-8}$ & 5.50 & $\times 10^{-2}$ & 180 & $\begin{array}{l}\text { Pfeifle, et a1., Based on } 3 \text { tests. } \\
\text { (1983) p.42 }\end{array}$ \\
\hline LSA 5 & $8.00 \times 10^{-3}$ & 5.30 & 9,810 & $4.1 \times 10^{-8}$ & 3.90 & $\times 10^{-2}$ & 96 & $\begin{array}{l}\text { Senseny, et al., Based on } 12 \text { tests. } \\
(1985) \text { p. } 42(\mathrm{c})\end{array}$ \\
\hline
\end{tabular}
(a) A, $n, Q / R$ are parameters in the steady-state creep law relating the steady-state creep rate $\varepsilon_{\text {ss }}$ to
axial stress difference $\sigma$ and the absolute temperature $T$ :

$$
\dot{\varepsilon}_{s s}=A \sigma^{n} \exp (-Q / R T)
$$

(b) ${ }^{*} \varepsilon_{\mathrm{ss}}, \varepsilon_{\mathrm{a}}$, and $\mathrm{B}$ are stress and temperature dependent inelastic deformation parameters in the equation relating total creep $\varepsilon_{c}$ to time $t$ :

$$
\begin{array}{ll}
\varepsilon_{c}=\dot{\varepsilon}_{s s}\left(t+\varepsilon_{a} / \dot{\varepsilon}_{s s}^{*}\left[1-\exp \left(-B \dot{\varepsilon}_{s s}^{*} t\right)\right]\right) & \text { for } \dot{\varepsilon}_{s s} \leqq \dot{\varepsilon}_{s s}^{*} \\
\varepsilon_{c}=\dot{\varepsilon}_{s s} t+\varepsilon_{a}\left[1-\exp \left(-B \dot{\varepsilon}_{s s} t\right)\right] & \text { for } \dot{\varepsilon}_{s s} \geqq \dot{\varepsilon}_{s s}^{*}
\end{array}
$$

(c) Creep parameters used in design (SGDRD, DOE, 1986b). 
been validated by actual observations. Hence, there are uncertainties about the constitutive equations themselves as well as the numerical values of the creep parameters, which are mathematical constants in the constitutive equations. Observations of creep closure of openings at the Waste Isolation Pilot Plant (WIPP) mine over the last several years (Bechtel, 1985) provide a preliminary basis for modifying and validating the creep models. Moreover, the effect of the interbeds, especially the mudstone seams, on the creep behavior of salt has not been studied. Extensive laboratory and field work on the creep properties of salt is to be performed during site characterization. Because of the limited data available, conservative values for these parameters were used in design.

\subsection{In Situ Stress at Repository Horizon. A discussion of in situ} stresses for strata overlying the LSA 4 is presented in Section 2.2.2.3. Two tests were conducted in salt strata, one each in LSA 4 and LSA 5 . The test data show the minimum in situ horizontal stresses 20 to 36 percent greater than the vertical, lithostatic pressure. Given the plastic nature of salt and the geologic age of the salt bed, a minimum horizontal stress so much in excess of the vertical lithostatic pressure appears questionable. In this respect, laboratory experiments by Boyce, et al., (1984) identify some difficulties in conventional interpretations of hydraulic fracturing tests carried out in salt. Conventional analysis of hydraulic fracturing tests appears to be capable of assessing minimum horizontal stress within approximately 15 percent. However, if the anisotropy of stress conditions is very large, conventional analysis may overestimate the minimum stress by as much as 60 percent. It is therefore relevant that, although salt is a viscoplastic material, at least small stress anisotropy, up to $2 \mathrm{MPa}$, has been assessed in natural salt samples based on laboratory measurements of present subgrain size (Carter and Hansen, 1983). Since the Boyce, et al., (1984) laboratory measurements of minimum stress were 15 percent more than applied stresses for strictly isotropic stress conditions, an overestimate of 20 to 36 percent might conceiveably arise from an anisotropic stress condition on the order of only $2 \mathrm{MPa}$. Based on these considerations, the salt strata test results as reported in Table 2.2-5 have been interpreted as possibly being influenced by some stress anisotropy. Nevertheless, stress conditions within these salt strata can be assumed approximately lithostatic (equal to overburden pressure) and isotropic for present design purposes. 
Because of the tectonic stability of the site, uncertainties about the in situ stress are not considered to be significant. The ratios of the two horizontal stresses to the vertical stress may vary to some degree from formation to formation. These stresses will be measured during site characterization.

\subsubsection{Thermal Properties of Repository Horizon}

Thermal conductivity measurements of salt have been reported by Tammemagi, et al., (1986), and are reproduced as Figure 2.2-8. As can be seen in this figure, thermal conductivity measurements vary by nearly a factor of two over the temperature range of $50^{\circ} \mathrm{C}$ to $150^{\circ} \mathrm{C}$. Recent data by Durham, et a1., (1987), further corroborate the variance of conductivity measurements on Permian Basin core samples ranging between 3.5 Watts/meter degree Kelvin (W/mK) and $6.7 \mathrm{~W} / \mathrm{mK}$ at $50^{\circ} \mathrm{C}$, and between $3.4 \mathrm{~W} / \mathrm{mK}$ and $5.4 \mathrm{~W} / \mathrm{mK}$ at $100^{\circ} \mathrm{C}$. Similar scatter in diffusivity is reported by Durham, et al., (1987), of 0.6 to $3.9 \times 10^{-6} \mathrm{~m}^{2} / \mathrm{s}$ at $50^{\circ} \mathrm{C}$ and 0.4 to $3.6 \times 10^{-6} \mathrm{~m}^{2} / \mathrm{s}$ at $100^{\circ} \mathrm{C}$. Thermal expansion of salt, as measured by Lagedrost and Capps (1983) ranged from 37 to $49 \times 10^{-6} / \mathrm{K}$, while measurements by Durham, et a1., (1987) ranged from 33 to $38 \times 10^{-6} / \mathrm{K}$. Durham, et al., (1987) reported that thermal expansion of salt appeared to be independent of test temperature and confining pressure.

Uncertainties about data on thermal properties are generally due to the limited number of tests done to date and to the fact that the data are not site specific. No quantification of the expected range can be made at this time.

The thermal property measurements on dolomite and anhydrite samples (Table 2.2-6) reported in Section 2.2 .2 .4 are the best available information on non-salt rocks in the vicinity of the repository horizon.

\subsubsection{Active and Potential Geologic and Hydrologic Processes}

If present at the site, processes such as volcanism, uplift/subsidence, faulting, salt dissolution, radical climatic and hydrologic changes, and diapirism could significantly impact design. Except for salt dissolution, none of these processes appear to be present at the site or to have a significant 


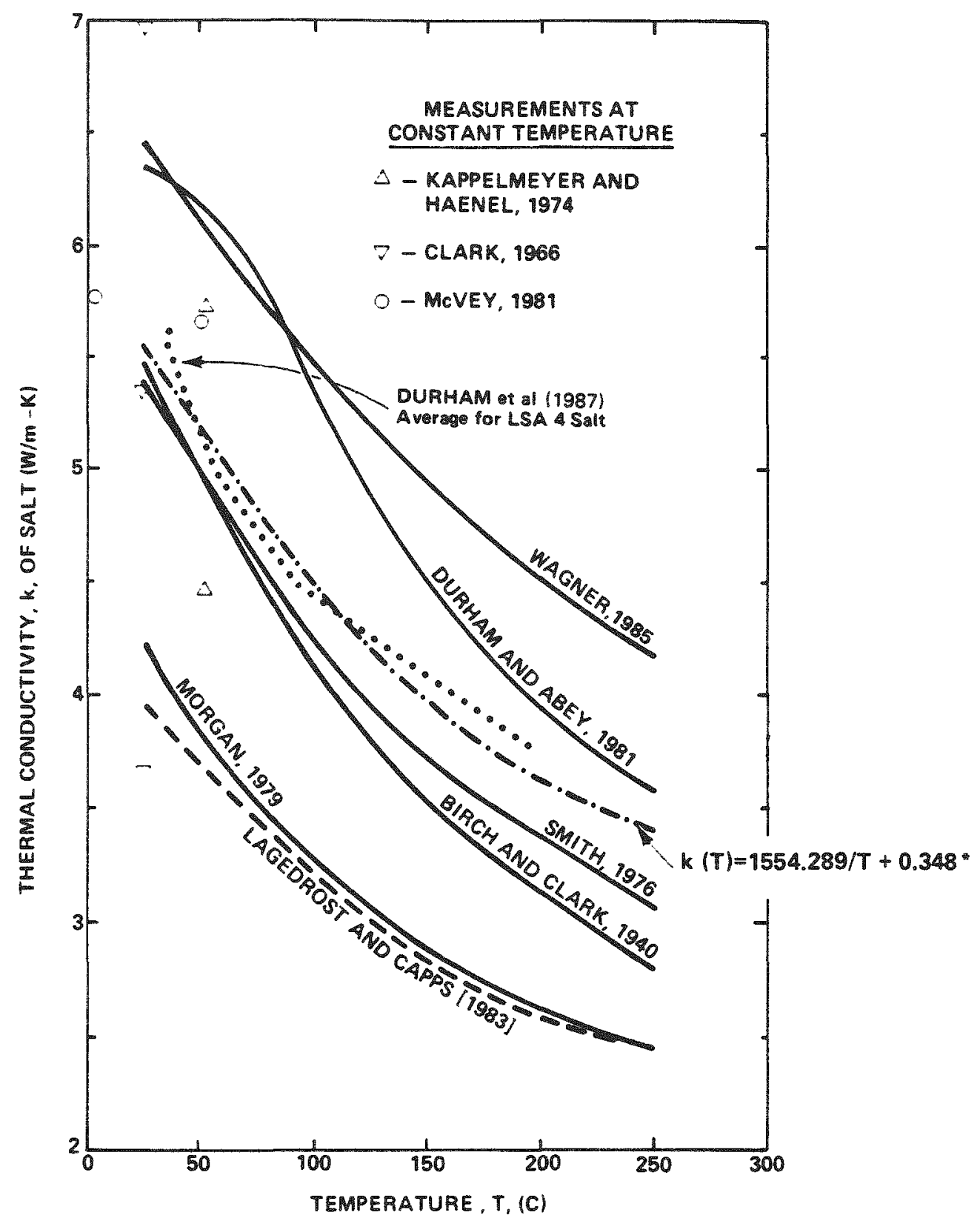

Fiqure after Tammemagi at al., 1986

- Thermal conductivity relationship used in design (SGDRD, DOE, 1986b)

THERMAL CONDUCTIVITY MEASUREMENTS OF SALT

FIGURE $2.2-8$ 
potential of occurring during the repository lifetime (see DoE, 1986a, EA, Sections 3.2 .3 .3 and 3.2 .5 ). These assumptions should be confirmed during site characterization studies.

The possibility of salt dissolution associated with the playas in and near the site is discussed in Section 2.2.1. Any potential for salt dissolution affecting the near-surface regime could impact foundation design and the stability of various surface and near surface structures. At present, no data relevant to such design that addresses the origin of the playas is available. However, various planned site characterization activities (such as drilling in the playas) 111 address this issue (see DOE, 1986a, EA, Section 4.1.1). When these data and pertinent evaubations are available, any impact on design will be assessed and suitable design measures will be incorporated into future design phases. Whenever possible, however, as explained in section 2.2.1, surface and near-surface structures should be located away from playa areas. 


\subsection{DATA AND ASSUMPTIONS FOR DESIGN}

This section describes the site-related design values used in the conceptual design of a repository at the Deaf Smith County, Texas site. Whenever possible, design values were obtained directly from the SGDRD (DOE, 1986b). This document was developed by a task force composed of representatives from the repository $A / E$ Contractor, the ESF A/E Contractor, the Deaf Smith site Geologic Project Manager, and the Site Characterization Manager. The task force evaluated the available data (such as that presented in Section 2.2) and, after a number of technical meetings and reviews, recommended a single set of geotechnical design values for use in the Salt Repository Program for both repository and ESF design. Issued as the SGDRD, the document contains design values for a number of hydrologic, rock mechanics, soil mechanics, seismic, and site stratigraphy parameters. The SGDRD includes both the design values and the rationale for their selection, such as using the average value of a group of laboratory test results or using engineering judgement if no measured data are available.

Section 2.2 summarizes available data. Section 2.3 is a summary discussion (explained in more detail in the SGDRD) of the derivation of values of site parameters used in design. Sections 2.3.1 to 2.3.3.5 summarize the derivation of design values. Design values in Section 2.3 are often derived from data

presented in Section 2.2. The geomechanical parameters presented in Tables $2.2-4$ and 2.3-3 are an example. Design values in Table 2.3-3 are generally the average of the range of values in Table 2.2-4, but this is not always the case. More than 20 design values in Table 2.3-3 have no corresponding actual data in Table 2.2-4. They are based completely on engineering judgement, as noted on Table 2.3-3 and explained in the SGDRD. The relationship between design hydrogeologic parameters presented in Section 2.3.2.2 and the actual data values presented in Section 2.2.2.2 is considerably more complex but is explained in detail in the SGDRD. In several instances the hydrogeologic design values presented in $: \mathrm{P}-\mathrm{CDR}$ Figure 2.3-4 do not fall within the range of measured data presented in SCP-CDR Table 2.2-2 because measured data were unavailable for some of the rock types within certain formations, and therefore, considerable professional judgement was used to derive the design values. 
In some instances (for example, direct shear strength) no data are included in the SGDRD although design values are considered in the repository conceptual design. When this occurs, the design values, the methodology used to derive them, and references to the actual measured data used are all presented in the SCP-CDR. For thermal parameters, measured data shown in Table 2.2-6 exhibit a pressure dependence of thermal expansion results. This pressure dependence is considered in the design values presented in Table 2.3-5 by including an appropriate expansion value for the overburden stress in the formation being considered.

Section 2.3 is divided into the same general subsections as Section 2.2, namely: (1) design values related to surface or near-surface structures (Section 2.3.1), (2) design values pertinent to design of shaft facilities above the repository horizon (Section 2.3.2), and (3) design values related to design of entries, pillars, and other underground facilities (Section 2.3.3).

\subsubsection{Bases for Design - Surface Structures}

\subsubsection{Climatic and Weather Conditions Considered in Design}

No direct air temperature data are available for the site. However, NUS (1984b) provides data for eight cities near and around the site. These cities are: Amarillo, Vega, Hereford, Dimmitt, Canyon, Tulia, Plainview, and Silverton. There is little variation among them. The annual average temperature is $57^{\circ} \mathrm{F}$. Monthly mean temperatures vary from $35.3^{\circ} \mathrm{F}$ in January to $78.8^{\circ} \mathrm{F}$ in July. Record low and high temperatures for the area are $-23^{\circ} \mathrm{F}$ and $109^{\circ} \mathrm{F}$, respectively. However, prolonged periods of extreme temperature are rare. Based on this information, the design dry-bulb temperature and the design wet-bulb temperatures are $98^{\circ} \mathrm{F}$ and $71^{\circ} \mathrm{F}$, respectively. Maximum design temperature and minimum design temperature are $105^{\circ} \mathrm{F}$ and $6^{\circ} \mathrm{F}$, respectively.

Precipitation information was obtained from NUS (1985). Palo Duro Creek watershed hydrologic information considered in the design include rainfall depth-duration-frequency data and other hydrographic data for the subbasins within the watershed. One design criterion requires containment of all 
precipitation falling within the surface facility area. This means that the site drainage, collection, and control systems must be designed to handle the effects of a probable maximum precipitation (PMP) storm. Based on data from NUS (1985) and standard extrapolation techniques, the site storm drainage system will be designed to handle 9.2 in. of rain in a 1-hr period. The storm water ponds will have a capacity sufficient to hold the volume of storm water accumulated on the site during the probable maximum $24 \mathrm{hr}$ rain of 24.5 in.

The maximum snow load observed at Amarillo was 15 pounds/square foot (psf). This value, obtained from American National Standards Institute (ANSI, 1982), is assumed as the maximum ground snow load at the site. Also assumed is $1.5 \mathrm{ft}$ for the approximate frost depth at the site (Bowles, 1977).

The annul extreme fastest-mile wind speed associated with a 100-yr mean recurrence interval is assumed to be $95 \mathrm{mph}$ (Southern Building Code Congress International, 1985). This wind measurement is defined as the wind speed associated with the fastest passage of a sustained, one mile "block" of wind (to discount gusts) past a measuring station located $30 \mathrm{ft}$ above the ground. Seasonal wind roses and the annual wind rose for Amarillo (Figures 2.3-1 and 2.3-2) are assumed to be applicable to the repository site and are the basis for design.

Winter and summer insulation values (rate of delivery of direct solar energy per unit of horizontal surface) were not considered during conceptual design. These will be determined later as necessary and as applicable to the design.

\subsubsection{Severe Natural Phenomena Considered in Design}

Section 2.3.1.1 addresses the fact that a probable maximum precipitation storm has been used in the design of the storm drainage system and the storm water ponds. The associated Probable Maximum Flood (PMF) was assumed in the design of those surface facilities located in the area designated as a PMF zone. The limits of this flood zone are shown in Figure 2.2-1. A proposed 

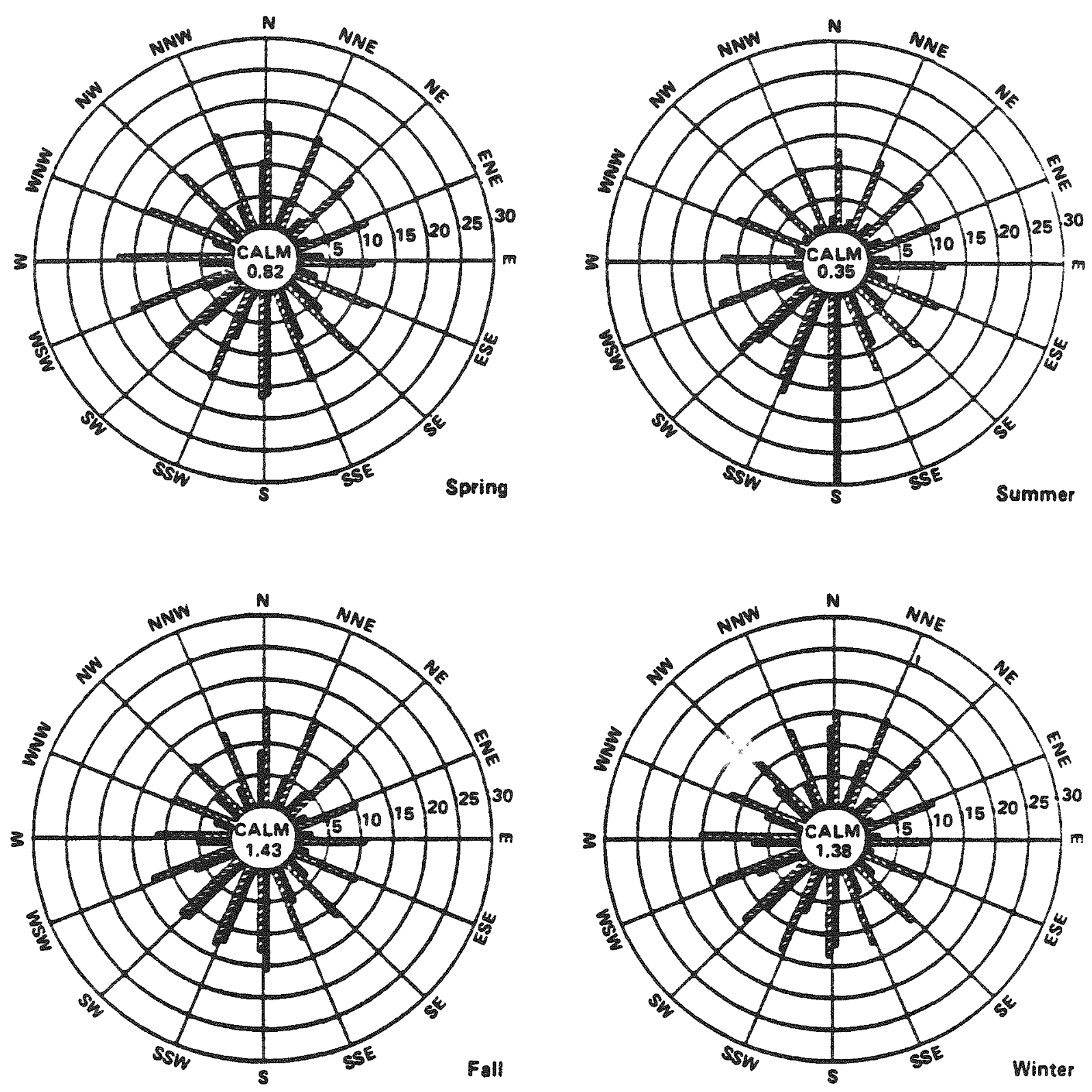

PEค1

Lagend:
Wind Direction (Percentage of time)
Wind Speed (mph) (Generally measured at $30 \mathrm{ft}$. above the ground surface)
CALM $=$ Percent Calms

Note: To conwert will houp to kilometers por houp, use conwrion factor 9.6093.

Source: NUS, $1984 b$

\section{SEASONAL WIND ROSES FOR AMARILLO, TEXAS}

FIGURE 2.3-1 


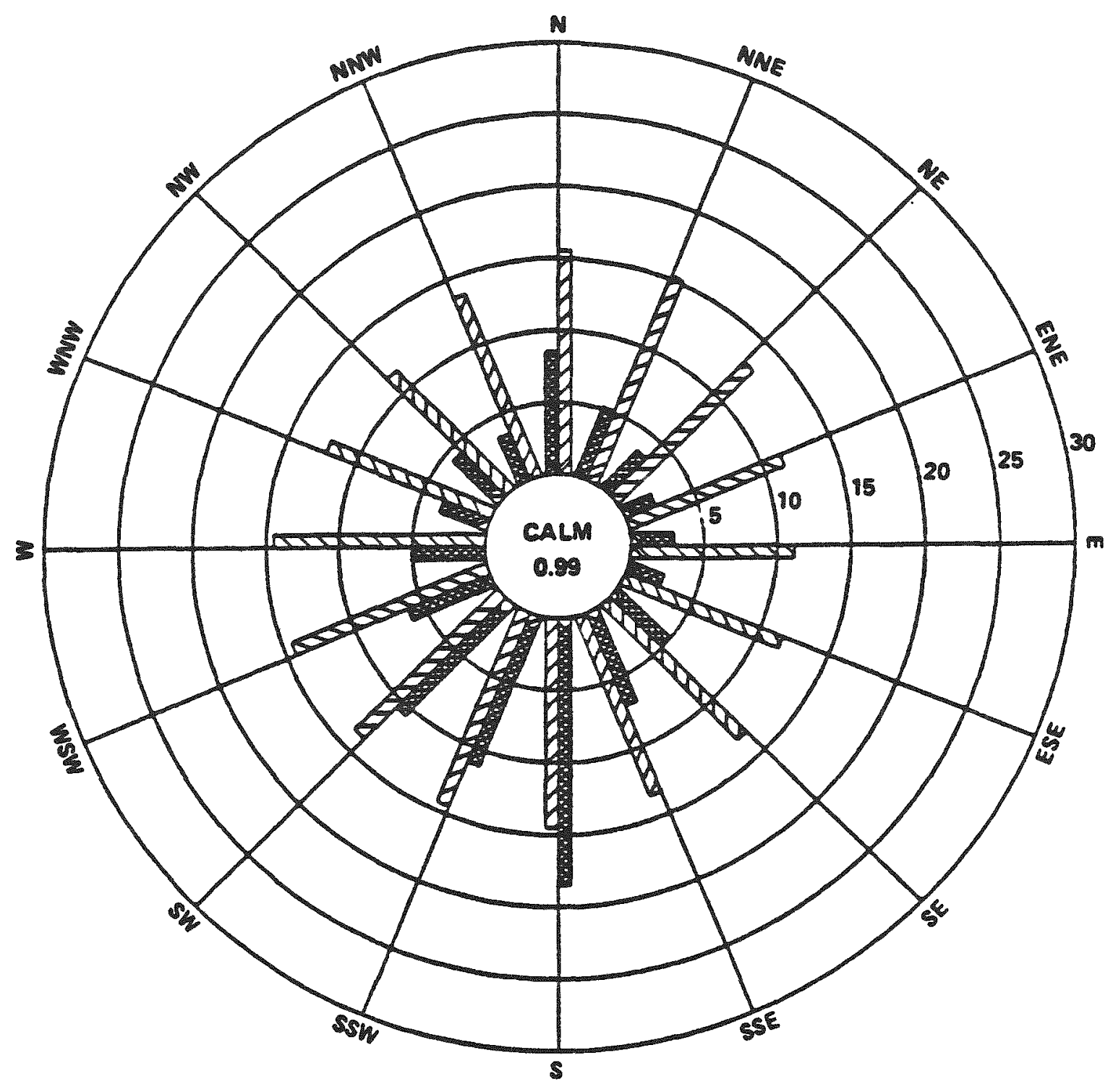

PERIOO OF RECORO I/176 - 12/31/20

Loend:

Wine Direction (x)

cocoses Wind speed (mph)

CALM - Prean Coms

Mere: To conven miles hour to hilometer cer hour, use conversion fortor 1.6003.

Sourea: NUS, 1904b

ANNUAL WIND ROSE

FOR AMARILLO. TEXAS

FIGURE 2.3-2 
design to protect facilities from the PMF is shown in Figure 4.2-1. This conventional design, entailing engineered compacted fill and erosion protection measures, is typically used to raise and protect facilities from the effects of a PMF.

Tornadoes are a relatively frequent occurrence in the region near the repository site, averaging eight per year for a $10,000 \mathrm{sq} \mathrm{mi}$ study area that includes the Deaf Smith site. Section 3.4.3.4 of the EA notes that the intensity of tornadoes observed in this area has seldom exceeded wind speeds of $113 \mathrm{mph}$ to $157 \mathrm{mph}$. The Repository Subsystem Design Requirements (RSDR) (Appendix A) indicates that DOE order 6430.1 should be used for facility design. Chapter IV, Section $9(\mathrm{~b})(2)$ of the order prescribes that wind loads for the facility consider those associated with a 1,000 yr mean recurrence level. Section $9(d)$ "Tornado Loads" prescribes that "use shall be made of site-specific tornado studies developed for DOE."

A project that involved modelling and estimating wind and tornado hazards for DOE sites in the United States was conducted by Lawrence Livermore Laboratory (Coats and Murray, 1985a). It included a facility in the vicinity of Amarillo, Texas. This study entailed an extensive review of available historic wind records for that area coupled with a risk analysis. The study resulted in hazard curves which showed that straight wind speeds of $100 \mathrm{mph}$ and $110 \mathrm{mph}$ would recur with return periods of 1,000 yrs and 10,000 yrs, respectively, and that tornadic wind speeds of $110 \mathrm{mph}$ and $170 \mathrm{mph}$ would recur with return periods of 10,000 years and 100,000 years, respectively. Based on engineering judgement, a tornadic wind speed of $200 \mathrm{mph}$ was selected for use in conceptual design. This tornado is assumed to have the following properties:

Maximum horizontal wind speed:

Translational wind speed:

Rotational wind speed:

Radius of maximum winds:

Total pressure change:

Rate of pressure change:
$200 \mathrm{mph}$

$50 \mathrm{mph}$

$150 \mathrm{mph}$

$175 \mathrm{ft}$

92 psf

$38 \mathrm{psf} / \mathrm{sec}$ 
Regarding earthquake phenomena, Section 3.2.5.3 of the EA (DOE, 1986a, EA, p. 3-76) states that a mean-value peak acceleration of $0.14 \mathrm{~g}$ could be taken as the estimate for the maximum earthquake ground motion at the Deaf Smith site. For conceptual design purposes it was considered appropriate to consider a higher level of ground acceleration. Another Lawrence Livermore Laboratory study (Coats and Murray, 1985b) modelled and estimated seismic hazards for DOE sites in the United States and included a facility in the vicinity of Amarillo, Texas. This study was similar to the wind study cited above in that it entailed an extensive review of available historic seismic records for that area coupled with a risk analysis. The study resulted in hazard curves which showed that earthquakes of approximately $0.2 \mathrm{~g}$ peak acceleration have a recurrence interval of 10,000 years for this area.

For SCP conceptual design, a maximum ground acceleration of $0.2 \mathrm{~g}$ is assumed for the design basis earthquake (DBE). A baselined DBE will be completed at a later date.

\subsubsection{Topography Considered in Design}

The current state of knowledge of the topographic and geomorphic features at the site is discussed in Section 2.2.1.1. The 1:2,400 scale topographic map of the site prepared by Litton Aero Services (1985) was the basis for site layout and elevation control. Design of the infrastructure (access roads, railroads, and utilities) is based on 1:24,000 scale USGS topographic maps.

\subsubsection{Near-Surface Stratigraphy and Geology Considered in Design}

The projected conditions of near-surface soil and rock stratigraphy at the site are discussed in Section 2.2.1.2. Assumed site conditions and values were used for SCP conceptual design, and are summarized as follows:

1. Upper $0 \mathrm{ft}$ to $7 \mathrm{ft}$ ( $3 \mathrm{ft}$ assumed average) are agricultural soils, Pullman Clay Loam, or Ulysses Clay Loam. Index properties of these soils are shown in Table $2.2-1$. 
2. Soft caliche may be present in the agricultural soil and underlying loess.

3. Underlying loess deposits occur to a depth of $65 \mathrm{ft}$ below ground surface.

4. A several-foot-thick layer of hard caliche, or caprock, is assumed to be present below the loess; this stratum is believed to mark the top of the Ogallala Formation.

5. The Ogallala Formation is quite variable in lithology, ranging from unconsolidated sand, silt, and clay to local gravel and local partially-cemented or well-cemented caliche.

6. Surface and near-surface soil stratigraphy is expected to be more complex around the playas and at the margins of draws. These areas should be avoided whenever possible in the location of surface facilities. Subsequent design phases will consider the results of site characterization work addressing the origin of these playas, including possible dissolution mechanisms (see Sections 2.2.1.1 and $2.2 .4)$.

\subsubsection{Surface Hydrology Considered in Design}

Flood limits used for the SCP conceptual design are those shown in Figure 2.2-2. Critical surface facilities will be constructed at elevations above the level of the PMF.

The assumed near-surface groundwater setting is discussed in Section 2.2.1.4. In particular, a brief discussion of the potential for perched water above the Ogallala water table is presented. For the purposes of the SCP conceptual design, it is assumed that local perched water zones may exist in the Ogallala Formation or in the overlying loess after periods of heavy rainfall. However, the yield from such zones is expected to be minor. It is assumed that groundwater control for deep excavations into these zones will be accommodated by small-diameter wells and sump-pumps. 


\subsubsection{Surface Geomechanical Parameters Considered in Design}

Assumed geomechanical parameters for near-surface soil and rock are presented in Table 2.3-1. These parameters were estimated from handbook values such as those presented in U.S. Department of the Navy, Foundations and Earth Structures Design Manual (1982) or from engineering judgement. These values are used for all preliminary foundation concepts in the SCP-CDR. Due to a lack of any site-specific or even site-vicinity surficial geotechnical data, the estimated values presented in Table 2.3-1 provide a reference bas is for preconceptual design of surface foundation systems. These parameters will be re-evaluated during site characterization.

\subsubsection{Foundation Parameters Considered in Design}

Considering that most surface soil properties and parameters are assumed values, the following foundation design parameters were used in the SCP conceptual design.

It is assumed that competent foundation material (caprock) is 65 ft below the ground surface. The $65-\mathrm{ft}$ depth is a best estimate extrapolation of available data on the site location. If thick engineered compacted fill is

placed where required, foundations extending to hard caliche (caprock) may not be necessary. Values of net allowable bearing pressures for spread footings are assumed to be 1,000 psf for the upper $40 \mathrm{ft}$ of the Blackwater Draw Loess and 2,000 psf for the lower part of the formation. Bearing pressures are assumed to vary from 6,000 to 10,000 psf for excavations extending to competent foundation material below the loess deposits. Bearing pressures for deep foundation systems were not estimated. For shafts extending through collapseprone soils, negative skin friction may develop. Skin friction along shafts with mass concrete against soil is assumed to be three-fourths of the friction angle, giving $22^{\circ}$ for silty sand soils (Department of the Navy, 1982, p. 7.2-194). Over-excavation of unsuitable surface soils (e.g., weak, expansive, or collapsible soils) will be required to various depths below foundations and building slabs. 
Table 2.3-1. Assumed Engineering Parameters of Near-Surface Soil and Rock

\begin{tabular}{|c|c|c|c|c|c|c|c|}
\hline $\begin{array}{l}\text { Soil or } \\
\text { Rock Type }\end{array}$ & $\begin{array}{l}\text { Approx. } \\
\text { Thickness } \\
\text { (ft) }\end{array}$ & $\begin{array}{c}\text { Dry } \\
\text { Density } \\
\text { (pcf) }\end{array}$ & $\begin{array}{l}\text { Moisture } \\
\text { Content } \\
\quad(\%)\end{array}$ & $\begin{array}{l}\text { Unconfined } \\
\text { Compressive } \\
\text { Strength } \\
\text { (psi) }\end{array}$ & $\begin{array}{l}\text { Angle of } \\
\text { Internal } \\
\text { Friction } \\
\text { (degrees) }\end{array}$ & $\begin{array}{l}\text { Cohesion } \\
\text { (psi) }\end{array}$ & Comments \\
\hline $\begin{array}{l}\text { Surface topsoil } \\
\text { (Pullman or } \\
\text { Ulysses Clay (a) } \\
\text { Loam) (OL-OH) }\end{array}$ & $0-3$ & & (Refer & to Table $2.2-1$ & for Index & operties) & \\
\hline Loess (ML-CL) & $3-40$ & 70 & 5 & $N / A^{(b)}$ & 20 & $\begin{array}{r}0 \\
\text { ential }\end{array}$ & Some collapse \\
\hline Loess (ML) & $40-65$ & 80 & 10 & $\mathrm{~N} / \mathrm{A}$ & 25 & 0 & \\
\hline Caliche Caprock & $65-75$ & 130 & 5 & 3,000 & 30 & 300 & \\
\hline $\begin{array}{l}\text { Ogallala } \\
\text { unconsolidated } \\
\text { silty sand (SM) }\end{array}$ & $75-290$ & 120 & $\begin{array}{l}10 \text { above wt }(\mathrm{c}) \\
15 \text { below wt }\end{array}$ & N/A & 30 & 0 & \\
\hline $\begin{array}{l}\text { Ogallala cemented } \\
\text { silty sand (SM) }\end{array}$ & $75-290$ & 130 & $\begin{array}{r}5 \text { above wt }(c) \\
11 \text { below wt }\end{array}$ & 3,000 & 30 & 300 & \\
\hline $\begin{array}{l}\text { Ogallala gravel } \\
\text { (GP) }\end{array}$ & $290-340$ & 120 & 15 & $\mathrm{~N} / \mathrm{A}$ & 35 & 0 & \\
\hline
\end{tabular}

(a) (Ol,-OH) (ML-CL), (ML), (SM), (GP) refer to Unified Soil Classification System.

(b) N/A refers to unconfined strength not applicable to cohesionless materials.

(c) Above water table. 


\subsubsection{Human-Induced Phenomena Considered in Design}

As discussed in Section 3.2.8 of the EA (DOE, 1986a), hydrocarbon occurrence and exploration potential in the Palo Duro Basin appears to be extremely low (Rose, $1986 \mathrm{a}, \mathrm{b}$ ). The site is not located along any of the known projected regional hydrocarbon migration pathways and, structurally, it lacks trapping characteristics. ' oil or gas has been produced in Deaf Smith County although some petroleum exploration continues in the northeastern area. Approsimately 350 wildcat wells drilled in the central Palo Duro Basin geologic anomalies have proved dry (except for the noncommercial discovery of the Mayfield No. 1 well). In August and September of 1984, a wildcat well was drilled approximately $5 \mathrm{mi}$ southeast of the site (SWEC, 1986). This well was terminated at approximately $8,212 \mathrm{ft}$ in Precambrian crystalline basement and proved dry.

Without institutional controls, it is possible that the site may be subjected to drilling in the future. However, the potential for development of other resources such as helium, potash, gypsum, and uranium is low. Sand, gravel, and clay deposits, while possibly present near the site, are not unique resources because they are present and exploited in many other areas in the Texas Panhandle. Exploitation of the groundwater resources is extensive and occurs to a depth of about $700 \mathrm{ft}$ to $900 \mathrm{ft}$, which leaves more than $1,500 \mathrm{ft}$ of relatively undisturbed formations between the near-surface aquifers and the repository horizon.

It is possible that continued overdraft of the surface aquifers may eventually lead to their depletion. However, technical and economic feasibility of producing potable or agricultural water supplies from deeper, low quality, low yield aquifers nearer the repository horizon appears minimal, though uncertain. This factor should be assessed in future studies.

Other forms of human-induced phenomena are considered in Section 6.2, Control of Radioactive Releases Under Accident Conditions. The A/E Contractor is not aware of any other types of human intrusion, such as routine overflights or weapons testing, that could affect repository surface or underground design. 
Exploration for, and utilization of, natural resources (other than ground water) is presently at a low level at the Deaf Smith site. In addition, no resources are known to be present that are not equally or more available in the surrounding area. The only present or projected future use of the area is for agriculture and its supporting infrastructure.

These conditions make it unlikely that any human-induced phenomena will adversely affect the site.

\subsubsection{Bases for Design - Shafts}

\subsubsection{Stratigraphy and Geology Considered in Shaft Design}

The stratigraphic column used in the SCP conceptual design was developed from the SGDRD (DOE, 1986b) and Table 3-3 of the EA (DOE, 1986a, pp. 3-34 to 3-37). Elevations and depths to the tops of the various formations were extrapolated to specific locations within the nine-square-mile site according to an estimation procedure proposed by SWEC. This procedure is described in the SGDRD and discussed below. During the course of the design effort, the $A / E$ Contractor made an independent evaluation of the formation top elevations and depths, with results that agreed closely with values derived using the SWEC procedure. This evaluation is also discussed below.

The estimated stratigraphy presented in the SGDRD (DOE, 1986b) and the EA (DOE, 1986a) is only applicable for a specific location (N411,161; E1,710,436 in Texas Coordinate System, North zone) because of the gentle southerly dip of the various formations across the site area. To estimate formation elevations and depths at any point within the site area, the SGDRD uses the following procedure:

1. Assume the top of the Ogallala is approximately equivalent to the ground surface and that the upper $65 \mathrm{ft}$ of the formation is likely to be agricultural soils and loess, as discussed in Section 2.2.1.2.

2. Use Figure 22 from "Ogallala Aquifer Mapping Program," by SwEC (1984a) to estimate the elevation of the top of the Dockum Group. 
3. Extrapolate from the EA, Table 3-3, "Estimated Stratigraphy" (DOE, $1986 \mathrm{a}, \mathrm{EA}, \mathrm{pp} .3-34$ to $3-37$ ) using the following contact dips for formation tops:
a. Dewey Lake
$20 \mathrm{ft} / \mathrm{mi}$
b. Alibates
$12 \mathrm{ft} / \mathrm{mi}$
c. Salado
$14 \mathrm{ft} / \mathrm{mi}$
d. Yates
$18 \mathrm{ft} / \mathrm{mi}$
e. Upper Seven Rivers
$22 \mathrm{ft} / \mathrm{mi}$
f. Lower Seven Rivers
$30 \mathrm{ft} / \mathrm{mi}$
g. Queen/Grayburg
$30 \mathrm{ft} / \mathrm{mi}$
h. Upper San Andres
$30 \mathrm{ft} / \mathrm{mi}$
i. Lower San Andres
$30 \mathrm{ft} / \mathrm{mi}$
j. Glorieta
$30 \mathrm{ft} / \mathrm{mi}$

Note that the formation elevations and depths presented in the Hypothetical Core Log at the ESF Location icale $1^{\prime \prime}=10^{\circ}$ ) in the SGDRD (DOE, 1986b) are identical to those in Table $3-3$ of the EA (DOE, 1986a).

4. For the purposes of this SCP conceptual design estimation, the formations are all assumed to dip due south so that elevation estimations can be made by simple north-south coordinate differences.

5. Adjust the elevations from the EA Table 3-3 (DOE, 1986a, pp. 3-34 to 3-37) based on the dips listed above.

The above procedure was used to estimate formation contacts at a representative area for shaft location at coordinates $N 411,261$ and $51,707,812$ in the north central portion of the site. The formation top elevations and depths at this point are listed in Table 2.3-2. The formation elevations and depths for the representative shaft location (RSL) are depicted in Figure 2.3-3.

The same procedure is presented in the SGDRD (DOE, 1986b). However, the Hypothetica1 Core Log at ESF Location (Scale $1^{\prime \prime}=10^{\circ}$ ) presented in the data base does not describe formations below LSA 4. Therefore, the procedure to 
Table 2.3-2. Estimated Ground Surface and Formation Top Elevation and Depth For Use in SCP-CDR Design

\begin{tabular}{|c|c|c|}
\hline \multirow[b]{2}{*}{ Formation } & \multicolumn{2}{|c|}{ 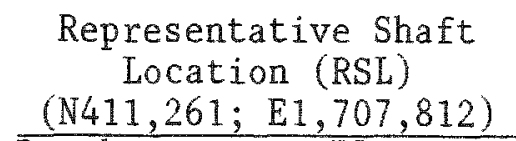 } \\
\hline & $\begin{array}{l}\text { Depth } \\
\text { (ft) }\end{array}$ & $\begin{array}{l}\text { Elevation } \\
(\mathrm{ft}, \mathrm{MSL})\end{array}$ \\
\hline Ground Surface & 0 & 4,030 \\
\hline $\begin{array}{l}\text { Topsoil and Blackwater Draw (Loess) } \\
\text { to } 65 \text { foot depth }\end{array}$ & 0 & 4,030 \\
\hline Ogallala & 65 & 3,965 \\
\hline Dockum & 337 & 3,693 \\
\hline Dewey Lake & 958 & 3,072 \\
\hline Alibates & 1,032 & 2,998 \\
\hline Salado & 1,064 & 2,966 \\
\hline Yates & 1,131 & 2,899 \\
\hline Upper Seven Rivers & 1,196 & 2,834 \\
\hline Lower Seven Rivers & 1,325 & 2,705 \\
\hline Queen/Grayburg & 1,519 & 2,511 \\
\hline Upper San Andres II & 1,699 & 2,331 \\
\hline Upper San Andres I & 2,005 & 2,025 \\
\hline Lower San Andres 5 & 2,173 & 1,857 \\
\hline Base of Salt in LSA 5 & 2,285 & 1,745 \\
\hline Lower San Andres 4 & 2,367 & 1,663 \\
\hline Base of Salt in ISA 4 & 2,528 & 1,502 \\
\hline Lower San Andres 3 & 2,617 & 1,413 \\
\hline Lower San Andres 2 & 2,737 & 1,293 \\
\hline Glorieta & 2,808 & 1,222 \\
\hline
\end{tabular}

NOTE: Estimated elevations at the ESF location (DOE, 1986a and 1986b) and the procedure described in the SGDRD (DOE, 1986b) were used to compute estimated elevations at RSL. Then RSL estimated depths were derived from RSL estimated elevations. 


\begin{tabular}{|c|c|c|c|c|c|c|c|c|c|}
\hline $\begin{array}{l}\text { FORMATION } \\
\text { AND (THICKNESS) } \\
\end{array}$ & $\begin{array}{c}\text { OLPTH } \\
\text { (FE) }\end{array}$ & GHAPHIC & $\begin{array}{l}\text { ELEV } \\
\text { IFIMSLI }\end{array}$ & GENERAL DESCRIPTION & guo & $\begin{array}{c}\text { JOINTS/ } \\
\text { FRACTURES }\end{array}$ & BEDOING & $\begin{array}{l}\text { HARDNESS/ } \\
\text { CEMENTATION }\end{array}$ & COMMENTS \\
\hline & 0 & & 4030 & (Ground Surface) & & & & & \\
\hline $\begin{array}{l}\text { BLACKWATER DRAW } \\
\text { AND TOPSOHL (65) }\end{array}$ & 65 & $0-1$ & 3965 & $\begin{array}{l}\text { Loess (silt) and some sand, density increases } \\
\text { downward. Topsoil } 3 \mathrm{ft} \text {, thick. }\end{array}$ & & & & & \\
\hline $\begin{array}{l}\text { OGALLALA } \\
\text { (272) } \\
\text { Static Water Level }\end{array}$ & 237 & 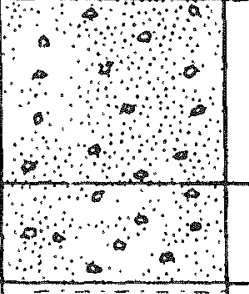 & 3693 & $\begin{array}{l}\text { Mostly fine-to-coarse sand with silt, } \\
\text { minor clay (generally coarser w/depth; } \\
\text { cementation generally increases w/depth) } \\
\text { - fluvial deposition-channel and over bank } \\
\text { deposits-zero to } 10 \text { feet of hard caliche } \\
\text { Dinear the top. Gravel and sand unit may } \\
\text { occur at base. }\end{array}$ & $\begin{array}{l}2 \\
10 \\
5\end{array}$ & $\begin{array}{l}\text { None } \\
\text { observed }\end{array}$ & $\begin{array}{l}\text { No } \\
\text { apparent } \\
\text { bedding }\end{array}$ & $\begin{array}{l}\text { Sand--friable } \\
\text { to unconsoli- } \\
\text { dated - Fine } \\
\text { grained soft } \\
\text { to very soff }\end{array}$ & \begin{tabular}{|l} 
Very \\
low percentage \\
recovery
\end{tabular} \\
\hline \multirow{3}{*}{$\begin{array}{l}\text { DocxUM } \\
(621)\end{array}$} & \multirow[b]{3}{*}{958} & & \multirow{3}{*}{3072} & $\begin{array}{l}\text { Upper part is mostly siltstone with lenses } \\
\text { of claystone and sandstone--poorly } \\
\text { consolditated. Identified engineering } \\
\text { properties caregories are numbers } 1 \text { and } 2 .\end{array}$ & $\begin{array}{l}70 \\
10 \\
100\end{array}$ & $\begin{array}{l}\text { Med. to } \\
\text { wide } \\
\text { spacing } \\
10^{\circ} \text { to } \\
60^{\circ} \text { dips }\end{array}$ & $\begin{array}{l}\text { Thin to } \\
\text { very thin } \\
\text { and faint }\end{array}$ & $\begin{array}{l}\text { Generally } \\
\text { soft- } \\
\text { Occasional } \\
\text { lithisied } \\
\text { beds }\end{array}$ & $\begin{array}{l}\text { Slakes } \\
\text { locally; } \\
\text { often } \\
\text { crodable }\end{array}$ \\
\hline & & 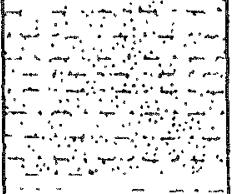 & & $\begin{array}{l}\text { Middle part is mustiy sandstone with some } \\
\text { siltstone and minor claysione - poorly } \\
\text { consolidated. Identified engineering properties } \\
\text { categories are numbers } 1,2 \text { and } 3 \text {. }\end{array}$ & $\begin{array}{l}32 \\
10 \\
98\end{array}$ & $\begin{array}{l}\text { None } \\
\text { observed }\end{array}$ & $\begin{array}{l}\text { Thin to } \\
\text { very thin } \\
\text { and faint }\end{array}$ & $\begin{array}{l}\text { Soft to } \\
\text { moderately } \\
\text { hard }\end{array}$ & $\begin{array}{l}\text { Minor } \\
\text { conglomerate } \\
\text { near the } \\
\text { base }\end{array}$ \\
\hline & & 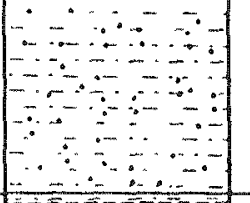 & & $\begin{array}{l}\text { Lawer part is mostly siltstone with some } \\
\text { sandstune and claystuns; contained some } \\
\text { conglomerate in J. Friemel-poorly } \\
\text { consolidated. Identified engineering propertues } \\
\text { categories are numbers } 1,2,3 \text { and } 4 \text {. }\end{array}$ & $\begin{array}{l}32 \\
\text { to } \\
94\end{array}$ & $\begin{array}{l}\text { Several } \\
\text { vertical } \\
\text { irregular }\end{array}$ & $\begin{array}{l}\text { Thin to } \\
\text { very thin. } \\
\text { faint and } \\
\text { irregular }\end{array}$ & $\begin{array}{l}\text { Generally } \\
\text { soft - } \\
\text { Occasional } \\
\text { lithified } \\
\text { beds }\end{array}$ & $\begin{array}{l}\text { Slakes } \\
\text { locally }\end{array}$ \\
\hline $\begin{array}{l}\text { DEWEY LAKE } \\
(74)\end{array}$ & 1032 & 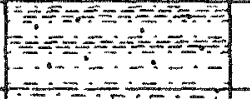 & 2998 & Interbedded siltstone and claystone. & $\begin{array}{l}86 \\
10 \\
98 \\
\end{array}$ & $\begin{array}{l}\text { Wide } \\
\text { spacing } \\
200-70^{0} \\
\end{array}$ & $\begin{array}{l}\text { Very thin, } \\
\text { weak }\end{array}$ & $\begin{array}{l}\text { Med. to } \\
\text { mod. hard }\end{array}$ & \\
\hline ALIBATES (32) & 1064 & (1) & 2966 & $\begin{array}{l}\text { Dolomite with siltstone interbed, Local anhydrite } \\
\text { and gypsum may be associated with dolomite. }\end{array}$ & 86 & Minor & Very thin & Hard & \\
\hline SALADO (67) & 1131 & 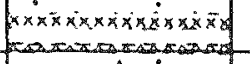 & 2899 & Mostly siltstone interbedded anhydrise. & 59 to89 & Minor & $\begin{array}{l}\text { None to } \\
\text { faint }\end{array}$ & $\begin{array}{l}\text { Hard to } \\
\text { mod hard }\end{array}$ & \\
\hline \begin{tabular}{|l} 
YATES (65) \\
UPOCD
\end{tabular} & 1196 & 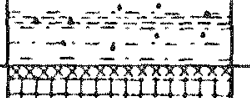 & 2834 & Interbedded siltstone and claystone. & $80: 089$ & $\begin{array}{l}\text { Wide } \\
\text { spacing } \\
30^{\circ}-90^{0} \\
\end{array}$ & $\begin{array}{l}\text { None to } \\
\text { faint }\end{array}$ & $\begin{array}{l}\text { Mostly mod. hard } \\
\text { locally med, soft }\end{array}$ & \\
\hline $\begin{array}{l}\text { UPPER } \\
\text { SEVEN RIVERS } \\
(129)\end{array}$ & 1325 & 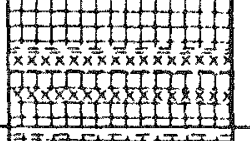 & 2705 & $\begin{array}{l}\text { Mostly salt, interbedded anhydrite and } \\
\text { claystone. }\end{array}$ & $\begin{array}{l}86 \\
\text { to } \\
90\end{array}$ & $\begin{array}{l}\text { Wide } \\
\text { spacing } \\
30^{\circ}-60^{\circ}\end{array}$ & $\begin{array}{l}\text { Numerous } \\
\text { lithology } \\
\text { changes }\end{array}$ & $\begin{array}{l}\text { Mod. hard, } \\
\text { locally sofi }\end{array}$ & $\begin{array}{l}\text { Clay seams } \\
\text { in salt }\end{array}$ \\
\hline $\begin{array}{l}\text { LOWER } \\
\text { SEVEN RIVERS } \\
\text { (194) }\end{array}$ & 1519 & 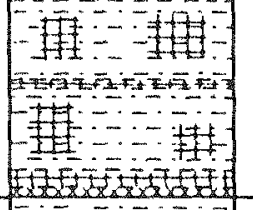 & 2511 & $\begin{array}{l}\text { Mostly salty siltstone with interbeds of } \\
\text { siltstone, claystone, salt and anhydrite. }\end{array}$ & NOT & CORED & AT & J. FRIEMEL & \\
\hline $\begin{array}{l}\text { QUEEN/ } \\
\text { GRAYBURG } \\
(180)\end{array}$ & 1699 & $-1=-1$ & 2.331 & $\begin{array}{l}\text { Interbedded silstone, sandstone and claystone. } \\
\text { Mostly sandstone in central portion. }\end{array}$ & 98 & $\begin{array}{l}\text { None } \\
\text { observed }\end{array}$ & $\begin{array}{l}\text { Thick } \\
\text { bedded } \\
\text { clastics }\end{array}$ & Mod. hard & \\
\hline $\begin{array}{l}\text { UPPER } \\
\text { SAN ANDRES II } \\
\text { (306) }\end{array}$ & 2005 & 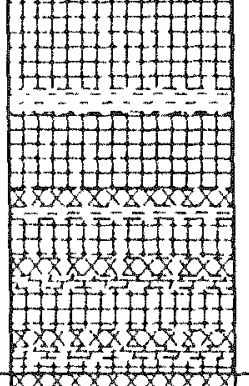 & 2025 & $\begin{array}{l}\text { Mostly salt with numerous thin clay seams and } \\
\text { admixtures of silt and clay, interbedded with } \\
\text { anthydrite and dolomite; minor siltstone, } \\
\text { claystone and sandstone. }\end{array}$ & $\begin{array}{l}92 \\
\text { to } \\
100\end{array}$ & $\begin{array}{l}\text { Minor } \\
20^{\circ}-90^{0} \\
\text { Some } \\
\text { salt } \\
\text { filled }\end{array}$ & $\begin{array}{l}\text { Very thin } \\
\text { to thick }\end{array}$ & $\begin{array}{l}\text { Mostly } \\
\text { mod. hard }\end{array}$ & $\begin{array}{l}\text { Siltstone } \\
\text { beds; } \\
\text { slake } \\
\text { locally }\end{array}$ \\
\hline $\begin{array}{l}\text { UPPER } \\
\text { SAN ANDRES I } \\
\text { (168) }\end{array}$ & 2173 & 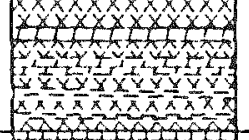 & 1357 & $\begin{array}{l}\text { Mostly anliydrite with } 10-15 \% \text { interbeds of } \\
\text { dolomite and occasional interbeds of shate. }\end{array}$ & $\begin{array}{l}98 \\
10 \\
100\end{array}$ & $\begin{array}{l}\text { Minor } \\
30^{\circ}-90^{\circ} \\
\text { Mostly salt } \\
\text { filled }\end{array}$ & $\begin{array}{l}\text { Very thin } \\
\text { to thick }\end{array}$ & $\begin{array}{l}\text { Mostly, } \\
\text { mod. hard, } \\
\text { locally soft }\end{array}$ & $\begin{array}{l}\text { Numerous } \\
\text { partings along } \\
\text { shale and } \\
\text { clay seams }\end{array}$ \\
\hline $\begin{array}{l}\text { LOWER } \\
\text { SAN ANDRES } \\
\text { UNIT } 5 \\
\text { (194) }\end{array}$ & 2367 & 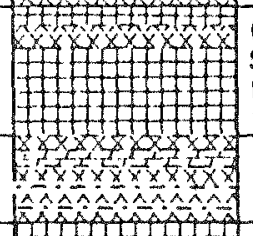 & \begin{tabular}{|l|} 
Base of \\
Salt in \\
LSA 5$)$ \\
1745 \\
1663 \\
\end{tabular} & $\begin{array}{l}\text { Upper part mostly salt, interbedded anhydrite } \\
\text { and silistone, salt conlains clay seams and } \\
\text { admixtures of silt and clay. Lower part mosily } \\
\text { antilydrite, interbedded dalomite and } \\
\text { siltstone. }\end{array}$ & 100 & $\begin{array}{l}\text { Very minor } \\
\text { in anhydrite } \\
\& \text { dolomites: } \\
\text { healed frac. } \\
\text { in salt }\end{array}$ & \begin{tabular}{|l|} 
Thick \\
bedded
\end{tabular} & $\begin{array}{l}\text { Mostiy } \\
\text { mod. hard }\end{array}$ & $\begin{array}{l}\text { Partings } \\
\text { along clay } \\
\text { or mudstone } \\
\text { seams }\end{array}$ \\
\hline $\begin{array}{l}\text { LOWER } \\
\text { SAN ANDRES } \\
\text { UNIT } 4 \\
(250)\end{array}$ & $\begin{array}{r}(1) \\
2528 \\
2617 \\
\end{array}$ & 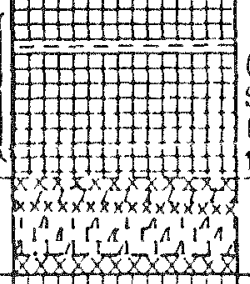 & $\begin{array}{l}(\text { Base of } \\
\text { Salt in } \\
\text { LSA 4) } \\
1502 \\
1413 \\
\end{array}$ & 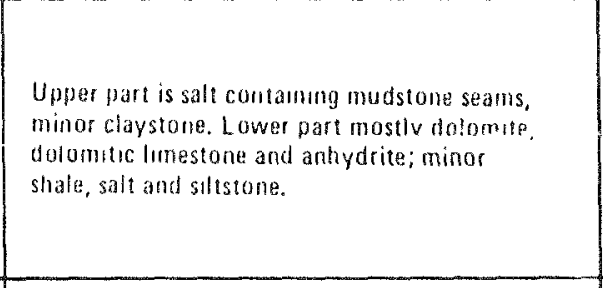 & $\begin{array}{l}98 \\
: 0 \\
100\end{array}$ & $\begin{array}{l}\text { Very munor } \\
\text { his antibutritie } \\
\text { \& dolomites; } \\
\text { healed frac. } \\
\text { in salt }\end{array}$ & $\begin{array}{l}\text { Thick } \\
\text { jedoued }\end{array}$ & $\begin{array}{l}\text { Mostly } \\
\text { med. inard, } \\
\text { locally med. } \\
\text { soft }\end{array}$ & $\begin{array}{l}\text { Numerous } \\
\text { partings } \\
\text { along } \\
\text { mudstone } \\
\text { seams }\end{array}$ \\
\hline $\begin{array}{l}\text { LOWER SAN } \\
\text { ANDRES UNIT } 3 \\
\text { (120) }\end{array}$ & 2737 & 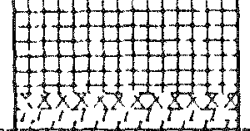 & 1293 & $\begin{array}{l}\text { Interbedded salt, salty mudstone, and saliy } \\
\text { anhydrite with dolomite at the base. }\end{array}$ & & & PT COR & & \\
\hline $\begin{array}{l}\text { LOWER SAN } \\
\text { ANDRES UNIT } 2 \\
\text { (7II) }\end{array}$ & 2808 & 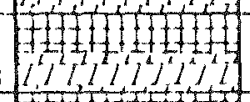 & 1222 & Salt and dolumite. & & & $\overline{A T}$ & & \\
\hline GLOAIETA & & EEAIIAf开 & & Interbedded salt, salty mudstone, and siltstone. & & J. & FRIEME & & \\
\hline
\end{tabular}

LEGEND.

\begin{tabular}{|c|c|c|c|}
\hline Sand: & $\begin{array}{l}\text { Interbedded Siltsione and } \\
\text { Mudstione or Claystonit }\end{array}$ & 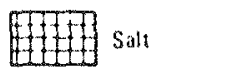 & [T, D, Dolumite \\
\hline S & Sand and G ravel & 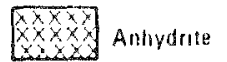 & 烈 \\
\hline
\end{tabular}

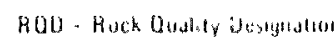

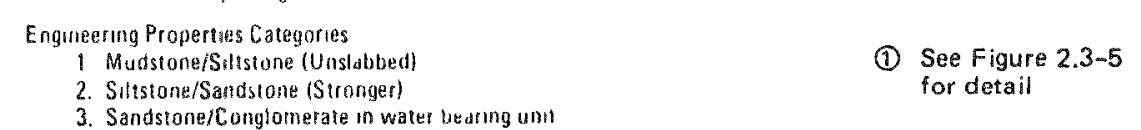

ESTIMATED STRATIGRAPHY

AT REPRESENTATIVE

2. Siltstone/Sandsitone istronigest)

3. Sandstone/Conglomerate
4. Very, very soft mudsione

See Figure 2.3-5
for detail

SHAFT LOCATION 
$$
\text { . }
$$ 
estimate formation depths and elevations at the RSL presented in the SGDRD (DOE, 1986b) must use Table 3-3 of the EA (DOE, 1986a, pp. 3-34 to 3-37) for elevations and depths of deeper formations.

As an independent evaluation of the formation contacts determined by the SGDRD (DOE, 1986b), the A/E Contractor employed a three-point solution with formation top elevations from the J. Friemel No. 1, Black No. 1, and Taylor No. 1 wells. This solution method assumes that the structural surface is a plane defined by the three formation top elevations in the three wells. Also considered were an assumed northward thinning of the strata and a slight increase in dip for successively deeper formations. The results from this alternative interpretation method were within $35 \mathrm{ft}$ of the elevations estimated using the SWEC procedure. This difference is well within the $150 \mathrm{ft}$ uncertainty range of the estimated stratigraphy shown in EA Table 3-3 (DOE, 1986a, EA, pp. $3-34$ to $3-37$ ).

Figure 2.3-3 contains general lithologic and engineering geology descriptions of each formation in addition to the formation depths and elevations. The engineering geology descriptions include rock quality designation (RQD), joint and fracture descriptions, bedding descriptions, hardness or degree of lithification, and other comments relating to behavior and partings.

\subsubsection{Hydrogeology Considered in Shaft Design}

The formations above the repository horizon consist of about $960 \mathrm{ft}$ of high permeability clastics which comprise the freshwater aquifer system (the Ogallala and the Dockum) and about 1,660 ft of lower permeability clastics (sandstone, siltstone, shale), dolomite, and evaporites (anhydrite, gypsum and salt). The Ogallala aquifer is Tertiary, the Dockum is Triassic, and the lower formations are Permian in age.

Table 2.2-2 includes only the values cited in the literature and collected in the vicinity of the Deaf Smith site. The design values contained in Figure 2.3-4 are the most appropriate estimates based on the measured data and derived values cited in the hydrogeologic literature. 


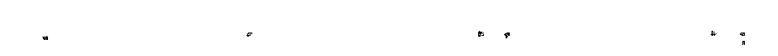

\begin{tabular}{|c|c|c|}
\hline & $\because$ & 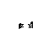 \\
\hline 멱 & $4=$ & 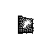 \\
\hline a & bu & 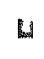 \\
\hline 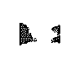 & Lu & IJ \\
\hline 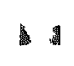 & 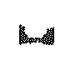 & $\because 4$ \\
\hline and & $M$ & w \\
\hline
\end{tabular}
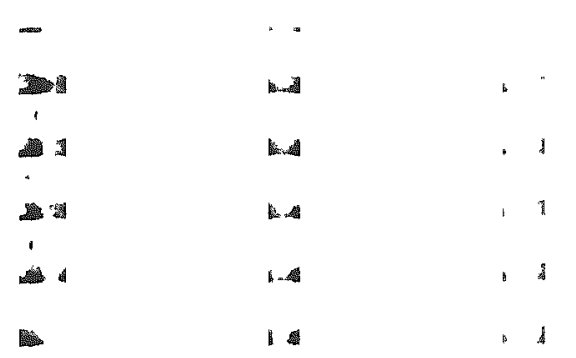

\begin{tabular}{|c|c|c|c|c|c|c|c|c|c|c|c|c|c|c|c|}
\hline $\begin{array}{l}\text { FORMAYION } \\
\text { (ANOTHICKNESS) } \\
\end{array}$ & $\begin{array}{l}\text { OEPIH } \\
\text { (F:I.) }\end{array}$ & GRAPHIC & 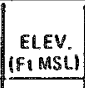 & GENEAAL OFSCRIPTION & $\begin{array}{l}\text { Jolars' } \\
\text { Fractures } \\
\end{array}$ & BEDUING & CEMENTATION & 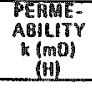 & 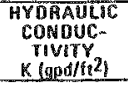 & $\begin{array}{l}\text { TEMPER } \\
\text { ATURE } \\
\text { T(PF) } \\
\end{array}$ & $\begin{array}{l}\text { Pone- } \\
\text { SIYY } \\
\times \\
\end{array}$ & $\begin{array}{l}\text { HYDAAU IC } \\
\text { GRAOIEGT }\end{array}$ & 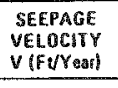 & 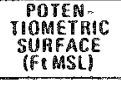 & MEMARKS \\
\hline & & & 4030 & (Ground Suff face) & & & & & & & & & & & \\
\hline 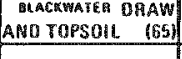 & 65 & 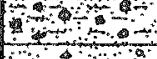 & 3965 & 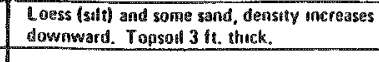 & & & & & & & & & & & \\
\hline $\begin{array}{l}\text { OGALLALA } \\
\text { (272) } \\
\text { Starec Whater L. Level }\end{array}$ & 237 & 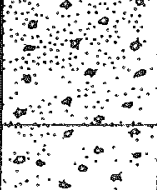 & 3793 & 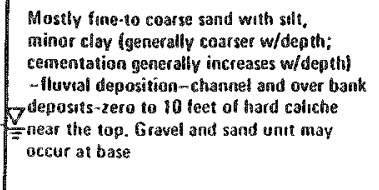 & \begin{tabular}{|l} 
None \\
observed
\end{tabular} & \begin{tabular}{|l} 
No \\
aposanent \\
beddudumg
\end{tabular} & 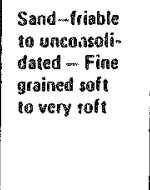 & 12,298 & 224 & 57 & 16.1 & .003 & 204 & 3793 & 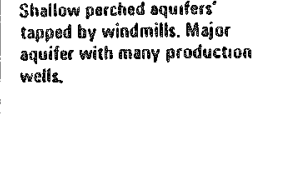 \\
\hline \multirow{3}{*}{ 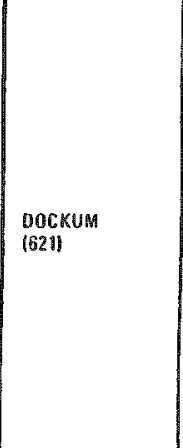 } & & & & 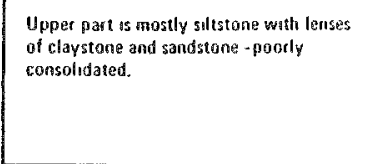 & $\begin{array}{l}\text { Med, to } \\
\text { wide } \\
\text { spanchy } \\
\text { 10 to } \\
60^{0} \text { dips }\end{array}$ & \begin{tabular}{|l} 
Thin no \\
very thin \\
and taint
\end{tabular} & 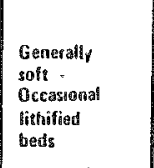 & \multirow{3}{*}{5160} & \multirow{3}{*}{94} & \multirow{3}{*}{72} & \multirow{3}{*}{24} & \multirow{3}{*}{.0024} & \multirow{3}{*}{46} & \multirow{3}{*}{3420} & \multirow{3}{*}{ 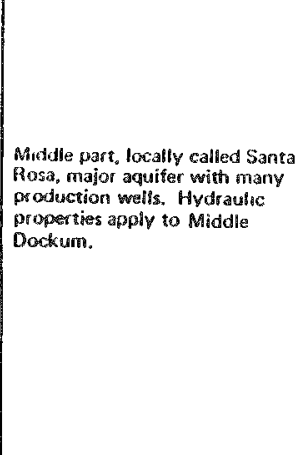 } \\
\hline & & & & $\begin{array}{l}\text { Middle part is mostly sandstone with sone } \\
\text { siltstone and minor claystone - pourly } \\
\text { consoliddateded. }\end{array}$ & $\begin{array}{l}\text { Nonen } \\
\text { otserved }\end{array}$ & \begin{tabular}{|l} 
Thun to \\
very thin \\
and farme
\end{tabular} & $\begin{array}{l}\text { Sort to } \\
\text { moderaty } \\
\text { hard }\end{array}$ & & & & & & & & \\
\hline & -958 & & 3002 & 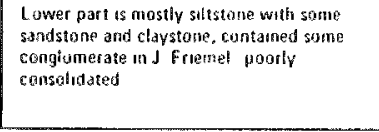 & \begin{tabular}{|l} 
Severat \\
vertsul \\
reregstar
\end{tabular} & 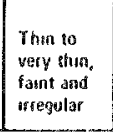 & 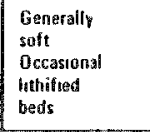 & & & & & & & & \\
\hline
\end{tabular}

$H$ - Horizontal Perneabitity

LEGENO:

\begin{tabular}{|c|c|c|c|}
\hline S.... Sandstone & $\begin{array}{l}\text { Mneabedded Sifrsione and } \\
\text { Mudatene or Claystone }\end{array}$ & 明形成 Sal & 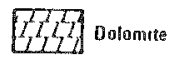 \\
\hline & 4. Sand and Gravel & $8 x$ & 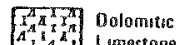 \\
\hline
\end{tabular}





Figure 2.3-4 summarizes the relevant SRP design hydrogeologic parameters, as agreed to at a final data integration meeting. The parameters selected include lithologic descriptions and structures dealing with porosity and permeability. These parameters, along with potentiometric surface, hydraulic gradient and seepage velocity, can be used in calculating flows into the shaft.

The design values for permeability and hydraulic conductivity are based on field pumping tests, laboratory tests, and weighted averages for rock lithologies, as discussed in the SGDRD (DOE, 1986b) and standard texts (Freeze and Cherry, 1979). Whenever possible, the design permeability values included in Figure 2.3-4 are based on actual field pump tests. This is the case for the Queen/ Grayburg clastics and the ISA 4 dolomites (SGDRD, DOE, 1986b). In these cases the field results are judged to be more representative than the laboratory derived values presented in Table 2.2-2. In other cases in which there are no field data, design permeability values shown in Figure $2.3-4$ are weighted mean horizontal values based on the relative thickness of each rock type present in the formation. The horizontal permeability value is used because it is generally equal to, or greater than, the vertical permeability, hence more conservative.

Water temperature which, along with total dissolved solids, affects the viscosity of the fluid, is based upon observed values and assumed geothermal gradient. Apart from the Ogallala $\left(57^{\circ} \mathrm{F}\right)$ there is a constant rise in aquifer temperature from $72^{\circ} \mathrm{F}$ in the Dockum to about $82^{\circ} \mathrm{F}$ in the LSA 4 unit.

The regional groundwater flow in the Ogallala and the Dockum is to the southeast with gradients of $3 \times 10^{-3}$ and $2.4 \times 10^{-3}$, respectively, as calculated from potentiometric surface maps. For the Permian formations (Dewey Lake to LSA 4) an integrated gradient is assumed to be about $9.8 \times 10^{-4}$, as calculated for LSA 4 dolomite.

The seepage velocity calculations use Darcy's equation with the parameters of hydraulic conductivity (K), hydraulic gradient ( $I$ ) and porosity ( $n$ ). The highest velocities occur in the Alibates, Lower Seven Rivers, Queen/Grayburg, and Upper San Andres II; these velocities range from $0.0058 \mathrm{ft} / \mathrm{yx}$ to $0.0026 \mathrm{ft} /$ yr. The values for potentiometric surface are determined from a finite-element model which takes into account formation pressures and fluid density. 
The design water quality data was obtained from chemical analyses of water and brine from representative wells, as summarized in Table 2.2.3.

\subsubsection{Geomechanical Parameters Considered in Shaft Design}

Table 2.3-3 provides a summary of geomechanical properties that were assumed for design purposes. The data are presented according to stratigraphic formation and lithologic classification. Parameters include uniaxial compressive strength, triaxial compressive strength, direct shear strength, indirect tensile strength, static Young's modulus, static Poisson's ratio, bulk density, and in situ stress. Values selected for design purposes were determined as follows:

1. Uniaxial compressive strength. Mean values presented in Table 2.2-4 were rounded to the nearest $50 \mathrm{psi}$.

2. Triaxial compressive strength. Laboratory test results compiled in the SGDRD (DOE, 1986b) were analyzed using Mohr-Coulomb strength criteria. Separate analyses were conducted for each lithologic class within each stratigraphic formation. The reader is referred to a rock mechanics text (e.g., Jaeger and Cook, 1979) for a discussion of Mohr-Coulomb strength analysis. For each laboratory triaxial test conducted, the specimen strength was characterized by the point p-q, where $p$ and $q$ are defined:

$$
\begin{aligned}
& \mathrm{p}=\left(\sigma_{1}+\sigma_{3}\right) / 2 \text { and } \\
& \mathrm{q}=\left(\sigma_{1}-\sigma_{3}\right) / 2
\end{aligned}
$$

where $\sigma_{1}$ and $\sigma_{3}$ are the axial stress and confining pressure, respectively, at failure. Lambe and Whitman (1979, p. 107) present a discussion of the use of $p-q$ plots in strength characterization. A plot of shear stress $(\tau)$ and normal stress $\left(\sigma_{n}\right)$ was then prepared for each lithology within each formation, by plotting one $p-q$ point for 
Table 2.. .. juratary of Geomechanical Properties for Destgn(e)

\begin{tabular}{|c|c|c|c|c|c|c|c|c|c|c|c|c|c|}
\hline FORMATrOA: & LITHOL.OGY & $\begin{array}{c}\text { UNIAXIAI. } \\
\text { CONPRESSIVE } \\
\text { STRENGH } \\
\text { psi }\end{array}$ & $\begin{array}{l}\text { TRI } \\
\text { Compressi } \\
\text { AMg1e of } \\
\text { Internal } \\
\text { Friftion } \\
\phi \\
\text { degrees } \\
\text { degres }\end{array}$ & $\begin{array}{l}\text { TAL } \\
\text { STRENGTH } \\
\text { Cohesion } \\
\text { psi }\end{array}$ & $\begin{array}{r}\text { DIRE } \\
\text { ST } \\
\text { ANGLE } \\
\text { FT } \\
\text { Peak } \\
\text { degree }\end{array}$ & 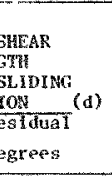 & $\begin{array}{l}\text { INDIRECT } \\
\text { TFNSIIT } \\
\text { STRENGTH } \\
\text { pSi }\end{array}$ & $\begin{array}{l}\text { STaTic } \\
\text { Young's } \\
\text { Monuts } \\
\times 10^{6} \mathrm{psi}\end{array}$ & $\begin{array}{c}\text { SAMY } \\
\text { POISSON'S } \\
\text { RATIO }\end{array}$ & $\begin{array}{l}\text { BUIK } \\
\text { LEWSITY(g) } \\
\text { pe E }\end{array}$ & $\frac{1 \mathrm{~N}}{\substack{\mathrm{HMin} \\
\mathrm{Ps} i / \mathrm{tat}}}$ & 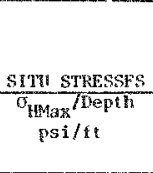 & $\begin{array}{l}\text { o/deepth } \\
\text { psi/ft }\end{array}$ \\
\hline Dockum & Clastics & 1,100 & 30 & 100 & -. & $\cdots$ & 40 & 1.3 & 0.22 & 141 & & & \\
\hline \multirow[t]{2}{*}{ Trewey i.ake } & Clastics & $3,000(f)$ & 30 & 109 & -- & -- & 60 & 0.7 & 0.28 & 150 & & & \\
\hline & Clastics & 3,100 & 30 & 300 & -. & -- & 150 & 1.2 & 0.14 & 150 & & & \\
\hline \multirow[t]{2}{*}{ Alibates } & Carbonates & 7,500 & 45 & 1,500 & -- & -- & $750(0)$ & 4.0 & 0.24 & 140 & & & \\
\hline & Anhydrites & 9,500 & 50 & 1,600 & -- & -- & 800 & 10.7 & 0.32 & 176 & & & \\
\hline \multirow[t]{2}{*}{ Salado } & clasties & 4,400 & 35 & 100 & 33 & -- & 60 & 1.8 & 0.21 & 150 & & & \\
\hline & Anthydrites & 15,700 & 50 & 3,100 & - & -- & $1,000(f)$ & 7.5 & 0.26 & 183 & & & \\
\hline Yates & Clastics & 4,100 & 30 & 800 & 17 & -- & 170 & 1.2 & 0.23 & 347 & & & \\
\hline tpper & Clastics & 1,500 & 25 & 300 & -- & -- & $150(f)$ & 1.8 & 0.26 & 136 & & & \\
\hline Seven & Anhydrites & 11,500 & 50 & 2,300 & -. & -. & $\mathrm{I}, 000(\hat{n})$ & 9.1 & 0.14 & 178 & & & \\
\hline Rivers & Sajes & 1,900 & 30 & 400 & -- & -. & 190 & 3.6 & 0.23 & 152 & & & \\
\hline \multicolumn{14}{|l|}{ Lawer } \\
\hline \multicolumn{14}{|l|}{$\begin{array}{l}\text { leven } \\
\text { Rivers }\end{array}$} \\
\hline \multirow{4}{*}{$\begin{array}{l}\text { Queen/ } \\
\text { Erayburg }\end{array}$} & Clastics & 5,400 & 30 & 1,100 & -- & -. & 430 & 3.5 & 0.27 & $15 \%$ & 0.60 & 0.69 & 1.00 \\
\hline & Anhydriteres & 15,000 & 50 & 3,000 & -- & .. & $1,000(f)$ & 6.8 & 0.15 & 182 & & & \\
\hline & Sa1ts & 2,400 & 30 & 500 & -- & .. & $240(f)$ & 2.8 & 0.22 & 144 & & & \\
\hline & Clastics & 8,400 & 40 & 1,700 & 25 & -- & $840(\mathrm{f})$ & 3.8 & 0.14 & 153 & & & \\
\hline drper & Carbonates & 10,000 & $40(c)$ & 1,700 & 40 & 28 & 340 & 4.8 & 0.22 & $10 \%$ & & & \\
\hline \multirow[t]{2}{*}{ San Andres } & Anhydrites & 16,700 & 50 & 3,300 & -- & -- & 1,150 & 20.5 & 0.30 & 183 & & & \\
\hline & Salts & 3,100 & 30 & 600 & 24 & -- & 250 & 3.9 & 0.26 & 130 & & & \\
\hline \multirow{4}{*}{$\begin{array}{l}\text { L wer } \\
\text { San Andres } \\
\text { Gint } 5\end{array}$} & Ciastics & $8,000(\mathrm{f})$ & 40 & 1,600 & -. & .. & $800(f)$ & $4.0(f)$ & 0.20157 & $756 i f 1$ & & & \\
\hline & Curtenates & 9,7006 & $55(\mathrm{~b})$ & 1,100 & -. & .. & 420 & 3.9 & 0.28 & 151 & & & \\
\hline & Muliverites & 16,300 & 50 & 3,300 & 28 & 22 & 980 & $11 . ?$ & 0.30 & 183 & & & \\
\hline & Saits & $(A)$ & (a) & (a) & 37 & 32 & (a) & (a) & $(A)$ & 133 & & & \\
\hline \multirow{4}{*}{$\begin{array}{l}\text { Wher } \\
\text { Sin Andres } \\
\text { Ent } 4\end{array}$} & ol astics & $8,000(t)$ & 40 & 1,600 & 18 & 18 & $800(f)$ & 2.4 & 0.40 & $10:$ & & & \\
\hline & Carbonates & 14,400 & $50(b)$ & 1,100 & 43 & .. & 1,070 & 6.5 & 0.27 & 160 & 19,49 & $\therefore .95$ & 1.06 \\
\hline & Antwdrites & 10,300 & 50 & 2,100 & -- & -. & 960 & 11.9 & 0.30 & 18 & & & \\
\hline & Salts & (a) & (a) & (a) & 43 & 30 & (a) & (a) & (a) & 135 & & & \\
\hline \multirow{4}{*}{ 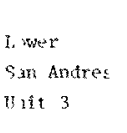 } & Clastics & 8,200 & 40 & 1,600 & $\cdots$ & -. & $820(\mathrm{f})$ & 5.7 & 0." & 169 & & & \\
\hline & Carbonates & 77,300 & 50 & 1,100 & -. & -. & 1,110 & 6.9 & 0.25 & 16.7 & & & \\
\hline & Ambrirites & $10,300(f)$ & 50 & 2,100 & .. & -. & 110 & $11.9(f)$ & $0.30(5)$ & $i n$ & & & \\
\hline & Salts & 3,300 & 30 & 700 & -- & -- & $230(\mathrm{f})$ & 3.3 & 0.17 & 146 & & & \\
\hline Glorieta & Clastics & 5,500 & 40 & 1,100 & -. & .. & $550(\mathrm{f})$ & 5.4 & 0.24 & 15,4 & & & \\
\hline \multicolumn{14}{|c|}{ 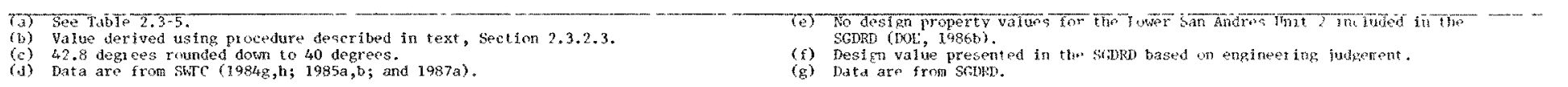 } \\
\hline
\end{tabular}



each test conducted. The best linear fit to each such plot of strength data was then calculated using least-squares procedures and established mathematical relationships. This best fit straight line, considered as a linear approximation of the failure envelope for the lithology, was characterized by the angle $(\beta)$ from the abcissa, and the intercept (S) with the ordinate. The angle of internal friction $(\phi)$ and the cohesion ( $C$ ) were then computed by the relationships:

$$
\sin \phi=\tan \beta \text { and } c=\frac{S}{\cos \phi}
$$

The values used for design were obtained by rounding the computed values of $\phi$ to the nearest five degrees and by rounding the computed values of cohesion to the nearest $100 \mathrm{psi}$.

3. Direct shear strength. Mean values of peak and residual friction angle were summarized from SWEC test reports (1984g, h; 1985a,b; and 1987a). Values were rounded down to the nearest degree.

4. Indirect tensile strength. Mean values presented in Table 2.2-4 were rounded to the nearest $10 \mathrm{psi}$.

5. Static Young's modulus. Mean values presented in Table 2.2-4 were rounded to the nearest $100,000 \mathrm{psi}$.

6. Static Poisson's ratio. Mean values presented in Table 2.2-4 were used without further rounding.

7. Bulk density. Values presented in $\mathrm{g} / \mathrm{CC}$ in the SGDRD (DOE, 1986b) were converted to pcf and rounded to the nearest 1 pcf.

8. In situ stress. In situ stress ratios presented in Table 2.2-5 for the six tested strata were included. It was assumed that in the salt strata, in situ stresses are lithostatic and equal to the overburden 
stress acting on the stratum. In nonsalt strata, based on comments in Borjeson and Lamb (1987), it was assumed that high lateral stresses are not present at the site.

\subsubsection{Seismic Parameters Considered in Shaft Design}

At this time there are no site-specific data relating to seismic parameters or the values to be used for shaft design purposes. Although methodologies have been developed to address the seismic design of shafts, tumels, and other underground structures (Dowding and Rosen, 1978; Yeh, 1974), no analyses were performed as a part of the SCP conceptual design.

While a maximum acceleration of $0.2 \mathrm{~g}$, as defined in Section 2.3.1.2, is considered reasonable for the site, the attenuation of ground acceleration with depth is poorly defined at this time, as are the range and variation of ground displacements with depth.

\subsubsection{Thermal Parameters Considered in Shaft Design}

Considerable work has been performed by others in the SRP on far-field thermal analyses, which consider all underground formations from the ground surface to depths well below the repository horizon. The A/E Contractor has used the thermal properties presented in the SGDRD (DOE, 1986b) for thermal analyses conducted as a part of the conceptual design report; design parameters are presented in Table $2.3-4$.

The thermal parameters presented in Table 2.3-4 were developed from the thermal properties according to rock type (1ithology) that were included in the SGDRD (DOE, 1986b). The specific heat and thermal expansion for a given formation in Table 2.3-4 are the weighted mean values based on the relative volume of each rock type included in the formation. The thermal conductivity for a given formation in Table $2 \cdot 3-4$ is calculated using the same method (presented in the SGDRD) used to calculate formation permeabilities 
Table 2.3-4. Thermal Parameters for Shaft and

Underground Design (Sheet 1 of 3 )

\begin{tabular}{|c|c|c|c|}
\hline Formation & $\begin{array}{l}\text { Specific } \\
\text { Heat } \\
(\mathrm{J} / \mathrm{Kg}-\mathrm{K})\end{array}$ & $\begin{array}{l}\text { Thermal } \\
\text { Conductivity } \\
(w / m-K) \text { (a) }\end{array}$ & $\begin{array}{l}\text { Thermal } \\
\text { Expansion } \\
\left(1.0 \mathrm{E}^{-6} / \mathrm{K}\right)\end{array}$ \\
\hline $\begin{array}{l}\text { Blackwater Draw } \\
\text { (loess) }\end{array}$ & 700 & $\begin{array}{c}0.5 \\
(0.5)\end{array}$ & 9 \\
\hline $\begin{array}{c}\text { Ogallala (above } \\
\text { water table) }\end{array}$ & 700 & $\begin{array}{l}2.6 \\
(2.6)\end{array}$ & 9 \\
\hline $\begin{array}{c}\text { Ogallala (below } \\
\text { water table) }\end{array}$ & 700 & $\begin{array}{l}2.8 \\
(2.8)\end{array}$ & 9 \\
\hline Dockum & 730 & $\begin{array}{l}2.5 \\
(2.4)\end{array}$ & 10 \\
\hline $\begin{array}{l}\text { Dewey Lake through } \\
\text { Yates }\end{array}$ & 780 & $\begin{array}{l}2.4 \\
(2.3)\end{array}$ & 12 \\
\hline $\begin{array}{l}\text { Upper Seven Rivers } \\
\text { (salt) }\end{array}$ & 900 & Eqn (b) & 36 \\
\hline $\begin{array}{l}\text { Upper Seven Rivers } \\
\text { (nonsalt) }\end{array}$ & 840 & $\begin{array}{l}3.8 \\
(3.1)\end{array}$ & 9 \\
\hline Lower Seven Rivers & 790 & $\begin{array}{l}2.4 \\
(2.3)\end{array}$ & 16 \\
\hline Queen/Grayburg & 770 & $\begin{array}{l}2.3 \\
(2.2)\end{array}$ & 13 \\
\hline $\begin{array}{l}\text { Upper San Andres } \\
\text { Salt II }\end{array}$ & 900 & Eqn (b) & 36 \\
\hline $\begin{array}{l}\text { Upper San Andres } \\
\text { Nonsalt II }\end{array}$ & 870 & $\begin{array}{c}4.7 \\
(4.2)\end{array}$ & 8 \\
\hline $\begin{array}{l}\text { Upper San Andres } \\
\text { Salt I }\end{array}$ & 900 & Eqn (b) & 36 \\
\hline $\begin{array}{l}\text { Upper San Andres } \\
\text { Nonsalt I }\end{array}$ & 860 & $\begin{array}{c}4.1 \\
(3.5)\end{array}$ & 9 \\
\hline LSA $5 \mathrm{Salt}$ & 900 & Eqn (b) & 36 \\
\hline
\end{tabular}


Table $2.3-4$ (Sheet 2 of 3 )

\begin{tabular}{|c|c|c|c|}
\hline Formation & $\begin{array}{l}\text { Specific } \\
\text { Heat } \\
(J / \mathrm{Kg}-\mathrm{K})\end{array}$ & $\begin{array}{l}\text { Therma } 1 \\
\text { Conductivity } \\
(W / m-K) \text { (a) }\end{array}$ & $\begin{array}{l}\text { Therma } 1 \\
\text { Expansion } \\
\left(1.0 \mathrm{E}^{-6} / \mathrm{K}\right)\end{array}$ \\
\hline LSA 5 Nonsalt & 880 & $\begin{array}{l}4.9 \\
(4.5)\end{array}$ & 8 \\
\hline LSA $4 \mathrm{Salt}$ & 900 & Eqn (b) & 36 \\
\hline LSA 4 Nonsalt & 840 & $\begin{array}{l}3.2 \\
(3.0)\end{array}$ & 9 \\
\hline LSA 3 Salt & 900 & Eqn (b) & 36 \\
\hline LSA 3 Nonsalt & 840 & $\begin{array}{c}3.5 \\
(3.1)\end{array}$ & 10 \\
\hline LSA 2 Salt & 900 & Eqn (b) & 36 \\
\hline LSA 2 Nonsalt & 850 & $\begin{array}{l}3.3 \\
(3.2)\end{array}$ & 9 \\
\hline Glorieta Salt I & 900 & Eqn (b) & 36 \\
\hline Glarieta Clastics & 770 & 2.2 & 13 \\
\hline Glorieta Salt II & 900 & Eqn (b) & 36 \\
\hline $\begin{array}{l}\text { Upper Clear Fork } \\
\text { Clastics }\end{array}$ & 770 & 2.2 & 13 \\
\hline $\begin{array}{l}\text { Upper Clear Fork } \\
\text { Salt }\end{array}$ & 900 & Eqn (b) & 36 \\
\hline $\begin{array}{l}\text { Upper Clear Fork } \\
\text { Anhydrite }\end{array}$ & 900 & 5.4 & 11 \\
\hline Tubb Clastics & 770 & 2.2 & 13 \\
\hline $\begin{array}{l}\text { Lower Clear Fork } \\
\text { Salt }\end{array}$ & 900 & Eqn (b) & 36 \\
\hline $\begin{array}{l}\text { Lower Clear Fork } \\
\text { Nonsalt }\end{array}$ & 820 & $\begin{array}{l}3.6 \\
(2.9)\end{array}$ & 13 \\
\hline
\end{tabular}


Table $2 \cdot 3-4$ (Sheet 3 of 3 )

\begin{tabular}{lccc}
\hline \multicolumn{1}{c}{ Formation } & $\begin{array}{c}\text { Specific } \\
\text { Heat } \\
(\mathrm{J} / \mathrm{Kg}-\mathrm{K})\end{array}$ & $\begin{array}{c}\text { Thermal } \\
\text { Conductivity } \\
(\mathrm{W} / \mathrm{m}-\mathrm{K})(\mathrm{a})\end{array}$ & $\begin{array}{c}\text { Therma1 } \\
\text { Expansion } \\
\left(1.0 \mathrm{E}^{-6} / \mathrm{K}\right)\end{array}$ \\
Red Cave & 780 & 2.5 & 13 \\
Wichita & 850 & $(2.3)$ & 13 \\
& & 3.8 & \\
\hline
\end{tabular}

(a) Numbers without parentheses refer to properties for horizontal heat flow parallel to bedding. Numbers with parentheses refer to properties for vertical heat flow perpendicular to bedding.

(b) Refer to equation 2.3-1, Section 2.3.3.5. 
in Figure 2.3-4. The weighted mean value, based on the relative volume of each rock type in the formation, represents the thermal conductivity for heat flow in the horizontal direction parallel to bedding, $k_{H}$.

$$
k_{H}=\frac{\Sigma k_{i} t_{i}}{\Sigma t_{i}}
$$

where $k_{i}$ and $t_{i}$ are the conductivity and thickness of a given rock type within the formation. Thermal conductivity for heat flow in the vertical direction perpendicular to bedding, $k_{\mathrm{V}}$ is:

$$
k_{V}=\frac{\sum t_{i}}{\sum \frac{t_{i}}{k_{i}}}
$$

In Table 2.3-4, thermal conductivity values without parentheses refer to horizontal heat flow parallel to bedding. Values enclosed in parentheses represent thermal conductivities for vertical heat flow perpendicular to bedding.

\subsubsection{Other Parameters Considered in Shaft Design}

The average lithostatic gradient resulting from the weight of the various formations overlying the host repository stratum, LSA 4 salt (DOE, 1986a, EA, p. 3-19), is used in a number of calculations for shaft and underground design. An average lithostatic gradient, expressed in terms of stress per unit of depth, of $1.0 \mathrm{psi} / \mathrm{ft}$ was calculated from the bulk densities presented in Table 2.3-3 and rock type proportions estimated from stratigraphic descriptions presented in the SGDRD (1986b) using the following procedure. Bulk density of each rock type was multiplied by rock type percentage in each formation and by formation thicknesses given in Table 2.3-1. The products were summed for all strata down to $100 \mathrm{ft}$ below the top of LSA 4. The average lithostatic gradient was determined by dividing the resultant sum by the total depth, then converting to units of psi/ft of depth. 


\section{3 .3 Bases for Design - Underground}

Section 2.3.3 discusses the various geologic and geotechnical design parameters determined for the proposed repository host stratum, the LSA 4 salt (DOE, 1986a, EA, p. 3-19). Certain parameters were also determined for an alternative host stratum, the ISA 5 salt. The two salt strata are discussed below.

\subsubsection{Stratigraphy and Geology Considered in Underground Design}

An estimated stratigraphic column at the RSL is discussed in Section 2.3.2.1. This column establishes the projected elevations and depths of the top and the bottom of the ISA 4 salt stratum at that location. This stratum is projected to be $161 \mathrm{ft}$ thick at that location. Corresponding depths and elevations elsewhere in the repository underground can be extrapolated assuming that the LSA 4 salt stratum strikes $N 90^{\circ} \mathrm{W}$ and dips $0.3^{\circ}$ to the south.

The lithology within the LSA 4 salt stratum is assuned to be as indicated by the hypothetical detailed LSA Unit 4 salt stratigraphy at RSL shown in Figures 2.3-5 and 2.3-6 (SGDRD, DOE, 1986b). This stratigraphy, in turn, is based on detailed examination of the core from the J. Friemel borehole by the Texas Bureau of Economic Geology (Hovorka, et al., 1985). In addition, the A/E Contractor has reviewed the core from the J. Friemel Borehole in order to identify mudstone beds that could be important to the positioning of the repository horizon within the salt stratum. Mudstone beds judged to be potentially important to positioning the repository horizon are depicted in Figures 2.3-5 and 2.3-6 as dark arrows. The estimated vertical thickness of these horizontal beds is also identified. Because observations were made significantly after the J. Friemel core was recovered, the identification of significant mudstone seams is an estimate; close observation of new LSA 4 core will be made in the field shortly after core is recovered during site characterization to assess the site-specific nature of any weak seams in the salt. 



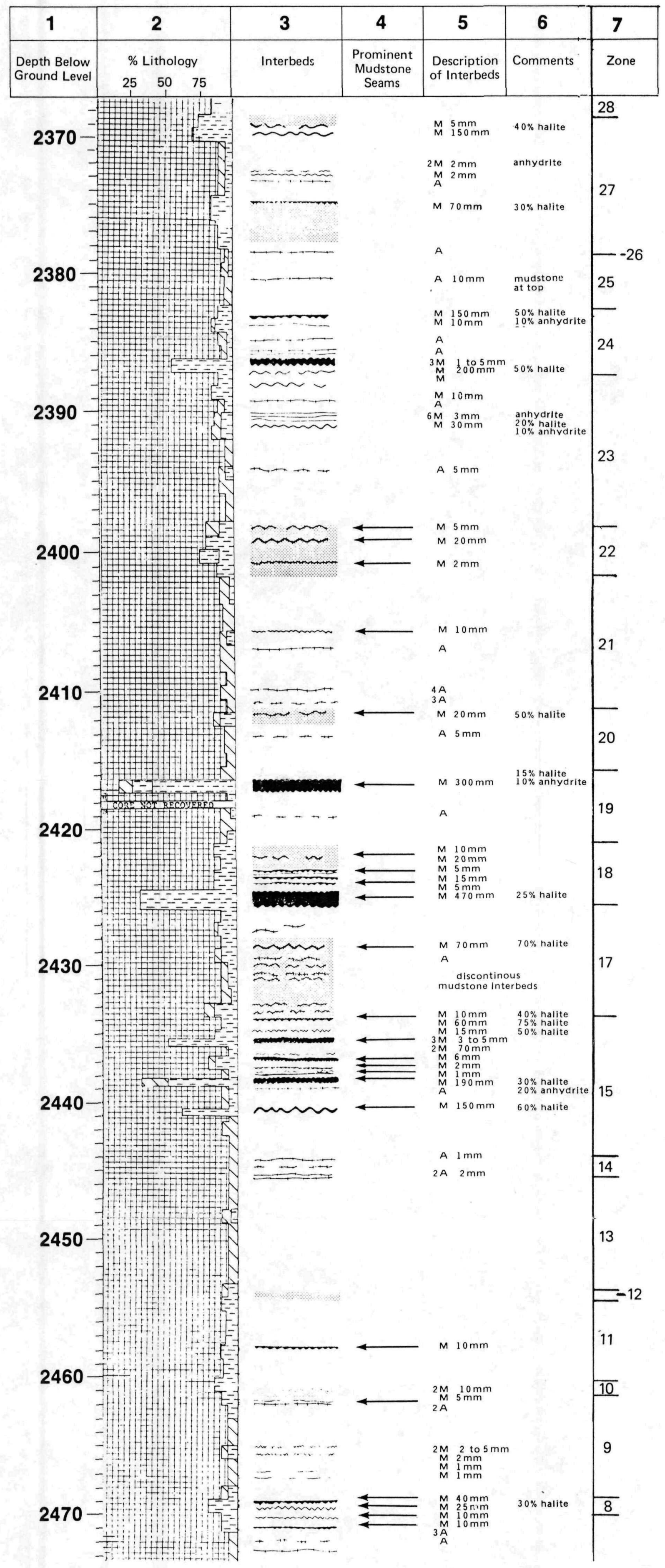

KEY
COLUMN 1: Depths in feet below ground level.
COLUMN 2: Estimated percent lithology.
MINERAL composition
COLUMN 3: Location, irregularity and estimated
Continuity of mudstone and anhydrite inter-
beds in halite.




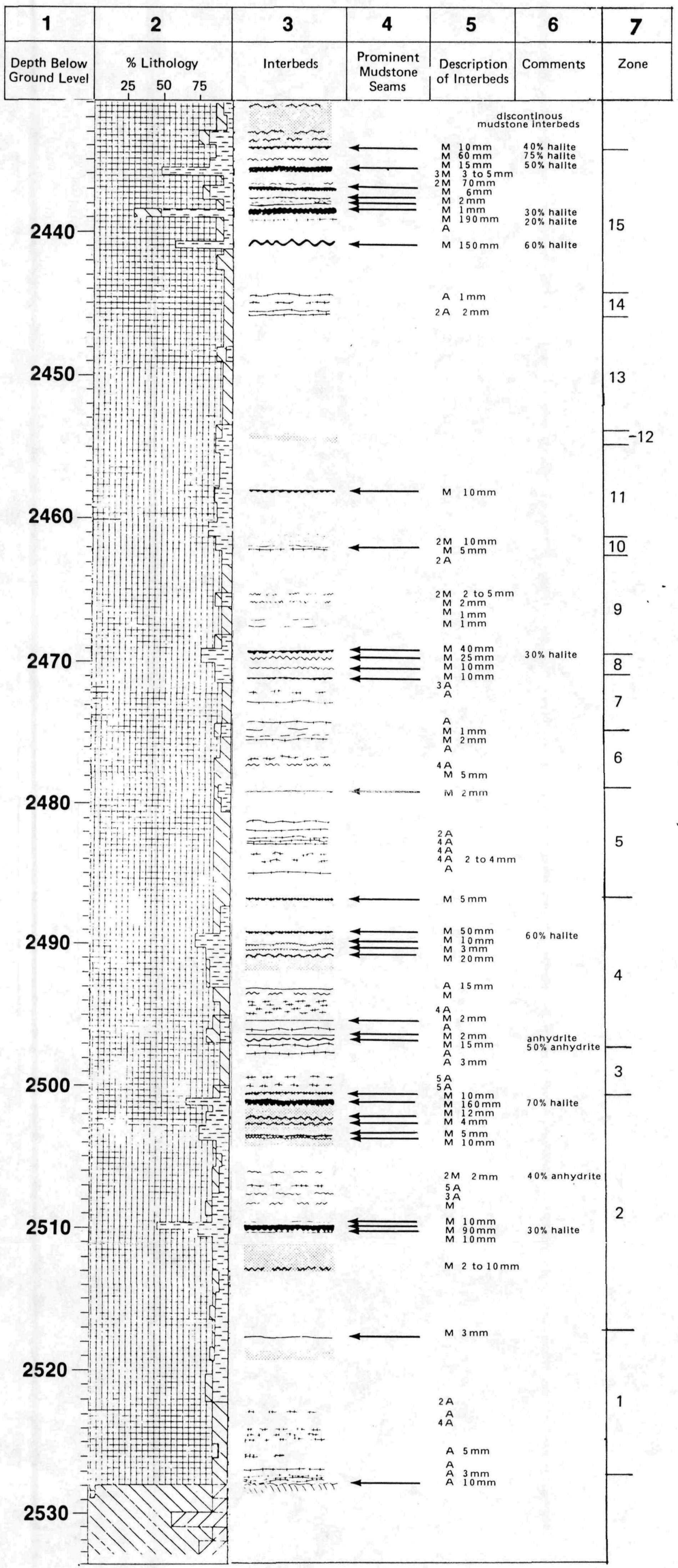

KEY
COLUMN 1: Depths in feet below ground level.
COLUMN 2: Estimated percent lithology.
MINERAL composition
COLUMN 3: Location, irregularity and estimated
continuity of mudstone and anhydrite inter-
beds in halite.


A high degree of lateral traceability of groups of mudstone beds between wells is demonstrated in Figure 2.2-7. These wells span lateral distances of tens of miles. Based on this information, the projection of such features from the J. Friemel well to the shaft location, some $5 \mathrm{mi}$ to the northwest, is considered appropriate for this stage of conceptual design. It is acknowledged, however, that the lithology of the LSA 4 salt stratum will probably not be exactly the same at the shafts or elsewhere within the repository as was encountered at the J. Friemel well, particularly regarding the occurrence of individual mudstone beds. These considerations are discussed in section 7.3 , Engineering Analysis of Design.

\subsubsection{Hydrogeology and Geochemistry Considered in Underground Design}

The LSA 4 unit consists of microcrystalline dolomite and dolomitic limestone, overlain by about $165 \mathrm{ft}$ (in the J. Friemel borehole) of relatively clean bedded salt (the repository host stratum). The measured laboratory permeability of salt ranges from $0.0073 \mathrm{mD}$ to $0.092 \mathrm{mD}$. A weighted average permeability value of $0.013 \mathrm{mD}$, based on lithologic averaging (SGDRD, DOE, 1986b) will be used for design purposes for formations containing salt.

For the underlying dolomites the permeability values range from 0.01 to $0.3 \mathrm{mD}$, obtained by pumping tests. A design value of $0.05 \mathrm{mD}$ will be used. The design potentiometric surface for the dolomites is $3,324 \mathrm{ft}$ MSL, based upon calculations using downhole pressure data from J. Friemel pumping tests with corrections for brine density.

The fluid inclusions in ISA 4 halite contain a high magnesium brine (DOE, 1986a, EA, p. 3-108), suggesting geochemical isolation from percolating waters. Table 2.2-3 summarizes the geochemistry of repository site halites and dolomites.

\subsubsection{Geomechanical Parameters Considered in Underground Design}

\subsection{Strength Parameters. Strength parameters were determined for} both the LSA 4 and LSA 5 salt strata. The strength data obtained from various sources for the LSA 4 salt are presented in Table 2.2-9. Similar data for the 
LSA 5 salt are presented in Table 2.2-10. In order to develop strength parameters for use in design, the data were analyzed according to Mohr-Coulomb strength criteria (Jaeger and Cook, 1979). Uniaxial and triaxial compressive strength data and the $\sigma_{1}$ versus $\sigma_{3}$ relationships are shown in Figures $2.3-6$ and 2.3-7 for the LSA 4 and LSA 5 salts, respectively. Test data for similar temperatures are grouped together.

Compressive tests of salt were conducted at room temperature by RSI and ARA. As seen in Tables 2.2-9, 2.2-10, and Figures 2.3-7 and 2.3-8, RSI conducted compression tests at both $68^{\circ} \mathrm{F}$ and $75^{\circ} \mathrm{F}$. Because no differences in strength were discernable at the two temperatures, results of tests conducted at both $68^{\circ} \mathrm{F}$ and $75^{\circ} \mathrm{F}$ were grouped together as room temperature tests. An obvious difference, however, was observed between the test results obtained by RSI and those obtained by ARA; the ARA data demonstrated consistently lower maximum principal stress values than the RSI data. Upon review of test procedures, it was observed that:

1. RSI conducted compression tests at a constant stress-rate of $0.025 \mathrm{MPa} / \mathrm{s}$ whereas ARA conducted compression tests at a constant strain-rate of $10^{-6} / \mathrm{s}$ (SGDRD, DOE, 1986b). Interestingly, these different experimental procedures result in similar specimen loading rates for the linear stress-strain portion of the loading cycle for salt, with a Young's modulus of about $4 \times 10^{6} \mathrm{psi}$ (see Section 2.3.3.3.2).

2. In cases where a clearly defined peak in the stress/strain curve did not develop, RSI carried its tests to about $12 \%$ axial strain and considered the stress difference at $12 \%$ strain to be the failure strength. ARA carried its tests to a much lower degree of strain, generally about $1 \%$ to $2 \%$. Over the range of axial strain investigated, salt specimens commonly exhibited increased axial stress with increased axial strain. Thus, the RSI test results show significantly higher strength levels than those of ARA. 


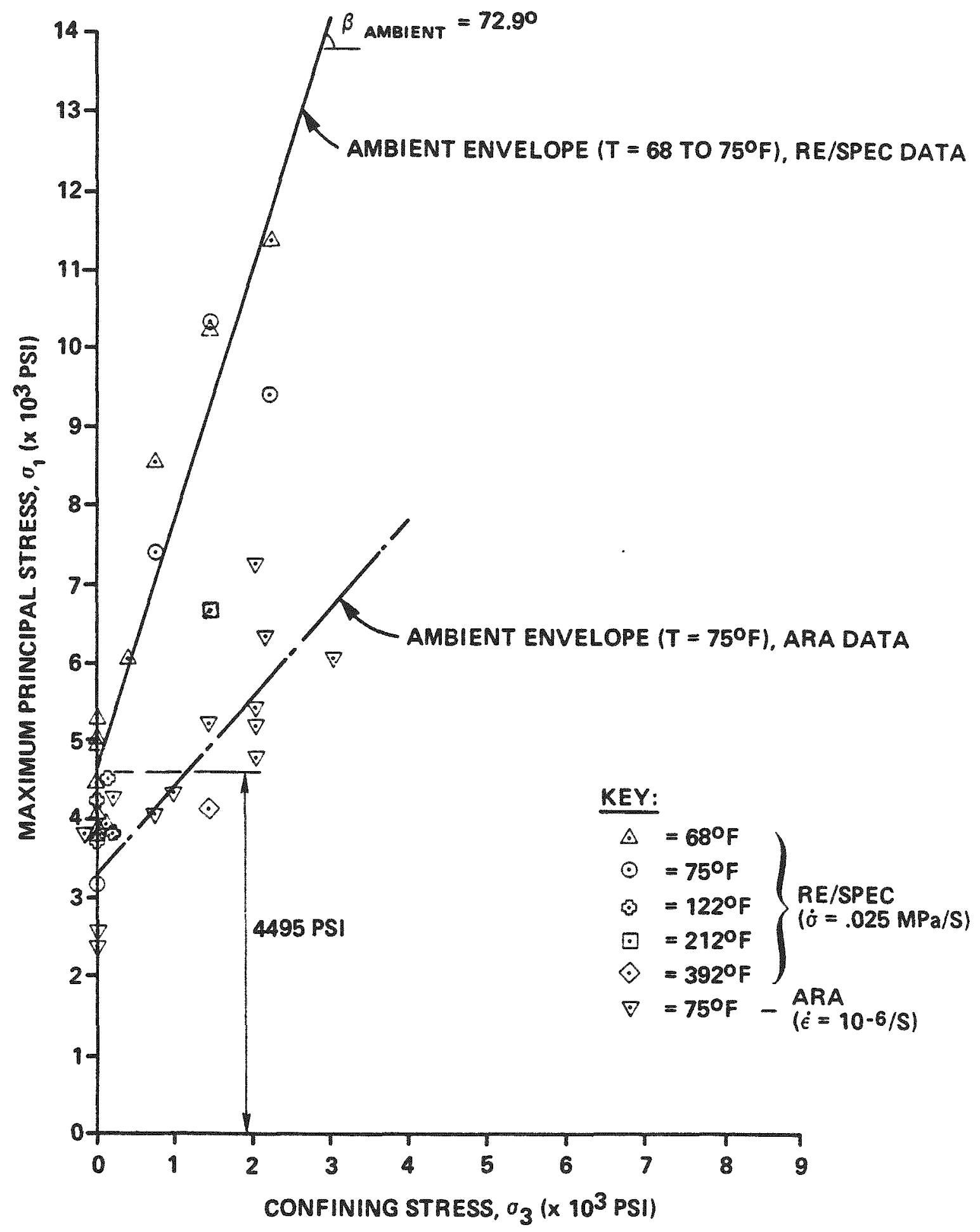

COMPAESSIVE STRENGTH

ENVELOPES, LSA 4 SALT

FIGURE $2.3-7$ 


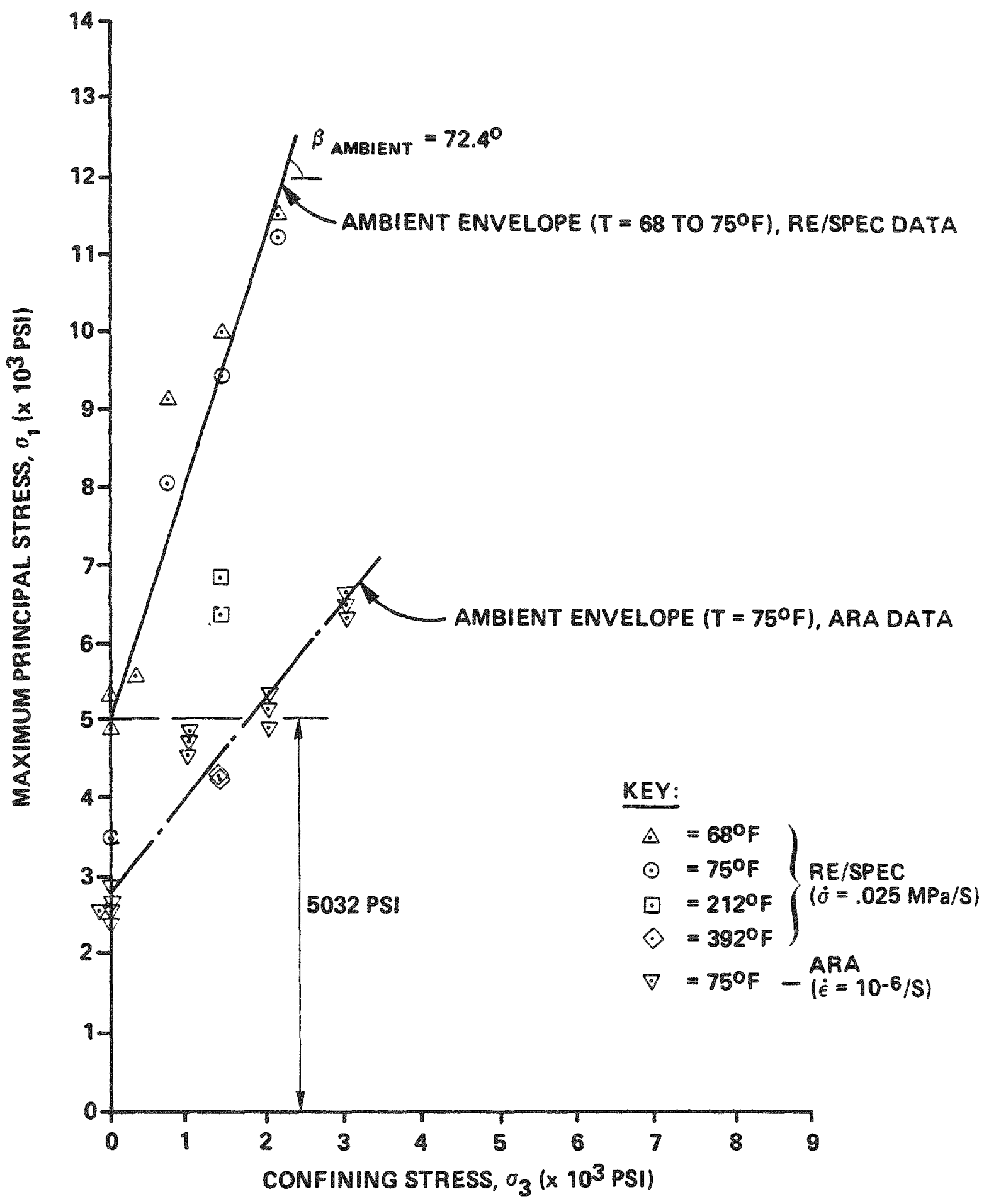

COMPRESSIVE STRENGTH

ENVELOPES, LSA 5 SALT

FIGURE $2.3-8$ 
The A/E Contractor believes that tests by ARA may have been terminated prematurely at unreasonably small axial strains. Analysis of the ARA test data showed compressive strength parameters far below those generally reported for salt. On this basis, it was decided that only the RSI data would be used to determine strength parameters of the LSA 4 and 5 salt strata. The remainder of this subsection addresses analyses having to do with the RSI data only.

A least-squares fitting procedure was employed to develop a straight line representation of the $\sigma_{1}$ versus $\sigma_{3}$ relationship using ambient temperature test data, where $\sigma_{1}$ and $\sigma_{3}$ are the axial stress and confining pressure, respectively, at failure. For the ISA 4 salt, the slope angle, $\beta$, and the vertical axis intercept, $\mathrm{S}$, were found to be:

$$
\begin{aligned}
& \beta=72.9^{\circ} \\
& S=4,495 \text { psi }
\end{aligned}
$$

ine correlation coefficients obtained as a result of the least-squares fitting procedure were 0.94 for LSA 4 salt, and 0.95 for LSA 5 salt. The values of $\beta$ and $S$ were then used to compute the angle of internal friction $(\phi)$ and the cohesion ( $C$ ) by the following relationships:

$$
\begin{aligned}
& \phi=2\left[\tan ^{-1} \sqrt{\tan \beta}-45^{\circ}\right] \\
& c=\frac{s}{2 \tan \left(45^{\circ}+\phi / 2\right)}
\end{aligned}
$$

These relationships are presented graphically and discussed in Jaeger and Cook (1979, pp. 87-91). The values of $\phi$ and C for LSA 4 and LSA 5 salts are shown in Eigure 2.3-9.

This procedure results in a straight line representation of the strength envelope. Wrile a straight line could have been graphically drawn to envelope the various Mohr circles shown in Figure 2.3-9, the procedure described above is a preferred, statistically sound approach for determining the "best-fit" $\phi$ 

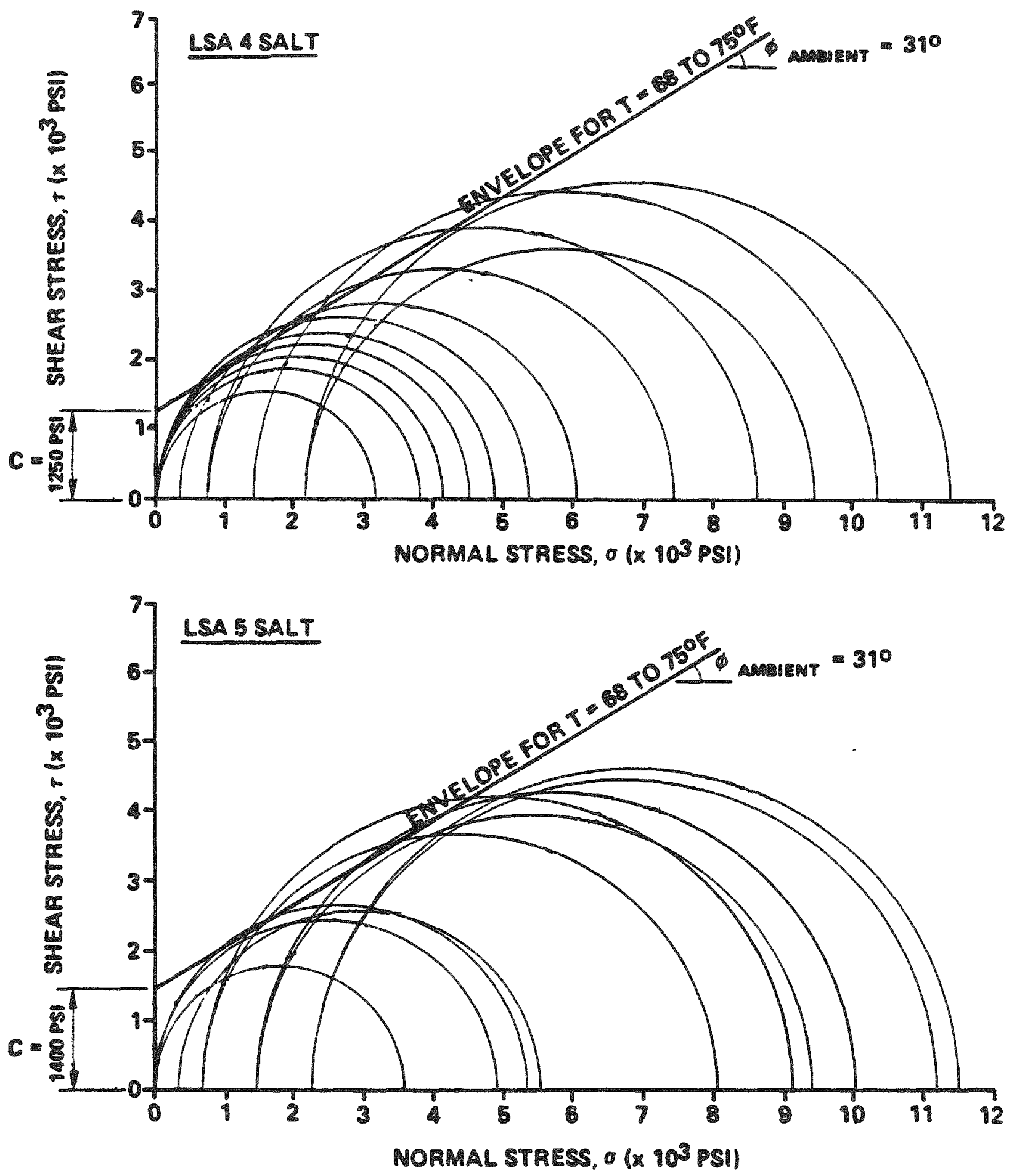

NOTE: All terts conducted at constant stres-rate of 0.025 MP®/S.

MOHR STRENGTH ENVELOPES. LSA A AND 5 SALT

FIGURE $2.3-9$ 
and $C$ values, and it provides an assessment of the statistical variability of these parameters. Variability of the strength parameters is discussed in Section 7.3, Engineering Analysis of Design. The fact that the straight line shown for ambient temperature lies below the tangent points of some of the test circles shows that the line is a slightly conservative representation of those test results. It should be noted, however, that for salt, it may be more appropriate to develop an expression for a curvilinear rather than a linear strength envelope. This point will be considered further in the advanced conceptual design phase. A linear strength envelope was considered sufficiently representative and suitably conservative for this level of design, given the sparsity of data.

The unconfined compressive strength of the salt is another strength parameter which was determined. The intercept of the least-squares line along the vertical axis of the stress plot of Figures 2.3-6 and 2.3-7 provides an estimate of this value. However, due to the nonlinear strength characteristics of salt, such straight line projections yield unacceptably high estimates of the true unconfined strength and are not considered appropriate for this conceptual design. The procedure followed for this design was to compute the mean unconfined compressive strength value from the actual uniaxial test results at the ambient temperature tabulated in Tables $2.2-9$ and 2.2-10. This procedure results in a discontinuity in salt strength between confined and unconfined conditions. However, considering the relatively small size of the discontinuity (approximately $250 \mathrm{psi}$ ) and the simple linear model for confined salt strength, it was judged to be an acceptable, reasonable representation of salt strength in SCP conceptual design. As discussed above, only the results of tests conducted by RSI were considered.

The design values for unconfined compressive strength, angle of internal friction, and cohesion for the LSA 4 and 5 salt strata are summarized in Table 2.3-5. The design values for unconfined compressive strength and cohesion were determined by rounding the computed values downward to the nearest $50 \mathrm{psi}$. The design value for the angle of internal friction was determined by rounding the computed value downward to the nearest degree. 
It is known that the strength of salt decreases with increased temperature. Here, the strength of salt is defined, as it customary, as the stress at which the load bearing capacity of the specimen starts to decrease. Tests were carried out at elevated temperatures. However, the number of tests performed was limited. Specifically, for LSA 4 salt, four uniaxial tests were conducted at $122^{\circ} \mathrm{F}$, and one triaxial test each was conducted at $212^{\circ} \mathrm{F}$ and $392^{\circ} \mathrm{F}$, at 1,450 psi confining pressure. For LSA 5 salt, two triaxial tests each were conducted at $212^{\circ} \mathrm{F}$ and $392^{\circ} \mathrm{F}$, and $1,450 \mathrm{psi}$ confining pressure. The results of these tests are presented in Table 2.2-9 and Figure 2.3-7 for LSA 4 salt, and Table 2.2-10 and Figure 2.3-8 for LSA 5 salt.

Increased temperature resulted in decreased failure stress. There is some indication from the test results that, at 1,450 psi confining pressure, the failure stress decreases linearly with temperature. However, more experimental data is required to quantitatively model the relationships between salt strength, temperature, and confining pressure.

\subsection{Other Quasi-Static Parameters. Values of test results for} static Young's modulus, static Poisson's ratio, and indirect tensile strength are tabulated in Table 2.2-9 for ISA 4 salt and Table 2.2-10 for LSA 5 salt. These results were analyzed for mean, standard deviation, and overall range of test results for each of the three properties. While the tables contain several values of Young's modulus and Poisson's ratio at elevated temperatures, there were insufficient data points to establish a reasonable variation of these properties with temperature. Therefore, only ambient temperature values were calculated for design purposes. These values were obtained by computing the mean values from the data and then rounding downward to the nearest 100,000 psi for static Young's modulus and to the nearest 10 psi for indirect tensile strength. The design value of Poisson's ratio is the unadjusted mean value. These values are presented in Table 2.3-5. 
Table 2.3-5. Geomechanical Parameters for Repository Horizon

\begin{tabular}{|c|c|c|c|c|c|c|}
\hline Salt Stratum & $\begin{array}{l}\text { Uniaxial } \\
\text { Compressive } \\
\text { Strength } \\
\text { (psi)* }\end{array}$ & $\begin{array}{l}\text { Angle of } \\
\text { Internal } \\
\text { Eriction, } \Phi \\
\text { (degrees)* }\end{array}$ & $\begin{array}{l}\text { Cohesion, } \\
\text { C, }(p s i) *\end{array}$ & 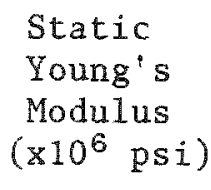 & $\begin{array}{l}\text { Static } \\
\text { Poisson s } \\
\text { Ratio }\end{array}$ & $\begin{array}{c}\text { Indirect } \\
\text { Tensile } \\
\text { Strength } \\
\text { (psi) }\end{array}$ \\
\hline LSA 4 (Ambient) & 4,200 & 31 & 1,250 & 4.0 & 0.27 & 230 \\
\hline LSA 5 (Ambient) & 4,600 & 31 & 1,400 & 4.4 & 0.27 & 220 \\
\hline
\end{tabular}

*NOTE: Tests conducted at a constant stress-rate of $0.025 \mathrm{MPa} / \mathrm{s}$.

2.3.3.3.3 Creep Parameters. As discussed in Section 2.2.3.3.3, creep parameters were developed by RSI for each of the salt strata. For both strata, preliminary calculations were based on the results of three tests, and the subsequent calculations were based on 12 additional tests, three of which repeated the test conditions applied in the preliminary tests. It was concluded that the creep parameters developed from the 12 tests were more representative. Thus, these parameters were used for design purposes. The values are presented in Table 2.3-6.

Table 2.3-6. Creep Parameters for Repository Horizon*

\begin{tabular}{|c|c|c|c|c|c|c|}
\hline \multirow[b]{2}{*}{ Stratum } & \multicolumn{3}{|c|}{ Steady-State Creep } & \multicolumn{3}{|c|}{ Transient Creep } \\
\hline & $\mathrm{MPa}^{-\mathrm{A}} \mathrm{s}^{-1}$ & n & $\begin{array}{l}\mathrm{Q} / \mathrm{R} \\
{ }^{\circ} \mathrm{K}\end{array}$ & $\stackrel{*}{\varepsilon}_{s s}$ & $\varepsilon_{\mathrm{a}}$ & $\begin{array}{l}\text { B } \\
-\end{array}$ \\
\hline LSA 4 & $6.5 \times 10^{-3}$ & 5.5 & 9,770 & $1.6 \times 10^{-8}$ & $6.8 \times 10^{-2}$ & 88 \\
\hline LSA 5 & $8.0 \times 10^{-3}$ & 5.3 & 9,810 & $4.1 \times 10^{-8}$ & $3.9 \times 10^{-2}$ & 96 \\
\hline
\end{tabular}

*NOTE: Refer to Table 2.2-11 for presentation of creep equations used in design. 
2.3.3.4 Seismic Parameters Considered in Underground Design

Seismic activity can cause two principal forms of ground motion: ground dislocation along faults or fault systems, and ground shaking. The probability of a fault intercepting the horizon and subjecting the repository to dislocation was assumed to be extremely remote. Thus, shaking caused by fault dislocation at significant distances from the repository was assumed to be the primary form of ground motion. In general, empirical evidence suggests that deep underground openings suffer little or no distress during seismic shaking. On this preliminary basis, it was assumed that seismic design is not a major consideration for deep underground design at this level of conceptual design. No detailed seismic design parameters were developed.

\subsubsection{Thermal Parameters Considered in Underground Design}

The A/E Contractor utilized the SGDRD (DOE, 1986b) thermal property relationships for salt rock of the repository horizon. The thermal conductivity relationship for salt as presented in the SGDRD is as follows:

$$
\mathrm{k}(\mathrm{T})=1554.289 / \mathrm{T}+0.348 \quad(\mathrm{Eq} \cdot 2.3-1)
$$

where $k(T)$ is thermal conductivity and $T$ is temperature in degrees Kelvin. Other thermal parameters for salt are a specific heat of $900 \mathrm{~J} / \mathrm{kg}-\mathrm{K}$ and a coefficient of thermal expansion of $36 \times 10^{-6} / \mathrm{K}$.

For nonsalt rock in the emplacement entry region, refer to the nonsalt strata above and below LSA 4 salt, presented on Table 2.3-4. The ambient temperature of the repository horizon, LSA 4 salt, is estimated to be $81^{\circ} \mathrm{F}$ (DOE, 1986a, EA, p. 3-104) as shown in Figure 2.3-5. 


\subsection{DESIGN REQUIREMENTS}

The design of surface and underground systems, structures, and components in the SCP conceptual design must satisfy both general and specific programmatic requirements. The designs must also be in sufficient detail to ensure that the site characterization data-gathering effort will provide all site data needed for the license application design. Design requirements have been developed for the repository program so that repository designs will comply with programmatic needs. Functional requirements and design criteria used in the SCP conceptual design were in effect at the start of CDR design activities (October, 1985), or added since. No requirements or criteria have become obsolete in the period from the start of SCP conceptual design to the completion of the design effort (April, 1987). The existing functional requirements and design criteria are summarized in this section. The arrangement is as follows: program baseline requirements, general design requirements, major design assumptions, and definition of repository scope.

\subsubsection{Program Requirements}

The design requirements for the repository are set forth in three program documents. The purpose and content of these documents are briefly summarized below.

1. The Mission Plan (DOE, 1985b) provides detailed information about the spent nuclear fuel and high-level radioactive waste requiring disposal under the NWPA. Part I contains the strategy and definition of the program the DOE intends to implement for the disposal of the above wastes. Part II provides specific details of the repository program and steps taken to resolve key issues by obtaining needed information. Such needed information is to be provided through site investigation, site characterization, and a variety of underground tests and evaluations. The mission plan has been prepared to fulfill the requirement of Section 301 (a) of the NWPA. 
The Mission Plan has recently been amended (DOE, 1987b) to restate DOE positions on the schedule for the first repository, wasteacceptance strategy, the Monitored Retrievable Storage (MRS) facility, and the schedule for the second repository. If the amended plan is adopted, Phase 1 operations at the first repository (Section 2.4.4.1) would be delayed five years, from 1998 to 2003. The MRS facility would be built and would start receiving waste in 1998 . The initial operation of the second repository would be deferred until the year 2023. The proposed changes in the waste acceptance schedule are illustrated in Table 2.4-1. As in the original Mission Plan (DOE, $1985 \mathrm{~b})$, the total emplacement in the repository is limited to 70,000 MTU in the amended plan.

The changes proposed in the Mission Plan Amendment have not been incorporated in the SCP conceptual design. The original Mission Plan (DOE, 1985b) is the basis for the SCP conceptual design. The Mission Plan Amendment may be used for further design evaluations during $A C D$.

2. The Generic Requirements for a Mined Geologic Disposal System (GRMGDS) (DOE, 1985a) is a baseline document for the Office of Geologic Repository program and provides consistency among the programs dealing with the various media being considered for waste disposal. This document lists the functional requirements, performance criteria, and constraints which must be considered.

The appendices of the GRMGDS provide interface information relating the waste source systems and transportation system to repository design and operation, cover generic requirements of the decommissioning phase of the repository, and describe the repository program position on ESF design, construction, and operation. Appendix $D$ of the GRMGDS describes the Office of Geologic Repositories (OGR) position on waste retrievability. 
Table 2.4-1. Comparison of Original and Amended Mission Plan Waste Form Receipt Rates

\begin{tabular}{|c|c|c|c|c|c|c|c|}
\hline \multirow[b]{2}{*}{ Year } & \multicolumn{4}{|c|}{1987 Mission Plan Amendment (a) } & \multicolumn{3}{|c|}{1985 Original Mission Plan(b) } \\
\hline & $\begin{array}{l}\text { Spent Fuel Re } \\
\text { From MRs (d) }\end{array}$ & $\begin{array}{c}\text { ceipts (MTU) (c) } \\
\text { Direct } \\
\text { From Reactors }\end{array}$ & $\begin{array}{c}\text { Defense HLW(e) } \\
\text { Receipts } \\
\text { (MTU Equiv.) }\end{array}$ & $\begin{array}{c}\text { Total Receipts } \\
\text { (MTU Equiv.) }\end{array}$ & $\begin{array}{c}\text { Spent Fue1 } \\
\text { Receipts (MTU) }\end{array}$ & $\begin{array}{c}\text { Defense HLW(e) } \\
\text { Receipts } \\
\text { (MTU Equiv.) }\end{array}$ & $\begin{array}{c}\text { Total Receipts } \\
\text { (MTU Equiv.) }\end{array}$ \\
\hline $\begin{array}{l}1998 \\
1999 \\
2000 \\
2001 \\
2002 \\
2003 \\
2004 \\
2005 \\
2006 \\
2007 \\
2008 \\
2009 \\
2010 \\
2011 \\
2012 \\
2013 \\
2014 \\
2015 \\
2016 \\
2017 \\
2018 \\
2019 \\
2020 \\
2021 \\
2022 \\
2023 \\
2024 \\
2025 \\
2026 \\
2027 \\
2028 \\
\text { Tota1 }\end{array}$ & $\begin{array}{r}400 \\
400 \\
400 \\
900 \\
1,800 \\
2,650 \\
2,650 \\
2,650 \\
2,650 \\
2,650 \\
2,650 \\
2,650 \\
2,650 \\
2,650 \\
2,650 \\
2,650 \\
2,650 \\
2,650 \\
2,650 \\
2,650 \\
2,650 \\
3,000 \\
3,000 \\
3,000 \\
3,000 \\
1,460 \\
59,760\end{array}$ & $\begin{array}{l} \\
350 \\
350 \\
350 \\
350 \\
350 \\
350 \\
350 \\
350 \\
350 \\
350 \\
350 \\
350 \\
350 \\
350 \\
350 \\
350\end{array}$ & $\begin{array}{l}400 \\
400 \\
400 \\
400 \\
400 \\
400 \\
400 \\
400 \\
400 \\
400 \\
400 \\
240\end{array}$ & $\begin{array}{r}400 \\
4,00 \\
400 \\
900 \\
1,800 \\
3,400 \\
3,400 \\
3,400 \\
3,400 \\
3,400 \\
3,400 \\
3,400 \\
3,400 \\
3,400 \\
3,400 \\
3,400 \\
3,240 \\
3,000 \\
3,000 \\
3,000 \\
3,000 \\
3,000 \\
3,000 \\
3,000 \\
3,000 \\
1,460 \\
70,000\end{array}$ & $\begin{array}{r}400 \\
400 \\
400 \\
900 \\
1800 \\
3000 \\
3000 \\
3000 \\
3000 \\
3000 \\
3000 \\
3000 \\
3000 \\
3000 \\
3000 \\
3000 \\
3000 \\
3000 \\
3000 \\
3000 \\
3000 \\
3000 \\
3000 \\
3000 \\
1100\end{array}$ & $\begin{array}{l}400 \\
400 \\
400 \\
400 \\
400 \\
400 \\
400 \\
400 \\
400 \\
400 \\
400 \\
400 \\
400 \\
400 \\
400 \\
400 \\
400 \\
400 \\
400 \\
400\end{array}$ & $\begin{array}{r}400 \\
400 \\
400 \\
900 \\
1,800 \\
3,400 \\
3,400 \\
3,400 \\
3,400 \\
3,400 \\
3,400 \\
3,400 \\
3,400 \\
3,400 \\
3,400 \\
3,400 \\
3,400 \\
3,400 \\
3,400 \\
3,400 \\
3,400 \\
3,400 \\
3,400 \\
3,400 \\
1,500\end{array}$ \\
\hline
\end{tabular}

a The Mission Plan Amendment (DOE, 1987b) may be used for future repository design evaluations.

b DOE, 1985b. Thls is the basis for this SCP conceptual design.

c MTU - Mecric tons uranium or equivalent.

d MRS - Monitored Retrieval Storage Facility.

e H.W - High-level waste. Includes West Valley high-level waste. 
3. The Interim Repository Subsystem Design Requirements (RSDR)

(Appendix A) provides design details above and beyond those specified in the GRMGDS. The RSDR defines the technical basis for the conceptual design of a nuclear waste repository in salt. The RSDR will be superceded by the Salt Repository Project Requirements Document (SRP$\mathrm{RD}$ ). The SRP-RD, will be used as the basis for future updates of the salt repository design.

\subsubsection{General Design Guidelines}

To facilitate the conceptual design process, the $A / E$ contractor defined general design guidelines or requirements. The guidelines cover topics for which specific baseline requirements have not yet been identified, but which do require direction to assure a complete, balanced design. Included in the guidelines are trade-off studies which were not formally pursued for the SCP-CDR, but are expected to be a part of ACD. The general design guidelines are:

1. Conservative design parameters will be used to provide a design with a sufficient safety margin to account for uncertainties that could adversely affect repository performance.

2. Reasonably available technology will be applied to the design, construction, operations, decommissioning, and postclosure phases. A prudent approach to satisfying $10 \mathrm{CFR} 60$ and $10 \mathrm{CFR} 960$ is to assume that any technology having a safety significance should be developed by the time of license application. Therefore, it is assumed that all major elements of the design will be proven prior to the start of final procurement and construction design.

3. All surface and underground facilities will be designed so that they can be constructed and operated to perform the required functions, but in a manner that minimizes their impact on the environment. The requirement to minimize environmental impacts is in addition to the performance requirements related to the protection of public health and safety. 
4. The design, construction, and operation of the repository will be based on the most cost-efficient options without sacrificing health, safety, and technical conservatism.

5. The cost-efficient use of nonrenewable energy sources will be considered for the design of buildings, heating and cooling systems, and all electrical power uses. Energy conservation, energy recovery systems, and alternative energy sources will be used in the final design whenever economically justifiable.

6. As a minimum, radiation exposure to operating personnel and to the public will meet the requirements of 10 CFR60 and 10CFR20 and further, will be kept as $10 w$ as reasonably achievable.

\subsubsection{Major Design Assumptions}

\subsubsection{General Design Concepts}

The SCP conceptual design is based on several general design concepts that are either new or revisions of concepts of previous salt repository designs. These general design concepts are:

1. The two-phase repository concept has been incorporated into the SCP conceptual design (see Section 1.4 and 2.4.4.1 for details). This concept is identified in the Mission Plan (DOE, 1985b).

2. The requirements of 30CFR57, including Subpart $T$, Gassy Mines, were followed with a modification of the requirements for 100-ft maximum distances between entry center lines. The gassy mine safety regulations are assumed in the design basis even though the site is currently not considered to have gassy conditions. These requirements address concerns with mine ventilation during construction. The repository design will, in a manner consistent with Mine Safety and Health Administration (MSHA) and/or state regulations, utilize acceptable alternative means of providing adequate ventilation during construction, thus allowing a subsurface configuration determined 
by the $A / E$ contractor to be more suitable for waste emplacement and isolation. Furthermore, the design complies with MSHA proposed regulations 30CFR57.36000, Category III Mines.

3. At the direction of SRPO, the A/E Contractor prepared conceptual designs for a reference case using the vertical emplacement mode and a passive alternate case using the horizontal emplacement mode. This design describes the reference case, which is based on vertical emplacement in boreholes in the floors of the emplacement entries. The passive alternate case design, which is based on horizontal emplacement, is addressed in a separate report (Fluor Technology, Inc., 1987b).

4. This SCP conceptual design assumes the ESF shafts as well as the underground excavations will be integrated with repository operations (DOE, 1985a, App. E).

5. Areal thermal loading has been investigated by the $A / E$ Contractor and revised in this SCP conceptual design. The design is now based primarily on retrievability requirements which yield a lower, more conservative areal loading than in previous salt repository designs. (See Section 6.4.4 for a discussion of factors limiting areal thermal loading.)

\subsubsection{Specific Design Assumptions}

Major assumptions required to complete the SCP conceptual design are:

1. All on-site generated radwaste will be solidified in 55 gallon drums and placed in a dedicated interim surface storage area for eventual shipment offsite. This surface storage area will be provided within the repository fenceline.

2. During Phase I, the PWR disposal containers will contain four SFAs with a heat load of $2.2 \mathrm{~kW}$ or four RCSF boxes with a heat load of $4.4 \mathrm{~kW}$. The BWR disposal containers will contain nine SFAs or nine RCSF boxes with heat loads of 1.62 or $3.24 \mathrm{~kW}$, respectively. 
3. During Phase II, the PWR disposal containers will contain 12 consolidated fuel assemblies with a heat load of $6.6 \mathrm{~kW}$ or four RCSF boxes with a heat load of $4.4 \mathrm{~kW}$. The BWR disposal containers will contain 30 consolidated assemblies with a heat load of $5.4 \mathrm{~kW}$ or nine RCSF boxes with a heat load of $3.24 \mathrm{~kW}$. DHLW and WHLW containers will hold one canister each. Their heat loads are $0.42 \mathrm{~kW}$ and $0.23 \mathrm{~kW}$, respectively.

4. During Phase II, approximately ten percent of the SFAs will not be susceptible to disassembly and consolidation. These assemblies will be packaged intact in containers with capacities as in item No. 2 above.

5. FAH disposal containers will hold compacted hardware from 18 PWR or 45 BWR assemblies. Some end fitting removal may be required for the intact disposal of longer BWR assemblies. Since a BWR end fitting provides structural support to the assembly, the entire end fitting will not be removed. Portions will be removed to shorten the assembly sufficiently. In those cases, end fitting pieces will be packaged in $\mathrm{FAH}$ containers with capacities equivalent to $90 \mathrm{BWR}$ assemblies.

6. The emplacement borehole annulus will be backfilled with crushed salt packing material. Crushed salt will be used above the container in the emplacement borehole for shielding purposes.

7. Waste receipts will be based on five rail casks per train and one truck cask per truck. Each rail cask will contain waste in one of the following quantities: 12 PWR assemblies, 32 BWR assemblies, 32 RCSF boxes, or five HLW canisters. Each truck cask will contain one of these quantities: two PWR assemblies, five BWR assemblies, or five RCSF boxes. All DHLW and WNHLW canisters will arrive by rail. It is assumed that individual casks will be loaded with only one waste type, not a mixture. 
8. Facilities for receiving shipping casks will be designed for alternative scenarios that include receiving as much as $80 \%$ of the waste by rail and as much as $70 \%$ of the waste by truck.

9. The capability to provide ventilation backflow in the emplacement area by reversing the ventilation system is not required. However, this capability is required in the development area.

10. Underground areal heat loading will be based upon either an acceptable retrieval scenario or on very near-field constraints, whichever is most limiting.

Acceptable retrieval scenarios will be based on creep rates and environmental temperature in the emplacement entries during retrieval. The acceptable design will consider variations in the length of the emplacement entries, emplacement geometry, ventilation, and the time required for retrieval of the waste packages.

Very near-field temperature constraints are spent fuel cladding temperatures at $707^{\circ} \mathrm{F}\left(375^{\circ} \mathrm{C}\right)$, glass HLW temperatures at $932^{\circ} \mathrm{F}$ $\left(500^{\circ} \mathrm{C}\right)$ and salt temperatures at $482^{\circ} \mathrm{F}\left(250^{\circ} \mathrm{C}\right)$ (Appendix A).

11. Exploratory shafts will be integrated into the repository to support early development and functional needs of the repository. The ESF Title I Design layout was used. The layout will change on the basis of the completed ESF Title II Design.

12. Ground consolidation and water control during shaft construction in the Ogallala and Dockum formations will be achieved by means of ground freezing techniques. Grouting will be employed to control water inflows in minor aquifers.

13. Underground performance confirmation areas will be designated for emplacement, storage, and monitoring of waste packages. These areas may be heated to duplicate the thermal environment of the emplacement areas. Partial backfill will be included. Two packages will be removed per year for performance confirmation testing. 
14. The U.S. Nuclear Regulatory Commission (NRC) will allow entry backfilling immediately after emplacement is completed in an entry.

15. Exposure of repository operations personnel to radiation will be limited to a design goal of 20 percent of the 10CFR20 limits. This equates to a design goal worker exposure of 1,000 mrem or less per year. (See Section 2.5.1 for a discussion of this limit.)

\subsubsection{Definition of Repository Scope}

The repository will be designed to receive, handle, consolidate, and dispose of spent fuel assemblies and RCSF boxes from commercial light water reactors, and to receive, handle, and dispose of canisters of vitrified highlevel waste from commercial and defense-related facilities. The repository will have the facilities and equipment to retrieve any part of, or all of, the emplaced spent fuel and high-level waste.

The repository will also have the capability to monitor, collect, treat, solidify, and package all on-site generated radwaste. This waste will be packaged in drums and temporarily stored on site in a surface storage area. These radwaste drums will at some point be shipped offsite.

\subsubsection{Two-Phase Concept}

The repository will be constructed and operated in two overlapping phases. Section 1.4 discusses the rationale for the two phase concept. Phase I operation will begin on or before January 31, 1998, and continue through February, 2003. During this phase, waste will be received at a rate of 400 MTU per year. Only spent fuel assemblies and RCSF boxes will be received and they will be packaged intact with no rod consolidation. Also, during this phase, preparations for Phase II operations will be completed.

Phase II operations will begin in February, 2001 at a reduced receiving rate and reach the design receipt rate of 3,000 MTU per year by February, 2003. Phase II spent fuel will be disassembled before it is packaged and emplaced. 
Beginning in the year 2003, the repository will also be capable of receiving and handling canisters of high-level waste (DHLW and WWHLW) at a rate of 400 MTU equivalent per year.

\subsubsection{Waste Types}

The repository will be designed to receive the following waste types:

1. Intact spent fuel. LWR fuel assemblies.

2. Consolidated fuel rods. LWR fuel rods in steel boxes (RCSF boxes).

3. DHLW. HLW canisters from the Defense Waste Processing Facility.

4. WHLW. HLW canisters from the West Valley Demonstration Facility.

No liquid radioactive waste or solid waste in liquid packing (e.g., water filled shipping casks) will be accepted at the repository. Nor will any liquid waste forms be transferred to the repository underground.

The repository will be designed to handle spent fuel with nominal burnup (on the order of 33,000 MWd/MTU), that has been stored at least 10 yrs after discharge from the reactor. However, the repository will also have the capacity to receive, handle, and dispose of spent fuel with burnups as high as $60,000 \mathrm{MWd} / \mathrm{MTU}$ and that have been stored only 5 yrs after reactor discharge.

\subsubsection{Waste Throughput}

The total repository capacity for spent fuel and HLW will be equivalent to $70,000 \mathrm{MTU}$. This capacity is based on the following inventory:

1. 650 MTU equivalent of WVHLW.

2. 7,350 MTU equivalent of DHLW.

3. 62,000 MTU of spent fuel.

Expected waste receipt rates are given in the Repository Subsystem Design Requirements (Appendix A). That document summarizes these rates by year for both Phases $I$ and II in Table 2.4-2. 
Table 2.4-2. Waste Form Receipt Rates(a)(d) (Sheet 1 of 2)

\begin{tabular}{|c|c|c|c|c|c|c|c|c|c|c|c|c|c|c|c|c|}
\hline \multirow{4}{*}{ YEAR } & \multirow{4}{*}{ DATE } & \multicolumn{5}{|c|}{ PLIASE I } & \multicolumn{5}{|c|}{ PHASE II } & \multirow{4}{*}{$\begin{array}{l}\text { MTU } \\
\text { EQUIV. }\end{array}$} & \multirow{4}{*}{$\begin{array}{l}\text { DHLW/WVHLW } \\
\text { CANISTERS }\end{array}$} & \multirow{2}{*}{\multicolumn{3}{|c|}{ TOTALS }} \\
\hline & & \multirow{3}{*}{ MTU } & \multicolumn{4}{|c|}{ NUMBER OF WASTE UNTTS } & \multirow{3}{*}{ MTU } & \multicolumn{4}{|c|}{ NUMBER OF WASTE UNITS } & & & & & \\
\hline & & & PW & & $B W$ & & & & WR & & & & & \multirow[t]{2}{*}{ MTU } & \multicolumn{2}{|c|}{ SFAs $(c)$} \\
\hline & & & $\operatorname{RCSF}(b)$ & SFA(c) & $\operatorname{RCSF}(\mathrm{b})$ & SFA(c) & & $\operatorname{RCSF}(b)$ & $\mathrm{SFA}(\mathrm{c})$ & $\operatorname{RCSF}(b)$ & SFA(c) & & & & PWR & BWR \\
\hline 1 & 1998 & 400 & 110 & 336 & 160 & 481 & - & & & & & & & 400 & 556 & 801 \\
\hline 2 & 1999 & 400 & 100 & 357 & 143 & 513 & - & & & & & & & 400 & 557 & 799 \\
\hline 3 & 2000 & 400 & 89 & 379 & 127 & 545 & - & & & & & & & 400 & 557 & 799 \\
\hline 4 & 2001 & 400 & 34 & 488 & 50 & 702 & 500 & 43 & 610 & 62 & 876 & & & 900 & 1,252 & 1,802 \\
\hline 5 & 2002 & 400 & 14 & 529 & 20 & 759 & 1,500 & 52 & 1,982 & 76 & 2,850 & & & 1,900 & 2,643 & 3,801 \\
\hline 6 & 2003 & - & & & & & 3,000 & 55 & 4,064 & 80 & 5,840 & 400 & 185 & 3,400 & 4,174 & 6,000 \\
\hline 7 & 2004 & & & & & & 3,000 & 44 & 4,086 & 64 & 5,870 & 400 & 415 & 3,400 & 4,174 & 6,000 \\
\hline 8 & 2005 & & & & & & 3,000 & 33 & 4,108 & 48 & 5,904 & 400 & 800 & 3,400 & 4,174 & 6,000 \\
\hline 9 & 2006 & & & & & & 3,000 & 22 & 4,130 & 32 & 5,936 & 400 & 800 & 3,400 & 4,174 & 6,000 \\
\hline 10 & 2007 & & & & & & 3,000 & 11 & 4,152 & 16 & 5,968 & 400 & 800 & 3,400 & 4,174 & 6,000 \\
\hline 11 & 2008 & & & & & & 3,000 & - & 4,174 & - & 6,000 & 400 & 800 & 3,400 & 4,174 & 6,000 \\
\hline 12 & 2009 & & & & & & 3,000 & - & 4,174 & - & 6,000 & 400 & 800 & 3,400 & 4,174 & 6,000 \\
\hline 13 & 2010 & & & & & & 3,000 & & 4,174 & & 6,000 & 400 & 800 & 3,400 & 4,174 & 6,000 \\
\hline 14 & 2011 & & & & & & 3,000 & & 4,174 & & 6,000 & 400 & 800 & 3,400 & 4,174 & 6,000 \\
\hline 15 & 2012 & & & & & & 3,000 & & 4,174 & & 6,000 & 400 & 800 & 3,400 & 4,174 & 6,000 \\
\hline 16 & 2013 & & & & & & 3,000 & & 4,174 & & 6,000 & 400 & 800 & 3,400 & 4,174 & 6,000 \\
\hline 17 & 2014 & & & & & & 3,000 & & 4,174 & & 6,000 & 400 & 800 & 3,400 & 4,174 & 6,000 \\
\hline 18 & 2015 & & & & & & 3,000 & & 4,174 & & 6,000 & 400 & 800 & 3,400 & 4,174 & 6,000 \\
\hline 19 & 2016 & & & & & & 3,000 & & 4,174 & & 6,000 & 400 & 800 & 3,400 & 4,174 & 6,000 \\
\hline
\end{tabular}


Table 2.4-2 (Sheet 2 of 2 )

\begin{tabular}{|c|c|c|c|c|c|c|c|c|c|c|c|c|c|c|c|}
\hline \multirow{4}{*}{ YEAR } & \multirow{4}{*}{ DATE } & \multicolumn{4}{|c|}{ PHASE I } & \multicolumn{5}{|c|}{ PHASE II } & \multirow{4}{*}{$\begin{array}{l}\text { MTU } \\
\text { EQUTV. }\end{array}$} & \multirow{4}{*}{$\begin{array}{l}\text { DHLW/WVHLW } \\
\text { CANISTERS }\end{array}$} & & & \\
\hline & & \multirow{3}{*}{ MTU } & \multicolumn{3}{|c|}{ NUMBER OF WASTE UNITS } & \multicolumn{5}{|c|}{ NUMBER OF WASTE UNITS } & & & \multicolumn{3}{|c|}{ TOPALS } \\
\hline & & & & PWR & BWR & \multirow{2}{*}{ MTU } & \multicolumn{2}{|c|}{ PWR } & \multicolumn{2}{|c|}{ BWR } & & & \multirow{2}{*}{ MIU } & \multicolumn{2}{|c|}{ SFAS (c) } \\
\hline & & & $\operatorname{RCSF}(b)$ & ) SFA(c) & $\operatorname{RCSF}(b) \quad \operatorname{SFA}(\mathrm{c})$ & & $\operatorname{RCSF}(b)$ & SFA(c) & $\mathrm{RCSF}(\mathrm{b})$ & ) $\mathrm{SFA}(\mathrm{c})$ & & & & PWR & BWR \\
\hline 20 & 2017 & & & & & 3,000 & & 4,174 & & 6,000 & 400 & 800 & 3,400 & 4,174 & 6,000 \\
\hline 21 & 2018 & & & & & 3,000 & & 4,174 & & 6,000 & 400 & 800 & 3,400 & 4,174 & 6,000 \\
\hline 22 & 2019 & & & & & 3,000 & & 4,174 & & 6,000 & 400 & 800 & 3,400 & 4,174 & 6,000 \\
\hline 23 & 2020 & & & & & 3,000 & & 4,174 & & 6,000 & 400 & 800 & 3,400 & 4,174 & 6,000 \\
\hline 24 & 2021 & & & & & 3,000 & & 4,174 & & 6,000 & 400 & 800 & 3,400 & 4,174 & 6,000 \\
\hline 25 & 2022 & 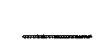 & - & 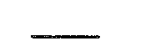 & - & 1,000 & - & 1,390 & & 2,000 & 400 & 800 & 1,400 & 1,390 & 2,000 \\
\hline TOTAL & UNITS & & 347 & 2,089 & 3,006 & & 260 & 82,958 & 3781 & $11.9,244$ & & 15,000 & & 86,261 & 124,006 \\
\hline TOTAL & MTU & 2,000 & & & & 60,000 & & & & & 8,000 & & 70,000 & & \\
\hline
\end{tabular}

(a) Based on data in Repository Subsystem Design Requirements (Appendix A).

(b) RCSF - boxes of Reactor Consolidated Spent Fuel. A box contains the rods from two spent fuel assemblies.

(c) SFA - Spent Fuel Assembly. A unit is intact assembly. 
Repository throughput rates were calculated from annual receipt rates. These rates are given in Table 2.4-3. Package throughput rates are based on no disassembly during Phase I operations and disassembly of only $90 \%$ of the spent fuel during Phase II. It is assumed that it will not be possible to disassemble the remaining $10 \%$ of the Phase II spent fuel which will be packaged intact.

\subsubsection{Shipping Cask Receipt Rates}

The GRMGDS (DOE, 1985a) requires for conservatism that the design receipt capacity of the repository be in excess of $100 \%$. The repository will be able to accommodate as much as $80 \%$ of the spent fuel arriving by rail and as much as $70 \%$ arriving by truck for an overall capacity of $150 \%$. The repository will accommodate $100 \%$ of HLW, all of which will arrive by rail.

Shipping cask receipt rates for both cases are given in Tables $2.4-4$ and 2.4-5 for WHB 1 and WHB 2, respectively. Rail cask capacities will exceed those of truck casks. Therefore, as the percentage of rail cask utilization increases, fewer overall casks will arrive at the repository. This is seen by comparing cases $\# 1$ and $\#_{2}$ on Tables $2.4-4$ and $2.4-5$. 
Table 2.4-3. Waste Package Throughput Rates (a)

\begin{tabular}{|c|c|c|c|c|c|c|c|c|c|c|}
\hline \multirow[b]{2}{*}{ Year } & \multirow[b]{2}{*}{ MIU } & \multicolumn{8}{|c|}{ Annual Container Quantities } & \multirow[b]{2}{*}{ Tota 1} \\
\hline & & $A(+)$ & B & c & D & E & $\mathbf{F}$ & G & в & \\
\hline 1998 & 400 & 53 & 84 & 18 & 28 & 5 & 0 & 0 & 0 & 188 \\
\hline 1999 & 400 & 57 & 89 & 16 & 25 & 5 & 0 & 0 & 0 & 192 \\
\hline 2000 & 400 & 61 & 95 & 14 & 22 & 6 & 0 & 0 & 0 & 198 \\
\hline 2001 & 900 & 88 & 137 & 13 & 20 & 56 & 46 & 26 & 0 & 386 \\
\hline 2002 & 1,900 & 116 & 182 & 11 & 17 & 168 & 149 & 86 & 0 & 729 \\
\hline 2003 & 3,400 & 64 & 102 & 9 & 14 & 325 & 305 & 175 & 185 & 1,179 \\
\hline 2004 & 3,400 & 66 & 102 & 7 & 11 & 327 & 306 & 176 & 415 & 1,410 \\
\hline 2005 & 3,400 & 66 & 103 & 6 & 8 & 328 & 308 & 177 & 800 & 1,796 \\
\hline 2006 & 3,400 & 66 & 103 & 3 & 5 & 332 & 310 & 178 & 800 & 1,797 \\
\hline 2007 & 3,400 & 67 & 104 & 2 & 3 & 335 & 311 & 179 & 800 & 1,801 \\
\hline $\begin{array}{l}2008(c) \\
\text { thru } \\
2021\end{array}$ & 3,400 & 67 & 104 & 0 & 0 & 336 & 313 & 180 & 800 & 1,800 \\
\hline 2022 & 1,400 & 21 & 35 & 0 & 0 & 111 & 104 & 60 & 800 & 1,131 \\
\hline Tota 1 & 70,000 & 1,663 & 2,592 & 99 & 153 & 6,702 & 6,221 & 3,577 & $15,000(d)$ & 36,007 \\
\hline
\end{tabular}

(t) Identifier

Container Type(b)

Container Contents

Heat Load

$\begin{array}{llll}\text { A } & \text { CO-1 } & \text { Intact BWR Fuel Assemblies } & 1.62 \mathrm{~kW} \\ \text { B } & \text { CO-1 } & \text { Intact PWR Fuel Assemblies } & 2.20 \\ \text { C } & \text { CO-1 } & \text { BWR RCSF Boxes } & 3.24 \\ \text { D } & \text { PWR RCSF Boxes } & 4.40 \\ \text { E } & \text { CO-1 } & \text { Fuel Assembly Hardware } & 0 \\ \text { F } & C 0-2 & \text { Consolidated PWR Spent Fuel } & 6.60 \\ \text { G } & C 0-3 & \text { Consolldated BWR Spent Fuel } & 5.40 \\ \text { H } & C O-4 & \text { DHLW and WVHLW } & 0.42(e)\end{array}$

(a) Based on recelpt rates in Table 2.4-2.

(b) Container types are specified in Table 2.1-2.

(c) Throughput rates are constant for years 2008-2021.

(d) 14,700 - DHL; 300 - WVILL.

(e) $0.42 \mathrm{~kW}$ - DHL; $0.23 \mathrm{~kW}$ - WVHW. 
Table 2.4-4. Shipping Cask Receipt Rates - WHB 1

\begin{tabular}{|c|c|c|c|}
\hline Year & $\begin{array}{c}\text { Annual } \\
\text { Rail } \\
\text { Casks }\end{array}$ & $\begin{array}{l}\text { Annual } \\
\text { Truck } \\
\text { Casks }\end{array}$ & $\begin{array}{l}\text { Annual } \\
\text { Total } \\
\text { Casks }\end{array}$ \\
\hline \multicolumn{4}{|c|}{ Case $\mathbb{N}_{1} 1-70 \%$ Truck $/ 30 \%$ Rail } \\
\hline 1998 & 17 & 245 & 262 \\
\hline 1999 & 18 & 252 & 270 \\
\hline 2000 & 18 & 258 & 276 \\
\hline 2001 & 20 & 288 & 308 \\
\hline 2002 & 21 & 299 & 320 \\
\hline $2003(a)$ & 37 & 0 & 37 \\
\hline 2004 & 83 & 0 & 83 \\
\hline 2005 & 160 & 0 & 160 \\
\hline 2006 & 160 & 0 & 160 \\
\hline 2007 & 160 & 0 & 160 \\
\hline 2008 to 2022 & 160 & 0 & 160 \\
\hline \multicolumn{4}{|c|}{ Case 非 $2-20 \%$ Truck $/ 80 \%$ Rail } \\
\hline 1998 & 46 & 70 & 116 \\
\hline 1999 & 47 & 72 & 119 \\
\hline 2000 & 48 & 74 & 122 \\
\hline 2001 & 54 & 82 & 136 \\
\hline 2002 & 56 & 86 & 142 \\
\hline $2003(a)$ & 37 & 0 & 37 \\
\hline 2004 & 83 & 0 & 83 \\
\hline 2005 & 160 & 0 & 160 \\
\hline 2006 & 160 & 0 & 160 \\
\hline 2007 & 160 & 0 & 160 \\
\hline 2008 to 2022 & 160 & 0 & 160 \\
\hline
\end{tabular}

(a) Waste is no longer shipped to WHB 1 in truck casks. Only DHLW and WVHW canisters are shipped to WHB 1 after the year 2002 and all canisters are shipped via rail casks. 
Table 2.4-5. Shipping Cask Receipt Rates - WHB 2

\begin{tabular}{llll} 
& Annual & Annual & Annual \\
Year & Rail & Truck & Total \\
Casks & Casks & Casks \\
\hline
\end{tabular}

Case 1 1 1 - $70 \%$ Truck $/ 30 \%$ Rail

1998

1999

2000

2001

2002

2003

78

360

385

158

1,122

1,200

2004

159

2,270

2,428

2005

159

2,276

2,435

2006

160

2,283

2,442

2007

2008 to 2021

160

161

2022

54

2,298

2,449

2,294

2,454

2,301

2,462

767

821

Case $H_{2}-20 \%$ Truck $/ 80 \%$ RaiI

1998

1999

2000

2001

67

103

170

2002

209

320

529

2003

423

649

1,072

2004

424

650

1,074

2005

425

2006

426

2007

427

2008 to 2021

428

652

1,077

654

1,080

656

1,083

2022

143

657

1,085

219

362 


\subsection{NUCLEAR SAFETY}

This section summarizes the parameters for radioactivity and criticality used in the SCP conceptual design. The design basis waste form is characterized, and the requirements and parameters for radiation protection and nuclear safety are discussed. The data and design approaches used to establish radiation exposure limits, waste form radionuclide concentration, radioactivity source terms, and nuclear criticality safety are summarized.

\subsubsection{Radiation Exposure Limits}

The standards for limiting the radiation dose to individual workers and the general public are specified in 10CFR20 and 40CFR191. The basis for maintaining exposures as low as reasonably achievable (ALARA) for workers is DOE Order 5480.1A, Environmental Protection, Safety and Health Protection Program for DOE Operations. The RSDR (Appendix A) states that as a design objective, worker annual dose will be one fifth of the permissible dose specified by 10CFR20, i.e., 1,000 mrem annually.

To ensure that the design objective annual dose for workers as specified by the above standards will not be exceeded, the A/E Contractor has utilized the following maximum design bases for dose levels in the repository work areas:

1. Restricted areas where workers are routinely present

2. Restricted areas where workers may be present for intermittent operations

3. Unrestricted areas within the surface facility site boundary
Design goal of less than $1,000 \mathrm{mrem} / \mathrm{yr}$

600 mrem in a calendar quarter, not to exceed $1,000 \mathrm{mrem} / \mathrm{yr}$

$500 \mathrm{mrem} / \mathrm{yr}$ 
These maximum levels include the dose contribution of all contamination from radiation and radioactive material sources. Layout and operational features incorporated into the design of the waste handling buildings to meet the dose design objectives are described in Sections 4.2.4, Waste Handling Building Layout Considerations, and 6.1.3.2, HVAC Systems for Waste Handling Buildings. These features include:

1. Building layout, barriers, decontamination areas, and HVAC systems to confine contamination and minimize worker exposure to contamination.

2. Robotic and remote operations and equipment in lieu of contact systems to reduce worker exposure to radiation.

3. Shielded process hot cells, maintenance hot cells, transfer corridors, and transfer casks to minimize worker exposure to radiation.

\subsubsection{Radionuclide Concentrations}

The LWR spent fuel waste form is the design basis for nuclear safety assessments. Two radionuclide concentration inventories were used to characterize this waste form. For conditions involving spent fuel with 30,000 MWD/MTU burnup and 10-yx decay, radionuclide concentration data from the DOE report, "Technology for Commercial Radioactive Waste Management" (DOE, 1979), were used. These data are for the DOE-identified, once-through fuel cycle case that assumes geologic disposal of the spent fuel. They were compiled by the DOE for a reference spent fuel composed of a mixture projected to be discharged from PWRs and BWRs. The curie content of significant fission products, activation products, and actinides for the 10-yr decayed reference spent fuel is summarized in Table 2.5-1.

The conditions involving IWR spent fuel with higher burnup and shorter decay times use radionuclide concentration data for PWR spent fuel with 60,000 MWD/MTU burnup and 5-yr decay. These data are from the National Waste Terminal Storage Data Base maintained by the Oak Ridge National Laboratory (ORNL, 1985b). The curie content of significant activation products, fission products, and actinide radionuclides are summarized in Table 2.5-2. 
Table 2.5-1. Summary of Radionuclide Inventory Data for

Reference Spent Fuel - 10-Yr Decay (a)

\begin{tabular}{|c|c|c|c|}
\hline \multicolumn{2}{|c|}{$\begin{array}{l}\text { ACTIVATION AND FISSION } \\
\text { PRODUCTS }\end{array}$} & \multicolumn{2}{|c|}{ ACTINIDES AND DAUGHTERS } \\
\hline Nuclide & $\mathrm{Ci} / \mathrm{MTU}$ & Nuclide & $\mathrm{Ci} / \mathrm{MTU}$ \\
\hline$H-3$ & $2.5 \times 10^{2}$ & $\mathrm{Ra}-226$ & $7.4 \times 10^{-9}$ \\
\hline$C-14$ & $7.4 \times 10^{-1}$ & $T h-230$ & $4.1 \times 10^{-6}$ \\
\hline$M n-54$ & $8.0 \times 10^{-2}$ & $T h-232$ & $1.1 \times 10^{-10}$ \\
\hline $\mathrm{Fe}-55$ & $4.0 \times 10^{2}$ & $U-233$ & $3.8 \times 10^{-5}$ \\
\hline $\mathrm{Co}-60$ & $1.0 \times 10^{3}$ & U-234 & $7.4 \times 10^{-2}$ \\
\hline $\mathrm{Ni}-63$ & $4.0 \times 10^{1}$ & $\mathrm{U}-235$ & $1.6 \times 10^{-2}$ \\
\hline $\mathrm{Kr}-85$ & $5.0 \times 10^{3}$ & $U-236$ & $2.2 \times 10^{-1}$ \\
\hline $\mathrm{Sr}-90$ & $5.2 \times 10^{4}$ & $U-238$ & $3.2 \times 10^{-1}$ \\
\hline$Y-90$ & $5.2 \times 10^{4}$ & A11 Other & 2.8 \\
\hline Tc -99 & $1.3 \times 10^{1}$ & Actinides \& & \\
\hline $\mathrm{Ru}-106$ & $3.4 \times 10^{2}$ & Daughters (b) & \\
\hline $\mathrm{Rh}-106$ & $3.4 \times 10^{2}$ & $\mathrm{~Np}-237$ & $3.1 \times 10^{-1}$ \\
\hline $\mathrm{Sb}-125$ & $5.3 \times 10^{2}$ & $\mathrm{Pu}-238$ & $2.0 \times 10^{3}$ \\
\hline $\mathrm{Te}-125 \mathrm{~m}$ & $2.2 \times 10^{2}$ & Pu $=239$ & $2.9 \times 10^{2}$ \\
\hline $\mathrm{Sn}-126$ & $5.5 \times 10^{-1}$ & Pu -240 & $4.5 \times 10^{2}$ \\
\hline$I=129$ & $3.3 \times 10^{-2}$ & $\mathrm{Pu}-241$ & $6.9 \times 10^{4}$ \\
\hline$C s-134$ & $5.7 \times 10^{3}$ & $\mathrm{Pu}-242$ & 1.6 \\
\hline $\mathrm{Cs}-135$ & $2.7 \times 10^{-1}$ & $\mathrm{Cm}-242$ & 8.5 \\
\hline $\mathrm{Cs}-137$ & $7.5 \times 10^{4}$ & $\mathrm{Am}-241$ & $1.6 \times 10^{3}$ \\
\hline $\mathrm{Ba}-137 \mathrm{~m}$ & $7.0 \times 10^{4}$ & $\mathrm{Am}-243$ & $1.4 \times 10^{1}$ \\
\hline $\mathrm{Ce}-144$ & $8.2 \times 10^{1}$ & $\mathrm{Cm}-244$ & $9.0 \times 10^{2}$ \\
\hline $\operatorname{Pr}-144$ & $8.2 \times 10^{1}$ & All other TRU (b) & $3.8 \times 10^{1}$ \\
\hline$P m-147$ & $6.4 \times 10^{3}$ & & \\
\hline $\mathrm{Sm}-151$ & $1.1 \times 10^{3}$ & & \\
\hline Eu-154 & $3.7 \times 10^{3}$ & & \\
\hline $\mathrm{Eu}-155$ & $1.2 \times 10^{2}$ & & \\
\hline A11 other (b) & $3.8 \times 10^{3}$ & & \\
\hline Total & $2.7 \times 10^{5}$ & Total & $7.5 \times 10^{4}$ \\
\hline
\end{tabular}

Note: See list of acronyms, abbreviations, symbols, and elements for definitions.

(a) Based on data from the DOE report, "Technology for Commercial Radioactive Waste Management," Tables 3.3.6, 3.3.7, 3.3.8, and 3.3 .10 , (DOE, 1979). Fuel burnup is assumed to be about 30,000 MWD/MTU

(b) Total contribution from all other radionuclides of the given category listed in the referenced report. 
Table 2.5-2. Summary of Radionuclide Inventory Data for 60,000 MWD/MTU Burnup Spent Fuel - 5-Yr Decay (a)

\begin{tabular}{|c|c|c|c|}
\hline \multicolumn{2}{|c|}{$\begin{array}{l}\text { ACTIVATION AND FISSION } \\
\text { PRODUCTS }\end{array}$} & \multicolumn{2}{|c|}{ ACTINIDES AND DAUGHTERS } \\
\hline Nuclide & $\overline{\mathrm{Ci} / \mathrm{MTU}}$ & Nuclide & $\mathrm{Ci} / \mathrm{MTU}$ \\
\hline $\mathrm{H}-3$ & $9.4 \times 10^{2}$ & $\mathrm{Ra}-226$ & $2.2 \times 10^{-7}$ \\
\hline$C-14$ & 2.4 & $T h-230$ & $9.1 \times 10^{-5}$ \\
\hline$M n-54$ & $1.8 \times 10^{1}$ & Th -232 & $1.6 \times 10^{-10}$ \\
\hline $\mathrm{Fe}-55$ & $1.8 \times 10^{3}$ & $\mathrm{U}-233$ & $3.4 \times 10^{-5}$ \\
\hline Co -60 & $5.6 \times 10^{3}$ & $U-234$ & 1.1 \\
\hline $\mathrm{Ni}-63$ & $1.0 \times 10^{3}$ & $\mathrm{U}-235$ & $9.0 \times 10^{-3}$ \\
\hline $\mathrm{Kr}-85$ & $1.0 \times 10^{4}$ & $U=236$ & $3.7 \times 10^{-1}$ \\
\hline $\mathrm{Sr}-90$ & $1.0 \times 10^{5}$ & $U-238$ & $3.1 \times 10^{-1}$ \\
\hline$Y-90$ & $1.0 \times 10^{5}$ & A11 othex & 3.1 \\
\hline Tc-99 & $2.1 \times 10^{1}$ & Actinides \& & \\
\hline $\mathrm{Ru}-106$ & $2.4 \times 10^{4}$ & Daughters (b) & \\
\hline $\mathrm{Rh}-106$ & $2.4 \times 10^{4}$ & $\mathrm{~Np}-237$ & $6.4 \times 10^{-1}$ \\
\hline $\mathrm{Sb}-125$ & $6.6 \times 10^{3}$ & $\mathrm{Pu}-238$ & $8.4 \times 10^{3}$ \\
\hline $\mathrm{Te}-125 \mathrm{~m}$ & $1.6 \times 10^{3}$ & $P u-239$ & $3.7 \times 10^{2}$ \\
\hline$S n-126$ & 1.5 & $\mathrm{Pu}=240$ & $6.8 \times 10^{2}$ \\
\hline$I-129$ & $5.7 \times 10^{-2}$ & $\mathrm{Pu}-241$ & $1.6 \times 10^{5}$ \\
\hline$C s-134$ & $6.8 \times 10^{4}$ & Pu-242 & 4.5 \\
\hline$C s=135$ & $7.7 \times 10^{-1}$ & $A m-241$ & $1.7 \times 10^{3}$ \\
\hline $\mathrm{Cs}-137$ & $1.6 \times 10^{5}$ & $A m-243$ & $7.2 \times 10^{1}$ \\
\hline $\mathrm{Ba}-137 \mathrm{~m}$ & $1.5 \times 10^{5}$ & $\mathrm{Cm}-244$ & $1.3 \times 10^{4}$ \\
\hline $\mathrm{Ce}-144$ & $1.2 \times 10^{4}$ & All other TRU (b) & $2.6 \times 10^{2}$ \\
\hline $\operatorname{Pr}-144$ & $1.2 \times 10^{4}$ & & \\
\hline$P m-147$ & $3.3 \times 10^{4}$ & & \\
\hline $\mathrm{Sm}=151$ & $5.1 \times 10^{2}$ & & \\
\hline Eu-154 & $1.7 \times 10^{4}$ & & \\
\hline Eu-155 & $8.1 \times 10^{3}$ & & \\
\hline A11 other (b) & $2.8 \times 10^{3}$ & & \\
\hline Total & $7.5 \times 10^{5}$ & Total & $1.8 \times 10^{5}$ \\
\hline
\end{tabular}

Note: See list of acronyms, abbreviations, and symbols for definitions.

(a) Based on data from the National Waste Terminal Storage Data Base reported in the Oak Ridge National Laboratory report, "Physical and Decay Characteristics of Commercial LWR Spent Fuel," (ORNL, 1985b).

(b) Total contribution from all other radionuclides of the given category listed in the referenced report. 
These radionuclide data have been used as the basis for accident analysis source terms, shielding, and criticality assessments. As the repository design is developed in the future, these data and assumptions will be re-evaluated.

\subsubsection{Radioactivity Source Terms}

Radioactivity source terms have been evaluated using the radionuclide concentration data for the waste forms consisting of the reference spent fuel and the high burnup spent fuel. The approach in evaluating the source terms was to consider two general conditions:

1. Source terms for waste handling areas, and for operations where SFAs are present in groups, are based on radionuclide concentrations for 10-yr-decay reference spent fuel (see Table 2.5-1). Examples of these handling areas and operations are:
a. Shipping cask handling
b. Surface storage arrays
c. Canister loading and handling
d. Disposal container handling, transport, and emplacement
e. Radwaste treatment operations

2. For waste handling operations that involve individual SFAs, upper limit radioactivity source terms have been evaluated based on the radionuclide concentration data for the high burnup, 5-yr-decay spent fuel (see Table 2.5-2). Examples of these operations are:
a. SFA unloading from shipping casks
b. SFA disassembly
c. Special function cell operations

Safety assessments of occupational and public exposure to radiation due to normal repository operations (see Section 6.1) are based on radionuclide inventory data on the reference spent fuel, Table 2.5-1. Analyses of potential DBAs (see Section 6.2) and the assessment of systems important to safety (see 
Section 4.6) are based on radionuclide inventory data on the high-burnup spent fuel, Table 2.5-2.

\subsubsection{Nuclear Criticality Safety}

The design of all radioactive waste operations and isolation systems is based on ensuring that nuclear criticality is not possible for normal or accidental conditions unless two or more unlikely, independent, and concurrent or sequential changes have occurred in the conditions essential to nuclear criticality safety. A criticality safe system is one that has a calculated effective multiplication factor $\left(\mathrm{K}_{\text {eff }}\right)$ of 0.95 or less after allowance for the bias in the method of calculation and the uncertainty in experiments used to validate the method of calculation (GRMGDS, DOE, 1985a). For the SCP conceptual design, criticality safety has been evaluated by engineering assessment. Detailed criticality analyses will be performed in the future as the technical and design data for the repository facilities, equipment, and operations are developed.

The approach of the SCP conceptual design to criticality safe systems considers safe geometry as the principal assurance of criticality control. In evaluating a criticality safe system, safe geometry design includes the worst credible conditions of the following:

1. The mass and concentration of fissile material in a system. This evaluation considers data on both unirradiated fuel assemblies and irradiated SFAs. Unirradiated fuel assemblies contain the highest mass and concentration of fissile uranium and none of the activation products, fission products, or actinides present in irradiated SFAs. The maximum U-235 content of as-fabricated uranium oxide fuel pellets is less than or equal to four weight percent. The four percent $\mathrm{U}-235$ fuel is fabricated for higher burnup (i.e., 60,000 MW/MTU). As a result of the fission process, irradiated SFAs are significantly reduced in fissile uranium (less than 1.0 weight percent U-235) and contain the activation product, fission product, and actinide radionuclides 1 isted in Tables $2.5-1$ and $2.5-2$. 
2. Presence and control of moderator. Neutron moderator control that may effect criticality safety ranges from the normal dry operating conditions to conditions that could result from an accident or accident mitigation steps.

3. Nuclear interaction of waste units as a function of geometry. Evaluations of geometric interaction that may effect criticality safety will range from the normal configuration of individual waste units and arrays of waste units to geometric changes that may result from abnormal operations or accidents. 


\subsection{REGULATORY REQUIREMENTS}

\subsubsection{General Regulatory Requirements}

The Nuclear Waste Policy Act of 1982 (NWPA) provides for the development of repositories for the disposal of high-level radioactive waste and spent nuclear fuel and establishes a program of research, development, and demonstration regarding the disposal of high-level radioactive waste and spent nuclear fuel. The NWPA requires the DOE, the U.S. Environmental Protection Agency (EPA), and the NRC to cooperate in (1) siting such a repository, (2) establishing radiological criteria limiting radiation exposures to the public, and (3) establishing criteria for the licensing of the repository. These agencies were also directed to cooperate in this effort with other Federal agencies, the public, state and local governments, and any affected Indian tribes. DOE has established as its policy that it will comply with applicable Federal, state and local statutory requirements not inconsistent with its responsibilities under the Nuclear Waste Policy Act of 1982 (NWPA) (DOE, 1986a, EA, p. 6-19).

This section provides a comprehensive source of statutes, regulations, and other regulatory guidance applicable to the repository conceptual design and to be used in conjunction with the SCP. The hierarchy of the primary federal statutes, federal regulations, and other guidance documents is shown in Figure 2.6-1. Detailed lists of federal laws, regulations, and other requirements affecting the repository design are contained in later sections.

\subsubsection{Nuclear Waste Policy Act}

The NWPA specifies the requirements for a HLW and spent nuclear fuel repository. It establishes the process for siting the repository, and it requires that the repository be licensed by the NRC, pursuant to the Atomic Energy Act and Section 202 of the Energy Reorganization Act of 1974. One significant part of the siting process is the characterization of the site to obtain data necessary to support the repository design and license application. Detailed guidelines for the siting of a repository have been published in DOE regulation 10CFR960. Section $113(\mathrm{~b})$ of the NWPA specifically requires that the 


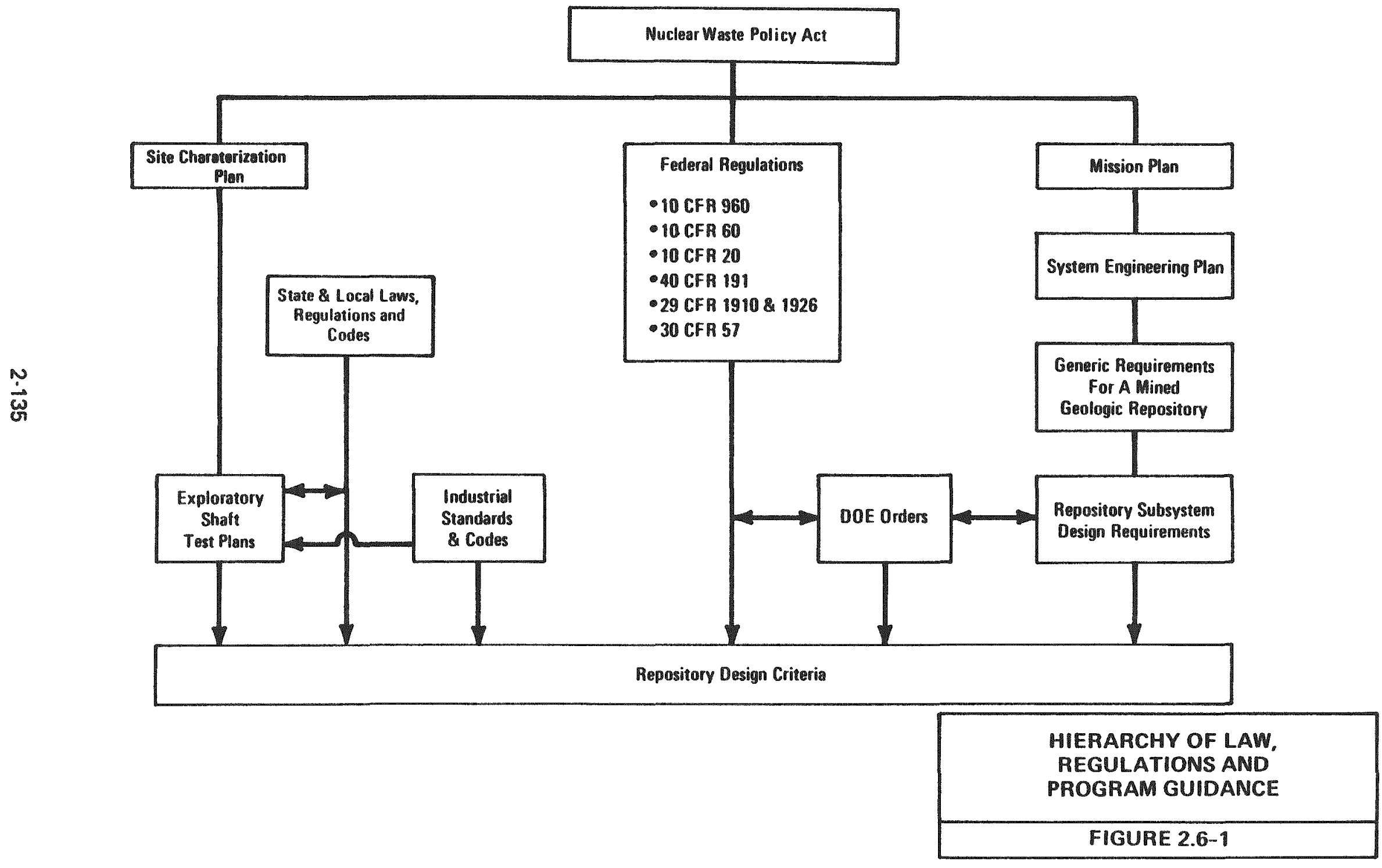


DOE submit the following to the Governor and Legislature of the state and to the governing body of any affected Indian tribe:

1. A general plan for conducting site characterization activities.

2. A description of the possible form or packaging of high-level radioactive wastes and spent nuclear fuel to be emplaced in the repository and information on the relationship between such waste form or packaging and the geologic medium of such a site.

3. A conceptual repository design that takes into account any likely site specific requirements.

This conceptual design report supports the design description that appears in Chapter 6 of the SCP.

\subsubsection{Federal Siting Guidelines and Licensing Regulations}

Pursuant to the NWPA, two significant regulations were developed to guide the siting and licensing of a geologic repository. The DOE promulgated 10CFR960 to establish the process for site selection and characterization, and the NRC promulgated 10CFR60 to provide procedures and criteria which must be followed as a condition of licensing the construction, operation, and decommissioning of the repository. In addition, the EPA established standards which must be met to prevent undue exposure of the public to radioactivity from repository activity. The EPA standards published in 40CFR191 are described more completely in Section 2.6.4.

\subsubsection{Repository Siting Guideline}

10CFR960 defines the general guidelines for recommendation of sites for the nuclear waste repositories. These guidelines are being used in the step-by-step process of site selection. They establish performance objectives for a repository system, define basic technical criteria that a site must meet, and specify how the site selection process will be implemented. During the site characterization phase, the DOE will collect detailed information on 
geologic, hydrologic, and other site characteristics to determine compliance with the requisites for a licensed repository. To be included in this information are results from tests made at emplacement depth which measure in situ stress, permeability, and heat transfer. Other activities conducted in parallel with site characterization are investigations into demographic, socioeconomic, and ecological characteristics of surrounding areas to show compliance with the National Environmental Policy Act of 1969 (NEPA).

\subsubsection{Repository Licensing}

Section 121 (b) of the NWPA requires that the NRC promulgate the technical requirements and criteria that it will use in licensing the DOE's repository. The NRC met the requirement to conform to the NWPA by modifying 10CFR60 to establish procedures and criteria to be followed in licensing the repository. 10CFR60 Subparts A through D contain procedural and administrative elements. Subpart E provides Technical Criteria with which the repository must comply. Subpart $F$ provides requirements for the Performance Confirmation Program. Subparts $G$ and $H$ contain requirements for Quality Assurance and Training and Certification of Personnel, respectively. This regulation incorporates by reference other regulations such as 10CFR2, 10CFR50 Appendix B, 10CFR51, and $10 \mathrm{CFR} 20$.

In addition to these regulations, NRC provides additional guidance in the form of Generic Technical Positions (GTP), Regulatory Guides and other guidance dealing with technical and administrative matters. An example of these guidance documents is the NRC Review Plan: Quality Assurance Programs for Site Characterization of High-Level Waste Repositories, (NRC, 1984). DOE has made a management decision that this NRC Review Plan is to be a program requirement. The review plan defines the criteria and methods by which the DOE Quality Assurance program for site characterization activities will be reviewed by the NRC staff during the prelicensing phase. DOE has adopted the Review Plan as a regulatory requirement.

10CFR2 contains the rules of practice which the commission will use in its repository licensing proceedings. 10CFR50 Appendix $B$ establishes quality assurance requirements for the design, construction and operation of those 
structures, systems and components that prevent or mitigate the consequences of postulated accidents which could cause undue risk to the health and safety of the public. 10CFR5 1 contains environmental protection regulations applicable to $\mathrm{NRC}$ domestic licensing and regulatory functions. These regulations are intended to implement Section 102(2) of the National Environmental Policy Act of 1969 , as amended.

10CFR20 sets upper limits for radiation exposures to individuals at the boundary of the surface facility, workers in unrestricted areas, and workers in restricted areas. 10CFR20 also prescribes limits for effluent releases from the facility under both normal operating and accidental conditions. The repository will be designed to assure that all operations can be conducted in compliance with 10CFR20. 10CFR20.101, 20.103,20.105, 20.106 and 20.303 are among the parts of 10CFR20 that will be considered in the design.

On-site generated radwaste will be processed to allow disposal in accordance with 10CFR20.301-20.311. Such processing will include volume reduction through use of compaction, liquid evaporation, and incineration. No release of radioactive liquids to a municipal sewage system is expected under the current design, although 10CFR20.303 permits such activity on a limited basis.

The NRC is also required to implement 40CFR191 (described below) in licensing the repository and its related activities.

\subsubsection{EPA Environmental Standards}

Section 121(a) of the NWPA requires the EPA to develop a framework of requirements needed to assure protection of public health and the environment, and to publish its standards in the Code of Federal Regulations. In response, EPA published in August, 1985 its final rule "Environmental Standards for the Management and Disposal of Spent Nuclear Fuel, High-level and Transuranic Radioactive Wastes." The standards are codified in 40CFR191. The standards are contained in two subparts. Subpart A establishes the environmental standards for the management and storage of such wastes during the repository preclosure period. Subpart $B$ establishes the standards for disposal of the wastes during the postclosure period. 
Subpart $A$ limits the amount of radiation exposure members of the public may receive from the management and storage of the above wastes prior to closure of the repository. It requires that the annual radiation exposure of any member of the public in the general environment shall not exceed 25 mrem to the whole body, 75 mrem to the thyroid and 25 mrem to any other critical organ. These exposure limits apply to exposures received from direct radiation and from any discharge of radioactive material outside the site boundary.

Subpart B establishes the postclosure standards for (1) radioactive exposure of members of the public, (2) radioactive materials which may be released to the accessible environment, and (3) permissible radioactive contamination of ground waters as a result of the disposal of spent nuclear fuel, HLW, and TRU wastes. These standards include requirements for waste containment, performance assessments, and a variety of institutional controls designed to assure that releases to the accessible environment are within limits established to assure protection of the public from any of the radioactive materials. Appendix A of Subpart B provides limits for cumulative releases from the repository to the accessible environment over a period of 10,000 yrs after disposal. Appendix B of Subpart B provides guidance for implementation of all the requirements of the subpart.

\subsubsection{Mission Plan}

The Mission Plan is required by Section 301(a) of the NWPA. This plan provides detailed background information on the spent nuclear fuel and on the high-level radioactive waste requiring disposal under the NWPA. It is presented in two parts. Part I describes the overall goals, objectives and strategy for the disposal of the above wastes. The SCP is one part of the DOE's research program to obtain data required for a licensed repository as mandated by Part I. Part II provides detailed information for the program and identifies plans and steps taken to resolve key issues by fulfilling information needs. This information is to be acquired through site investigation, site characterization, a variety of underground tests and evaluations, and other special studies. 
The Mission Plan also serves as a compendium of information, including but not limited to:

1. The comparative advantages and disadvantages of each medium for repository siting.

2. Descriptions of known sites at which characterization should be undertaken.

3. Identification of processes for solidification of high-level waste and packaging of spent nuclear fuel.

4. Estimates of needed repository capacity; the schedule for repository construction; the period of time each repository will be expected to receive waste and spent nuclear fuel; and estimates of costs for the construction, operation, and closure of the repositories.

\subsubsection{Other Federal Laws, Regulations, and Executive Orders}

The Federal regulations and standards described in Section 2.6.3 and 2.6.4 are not all inclusive. Other Federal regulations have direct impact upon the design and/or operation of the repository. Table 2.6-1 is a list of known federal laws, regulations, and executive orders. Some of the more important among these are 29CFR1910 and 1926; 30CFR Parts 0-199; 40CFR Part 436; and 49CFR100-200.

29CFR 1910 and 1926 contain the Occupational Safety and Health Administration (OSHA) requirements which must be followed during the repository's above ground construction and operations not involved in mine support. MSHA regulations found in 30CFR Parts $0-199$ apply to mining activities including the repository shafts and underground. In particular, 30CFR57, titled "Safety and Health Standards - Underground Metal and Nonmetal Mines," promulgates applicable regulations for the repository, which at this time is not considered to be a gassy mine. However, for conservatism, this design conforms to gassy mine regulations. 40 CFR 436 regulations govern the release of pollutants from site excavating and mining operations. Details of this impact are explained in Section 2.4. The U.S. Department of Transportation (DOT) regulations (49CFR Parts 100-200) 
Table 2.6-1. List of Most Important Federal Laws, Regulations, and Executive Orders Affecting Repository Design(a)

(Sheet 1 of 3 )

Eederal Laws

Nuclear Waste Policy Act of 1982

Atomic Energy Act of 1954

Energy Reorganization Act of 1974

National Environmental Policy Act of 1969

Clean Air Act as Amended

Clean Water Act of 1977

Occupational Safety and Health Act of 1970

Toxic Substance Control Act

Energy Supply and Environmental Coordination Act

Federal Land Policy and Management Act of 1976

Mine Safety and Health Act of 1977

Resource Conservation and Recovery Act of 1976

Federal Regulations

10CFR960 Guidelines for the Recommendation of Sites for Nuclear Waste Repositories; Final Siting Guidelines

10CFR961 Standard Contract for Disposal of Spent Nuclear Fuel and/or

High-Level Radioactive Waste

10CFR60 Disposal of High-Level Radioactive Wastes in Geologic Repositories

40CFR191 Environmental Radiation Protection Standards for the Management and Disposal of Spent Nuclear Fuel, High-Level, and Transuranic Radioactive Wastes.

10CFR20 Standards for Protection against Radiation 
Table 2.6-1 (Sheet 2 of 3)

\begin{tabular}{|c|c|}
\hline 10 CFR50 & Quality Assurance Criteria for Nuclear Power Plants and Fuel \\
\hline App. B & Reprocessing Plants \\
\hline 10CFR51 & $\begin{array}{l}\text { Environmental Protection Regulations for Domestic Licensing and } \\
\text { Related Functions }\end{array}$ \\
\hline 10CER 1022 & Flood Plains/Wetlands Environmental Review Requirement \\
\hline 29 CFR 1910 & Occupational Safety and Health Standards \\
\hline 29 CFR 1926 & Safety and Health Regulations for Construction \\
\hline 30CFR 18 & Electric Motor Driven Mine Equipment and Accessories \\
\hline 30CFR31 & Diesel Mine Locomotives \\
\hline $30 \mathrm{CFR} 32$ & Mobile Diesel-Powered Equipment for Noncoal Mines \\
\hline 30 CFR36 & $\begin{array}{l}\text { Mobile Diesel-Powered Transportation Equipment for Gassy Noncoal } \\
\text { Mines and Tunnels }\end{array}$ \\
\hline $30 \mathrm{CFR} 48$ & Training and Retraining of Miners \\
\hline $30 \mathrm{CFR} 49$ & Mine Rescue Teams \\
\hline $30 \mathrm{CER} 57$ & Safety and Health Standards - Underground Metal and Nonmetal Mines \\
\hline 40 CFR $264-265$ & Hazardous Waste Management System; Standards for Facilities \\
\hline $40 \mathrm{CFR} 436$ & $\begin{array}{l}\text { Mineral Mining and Processing Point Source Category Effluent } \\
\text { Guidelines and Standards }\end{array}$ \\
\hline
\end{tabular}


Table 2.6-1 (Sheet 3 of 3 )

49CER100-200 Transportation of Nuclear Materials

Executive orders

Order \#12088 Federal Compliance with Pollution Control Standards

Order 非1 1988 Floodplain Management

Order $\$ 11990$ Protection of Wetlands

(a) A reasonably complete list known to be applicable in design. 
indirectly affect surface facility design since the facility and equipment must accommodate prescribed packages for hazardous materials, their controlled storage, and systems used in transporting them. 49CFR Parts 100-200 establishes detailed requirements of the packaging, transportation and in-transit storage of hazardous materials.

The Generic Requirements (GR) for a Mined Geologic Disposal System (MGDS) (DOE, 1985a) baselines the essential Federal laws, regulations, and executive orders applicable to major demands of the disposal system.

\subsubsection{DOE Orders}

The DOE is required by law to follow regulations issued by a variety of other federal agencies including but not limited to OSHA, EPA, and the Bureau of Land Management (BLM). The DOE is required to issue orders which contain detailed guidance on how it will enforce its own regulations and those promulgated by other Federal agencies. These orders are to provide agency-wide consistency in the subject matter. A list of orders having particular importance to repository design or operation are identified by number and title in Table 2.6-2. DoE orders 4320.1A, 5440.1B, 5480.1A, 5700.6A, 6410.1 and 6430.1 are of particular importance to the conceptual design and the characterization studies to be conducted during the SCP.

The GR also baselines the essential DOE orders that are applicable to the major elements of the disposal system.

\subsubsection{Industrial Codes and Standards}

Some of the regulations and orders listed in Tables $2.6-1$ and $2.6-2$ invoke well-known industrial codes and standards, and repository facilities, equipment, and operations will be designed and operated in compliance with these codes and standards. Pursuant to the RSDR (Appendix A), situations where compliance cannot be met must be identified and justified, and deviations must be approved by the DOE. 
Table 2.6-2. List of Most Important DOE Orders Affecting Repository Design(a) (Sheet 1 of 2 )

Order 4320.1A Site Development and Facility Utilization Planning

Order $5440.1 \mathrm{C}$ Implementation of NEPA

Order 5480.1A Environmental Protection, Safety, and Health Protection for DoE Operations

Order 5480.2 Hazardous and Radioactive Mixed Waste Management

Order 5480.4 Environmental Protection, Safety and Health Protection Standards

Order 5481.1A Safety Analysis and Review System

Order 5483.1A OSHA Program for DOE Contractor Employees at Government-Owned Contractor Operated Facilities

Order 5500.3 Reactor and Non-Reactor Emergency Planning, Preparedness, and Response Program for DOE Operations

Order 5610.3 Program to Prevent Accidental or Unauthorized Nuclear Explosive Detonations

Order 5630.2 Control and Accountability of Nuclear Materials, Basic Principles

Order 5632.4 Physical Protection of Security Interests

Order 5700.6A Quality Assurance

Order 5820.2 Radioactive Waste Management 
Table 2.6-2 (Sheet 2 of 2)

Order 6410.1 Management of Construction Projects

Order 6430.1 General Design Criteria for DOE Facilities

(a) A reasonably complete list known to be applicable in design. 
Examples of such codes and standards are:

1. Practices for Repository Protection (ANSI 288.2)

2. Department of Defense Explosive Board Standards

3. National Fire Protection Code

4. National Electrical Code ANSI/NFPA \$10-1984

5. National Plumbing Code

6. Standard Building Code

\subsubsection{State and Local Regulations}

The Mission Plan and the program guidance documents described in Section 2.4 generally stipulate that all state and local regulations will apply to repository design and operations. However, whether this government owned and operated facility should conform to all of the procedural elements contained in these regulations has not been determined. It is noteworthy that Texas Radiation Control regulations do not appear to apply to NRC Iicensed repository operations because of the specific language in Article II.A.4 of the Agreement for Cooperation between the State of Texas and the NRC as amended March 24, 1982.

Table 2.6-3 is a list of such state laws and regulations having impact upon repository activities. 
Texas Laws

1. Texas Clean Air Act

2. Texas Water Quality Act

3. Solid Waste Disposal Act

4. Water Wells and Drilled or Mined Shafts Act

5. The Water Well Drillers Act

\section{Texas Regulations}

1. Texas Air Control Board

a. General Rules

b. Regulation I - Control of Air Pollution from Visible Emissions and Particulate Matter

c. Regulation VII - Control of Air Pollution from Nitrogen Compounds

d. Regulation VIII - Control of Air Pollution Episodes

e. Regulation IX - Control of Air Pollution from Carbon Monoxide Standard Exemption List

2. Texas Department of Health

a. Rules and Regulations for Public Water Systems, adopted 1978

b. Drinking Water Standards Governing Drinking Water Quality 
Table $2.6-3$ (Sheet 2 of 2 )

3. Texas Administrative Code

Sections 335.1-335.505 - Industrial Solid Waste Management

4. High Plains Underground Water Conservation District $\#_{1}$

Rule 23 Permitting and Regulation of Drilled or Mined Shafts, effective June 1980

(a) A reasonably complete list known to be applicable in design.

Note: See EA, Table 6-3 (DOE, 1986a, EA) for a listing of additional state laws and regulations. 
2.7 STRUCTURES, SYSTEMS, AND COMPONENTS IMPORTANT TO SAFETY, AND IMPORTANT TO WASTE ISOLATION

The Q-list classification methodology used, together with a preliminary Q-1ist, is presented in Section 4.6 . 


\section{SALT REPOSITORY OPERATIONS AND FUNCTIONS}

This chapter provides an overview of the principal operations that will be performed in the salt repository. These operations include (1) waste handling and emplacement, (2) underground development, and (3) ventilation. The description of these operations is supplemented by several flow diagrams and figures which display graphically the repository operations and equipment at the conceptual stage of design.

\subsection{WASTE HANDLING AND EMPLACEMENT}

The repository will have facilities, equipment, procedures, and personnel to receive, process, package, and emplace the types of nuclear waste listed in Section 2.1, Waste Package, and the quantities of waste listed in Section 2.4, Design Requirements. Most of these operations will be located within two large surface buildings called the waste handling buildings (WHB 1 and WHB 2). These two buildings will be adjacent to each other and connected to a common turntable building. The turntable building will be the access point to the waste shaft (see Figure 4.2-2, Surface Facility Arrangement). Each waste handling building will package waste in disposal containers which will then be transferred via the waste shaft to the underground for emplacement.

At full capacity, the repository will receive over 10,000 spent fuel assemblies (SFA) and 800 defense high-level waste (DHLW) canisters per year. Based on 365 days per year, this equates to an approximate average of 28 SFAs and 2 DHLW canisters per day. After processing and packaging, approximately three containers per day containing spent fuel components and two containers per day containing DHLW will be delivered to the waste shaft for emplacement in the repository underground.

\subsubsection{Functional Flow Description}

The operations necessary to receive, package, and emplace nuclear waste at the repository are listed in three functional flow diagrams included in this section. These functional flow diagrams identify and describe the functions and actions that operate on waste from the time it arrives at the repository until 
it is emplaced in the underground. The description contained in these diagrams is further expanded in the Mechanical Flow Description, Section 3.1.2. The mechanical flow diagrams contain preliminary engineering definitions of operation that will occur as waste is received, packaged, transferred to the subsurface, and emplaced. The diagrams emphasize the sequential waste handing and emplacement operations for WHB 2 (Figure 3.1-1) and the two operational phases of WHB 1 (Figures 3.1-2 and 3.1-3). Equipment and building design concepts for the performance of these operations are discussed in further detail in Section 4.2, Surface Facilities.

\subsubsection{Mechanical Flow Description}

Three mechanical flow diagrams in this section present in a condensed, illustrated format the waste handling tasks listed in the functional flow diagrams. These mechanical flow diagrams are intended to expand the information presented in the functional flow diagrams by showing the concepts for the equipment that will process and transport the waste and the related shipping or packaging components. Operations performed in common locations or hot cells are grouped together in titled boxes. These diagrams also identify major equipment items by name, radiation environment (i.e., remote hot cell, remote robotic not in hot cell, or contact operations) and location in the building. First-of-a-kind equipment that will require research and development programs is identified in each figure. Equipment development programs are also discussed in Section 8.2, Surface Facilities. Material flow rates throughout the operations are also listed. At the top of each titled box is the functional flow number which corresponds to the steps in the functional flow diagrams (Figures $3.1-1,3.1-2$, and $3.1-3$ ).

Following are descriptions of the operations within each operational grouping for WHB 2 (Figure 3.1-4). Table 3.1-1 lists the major equipment to be used in WHB 2, the equipment to be used outside the building, and the equipment in the underground to be used in common with WHB 1 operations. 


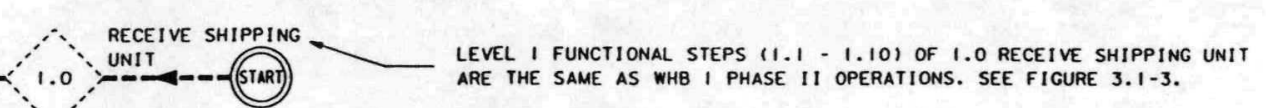

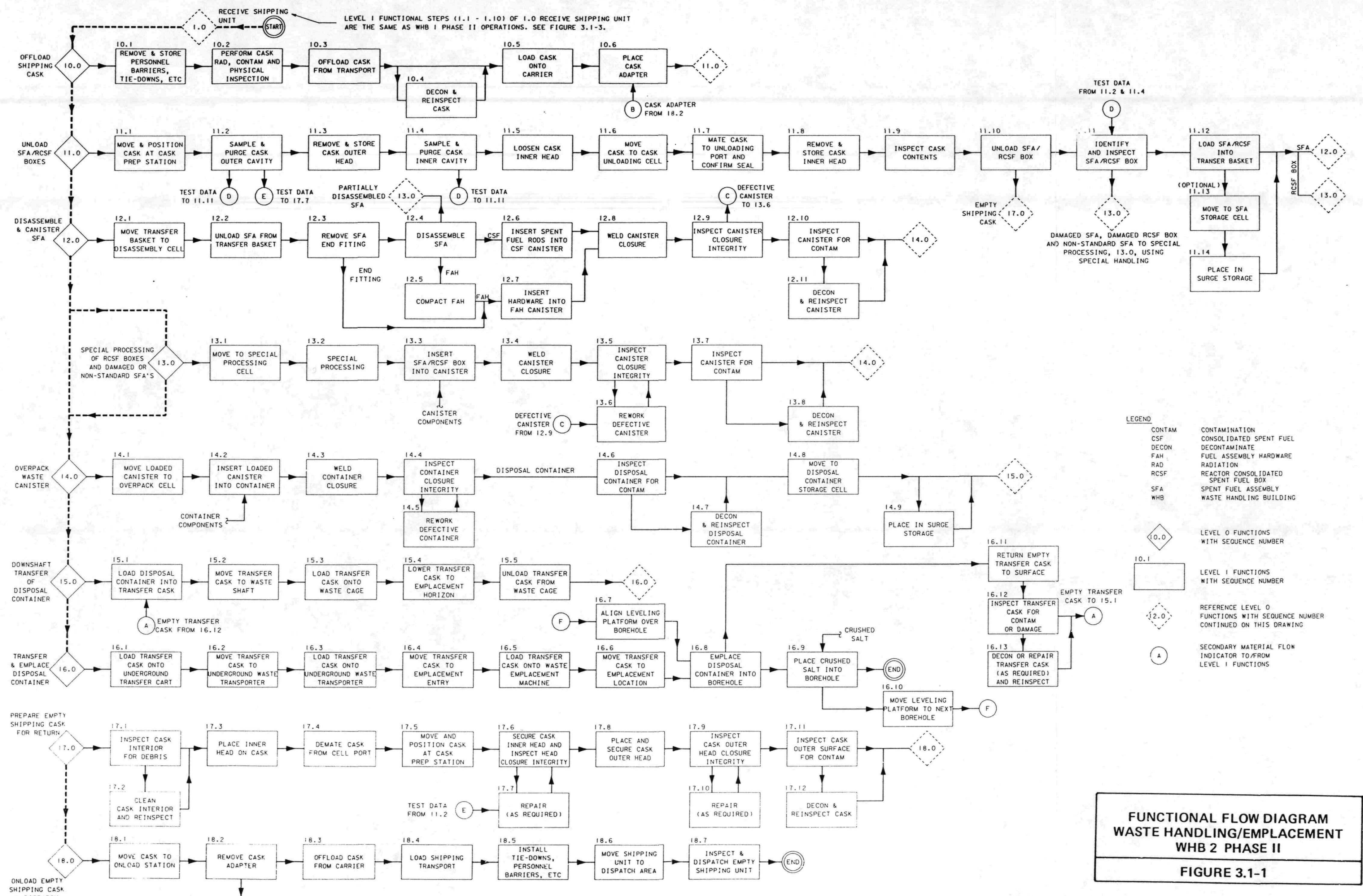




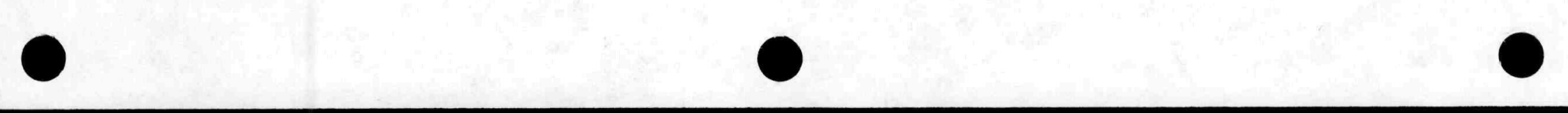




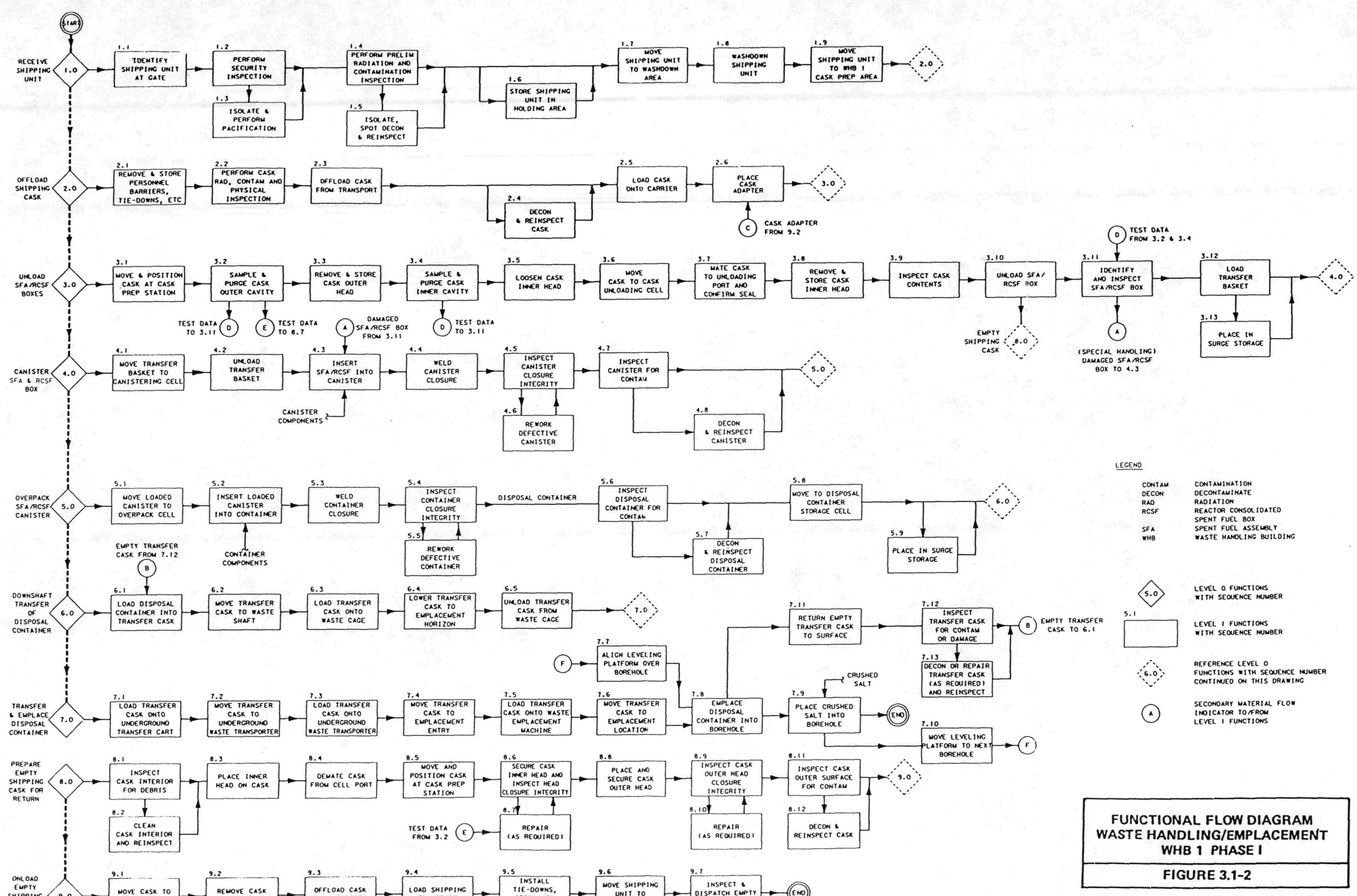


- 10 


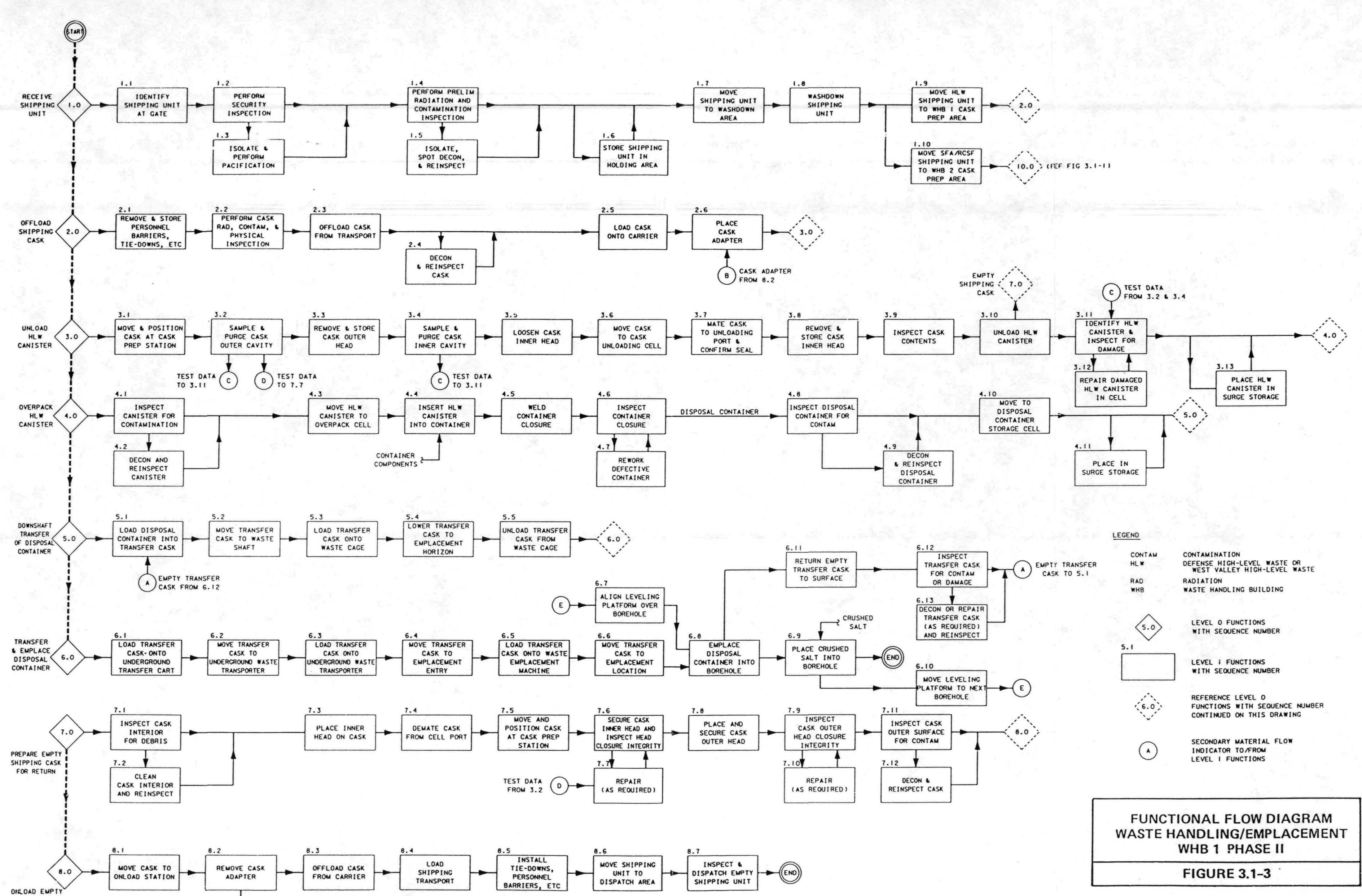


$0 \quad 0$ 

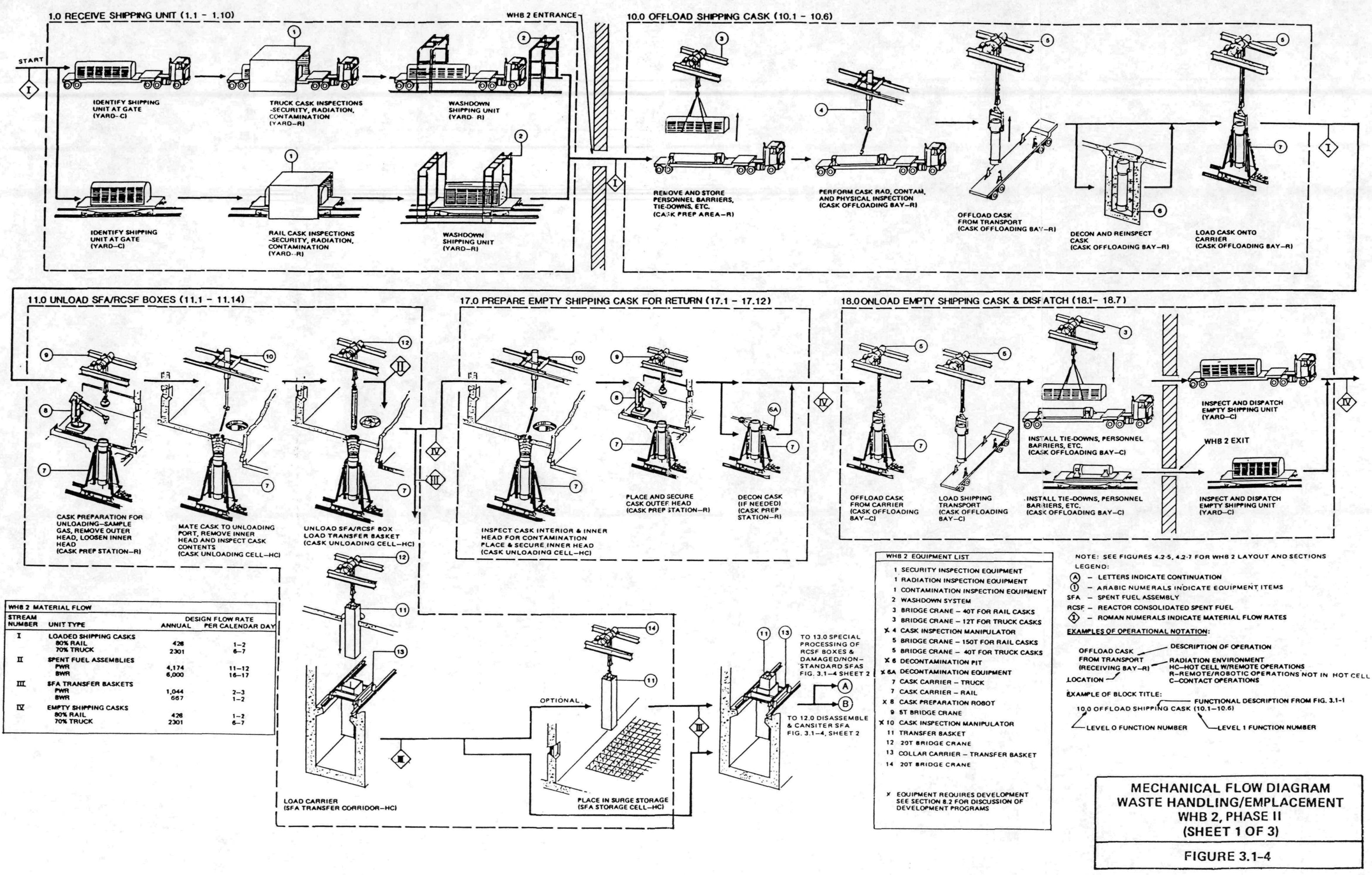
$0 \quad 0$ 


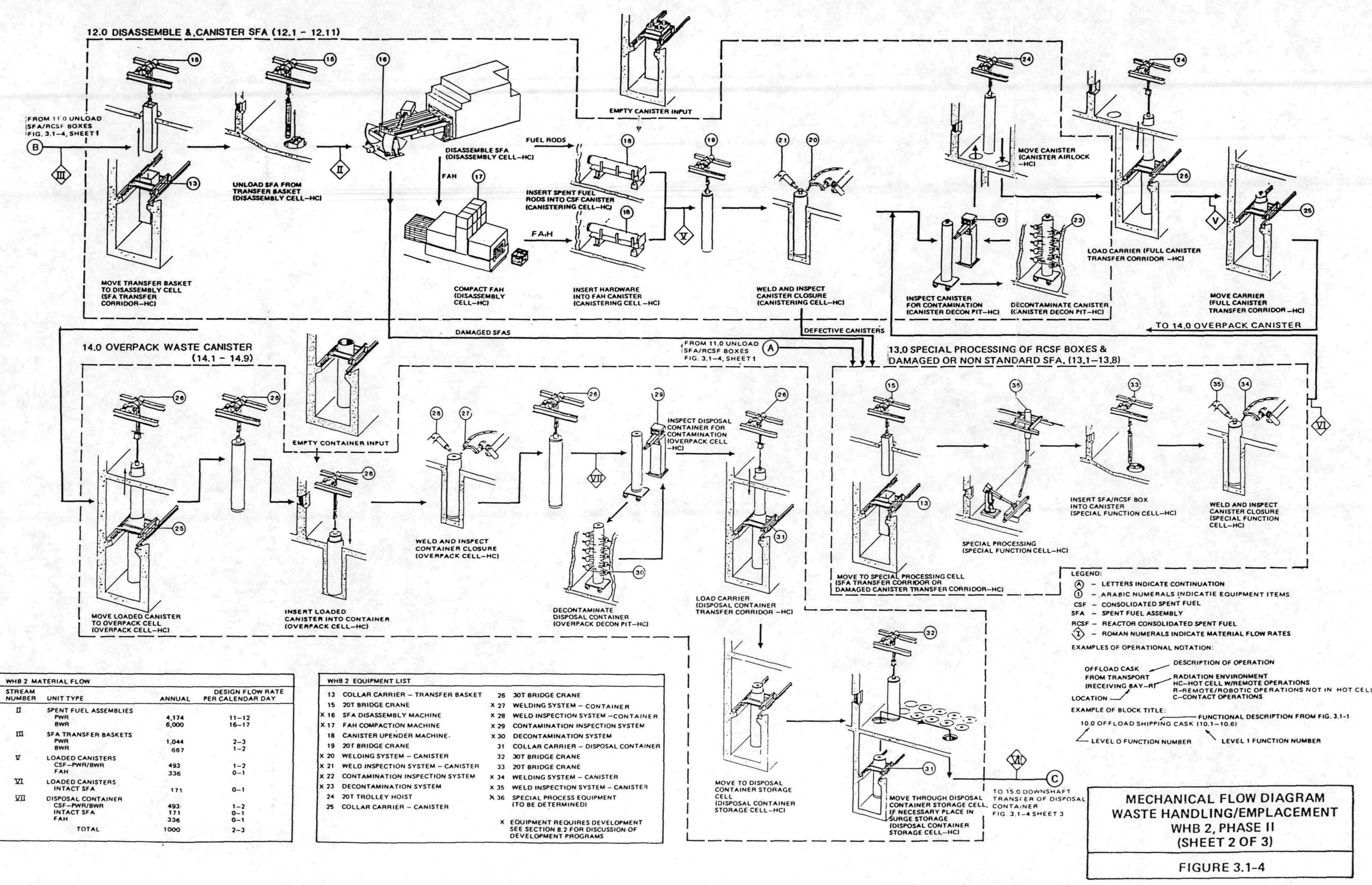


$0 \quad 0$ 

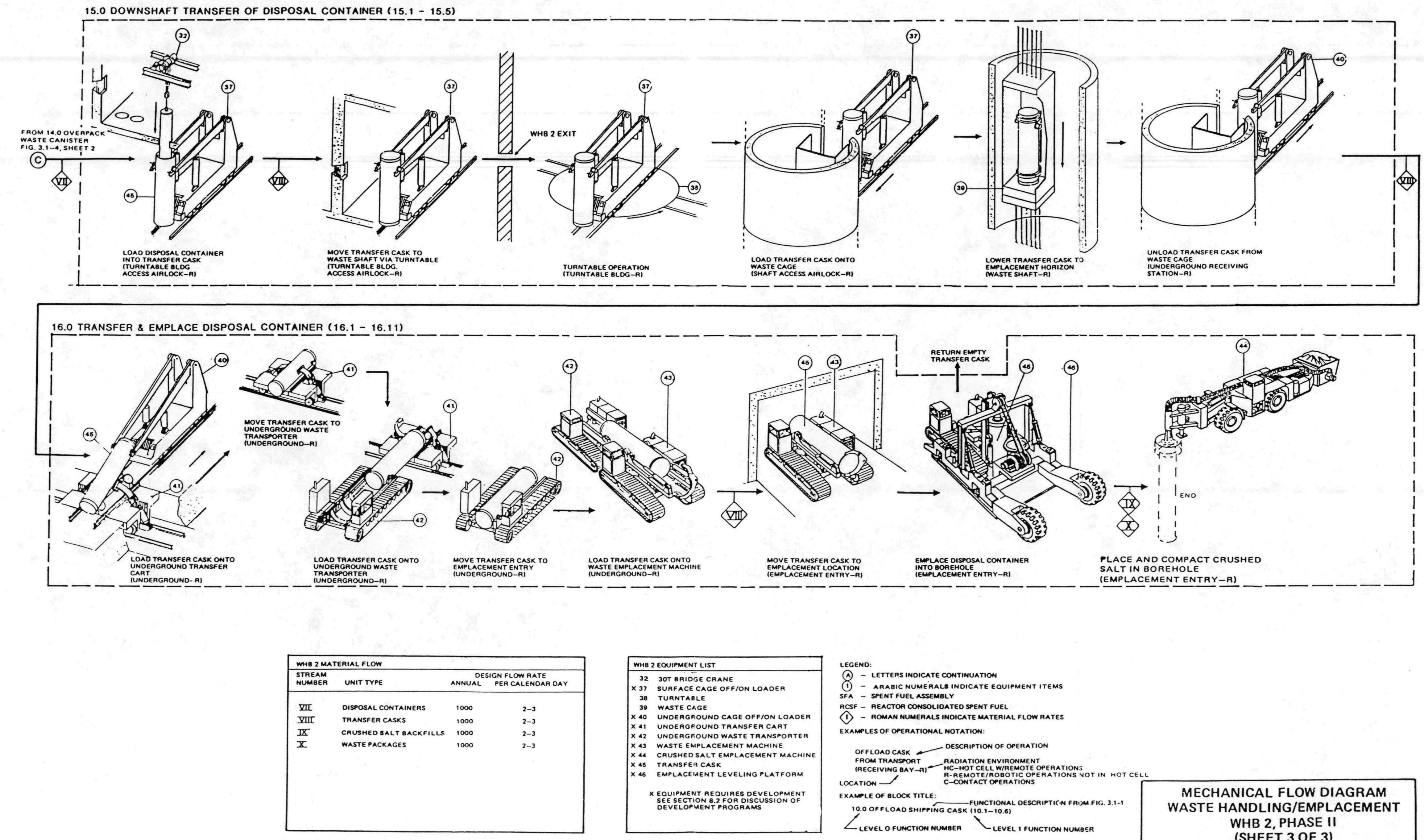

MECHANICAL FLOW DIAGRAM WASTE HANDLING/EMPLACEMENT WHB 2, PHASE II
(SHEET 3 OF 3) FIGURE 3.1-4 
0 
Table 3.1-1. List of Major Waste Handling Equipment for WHB 2, Receiving Yard, Waste Shaft, and Underground (a) (Sheet 1 of 3)

\begin{tabular}{|c|c|c|c|}
\hline \multicolumn{4}{|l|}{ Major } \\
\hline Equipment & & & Requires \\
\hline $\begin{array}{l}\text { Item } \\
\text { Number (b) }\end{array}$ & Equipment Description & Quantity & $\begin{array}{l}\text { Development } \\
\text { (d) }\end{array}$ \\
\hline
\end{tabular}

RECEIVING YARD (a)

Receive Shipping Unit (c)

1 Security Inspection Equipment 1

1 Radiation Inspection Equipment

1 Contamination Inspection Equipment 1

2 Washdown System 2

WHB 2

Offload Shipping Cask

3 Bridge Crane - 40 Ton (Rail Cask 1

3 Bridge Crane - 12 Ton (Truck Cask 1

4 Cask Inspection Manipulator - 2 X

5 Bridge Crane - 150 Ton (Rail Cask 2

5 Bridge Crane - 40 Ton (Truck Cask 2

6 Cask Decontamination Pit and Equipment 11 X

6 A Cask Decontamination Equipment (e) 11

$7 \quad$ Cask Carrier - Rail 3

7 Cask Carrier - Truck 7

Unload SFA and RCSF Boxes

$\begin{array}{rlrr}8 & \text { Cask Preparation Robot (Rail and Truck) } & 10 & \text { X } \\ 9 & \text { Bridge Crane - 5 Ton (Cask Preparation) } & 2 & \text { X } \\ 10 & \text { Cask Inspection Manipulator } & 2 & 40 \\ 11 & \text { Transfer Baskets } & 2 & \\ 12 & \text { Bridge Crane - 20 Ton (Unloading } & 1 \\ & \text { Station) } & 2\end{array}$


Table $3.1-1$ (Sheet 2 of 3 )

\begin{tabular}{l} 
Major \\
$\begin{array}{c}\text { Equipment } \\
\text { Item } \\
\text { Number (b) }\end{array}$ \\
\hline
\end{tabular}

WHB 2 (Continued)

Disassemble and Canister SFA

\begin{tabular}{|c|c|}
\hline 15 & $\begin{array}{l}\text { Bridge Crane - } 20 \text { Ton (Disassembly } \\
\text { Cell) }\end{array}$ \\
\hline 16 & SFA Disassembly Machine \\
\hline 17 & FAH Compaction Machine \\
\hline 18 & Canister Upender Machine \\
\hline 19 & Bridge Crane - 20 Ton (Canistering) \\
\hline 20 & Welding System (Canister) \\
\hline 21 & Weld Inspection System (Canister) \\
\hline 22 & Contamination Inspection System \\
\hline 23 & Decontamination System \\
\hline 24 & $\begin{array}{l}\text { Trolley Hoist - } 20 \text { Ton (Canister } \\
\text { Airlock) }\end{array}$ \\
\hline & Collar Carrier (Canister) \\
\hline
\end{tabular}

4

Overpack Waste Canister

$\begin{array}{ll}26 & \text { Bridge Crane - 30 Ton (Overpack Cel1) } \\ 27 & \text { Welding System (Container) } \\ 28 & \text { Weld Inspection System (Container) } \\ 29 & \text { Contamination Inspection System } \\ 30 & \text { Decontamination System } \\ 31 & \text { Collar Carrier (Disposal Container) } \\ 32 & \text { Bridge Crane - 30 Ton (Disposal } \\ & \text { Container Storage) } \\ & \text { Container Weld Repair Station (not } \\ & \text { shown) }\end{array}$

Special Processing (Special Function Cell)

33

34

35

36
Bridge Crane - 20 Ton

Weld Repair System

Weld Inspection System

Special Process Equipment (to be Determined)

$\begin{array}{rr}8 & X \\ 4 & X \\ 12 & \\ 4 & X \\ 8 & X \\ 8 & X \\ 2 & X \\ 2 & X \\ 2 & \\ 3 & \end{array}$

$x$

$x$

$\mathrm{x}$

$\mathrm{X}$

$x$

$X$

$\mathrm{X}$

$X$

$\mathrm{X}$

$X$

2

$1 \quad \mathrm{X}$

$1 \quad \mathrm{X}$

$1 X$ 
Table 3.1-1 (Sheet 3 of 3 )

Major

Equipment

Requires

Item

Number (b)

Equipment Description

Quantity

Development

(d)

WHB 2 (Continued)

Equipment Not Shown

Remote Maintenance Cell

Equipment to be Determined

WASTE SHAFT AND UNDERGROUND (a)

Downshaft Transfer of Disposal Containers

37

38

45
Surface Cage off/on Loader

Turntable

Transfer Cask

$\begin{array}{rr}2 & X \\ 1 & X \\ 10 & \end{array}$

X

Transfer and Emplace Disposal Container

39 Waste Cage

$40 \quad$ Underground Cage Off/On Loader

41 Underground Transfer Cart

42 Underground Waste Transporter

43 Waste Emplacement Machine

44 Crushed Salt Emplacement Machine

46

Emplacement Leveling Platform

$\begin{array}{ll}1 & X \\ 2 & X \\ 3 & X \\ 3 & X \\ 3 & X \\ 3 & X\end{array}$

(a) Note that the equipment in the Receiving Yard, Waste Shaft and Underground Areas is included here with WHB 2. This equipment is used in common with WHB 1. Table 3.1-2 identifies the equipment in WHB 1.

(b) Equipment Identification Numbers are shown on Figure 3.1-4.

(c) Functional descriptions correspond to those in Figure 3.1-4.

(d) Equipment requires development, see Section 8.2 for discussion of development programs.

(e) Equipment is shown in "Prepare Empty Shipping Cask for Return" functional description. 


\subsubsection{Receive Shipping Unit (1.0)\%}

Each shipping unit will consist of a rail car or truck trailer, the attached cask, and the personnel barriers surrounding the cask. Upon arrival at the repository, the shipping units will undergo several inspections and operations to prepare the cask for entry into the waste handling building. The initial series of inspections will focus on security concerns and radiation and contamination levels, if any. These inspections will take place near the entry to the repository site. Should a shipping unit have a serious security problem, it will be moved to a shipping unit pacification area on the repository site for further inspection and pacification if necessary. Should abnormal radiation or contamination levels be found, special steps will be taken to correct the problem without unnecessarily exposing surface facilities and site personnel.

After these initial inspections, each shipping unit will be moved through a shipping unit washdown building. Equipment in this building will remove the road dirt and debris. Water used for this purpose will be collected and surveyed for possible contamination. If found to be clean, it will be recycled to the water treatment facility. If found to be contaminated, it will be sent to the liquid radwaste treatment system in WHB 2 (Section 6.1.1, Liquid Radwaste).

As the shipping unit is moved through these preparation operations, it may be temporarily stored in a holding area within security fences. Upon completion of the operations shown in Box 1.0 of Figure $3.1-4$, the shipping unit will be ready to enter WHB 2 .

*Parenthetical numbers in headings of Sections 3.1 .2 .1 through 3.1 .2 .10 correspond to level 0 function numbers in Figure 3.1-4. 
Operations on truck and rail casks after they enter WHB 2 are shown on Figure 3.1-4. A truck cask is shown, but the procedures used with a rail cask will be nearly identical. The personnel barriers around the cask will be removed, providing the first opportunity to inspect the entire exterior of the cask. This inspection will consist of measuring both radiation and contamination levels. Robotic equipment will be used so as to limit the radiation exposure of personnel. (See Section 4.2.4.2.)

When this inspection is complete, the shipping unit will be moved to an off-loading area where the cask will be uprighted and lifted off the truck trailer or rail car. If necessary, the exterior surface of the cask will be decontaminated at this time. The cask will then be placed on a cask carrier for movement to a cask preparation station. Although not shown, an adapter will be placed on the top surface of most casks. This will provide a common hot cell seal interface.

\subsubsection{Unload Spent Fuel Assemblies (SFAs) and Reactor Consolidated Spent Fuel (RCSF) Boxes (11.0)}

Preparation for cask unloading will begin at the cask preparation station. This station will contain a robotic arm and an overhead crane to prepare the cask for opening and unloading of its waste forms. Preparation will include sampling of gases in the cask's cavities to determine the condition of the spent fuel and the cask head seals. The cask's outer head will be removed, and the inner head nuts will be loosened and removed from their studs. The inner head will not be removed at the preparation station. Should sampling of the inner cavity indicate a higher than normal level of fission gasses, loosening of the inner head will be delayed until the cask is at the cask unloading cell. This will prevent release of these radioactive gasses at the cask preparation station.

Robotic cask preparation will minimize the cumulative radiation dose to personnel. However, since the cask will not be opened at the station, operating personnel will be permitted direct access to the cask on infrequent 
occasions when equipment fails or the cask presents a unique problem requiring personnel access.

After preparation, the cask will be moved under an unloading port at the cask unloading cell. Here, an expandable seal will be lowered and expanded to isolate the exterior of the cask and the surrounding preparation area from the interior of the cask unloading cel1. The inner cask head will then be removed. An overhead manipulator with a video camera will be used to inspect the interior of the cask to determine the condition of the cask and its waste units. An unloading crane will then be moved over the cask to unload the SFAs and RCSF boxes. Each item will be moved to a nearby shielding window to permit personnel to confirm visually the identity of the waste unit and to determine if it is damaged. After this inspection, the waste unit will be lowered into a transfer basket positioned in a small holding pit adjacent to the cask unloading port.

Transfer baskets will be portable structural frames of partially open construction designed to hold several waste units. The assumed capacity for the conceptual design was four pressurized water reactor (PWR) SFAs and RCSF boxes or nine boiling water reactor (BWR) SFAs and RCSF boxes. Transfer baskets will be used to move and temporarily store SFAs and RCSF boxes for the following reasons:

1. They will increase the efficiency of the complex logistical operation of intra and inter-cell waste handling by permitting the transfer of several waste units simultaneously.

2. They will provide a partial containment barrier by collecting contaminated material dislodged from the waste units as they are moved or stored.

3. They will provide a support frame for stable storage of waste units in surge storage pits.

4. They will be specifically designed for efficient transfer of SFA decay heat when stored in a dense storage matrix. 
After a transfer basket is filled with its full complement of waste units, a bridge crane will lift it out of its holding pit and transfer it to an exit port in the unloading cell. There the basket will be lowered onto a rail-mounted carrier travelling in a dedicated transfer corridor connecting the cells. The carrier will have a structural frame designed to receive and secure the basket during movement between cells. Similar carriers will be used to transfer canisters and failed equipment components in other dedicated transfer corridors. These carriers will transfer items by receiving them from a port in the cell floor and traveling to a position under a port in the floor of the destination cell.

If equipment in these cells is available at the time the basket leaves the cask unloading cell, the transfer baskets containing SFAs and RCSF boxes will be transferred to a disassembly cell or special function cell. However, it is expected that some waste units will be temporarily stored in the surge storage cell until a processing cell is ready to receive them. This will be particularly true for SFAs since it is expected that disassembly machines will operate on campaign runs in which the machines will have their support fixtures changed only when a sufficient quantity of a specific type of SFA is present within the building. The surge storage cell will also provide the main buffer between cask unloading and processing/packaging operations. Should either of these operations be significantly reduced in capacity, the surge storage buffer will allow the other operation to continue.

\subsubsection{Disassemble and Canister SFA (12.0)}

SFAs will arrive at the disassembly cell in the transfer baskets. They will be lifted into the cell and placed in a small storage pit adjacent to the disassembly machine. Individual SFAs will then be removed from the transfer baskets by a cell crane and secured into the support frame of the disassembly machine. One SFA end fitting will be removed to permit access to the fuel rod ends.

The disassembly machine will simultaneously extract the fuel rods from three PWR assemblies or seven BWR assemblies. The extracted rods will be collected and inserted into a canister in the adjacent canistering cell. After 
fuel rod removal, the remaining fuel assembly hardware will be moved to a nearby compaction machine for compaction and insertion into another canister in the canistering cell. Should the disassembly machine encounter serious difficulty in removing all the fuel rods from an SFA, the SFA will be removed from the machine, placed in an empty transfer basket and moved to the special function cell.

Canisters will be filled by positioning incoming empty canisters at loading ports in an isolation wall separating the disassembly and canistering cells (see Section 4.2.5.5 Surface Facilities). The loading port will be designed to minimize the movement of contaminated airborne material from the heavily contaminated disassembly operation to the less contaminated canistering operations.

After the canister is filled with fuel rods or compacted fuel assembly hardware (FAH), it will be moved to a welding and inspection station. There, a robotic welding machine will seal it by welding a cover plate onto it. (It is assumed that it will not be necessary to backfill the canister with inert gas.) A robotic inspection device will then be used to inspect the weld. Canisters with failed welds that cannot be repaired will be transferred to the special function cell. Canisters with successful welds will proceed to an inspection and decontamination station.

The contamination control philosophy of WHB 2 will require that all spent-fuel canisters be inspected to verify that they are free of surface contamination prior to being transferred to the overpacking cell. Since the canistering cell can be contaminated by leakage of airborne material through the canister loading ports, the welded canister must be removed from the cell environment for its contamination inspection. The canister will be lowered into a subcell beneath the canistering cell, which is an area designed to isolate the canister from the canistering cell environment. A contamination inspection will consist of taking several smear samples and surveying the activity of these samples in an isolated area. Should the canister require decontamination, it will be decontaminated and reinspected to verify that it is now uncontaminated. The canister will then be raised into a transfer airlock for loading onto an inter-cell carrier and transfer to the overpacking cell. 


\subsubsection{Overpack Waste Canister $(14.0)$}

A thick-walled steel container will provide the primary long-term containment barrier around the contents of the canisters. The waste canister will be placed in the container, and a head will be welded to the container to provide a completely sealed barrier. This weld will be a critical waste packaging operation since it will directly effect the long-term isolation capability of the emplaced waste package. Therefore, after welding, the container will undergo a careful weld inspection to verify the weld quality. Should the weld not meet stringent quality control requirements, it will be transferred within the cell to a repair station for repair of the weld or removal of the head and replacement with a specially fitted head.

After successful weld inspection, the disposal container will undergo a contamination inspection. Unlike the canister decontamination inspection, which will require a separate subcell, the container decontamination inspection will be done within the environment of the overpacking cell since this cell will be maintained as an uncontaminated cell. After the disposal container is verified to be free of contamination, it will be lowered through an exit port in the cell floor onto a carrier for transfer to the disposal container surge storage cell.

If a disposal container is found to be contaminated, the source of the contamination will be identified to prevent contamination migration to the shaft and underground. Possible causes could include a faulty canister weld not identified during canister weld inspection, or failure of the airlock and ventilation controls that isolate contaminated cell environments from the overpacking cell environment. After identification and correction of the cause of the contamination, the overpacking cell and any contaminated areas adjacent to it will be decontaminated as necessary. The contaminated container will be lowered into a subcell beneath the overpacking cell for decontamination. Containers and equipment present in the cell when the contamination is discovered will be inspected to ensure that all disposal containers going to the underground are uncontaminated. 
Disposal containers may be temporarily stored in a dedicated storage cell. This cell will also provide an important buffer storage location between the waste packaging and emplacement operations. Disposal containers will be transferred to the underground when all the equipment to receive and emplace the disposal container is ready.

\subsubsection{Process RCSF Boxes and Damaged or Nonstandard SFAs as Required (18.0)}

A special function cell will be devoted to processing those SFAs, RCSF boxes and spent fuel canisters which will not or cannot be processed within standard operating procedures. This cell will not contain equipment to disassemble SFAs. For the conceptual design, it was assumed that $10 \%$ of SFAs will not be disassembled. The items to be processed include:

1. Incoming SFAs which do not meet repository standards for disassembly, or which are damaged to an extent that disassembly would be difficult or impractical, will be routed to the special function cell for intact placement into canisters without disassembly. This may include cutting off one or both end fittings of SFAs whose length exceeds the length of the canister. After the canister is filled, it will be welded and decontaminated following the same procedure used in the canistering cells.

2. SFAs which cannot be completely disassembled because the fuel rods have become stuck during fuel rod extraction, or because of other unforeseen difficulties, will be removed from the disassembly machine and transferred to the special function cell for intact placement in canisters. The full range of operations of the special function cell will be further defined in the advanced conceptual design (ACD) and license application design (LAD) phases.

3. Beginning in the sixth year of repository operations RCSF boxes will be processed in WHB 2 so that WHB 1 can be devoted to processing defense high-level waste (DHLW) :.dd West Valley high-level waste (WVHLW) canisters. RCSF boxes will be placed in canisters and sealed in the same manner as intact SFAs. 
4. Canisters with welds which do not meet quality control standards and which cannot be repaired within the canistering cell will be transferred to the special function cell. There they will be repaired, or if that is not possible, they will be opened, and the contents of the canister will be loaded into a new canister. The defective canister will then be compacted and transferred to solid radwaste treatment.

\subsubsection{Transfer Disposal Container to Underground (15.0)}

Since the disposal containers will have a radiation level that does not permit continuous personnel exposure, they will be moved down the shaft and through the underground in transfer casks which will provide additional shielding until they are emplaced (see Section 4.2.4.2, Limiting Occupational Dose).

When underground operations are ready to receive a disposal container, a surface cage off/on loader carrying a transfer cask will be positioned under a transfer port in the floor of the disposal container storage cell. The head cover of the transfer cask will then be removed. The disposal container will be lowered from the storage cell into the transfer cask, and the head cover will be resecured. The off/on loader will then be moved to the adjacent turntable building and onto a large turntable which will orient the off/on loader with the waste cage (see Figure 4.2-8).

When the off/on loader is in the shaft loading position, it will position the cask over a support frame and gradually lower it until its full weight is supported by the cage floor. The off/on loader will not have to travel onto the cage to support the full weight of the loaded transfer cask (maximum weight $=48.0$ tons) during cage loading. The cage hoist ropes will stretch two to three inches as the cage is loaded. The off/on loader will then be withdrawn, and the transfer cask and enclosed disposal container will be lowered to the repository horizon. At full throughput capacity, the hoist will make approximately five round trips per day lowering waste containers and raising empty transfer casks. 
After the waste cage arrives at the repository horizon, an underground cage off/on loader will remove the transfer cask in a manner similar to surface loading. As the load transfers from the cage to the off/on loader, the cage will rise approximately 18 inches because of elastic rebound in the 2,340 feet of cage support wire rope. (See Section 4.3 .3 .2$. )

\subsubsection{Transfer and Emplace Disposal Container (16.0)}

The underground cage off/on loader will move the transfer cask a short distance from the waste cage and place it in a horizontal position on an underground transfer cart. This cart will move the transfer cask from the waste shaft drift to a parallel drift used by the underground waste transporter. (Two underground transfer carts will be required, one for the loaded transfer cask and one for the returning empty transfer cask.) The transfer cask will next be transferred from the transfer cart to the underground waste transporter. The transporter will travel at approximately six miles per hour to the emplacement entry. There the cask will be transferred to the waste emplacement machine. The emplacement machine will then move the cask into the emplacement entry and drive onto the leveling platform. The leveling platform will be in position and leveled over the emplacement hole.

At the emplacement position, the transfer cask will be remotely rotated to a vertical position and then lowered into the counterbored portion of the emplacement hole. Then the container will be lowered into the borehole. The empty transfer cask will then be removed from the borehole and returned to the surface using the same equipment that brought it down.

After insertion of the disposal container into the emplacement hole, the borehole will be filled with crushed salt. This will complete the emplacement operation. (See Section 4.5.3, Emplacement Operations, for a more detailed description of emplacement operations.)

Each of the four major underground waste handling and emplacement functions--transfer cask receiving, transportation, emplacement, and shielding-requires a different type of machinery and control mechanism. If these functions are combined into one vehicle, the result would be an extremely complex machine. 
Experience has shown that such a complex machine would be less reliable than desired and have poor maintenance access. To minimize equipment complexity, separate pieces of equipment will be designed to perform each of these tasks. As a result, the machines will be safe, simple, rugged, reliable, and maintainable, but require transfer of the casks from machine to machine. In addition, the design size of the machines is constrained by the small operating envelope dictated by the underground drift sizes. The design of the machines and the required transfers of casks will be reassessed during $A C D$.

\subsubsection{Prepare Empty Shipping Cask for Return (17.0)}

After all waste forms have been removed from shipping casks, they will be remotely inspected to verify that they are clear of waste material. They will then be moved back to the preparation station. The inner and outer head covers will be inspected and secured onto the casks, and tests will be conducted to verify seal integrity. The casks will also undergo a contamination inspection and decontamination as necessary. The decontamination process will be designed to minimize or avoid production of mixed radioactive and hazardous chemical wastes. When these operations are completed, a cask carrier will move them from the preparation station to the cask offloading area. Empty shipping cask preparation functions will be designed to minimize cask turn-around time.

\subsubsection{Onload Empty Shipping Cask and Dispatch (18.0)}

Casks will be offloaded from the carrier and secured onto rail or truck carriers and all personnel barriers will be replaced. They will then be moved out of the building for a final inspection prior to dispatch out of the repository.

\subsubsection{Waste Handling Building 1 - Phase I}

Most of the operations performed during Phase I of WHB 1 (Figure 3.1-5) will be identical to those in WHB 2. The major differences will be a lower throughput rate and the placement of SFAs in canisters without rod consolidation. This lower throughput rate will permit training of operators in preparation for the increased throughput rates that will occur during Phase II. 


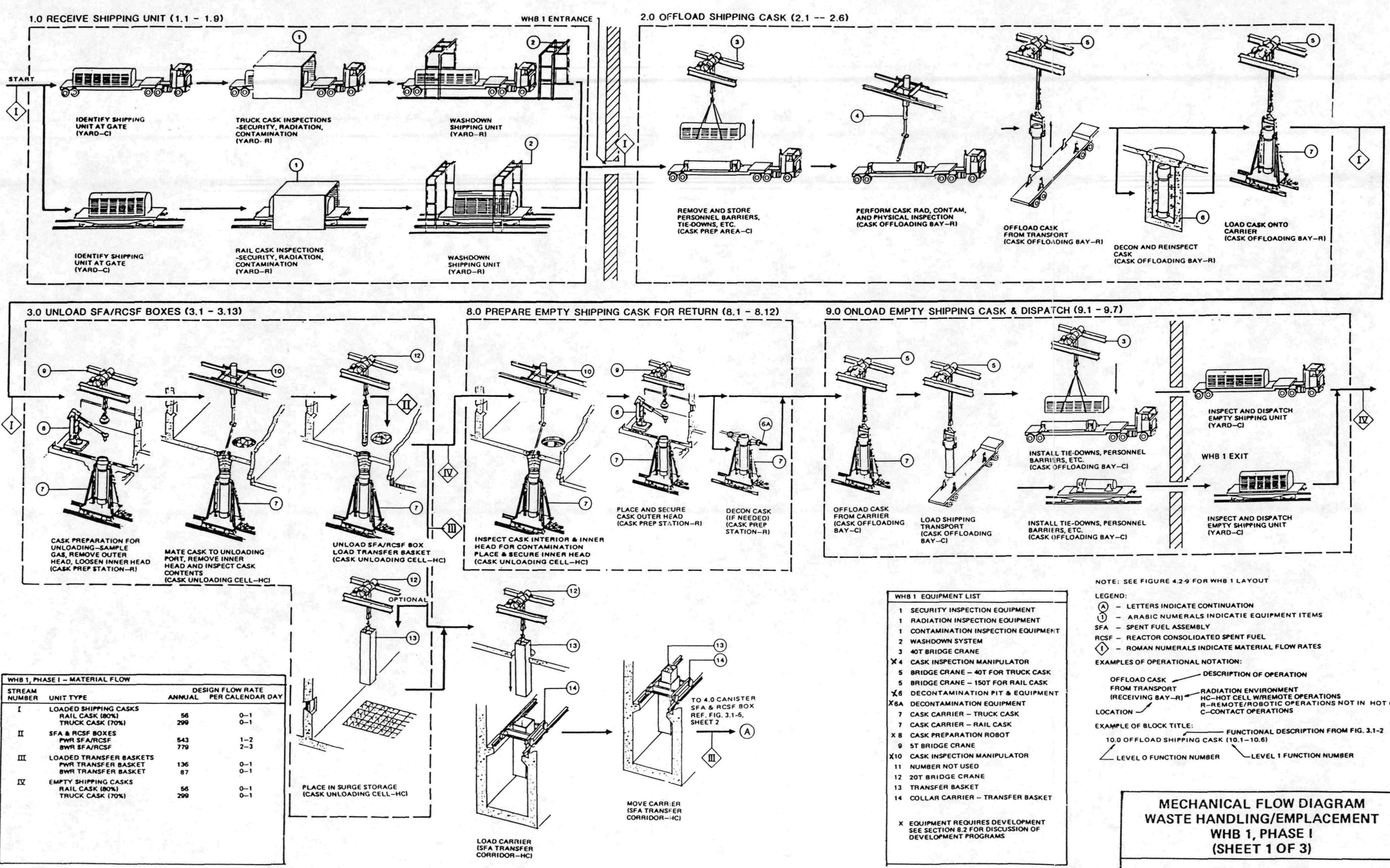

NOTE: SEE FIGURE 4.3 For Wug i Lavour

LEGEND:

(1) - ARABic NUMERALS INOICATIE EQUiPMENT ITEMS RCSF - REACTOR CONSOLIOATEO SPENT FU -110 - a Descaption of oespation FOM TRANSPORT IRECEIVING Bay Location

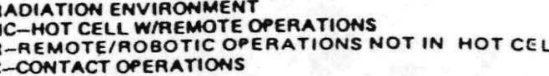
Funcrional OESCRAPTTON FROM FIG. 3.1-2 LEVEL O FUNCTION NUMBER

\begin{tabular}{|c|}
\hline $\begin{array}{c}\text { MECHANICAL FLOW DIAGRAM } \\
\text { WASTE HANDLING/EMPLACEMENT } \\
\text { WHB } 1, \text { PHASE } 1 \\
\text { (SHEET 1 OF } 3 \text { ) }\end{array}$ \\
\hline FIGURE $3.1-5$ \\
\hline
\end{tabular}




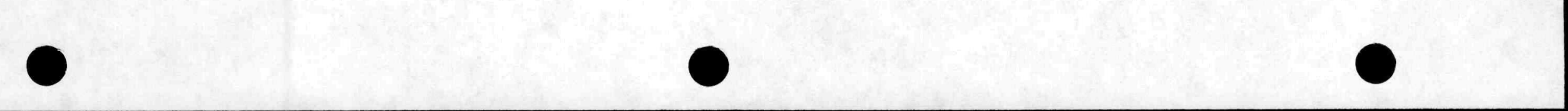



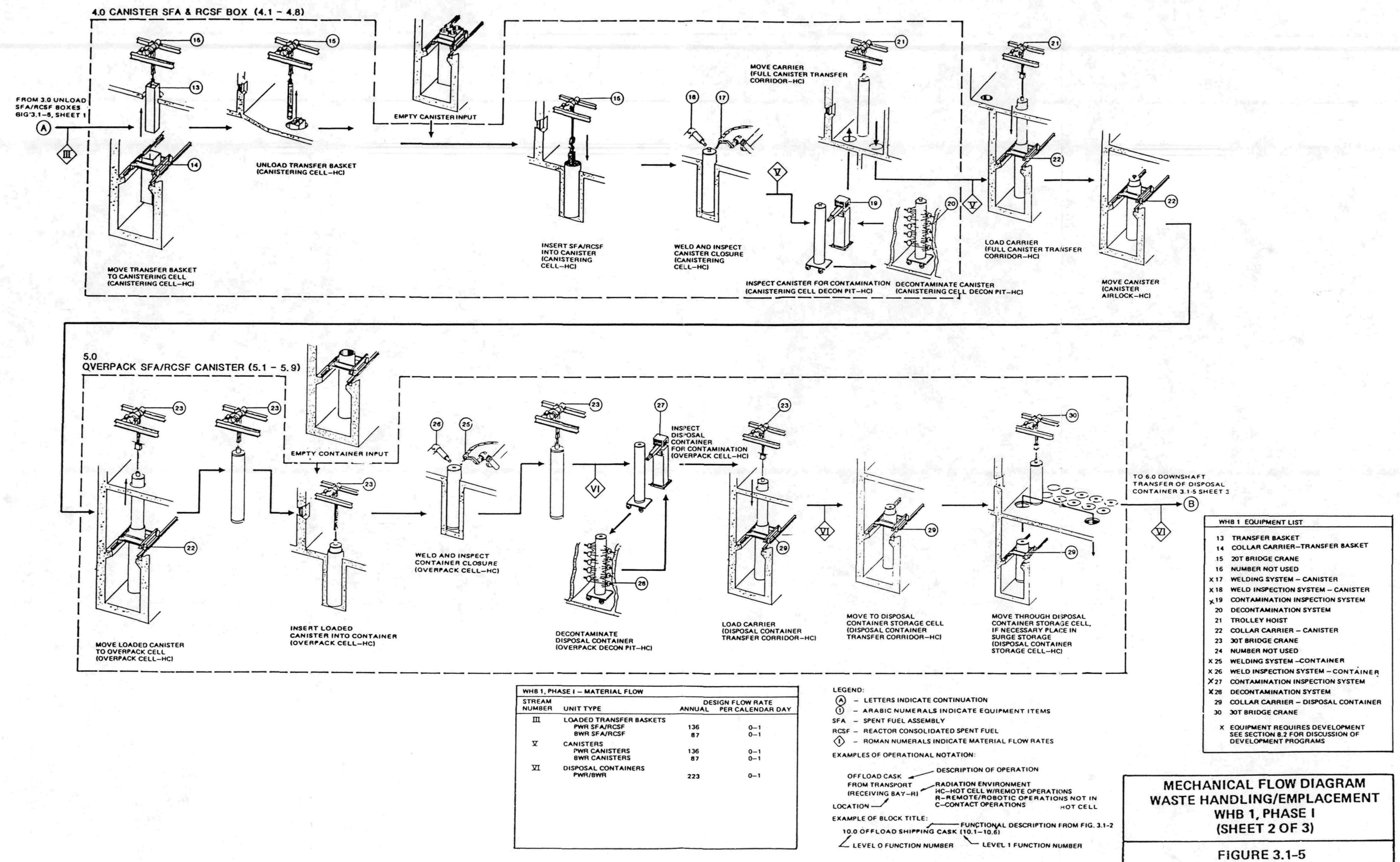

MECHANICAL FLOW DIAGRAM WASTE HANDLING/EMPLACEMENT WHB 1, PHASE I
(SHEET 2 OF 3)

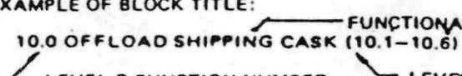
FIGURE 3.1-5 
O 100 

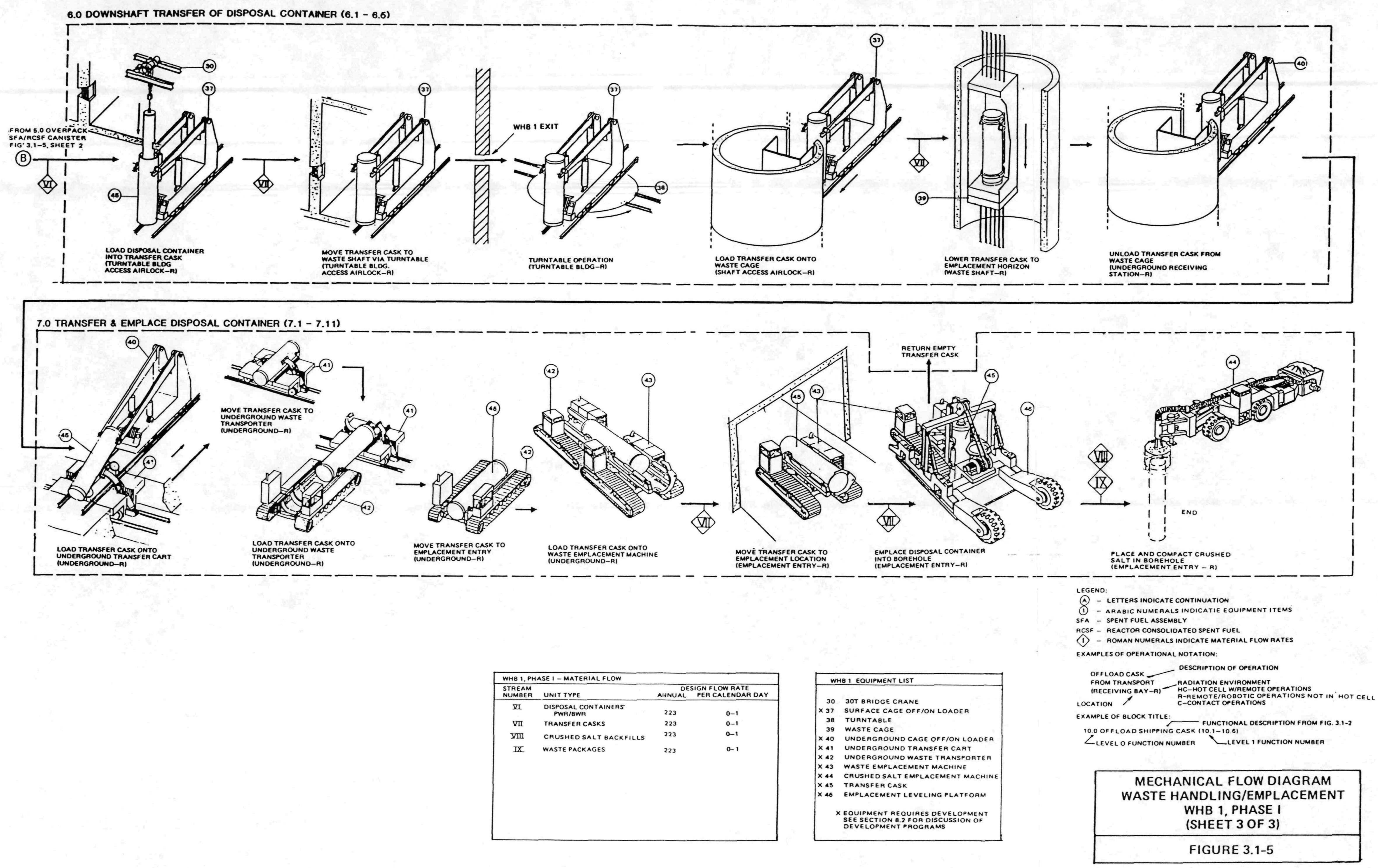
$0 \quad 0 \quad 0$ 
The following paragraphs describe only those operations that differ from those in WHB 2. Table 3.1-2 lists the major equipment within WHB 1 to be used in both operational phases of the building.

\subsubsection{Spent Fuel Surge Storage $(3.0) \%$}

The relatively small number of SFAs and RCSF boxes will be stored in a surge storage pit within the cask unloading cell rather than in a dedicated storage cell. During surge storage, transfer baskets will be used in the same manner as WHB 2 .

\subsubsection{Spent Fuel Canistering (4.0)}

SFAs and RCSF boxes will be placed intact into canisters. No disassembly machines or cells will be present in WHB 1. Neither will there be a special function cell since the canistering cell will contain equipment to process or repair defective SFAs and canisters. Some BWR SFAs will require the removal of one or both end fittings prior to placement in the canister. Operations after canister welding in WHB 1 will be identical to those in WHB 2 .

\subsubsection{Waste Handling Building 1 - Phase II}

During Phase II operations (Figure 3.1-6), WHB 1 will be dedicated to receiving and overpacking DHLW and WVHLW canisters. Equipment and cells associated with spent fuel canistering during Phase $I$ are not expected to be used during Phase II operations, except for the canistering cell which may occasionally be used to process defective DHLW and WVHLW canisters.

\footnotetext{
*Parenthetical numbers in headings of Sections 3.1 .3 .1 and 3.1 .3 .2 correspond to level 0 function numbers on Figure 3.1-5.
} 
Table 3.1-2. List of Major Waste Handling Equipment for WHB 1 (a) (Sheet 1 of 2)

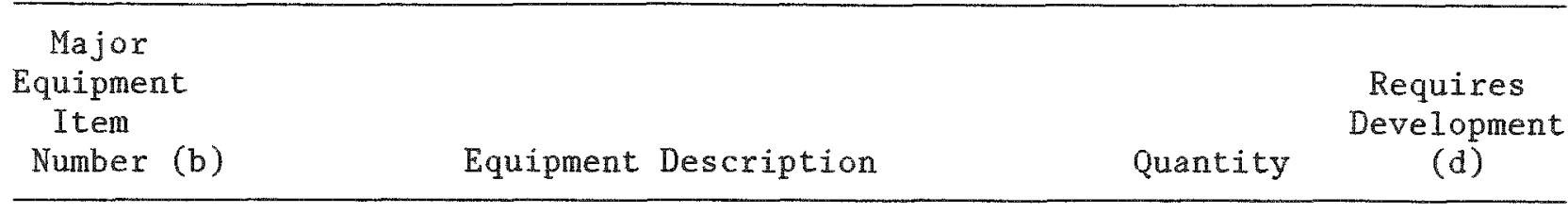

WHB 1

Offloading (c)

3 Bridge Crane - 40 Ton (Rail Cask 1

4 Preparation)

5 Bridge Crane - 150 Ton (Rail Cask

5 Bridge Crane - 40 Ton (Truck Cask 1

6 Decontamination Pit and Equipment 1 X

7 Cask Carrier - Rail

7 Cask Carrier - Truck

Unloading

8

9

10

11

12

13

14

\section{Canistering (e)}

15

16

17

18

19

20

21

22
$1 \quad \mathrm{X}$

1

1
6A Cask Decontamination Equipment (e) 11 X

2
Cask Preparation Robot (Rail and Truck)

Bridge Crane - 5 Ton

Cask Inspection Manipulator

Number Not Used

Bridge Crane - 20 Ton (Unloading 2 Station)

Transfer Basket

Collar Carrier (Transfer Basket)
$\mathrm{X}$

$\mathrm{x}$ Ce11)

Number Not Used

Welding System (Canister)

Weld Inspection System (Canister)

Contamination Inspection System

Decontamination System

Trolley Hoist - 20 Ton

Collar Carrier (Canister)
$\mathrm{X}$

$\mathrm{X}$

$\mathrm{X}$

$\mathrm{X}$ 
Table 3.1-2 (Sheet 2 of 2)

\begin{tabular}{|c|c|c|c|}
\hline \multicolumn{4}{|l|}{ Major } \\
\hline Equipment & & & Requires \\
\hline Item & & & Development \\
\hline Number (b) & Equipment Description & Quantity & (d) \\
\hline
\end{tabular}

WHB 1 (Continued)

Overpacking

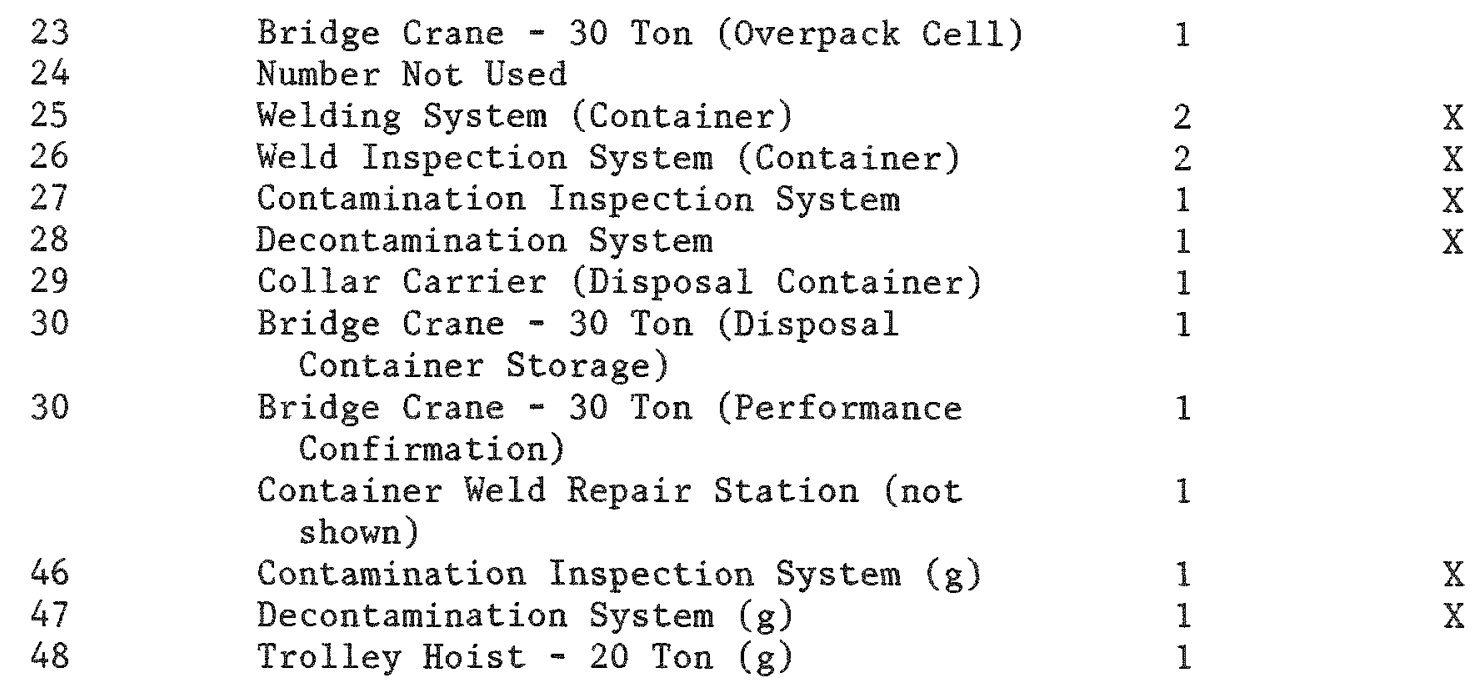

Equipment Not Shown

Remote Maintenance Cell

Equipment to be Determined

Performance Confirmation Cell

Equipment to be Determined

(a) Note that waste handling equipment in the Receiving Yard, Waste Shaft, and Underground is used in common with WHB 2. This equipment is shown in Table 3.1-1, List of Major Waste Handling Equipment for WHB 2.

(b) Equipment Identification Numbers are shown on Figures $3.1-5$ and $3.1-6$.

(c) Functional Descriptions correspond to those in Figures 3.1-5 and 3.1-6.

(d) Equipment requires development, see Section 8.2 for discussion of development programs.

(e) Equipment is shown in "Prepare Empty Shipping Cask for Return" functional description.

(f) This canistering equipment is not used on a daily basis during Phase II operation. It is used as standby equipment for off-normal operations only.

(g) Equipment used in Phase II operation. 


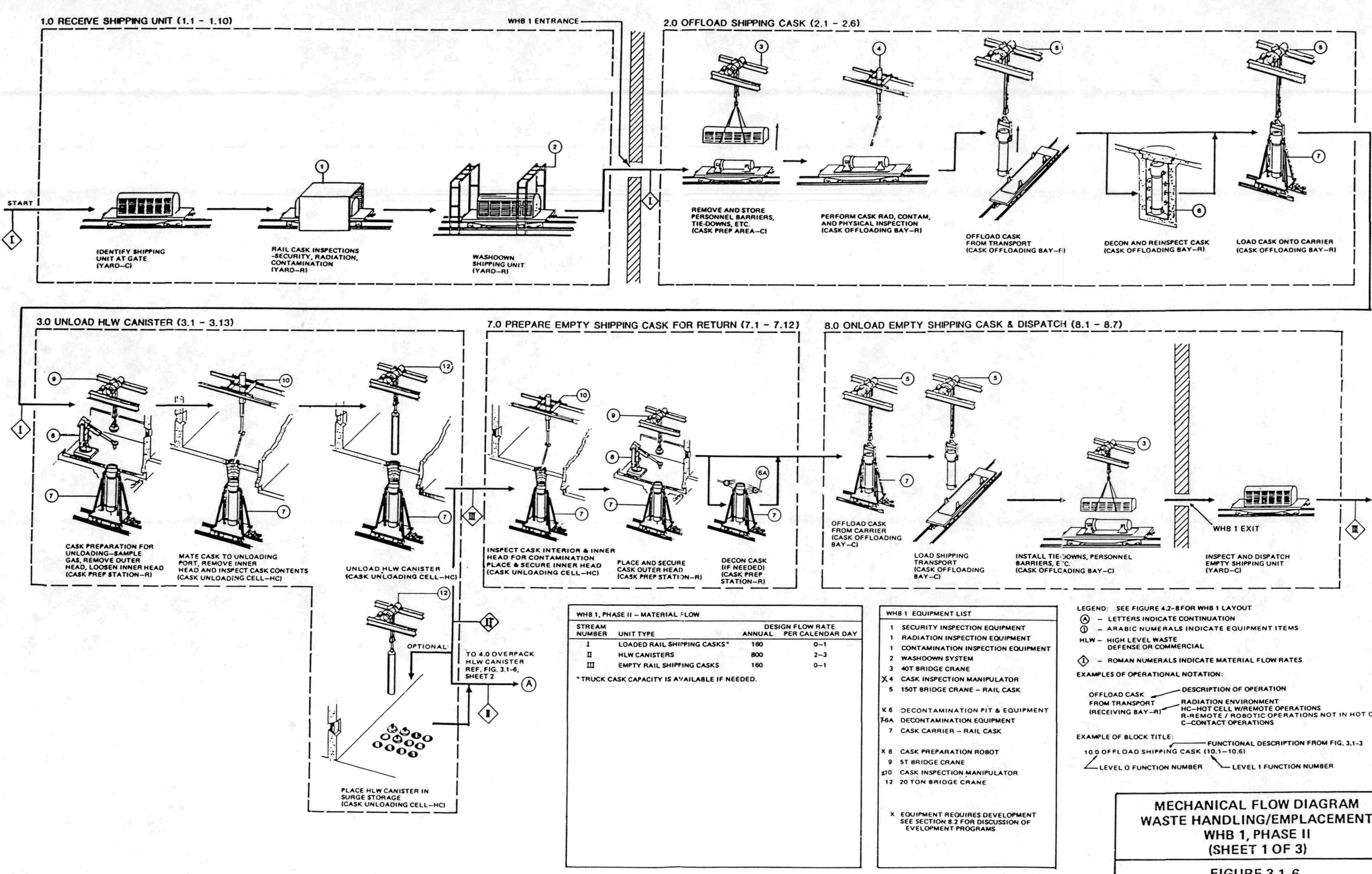

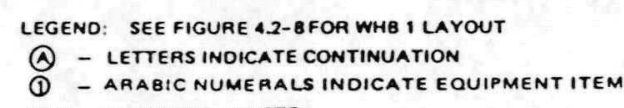

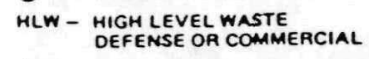

(1) - ROMan Numerals inoicate material flow pates

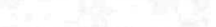

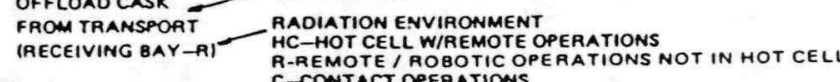

EXAMPLE OF BLOCK TITLE:

FUNCTIONAL DESCRHPTION From FIG. 3.1.-1-

$Z_{\text {LeVEL O fUNCTION NUMBER }} \mathrm{L}_{\text {LEVEL I Function NuMGer }}$

MECHANICAL FLOW DIAGRAM WASTE HANDLING/EMPLACEMENT WHB 1, PHASE II

FIGURE 3.1-6 


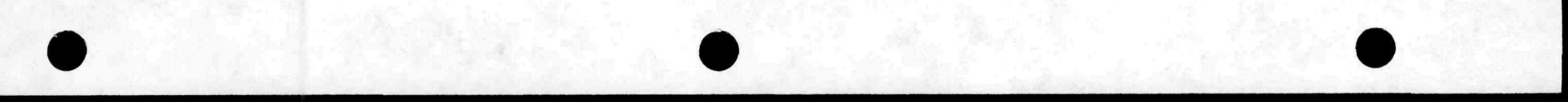


4.0 OVERPACK HLW CANISTER (4.1-4.11)
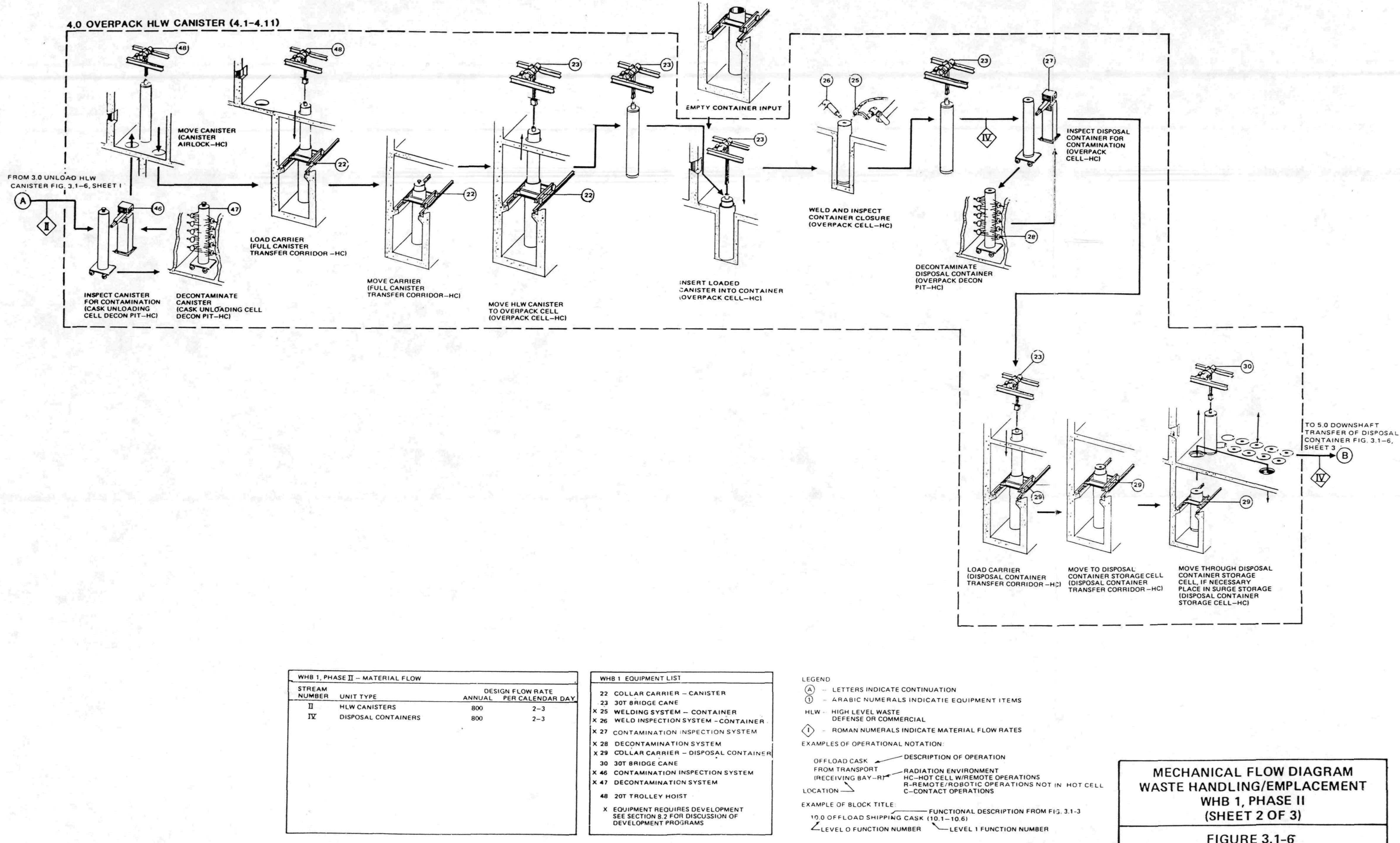

Legend
(A) - Letteps inoicate Continuation

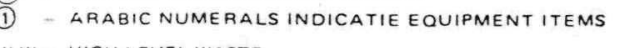

HLW. HIGH LEEL WASTE DECAL

(1)

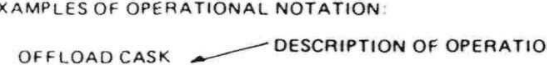

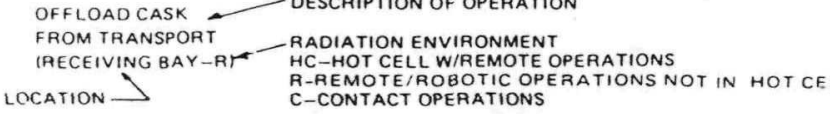

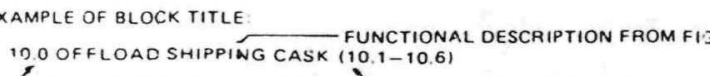

MECHANICAL FLOW DIAGRAM WASTE HANDLING/EMPLACEMENT

(SHEET 2 OF 3)

L LEVEL O FUNCTION NUMBER L L LEVEL I FUnCTION NUMBER

FIGURE 3.1-6 
$\begin{array}{lll}0 & 0 & 0\end{array}$ 

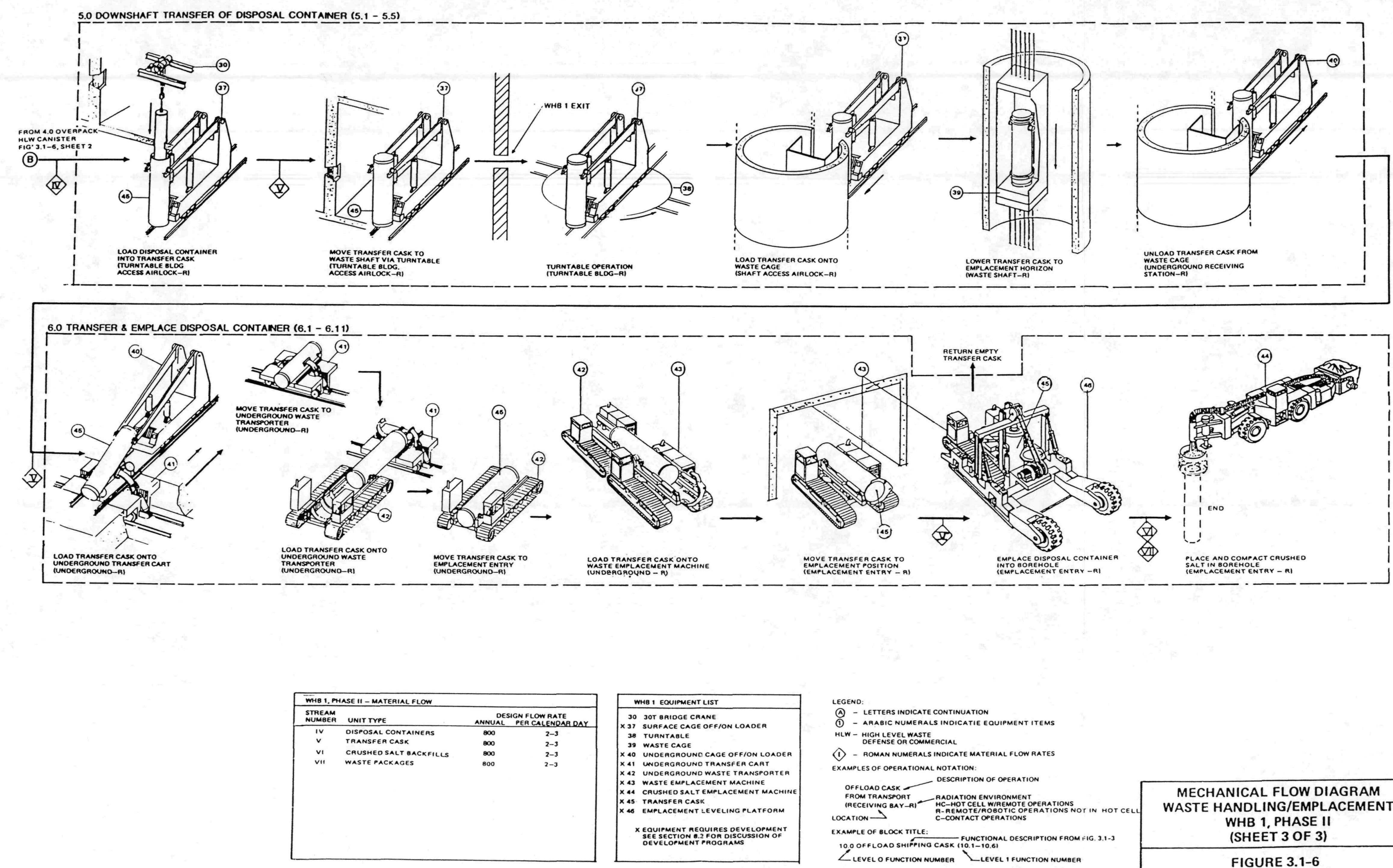

MECHANICAL FLOW DIAGRAM
WASTE HANDLING/EMPLACEMENT
WHB 1, PHASE II
(SHEET 3 OF 3)


- 100 
After cask unloading, the DHLW and WVHLW waste canisters will be transferred directly to the overpacking cell or temporarily stored in the surge storage pit in the cask unloading cell. Transfer baskets will not be used for storage or handling of these canisters. An inspection and decontamination subcell in the cask unloading cell, similar to that in the canistering cell, will be used to verify that DHLW and WVHLW waste canisters leaving the cask unloading cell are free of contamination.

\subsection{WASTE RETRIEVAL}

The requirement of waste retrievability has been considered in the SCP conceptual design. The retrieval philosophy is based on requirements imposed by the NWPA and satisfies the performance objectives specified in the NRC regulations (10CFR60.111(b)). The philosophy, approach and engineering concepts for retrievability and retrieval are compiled into Section 6.3 , waste Retrieval, of this CDR. Included in Section 6.3 are detailed discussions of retrieval operations, relying on a block flow diagram, a mechanical flow diagram, and equipment sketches to describe the system. A list of major equipment items involved with retrieval is provided on the mechanical flow diagrams. 


\subsection{UNDERGROUND DEVELOPMENT}

This section discusses the excavation method for the repository horizon, the mined-salt handling system, and the development sequence. Also described are impacts of Mine Safety and Health Administration (30CFR57) regulations, ground control methods, and equipment needing development. Other components of the underground repository are discussed in Section 3.4, Ventilation; Section 4.3, Shaft Facilities; Section 4.4, Underground Facilities; Section 4.5, Subsurface Repository Operations; and Section 8.4, Underground.

\subsubsection{Excavation Method}

Within the bedded salt formation (ISA 4) in the Palo Duro Basin, openings (referred to as entries) will be excavated to develop repository facilities and emplacement areas. Typical entries will be rectangular and excavated $15 \mathrm{ft}$ high and $24 \mathrm{ft}$ wide in mains, submains and emplacement exhaust entries; $24 \mathrm{ft}$ high and $20 \mathrm{ft}$ wide in emplacement entries; and $15 \mathrm{ft}$ high and $20 \mathrm{ft}$ wide in crosscuts of mains and submains (as shown in Figure 3.3-1).

The salt is amenable to the use of a mechanical milling process for excavation. A variety of mobile milling-type continuous mining machines are available for excavating salt. The underground facility will be excavated using a boom-type continuous miner commonly referred to as a roadheader.

The class of roadheaders envisioned for the repository development can excavate headings in the range of $8 \mathrm{ft}$ to $18 \mathrm{ft}$ high and $14 \mathrm{ft}$ to $24 \mathrm{ft}$ wide in a single pass. Mining of emplacement entries will require a "two-pass" mining operation due to the height requirements of vertical emplacement. (While it is conceivable that a specially designed and built roadheader could excavate the required entry configuration in a single pass, it was decided that currently available machinery would be used.) The roadheader is capable of mining $90^{\circ}$ intersections. It has a rotating cutting head which is laced with tungstencarbide tipped bits and mounted on a boom. The boom moves from side to side and up and down to excavate the required entry configuration. 


Figure 3.3-2 shows the emplacement entry excavation sequence, and Figure $3.3-3$ includes a portrayal of a continuous miner.

Salt is mined by forcing the rotating head against the entry face, milling the salt from the solid formation. The loose salt falls to the floor where it is collected and pushed by a gathering device onto a conveyor. The chain conveyor, an integral part of the roadheader, carries the salt away from the face and discharges it into the haulage system. Depending on the layout configuration, the projected rate of advance in an entry is $13 \mathrm{ft}$ to $18 \mathrm{ft}$ per 8-hr shift. Average unit shift production rate for advancing mains and submains is estimated at 420 tons/shift. The estimated average tonnage rate for driving emplacement entries is 330 tons/shift.

It should be noted that the cutting and conveying systems on the miner operate independently. Therefore, it is possible to cut without conveying until accumulated material inhibits mining. This feature aids production in that it allows the continuous miner to cut when no haulage vehicle is present to load.

The roadheader for these development operations will be electrically powered utilizing a trailing cable for power supply. This machine must be certified and maintained as permissible according to MSHA regulations discussed in Section 3.3.4, Impacts of MSHA Regulations. It will be crawler-mounted for mobility.

Operations in the dead-end entry will be ventilated with an exhaust auxiliary system to provide fresh air to the working area, and to dilute and carry away gases and dust. This system will consist of a fan and an arrangement of rigid tubing that will be extended in increments as the excavation advances. The fan will draw air into the entry to the face area and out through the tubing. 


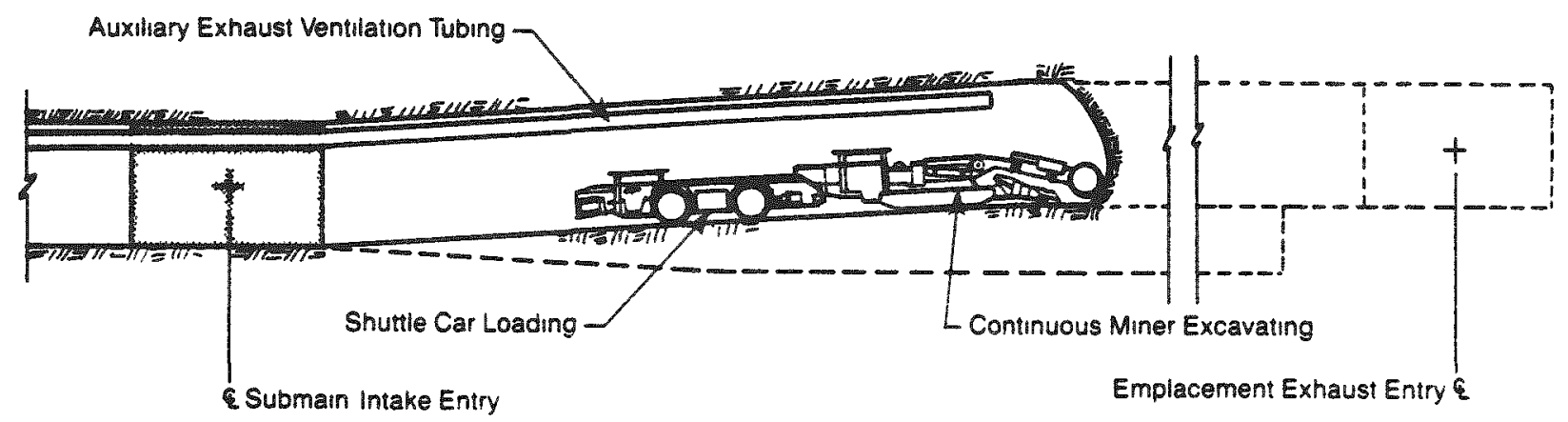

FIRST EXCAVATION PASS

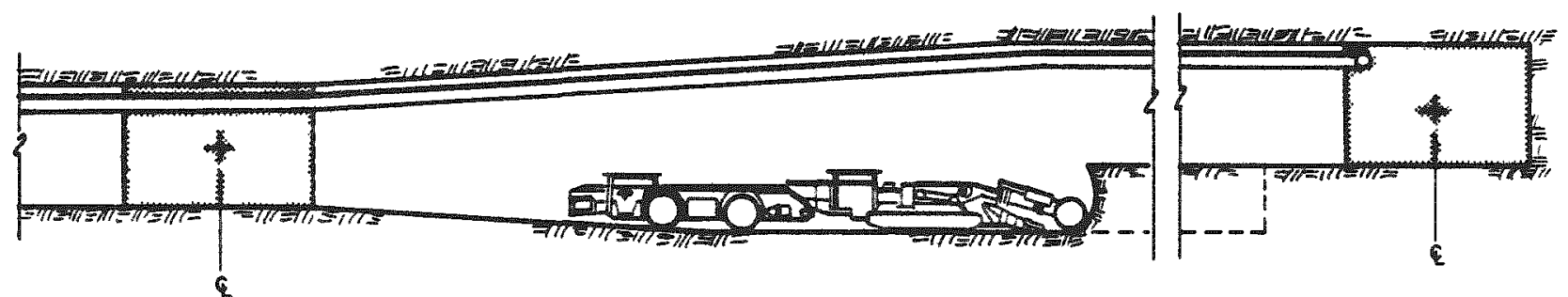

SECOND EXCAVATION PASS

\section{EMPLACEMENT ENTRY EXCAVATION SEOUENCE}

FIGURE $3.3-2$ 

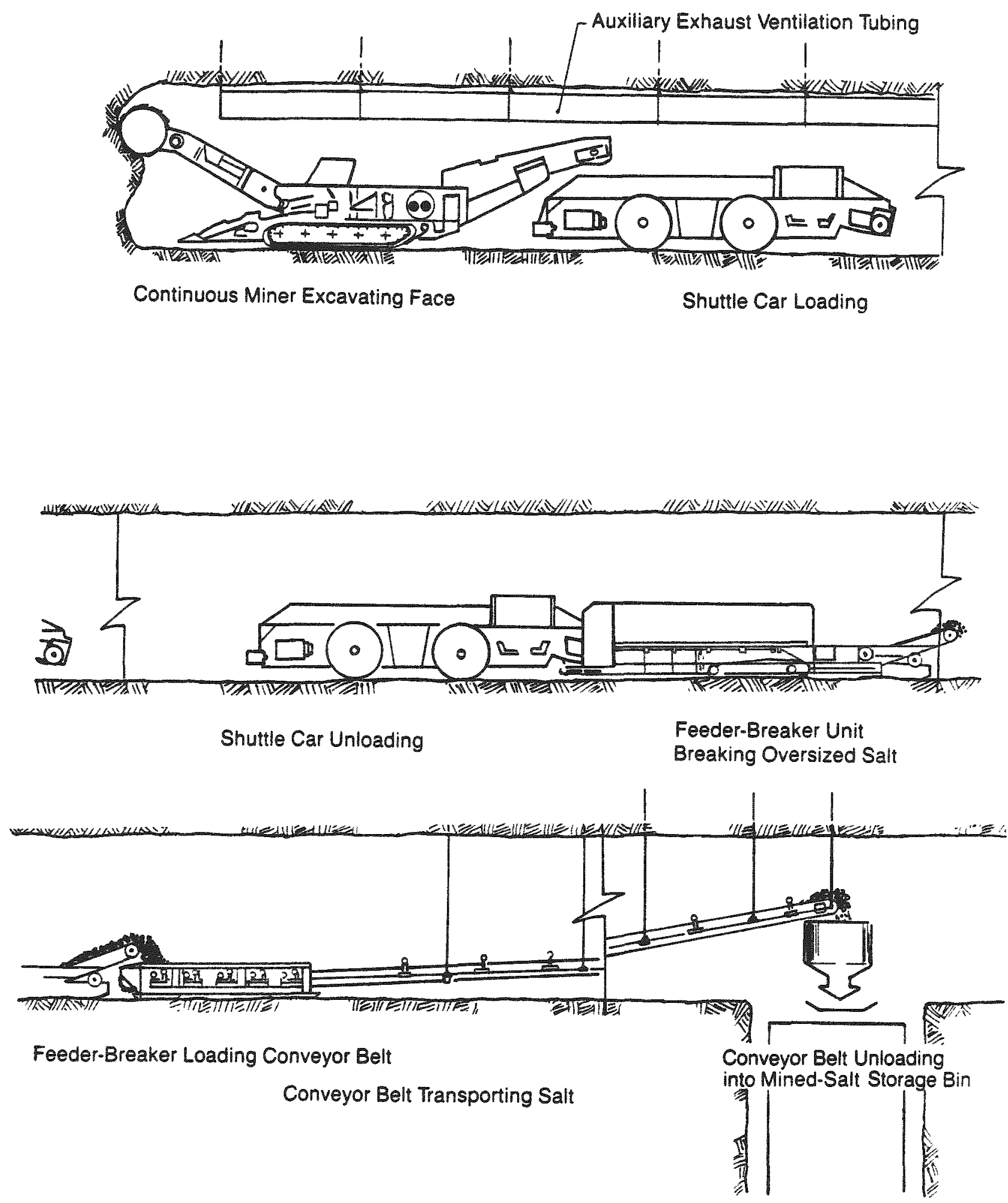

NOTE: See Figure $4.4-11$ for Entire Mined Salt Process Flow Diagram.

\section{UNDERGROUND DEVELOPMENT EXCAVATION CONCEPTUAL FLOW DIAGRAM}

FIGURE 3.3-3 


\subsubsection{Mined-Salt Handling System}

The process of transporting mined-salt will begin with the discharge of salt from the miner into a shuttle car which has rubber tires and an electric trailing cable for power. Like the continuous miner, the shuttle car must be permissible according to MSHA regulations discussed in Section 3.3.4. When loaded, the shuttle car will travel to a feeder-breaker located between $60 \mathrm{ft}$ and 1,400 ft away. It will then discharge its 21 -ton payload into the feederbreaker within approximately 30 seconds and return to the miner for another load.

The shuttle car will be equipped with a cable reel and electric cable of a maximum length of $750 \mathrm{ft}$ (see Section 3.3.4). The cable will be anchored approximately $700 \mathrm{ft}$ from the feeder-breaker or at the feeder-breaker if the haulage distance is less than $700 \mathrm{ft}$. The cable reel will automatically pick up cable as the shuttle car approaches its anchor point and let it out as the shuttle car moves away from the anchor. This arrangement will allow the shuttle car to handle haulage distances up to approximately twice its cable length. It is recognized that other face haulage methods may be applicable; they will be evaluated in subsequent design efforts.

As shown in Figure $3.3-3$, the feeder-breaker will be located next to a conveyor belt system. It will reduce large pieces of mined-salt to lumps small enough to be handled by the conveyor system, and load the material onto the conveyor at a uniform rate. The feeder-breaker will have sufficient capacity to receive material at the maximum rate at which the shuttle car can unload. It will discharge the material onto the conveyor at a slower rate thus allowing conveyor systems of lesser capacity than would be required if shuttle cars were to discharge directly onto the belt.

A system of conveyor belts will then transport mined salt from excavation areas to a storage bin located in the shaft pillar area, a distance of approximately 3-1/2 miles at the furthest point. The shaft pillar area will contain a mined salt handling system which is described in Section 4.4 .2 .6 , Mined Salt Handing Facilities. 


\subsubsection{Development Sequence}

\subsubsection{Repository Development Sequence}

Initial pre-emplacement development will be expedited by utilizing exploratory shafts (ESs) $F$ and $G$ for access to the underground repository horizon. If shaft $C$ (an alternative shaft scenario) is required for repository ventilation, it will be constructed concurrently with shafts $A, B, D$, and E. Figure 3.3-1 shows the locations of all shafts. Further information on the role of the exploratory shaft facility (ESF) during this development phase is provided in Section 7.3.3, The Effect of the ESE.

The area to be excavated during pre-emplacement development is shown in Figure 3.3-1. This development will be initiated upon receipt of construction authorization (CA), and will require a total of approximately five years from CA to first waste emplacement. The shaft pillar area, the first emplacement panel, and a portion of the system of main intake and exhaust entries will be excavated during pre-emplacement development. Approximately 3.25 million tons will be excavated during this development activity.

Phase I waste emplacement operations will begin upon completion of:

1. Repository Shafts A, B, D, and E.

2. Conversion of Shafts $F$ and $G$ to emplacement intake shafts or completion of alternate shaft $C$.

3. Ventilation systems.

4. Phase I surface facilities.

Once initiated, it is expected that waste emplacement operations will continue uninterrupted through Phase I and Phase II. Panels will be developed as indicated by the numbered sequence shown on Figure 3.3-1. Each panel will be completely excavated while on the development ventilation system. When completed, each panel will be added to the emplacement ventilation system by 
rearrangement of the substantial stoppings which separate the two systems (see Section 3.4.1.5). Panels will be excavated at approximately the same rate as they are utilized by emplacement operations. Normally, a panel will be completed only three to four months before it is needed for emplacement.

\subsubsection{Panel Development Sequence}

The panel development sequence will begin with the initiation of excavation of the three submain entries. One mining unit, consisting of a continuous miner, shuttle car(s), and auxiliary ventilation and electrical distribution systems, will advance the three submain entries and connect them with crosscuts. In addition to the submains and crosscuts, this unit will mine the first $40 \mathrm{ft}$ of the emplacement entries. This will facilitate the start-up of excavation of emplacement entries, minimize the time during which mining operations obstruct the submain entries, and prevent large amounts of dust from entering the submain intake air system.

After the submain entries have been advanced $300 \mathrm{ft}$ to $400 \mathrm{ft}$, two more continuous mining units will begin mining emplacement entries. The emplacement entries on the downdip side of the panel will be mined as the submain entries are advanced. Once the submain entries and all downdip emplacement entries are completed, the updip entries will be excavated in a retreat fashion. Downdip entries are mined first to provide a temporary holding area in the unlikely event of water inflows. Due to the gradient of the formation, a single downdip emplacement entry will hold over 1,000,000 gallons of water before overflowing into submain entries. Figure 3.3-1 shows the general panel development sequence for a panel on each side of the repository.

The emplacement exhaust entries (as shown on Figure 3.3-1) on the east side of the repository will be mined in segments when the panel adjacent to them is mined. Those on the west side will be mined in a continuous operation by a single mining unit after the central main entries are compluced but before Panel 5 is placed on the emplacement ventilation system. 


\subsubsection{Impacts of MSHA Regulations}

For this conceptual design activity, gassy mine conditions were assumed. The requirements of 30CFR57, including Subpart $T$, Gassy Mines, were followed with a modification from the requirement for a 100-ft entry centerline distance assumed. This modification allows a much lower extraction ratio which will enhance opening stability. Modern auxiliary ventilation equipment will allow mining in long dead-end headings with no compromise to the miners' health and safety. Current regulations require entries to be driven no more than $100 \mathrm{ft}$ apart and that they be connected by cross-cuts at least every $100 \mathrm{ft}$. Further, it was the $\mathrm{A} / \mathrm{E}$ Contractor's intent that the design also comply with MSHA proposed regulations 30CFR57.36000, Category III Mines. These regulations have the most impact in the areas of ventilation and mining equipment selection. Regulatory impacts on the ventilation systems are discussed in Section 3.4, Ventilation, while impacts on mining equipment selection are discussed below.

The primary impact of these regulations on the selection of mining equipment is the requirement that all diesel or electric machinery operated in dead-end entries must be permissible. Permissibility here means that the machine meets all the requirements of 30 CFR 18 for electric-powered machinery or 30CFR31 for diesel-powered machinery, that the machine is certified as permissible by MSHA, and that the user maintains the machine in permissible condition. In general terms, this means that the machine is incapable of initiating an explosion in an explosive atmosphere and requires that the continuous miners, shuttle cars, and auxiliary fans be permissible, as well as any other equipment which would enter a dead-end entry. Permissible machinery requires a higher capital investment than comparable nonpermissible equipment. In addition, regular permissibility checks are required in addition to normal maintenance.

Gassy mining rules place strict limitations on the use of open flames underground. For example, frequent monitoring for methane is required to confirm that an area is safe for use of an open flame during cutting and welding operations. Smoking is also prohibited. 
Due to the length of the emplacement entries, the design of the electrical power system will require that the length of portable trailing cable on both the miner and shuttle car does not exceed the maximum length allowed by MSHA. For the miner, the maximum allowable length is $1,000 \mathrm{ft}$, while the shuttle car may carry $750 \mathrm{ft}$ of cable. In both cases, the maximum length is a function of cable size. Permissible circuit breakers will be installed at specific locations within the entry to feed power to the trailing cables of the miner and shuttle car. This method will allow mining of the long entries without exceeding allowable cable lengths.

\subsubsection{Ground Control Methods}

Ground support methods will be applied as appropriate in the mains, submains, and panel entries. While the conditions currently expected under ground would not normally require rock bolting, occasional rock bolting or other supports may be necessary at shaft stations, large excavations (such as shops and the warehouse), or locations where discontinuities or mudstone beds may be found within $3 \mathrm{ft}$ or $4 \mathrm{ft}$ above the roof of an entry. Since backfill in emplacement entries will enhance entry stability, it may be considered a ground support system. During retrieval, localized instability of host rock may be mitigated by using temporary roof support. Further discussions of ground support methods are provided in Section 7.1.3.7; Entries, Pillars, and Ground Support Methods.

\subsubsection{Equipment Needing Development}

Generally accepted mining practices were followed in selecting equipment, estimating advance rates, and establishing excavation and haulage plans. All major equipment planned for the development operations described above is currently available. 


\subsection{VENTILATION}

This section describes heating, ventilating, and air conditioning (HVAC) systems envisioned for the underground portion of the repository. The conservative approach to design included the assumption of gassy mine conditions. These systems will include facilities on the surface which are connected to the underground through shafts serving as air ducts to and from the repository horizon. This HVAC system will consist of two separate subsystems serving areas designated as development and emplacement.

\subsubsection{General Underground Descriptions}

The HVAC systems will provide the means to control the underground environment. Basic functions of repository HVAC systems are listed below:

1. Provide air of acceptable quality for underground workers (30CFR57).

2. Prevent the build up of flammable, explosive, noxious, and asphyxiating gases in the underground.

3. Prevent exposure of workers to unhealthful concentrations of dust and particulates from diesel exhaust emissions.

4. Control heat and humidity within acceptable levels.

5. Maintain a pressure differential such that any air leakage will flow from the development areas to the emplacement areas.

6. Control airborne radionuclide contamination if such should occur.

\subsubsection{Separate Ventilation Systems}

Underground ventilation will be accomplished using two independent systems, one for development operations and the other for emplacement operations. Each system will include a dedicated fan facility, intake and exhaust shafts, and heating/cooling facilities. The systems will be separated 
in the underground by substantial stoppings and air locks. Some of these stoppings and air locks must be removed and new ones installed whenever a panel is added to the emplacement system. See Section 3.4.1.5 for a description of the changeover of panels from one system to the other. See Figure 6.1-11 for a logic diagram of the subsurface ventilation systems.

The development ventilation system will operate on a pressure mode. Fans located at the top of service/intake shaft $E$ will force air down that shaft, through the development area, and up mined-salt/exhaust shaft D. This will cause the air in the development system to remain above atmospheric pressure. The emplacement system fans, located atop the dedicated emplacement exhaust Shaft A, will pull air through the underground using negative pressure. This will cause the air in the emplacement system to remain below atmospheric pressure. Emplacement air will enter the underground through emplacement intake Shafts $F$ and $G$ or alternate Shaft $C$.

The pressure differential between the two ventilation systems will ensure that any underground air leakage will always be from the development (no contamination risk) to the emplacement system (1ow contamination risk). See Figure 3.4-1 for the pressure at various points in the two systems. The values plotted in Figure 3.4-1 represent the maximum design conditions for each system; however, it should be noted that these conditions will not occur simultaneously in the two systems. The maximum design condition is the period during the repository's operating life which requires the greatest total airflow within a system. Figure $3.4-1$ is intended only to show the general pressure relationship of the two systems.

Normal operations will require two of the three main fans in each system to be in operation. Figure 4.2-2 shows the locations of these surface ventilation facilities. Development system fans will be housed in building B7, while emplacement system fans will be located in building B6. The operation of any one of the six fans will maintain a pressure differential. The spare fan in each system and the standby on-site power will provide additional assurance of maintaining a pressure differential between the two systems. 



\subsubsection{Ventilation Control Devices}

Figure 3.4-2 shows five types of devices which will be used to direct and control the flow of air in the underground. The figure is intended only to show the basic function of the devices and not their actual construction. Further design work will be needed to develop construction techniques and designs capable of accommodating the forces of creep closure in an entry. Each ventilation device is listed below with a short functional description.

Regulator. Provides control over the quantity of air passing through an entry by adjustment of a sliding door.

Stopping. Blocks the passage of air with minimal leakage.

Substantial Stopping. Same basic function as a stopping but a more massive structure. Will be used to separate the two underground ventilation systems.

Check Curtain. Performs the same general function as a stopping but is temporary and allows more leakage.

Overcast. Allows one stream of air to cross another without mixing.

\subsubsection{Fan Facilities}

The fans envisioned for this design are single-stage axial-flow mine fans. Two fans in parallel will be employed on each of the two ventilation systems. Each system will also contain a third fan on standby, increasing the overall system reliability. In order to allow the systems to operate at their highest possible efficiency over a wide range of quantity and pressure conditions, the fans will have variable speed control and adjustable pitch blades which can be repositioned during operation. All ventilation equipment is currently available, and no new equipment development is required. 


The underground ventilation systems will comply with MSHA gassy mine regulations. In part, these regulations require that the main fans be located on the surface and offset at least $15 \mathrm{ft}$ from the mine opening, that all ductwork and fan housings be flame proof, and that explosion doors be installed in line with potential explosive forces coming from the underground (30CFR57).

Under current gassy mining regulations (30CFR57), fan systems must have the ability to permit prompt reversal of airflow. In this design, the ability to reverse flow is incorporated in the development system but not in the emplacement system. This would tend to minimize worker exposure following the unlikely occurrence of a contamination event in the underground. In order to allow this reversal and still maintain the correct pressure differential (see Section 3.4.1.1), an additional set of two fans will be located near the top of mined-salt/exhaust shaft D. If reversal is required, the main fans on service/intake Shaft $E$ will be shut down and the Shaft $D$ fans turned on so that the air in the underground development area will remain above atmospheric pressure.

The emplacement exhausting fan facility, located at emplacement exhaust Shaft $A$, will be designed for diversion of flow into a high-efficiency particulate air (HEPA) filtration system in the event of contamination in the underground air stream. Subsurface radiation monitoring systems to be employed in the repository have not been defined. However, it is assumed that complete monitoring stations for air velocity, temperature, carbon monoxide, methane, and particulates in addition to radiation will be installed at regular intervals in all main air courses as well as other strategic points in the shafts and subsurface. While the filtration system has not been defined, it is expected that changeover to HEPA filtration could be accomplished in less than five minutes with the use of dampers to divert flow automatically upon detection of contamination. It is assumed that discovery of contamination in the underground would cause normal operations to cease temporarily. Therefore, it is expected that airflow in the emplacement system would be reduced during such an event.

No filtration for removal of salt dust is planned on the development exhaust or for either intake. Current Environmental Protection Agency (EPA) 
and Texas Air Control Board (TACB) regulations do not require filtration for dust emissions of the magnitude expected to come from the underground ventilation exhaust. No new development of filtration technology is required.

\subsubsection{Intake Heating and Cooling Systems}

Intake air will be heated to $35^{\circ} \mathrm{F}$ whenever the outside air temperature falls below that level to prevent shaft icing and temper intake air for comfort during periods of extreme cold. Heating will be provided at each intake location (Shafts F, G, and E) and for the air entering waste Shaft $B$. The $1 \%$ design winter temperature for the site is $6^{\circ} \mathrm{F}$ (ASHRAE, 1981). The estimated energy consumption for the development system is approximately $8,100 \mathrm{~kW}$ at the maximum design quantity and $1 \%$ design intake temperature. Maximum power consumption for the emplacement system is estimated at $9,500 \mathrm{~kW}$. The configuration of the heating system will be developed in subsequent design efforts.

Bulk cooling will also be provided at each intake location to maintain the air entering the underground at $80^{\circ} \mathrm{F}$ effective temperature. Effective temperature is an empirical heat-stress index which combines dry bulb and wet bulb temperatures and air velocity. An effective temperature of $80^{\circ} \mathrm{F}$ is the maximum value which will theoretically allow $100 \%$ efficiency of workers. The $1 \%$ design summer ambient conditions were assumed to be $98^{\circ} \mathrm{F}$ dry-bulb and $71^{\circ} \mathrm{F}$ wet-bulb (see Section 2.3.1.1). Air traveling down the intake shafts will undergo a $15^{\circ} \mathrm{F}$ dry-bulb compression-induced temperature rise (Hartman, 1982). When needed, cooling will be provided by chilled water circulated in cooling coils in the intake air stream; however, air will be allowed to bypass the cooling coils whenever cooling is not needed. The development system will require approximately $6,800 \mathrm{~kW}$ in cooling power while the emplacement system will use approximately $5,500 \mathrm{~kW}$ during the $1 \%$ design summer conditions and the maximum design airflow quantity.

The ambient rock temperature at the Deaf Smith repository horizon is assumed to be $81^{\circ} \mathrm{F}$ (DOE, 1986a, EA, p. 3-104). Generally, the dry bulb air temperature will be within a few degrees of this value year round in the working areas of the subsurface. Exceptions to this will be in the intake 
areas of the shaft pillar where dry bulb temperatures will fluctuate from approximately $50^{\circ} \mathrm{F}$ in winter to around $95^{\circ} \mathrm{F}$ in summer. The summer time effective temperature in the shaft bottom areas should not exceed $80^{\circ} \mathrm{F}$ due to the arid surface conditions and assumed lack of significant groundwater inflow which will result in low relative humidity in the intake air stream.

\subsubsection{Panel Ventilation Changeover}

The two ventilation systems will be separated in the underground by substantial stoppings and air locks. Approximately once every three years, it will be necessary to reconfigure the arrangement of the substantial stoppings in order to change a newly developed panel from the development system to the emplacement system. This procedure is described below.

When development operations are completed within a panel, the development system will circulate $50,000 \mathrm{cfm}$ of air to maintain ventilation during construction of the new substantial stoppings. When the changeover is completed, the emplacement system will supply 50,000 cfm to ventilate the panel until it is needed for emplacement operations.

A normal panel will require that eight new substantial stoppings be built. However, the number to be removed will depend on the panel's location. Six of the eight stoppings can be built without affecting the airflow in the panel. once thes six are built, a 1-day to 3-day changeover period will begin.

During the changeover period, ventilation to the new panel will be interrupted while the last two new stoppings are completed and two old stoppings are removed. Air quality in the panel will be monitored continuously, if necessary, during the ventilation interruption to ensure that no unsafe concentrations of methane or other gases will be released into the emplacement system when ventilation is re-established. It is assumed that both development and emplacement operations will cease during the changeover period.

Substantial stoppings which are no longer needed may be mined out using a roadheader since it is expected that they will be constructed of salt blocks and salt backfil1. Some of these substantial stoppings will include air lock 
manways. These manways can be installed off center of the stoppings to provide working room for removal by continuous miner (see Figure 3.4-2). The steel manway and doors can be removed after the miner has cut through the salt block walls and backfill. Salt left from the stopping removal will be hauled into the active emplacement panel and placed at the ends of emplacement entries which are awaiting backfill.

\subsubsection{Applicable Mining Regulations}

The ventilation systems were designed to conform with 30CFR57, Safety and Health Standards Underground Metal and Nonmetal Mines, including Subpart T, Gassy Mines. The only assumed ventilation modification to these regulations was that reversibility of the main air stream was not incorporated in the emplacement ventilation system. It was considered inappropriate to provide and maintain HEPA filtration systems at four shaft locations instead of one. (Reversal of the emplacement system flow would cause air to come out of Shaft $B, F$ and G.) In lieu of reversibility, fire doors will be installed near the bottoms of Shafts $F$ and $G(30$ CFR57.4760).

The use of 30CFR57 as a design criterium is mandated in 10CFR60, and the Interim Repository Subsystem Design Requirements (Appendix A).

\subsubsection{Underground Development Ventilation System}

\subsubsection{Flowpath Description}

The development system will be ventilated on a pressure mode. The fan facility will be located on the surface near the service/intake shaft. (Figures $3.4-3$ and $3.4-4$ show airflow paths during two periods in the repository life.) Fans will draw outside air into the fan facility. Whenever necessary, the air will pass across cooling or heating coils to maintain subsurface temperatures within a range of approximately $50^{\circ} \mathrm{F}$ to $95^{\circ} \mathrm{F}$. When neither heating nor cooling is required, air will be allowed to bypass the coils and directly enter the ductwork leading to the fans. When air enters the fans, the air pressure will rise to approximately 10.4 in of water in the 


\begin{tabular}{|c|c|c|c|}
\hline ' & 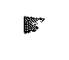 & a: & 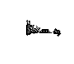 \\
\hline$\therefore$ & w & A: & m. \\
\hline : & $w_{n}$ & $B$ & b. \\
\hline : & 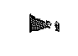 & 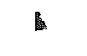 & $1:$ \\
\hline ! & bs & A. & $A$ \\
\hline
\end{tabular}

A. $\quad$ Bis $\quad$ b

ind

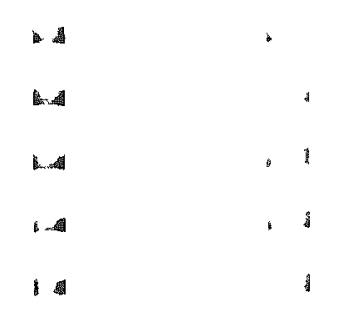
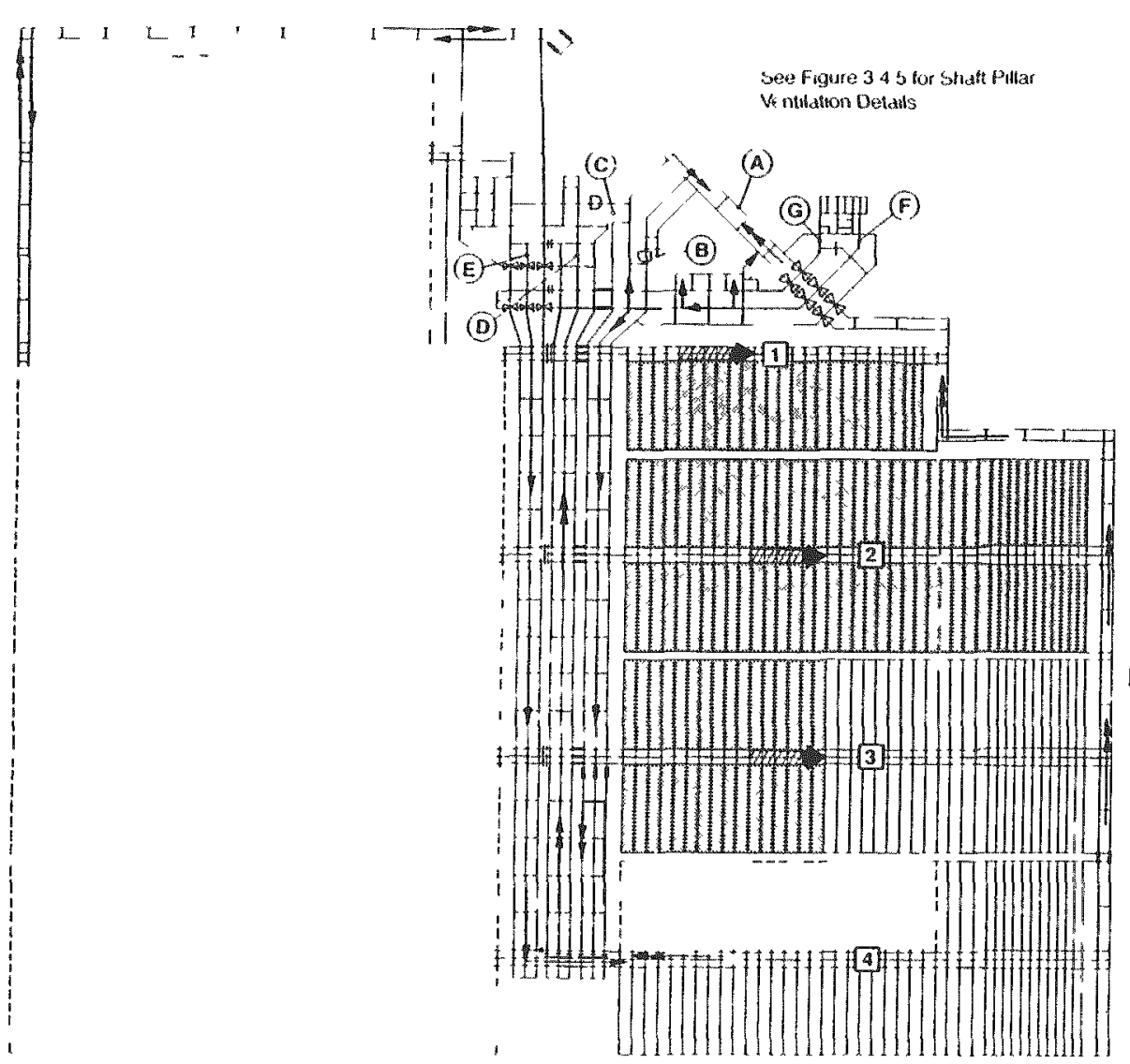

\section{LEGEND}

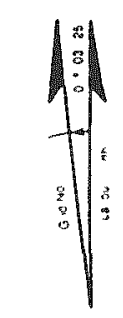

(A) Emplacement f xhaust Shaft

(B) Waste Shaft

(c) Alternate Location for Emplacement Intake Shaft

(D) Mined Salt/Exh uust Shatt

(E) Service/ntake shaft

(F) Emplacement lintake Shaft

(G) Emplacement Intake Shaft

1] Panel Development Sequence, Numbers indicate

Xvercast

Substantiat Sto ypung

Stopping

Substantial Equipment Doors/Arr Lock

Intake Arfflow

Exhaust Aurflow

Future Excavaat in Boundary

Backfill Area

NOTE Thin line depict centerlines of entres

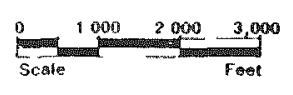

UNDER HGROUND AIRFLOW PATHS - YEAR 9

F'GUat 343 

maximum design condition. After passing through the fans, the air will travel through more ductwork until it reaches the inlet to the shaft. It will enter the shaft and travel downward to the repository horizon. As it passes down the shaft, the volume of air will be reduced by approximately $10 \%$ resulting in a temperature rise of approximately $15^{\circ} \mathrm{F}$ due to adiabatic compression. Maximum air velocity in the shaft during the time of maximum design condition will be approximately $2,125 \mathrm{ft} /$ min near the top of Shafts $E$ and $D$.

Lpon reaching the repository horizon, the air will split in two directions. Approximately $225,000 \mathrm{cfm}$ will ventilate various shaft pillar areas, including the shops, warehouse, re-fueling area, and mined-salt handling areas (see Figure 3.4-5). This air will be directed to the development exhaust entries and not used to ventilate any other portion of the underground. The remainder will enter the development main intakes and flow toward the active development operations.

The development main intakes will be the western most three entries of the nine entry main system which will run down the central north-south axis of the repository (see Figures $3.4-3$ and $3.4-4$ ). When the air reaches a panel under development, part of the flow will go into the panel. The rest will continue along the mains.

Figure 3.4-6 shows the flowpaths envisioned within a panel under development. Note that the air intended for ventilation of the mining units is first directed through the already completed entries of the panel in sets of four, five, or six entries to maintain a minimal airflow in all open areas. The air works its way back and forth up one side of the panel and down the other side toward the active mining operations. Upon reaching the entries being excavated, the auxiliary ventilation systems will draw a portion of the air into the entries, to the face area, and back through rigid tubing to the panel exhaust entry. The air not entering the mine entries will pass over the auxiliary fans, minimizing potential recirculation. Once past the mining operations, the air will travel out of the panel through the panel exhaust entry and into the development main exhaust entries, the center set of three entries in the mains. When it reaches these entries, it will travel back to the shaft pillar and enter the bottom of Shaft $D$, the mined salt exhaust 





shaft. From there, it will rise to the surface, expanding and cooling in the reverse of the process occurring in the intake shaft, and exit through the ventilation bypass (see Eigure 4.3-7) into the atmosphere.

Figure 3.4-7 shows the ventilation flowpaths during concurrent main and panel development. Note that only six mining units are shown. The maximum design case of eight mining units will require two units mining in a second panel. This general flow pattern will be used until the mains are completed approximately three years after emplacement begins. (Figure 3.4-8 shows a more detailed view of the mining areas in a panel.) After completion of the mains, the number of mining units, and therefore the air quantity requirements, will be reduced. Mining effort will then center on panel development, as well excavation of the western emplacement exhaust entries.

\subsubsection{Air Quantity Determination}

The intake air quantity allotted at the main fan for each unit excavating $15 \mathrm{ft} \times 24 \mathrm{ft}$ entries is $48,000 \mathrm{cfm}$. Of this amount, $25 \%$ or $12,000 \mathrm{cfm}$, is assumed to leak into the exhaust entries before reaching the mining areas. The remaining $36,000 \mathrm{~cm}$ will reach the last open crosscut near the mining operations. The auxiliary ventilation system will draw $24,000 \mathrm{cfm}$ into the dead-end entry being mined. Again, $25 \%$ of this quantity is assumed to leak into the tubing, primarily at joints. A minimum of $18,000 \mathrm{cfm}$ is expected to reach the face to maintain required air quality. (Fan intake quantity for units in $20 \mathrm{ft} \times 24 \mathrm{ft}$ emplacement entries is $64,000 \mathrm{cfm}$, with a minimum of $24,000 \mathrm{cfm}$ reaching the face.) Table 3.4-1 shows the air quantity during the maximum design operating condition.

\subsubsection{Quantity/Pressure/Power Projection}

The maximum design conditions will occur early in the development period for approximately three to four years. The maximum fan quantity is expected to be approximately $808,000 \mathrm{cfm}$. This quantity will require approximately $10.4 \mathrm{in}$. of water pressure and 2,035 brake horsepower at $65 \%$ system efficiency. 





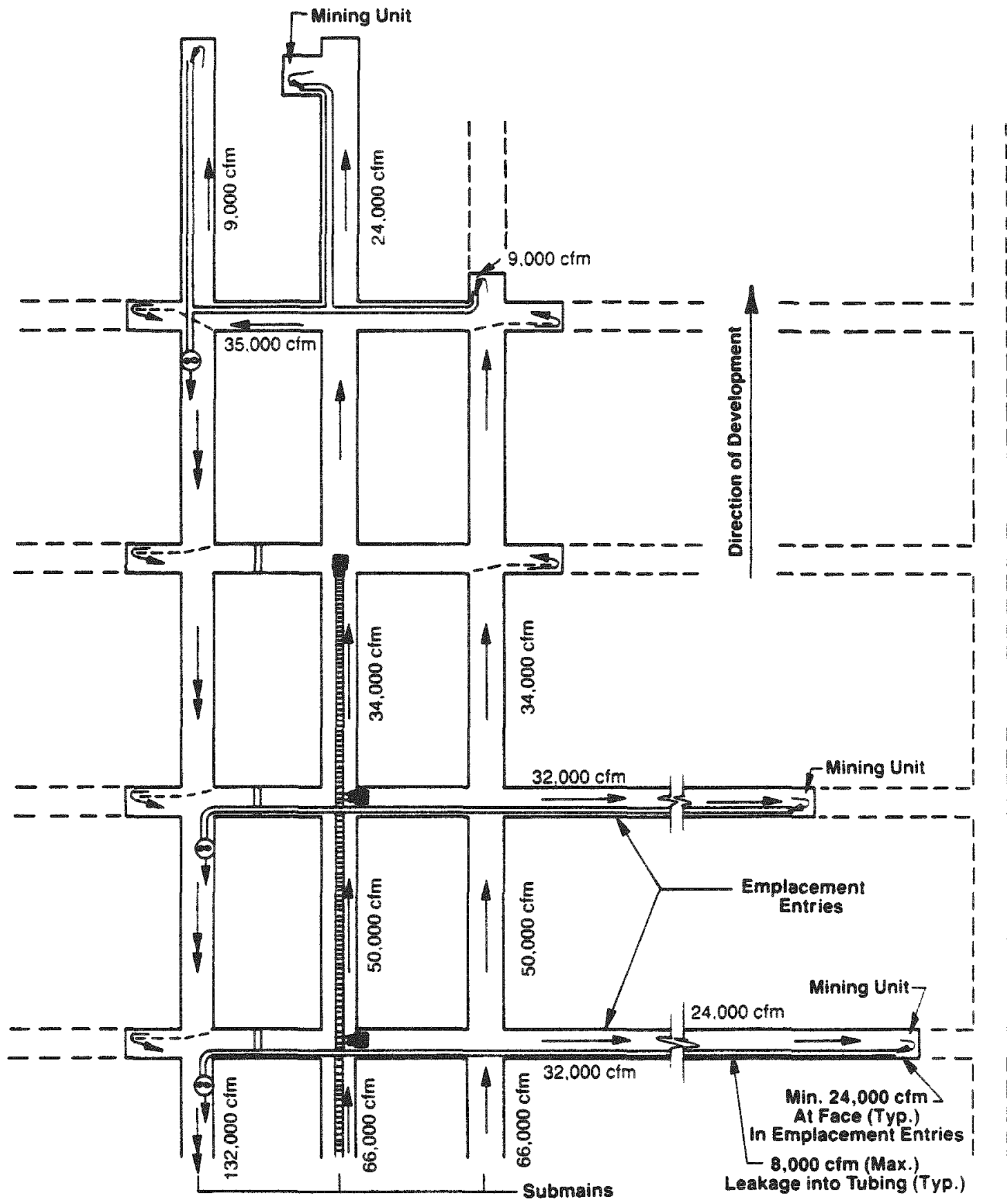

LEGEND:

Panel Conveyor
Auxiliary Vent Tubing
Auxiliary Fan
Feeder Breaker
Line Curiain
Stopping
Intake Airlow
Exhaust Airtiow

VENTILATION DETAIL OF PANEL MINING OPERATIONS 
Table 3.4-1. Underground Development Ventilation Air Quantity Assignments

\begin{tabular}{lc}
\hline \multicolumn{1}{c}{ Function } & Air Quantity, Acfm \\
\hline & \\
Mining Units $(3 \mathrm{at} 48,000 \mathrm{cfm})$ & 144,000 \\
$\quad(15 \mathrm{ft} \times 24 \mathrm{ft}$ entries $)$ & 320,000 \\
Mining Units $(5 \mathrm{at} 64,000 \mathrm{cfm})$ & \\
$\quad(20 \mathrm{ft} \times 24 \mathrm{ft}$ entries $)$ & $50,000(\mathrm{~b})$ \\
Idle Panel Ventilation & 150,000 \\
Shops \& Warehouse & 50,000 \\
Salt Handing Area & 25,000 \\
Refueling Area & $739,000(\mathrm{a})$ \\
Total & \\
\hline
\end{tabular}

(a) Underground quantity. Fan quantity on surface will be higher due to auto-compression effects.

(b) $50,000 \mathrm{cfm}$ will be split into parallel flow in five entries and used to keep an idle panel clear of gases and other airborne contaminants.

\subsubsection{Emplacement Ventilation System}

\subsubsection{Flowpath Description}

The emplacement system will be ventilated on an exhaust mode. The fan and HEPA filtration system will be located on the surface near the top of the emplacement exhaust Shaft A (Item B8 on Figure 4.2-2). When surface air temperatures require heating or cooling, air will enter a heating/cooling building located between Shafts $F$ and $G$. A small amount will also enter through waste Shaft $B$. The system for Shaft B is discussed further in Section 3.4.3.4. The air will split and travel through ductwork to Shafts $F$ and $G$. If no heating or cooling is needed, it will bypass the heating/cooling coils. The air which travels down the two former exploratory shafts (ESs) will experience the same compression and temperature rise described for the development system. If the ESs are not used for this repository ventilation 
function, alternate shaft $C$ will be required for intake (see Figure 3.4-5). Note that Shaft $C$ will not be constructed if the ESs are used for this ventilation function.

At the shaft bottom the air will split with 53,000 cfm going to the ESF and 27,000 cfm to the performance confirmation area within the shaft pillar. The remainder will move toward the emplacement main intakes by crossing under the six overcasts (see Figure 3.4-5). Small air splits will ventilate the shop, office, warehouse, and refueling areas before the main intake volume reaches the north-south oriented emplacement main intakes. The majority of the air will flow south toward the emplacement areas while a small amount moves north to ventilate the north end of the backfill belt conveyor area. The air will then go into the emplacement main exhaust near shaft $A$.

It should be noted that there is no dedicated air quantity for a decontamination station. It is assumed that the possibility of contamination occurring in the subsurface will be extremely remote given the rigorous surface decontamination measures and robust container configuration. It is planned that, if decontamination is required, it will be performed using a portable decontamination arrangement in one of the emplacement system shops. If decontamination is being performed in the emplacement shops, the air will be vented directly to the main emplacement exhaust entries.

Most of the air will flow through the emplacement main intakes toward the active emplacement panel. As it flows past backfilled panels (i.e., panels in which emplacement operations are complete), a split of approximately $27,000 \mathrm{cfm}$ will be used to ventilate the three submain entries, which will be left open to accommodate access for possible retrieval efforts. The bulk of the intake air will travel through the main intake to the active emplacement panel.

Figure $3.4-9$ shows a typical emplacement panel with ventilation flowpaths indicated. Estimated air quantity requirements are shown for the three basic emplacement operations: hole drilling, disposal container emplacement, and backfilling. Entries in which emplacement is idle and incomplete will be ventilated by minimal airflows of approximately $12,000 \mathrm{cfm}$ each. Entries in 



\begin{tabular}{|c|c|c|c|c|c|c|c|c|c|c|}
\hline " & $=$ & 10 & $\mathrm{~L}$ & $\therefore$ & 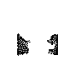 & 12 & : & 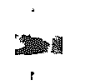 & bux & 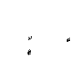 \\
\hline$\because$ & * & E: & L. & $\therefore$ & L. & 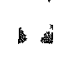 & $w$ & 2 & 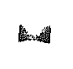 &. \\
\hline$\cdots:$ & w & $B:$ & $r:$ & $D:$ & A & $\omega$ & a & i & wa & . 1 \\
\hline $6 \cdots$ & $m$ & $1:$ & $5:$ & $\because 1$ & 11 & w & H & - A & w & 14 \\
\hline 6 & W & A.. & $A$ & 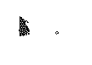 & a & $M$ & us & 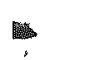 & 14 & $\Rightarrow t$ \\
\hline
\end{tabular}
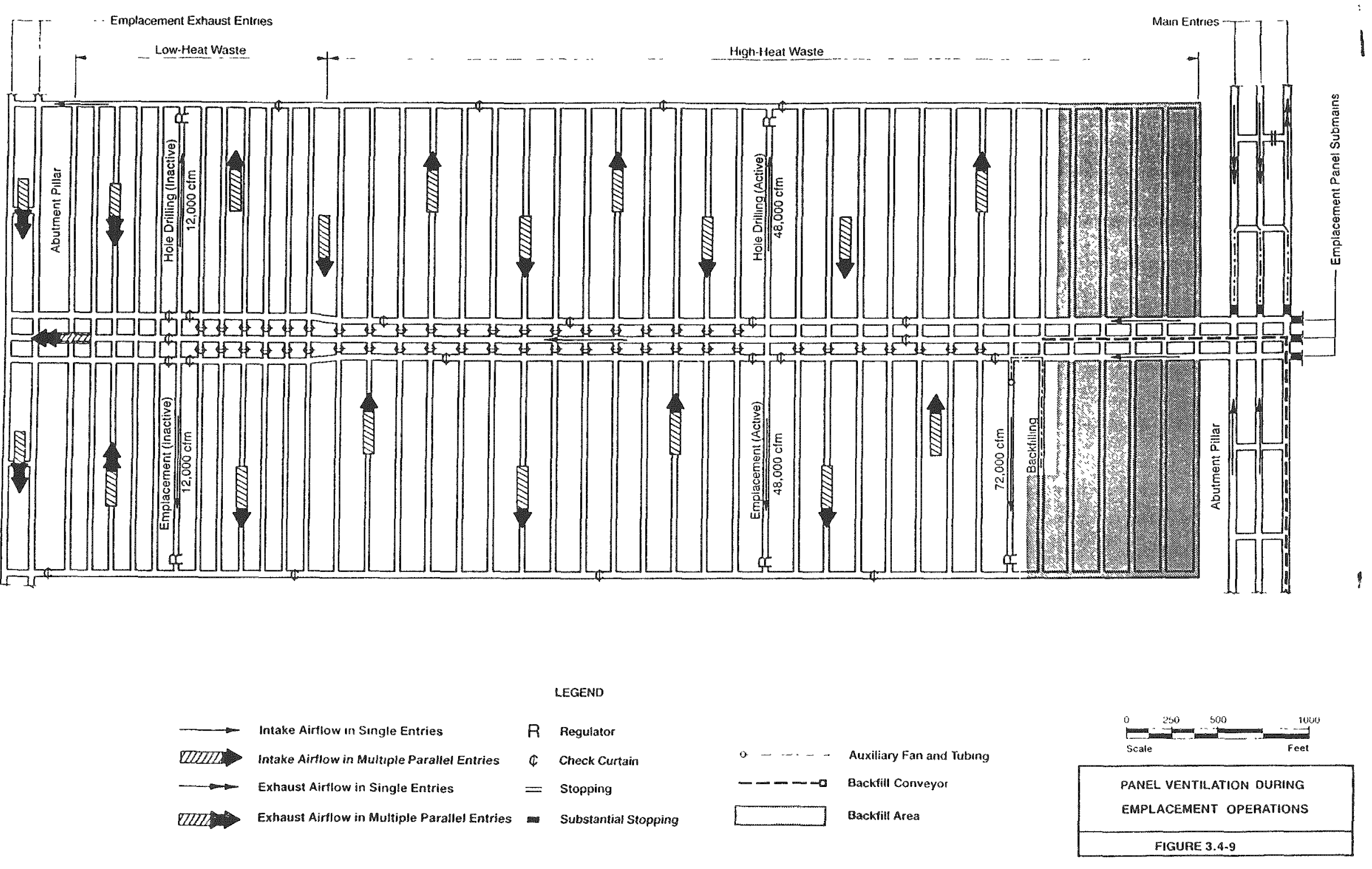

which package emplacement is complete, but which have not yet been backfilled, may be ventilated with exhaust air or fresh air depending on the particular situation. Emplacement entries that are idle and awaiting the start of emplacement will be ventilated by the exhaust air from emplacement operations. The flow will be directed back and forth in sets of four or five entries until the air reaches the emplacement main exhaust entries. Once in the exhaust entries, it will flow back toward the shaft pillar to shaft $A$. It will travel up the shaft and enter ductwork which, under normal conditions, will direct the air straight to the fans and out through an evase to the atmosphere. If contamination is detected in the subsurface, the air can be diverted through HEPA filtration before it reaches the fans and exhaust. The HEPA filter facility will contain an additional set of fans to handle increased pressure caused by HEPA filtration.

A second option available in the unlikely event of subsurface contamination is simply to shut down the emplacement ventilation system. Dampers on intake and exhaust would close, isolating the emplacement side of the subsurface. Emplacement personnel would be trained to proceed to airlocks and enter the development system.

\subsubsection{Air Quantity Assignments}

Table $3.4-2$ shows the air quantity assignments during the maximum design operating condition.

\subsubsection{Quantity/Pressure/Power Projection}

The maximum design conditions will occur near the end of emplacement operations for a period of less than a year. This is a conservative projection since it assumes that such functions as a retrieval demonstration could occur simultaneously with the maximum operating quantity requirement. The maximum estimated quantity requirement is approximately $950,000 \mathrm{cfm}$. This will require a pressure of approximately 14.4 in of water and 3,300 bhp at a system efficiency of $65 \%$. 


\subsubsection{Waste Shaft Ventilation}

The waste shaft, Shaft $B$, and the underground waste transporter off/on loading station will be ventilated by a dedicated split of air in the emplacement ventilation system. Approximately $20,000 \mathrm{cfm}$ will be drawn down Shaft $B$ through the shaft bottom waste handling area and directed into the emplacement exhaust (see Figure 3.4-5). During normal operations, this air will pass through a regulator and into the emplacement main exhaust. If contamination is detected in the waste handling area, flow will be diverted through a HEPA filtration facility prior to release into the emplacement exhaust. The waste shaft ventilation split will be isolated from the emplacement intake air by an air lock system. See Figure 3.4-5 for the location of substantial equipment doors arranged as an air lock and HEPA filtration system. Heating and cooling facilities for this split will be located on the surface near the top of the waste shaft. 
Table 3.4-2. Waste Emplacement Ventilation Air System Quantity Assignments

\begin{tabular}{|c|c|}
\hline Function & Air Quantity, Acfm \\
\hline Hole Drilling & 48,000 \\
\hline Package Emplacement & 48,000 \\
\hline Backfilling & 72,000 \\
\hline Idle Panel & $50,000^{(b)}$ \\
\hline $\begin{array}{l}\text { Submain Access Entries } \\
\quad(6 \text { \& } 27,000 \mathrm{cfm} \mathrm{ea.})\end{array}$ & 162,000 \\
\hline $\begin{array}{l}\text { Performance Confirmation } \\
\quad(3 \text { approx. } 27,000 \mathrm{cfm} \text { ea. })\end{array}$ & $80,000^{(c)}$ \\
\hline ESF Ongoing Operations & 53,000 \\
\hline $\begin{array}{l}\text { Container Removal } \\
\text { (re: Performance Confirmation) }\end{array}$ & $200,000^{(c)}$ \\
\hline Waste Shaft Split & 20,000 \\
\hline $\begin{array}{l}\text { Idle Entries in Active Panel } \\
(5 @ 12,000 \mathrm{cfm} \text { ea. })\end{array}$ & 60,000 \\
\hline Miscellaneous & 75,000 \\
\hline Total & $868,000^{(a)}$ \\
\hline
\end{tabular}

(a) Underground quantity. Fan quantity on surface will be higher due to auto-compression effects.

(b) 50,000 Acfm will be split into parallel flow in four entries and used to keep an idle panel clear of gases and other airborne contaminants.

(c) 80,000 Acfm is provided for ventilation of the three performance confirmation areas. When containers are removed from a performance confirmation area at elevated temperatures, $200,000 \mathrm{Acfm}$ is needed to ventilate the entry, mostly for heat removal. 



\section{SALT REPOSITORY DESIGN DESCRIPTION}

This chapter provides a comprehensive description of the overall salt repository design. The important features of the repository site and the surrounding region are discussed, and the design concepts for the general arrangement of the surface facilities, the shafts, and the underground facilities are described in detail. This chapter also addresses underground repository operations, and it discusses structures, systems, and components that are important to safety, engineered and natural barriers important to waste isolation, and the methodology used to arrive at the preliminary Q-list.

\subsection{THE SITE AND ITS ENVIRONS}

Descriptive information for this section was obtained from Chapter 3 (The Site) of the Environmental Assessment (EA) for the Deaf Smith County Site (DOE, 1986a). The repository site is located in the north-central part of Deaf Smith County, Texas, which in turn is located on the western edge of the Texas Panhandle. The site is in the Southern High Plains of the Panhandle, approximately 40 air miles west of Amarillo.

The surface of the plains is nearly flat with a southeasterly slope of approximately $10 \mathrm{ft}$ per mile. Superimposed on this gentle regional slope are local topographic features such as small, internally drained lake basins (playas) and narrow stream valleys that contain or carry surface water after rainfalls. The north side of the site is bordered by an unnamed tributary to North Palo Duro Creek. Drainage is to the east across most of the site with some local drainage into the playas or northward into the North Palo Duro drainage.

Most of the land in Deaf Smith County is used for agricultural purposes. Most of the terrain is considered cropland. However, there are expanses of rangeland within the site and in its vicinity. The farmland is generally classified as "prime." It has fertile soils, flat to gentle slopes, and sufficient precipitation or irrigation water. Additional information on the site terrain and topography is contained in Section 2.2.1.1, Surface Topographic/Geomorphic Data. 
The climate is semiarid to subhumid, with warm summers, cold winters, and relatively high average winds. The annual average temperature near the site is about $57^{\circ} \mathrm{F}$, with raxe prolonged periods of extreme temperatures. Most precipitation in the area occurs from April to October as the result of thunderstorms and the intrusion of warm, moist tropical air from the Gulf of Mexico. Annual precipitation averages about 19 inches for the area. Snowfall is usually light and dissipates quickly. The annual mean wind speed is 13.7 miles per hour. Severe weather, such as heavy thunderstorms, is a relatively frequent occurrence near the site. An average of eight tornadoes per year has been observed within a $10,000 \mathrm{sq}$ mi study area encompassing Deaf Smith County. More specific discussions of the climate near the site are contained in Section 2.3.1.1., Climatic Weather Conditions Considered in Design.

There are no major bodies of water at the site, nor are there any comnercially navigable waterways in the region. Irrigation water comes from the High Plains aquifer, which consists primarily of the Ogallala Formation and partly of the Dockum Group. There are relatively few surface water resources because of the climate, and the rate of evapotranspiration exceeds precipitation. Palo Duro Creek and the numerous playas are dry most of the year. (The water supply for the repository will probably be obtained from onsite wells.)

The site is located in a rural setting where the population density averages about four persons per square mile. The nearest cities and towns include Hereford in Deaf Smith County, Vega in OIdham County, Canyon in Randall County, and Amarillo in Randall and Potter Counties. The majority of the population in Deaf Smith County and the surrounding counties is concentrated in the cities and towns. Amarillo is the regional population center.

Economically, the major employment sectors of the region that includes Deaf Smith County are government, retail trade, services, manufacturing, transportation, and agriculture. The Amarillo Standard Metropolitan Statistical Area, which includes both Potter and Randall Counties, had a population of 173,699 in 1980 . It is a major industrial and commercial center in the area. Within the region, labor force participation rates were 50 percent for females and 81 percent for males. The major employment sectors 
account for the following percentages of the overall labor force: government (18 percent), retail trade ( 15 percent), services ( 14 percent), manufacturing (10 percent), and agriculture (10 percent). Some of these employment sectors are closely related to, or support, regional agricultural industry. For example, in the manufacturing sector, production of food and food products, agricultural chemicals and fertilizers, and farm equipment composes 40 to 45 percent of the sector.

The nearest interstate, controlled-access highway is Interstate 40 (I-40) which replaced U.S. Route 66 (US 66). I-40 connects Amarillo, Vega, and Adrian. It runs approximately east-west, approximately eight miles north of the site. US 385 runs north-south, connecting Vega and Hereford. It is approximately three miles east of the site. US 60 runs southwest-northeast and connects Hereford with Canyon. At its closest point, US 60 passes approximately 18 miles south-southeast of the southeast corner of the site. Farm-to-Market Road (FM) 2587 runs east-west through the southern part of the site. These are the major roads in the vicinity; however, numerous other local roads serve the area.

The proposed access route to the site would be from Interstate 40 following US 385 to FM 2587, and then to a point due south of the repository plant site. From there a new access road would be constructed northward into the plant area. FM 2587 would require upgrading to serve the expanded traffic requirements.

The major regional rail center is in Amarillo. The closest major rail line is the Atchison, Topeka, and Santa Fe which parallels US 60 through Hereford and Canyon. At its closest approach it is approximately 18 miles southeast of the site. Another railroad right-of-way runs parallel to $I-40$, approximately eight miles north of the site. This is the route of the old Chicago, Rock Island, and Pacific railroad. However, the tracks have been removed west of Bushland, which is approximately $22-1 / 2$ miles east of the site. The existing track east of Bushland is managed by Burlington Northern.

Presently, the primary rail service to the area is via the Atchison, Topeka, and Santa Fe railroad. Until operating plans of other railroads in the 
region are known, this railroad is assumed to be the starting point for rail service to the site. The proposed rail route would utilize an existing rail spur at Hereford which passes under US 60 and terminates approximately two miles west of US 385 . The proposed route would depart from the spur approximately 1.5 miles west of US 385 and after a series of curves would turn northward and progress the final 22 miles to the repository plant site. Approximately 23 miles of new railroad corridor would be needed for site access.

Alternate railroad routes to the site are possible. These routes are shown in Figure 4.1-1 as potential railroad transportation corridors. Holding particular promise is the route from the north which utilizes the old Chicago, Rock Island, and Pacific roadbed. If utilized, this route would require restoring the old railroad from Bushland to approximately four miles west of Vega. From this point a new railroad would be constructed southward approximately nine miles to the repository plant.

The nearest commercial airport is at Amarillo, approximately 43 miles northeast of the site. The second nearest is at Lubbock, approximately 112 miles south of the site. Other airports in the area, such as the Hereford Municipal Airport (approximately 21 miles south-southeast of the site), serve small aircraft but have no regular commercial service.

The Texas Public Utilities Commission regulates electric utilities in Texas. In the site area, electricity is provided mainly by Southwestern Public Service Company (SWPSC) of Amarillo. This company provides electricity directly within some municipalities, and also sells it wholesale to certain rural cooperatives which in turn retail it to the public. Electricity consumers in the cities of Amarillo, Hereford, Canyon, and Vega purchase electricity from SWPSC. At the Deaf Smith County site, electricity is provided by the Deaf Smith Electric Cooperative, Inc., which provides electricity to portions of Oldham, Deaf Smith, Parmer, and Castro Counties. This rural cooperative purchases electricity wholesale from SWPSC. The closest electrical substation is located east of the site at the intersection of US 385 and FM 2587. Another substation is located at Bushland. Electricity from both of these sources may be required to support repository operations. 


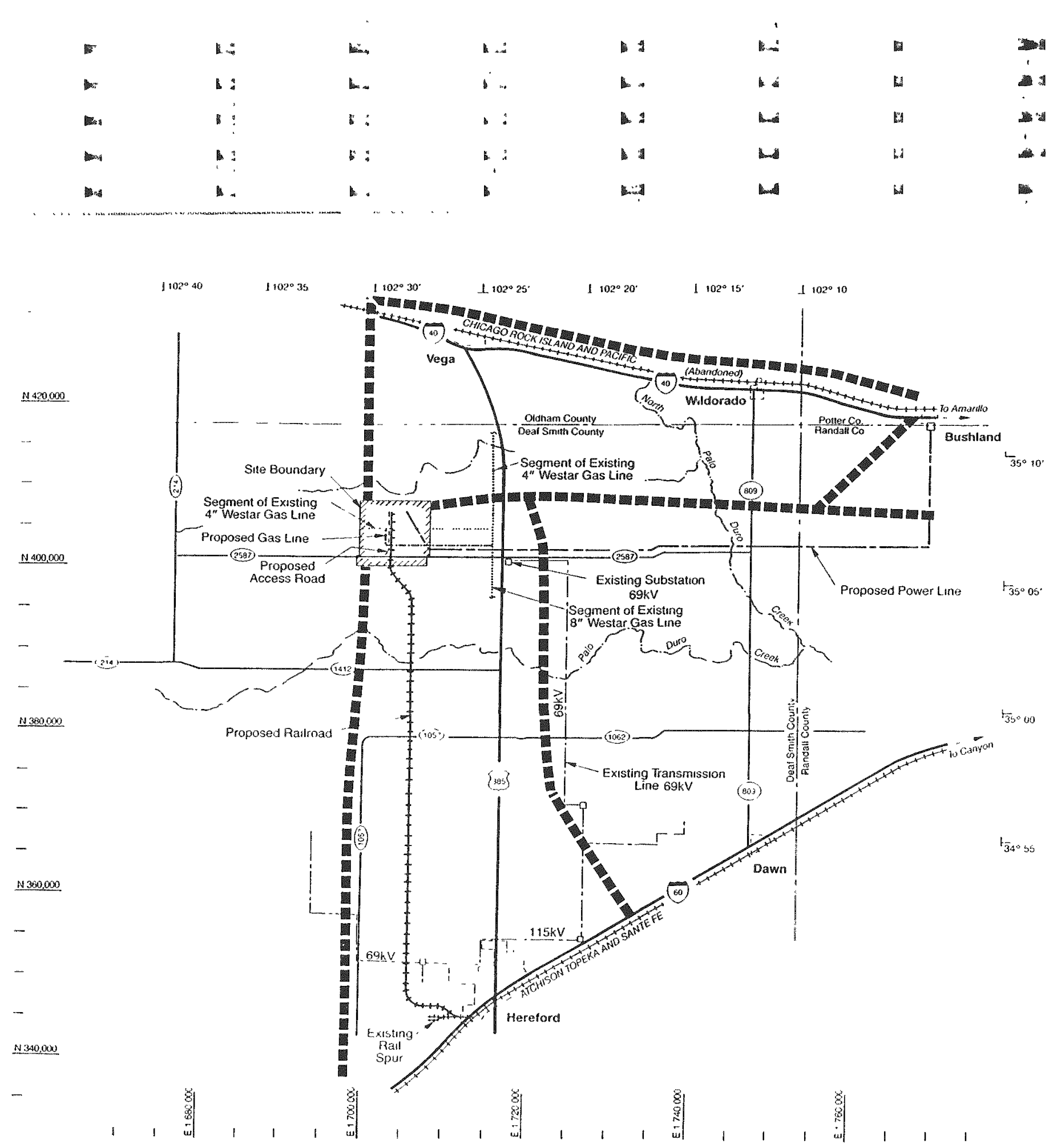

1



The proposed electrical power line to the site would tie to the existing substation at Bushland because it has a greater capacity. Additional or backup pawer may require connection to the substation at the intersection of FM 2587 and US 385 .

The Westar Gas Company supplies natural gas at the site. Primary gas utility structures near the site include 4 in and 8 in gas pipelines.

Projections of natural gas consumption at the repository indicate that a 4 in gas line may be adequate to provide the necessary service. However, because of variables and uncertainties in present and future regional, commercial, and residential consumption and because the availability of gas in the existing 4 in line is not known at this time, the conservative approach of tapping the 8 in line adjacent to US Highway 385 is proposed. This gas line will parallel a portion of the proposed electrical power line to the site boundary.

No municipal water supply or sewage treatment exists at the site. The nearest public water supply and sewage treatment facilities are in Vega. It is proposed that water supply and sewage treatment facilities be developed on site.

Figure 4.1-1, Regional Transportation and Utility Map, highlights the major infrastructure and utility features as described herein. This figure also shows other potential railroad transportation corridors that could be developed to provide all rail service to the site in the event the proposed railroad route proves unavailable. Only the proposed road, railroad, and utility lines are included in the current conceptual design. 


\subsection{SURFACE FACILITIES}

\subsubsection{Facility Layout Description}

The repository surface facilities described in Section 4.2 .2 will be located on approximately 700 acres of land. This will include space for the exploratory shaft facility (ESF). The area of the nine-square-mile site will extend beyond the perimeter of the surface facility; therefore, a controlled area extending to the site boundary will be established. Future activities such as drilling or mining will be prohibited within this controlled area, but various controlled surface uses may be permitted. Existing structures within the controlled area such as farm and ranch facilities including houses, silos, water tanks and towers, and irrigation systems will most likely be affected by repository construction and operations. It may be necessary to remove, relocate, or demolish such structures although the extent of such actions is not known at this time.

Figure 4.2-1, Overall Site Layout, shows the general position of the surface facilities on the nine-square-mile site property. The location of surface facilities is established by the locations of the shafts, which in turn are governed by the requirements of the underground layout. Approximately $10 \%$ of the site area will be dedicated to the surface facilities. Other features shown on the overall site layout include road and rail access, routing of offsite utilities, and the storm water and brine ponds. These features are discussed in the following paragraphs.

Road and rail access to the site will be designed to support the movement of personnel, material, and waste. The main gate will be at the south fence line and will be entered via either the access road that will extend north from FM 2587 or the railroad tracks that will parallel this road (see Figure 4.1-1). Utilities acquired from offsite such as electric power and natural gas will be run to locations that service the entire repository. (For additional discussion of these topics, see Sections 4.2 .3 .10 and 4.2.3.11.) 


\section{NOTES:}

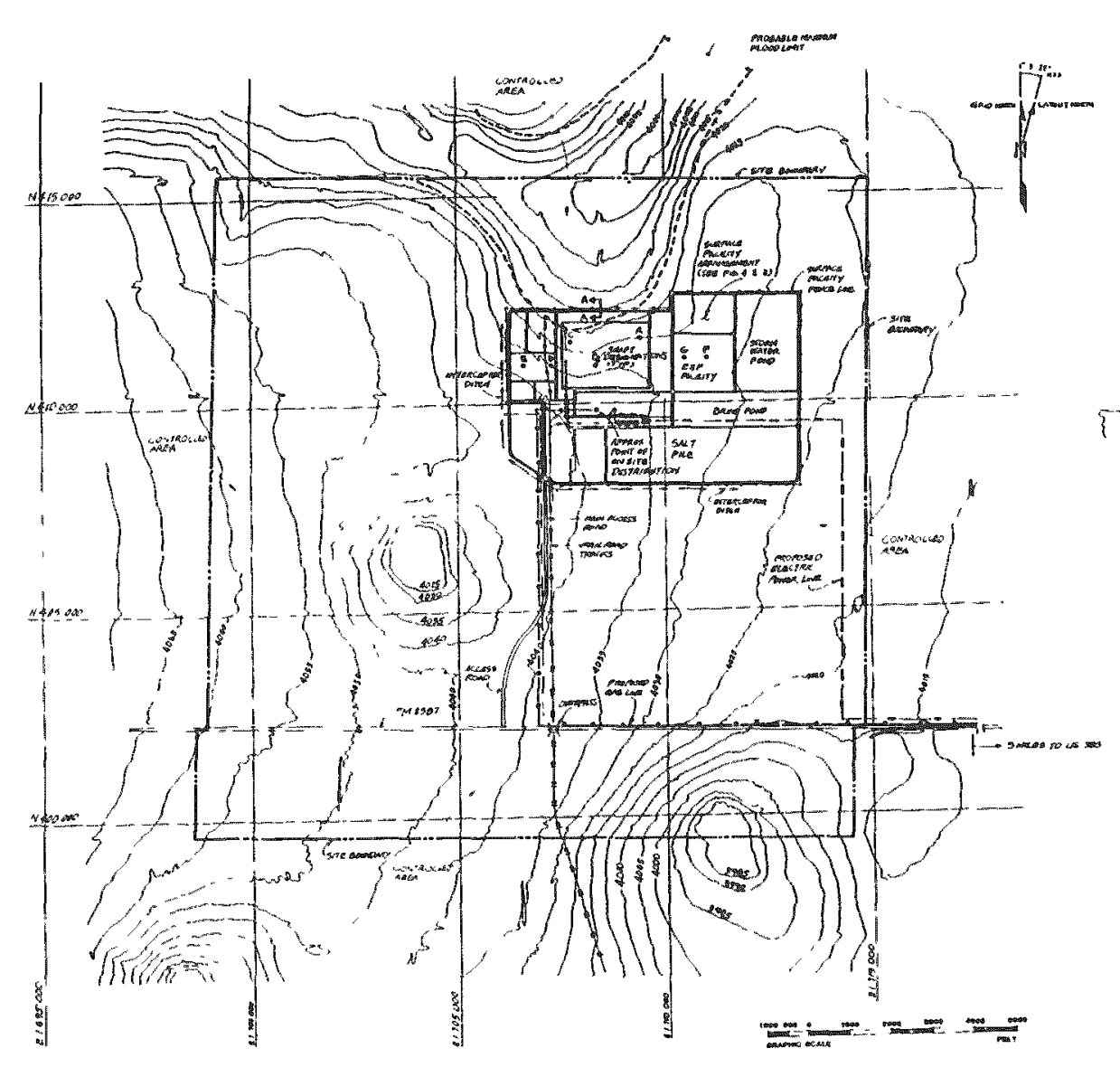

1. Topogr aphic map information was provided by Lizton Aero Service. Litton is a contap in tor to Par exploratory shatt contractor for the Salt Repository Project Office.

3. The surface facility area within the probable maximum flood zone is proposed to be graded to a final elevation approximately 2 feet above the probable maximum flood level. Flood information

obtained from NUS, 1985.

4. Topography shown is 'existing" and does not represent 'Final Grades' at the site.

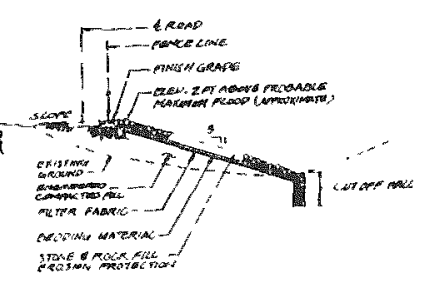

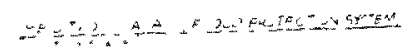


Runoff affecting repository surface facilities will flow via underground systems and/or open channels to the storm water pond. Precipitation falling on the surface facility area will be impounded, monitored, and recycled to supplement the water supply for the plant. The plant will not receive runoff from outside the 700 acre surface facility area. Since the natural drainage patterns around the site may be altered as a result of constructing surface facilities, necessary provisions will be made to minimize the impact on surrounding properties. Storm water will not be discharged beyond the boundary of the surface facility until it has been collected, monitored, and found suitable for discharge. Runoff from the salt pile will drain to the brine pond. Collection ponds will be located to the east of the surface facilities at a slightly lower elevation to accommodate gravity flow drainage design. (Factors considered in locating these ponds are discussed in Section 4.2.3.2.) Treated waste water will be discharged from the industrial waste water treatment system and the sanitary sewage treatment system to the reclaimed water pond shown on Figure 4.2-2. From there it will be pumped to the repository reclaimed water system.

The area between the main facilities and the water ponds will be utilized for the development of the ESF. The repository layout therefore includes an allowance of about 45 acres for the ESF operations area, service and support buildings, excavated material piles, evaporation/retention and sediment ponds, and other components.

The salt pile will be located just south of the brine pond along the southern perimeter of the surface facilities. This location will be accessible to both the terminus of the salt handling conveyor and the brine pond.

Figure 4.2-2 presents the arrangement of the surface facilities. The most prominent features of these facilities will be the two waste handling buildings. They will be arranged to provide direct access from both buildings to the waste shaft (Shaft B). The buildings housing the emplacement air exhaust fans and filters will be located adjacent to the emplacement exhaust shaft (Shaft A) in order to minimize the length of the exhaust duct run. These buildings, together 



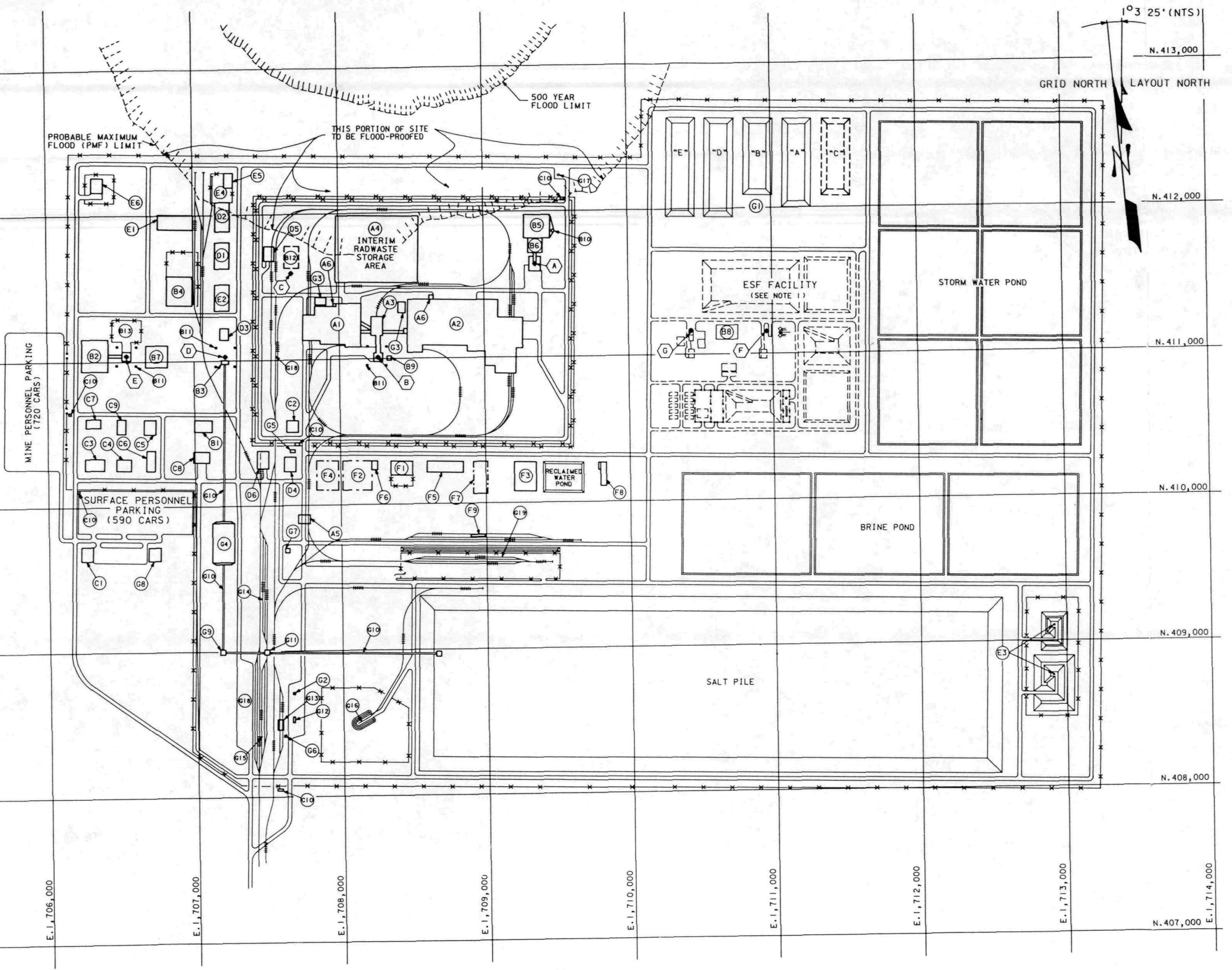

SHAFTS (1) WASTE SHAF

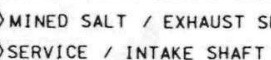

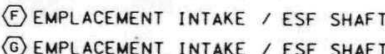

\section{* SECURITY Fencing}

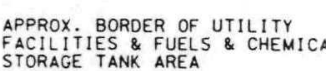

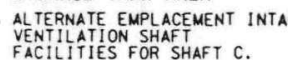

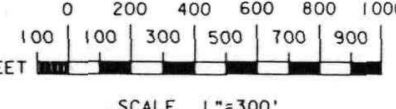

Nones

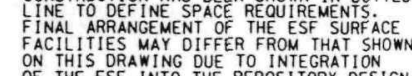

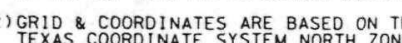

MAREHOUSE \& STORAGE YARO

EMPLACEMENT Exhaust SAafi fiLter blog.

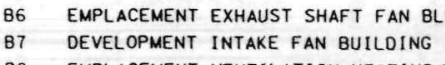

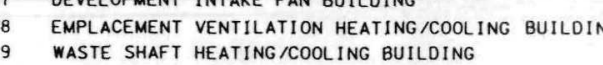

BII GEAOFRAME SUPPORT STRUCTURE (3)

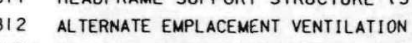
adMinistiation BULLINGS

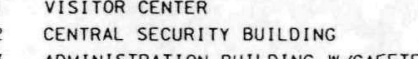

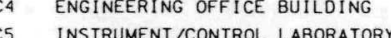

C6 HEALTH PHYSICS LABORATORY

CB FIRE STATION

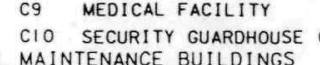

DI MAINTENANE SHOP
02

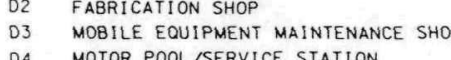

CASK REPAIR BUILIIING STI

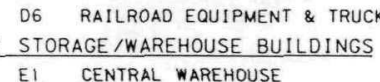

3 ExPLOSIVE \& CAP STTOAGE BLOOS (2)

ST
STORACE SHED

MATERIaLS STORAGE BULLING

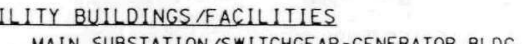

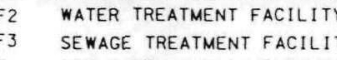

E5 COMPRESSOR / HHLLER BUILOING

67. FUELS \& CHEMICAL STOPACE TANK APEA

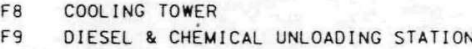

G MISCELLANEOUS BUILOINGSSTRRUCTURES

G2

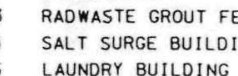

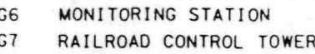

HOUSING BUILDING
SALT CONVEYOR TPANSES TORE

SALT CONVEYOR TRANSER TOMER
SALT CONVEOR (3)

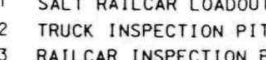

C14 EMPTY SALT RAILCAR STORAGE
G15 FULL SALT RAILCAR STORAGE

G16 SHIPPING UNIT PASIF II IAATI ION ARELA

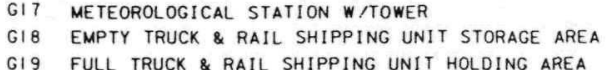

\begin{tabular}{|c|}
\hline $\begin{array}{c}\text { SURFACE FACILITY } \\
\text { ARRANGEMENT }\end{array}$ \\
\hline FIGURE $4.2-2$ \\
\hline
\end{tabular}


$0 \quad 00$ 
with other process related facilities (e.g., cask repair building, radwaste storage), will be grouped within a double fenced security zone. Both road and rail access will be provided to most of the buildings in this area.

The remaining surface facilities will be grouped according to function (i.e., utilities, maintenance/warehousing, subsurface support, administration). These groups will be adjacent to the waste handling and processing area discussed in the previous paragraph. This layout will provide direct access from the balance of plant facilities to the waste handling and processing facilities. Some buildings and facilities, to be located at the plant entrance, will be primarily for security and monitoring operations. These will include the truck and rail inspection stations, scalehouse, shipping unit pacification area, and the visitors' center.

A perimeter fence will enclose the entire surface facility, with the exception of the visitors' center, housing building, and parking lots. Guard houses will be provided at all points of entry.

\subsubsection{Building and Facility Descriptions}

A Building/Facility List, Table 4.2-1, summarizes the major features of the repository buildings, facilities, and structures. This list contains the following: (1) building/facility name, (2) principal dimensions, (3) building gross area, (4) number of stories, and (5) a basic construction description.

Each building will be sized to accommodate estimated functional space requirements. All facilities will be located within the site according to their functions and in relation to the systems they serve. In addition to function, limited consideration has also been given to noise, dust, direction of the prevailing wind, other environmental factors, and the utilization of the existing topography to the best advantage. In a later design phase, trade-off studies will be performed to determine the most economical grouping of buildings . 
Table 4.2-1. Building/Facility list (Sheet 1 of 6)

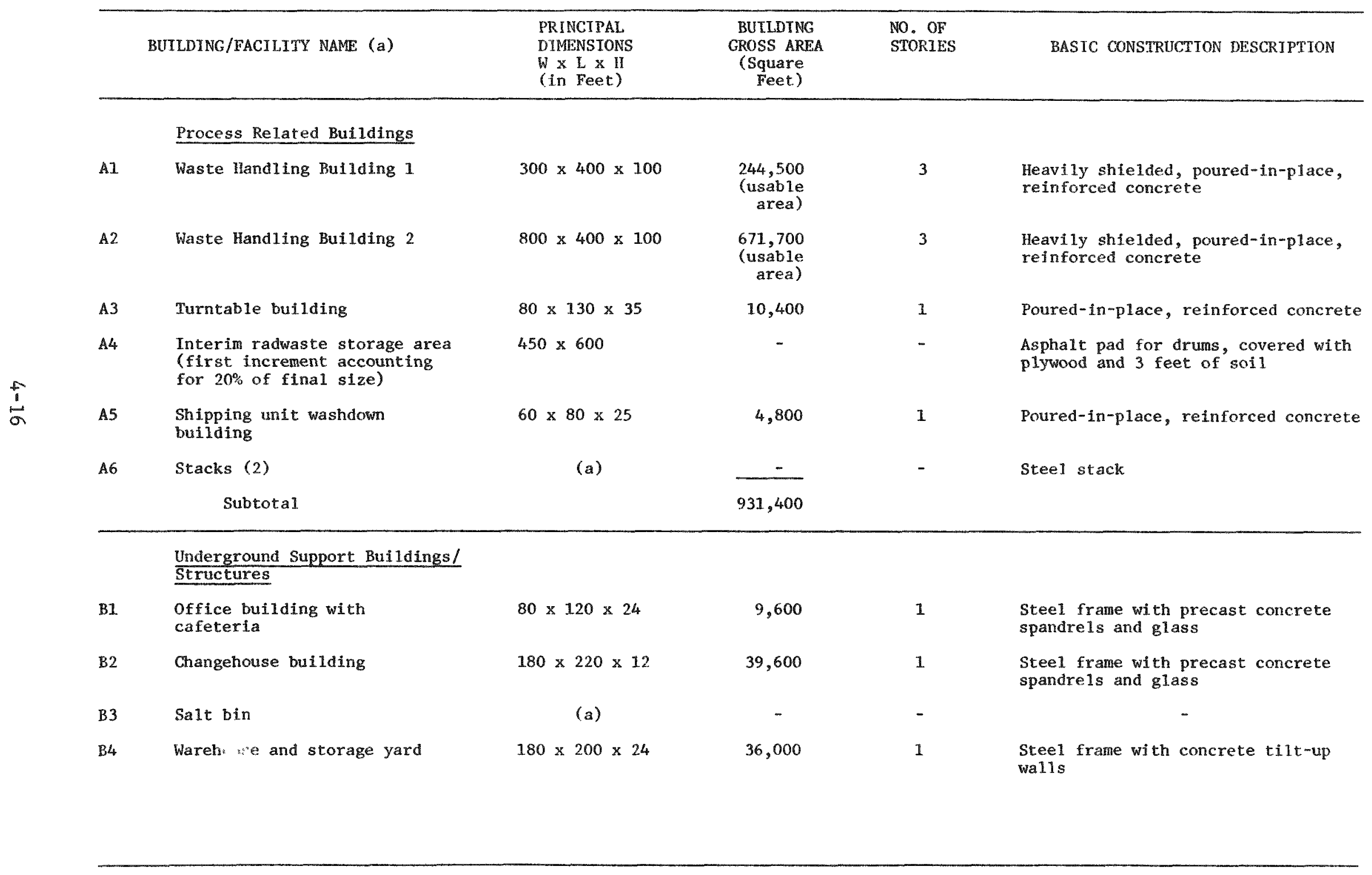


Table 4.2-1 (Sheet 2 of 6 )

\begin{tabular}{|c|c|c|c|c|c|}
\hline & BUILDTNG/FACILITY NAME (a) & $\begin{array}{l}\text { PRINCIPAI } \\
\text { DTMENSTONS } \\
\text { W } \times \text { L } \times H \\
\text { (in Feet) }\end{array}$ & $\begin{array}{c}\text { BUTLDTNG } \\
\text { GROSS AREA } \\
\text { (Square } \\
\text { Feet) }\end{array}$ & $\begin{array}{l}\text { NO. OF } \\
\text { STORIES }\end{array}$ & BASTC CONSTRUCTION DESCRTPTION \\
\hline B5 & $\begin{array}{l}\text { Emplacement exhaust shaft } \\
\text { filter building }\end{array}$ & $160 \times 180 \times 50$ & 57,600 & 2 & $\begin{array}{l}\text { Steel frame with concrete tilt-up } \\
\text { walls }\end{array}$ \\
\hline B6 & $\begin{array}{l}\text { Emplacement exhaust shaft } \\
\text { fan building }\end{array}$ & $100 \times 100 \times 25$ & 10,000 & 1 & $\begin{array}{l}\text { Steel frame with concrete tilt-up } \\
\text { walls }\end{array}$ \\
\hline B7 & $\begin{array}{l}\text { Development intake fan } \\
\text { building }\end{array}$ & $150 \times 150 \times 25$ & 22,500 & 1 & $\begin{array}{l}\text { Steel frame with concrete tilt-up } \\
\text { walls }\end{array}$ \\
\hline B8 & $\begin{array}{l}\text { Emplacement ventilation } \\
\text { heating/cooling building }\end{array}$ & $100 \times 150 \times 25$ & 15,000 & 1 & $\begin{array}{l}\text { Steel frame with concrete tilt-up } \\
\text { walls }\end{array}$ \\
\hline B9 & $\begin{array}{l}\text { Waste shaft heating/cooling } \\
\text { building }\end{array}$ & $30 \times 30 \times 25$ & 900 & 1 & $\begin{array}{l}\text { Steel frame with concrete tilt-up } \\
\text { walls }\end{array}$ \\
\hline B.10 & Stack & - & - & - & Steel exhaust stack \\
\hline B11 & Headframe structures (3) & $50 \times 50 \times 220$ & 2,500 & 1 & Steel framed structure \\
\hline $\mathrm{B} 12$ & $\begin{array}{l}\text { Potential emplacement } \\
\text { ventilation heating/cooling } \\
\text { building }\end{array}$ & $100 \times 150 \times 25$ & 15,000 & 1 & $\begin{array}{l}\text { Steel frame with concrete tilt-up } \\
\text { walls }\end{array}$ \\
\hline B13 & $\begin{array}{l}\text { Material and equipment } \\
\text { storage area }\end{array}$ & (a) & - & - & - \\
\hline & Subtotal & & 208,700 & & \\
\hline
\end{tabular}

\section{Administration Buildings}

ca

\section{Visitor center}

$80 \times 120 \times 12$

9,600

1

Steel frame with precast concrete spandrels and glass

c2 Central security building

$80 \times 80 \times 12$

6,400

1

Heavily shielded, poured-in-place, reinforced concrete

C3 Administration building with cafeteria

$80 \times 120 \times 24$

19,200

Steel frame with precast concrete spandre $1 \mathrm{~s}$ and glass 
Table 4.2-1 (Sheet 3 of 6)

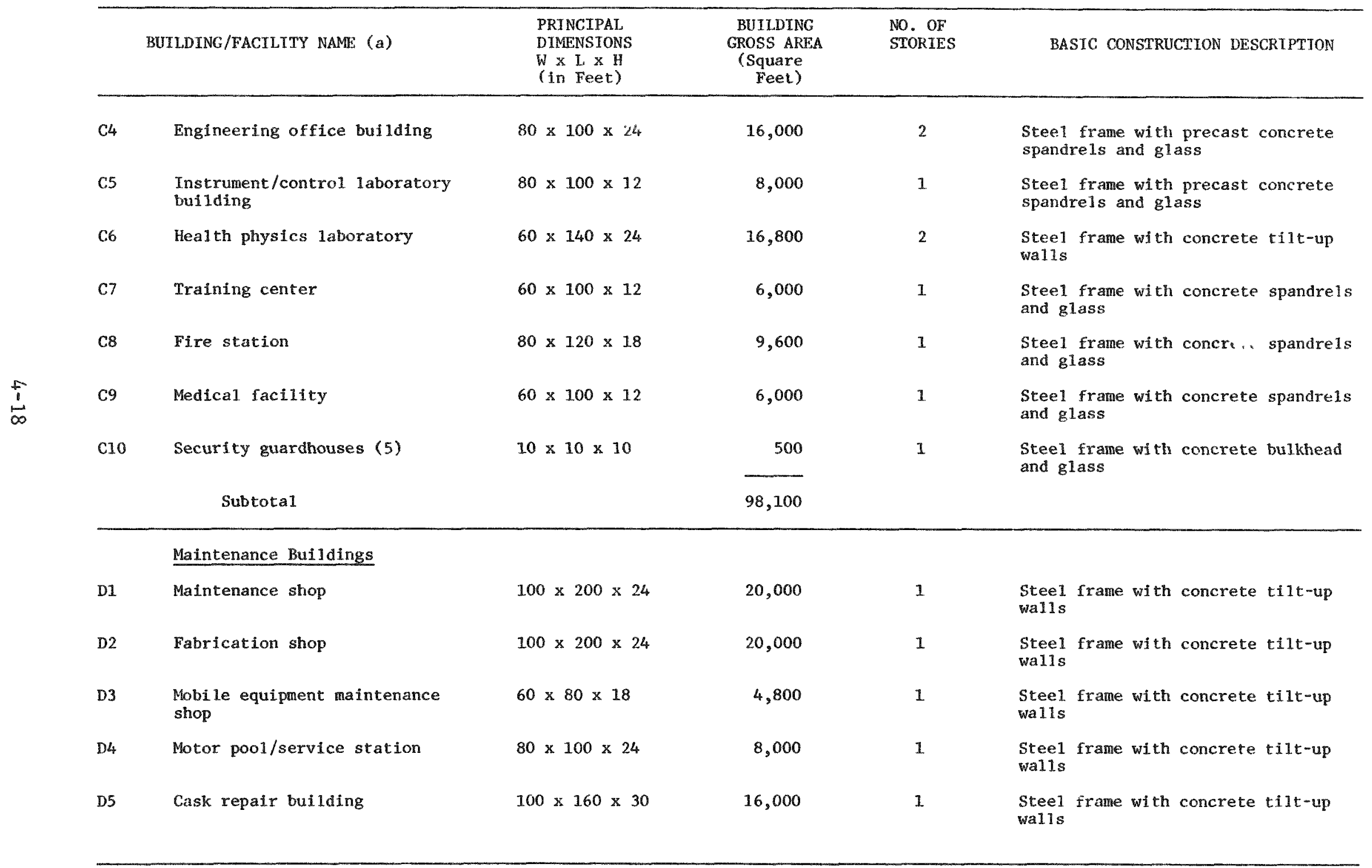


Table 4.2-1 (Sheet 4 of 6 )

\begin{tabular}{|c|c|c|c|c|c|}
\hline & BUTLDING/FACTEITY NAME (a) & $\begin{array}{l}\text { PRINCIPAL } \\
\text { DTMENSIONS } \\
\text { W } \times \text { L } \times H \\
\text { (in Feet) }\end{array}$ & $\begin{array}{c}\text { BUILDING } \\
\text { GROSS AREA } \\
\text { (Square } \\
\text { Feet) }\end{array}$ & $\begin{array}{l}\text { NO. OF } \\
\text { STORIES }\end{array}$ & BASIC CONSTRUCTION DESCRIPTION \\
\hline D6 & $\begin{array}{l}\text { Railroad equipment and truck } \\
\text { transporter maintenance } \\
\text { building }\end{array}$ & $80 \times 1.20 \times 30$ & 9,600 & 1 & $\begin{array}{l}\text { Steel frane with concrete tilt-up } \\
\text { walls }\end{array}$ \\
\hline & Subtotal & & 78,400 & & \\
\hline
\end{tabular}

\section{Storage/Warehouse Buildings}

E1 Central warehouse

$100 \times 240 \times 24$

24,000

Steel frame with concrete tilt-up walls

E2 Warehouse

$100 \times 180 \times 24$

18,000

800

$\frac{5}{6}$

Explosive and cap storage

buildings (2)

$20 \times 20$

1

Steel frame with concrete tilt-up wa11s

E4 Storage yard

E5

Storage shed

$60 \times 100 \times 24$

6,000

$40 \times 60 \times 12$

2,400

Hazardous materials storage building

Subtota1

\section{Utility Buildings/Facilities}

F1 Main substation/switchgear generator building

F2 Water treatment facility

$100 \times 160 \times 30$

16,000

$200 \times 200$

F3 Sewage treatment facility

$150 \times 200$

51,200

Prefabricated type, as required

Steel frame with prefinished metal roof panels

Prefabricated type, as required, enclosed and fenced
Poured-in-place, reinforced concrete

Concrete gravel area for equipment, with enclosures as required

Concrete gravel area for equi pnent, with enclosures as required

Concrete gravel area for equipment 
Table $4.2-1$ (Sheet 5 of 6 )

\begin{tabular}{|c|c|c|c|c|c|}
\hline & BUILDING/FACTLTTY NAME (a) & $\begin{array}{l}\text { PRINCIPAL } \\
\text { DIMENSIONS } \\
\text { W } \times \mathrm{L} \times \mathrm{H} \\
(\text { in Feet })\end{array}$ & $\begin{array}{l}\text { BUILDING } \\
\text { GROSS AREA } \\
\text { (Square } \\
\text { Feet) }\end{array}$ & $\begin{array}{l}\text { NO. OF } \\
\text { STORIES }\end{array}$ & BASIC CONSTRUCTION DESCRIPTION \\
\hline F5 & Compressor/chiller bullding & $75 \times 250 \times 40$ & 18,750 & 1 & $\begin{array}{l}\text { Steel frame with concrete tilt-up } \\
\text { walls }\end{array}$ \\
\hline F6 & Utilit: ntrol building & $40 \times 60 \times 15$ & 2,400 & 1 & $\begin{array}{l}\text { Steel frame with concrete tilt-up } \\
\text { walls }\end{array}$ \\
\hline F7 & $\begin{array}{l}\text { Fue } 1 \text { s and chemical storage } \\
\text { tank Area }\end{array}$ & (a) & $=$ & - & $\begin{array}{l}\text { Concrete gravel area for equipment/ } \\
\text { tanks }\end{array}$ \\
\hline F8 & Cooling tower & (a) & - & - & $\begin{array}{l}\text { Concrete and wooden structures and } \\
\text { fillings }\end{array}$ \\
\hline \multirow[t]{3}{*}{ F9 } & $\begin{array}{l}\text { Diesel and chemical unloading } \\
\text { station }\end{array}$ & (a) & - & - & $\begin{array}{l}\text { Elevated plat form with unloading } \\
\text { Equipment }\end{array}$ \\
\hline & Subtotal & & 37,150 & & \\
\hline & $\begin{array}{l}\text { Miscellaneous Buildings/ } \\
\text { Structures/Facilities }\end{array}$ & & & & \\
\hline G1 & $\begin{array}{l}\text { Excavated shaft material } \\
\text { stockpiles }\end{array}$ & (a) & - & - & Open space on grade \\
\hline G2 & Scalehouse & $10 \times 20 \times 10$ & 200 & 1 & Metal building \\
\hline 63 & $\begin{array}{l}\text { Radwaste grout feed } \\
\text { buildings (2) }\end{array}$ & $50 \times 75 \times 24$ & 7,500 & 1 & Metal bullding \\
\hline G4 & Salt surge building & $160 \times 270 \times 24$ & 43,200 & - & Metal building \\
\hline G5 & Laundry building & $20 \times 30 \times 12$ & 600 & I & $\begin{array}{l}\text { Steel frame with concrete tilt-up } \\
\text { walls }\end{array}$ \\
\hline G6 & Monitoring station & $10 \times 20 \times 10$ & 200 & 1 & Metal building \\
\hline G7 & Railroad control tower & $8 \times 8 \times 60$ & 64 & - & $\begin{array}{l}\text { Steel frame with metal wall panels } \\
\text { for control station at top }\end{array}$ \\
\hline G8 & Housing building & $80 \times 100 \times 12$ & 8,000 & 1 & $\begin{array}{l}\text { Steel frame with concrete spandrels } \\
\text { and glass }\end{array}$ \\
\hline
\end{tabular}


Table 4.2-1 (Sheet 6 of 6 )

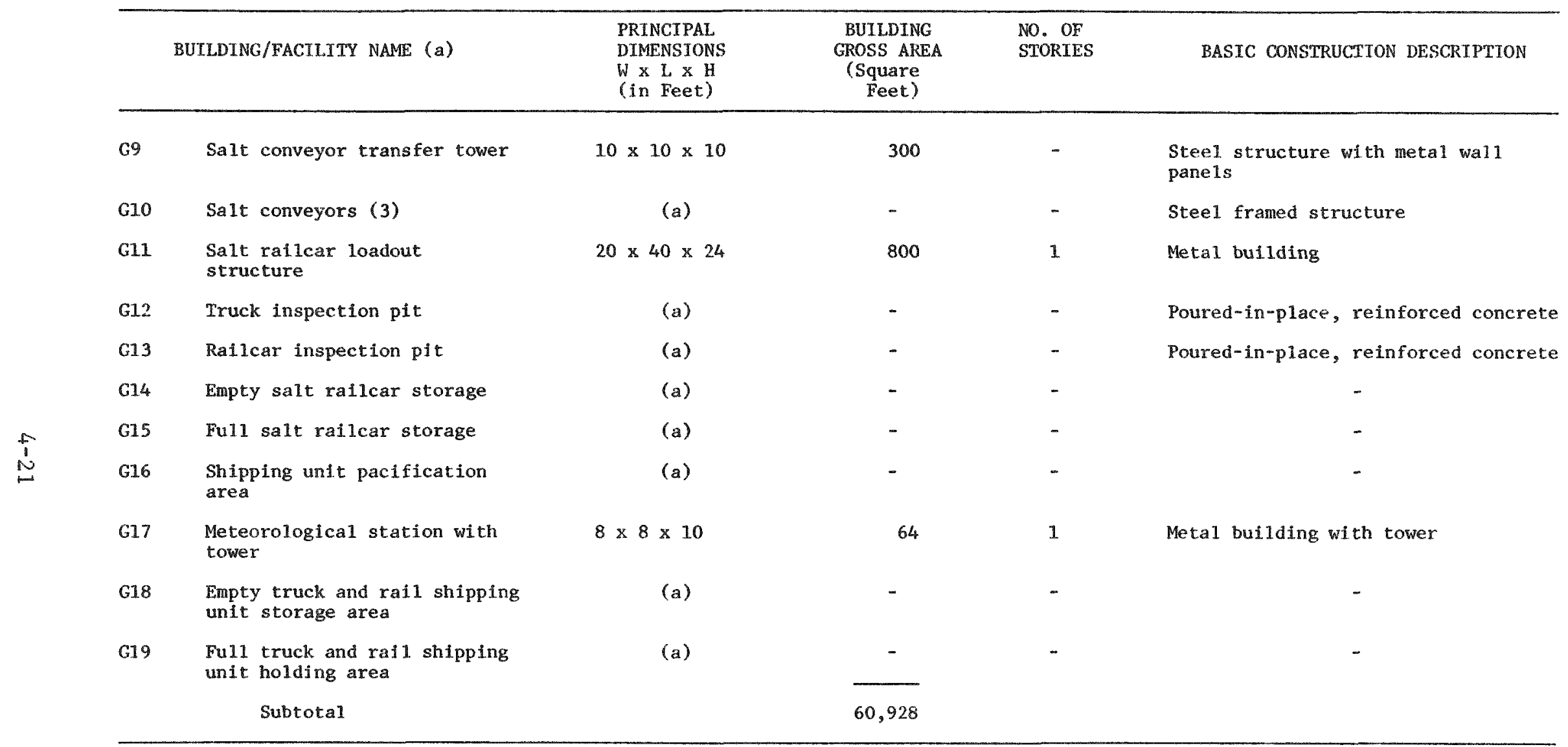

NOTE: Approximate Gross Square Footage of A11 Buildings and Categories A-G: 1,465,000

(a) See Figure 4.2-2, "Surface Facility Arrangement." 
Wherever possible and prudent, the repository buildings will accommodate physically handicapped persons. All buildings or portions of buildings with permanent populations will be air conditioned. Buildings without permanent populations will be heated and ventilated only. All buildings and facilities will be designed to be energy efficient. Certain buildings, facilities, and areas (e.g., administration buildings) will be designed for future expansion as required.

Space for mechanical and electrical equipment, offices, toilets, and other uses will be provided in buildings and facilities. Most of the architectural and structural details for buildings and facilities, such as definitive dimensions, configurations, and construction types, will be determined in later stages of design. The descriptions of buildings and facilities and related information contained in this section are only preliminary in nature.

All buildings and facilities will be grouped into the following categories based on their usage and functions: (designations correspond to those noted on Table $4.2-1$ )

1. Process related buildings

2. Underground support buildings and structures

3. Administration buildings

4. Maintenance buildings

5. Storage and warehouse buildings

6. Utility buildings and facilities

7. Miscellaneous buildings and structures

More detailed discussions of these facilities are presented below. 


\subsubsection{Process Related Buildings}

Process related buildings and facilities (see Sheet 1 of Table 4.2-1) will be provided for direct support of waste handling and packaging operations. The most important of these facilities are:

1. Waste Handling Buildings 1 and 2 (described in detail in Sections 4.2 .4 through 4.2 .6$)$.

2. The turntable building. Located between the waste handing buildings, it will house the turntable used to orient the surface cage off/on loader so that it may pick up transfer casks from either building and carry them to the top of the waste shaft.

3. The cask washdown buildings. These will contain facilities to remove road dirt from incoming waste units.

4. The radwaste storage facility. Containerized radwaste will be stored here while awaiting shipment off site.

\subsubsection{Underground Support Buildings and Structures}

The underground support buildings and structures will support underground development and emplacement operations. They will be typical mining surface facilities, e.g., headframes, changehouse, and certain warehouse and maintenance buildings. These facilities are listed beginning on sheet 1 of Table 4.2-1. Following are descriptions of the most important of these facilities:

1. The office building with cafeteria will contain administrative and management offices, and a cafeteria for office and mining personnel supporting underground operations. This cafeteria will operate separately from the cafeteria in the main administration building in order to better satisfy any specific requirements of underground mining workers. 
2. The changehouse building will allow personnel to enter and exit mine operations after proper monitoring, security badge checking, changing of clothes in the change room, and passage through air locks for contamination control. In addition, this facility will be designed to accommodate sundries and storage requirements for the total number of personnel supporting mine operations. However, only a fraction of this population will be present in the building at any one time.

3. The warehouse will contain space for parts, supplies, tools, equipment, and consumables for mine-related activities. It will have a loading dock, and it will be provided with bridge cranes to handle large items. A storage yard will also be provided.

Supplies and replacement parts used in the underground will be stored separately from surface related requirements to preclude use by surface related organizations. Tradeoff studies during the Advanced Conceptual Design will be used to determine whether this and other warehouse buildings could be combined. In this report, the approach is to provide a separate building for each major function.

4. The emplacement exhaust filter building will house high-efficiency particulate air (HEPA) filters and fans for filtering exhaust air from the emplacement area of the mine in the event of an underground radioactive release.

5. The emplacement exhaust fan building will house the exhaust ventilation fans for the emplacement area of the mine for normal operations .

6. The development intake fan building will house the main air supply fans for the development area of the mine. This building will also contain heating and cooling coils to temper underground ventilation air. 
7. The emplacement ventilation heating and cooling building will house air conditioning coils to temper air to be supplied to the emplacement area.

8. The waste shaft heating and cooling building will house the air conditioning coils to temper the air supply to the waste shaft and the underground waste transporter off/on loading station. (See Section 3.4.3.4 for additional discussion of this subject.)

\subsubsection{Administration Buildings}

Administration buildings will be located throughout the site to provide for office, security, emergency, and other personnel requirements. These are listed beginning on Sheet 2 of Table 4.2-1. Following are descriptions of the most important buildings and facilities:

1. The visitor center will be located outside the main security fence and will contain a general information center, presentation rooms and counters.

2. The central security building will be a heavily reinforced, hardened concrete facility. It will be the main check point for all incoming and outgoing employees and visitors. Both vehicle and pedestrian traffic will be controlled. This building will also serve as a center for all guard and security activities such as issuing identification badges and storing security records. The building will contain a waiting area, monitoring devices, offices, a lunch room, record and file storage rooms, a squad room, a gun room, and a communications center.

Radio and telephone communications will link the security building to the fire station, medical facility, and all security personnel stations (guardhouses, vehicles, etc.). Communication links will also be maintained with offsite fire, police, and medical services. (See item 10 of this section and Section 4.2.2.7, items 5 and 6, for additional discussions of security related buildings.) 
3. The main administration building will house overall repository administrative and management functions. The building will contain a reception lobby, a computer room for accounting and payroll, a central secured file area, a telephone and communications center, and a mail room and distribution center. This building will also contain a cafeteria for office staff and visitors.

4. The engineering office building will house engineering offices, a drafting area, a document reproduction and storage area, and conference rooms. This building was planned as a separate facility because certain engineering activities could be of a confidential nature and might be compromised if carried out in a multi-function building such as the administration building.

5. The instrument and control laboratory building will act as the center for instrument calibration and material test and analysis.

6. The health physics laboratory will contain facilities for health physics, radiology, and control of badge exposure.

7. The training center will serve as a training facility for repository personnel.

8. The fire station will provide storage space for fire fighting equipment and chemicals, garage space for fire trucks, and a crew room. Provisions for radio communications will be included. Mine emergency and rescue capabilities will also be provided through this facility.

9. The medical facility will provide emergency aid for repository personnel.

10. Security guardhouses will be located at plant access points such as service entries, cask truck entries, and cask rail car entries. The guardhouses will be provided with check-in counters and communications equipment. 


\subsubsection{Maintenance Buildings}

Maintenance buildings will be located in appropriate areas to support maintenance and storage requirements. They are listed beginning on Sheet 3 of Table 4.2-1. Following are descriptions of the most important of these buildings:

1. The maintenance shop will be the center for repair and maintenance of plant equipment and repository buildings. The building will be located near storage yard areas and adjacent to a service road.

2. The fabrication shop will contain machine, pipefitting, welding, sheet metal, carpentry, plastics, electrical, instrumentation, and paint shops. It will serve as the fabrication center for the repository. The fabrication shop will also include special areas that duplicate the waste handling building hot cell mechanical conditions. These areas will be used for pre-assembly, mock-up, and cold testing of remote equipment prior to placement in the waste handling building hot cells .

3. The mobile equipment maintenance shop will serve as the plant maintenance center for vehicles such as loaders and transporters used in mined-salt surface storage and disposal operations. It will have service pits, recharging stations, and other maintenance equipment.

4. The motor pool and service station will function as the main repair and maintenance center for plant autos and trucks. It will contain service bays and will also be provided with a dispatch center and an office. The station will include a nearby gasoline and diesel fuel dispensing island.

5. The cask repair building will contain equipment for repairing shipping casks delivered by trucks and railcars. This function will be limited to remedial repair required to get casks back on the road. Full maintenance, repair, and five-year inspection will be performed offsite at a centralized DOE maintenance facility. 
6. The railroad equipment and truck transporter maintenance building will contain equipment for repair and maintenance of rail cars, trackage, and truck transporters.

\subsubsection{Storage and Warehouse Buildings}

Storage and warehouse buildings are listed beginning on sheet 4 of Table 4.2-1. Following are descriptions of the most important of these facilities:

1. The central warehouse will function as the receiving, storage, and dispensing facility for supplies and spare parts (waste package components excepted). The building will be provided with a loading dock, offices, storage racks and bins, and space for bulk storage. It will contain suitable bridge cranes. The building will be located near a storage yard and adjacent to a service road and a railroad spur.

2. An additional warehouse will house receiving, inspection, storage, and dispensing of all waste container components. This building will contain space for parts, supplies, tools, equipment, consumables, engineered components, and waste container components. It will have a loading dock, offices, and will be provided with suitable bridge cranes for handling large equipment. The building will be located near the central warehouse. It will be a controlled-access building and will provide necessary atmosphere protection for stored components .

3. The explosive and cap storage building will be used for the storage, protection, monitoring, and distribution of explosives used in mining operations. It will be located in an area far removed from the plant buildings, and it will be served by a separate service road.

4. The hazardous materials storage building will be a separate building for the storage of hazardous materials such as chemicals, acids, solvents, and toxic materials. It will be located within a fenced, secured area. 


\subsubsection{Utility Buildings and Facilities}

The utility buildings and facilities will house a complex network of utilities including electric power, liquid fuel, $s$ and chemical storage, sewage and industrial waste, steam and condensate systems, and water treatment. These buildings and facilities are listed beginning on sheet 4 of Table 4.2-1. Following are descriptions of the most important of these facilities:

1. The emergency power and switchgear building will house emergency generators and distribution switchgear. The generators will be sized to provide emergency power for necessary repository systems.

2. The water treatment facility will process the raw water supply to make it suitable for use in several services. The systems supplied by this facility will include softened water, demineralized water, potable water, and the fire fighting water system.

3. The sewage treatment facility will process industrial and sanitary waste water to make it suitable for reuse in the repository.

4. The steam generation facility will consist of the boiler plant and related equipment (i.e., deaerator, pumps, drums, etc.). These units will produce steam for process uses and heating purposes.

5. The compressor/chiller building will house the compressors, chillers, and related equipment. Chillers will produce and distribute chilled water to provide cooling to the balance of plant surface facilities. They may also be used to cool air going to the underground. The air compressors will also be housed in this building.

6. The utility control building will serve as a control center for the principal operations associated with the repository utilities.

7. The storage tank area for fuels and chemicals will consist of tanks, drums, vessels, and other related equipment to provide storage and distribution of those fluids necessary for repository processes and 
operations. Stored fluids will include diesel fuel, raw water, liquid nitrogen, liquid argon, nitric acid, sulfuric acid, and caustic.

8. A forced-draft cooling tower will remove waste heat from the repository cooling water system. The cooling water supply will be pumped from the cooling tower to the various repository users.

\subsubsection{Miscellaneous Buildings and Structures}

Miscellaneous buildings and structures are listed beginning on sheet 5 of Table 4.2-1. The more important of these are discussed below:

1. The salt surge building will provide short-term surge capacity for the storage of salt prior to transfer to the onsite salt pile or the rail car loadout station.

2. The salt conveyor system consisting of three overland 36 inch belt conveyors and two transfer towers will move mined salt from the mined salt shaft to either the onsite salt pile or the rail car loadout station. The transfer towers will serve as junction points to divert the salt flow to either of the destinations mentioned above.

3. The salt rail car loadout structure will house a 200 ton capacity silo which will be fed by a belt conveyor from the salt transfer tower. Rail cars will be positioned under the silo for loading.

4. The housing building will be used to provide temporary quarters for visitors, public officials, DOE personnel, etc. It will also be available for occasional use--during weather emergencies, for example--when some personnel must stay on site round the clock.

5. The truck inspection pit and rail car inspection pits will be located at the rail car and truck entrance to the repository. These pits will allow the undersides, the tops, and the sides of arriving vehicles to be inspected for radiological contamination, explosives, 
and contraband. This operation will take place in an area sufficiently removed from the other surface facilities to minimize damage and injury should an explosion occur during inspection.

6. The shipping unit pacification area will provide a secure area for the isolation and servicing of suspect trucks and rail cars. This area will be located within a bunkered revetment to which access will be controlled.

\subsubsection{Layout Factors}

The following subsections discuss the major factors that were considered in arriving at the surface facility layout. Each factor's influence on the surface facility arrangement is described. Where appropriate, this is followed by a discussion of the criteria and layout guidelines that were developed and applied as a result of analyzing the effect of that influence.

\subsubsection{Shaft Locations and Underground Layout}

The shaft locations were established by the requirements of the underground layout. These locations then dictated the positions of several key components of the surface facilities that must be located at, or in close proximity to, the shafts they serve. For example, the headframes, ventilation structures, filter buildings, waste handling buildings, and salt handling system will be located so as to be compatible with the shaft design and alignment at the points of interface. The underground operations and maintenance support buildings will be located in close proximity to the service and mined-salt shafts in order to minimize the travel time of men and materials.

\subsubsection{Surface Terrain and Natural Site Features}

Topographic conditions will influence the location of certain facility components. All vital plant facilities including the shafts and waste handling buildings will be located at surface elevations above and away from the probable maximum flood (PMF) area associated with the unnamed tributary to North Palo Duro Creek. The salt pile and brine pond will also be located away 
from the PMF area to eliminate the possibility of contaminating the tributary during a flood. The storm water pond will be located to the east of the main plant because the natural surface elevation slopes gently downward in that direction, thus facilitating gravity flow to that pond.

Foundations for heavy and complex surface structures and buildings may entail the use of reinforced concrete mats, caissons, or drilled piers because the near-surface loess soil layers have low bearing capacities. Such foundations influence site layout by requiring adequate space around affected facilities for drilling, excavation, hauling, and placement of equipment during construction. The layout allows sufficient space around the surface facilities for these purposes.

\subsubsection{Site-Specific Natural Phenomena}

Elements of normal natural phenomena will have some influence on the location of certain repository facilities. Stockpiles for salt and excavated shaft materials will be located so as to minimize the effects of wind blown salt and dust on repository operations and offsite property adjacent to the site. The cooling tower will also be positioned so as to avoid wind blown spray on the operations area and offsite property. Finally, the layout has been checked to ensure that adequate space will be allocated for ditches, culverts, storm sewers, drainage structures, and ponds required for the collection and control of storm water.

\subsubsection{Integration of the Exploratory Shaft Facility (ESF)}

The principal features of the ESF are shown in dashed lines in Eigure 4.2-2, Surface Facility Arrangement. The surface facilities will be arranged so that construction and operation of the repository will not interfere with the testing activities of the ESF and vice versa.

\subsubsection{Site Security}

The surface facility arrangement includes several security related features and components: 
1. The surface facilities will be enclosed by a perimeter fence with provision for controlled ingress and egress. Guardhouses will be adjacent to all points of entry.

2. The radiological operations area will be located within a separately fenced and protected area. Guardhouses will also be located at points of entry to this area.

3. A patrol road will be constructed just inside the perimeter fence. Other important facilities will be located at or near the rail car and truck entrance for the purpose of inspecting or servicing incoming shipping units. These include truck and rail car inspection pits, a monitoring station, and a shipping unit pacification area. See Section 4.2.2.7, items 5 and 6 , for descriptions of some of these facilities.

\subsubsection{Visual Aesthetics}

Since the site is expected to be fairly level, it will not lend itself to utilizing topographical features to maximize the aesthetic appearance of the repository. However, the visual impact will be mitigated in part because many components and facilities will be located underground for functional and technical reasons. For the rest, such features as decorative insulated panels on the waste handling buildings, earth-tone exterior colors, landscaped berms, and tree screens will be used to maximize the aesthetic appearance of the surface facilities.

\subsubsection{Future Site Expansion}

The surface facility arrangement will provide adequate space for future site expansion. Areas directly north and east of the radwaste storage area could be utilized as well as some areas to the south of the waste handling buildings. A fairly large area will be left open adjacent to the maintenance and warehouse buildings at the west fence line. Additional space can also be made available in the area of the ESF when site characterization activities are completed. All of the aforementioned locations will be accessible for 
construction and located to minimize interference with ongoing operations and maintenance.

\subsubsection{Area and Regional Environmental Impacts (Air and Water Quality)}

Air and water quality concerns were taken into account when the layout was developed. Air quality did not prove to be a controlling parameter in locating the air pollution control components (e.g., filter buildings and stacks were placed adjacent to their respective ventilation exhaust shafts).

Facilities that provide for monitoring, impounding, and treatment of all potentially contaminated waste waters are shown in Figure 4.2-2, Surface Facility Arrangement. These include the waste water treatment facility, storm water pond, brine pond, and reclaimed water pond. The rationale that established the locations of these facilities is discussed in Section 4.2.3.2.

\subsubsection{Storage and Disposal of Excavated Materials}

The surface facility layout will include large areas for piling salt and other excavated materials. Unrestricted corridors for conveying systems and truck haul from the shaft unloading locations to these areas will be provided. The locations of these areas are discussed in Sections 4.2 .3 .2 and 4.2.3.3.

\subsubsection{Offsite Utility Supply}

Routing of the plant utility systems from their sources to the site boundary will be based on economic, safety, and reliability considerations; state and local regulations; and ease of construction. Buildings, structures, systems, and components that connect to these systems will be designed so as to provide convenient interfaces with the incoming systems. The electrical substation will be located inside the surface facility security fence (see Figure 4.2-2 for location). 


\subsubsection{Offsite Rail and Road Access}

Routing of the transportation corridor from the existing highways and railroad will be based on economic and environmental considerations, state and local regulations, and ease of construction. The road and rail entrances to the site and their related facilities will be positioned to provide for convenient interface with existing highways and railroads (see Figure 4.1-1).

\subsubsection{Waste Handling Building Layout Considerations}

Section 3.1 describes the operations and equipment required to receive, process, package, and emplace nuclear waste. This section and Sections 4.2.5 and 4.2.6 describe the physical arrangement of the remote hot cells within the waste handling buildings and the areas in which most of the operations described in Section 3.1 will be performed.

The two waste handling buildings (WHB 1 and WHB 2) are shown in Figure 4.2-2, Surface Facility Arrangement. These buildings will contain hot cells, equipment, contamination barriers, and radiation shielding designed for safe reception, processing, and packaging of the types and quantities of waste forms identified in Chapter 2. Due to the relatively high production rate required, the buildings will contain extensive parallel production capacity. Numerous inter-cell handling systems will be necessary to efficiently transfer waste units, packaging components, and failed equipment components among operations that require different contamination control zones.

Each waste handling building will have three primary waste handling and processing levels. Figure 4.2-3 schematically represents the sequence of waste flow through the three levels of WHB 2. Although WHB 1 will receive and process different types and quantities of waste forms, its layout considerations are very similar to WHB 2. Most processing and packaging operations will be located in hot cells on the second level of each building. Waste will be transferred by first lowering the item--a canister for example--through the floor of its cell into one of several inter-cell carriers. The carrier will travel in dedicated transfer corridors in the first level of each building to a position under the destination cell, and the item will be 



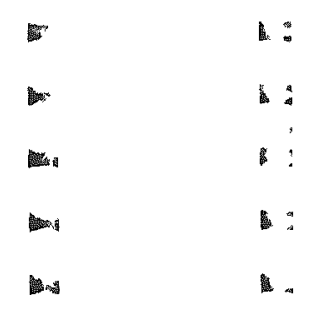

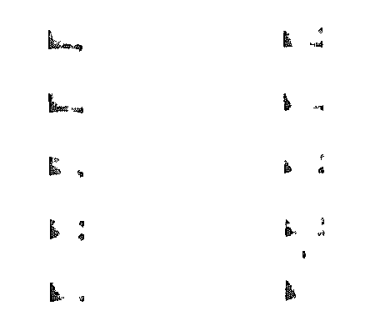

\begin{tabular}{|c|c|}
\hline$\forall$ & Im. \\
\hline L. & 4.4 \\
\hline L: & $w$ \\
\hline 11 & $M$ \\
\hline and & $\Delta$ \\
\hline
\end{tabular}
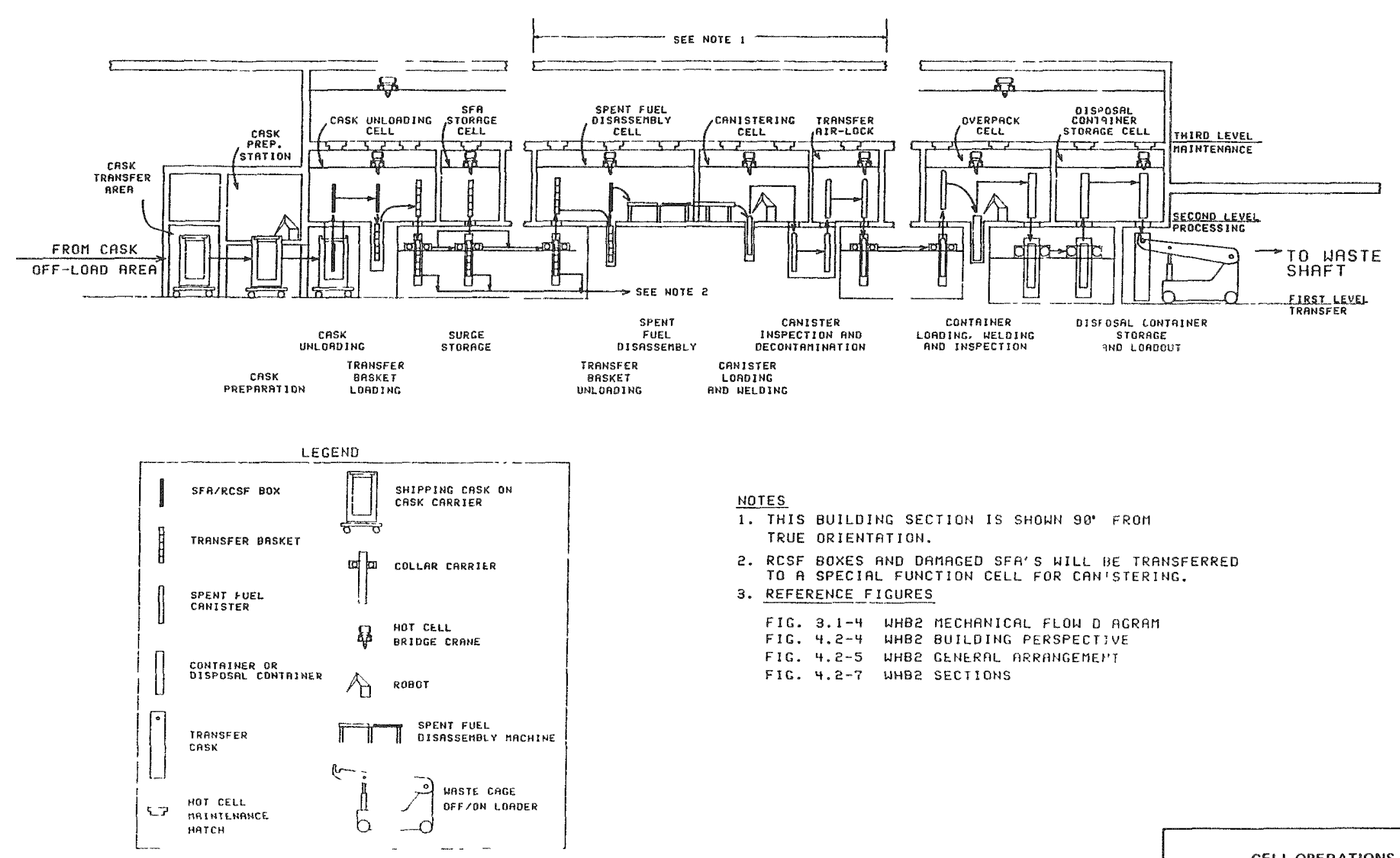

$\frac{\text { NOTES }}{1 . \text { THIS BUILDING SECTION IS SHOWN } 90^{\circ} \text { FROM }}$

THIS BUILDING SEC
TRUE DRIENTATION.

2. RCSF BOXES AND DAMAGED SFA'S WILL BE TRANSFERRED

3. REFERENCE

3. REFERENCE FI GURES

FIG. $3.1-4$ WHBE MECHANICAL FLOW D RGRAM

FIG. $4.2-4$ WHBE BUILDING PERSPECTIVE

FIG. $4.2-7$ WHBE SECIIONS 

lifted into the cell. Since most waste items will have a long slender shape (SFAs, transfer baskets, canisters, containers, etc.), vertical movement through the ports will minimize the necessary size of the ports and thus reduce the potential for contamination migration across cell boundaries.

The third level of each waste handling building will be used for overhead access to the hot cells. This will provide for maintenance activities that require removal and transfer of large equipment components to and from remote equipment maintenance cells or new parts supply areas. Several large capacity cranes in the third level will be used to temporarily remove concrete hatches in the ceilings of the individual hot cells and then transfer the necessary equipment items. All operations within the affected hot cells will be shut down, and cell ventilation will be regulated during these transfer operations. This will minimize the travel of airborne contamination to the third level. Small equipment components will be transferred via the first level inter-cell transfer system so as to minimize the interruption of process operations.

The layout of the two buildings is primarily based on three design considerations: contamination control, limiting occupational dose, and operational efficiency.

\subsubsection{Contamination Control}

The receipt, handling, and processing of incoming waste forms, particularly spent fuel assemblies, will result in varying levels of tactile and airborne radioactive contamination in the hot cells. Therefore, this material must be safely confined within defined contamination control zones. These zones will operate in conjunction with the building ventilation systems to contain the contamination and to prevent its spread outside the hot cells.

The design philosophy to maintain contamination control requires a combination of structural barriers, air pressure controls, seals, contamination surveys, radiation monitors, and operating procedures to restrict contamination to those areas which are designed to operate in a contaminated condition. 
These normally contaminated areas will include the cask unloading, spent fuel disassembly, canistering, special function, and remote equipment maintenance cells and the inter-cell transfer corridors. (For further discussion, see Sections 6.1, Control of Radioactive Releases During Normal Operations, and 6.2., Control of Releases Under Abnormal Conditions). Within these normally contaminated cells, a decontamination policy will be established to prevent the continuous accumulation of contaminated material over the operating life of the repository. This policy will benefit not only the operational phase of the waste handling buildings, but also their decommissioning.

The decontamination policy will specify the maximum permissible level of contamination for each cell. It will also define schedules and procedures for determining the contamination level in each cell and specify the method of decontamination and restriction of operations prior to, during, and after the decontamination. For example, the disassembly cells are expected to have the highest level of permissible contamination since they enclose the operation generating the largest amount of contamination. They will also be remotely operated and maintained without the need for personnel entry. Other celis such as the canistering cell will have lower permissible levels of contamination in order to minimize the need for decontamination of canisters and also allow infrequent personnel entry without major cell decontamination.

Operations associated with decontaminated spent fuel canisters, defense high-level waste (DHLW) and West Valley high-level waste (WVHL) canisters, and disposal containers will be maintained in an uncontaminated condition. Should contamination be detected in cells or corridors containing these items, the area will be decontaminated and the source of the contamination identified and corrected. Strict enforcement of these procedures will ensure that both waste handling buildings will continue to operate throughout the life of the repository without the threat of contaminating the shaft, the underground, or personnel occupied areas of the surface. 


\subsubsection{Limiting Occupational Dose}

Handling and processing of high-level nuclear waste will require that occupational radiation dose be limited to the levels listed in Section 2.5.1. This will be accomplished by one or more of the following methods:

1. Shielding to reduce radiation to levels permitting operating personnel to perform required operating and maintenance tasks.

2. Remote or robotic operating equipment to permit operating personnel to maintain a sufficient distance from the radiation source(s).

3. Administrative control of the time during which operating personnel will be in the vicinity of radiation sources.

The primary form of shielding in the waste handling buildings will be heavily reinforced concrete hot cells. These cells will permit high-level nuclear waste forms to be handled and processed remotely by operators shielded by the concrete walls and shielding windows. Arriving shipping casks will include sufficient shielding to reduce surface dose rates to 200 mrem per hour as required by U.S. Department of Transportation (DOT) regulations (49CFR173.400). This shielding will not be sufficient for repository personnel to be in close daily proximity with loaded casks during the time-consuming operations of preparing the casks for unloading. Thus, to achieve as low as reasonably achievable (ALARA) goals, cask preparation activities will be performed remotely. Personnel will be permitted occasional access to loaded casks (within administrative controls) to deal with specific problems until the outside head is removed. However, in normal operations the entire preparation process will be controlled from a remote location.

Disposal container handling outside the hot cells may require personnel to be present, even though the primary control of handling equipment will be remote. To accommodate personnel in these areas, the transfer casks will constitute a second, portable shield system. They will provide shielding in the turntable building, the waste shaft, and the underground entries. The transfer casks will be cylindrical, thick-walled vessels into which the 
disposal containers will be placed. The casks will have removable heads at both ends to facilitate loading the disposal containers into the casks and unloading the disposal containers during emplacement.

The conceptual design of the transfer casks is based on limiting the cask surface dose rate (excluding neutrons) to 50 mrem per hour when transferring a consolidated pressurized water reactor (PWR) disposal container. (Additional design for shielding of neutrons will take place in ACD.) While this dose rate will not allow continuous personnel exposure at the surface of a loaded cask, it will permit intermittent exposure nearby as necessary, or continuous work in the general area. Two transfer cask concepts have been developed for the conceptual design. They are described in Table 4.2-2. The primary difference between the two is length, which is determined by the disposal container each is designed to handle.

\subsubsection{Operational Efficiency}

Contamination control and limiting occupational dose are important design issues that affect public and operating personnel safety. Once these issues have been satisfactorily addressed, design of the waste handling buildings must be cost effective in meeting the production goals of the repository.

The handing, processing, and emplacement of nuclear waste will require a complex series of operations involving equipment and associated building space. The cost of this equipment and building space, particularly in hot cells, will be a significant portion of the surface facility capital costs. Consequently, an operational analysis of the waste handling system using a computer simulation model was performed during the SCP conceptual design. Its goal was to minimize the amount (and cost) of equipment and building space while maintaining a high degree of confidence that the production goals stated in Chapter 2, Basis for SCP Salt Repository Conceptual Design, will be met.

\subsection{Computer Simulation Model - Description. Due to the large} number and the complexity of repository operations, a computer simulation model was developed and used to evaluate various building design concepts. The computer model simulated all waste handling and processing operations from 
Table 4.2-2. Transfer Cask Design Specifications

\begin{tabular}{lcc}
\hline & $\begin{array}{c}\text { Transfer } \\
\text { Design Feature }\end{array}$ & $\begin{array}{l}\text { Transfer } \\
\text { Cask 2 (a) }\end{array}$ \\
\hline Container OD, in & 37.3 (b) & 33.4 \\
Container Length, ft & 15.9 (b) & 11.1 \\
Cask OD, in & 53.1 & 49.2 \\
Cask Thickness, wall, in & 6.9 (c) & 6.9 \\
Cask Thickness, head, in & 3.7 (d) & 3.7 \\
Cask Overall Length, ft (e) & 17.0 & 12.2 \\
Cask Weight, empty, tons & 25.3 & 16.8 \\
Cask Weight, gross, tons & 48.3 (f) & 26.9 \\
\hline
\end{tabular}

\footnotetext{
(a) Transfer Cask 1 - SF (Phases 1 and 2), FAH (Phase 2). Transfer Cask 2 DHLW, WHLW (Phase 2).

(b) Dimensions of largest container (BWR SF) - Used as basis for Cask 1 design.

(c) Shield thickness based on surface dose rate of $50 \mathrm{mrem} / \mathrm{hr}$.

(d) Same dose as wall, shield contribution from thick container head considered.

(e) Length for largest package with a 6 inch void added.

(f) Maximum gross weight - cask and consolidated BWR disposal container.
} 
shipping cask arrival to waste package emplacement (see Section 7.1.2, Surface Elements). These repository operations are well suited for computer simulation since they consist of a sequence of discrete activities requiring defined equipment and durations. The $A / E$ Contractor used this model as a design evaluation tool to evaluate overall system performance with given operating characteristics of equipment and the operating procedures defined in Section 3.1.

Input data consisted of building configuration parameters, estimated equipment capacities, estimated durations of operations, probabilities of inspection failures, and waste receipt rates. Output data consisted of production (emplacement) rates and equipment utilization rates. The utilization rate is defined as the percentage of total simulated time during which the individual item of equipment is being productively used. Several building design options were simulated, and the concept which met the emplacement goal while maximizing equipment utilization rates was selected.

The current development stage of the model does not provide for it to simulate nonproductive time durations such as repairing of failed equipment, preventive maintenance, decontamination, and utility outages. Therefore, the maximum permissible utilization rate for any equipment item was selected at a level that allows a sufficient margin for these nonproductive time durations. Also, the philosophy used in the conceptual design was to require at least one operational spare for all critical systems and all remote equipment directly involved in waste handling and packaging operations, regardless of the predicted utilization rate of a single item or system. 
The model was not used for sizing of surge storage areas. The need for surge storage will be based on two considerations: (1) equipment or system failures which temporarily halt throughput and, (2) scheduling of disassembly and emplacement operations by waste type. Neither of these two considerations are currently part of the simulation model, but they will be added in future expansions of the model.

\subsection{Computer Simulation Model - Significant Results. Significant} results obtained from the simulation model and incorporated in the conceptual design are discussed below.

4.2.4.3.2.1 Number of truck and rail receiving stations. The design criteria states in Section 2.4 require that each waste handling building shall have the capability to receive waste forms in either of two transportation modes: $70 \%$ truck $/ 30 \%$ rail or $20 \%$ truck $/ 80 \%$ rail. The simulation showed that seven truck stations and three rail stations would meet this requirement in WHB 2 with adequate spare capacity. In WHB 1, two truck stations and one rail station will meet the receiving requirements of phase I operations. Since phase II operations of WHB 1 primarily involve rail receipt of DHLW and WVHLW canisters, the model indicated that one rail line would be sufficient for these receipts. Nevertheless, WHB 1 will have two rail stations and one truck station for the following reasons:

1. One of the two rail stations can be converted to receive truck casks to accommodate the $70 \%$ truck/ $30 \%$ rail receiving option in phase $I$.

2. As stated previously, the philosophy used in the conceptual design was to require at least one operational spare for all systems and equipment directly involved in waste handling and packaging operations.

4.2.4.3.2.2 Number of disassembly cells and machines. The number of disassembly cells and the number of machines in each cell have a significant influence on the size of WHB 2. The A/E Contractor selected a total of four disassembly cells for WHB 2. Each cell will contain two disassembly machines. 
Two cells will be dedicated to pressurized water reactor (PWR) SFA disassembly, and two will be dedicated to boiling water reactor (BWR) SFA disassembly.

The most important design parameter affecting the number of disassembly machines is the expected throughput capacity of a typical machine. Westinghouse has identified a design criterion requiring 1.87 hours for a PWR disassembly and 1.13 hours for a BWR disassembly using a $50 \%$ hot cell operating factor (Westinghouse Electric Corporation, 1984). However, the A/E Contractor applied additional operating factors, which further reduced the expected machine output, in recognition of the following concerns:

1. The disassembly machines will be the most complex pieces of equipment in WHB 2. As currently envisioned in the Westinghouse conceptual design, each machine will simultaneously extract the full complement of fuel rods from three PWR or seven BWR assemblies. Since these machines are currently in a very early stage of development, the philosophy of the $A / E$ Contractor was to establish a conservative building size that will accommodate the unknowns of equipment development and performance. As the development program for the disassembly machine proceeds, this design area will be updated to reflect development results.

2. The operation of the disassembly machines will require a high level of operator interaction. It is expected that the current design durations for disassembly will increase due to shift changes, varying levels of operator skill, and other operator/machine interface factors.

The simulation model indicated that the utilization rates of equipment supporting the disassembly machines will be much lower than that of the machines themselves. Therefore, a cell configuration with two disassembly machines sharing the use of a single fuel assembly hardware (FAH) compaction machine, handling crane, and holding pit has been adopted to increase the utilization of this equipment. 
4.2.4.3.2.3 Canister and Canister welding machines. The simulation model indicated that one canister welding machine in each canistering cell (or special functional cell) and one welding machine in each overpacking cell would be sufficient to meet production goals. However, the conceptual design of both waste handling buildings includes two welding machines in each of the cells to maintain the guideline of having one operational spare available for critical equipment regardless of utilization.

The time duration used in the simulation model for the disposal container seal weld was estimated by the $\mathrm{A} / \mathrm{E}$ Contractor and based on performing and inspecting the narrow gap groove weld specified in ONWI-517 (Westinghouse Electric Corporation, 1986). Considerations in estimating the amount of welding time for the disposal container included the circumference of the weld groove, the volume of the groove, and the speed of the welding head.

\subsection{Waste Handling Building 2 Description}

Operations will start up in WHB 2 in the year 2001. The building's primary mission will be to receive, consolidate, and package spent fuel assemblies (SFAs). It will also receive and package RCSF boxes from the year 2001 to 2007 (Table 2.4-2). Figure 4.2-4 displays a perspective view of WHB 2 .

Figure 4.2-5 displays the general arrangement of WHB 2. The central core of the building will consist of a series of hot cells enclosed by reinforced concrete walls. The hot cells will be located on the second level and will be surrounded by operating galleries. The first level will contain several transfer corridors to be used for remote inter-cell transfer of waste forms, failed equipment components, and waste packaging components. The third level will provide access into the hot cells for major maintenance operations. Surrounding the core of the building will be several support areas including canister and container component receiving and storage, radwaste processing, control rooms, health physics offices, personnel offices, and contact maintenance areas. 





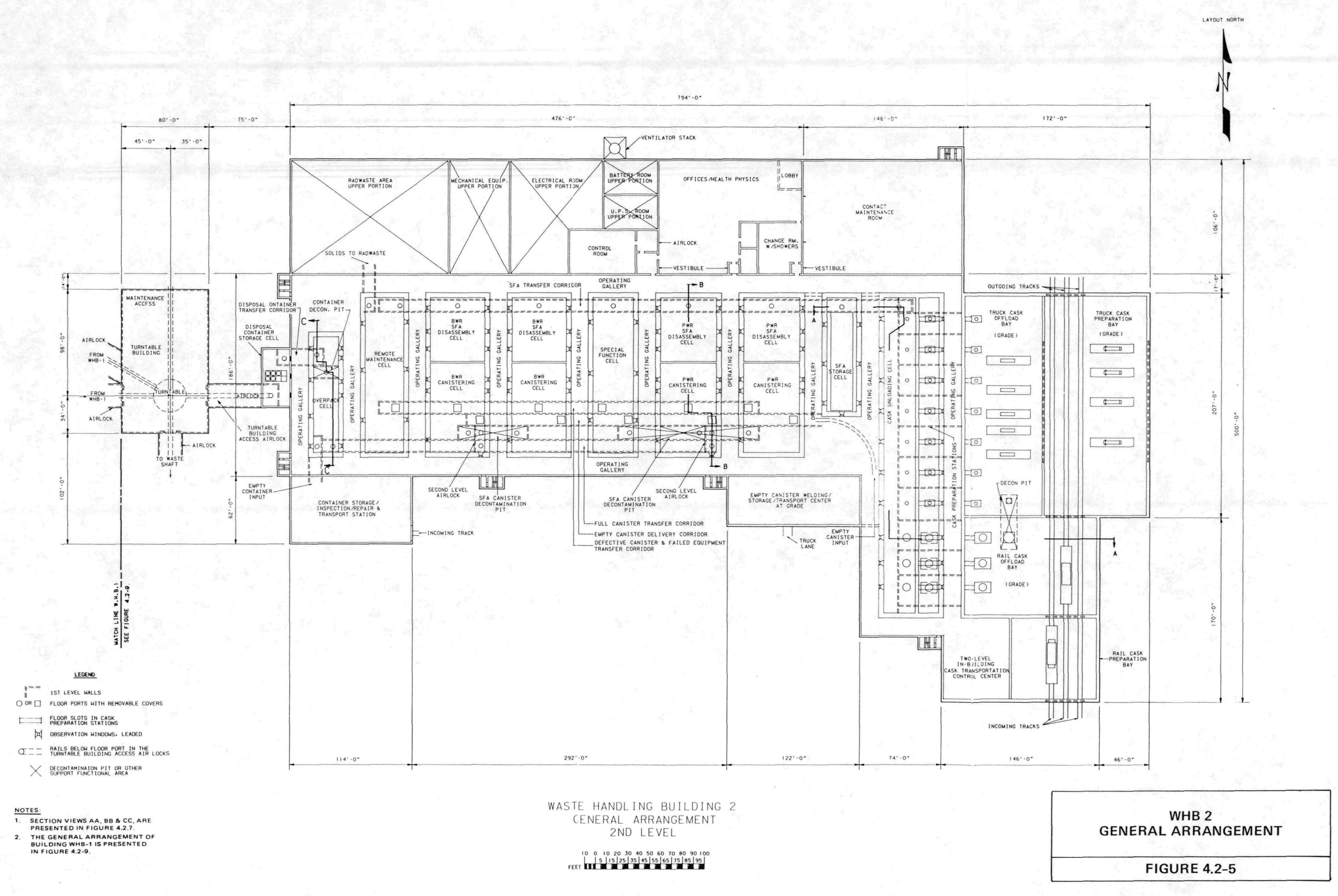


O 100 
The size of the building was determined by results from severai concurrent design efforts. Generalized cell layouts were done to establish the physical size of individual cells. Results from the simulation model (Section 4.2.4.3) established the number of cells and the quantity of major equipment required. Maintenance, support, and utility needs further defined the size of the building required to provide these services.

Figure 4.2-6 displays the cell layouts of the disassembly, canistering, and overpacking cells. They account for approximately $75 \%$ of the building's hot cell area. These layouts are based on estimated equipment sizes and typical hot cell layout considerations such as crane coverage, renote viewing angles, and dedicated handling paths. Figure 4.2-7 displays elevation views of these cells and the cask receiving and unloading areas.

The following subsections briefly describe the functions of each area or hot cell in WHB 2 .

\subsubsection{Cask Receiving and Offloading (Figure 4.2-7, Section A-A)}

Each truck cask on its trailer will enter WHB 2 through one of several doors at the east end of the building. After the personnel barriers and shipping unit components are removed, the cask will be moved to an offloading bay where it will be lifted off the trailer and placed on one of seven cask carriers serving the cask unloading lines. Rail casks will will enter the building on one of three north-south spurs which will pass through the east end of the building. This pass through arrangement will increase the efficiency of handling rail shipping units.

It is assumed that all casks will leave the repository on the same shipping units on which they arrive. A decontamination pit with access from either area will be located between the truck and rail cask offloading areas. Should an incoming shipping cask require decontamination, it will be lowered into this pit for decontamination prior to waste unloading. 


$$
\ldots
$$

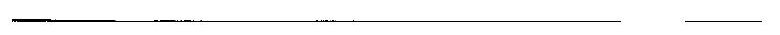





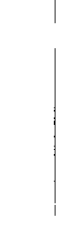

1 


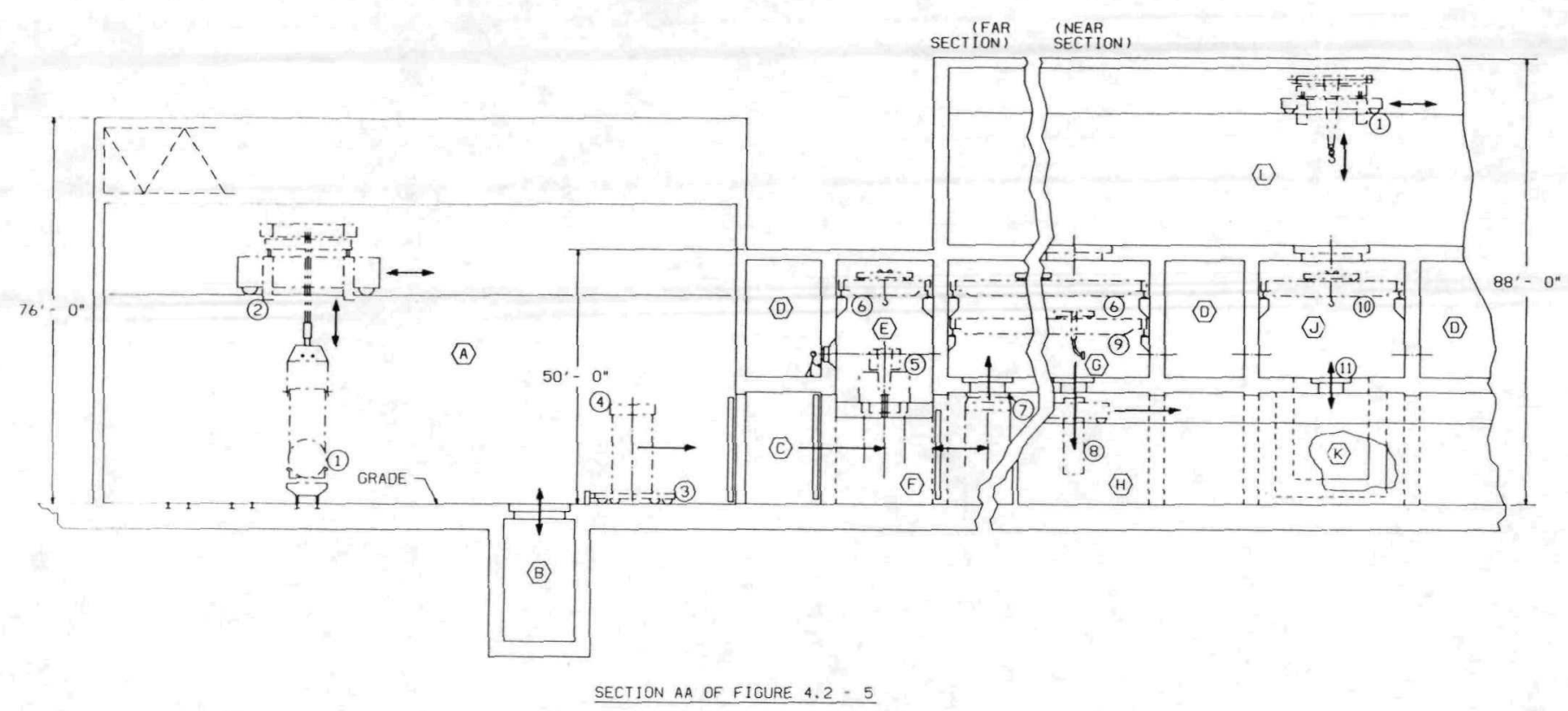

SECTION AA OF FIOURE 4.2-5

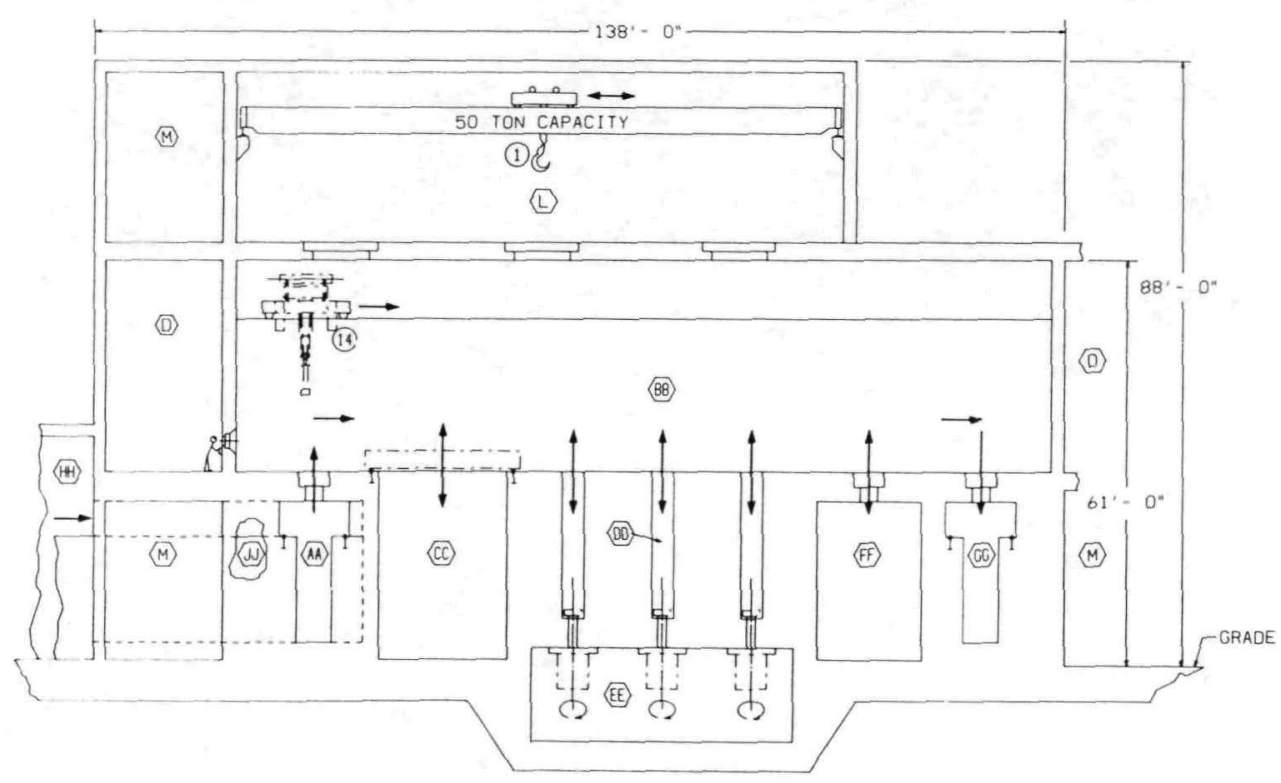

SECTION CC OF FIGUARE 4.2.-5

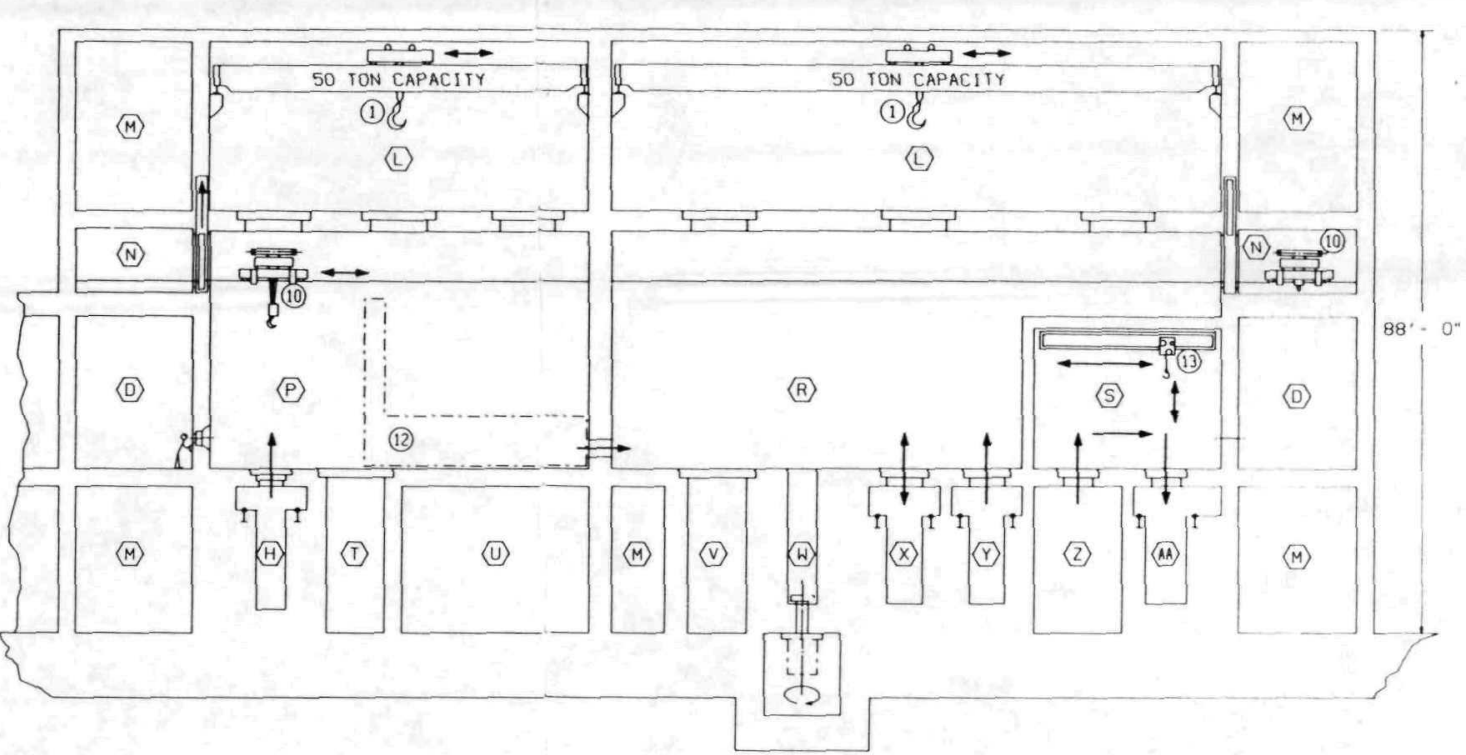

AAEAS

(4) Rall CASK OFFLoading Be

(B) DECONAAMINATION PII

(ENAT AREA

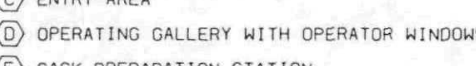

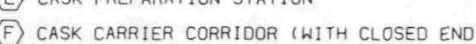

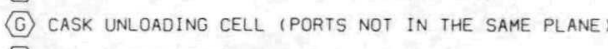
SPA SFA TRRASFER CORRIDOC

(X) SUROE STORAGE PIT

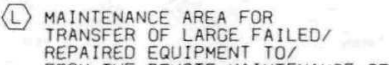

(M) UTLLITY CORRIDORS

(40) Brioge CRANE MaINTENANCE ROOMS

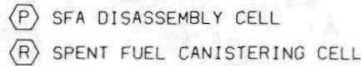

(5) AIR LOCK - CELL EXIT

(I) SFA LLG STOOAGE PII

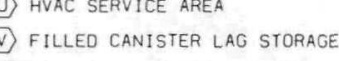

Nance RoOM BELOW,

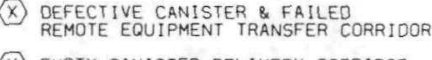

(2) ENPTY CANISTER DELLIVERY CORRIOOR

(4凶) FULL CANISTER TRANSEER CORRI DOO

(308) OVERPACK CELL

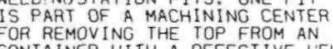

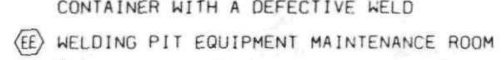

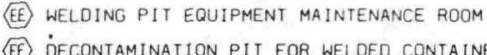

(®i) DISPOSAL CONTA INER TRANSEER CORR IDOR

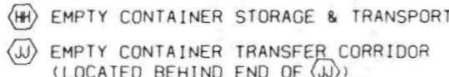

WHB 2 SECTIONS

FIGURE $4.2-7$

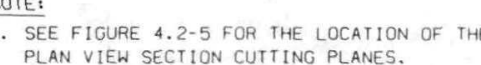

\begin{tabular}{|c|}
\hline $\begin{array}{c}\text { WHB 2 } \\
\text { SECTIONS }\end{array}$ \\
\hline FIGURE 4.2-7 \\
\hline
\end{tabular}


$0+0$ 


\subsubsection{Shipping Cask Unloading Lines}

WHB 2 will contain seven truck cask unloading lines and three rail cask unloading lines. Each cask unloading line will have a carrier traveling in an individual corridor to transport the cask from the cask offloading area to a cask preparation station and then to a port in the floor of the cask unloading cell.

The cask preparation station will be on the second level. A wide slot in its floor will permit movement and positioning of the top of the cask near a robotic arm. This feature will allow the operator in an adjacent area to view the top of the cask and the operation of the robotic arm.

The west end of each cask unloading corridor will be at a point beneath a separate port for each corridor in the floor of the cask unloading cell. As described in Section 3.1.2, an expandable seal assembly will be used during unloading to isolate the exterior of the cask and the transfer corridor from the contaminated environment of the cask unloading cell.

\subsubsection{Cask Unloading Cell}

The cask unloading cell will contain ten entry ports for unloading waste forms from shipping casks. A small holding pit will be located adjacent to each port for temporary storage of waste forms in transfer baskets [see Section 3.1.2.3, Unload Spent Fuel Assembly/Reactor Consolidated Spent Fuel (SFA/RCSF) Boxes]. An overhead manipulator will travel the full length of the cell for inspection of cask interiors before and after unloading. Two bridge cranes will handle all waste forms and transfer baskets. Both full and empty transfer baskets will enter and leave the cell through an exit port at the north end. The transfer baskets will leave and arrive on a collar carrier traveling in a first level corridor under several cells, as shown on Figure 4.2-7, Section BB, Area $H$. The carrier will transport the transfer baskets containing waste forms either to one of the disassembly cells or to the surge storage cell. 


\subsubsection{SFA Surge Storage Cell}

A dedicated surge storage cell will be located between the cask unloading cell and the disassembly cells. This cell will have a storage capacity of $750 \mathrm{MTU}$, including approximately 1,000 PWR SFAs and 1,500 BWR SFAs which is equivalent to the quantity of SFAs to be received in three months. The use of an isolated cell for temporary storage of SFAs in transfer baskets is based on the following needs:

1. The cell will provide a buffer storage area between two major building operations: cask receiving and unloading, and spent fuel disassembly. Should either operation be halted or reduced in capacity, the other will be able to continue operation.

2. The spent fuel disassembly machines will have replaceable indexing fixtures that will be unique to the type, size, and manufacturer of each specific assembly. Therefore, the operation of disassembly machines will be conducted on a campaign basis. Incoming SFAs with common features will be temporarily stored in the SFA surge storage cell until a sufficient number have been received to justify the time necessary to change a machine's fixtures and begin a new campaign run.

3. The storage of incoming assemblies in an enclosed cell will permit the use of a dedicated cooling system for removal of decay heat and control of SFA fuel rod temperature.

\subsubsection{Disassembly and Canistering Cells (Figures 4.2-6 and 4.2-7, Section B-B)}

A large portion of the remote hot cell areas in WHB 2 will be within the disassembly and canistering cells. WHB 2 will contain four disassembly cells, two dedicated to PWR SFAs and two dedicated to BWR SFAs. (See Section 4.2.4.3.2.) Each cell will contain two disassembly machines and will share the use of an FAH compaction machine, a combination bridge crane and manipulator, and a 
holding pit for temporary storage of transfer baskets. Hardware fixtures for the disassembly machines will also be stored in common wall mounted racks.

Each disassembly cell will be separated from the adjacent canistering cell by a common isolation wall. This wall will contain three horizontal loading ports for transfer of extracted fuel rods from the two disassembly cells and compacted FAH hardware from the single compaction machine into canisters positioned on the opposite side of the loading ports. These loading ports will be designed to minimize the movement of contaminated material from the heavily contaminated disassembly cell to the canistering cell.

Each canistering cell will also contain two welding robots, two weld inspection robots, and a combination bridge crane and manipulator. An exit port in the floor at the south end of each cell will be used to lower the sealed canisters into an inspection and decontamination subcell shared by adjacent canistering cells. After inspection, and decontamination if necessary, the canisters will be moved via an air lock onto a collar carrier traveling in a transfer corridor connecting all the canistering cells and the overpacking cell.

Empty canister components will be brought into the cell by another collar carrier traveling in a transfer corridor beneath the canistering cells. Canister components will be loaded onto the carrier at a loading point within the empty canister storage area.

Another carrier and transfer corridor beneath the canistering cells will be used to transfer canisters with defective welds to the special function cel1. This carrier will also transfer small failed equipment components to a remote maintenance cell.

\subsubsection{Special Function Cell}

A special function cell will be located between the PWR and BWR disassembly cells. This cell will be served by transfer corridors from several areas within the building and will be used to process the items described in Section 3.1.2.6. The cell will play an important role in maintaining the high 
production rate required in WHB 2. Should an SEA or spent fuel canister develop a problem that cannot be quickly corrected, it will be transferred to the special function cell. This will allow the disassembly and canistering cells to continue operation at their required production rate.

The operations and equipment in the special function cell will correct production problems or repair waste packaging components to an acceptable repository standard. For example, a partially disassembled SFA that has been removed from a disassembly cell because the fuel rods are stuck will be packaged intact with no further attempt to disassemble the remaining fuel rods. For spent fuel canisters with defective welds, equipment will attempt to repair or patch the defective area and recertify the canister to avoid having to transfer the canister's contents to a new canister, although this will be posible when necessary.

\subsubsection{Overpacking Cel1 (Figures 4.2-6 and 4.2-7, Section C-C)}

The overpacking cell will seal spent fuel canisters in thick-walled steel containers suitable for emplacement as disposal containers. This cell will be operated in an uncontaminated environment since all entering canisters will have been previously decontaminated. Operation in this mode will permit personnel entry for equipment maintenance and repair once all waste forms have been removed or temporarily shielded. The cell will contain two welding and one inspection robot for the critical operation of welding the container seal. Prior to transfer out of the cell, each sealed container will be inspected for contamination. Only if the container requires decontamination will it be lowered into a decontamination subcell beneath the cell. After decontamination, it will be raised back into the cell for reinspection. The overpacking cell will also have a repair station containing special equipment to remove the tops of disposal containers having defective welds that cannot be repaired.

\subsubsection{Remote Equipment Maintenance Cell}

Equipment in the processing cells (except the overpacking cell) will be remotely maintained or repaired in place to the maximum extent possible. When 
an equipment component must be removed or replaced, it will be taken to the remote equipment maintenance cell. This cell will have extensive remote capabilities to repair or dispose of failed equipment. A dedicated carrier and transfer corridor at the south end of the cell will be used to remove radwaste to the adjacent radwaste processing area. The turntable building will be located between the two waste handling buildings and will be constructed with WHB1.

The method of transferring failed equipment components to and from this hot cell will depend on the size of the component. Small components will be transferred by one of the waste form carriers in the first level transfer corridors. Large items will be moved by cranes operating in the third level transfer area through overhead cell hatches (see Figures 4.2-3 and 4.2-7). To minimize the spread of contamination to the third level during this transfer, all operations in the affected cell will be shutdown and the cell ventilation will be appropriately regulated while the overhead hatches are open.

\subsubsection{Disposal Container Storage Cell}

The disposal container storage cell will provide the main surge storage point between the surface packaging operations and the underground emplacement operations. Disposal containers will enter the cell from the overpacking cell. Normally, disposal containers will not be stored in the cell unless (1) all emplacement equipment described in Sections 3.1.2.7, Downshaft Transfer of Disposal Container, and 3.1.2.8, Transfer and Emplace Disposal Container, is not available, or (2) there has been a temporary shutdown in underground emplacement operations. When ready to be emplaced, each disposal container will be lowered into a transfer cask which itself will be supported by the surface cage off/on loader as shown in Figure 4.2-8. After insertion of the waste container into the transfer cask, the cask will be closed and transferred out of WHB 2 to the turntable building and waste shaft.

\subsubsection{Waste Handling Building 1 Description}

As noted in Section 2.4, Design Requirements, WHB 1 will be operated during Phase I and Phase II. During Phase I, from 1998-2002, WHB 1 will receive and package intact SFAs and RCSF boxes. Starting in 2003, WHB 1 will 



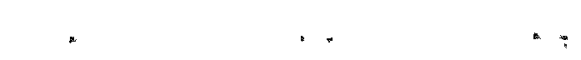

A.

NOMENCLATURE

(1) WASTE SHAFT

(2) TURNTABLE BUILDING

(3) TRANSFER CASK WITH DISPOSAL CONTAINER

(4) WASTE SHAFT CAGE

(5) SURFACE CAGE OFF/ON LOADER

(6) STABILIZING ARMS-ARTICULATED

(7) CASK COVER WITH CAPTIVE BOLTS

(8) DISPOSAL CONTAINER BEING LOWERED INTO

CASK BY BRIDGE CRANE

(9) TURNTABLE

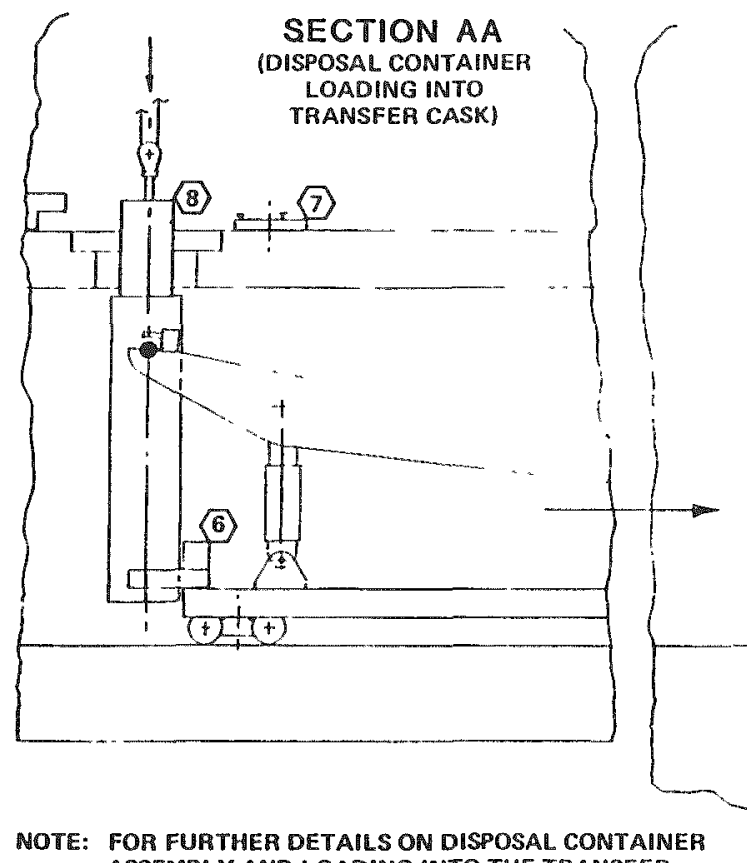

SECTION AA LOADER AND CASK ON TURNTABLE! ASSEMBLY AND LOADING INTO THE TRANSFER

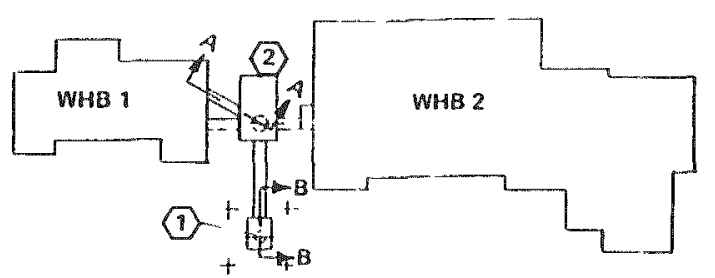

GEN'L ARRANGEMENT AT WASTE SHAFT (AS IN FiG. 4.2-2)
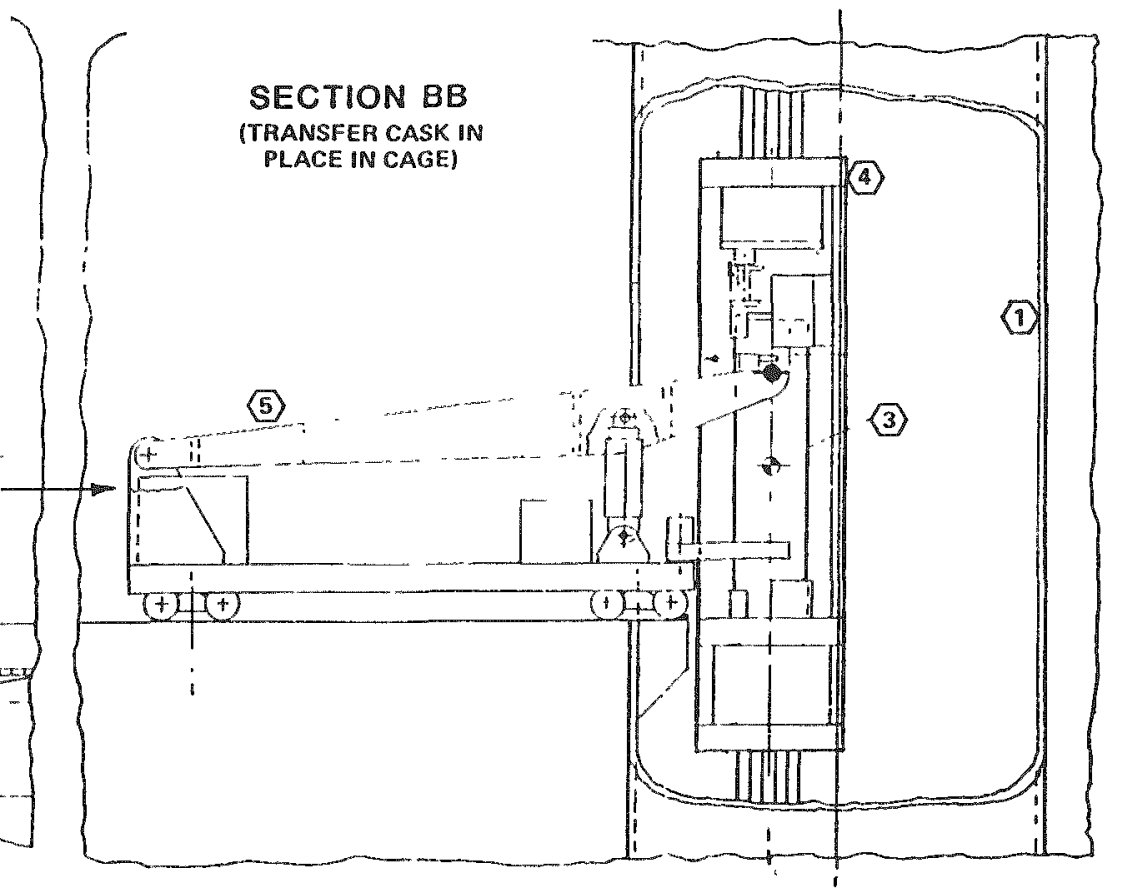

SECTION BB PLACE IN CAGE)

\section{(9)}

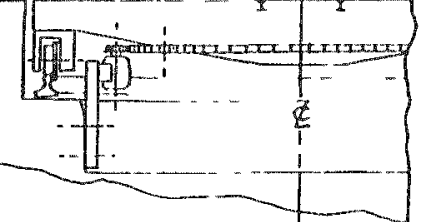

$+$

WASTE SHAFT LOADING AREA LAYOUT AND ELEVATIONS 

begin receiving and overpacking DHLW and WHLW that will have been canistered previously at other sites. Additionally, all surface related performance confirmation operations will be located within WHB 1. Minor equipment modification and decontamination of selected areas of the building will be necessary in the transition from Phase I to Phase II operations.

Figure 4.2-9 displays the layout of WHB 1 . The main differences in operation of WHB 1 from WHB 2 will be in the following two areas:

1. WHB 1 will receive a much smaller annual quantity of shipping casks in both operating phases. Thus the cask receiving, preparation and unloading areas will be smaller.

2. During Phase I, SFAs will be placed intact into canisters rather than being disassembled. During Phase II, DHLW and WWLW canisters will not require many of the operations of WHB 2. These simpler operations reduce the number of required hot cells in WHB 1.

Although because of these differences WHB 1 will be a smaller building than WHB 2, the annual output of disposal containers from the two buildings will be approximately equal. This is primarily due to disassembly of the SFAs which significantly reduces the specific volume of spent fuel packaged in canisters (see Table 2.1-2).

The configuration of the overpacking cell in WHB 1 will be identical to the overpacking cell in WHB 2 described in section 4.2.5.7. This is because the throughput of DHLW canisters in WHB 1 is approximately equal to the throughput of spent fuel canisters in WHB 2. The following sections describe areas in WHB 1 where there are major differences from similar areas in WHB 2, and those areas and cells in WHB 1 that are not found in WHB 2 .

\subsubsection{Cask Receiving and Offloading}

The cask receiving rate of WHB 1 will require only three cask unloading lines. Truck and rail cask preparation and offloading areas will therefore be combined. Both truck and rail shipping units will enter and leave at the west end of the building. 





\subsubsection{Cask Unloading Cell}

The cask unloading cell will contain three unloading ports. During Phase I operations, SFAs and RCSF boxes will be loaded into transfer baskets and then removed from the cell by a carrier travelling in a corridor beneath the south end of the cask unloading and canistering cell. This corridor will also extend to the remote maintenance cell for transfer of small failed equipment components. Should the canistering cell not be able to receive a transfer basket immediately, the basket will be stored temporarily in a surge storage pit within the unloading cell rather than in a separate storage cell as in WHB 2. The capacity of this storage pit will be 100 MTU equivalent, including approximately 300 SFAs (Phase I) or 200 DHLW canisters (Phase II). The cask unloading cell, canistering cell, and their common transfer corridor will be operated in a contaminated condition throughout Phase I operations.

Most of the Phase II operations will only involve receiving rail casks containing DHLW and WHLW canisters. It is expected that these waste forms will be received in an uncontaminated condition. Therefore, they will be transferred directly to the overpacking cell by a carrier travelling in a transfer corridor at the north end of the unloading cell. This is the same carrier that will transfer decontaminated SFA canisters from the canistering cell to the overpacking cell during Phase I. However, before HLW canisters are transferred to the overpacking cell, they will be lowered into a decontamination and inspection subcell at the north end of the cask unloading cell for a contamination inspection. After inspection (and decontamination if necessary) the canisters will be transferred via an air lock onto the carrier for transfer to the overpacking cell.

The use of separate transfer corridors for removing contaminated SFAs and RCSE boxes in Phase I and HLW canisters in Phase II will have a significant advantage to repository operations. Upon completion of Phase I operations, only the cask unloading cell will require decontamination to prepare it for receiving the uncontaminated DHLW and WHLW canisters. The SFA transfer corridor is not expected to be used on a regular basis during Phase II operations. 


\subsubsection{Canistering Cell}

During Phase $I$, the canistering cell in WHB 1 will be used to seal intact SFAs and RCSF boxes in canisters prior to overpacking. It is expected to operate in a contaminated environment due to the continuous presence of the incoming contaminated waste forms. The cell will include an inspection and decontamination subcell and an air lock transfer cubicle at its north end. The subcell design will be similar in layout and function to the decontamination subcell and air lock in the cask unloading cell. An additional transfer corridor at the north end of the cell will be used to supply empty canister components from a canister component receiving and assembly area. In WHB 1 , the canistering cell will also operate as a special function cell. This cell is not expected to be used on a regular basis during Phase II operations.

\subsubsection{Performance Confirmation Cell}

The surface operations associated with the waste package performance confirmation program (described in Section 6.5. Performance Confirmation) will be located adjacent to the disposal container storage cell at the east end of WHB 1. All disposal containers removed from the repository underground during both Phase I and Phase II operations as part of the performance confirmation program will be transported to the performance confirmation cell in transfer casks similar to those used for disposal containers (Section 4.2.4.2). The transfer casks will be opened and positioned under a port in the performance confirmation cell through which the performance confirmation package will be lifted into the cell.

The performance confirmation cell will have the necessary equipment to do all testing to be performed at the repository. As a minimum, the cell will have the capability to carefully remove all encrusted salt material around the disposal container for investigation of the salt/package surface interaction. Beyond this capability, the cell design will permit the following operations:

1. If the disposal container is in good condition, return it to the underground for emplacement by transferring it to the adjacent 
disposal container storage cell via a decontamination pit shared by the two cells.

2. Open the disposal container and remove and inspect the enclosed canister. The canister can then be transferred to the overpacking cell for repackaging. Transfer will be via a carrier traveling in a dedicated transfer corridor between the two cells. If required for detailed examination, the empty container can then be shipped offsite via the performance confirmation shipping station adjacent to the cell.

3. Ship the entire disposal container, including the enclosed canister, offsite via the performance confirmation shipping station. This will allow detailed testing of the entire container to be conducted offsite. 


\subsection{SHAFT FACILITIES}

The underground repository horizon will be accessed through vertical shafts connecting with the surface facilities. The following sections describe the number and functions of the shafts, lining and seal systems applicable to shaft structures, and required equipment and facilities for each shaft.

This design assumes that the exploratory shaft facility (ESF) will be designed and constructed to licensable standards allowing integration with the repository. ESF/repository integration is discussed further in Section 7.3 .3 , The Effect of the ESF.

The underground development sequence at the emplacement horizon is covered in Section 3.3, Underground Development. Section 3.4, Ventilation, addresses repository ventilation and the role of shafts in this function. Sections 4.4, Underground Facilities, and 4.5, Subsurface Repository Operations, describe the underground facilities and operations.

\subsubsection{Shaft Requirements}

\subsubsection{Number of Shafts}

Six shafts will be required for the repository underground facility. Two of them ( $F$ and $G$ ) will be constructed during site characterization as part of the ESF. Four additional shafts (A, B, D, and E) will be required for the repository. If Shafts $F$ and $G$ are not used as emplacement air intakes, then a single, larger diameter shaft (Shaft $C$ ) will be constructed to provide the same functions as the two exploratory shafts (ESs). Shaft $C$ will be similar in design to shaft $A$. The shaft locations are shown in Figure 3.3-1, and various details of each shaft are shown in Table 4.3-1.

\subsubsection{Shaft Functions and Sizes}

\subsection{Shaft Functions. Service, waste, and mined-salt hoisting} functions will be assigned to specific shafts. In addition, all shafts will serve various ventilation functions during the life of the repository. The 
Tab1e 4.3-1. Shaft Functions, Dimensions, Airtlows, and Hoisting Systems Details

\begin{tabular}{|c|c|c|c|c|c|c|c|c|c|}
\hline \multirow[b]{2}{*}{$\begin{array}{l}\text { Shaft Designat in } \\
\text { Shatit Function }\end{array}$} & \multicolumn{2}{|c|}{ Pre-knpiacement Const ruction } & \multicolumn{7}{|c|}{ Develogment/Cmplacement } \\
\hline & $\begin{array}{c}\text { F (ESF) } \\
\text { Mned-Salt/ } \\
\text { Frhaust }\end{array}$ & $\begin{array}{l}\text { G (ESF) } \\
\text { Servicel } \\
\text { Intake }\end{array}$ & $\begin{array}{c}\text { A } \\
\text { Eapplacement } \\
\text { Exthaust }\end{array}$ & $\begin{array}{l}\text { B } \\
\text { Waste } \\
\text { Shaft }\end{array}$ & $\begin{array}{c}\text { Mined-Salt/ } \\
\text { Exiatast }\end{array}$ & $\begin{array}{c}\mathrm{E} \\
\text { Service/ } \\
\text { Intake }\end{array}$ & $\begin{array}{l}\text { F (ESF) } \\
\text { Emplacenent } \\
\text { Int ake }\end{array}$ & $\begin{array}{l}\text { G (CSE) } \\
\text { Fappacement } \\
\text { Intake }\end{array}$ & $\begin{array}{l}\text { C(a) } \\
\text { Caplacentent } \\
\text { Intake }\end{array}$ \\
\hline \multicolumn{10}{|l|}{ Shaft Dianeter (ft) } \\
\hline Finisted, Inside & 13 & 12 & 18 & 18 & 22 & 22 & 12 & 12 & 18 \\
\hline Maxinuta Fxcavated & $2 n$ & 20 & 28 & 28 & 33 & 33 & 20 & 20 & 28 \\
\hline Shaft Depth (ft)(b) & 2,055 & 2,524 & 2,481 & 2,600 & 2,655 & 2,602 & 2,665 & 2,529 & 2,481 \\
\hline Maximum Air Volunie (cfm) & 304,000 & 304,000 & 949,000 & $22,000(d)$ & 808,000 & 808,000 & 463,500 & 463,500 & 927,000 \\
\hline Maxismum Air Veloctty (fpr) (c) & 2,690 & 2,690 & 3,730 & 90 & 2,125 & 2,125 & 4,100 & 4,100 & 3,650 \\
\hline \multicolumn{10}{|l|}{ Hoist } \\
\hline Type & pouble Druin & Doub1e Drum & -- & Friction & Friction & Friction & -- & -- & -- \\
\hline Frun size (dia in $x$ width in) & $120 \times 56$ & $144 \times 72$ & - & 190 dia & 114 d1a & $163 \mathrm{dia}$ & - & -- & - \\
\hline Horsepower & 1,200 & 1,000 & -- & 3,250 & 2,000 & 1,500 & -- & -. & -- \\
\hline Hoist ing Speed (fpm) & 1,500 & 1,200 & -- & 500 & 1,800 & 1,500 & -- & - & -- \\
\hline \multicolumn{10}{|l|}{ Conveyances } \\
\hline Type & ShIP/CB & Cage' 'wr & -- & Cage/CWT & 2 SkipstcB & Cage/Crix & & & \\
\hline Size (ft) & $3.5 \times 6 \times 24$ & $8 \times 8 \times 15$ & -- & $8 \times 8.67 \times 43$ & $4 \times 6 \times 3 ?$ & $9315: 48$ & -- & -- & -- \\
\hline Design Fayload (each: (wns) & 10 & 15 & -- & 48 & 15 & 25 & & & \\
\hline \multirow{2}{*}{\multicolumn{10}{|c|}{ Headropes }} \\
\hline & & & & & & & & & \\
\hline Number (each conveyance) & 3 & $i$ & -.- & 6 & 4 & 4 & -- & -- & -- \\
\hline piameter (in) & 2.5 & 1.75 & -- & 1.625 & 1.125 & 1.3 .5 & -- & -. & -- \\
\hline Breakung itrength Per kope (tom) & 122 & $16 \hbar$ & -. & 162 & 78 & 116 & -. & -- & -. \\
\hline Rope Safery Factor & 5.5 & 5.5 & -- & 6.7 & 6.8 & 6.3 & - & -- & -. \\
\hline \multicolumn{10}{|l|}{ Taij Fones } \\
\hline Type & -. & -. & -. & $\mathrm{Bs}$ & PS & $\mathrm{ns}$ & -. & -- & -- \\
\hline Nusber & - & -. & -- & 4 & 2 & 2 & -. & -. & -. \\
\hline Lameter (ar) & -. & -- & -- & 2.375 & 2.25 & 1.875 & -. & -. & -- \\
\hline \multicolumn{10}{|l|}{ Guides } \\
\hline Main conveyancos & Rigzad/rititer & Rigid/Tirbes & -. & $\mathrm{Rupe} / \mathrm{HIC}$ & Puperem & knpe/mi & -. & & -. \\
\hline Emergency/Irepection Loulvevances & $\cdots$ & $\cdots$ & Figid/Tiniber & Rigid/Tinter & -. & Rigid/T Inbex & FigidTinter $\mathrm{r}$ & Rigid/Tinter & Kigith inber \\
\hline 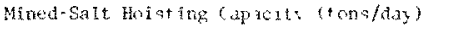 & 4,500 & -. & - & -- & 7.500 & -. & -. & -. & -- \\
\hline$O B$ - Counterbalatued ChT counterweigh & $\mathrm{rLC}=\mathrm{Fu} 1$ & Lork conl & - Mat tened St & $\mathrm{HLC}=\mathrm{Ha}$ & If Lock Conl & is = Round Stiat & & & \\
\hline
\end{tabular}



underground facility will use separate ventilation systems for development and emplacement operations as discussed in Section 3.4, Ventilation. Shafts A, B, $F$, and $G$ will serve the emplacement ventilation system, and Shafts $D$ and $E$ will be part of the development ventilation system. Shaft functions and ventilation modes used during the two operational phases, pre-emplacement construction and development/emplacement, are shown in Table 4.3-1.

The finished diameters of Shafts $A, D$, and $E$ are determined by ventilation requirements. The diameter of Shaft $B$ is dimensioned for the waste conveyance and counterweight, plus required operating clearances.

\subsection{Emplacement Ventilation Shafts (Shafts A, F, and G). During} pre-emplacement construction, Shafts $F$ and $G$ will be equipped to provide mined-salt hoisting, service hoisting, and ventilation capabilities for repository construction. For the development/emplacement phase of the repository, Shafts $F$ and $G$ will be converted to emplacement air intakes.

Fresh air will enter the underground repository through shafts $F$ and $G$ and exhaust through Shaft $A$. Shafts $F$ and $G$ will be $12 \mathrm{ft}$ in diameter as constructed to serve the site characterization program. Shaft A will be $18 \mathrm{ft}$ in diameter to accommodate the required ventilation volume and maintain the airflow velocity within practical limits.

4.3.1.2.3 Waste Shaft (Shaft B). Disposal containers will be placed in transfer casks to minimize exposure of personnel to radiation during waste handling at the shaft. The full transfer casks will be lowered from the surface to the waste emplacement horizon. The waste hoisting facility will also be used to hoist empty transfer casks, performance confirmation packages, and retrieval packages to the surface. This facility has been sized to handle the projected amounts of disposal containers. The hoisting system is designed to handle a payload of 48 tons, which is the weight of a transfer cask with a disposal container inside. Shaft $B$ will be $18 \mathrm{ft}$ in diameter to accommodate the cage, counterweight, and required operating clearances. 
Shaft B will be supplied with $22,000 \mathrm{cfm}$ of intake air, as described in Section 3.4. This air will exhaust through Shaft $A$, the main emplacement exhaust shaft. This ventilation air quantity does not influence the required shaft diameter.

4.3.1.2.4 Mined-Salt/Exhaust Shaft (Shaft D). Shaft D will accommodate development exhaust ventilation and mined-salt hoisting. The mined-salt hoisting capacity is based on the quantity of excess salt not immediately required for backfilling and which must be hoisted to the surface for storage or offsite disposal. The maximum quantity of stored salt will occur in Year 7. This will require an annual average hoisting rate of 5,800 tons per three-shift operating day. Actual peak hoisting rates are expected to exceed the annual average by 1,000 to 1,700 tons per day; therefore, the mined-salt hoist will be sized to handle 7,500 tons per day.

Twenty-seven years after construction authorization, mined-salt hoisting will cease and the mined-salt shaft will be converted to transferring salt from the surface to the subsurface at an average rate of 2,900 tons per three-shift operating day. For this function, a dedicated backfill pipe will be installed. Reclaimed salt from the surface stockpile will be crushed, screened, and transported to a feeder at the top of the backfill pipe. At the shaft bottom the salt will be collected in a hopper and transferred to a storage bin. Backfill salt will be distributed by conveyor to the backfill areas as required.

Shaft D will be $22 \mathrm{ft}$ in diameter which is an adequate cross section to keep the velocity of the ventilation airflow within practical limits. Exhaust air from the development side of the repository will enter the shaft at the emplacement horizon and discharge through a ventilation bypass at the shaft collar.

\subsection{Service/Intake Shaft (Shaft E). Shaft E will be equipped for} hoisting and lowering personnel, equipment, and materials. The hoisting capacity will be 100 persons or a maximum of 25 tons for equipment and materials. In addition, this shaft will serve as the intake airway for the development ventilation system. 
Shaft $\mathrm{E}$ will be $22 \mathrm{ft}$ in diameter. Air from the intake fans will enter the shaft through a ventilation bypass at the collar and exit into the entries at the repository emplacement horizon.

\subsubsection{Shaft Linings and Operational Seals}

\subsubsection{Shaft Linings}

4.3.2.1.1 General Shaft Lining Description. The four repository shafts constructed during pre-emplacement development and the two ESs constructed during site characterization will be circular in cross section with fully watertight linings in water-bearing strata. At the tops and bottoms of watertight lining sections, operational seals will be installed to prevent groundwater from flowing into the shafts. Operational seals will also be installed behind the watertight linings to prevent vertical water migration along the backs of the linings between major aquifers. The shaft linings are designed for minimum maintenance, such as repainting the inner steel liner or grouting the operational seal areas, during their nominal $100 \mathrm{yr}$ design life. The linings will be permanent structures within the shafts with the exception of limited portions which may be removed to accommodate installation of bulkheads during decommissioning.

Lining designs will be determined primarily by site geology, site geohydrology, and the required shaft sizes. Major aquifers in the Ogallala Formation and Dockum Group, along with the presence of water in the Lower Seven Rivers, Queen/Grayburg, and Upper San Andres formations, dictate the need for water tight linings. The upper watertight lining section in each shaft will be designed to withstand uniform hydrostatic loading from the surrounding column of asphaltic sealant material. The primary lining, installed to provide temporary ground support during construction, will be designed to support nonuniform loadings such as unbalanced rock pressures and pressures resulting from freezing and thawing. The lower watertight lining will be designed to withstand hydrostatic and nonuniform loadings. Since these loadings increase with depth the lining thicknesses will also increase, imposing practical limitations on the shaft diameter. The selected shaft diameters for the main ventilation shafts are a compromise between: (1) the ventilation requirements, 
(2) the practical watertight lining constraints, and (3) designs that do not exceed current technology.

Although watertight linings and operational seals will be designed to prevent the inflow of water into the shafts, the design of shaft linings which include sections of watertight and nonwatertight lining typically allows for a small residual inflow. For the repository conceptual design, a total measurable residual inflow of $0.3 \mathrm{gpm}$ is assumed for each shaft during the preclosure period. A portion of the residual water inflow will be evaporated by the ventilation air. The remaining water will be collected in the shaft sumps and transferred by small pumps in each shaft to the repository dewatering pump station.

As shown in Figure 4.3-1, watertight linings will be installed from the surface to $1,147 \mathrm{ft}$ and from $1,292 \mathrm{ft}$ to $2,051 \mathrm{ft}$. The bottom of each watertight lining section will extend below the water bearing formation so the opertional seals and bearing key can be located in impervious and competent rock. Nonwatertight lining will be installed from 1,147 ft to $1,292 \mathrm{ft}$ and from $2,051 \mathrm{ft}$ to the shaft bottom. Nonwatertight linings will be used in these locations since the groundwater inflows do not exceed the allowable residual inflow. Figure 4.3-1 also shows the stratigraphy and groundwater inflow rates in the shaft area and two alternate shaft lining general arrangements.

\subsection{Shaft Lining Components. Lining general arrangements and} details for Shafts $A, B, D$, and $E$ are shown in Figures 4.3-1, 4.3-2, 4.3-3, 4.3-4 and 4.3-5. Steel, tubbing, and concrete thicknesses for the various lining components are shown in Table 4.3-2.

Each shaft will include a reinforced concrete collar as shown in Figure 4.3-2, Detail 1. A freeze cellar will be incorporated into the collar to accommodate the top of the freeze pipes and the refrigerant inlet and outlet manifolds. Ground freezing, used for ground and water control during construction, is described in Section 4.3.5.1.1. A small cellar is also included in the collar to house the asphaltic sealent material monitoring and refill equipment. This asphaltic sealent material (or asphalt) will be used to form the operational seals and is described in Section 4.3.2.2. 

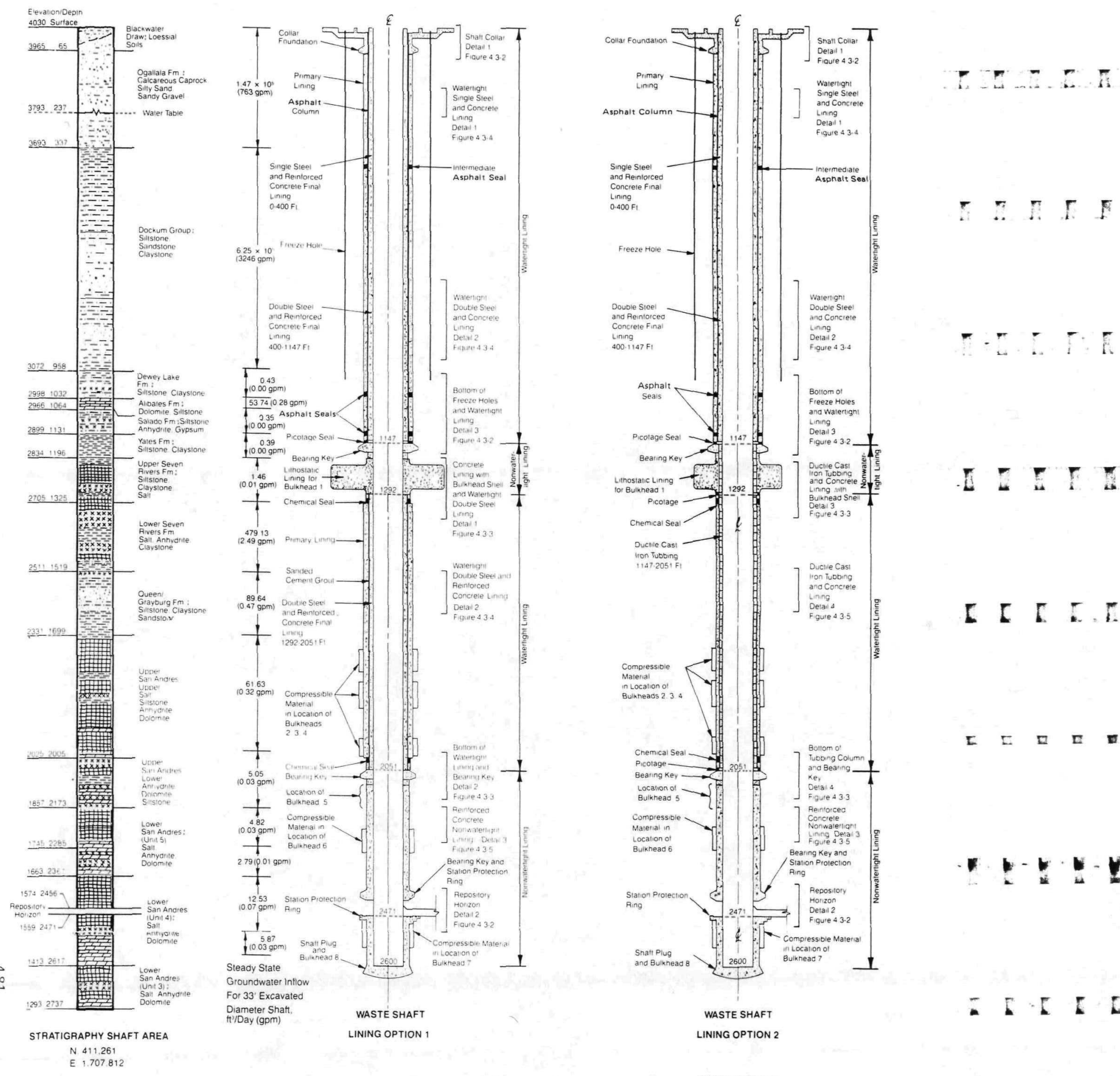

II 1

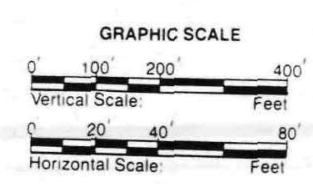




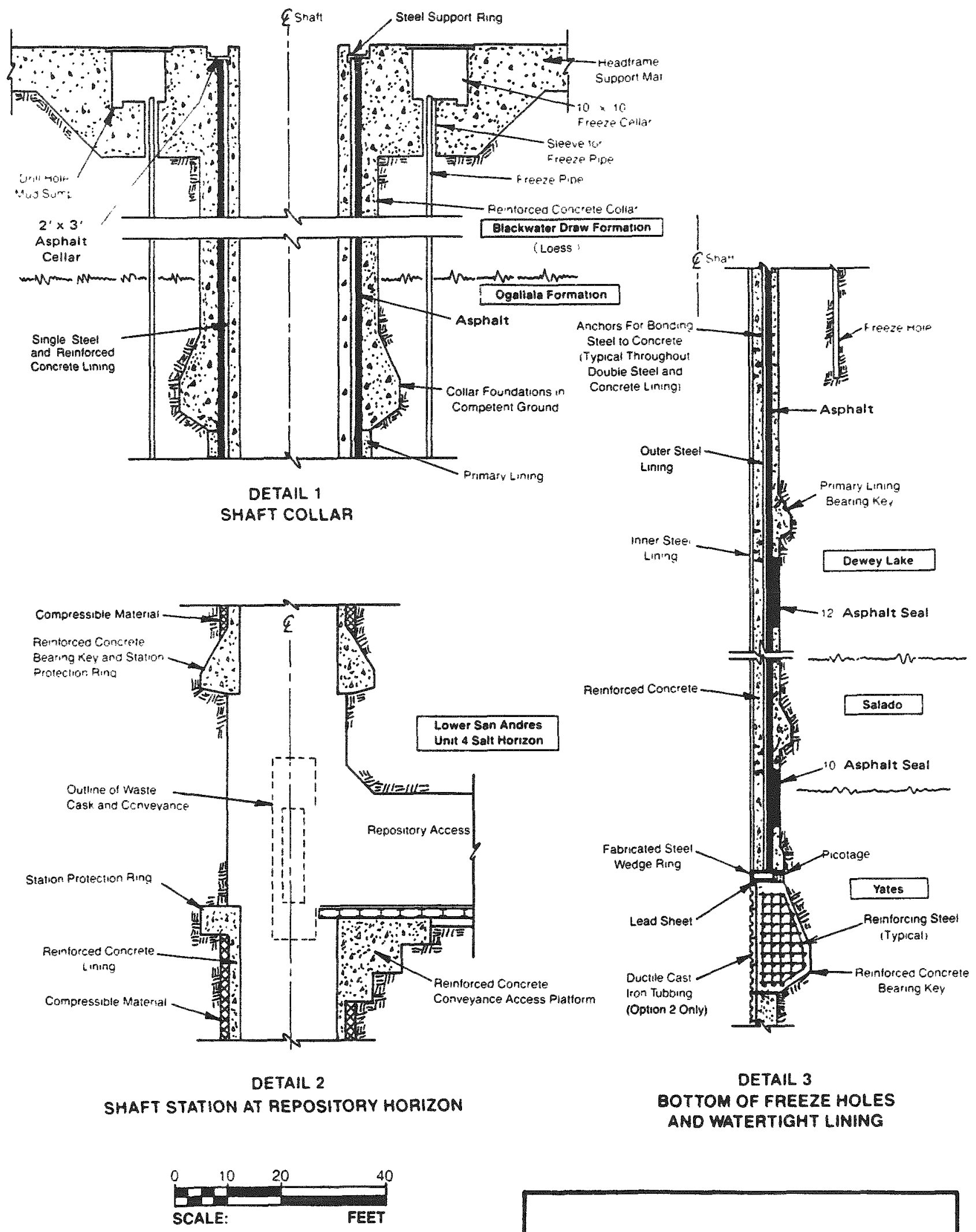

DETAILS OF LINING ARRANGEMENTS

FIGURE $4.3-2$ 
$\because$

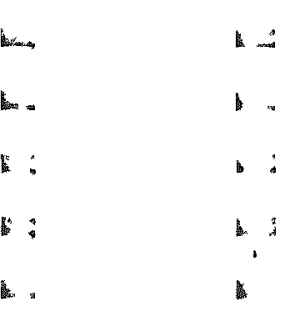

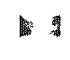

1.

1.

1.

2.

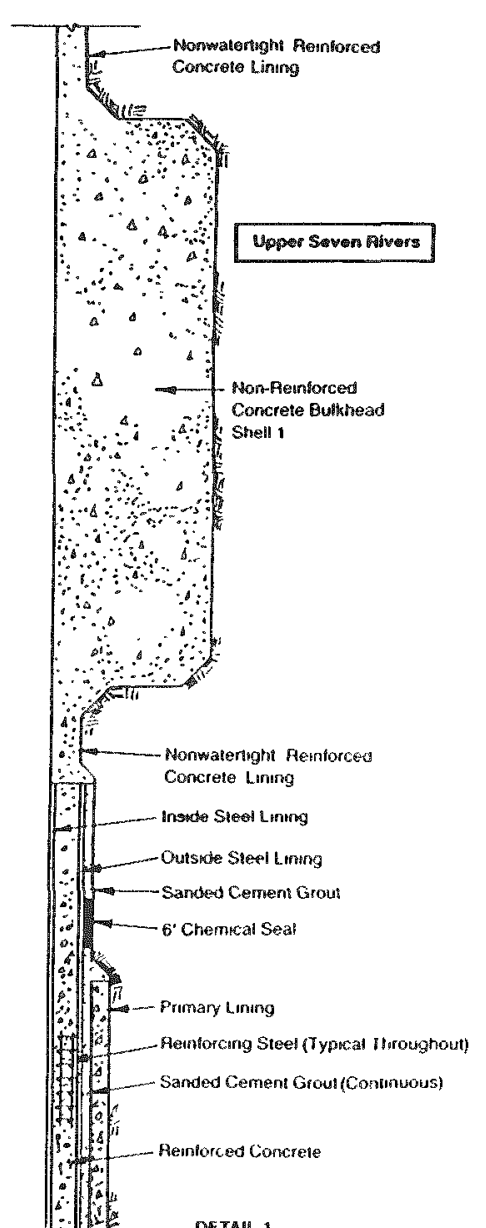

COACAETE LINANG

WTERTIGATS DOUBLE STEEL LABHAC

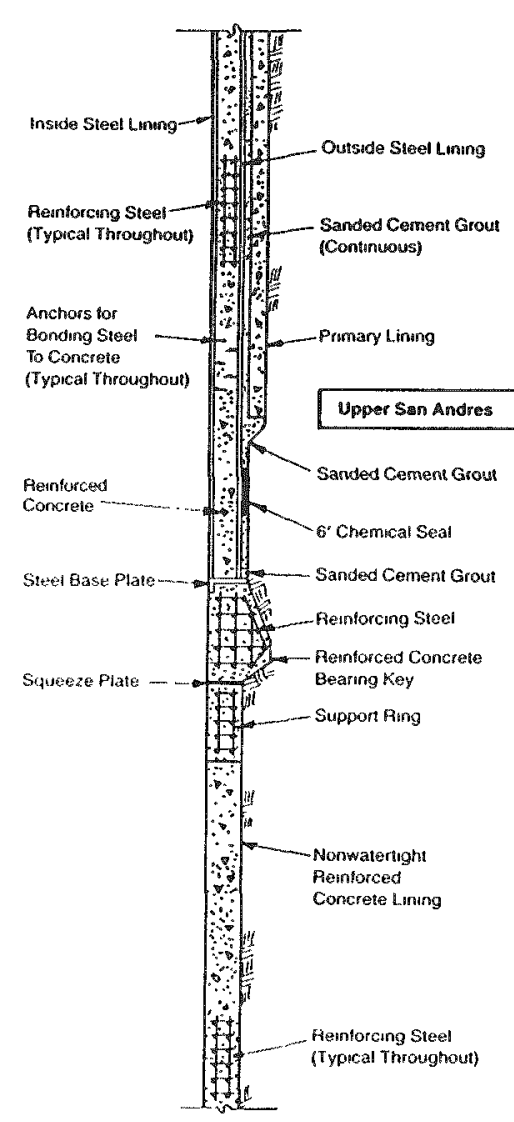

DETAM 2

BOT TOM OF MATEATIGH KEY AND HON TERTEGH CORCAE TE LINANG

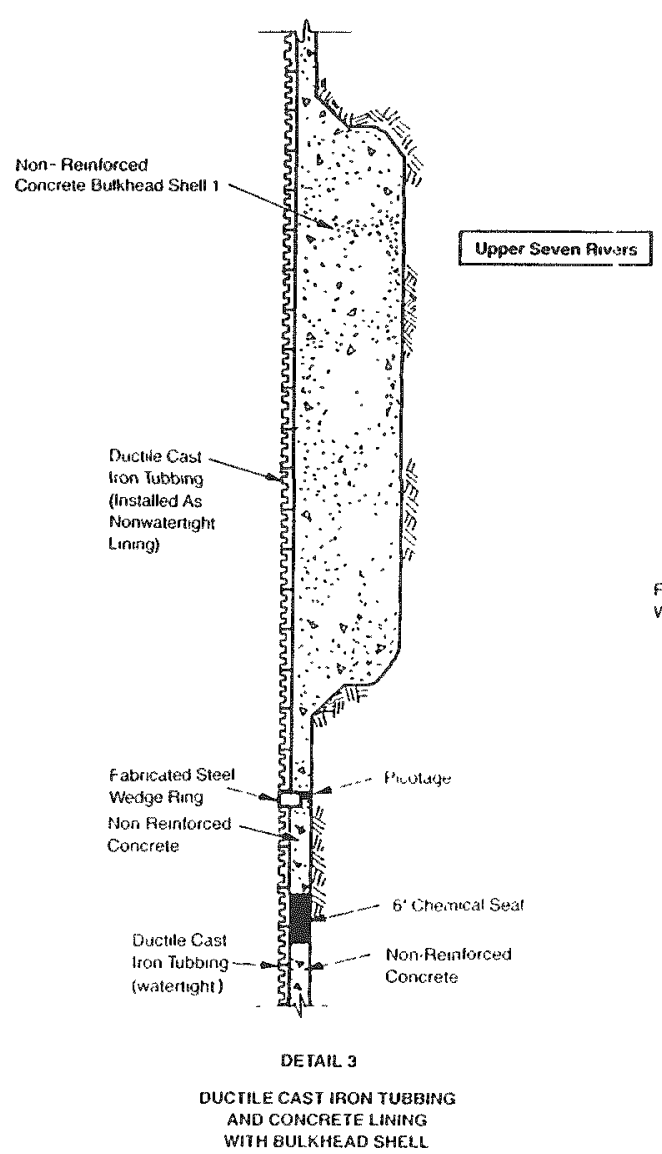
AND CONCRETE LNNING

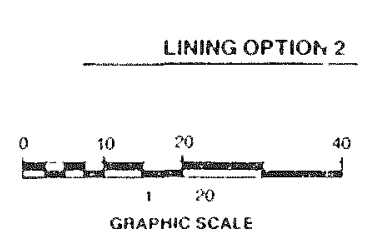

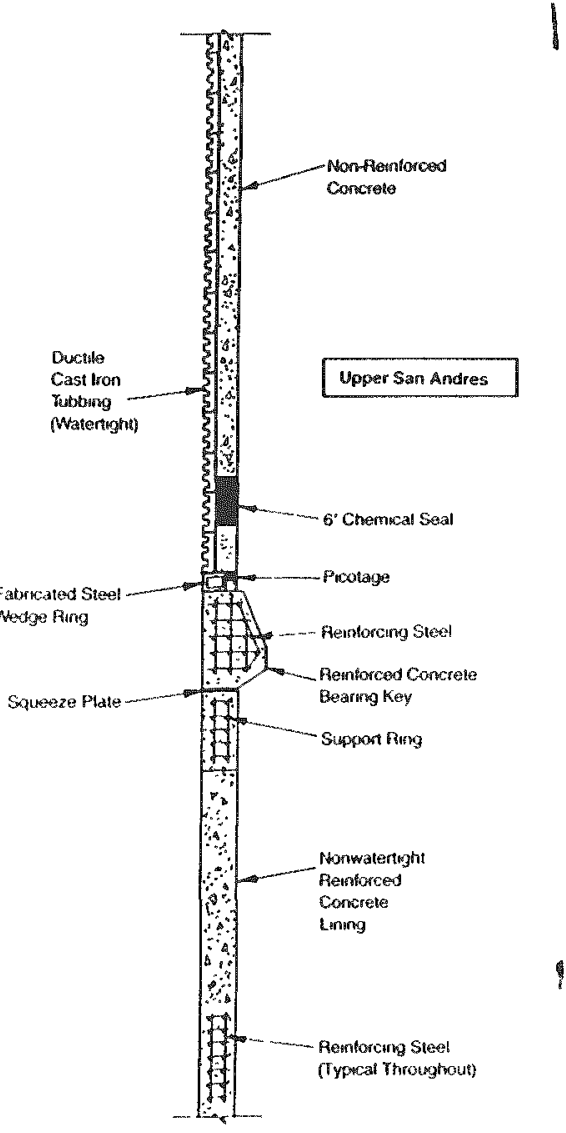

DETAIL 4

BOTIOM OF TUBBING COLUAN

ONWGT EATIGH CONCREIE LINHI

DE TALS OF LINING ARRANGEMENIS 




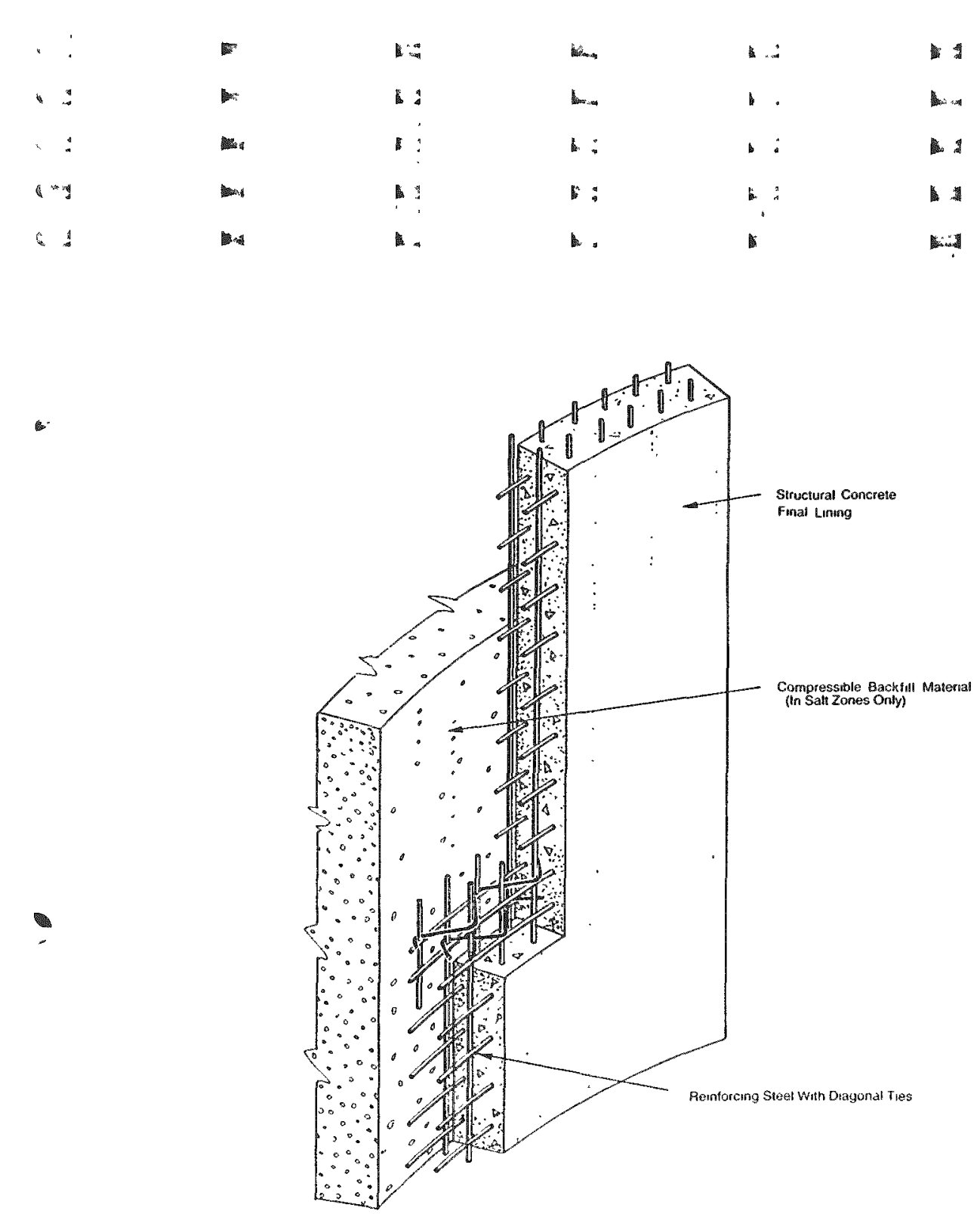

DETAL 3 AEENFORCED CONCHETE NONWATERTIGH L LANA

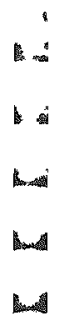

.

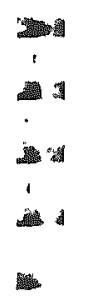

4

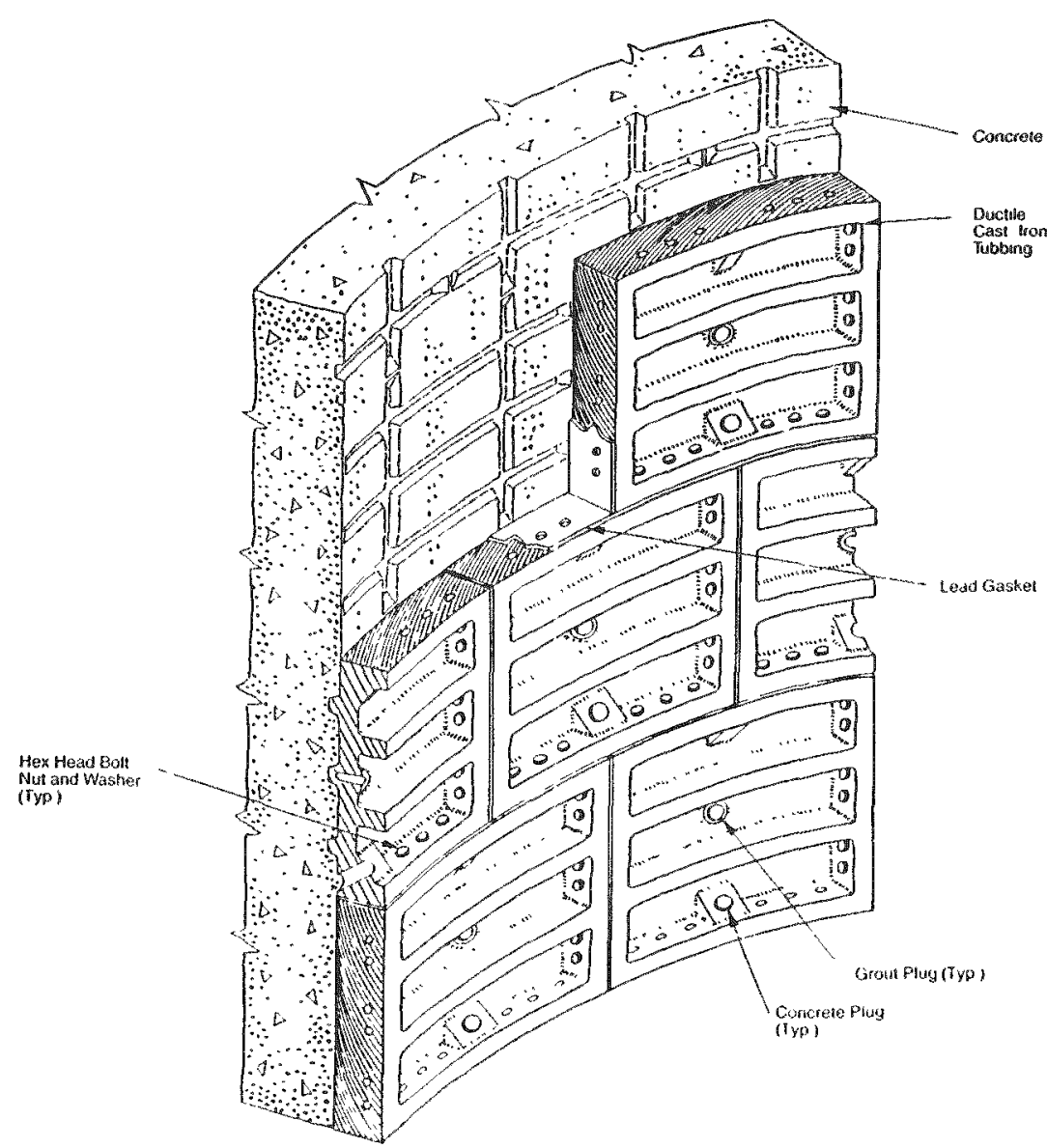

DE TAIL 4 TUBBING AND CONCRE IE LINING 
Table 4.3-2. Typical Shaft Lining Details (Sheet 1 of 2 )

\begin{tabular}{|c|c|c|c|c|c|c|c|c|c|}
\hline \multirow[b]{2}{*}{ Designation } & \multicolumn{2}{|l|}{ Shaft } & \multirow[b]{2}{*}{ Type } & \multicolumn{3}{|c|}{ Lining } & \multicolumn{3}{|c|}{ Operational Seal Locations } \\
\hline & Function & $\begin{array}{c}\text { Diameter, } \\
\text { ft }\end{array}$ & & $\begin{array}{c}\text { nepth. } \\
\text { it }\end{array}$ & $\begin{array}{c}\text { Cnncrete } \\
\text { Thickness, in. }\end{array}$ & $\begin{array}{l}\text { Steel/Tubbing } \\
\text { Thickness, in. }\end{array}$ & $\begin{array}{l}\text { Asphalt } \\
\text { Depth, ft }\end{array}$ & $\begin{array}{l}\text { Gemical } \\
\text { Depth, ft }\end{array}$ & $\begin{array}{l}\text { Picotage } \\
\text { Depth, it }\end{array}$ \\
\hline A & $\begin{array}{l}\text { Froplacenent } \\
\text { Fishaust Shaft }\end{array}$ & 18 & $\begin{array}{l}\text { Watertight } \\
\text { Single sitee with heinforced } \\
\text { Concrete snd Asphalt }\end{array}$ & $2 \frac{0-1,147}{0.400}$ & 26 & 0.375 & $387-397$ & & \\
\hline B & Waste Shaft & 18 & & & & & & & \\
\hline \multirow[t]{15}{*}{$c$} & \multirow[t]{15}{*}{$\begin{array}{l}\text { Erpplacement } \\
\text { lat ake Shaft }\end{array}$} & \multirow[t]{15}{*}{18} & \multirow{4}{*}{$\begin{array}{l}\frac{\text { Watertight }}{\text { Dewblr Stee }} \\
\text { Concrete and Asphalt Reinfurced }\end{array}$} & $400-600$ & 20 & $\begin{array}{l}0.5 \text { inside } \\
0.375 \text { out sinte }\end{array}$ & & & \\
\hline & & & & $600-800$ & 20 & $\begin{array}{l}0.5 \text { inside } \\
0.5 \text { outside }\end{array}$ & & & \\
\hline & & & & $800-1,000$ & $2 n$ & $\begin{array}{l}0.75 \text { inside } \\
0.5 \text { cut } 81 \text { de }\end{array}$ & & & \\
\hline & & & & $1,000-1,147$ & 26 & $\begin{array}{l}1.0 \text { inside } \\
0.625 \text { out side }\end{array}$ & $\begin{array}{l}1,000-1,012 \\
1,127-1,137\end{array}$ & & $1,245-1,147$ \\
\hline & & & $\frac{\text { Nonwatert ight }}{\text { Reintorced Concrete }}$ & $\frac{1,147-2,051}{1,147-1,292}$ & 18 & & & & \\
\hline & & & \multirow{4}{*}{$\begin{array}{l}\text { Watertight } \\
\text { Dowble steel with Reintorced } \\
\text { Concrete and Grout }\end{array}$} & $1,292-1,500$ & $3 \%$ & $\begin{array}{l}1.0 \text { Inside } \\
0.75 \text { Outside }\end{array}$ & & $1,304-1,310$ & \\
\hline & & & & $1,500 \cdot 1,700$ & 32 & $\begin{array}{l}\text { 1.375 Inside } \\
\text { 1.0 Outside }\end{array}$ & & & \\
\hline & & & & $1,700-1,900$ & 32 & $\begin{array}{l}1.625 \text { Inside } \\
1.375 \text { butside }\end{array}$ & & & \\
\hline & & & & $1,900-2,051$ & $3 ?$ & $\begin{array}{l}\text { 1.875 Instade } \\
\text { l.6.625 Cutside }\end{array}$ & & $2,037-2,063$ & \\
\hline & & & \multirow{4}{*}{$\begin{array}{l}\text { Nonwatertight } \\
\text { Tubbing and Concrete } \\
\text { Wutertight } \\
\text { Tubbing and Concrete }\end{array}$} & $1,147-2,051$ & & & & & \\
\hline & & & & $1,14,-1,292$ & 19 & 3.5 (Tubbing) & & & \\
\hline & & & & $1,29 . \cdot 1,700$ & 18 & 3.5 ('ubbing) & & $1,304-1,310$ & $1,292-1,204$ \\
\hline & & & & $1,700-2,051$ & 18 & 4.0 (Tubbingy) & & $2,037-2,043$ & $2,049-2,053$ \\
\hline & & & \multirow{2}{*}{$\begin{array}{l}\text { OPrTONS 1 AND2 } \\
\frac{\text { Nonwatertight }}{\text { Reintorced corome }}\end{array}$} & $2,051-2,600$ & & & & & \\
\hline & & & & $2,051-2,500$ & 14 & & & & \\
\hline
\end{tabular}

NotES: (Apply to $18 \mathrm{ft}$ diameter shafts)

1) 6,000 psi concrete used throughour.

2) Reinforced concrete collar oft to $75 \mathrm{ft}$ for all shafts.

3) Concrete prinary linhe 75 fe

4) For double steel lining, "inside" indicates the steel sheet closest "o the stiatt center line, and "outside" indicates the steel sheet closest to the excavation wall. 
Cl 
Table 4.3-2. Typical Shaft Lining Detalis (Sheet 2 of 2)

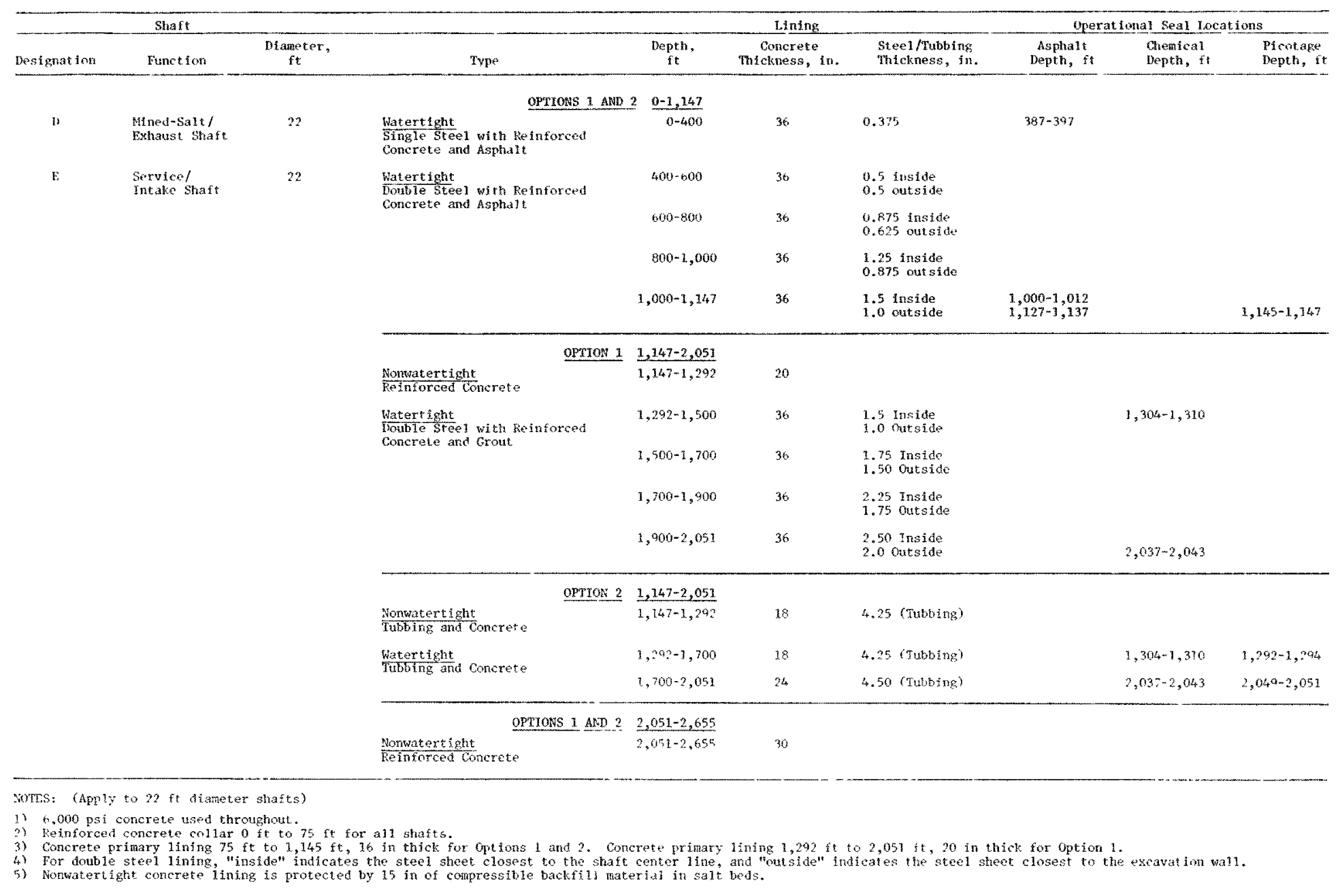


A concrete primary lining as described in Section 4.3.5.1.2 will be placed from a depth of $75 \mathrm{ft}$ to $1,145 \mathrm{ft}$ as each shaft is deepened. A watertight steel and concrete lining encased with asphalt will be installed upward from $1,147 \mathrm{ft}$ to the surface. The $2 \mathrm{ft}$ difference between the base of the watertight lining and the primary lining is to accommodate the $2 \mathrm{ft}$ high wedge ring and picotage. The load-bearing components of the watertight lining from the surface to approximately $400 \mathrm{ft}$ will consist of a single steel sheet and reinforced concrete as shown in Figure 4.3-4, Detail 1. The welded steel sheet will form a watertight membrane in this interval. Double steel and reinforced concrete lining as shown in Figure 4.3-4, Detail 2, will be the load-bearing components from $400 \mathrm{ft}$ to $1,147 \mathrm{ft}$. The steel sheets will be firmly bonded to the concrete by anchors to ensure structural integrity. The outer welded steel sheet will be the main watertight membrane and structural member. The inner welded steel sheet will be primarily a structural member although it will also function as a secondary watertight membrane. Corrosion of the outer steel sheet is expected to be minimal during the shaft lifetime because of asphalt protection and lack of free oxygen. Figure 4.3-4, Details 1 and 2, show heavily reinforced concrete which will be used as the single steel lining approaches the collar and as the double steel lining approaches the bearing key. Alternate methods of reinforcing such as steel fibers, fiberglass fibers, or welded wire mesh may be used throughout the remaining watertight lining section.

Two alternate lining arrangements are shown in Figure 4.3-1 for the shaft section from 1,147 feet to 2,051 feet. During shaft sinking operations, water inflows in this interval are expected to be small enough to be tolerated during construction without ground freezing. Either of the two lining arrangements shown in Figure 4.3-1 will prevent water from entering the shaft in this area.

In the first lining arrangement (Option 1), a nonwatertight concrete lining will be installed in the dry zone from 1,147 feet to 1,292 feet. Instrumentation will be installed in this concrete lined section to detect any leakage or migration of water or asphalt from the watertight lining section above. Should this occur, grout can be injected through the concrete lining or 
bearing key to seal the leakage. Double steel and reinforced concrete surrounded by grout, as shown in Figure 4.3-4, Detail 2, will be installed as a watertight lining between 1,292 feet and 2,091 feet. Throughout this interval, a primary lining will be placed as the shaft is deepened.

The second lining arrangement (Option 2) consists of ductile cast iron tubbing and concrete as shown in Figure 4.3-1 and Figure 4.3-5, Detail 4. Concrete will be placed behind the tubbing to bond it to the rock. A primary lining is not required for this lining arrangement. The tubbing section from 1,147 feet to 1,292 feet will not be required to function as a watertight lining since this is a dry zone. Instrumentation installed through grout holes in the tubbing segments will detect any leakage of water or asphalt from the watertight lining section above. Grout and concrete holes will be left open to provide an opportunity to further monitor the performance of the watertight lining above. Should leakage occur, grout can be injected into the rock behind the tubbing to seal the leakage area. The tubbing section can also be made to function as a watertight lining by installing the grout plugs and concrete plugs if conditions require. In the process of making this zone watertight, it will not be necessary to retrofit any operational seals since watertight seals already exist above and below. The ductile cast iron tubbing and concrete will be installed as a watertight lining between 1,292 feet and 2,051 feet. Grouting behind the tubbing will help ensure watertightness.

Nonwatertight reinforced concrete lining as shown in Figure 4.3-5, Detail 3, will be installed from 2,051 ft to the shaft bottom for either lining option. In the salt beds below 1,696 feet, a compressible material, such as expanded polystyrene or vermiculite blocks, will be placed behind the shaft lining to prevent or defer damage which may result from closure of the excavation. Those bearing keys and shaft station protection rings that are located in salt will be designed to withstand the full lithostatic pressure. The shaft wall and shaft station brow below the shaft station protection ring will be supported as necessary. Rock bolting with wire mesh is a suitable method for providing this support. 


\subsubsection{Shaft Operational Seals}

Asphalt seals, chemical seals, and the picotages referred to in Table 4.3-2 and Figure 4.3-1, will be installed at terminations of watertight lining sections to prevent inflows into the shafts. All seals will be located in competent, unfractured, and impervious rock and placed around the shaft between watertight linings and shaft walls. These seals will be confined above and below by concrete or sanded grout.

The two lining options illustrate the use of three types of operational seals for watertight linings. This is intended to show that various types of seals exist which are suitable for the repository shafts. Asphalt is shown in the upper shaft in conjunction with a wooden picotage. The picotage seal will act as a secondary water seal and will also reduce the potential for leakage of asphalt around the bearing key. Asphalt cannot be used below the nonwatertight lining section between 1,147 feet and 1,292 feet. The asphalt column must be uninterrupted from the surface to the required seal elevation in order to develop the necessary hydrostatic head to prevent groundwater inflow.

Picotage and chemical seals are often used together to provide redundancy in seal design. However, either the picotage or chemical seals can be used alone. In some cases two or even three seals may be installed. Final selection of the seal type and number of seals will be decided during LAD when more specific information on ground and water conditions will be available.

Two asphalt seals will be installed at the bottom of the steel lining below the freeze zone as shown in Figure 4.3-2, Detail 3. An intermediate asphalt seal will also be placed in the upper part of the Dockum Formation to prevent water migration between the two major aquifers. In seal areas the asphalt must be in direct contact with the surrounding rock to be effective. The use of high specific gravity asphalt plus the uninterrupted height of the asphalt column will create a hydrostatic pressure greater than the surrounding ground water, thus preventing the migration of water past the seal.

Chemical seals will be installed at the top and bottom of the lower watertight section as shown in Figure 4.3-1 and Figure 4.3-3. This type of 
chemical seal consists of an inert polymeric compound which swells on contact with water, creating a tight, impervious barrier.

T' picotage will be installed near the top and at the bottom of the tubbing column as shown in Figure 4.3-1, Option 2, and Figure 4.3-3, Details 3 and 4. The picotage consists of wooden blocks, wedges, and needles driven tightly between a steel wedge ring and the excavation wall. The wood, either redwood or pitch pine with oak needles, tends to swell on contact with water, creating a watertight barrier.

The picotage will be located below the asphalt column in the upper water tight lining section as shown in Figure 4.3-2, Detail 3. This seal will be installed to prevent any leakage of asphalt into the shaft. A layer of dense asphalt may be installed on top of layers of sanded asphalt and sanded cement grout may be used as an alternate method of preventing leakage at the base of the asphalt column.

The picotage has a demonstrated useful life of over 100 years. Although asphalt and chemical seals do not have such a long record of operating history, both seals are expected to have a useful life equal to that of the picotage seal. Seal installation is described in Section 4.3.5.3.

\subsubsection{Decommissioning Considerations}

For the SCP, eight locations for decommissioning bulkheads have been identified as shown in Figure 4.3-1 (See discussion in Section 5.2.1). It is proposed that one decommissioning seal be located in the nonwatertight lining section between $1,147 \mathrm{ft}$ and 1,292 ft. Three decommissioning seals are proposed for location in salt beds behind the watertight lining section between 1,292 $\mathrm{ft}$. and 2,015 ft. The remaining four, including the shaft bottom plug, will be located in the nonwatertight lining section of the shaft below 2,051 ft. Careful excavation during shaft sinking will be necessary to minimize ground disturbance in the decommissioning seal areas.

A concrete shell for Bulkhead 1 will be designed to withstand full lithostatic pressure and will be installed at the time of shaft construction. 
The shell will be located as shown in Figure 4.3-3, Details 1 and 3. Completion of this seal at the time of decommissioning will require removal of the tubbing for Option 2, and any deteriorated concrete lining for either option.

The installation of Bulkheads 2 through 4 will require removal of watertight lining at the bulkhead locations. Potential saturation of salt beds behind the lower watertight section during the shaft lifetime may render these three locations unsuitable for decommissioning seals.

The installation of Bulkheads 5 through 7 will require that sections of concrete lining and compressible backfill material, where installed, be removed and the ground behind excavated to the required dimensions to form keyways for the decommissioning seals. The shaft bottom plug will remain intact as originally constructed. This plug is being considered as a decommissioning bulkhead. Further design of the shaft sealing system and the performance of the shaft bottom plug prior to decommissioning will determine its suitability as a decommissioning bulkhead. Section 5.2, Sealing of Shafts, provides further details on decommissioning seals.

\subsubsection{Hoisting Systems}

\subsubsection{General Hoisting System Description}

Friction hoists are proposed for the waste, mined-salt/exhaust and service/intake shafts. For waste handling, the weight of the disposal container, transfer cask, and cage necessitates the selection of a multi-rope friction hoist system. In the case of the mined-salt/exhaust and service/intake shafts, friction hoists have also been selected. The conveyances (or conveyance and counterweight) in each of these shafts will use rope guides which create less resistance to airflow than rigid guides and buntons. The repository depth is within the optimum range for friction hoists which are best suited for single-level underground operation.

Friction hoists must have two conveyances (or conveyance and counterweight) operating in balance. As the name suggests, these hoists rely on friction 
between the headropes and the hoist drum for lowering and raising the conveyances. Headropes pass over the hoist drum and are attached to the top of the two conveyances (or conveyance and counterweight). Tail ropes are attached to the underside of the conveyances for balance. Headrope attachments will include hydraulic rope tensioning adjustment linkages to ensure uniform tread pressure on the hoist drum. Headrope deflection sheaves will position the conveyances and counterweights in the shafts.

The headframes will be constructed of steel and mounted on reinforced concrete piers. Each headframe and its foundation will be designed to resist the overturning moment of high winds, earthquakes, and other severe natural phenomena.

The core tower structure is the central part of the headframe located inside the headframe legs. This part of the service and mined-salt headframes will be covered with steel siding to provide protection against the elements. The waste shaft core tower structure, however, will be covered with a more substantial steel paneling to address the particular concerns of security and tornado damage to this structure. Ventilation air locks will be included in the core tower structure of each headframe. The steel headframe towers, as shown in Figures 4.3-6, 4.3-7, and 4.3-8, can be erected over the sinking headframe allowing simultaneous shaft construction, headframe erection, and hoist equipment installation. Hoists will be mounted within the headframe tower.

The drilled concrete piers which support the headframe will pass through the unconsolidated loess and will be seated in the caprock of the Ogallala Formation. The headframe legs will be founded outside the freeze zone to prevent movement from ground heave. A reinforced concrete mat will tie the headframe legs together and provide additional resistance to wind loading and seismic activity. The concrete mat will be constructed in two parts, the area above the freeze zone being poured once the ground has thawed and settled. Jacking points at the base of the headframe legs will allow adjustment in the event of ground settling. 



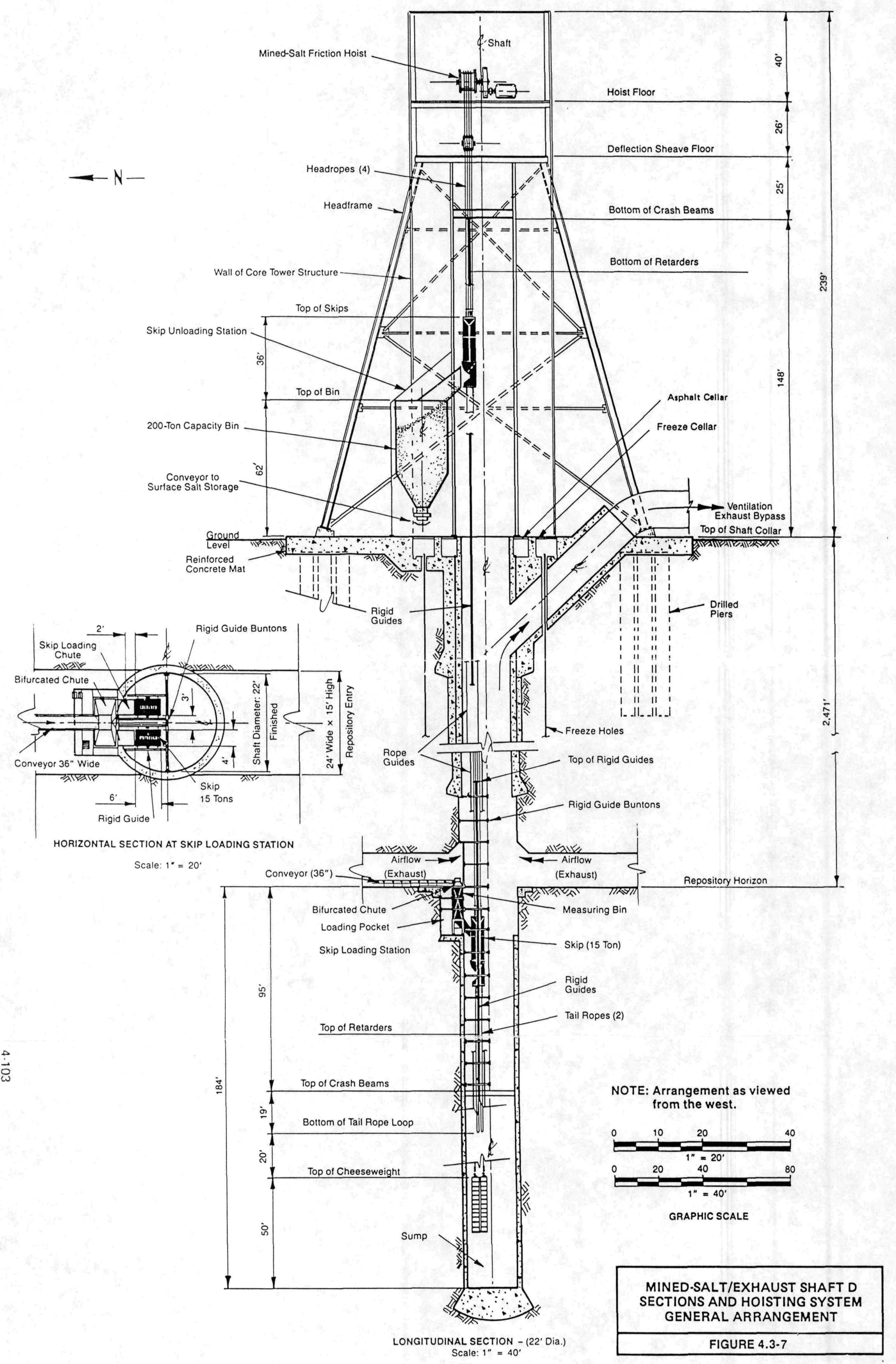


O 0 


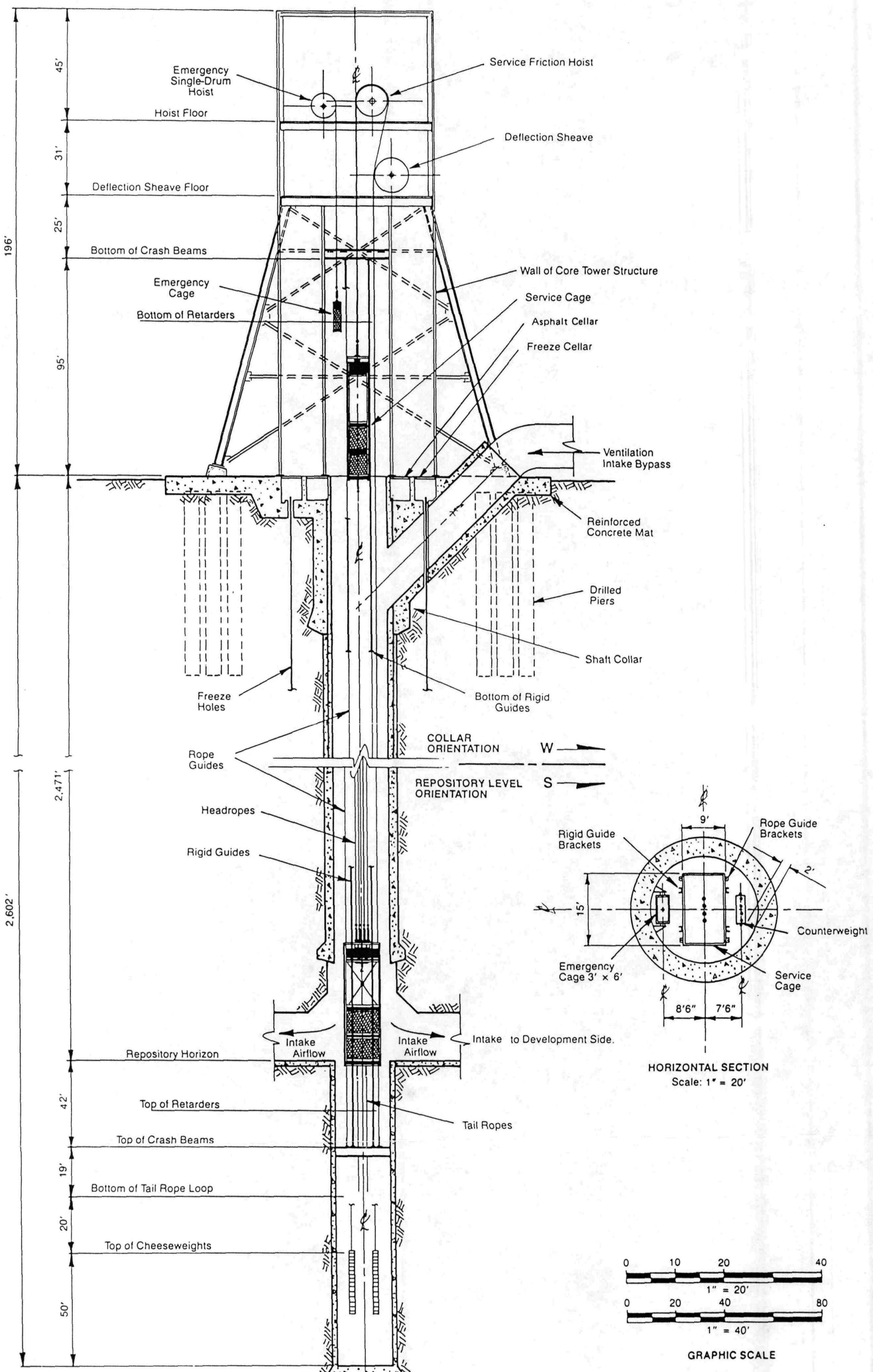

LONGITUDINAL SECTION - (22' Dia.) Scale: $1^{\prime \prime}=40^{\prime}$

SERVICE/INTAKE SHAFT E SECTIONS AND HOISTING SYSTEA GENERAL ARRANGEMENT 


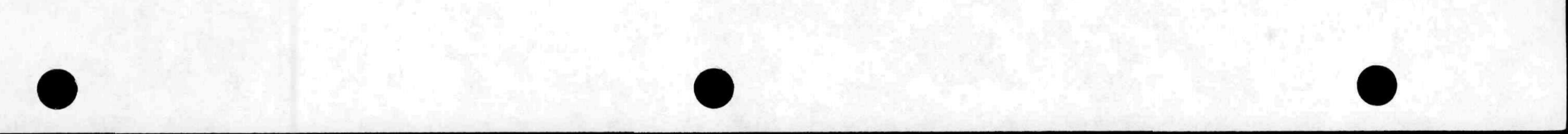




\subsubsection{Waste Hoisting}

The waste hoisting system is shown in Eigures $4.3 .-6$ and 4.3-9. It will include a cage, counterweight, and a six-rope friction hoist. The waste cage will be loaded at the shaft collar using the surface cage off/on loader. As the cage takes the full load of the transfer cask with the disposal container inside, there will be approximately 1 in of rope stretch which the loader will accommodate. The cage-locking mechanism will secure the transfer cask before the loader arms are disengaged from the trunnions. The loader will then back away from the cage, and the cage will be lowered with the transfer cask to the repository level

Here the underground cage off/on loader will move into place and engage the trunnions. The locking mechanism will be released and the transfer cask lifted 24 in to take up approximately 18 in of rope stretch and provide and additional 6 in of clearance between the cage floor and the transfer cask. The underground cage off/on loader will back away from the cage with the transfer cask, and load it onto the transfer cart. Empty transfer casks, performance confirmation packages, and retrieval packages will be loaded onto the cage using the same process in the reverse order. Further details of the waste hoisting system are shown in Table 4.3-1.

\subsubsection{Mined-Salt Hoisting}

Details of the mined-salt (Shaft $D$ ) hoisting system are shown in Figure 4.3-7 and Table 4.3-1. This system will consist of two 15-ton capacity, counterbalanced skips and a 4-rope friction hoist. The skips will operate at a maximum speed of $1,800 \mathrm{fpm}$ to give a daily hoisting capacity of 7,500 tons of salt. This capacity will be adequate to meet peak rates for development mining as described in section 4.3.1.2.4. 


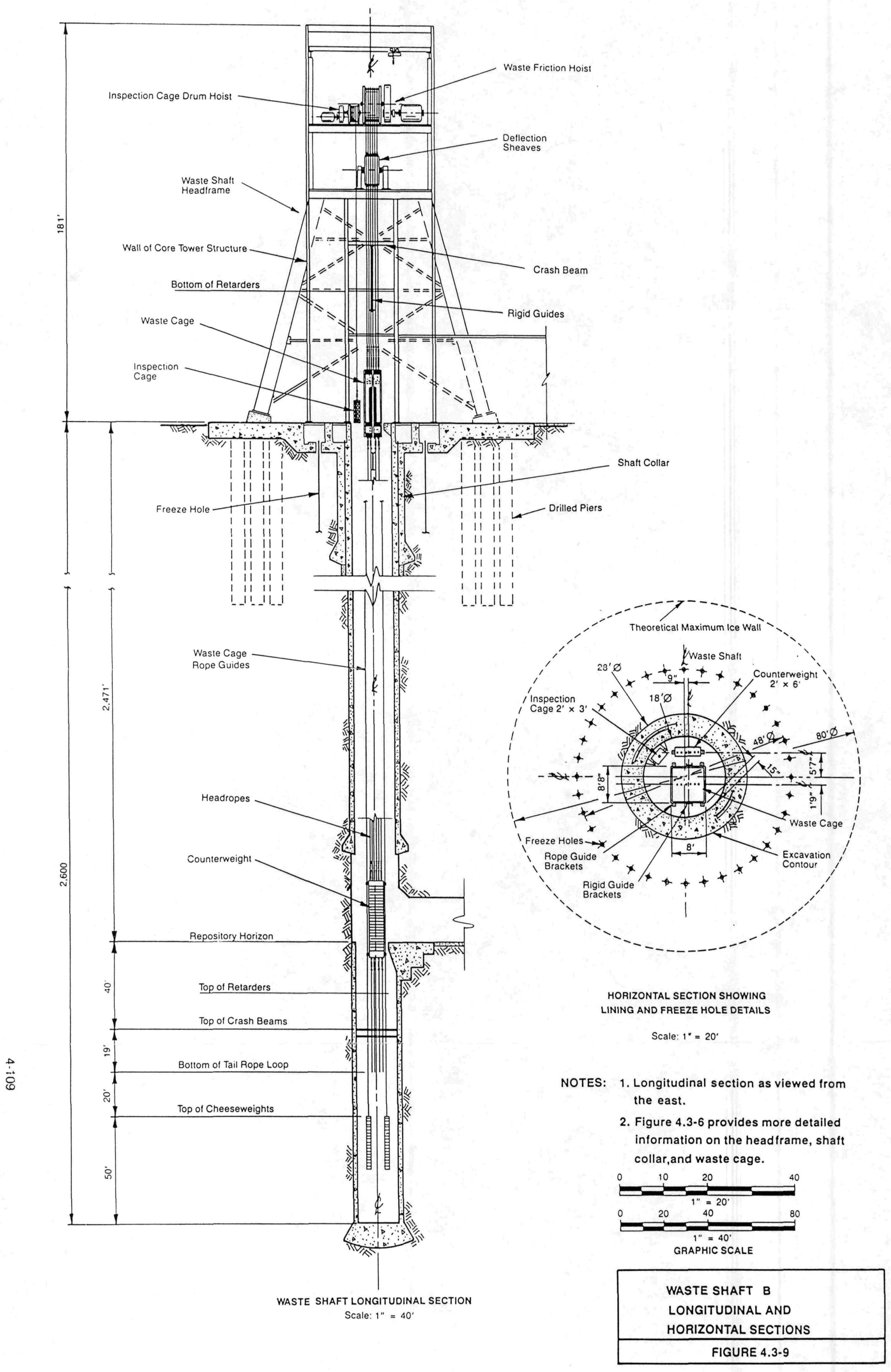


$\begin{array}{lll}0 & 0 & 0\end{array}$ 
The skips will be loaded from measuring bins at the underground skip loading station. A 36 in conveyor feeding from a 500 ton distribution bin will fill these measuring bins with a preweighed load. The skips will discharge the salt into a 200 ton bin at the surface.

\subsubsection{Service (Materials and Personnel) Hoisting}

The service hoisting system (Shaft E) is shown in Figure 4.3-8, and additional details are given in Table 4.3-1. The service hoisting system will include a 25 ton capacity cage in balance with a counterweight and a 4-rope friction hoist. The normal hoisting speed for the service cage will be $1,500 \mathrm{fpm}$, but it will operate at slower speeds for heavy loads. The cage will contain two decks for personnel and small materials. It will be possible to remove the middle deck to make room for large, heavy pieces of equipment. This equipment will be lifted into place by an overhead crane installed in the cage.

\subsubsection{Emergency, Inspection, and Maintenance Hoisting}

Table 4.3-1 indicates the location of the emergency and inspection hoists which will operate independently from the main hoisting systems. An emergency hoist will be installed at Shaft $E$ to evacuate personnel and provide access to the underground when the main service hoist is out of commission. An inspection hoist will be installed at Shaft $B$ to inspect the shaft linings and facilitate inspection of the waste cage if it stops in the shaft. Special procedures will be implemented during inspections of the loaded waste cage to minimize the radiation dose to personnel.

Inspection hoists will be installed in Shafts A, C (if constructed), F, and $G$ to inspect the linings. Ventilation air locks will be incorporated into the headframes of these shafts so that inspection cages can enter them shaft without interrupting the emplacement ventilation air flow.

The service and waste shaft emergency and inspection hoists will be tower-mounted; others will be ground-mounted. In both cases, the hoisting system will consist of a single-drum hoist (with a single, 0.75 in diameter flattened strand rope), and a small conveyance traveling on rigid guides. 
Maintenance work decks will be required in Shafts $A, F$, and $G$ and kept on surface until they are required. A set of deck winches, as shown in Figure 4.3-10, will be installed for each of the three shafts. For Shafts B, D, and $E$, special maintenance work decks will be attached to the main conveyances for shaft maintenance work. The emergency and inspection hoists will be used to provide access to the maintenance work decks.

\subsubsection{Shaft Equipment}

Repository shafts will be equipped according to their functions. The major shaft equipment consists of the hoisting system components as shown in Table 4.5-1, Subsurface Repository Operations. Additional shaft equipment will include conveyance guidance systems, utility cables and pipelines, shaft communications, control and monitoring systems, underground communications systems, and testing and monitoring cables.

\subsubsection{Conveyance Guidance Systems}

The main conveyances in Shafts $B, D$, and $E$ will be guided on wire ropes. The cages and skips will each have four 1.75 in diameter half locked, coil guide ropes, and the counterweight will have two ropes. The guide ropes will be suspended from rope decks in the headframes. Each rope will be tensioned by cheeseweights in the shaft bottom. Use of rope guides for the personnel conveyance in Shaft $\mathrm{E}$ is inconsistent with the State of California Mine Safety Orders; therefore the DOE variance procedure will be implemented to allow this deviation.

Rigid steel guides, supported by steel buntons, will be installed at the repository and collar landings as well as at the ventilation bypasses at the collars. These rigid guides will stabilize the conveyances during loading and unloading and reduce movement resulting from air turbulence at the ventilation bypasses. 


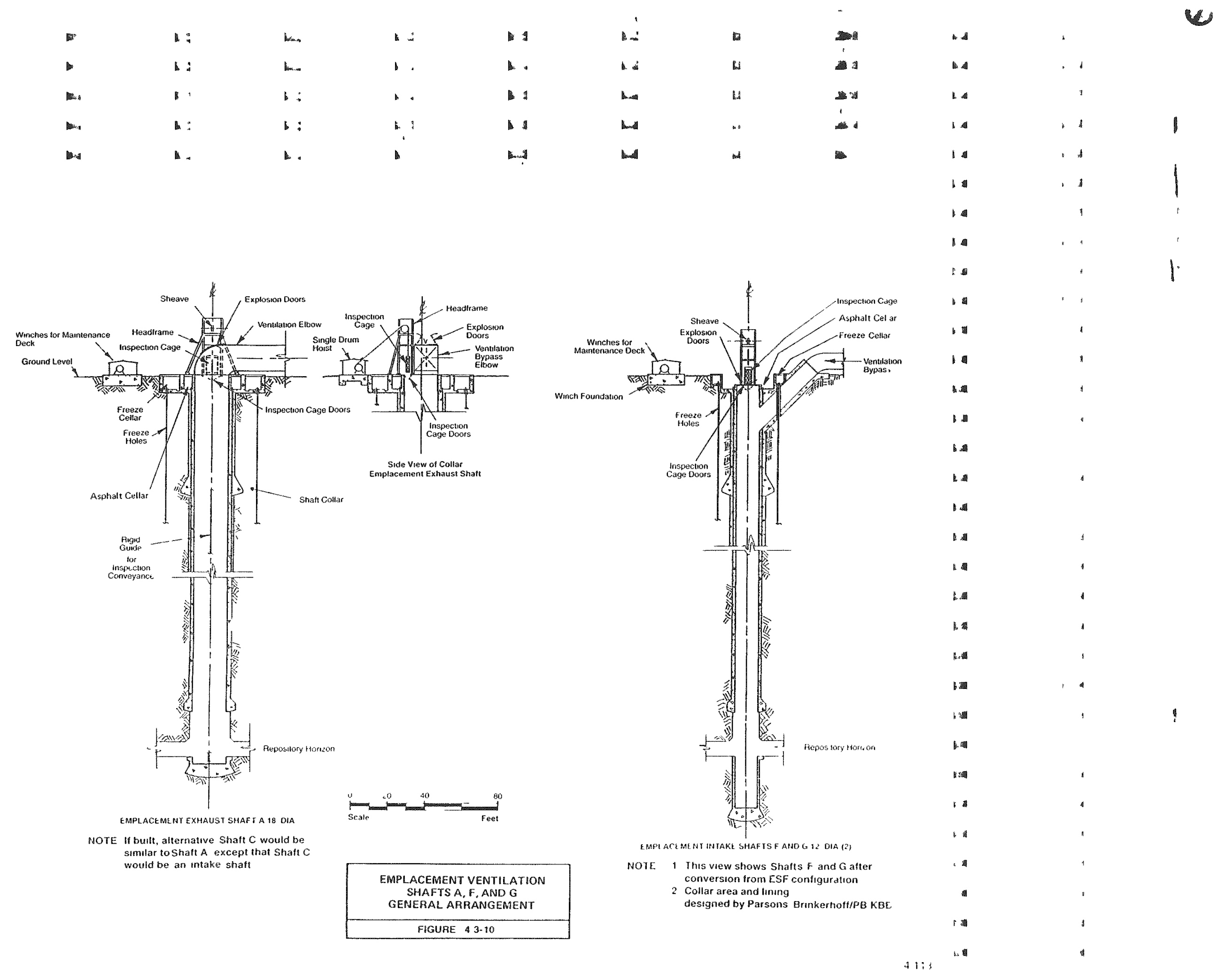





\subsubsection{Utilities and Communications, Testing, and Monitoring Systems}

The utilities will include electrical power, potable and process water, fuel, and pump lines. Utility lines will be located in Shaft E. Adequate clearance will be made between high-power electrical feeder cables and lowerpower instrumentation, control, and communication lines to reduce interference. Redundant (spare) utility and power lines will be installed for backup. Power cables and steel pipelines will be attached to brackets mounted on the shaft wall.

Underground and shaft communications, testing, and monitoring cables will be protected by armored sheathing. The cables will be supported on brackets mounted on the shaft walls.

\subsubsection{Shaft Construction Methods}

The two exploratory shafts (ESs) and the four repository shafts will be constructed using similar shaft sinking methods. In the watertight lining section between the surface and 1,147 ft, freezing will be employed to stabilize loose ground and control water.

\subsubsection{Ground and Water Control}

4.3.5.1.1 Ground Freezing. Ground freezing will create an impervious ice wall around the shaft. The ice wall will be established by circulating chilled refrigerant through vertical freeze holes drilled around the shaft as shown in Figure 4.3-9. The freeze holes, drilled to a depth of $980 \mathrm{ft}$ and lined with steel casing, will be bottomed in competent, unfractured, and impervious rock. Approximately three months will be required to establish the freeze wall, after which time sinking will commence. Upon completion of the watertight lining, freezing will cease. Once the ground has thawed, the freeze holes will be perforated and sealed with grout to prevent any water migration through the holes.

Since freezing will create ground heave near the surface, the foundations for the headframe and surface structures will not be placed in the heave area. 
This is the main reason for selecting steel headframes with the support legs and foundations placed outside he freeze zone as described in Section 4.3.3.1.

4.3.5.1.2 Primary Lining. Primary lining will be installed prior to installation of single and double steel watertight lining. Primary lining consisting of unreinforced concrete will be placed as the shaft is deepened. It will prevent loose rock and frozen ground from falling into the shaft during construction. Concrete block masonry may be installed as an alternative to the unreinforced concrete primary lining.

4.3.5.1.3 Temporary Ground Support. Either rock bolts and wire mesh or bolted steel liner segments may be used for temporary ground support where necessary with the exception that bolts will not be installed in zones identified for the decommissioning bulkheads.

4.3.5.1.4 Grouting. Grouting consists of injecting cement or chemical slurries into water bearing strata to reduce water inflow. Grouting will be employed in any seepage zones below $1,147 \mathrm{ft}$ behind the tubbing and reinforced concrete sections of the shaft lining.

\subsubsection{Excavation Methods}

Conventional drilling and blasting may be the primary method of shaft excavation. In this case, drilling will be undertaken with compressed air percussion or electric/hydraulic rotary drills which may be hand-held or jumbo-mounted. Blasting will be used to fragment the rock. Time-delayed electric detonators will be used to initiate the blasting. Smooth-wall blasting and pneumatic rock breakers will be employed as necessary to minimize ground disturbance. As an alternative to drilling and blasting, mechanical excavation methods may be employed to minimize ground disturbance. Removal of broken rock (mucking) involves loading at the shaft bottom, hoisting, and dumping at the surface. Mucking will be performed by either a cactus grab, clamshell, or a crawler mounted loading machine. Muck will be dumped into a sinking bucket to be hoisted to the surface for storage as described in Section 4.2.3.9, Storage and Disposal of Excavated Materials. 


\subsubsection{Construction Sequence}

The ESs will be constructed for site characterization several years before the repository shafts are built. Shafts A, B, C (if constructed), D, and E will be sunk simultaneously following construction authorization for the repository. The construction sequence is described below and will be the same for all shafts.

Each shaft will start with construction of the collar followed by drilling of the freeze holes. Shaft excavation will commence once the freeze wall has been established and the sinking headframe, hoisting system, and other sinking equipment are installed.

First, the shaft openings will be excavated and the primary lining installed. The primary lining will be poured in $20 \mathrm{ft}$ lifts, using slip forms and curb ring, as the shaft is deepened from the base of the collar to 1,147 ft. This lining will be carried $40 \mathrm{ft}$ to $50 \mathrm{ft}$ above the shaft bottom to provide working clearance and reduce the risk of blasting damage to the concrete and steel forms. The primary lining may be carried closer to the shaft bottom if pneumatic rock breakers or other mechanical excavation methods are used for shaft sinking.

The bearing key, wedge ring, and picotage will then be constructed and the watertight lining installed upward from 1,147 ft to the surface. The steel sheet for the watertight lining will be lowered in manageable segments, clamped into position, and welded. Ground freezing will provide the dry conditions necessary for high quality welding. All welds will be tested to ensure watertightness. Steel reinforcing will be assembled into mats, lowered, and spliced into place. Asphaltic sealing material will be poured between the outer steel sheet and primary lining after concrete is placed between the double steel lining.

In Option 1, each shaft will then be deepened from 1,147 ft to 1,292 ft with nonwatertight concrete lining installed in lifts. A primary lining will be installed from 1,292 ft to 2,051 ft where a bearing key will be constructed. This will be followed by installation of the lower watertight lining from $2,051 \mathrm{ft}$ upward to $1,292 \mathrm{ft}$ proceeding in a manner similar to the upper 
watertight lining. Sanded cement grout will be placed between the outer steel sheet and primary lining instead of asphalt.

In Option 2, ductile cast iron tubbing will be installed continuously from $1,147 \mathrm{ft}$ to $2,051 \mathrm{ft}$ as the shaft is deepened. Individual segments of the tubbing will be bolted into a ring configuration and completed rings suspended from those already installed above. The horizontal and vertical joints between segments and rings will be sealed with lead gaskets. The tubbing will be coupled to the excavation wall by backfilling with concrete.

As the shaft lining is constructed from 1,147 ft to 2,051 ft for either lining arrangement, the lithostatic lining for Bulkhead 1 and the compressible material for Bulkheads 2 through 4 will be installed. Chemical seals and picotages will be installed at the top and bottom of the watertight lining section at elevations indicated in Figure 4.3-1 and Table 4.3-2.

Once the shaft lining has been completed to $2,051 \mathrm{ft}$, the shaft will be excavated to the shaft station at $2,471 \mathrm{ft}$. The nonwatertight lining will be installed as the shaft is deepened. Where compressible backfill material is required, the lining will be installed upward from a bearing key located below the zone. Compressible backfill material will be installed behind the lining in each salt bed except in the areas of the bearing key and station protection rings. The portion of the shaft below the repository horizon will then be excavated and the concrete lining placed as the shaft is deepened.

\subsubsection{Shaft Equipping}

Shaft equipment, as described in Section 4.3.4, will be installed from the sinking deck once the linings have been completed. Pipes and cables will be attached to brackets which will be either welded to the steel sheet or bolted to embeds set in the concrete. Buntons and rigid guides will be installed from the sinking deck. Once the sinking deck has been removed, guide ropes will be suspended from the headframe and the shaft conveyances will be installed. 


\subsection{UNDERGROUND FACILITIES}

This section describes the design concepts for the underground facilities including those required for support, development, and waste emplacement. Additional descriptions specific to underground excavation and repository development and to underground ventilation are presented in Sections 3.3 , Underground Development, and 3.4, Ventilation, respectively. Major elements of the underground layout design are also described and illustrated in this section.

\subsubsection{Design of Underground Facilities}

The underground will be comprised of facilities which will be both longand short-lived. Facilities such as submain entries, main entries, and shafts must not only be operable over the time period during which emplacement occurs but also beyond if the option for retrieval is to be maintained. On the other hand, emplacement entries will have a relatively short life between the time of excavation and backfilling.

\subsubsection{Exploratory Shaft Facility}

The first facility that will be developed in the repository horizon is the exploratory shaft facility (ESF). This facility will be used for site characterization, an activity that will be completed prior to initiation of repository construction.

The ESF will include surface facilities, two 12-ft diameter exploratory shafts (ESs), and excavations within the repository horizon which are designed for simulated vertical waste emplacement. The ESF Title I Design layout is shown in Figure 4.4-1. The layout will change on the basis of the completed ESF Title II Design. The utilization of this facility during pre-emplacement and emplacement phases of repository development is described further in Section 7.3.3, The Effect of the ESF. 


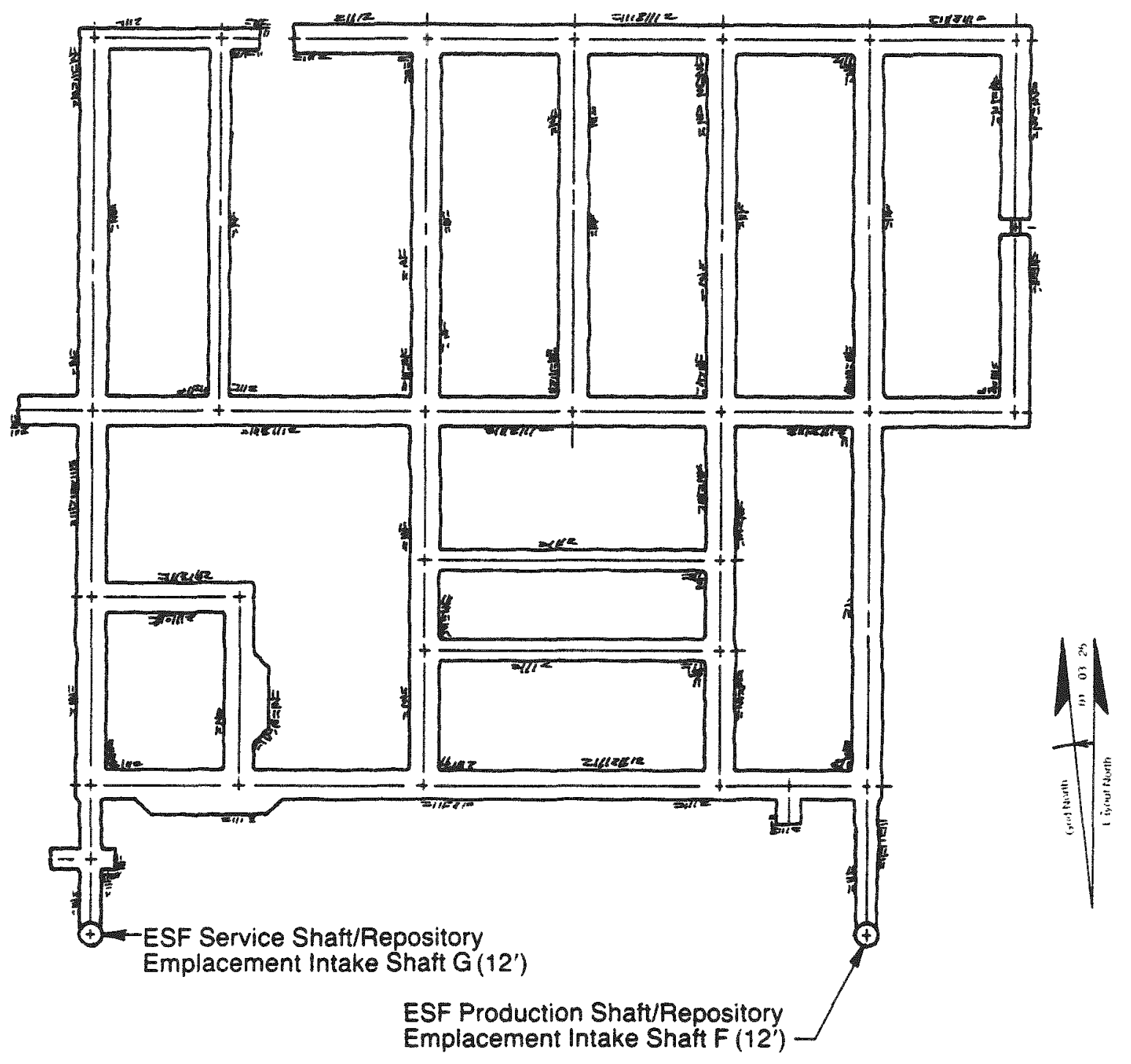

NOTES:

1. This view shows the ESF as it would appear during site characterization.

2. Layout based on PB/PB-KBB design of ESF.

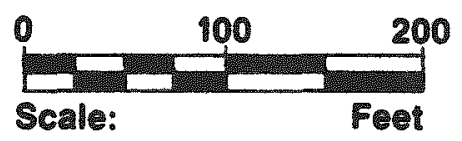

\section{LAYOUT OF EXPLORATORY \\ SHAFT FACILITY}

FIGURE 4.4-1 


\subsubsection{Repository Horizon}

The LSA 4 Salt horizon contains a zone of relatively pure salt thick enough to meet the requirements of the vertical emplacement mode. This mode will require a $24 \mathrm{ft}$ high interval for the emplacement entry envelope, plus an additional interval immediately below the entry for the waste package and shielding counterbore. This lower interval will range in thickness from $17.1 \mathrm{ft}$ to $22.5 \mathrm{ft}$.

The horizon selected within the salt zone will provide a $10 \mathrm{ft}$ thick roof beam composed of relatively pure salt which is free of strong partings. This is expected to provide both stable roof conditions and some allowance for remining. The floor will be composed of $15 \mathrm{ft}$ of relatively pure salt containing several partings. The emplacement horizon selected will also provide a relatively pure salt section for stable pillars. The emplacement boreholes will penetrate through the floor beam and into the interval below which contains thin interbeds of mudstone and anhydrite as well as several partings. Figure 4.4-2 shows the selected emplacement horizon and a part of the stratigraphic column of the LSA 4 salt at J. Friemel No. 1 borehole, which is located approximately five miles away from the repository shaft locations. The depths of the roof, floor, and emplacement horizon shown in Figure 4.4-2 are applicable to the J. Friemel No. 1 borehole location only. They will be different at shaft locations due to geologic structure and topographical features. A more detailed description of the methodology and rationale for horizon selection can be found in Section 7.1.3, Underground Elements.

\subsubsection{Arrangement of Shafts}

The number of shafts, their functions, and their sizes are discussed in Section 4.3, Shaft Facilities. Their locations are shown in Figure 4.4-3. After considering the underground layout, the $A / E$ contractor arranged the shafts to meet several major requirements:

Ventilation. Repository development and emplacement operations will be ventilated by separate systems isolated from each other by substantial stoppings. To this end, emplacement exhaust Shaft A, waste Shaft B, and 

Deaf Smith County, J. Friemel No. 1, Lower San Andres Unit 4 Salt

Depth Below Estimated Percent Location of Apparent Interbed U. of Texas Zone Emplacement

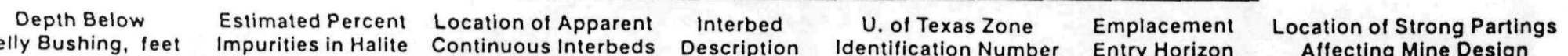

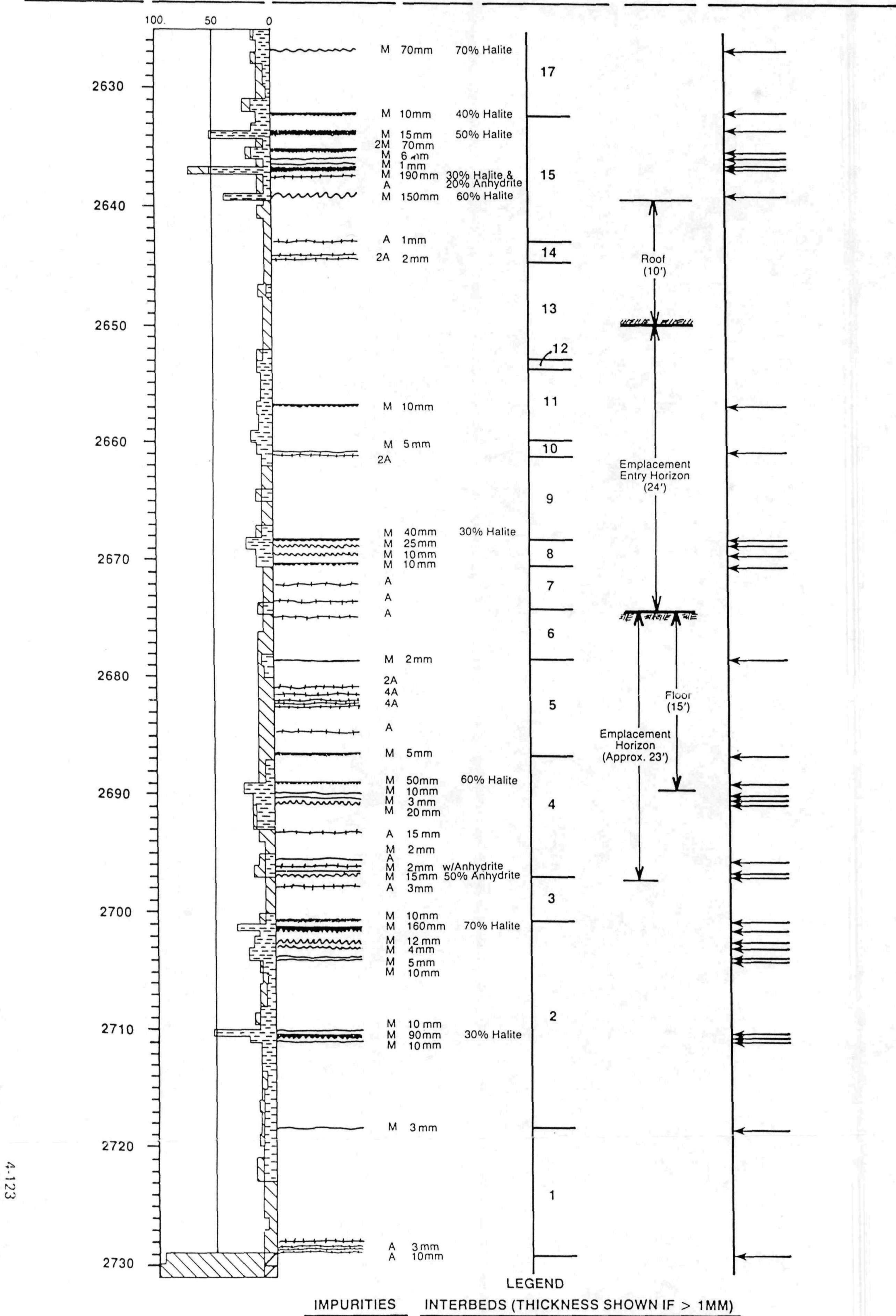

Kelly Bushing

Elevation $=4024.9 \mathrm{ft}(\mathrm{MSL})$

Mudston

Mudstone (M)

Ground Surface

Elevation $=4015.9 \mathrm{ft}$ (MSL)

D Anhydrite

$+H$ Anhydrite (A)

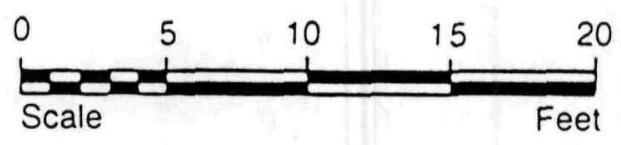

Reference: Hovorka, S., B. Luneau, and S. Thomas, 1985. Stratigraphy of Bedded Halite in the Permian San Andres Formation Units 4 and 5 ,

Palo Duro Basin, Texas, U. of Texas at Austin, Bureau of Economic Geology. 
- 100 


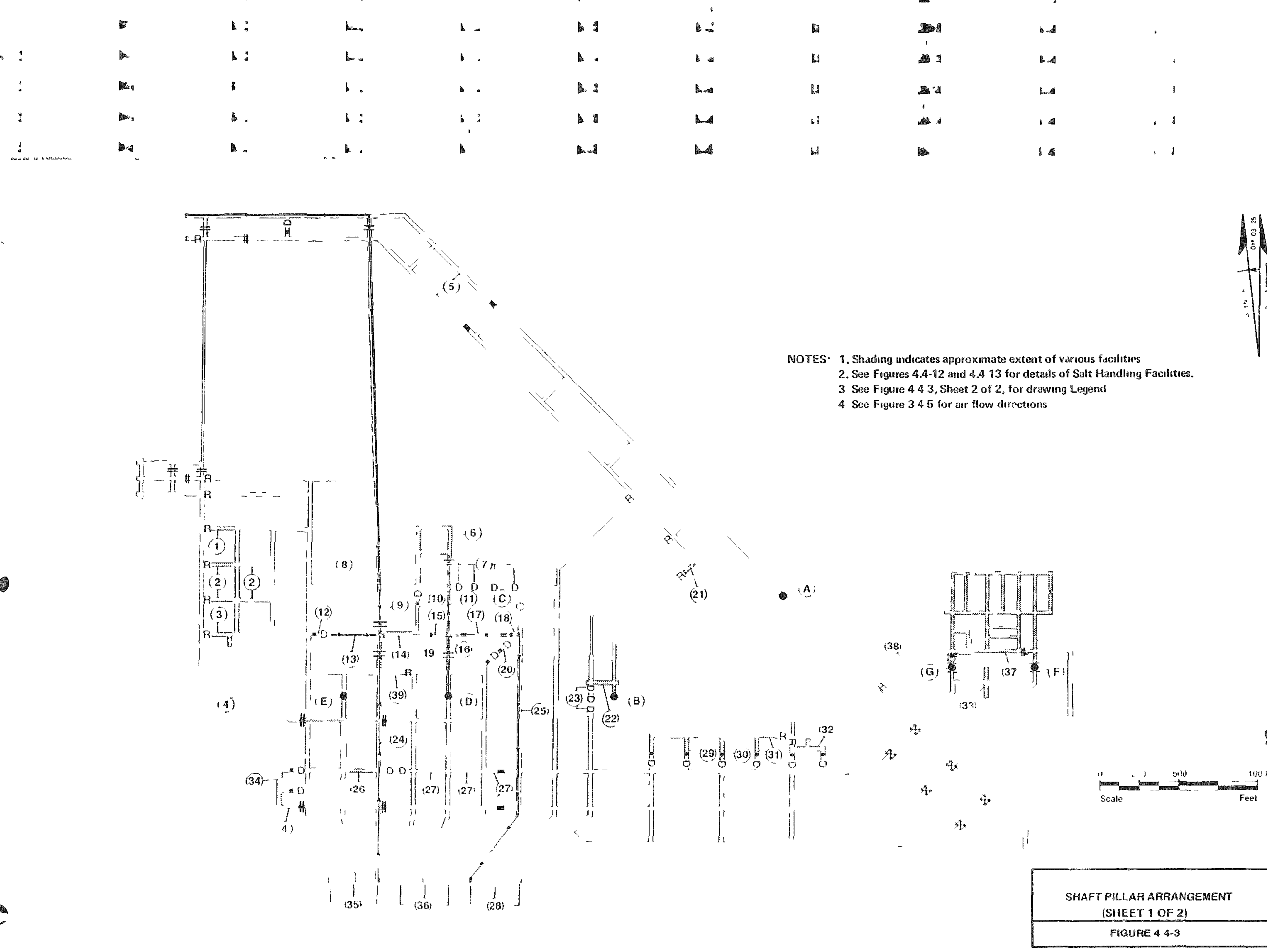





\section{LEGEND}

(1) Development Side Ortice Area

(2) Devolopment Side Shop Area

(3) Devolopment Side Wrehouse Area

(4) Wntilation Exhaust Entry

(5) Emplacement Exhoust Main Entry

(6) San Block Plant Area

(7) Substantial Equipmen Doors/Air Lock

(3) Emplacement Side Access Entry

(9) Temporary Development Belt Conveyor

(10) Sant Siorage Reclaim Area Maintenance Access

(11) Bent Conveyor to Sant Block Plant

(12) Ventiation Intake/ Access Entry

(13) Shutte Conveyor

(14) Mined-Salt Surge Storage Bin

(15) Salt Storge Reclaim Dell Conveyor

(16) San Distribution Ein

(17) Delt Conveyor to Beckitil Passthrough Point

(18) Screw Conveyor Becktill Passthrough System

(19) Dent Conveyor to Sont Hoisting Facility

(20) Wentilation ExhaustMaintenance Access Entry

(21) Waste Shaft MEPA Fittering Facility.

(22) Transter Cosk Manding Area

(23) Substantial Equipment Doors/Air Lock

(24) Development Collection Conveyor

(25) Lacktill Rett Conveyor

(26) Dewatering Pump Station

(27) Construction Crosecut

(28) Emplacement intake/Access Main Entry

(29) Emplacment Side Otrice Area

(30) Emplacement Side Warthouse Area

(31) Emplacement Side Shop Area

(32) Emplacement Side Retueling Area

(33) Temporiny Construction Shop Ares

(34) Development Side Rehuling Area

(35) Development intake/Access Main Entry

(36) Development Exhaust Main Entry

(37) ESF Performance Confirmation Area

(38) ESF Ventilation Exhaust Entry

(39) Electrical Substation
(A) Emplecement Exhaust Shatt

(3) Manding Shat

(C) Location for Emplacement Intake Shaft if ES's are Not Used for This Purpose

(D) Development Exhaust Shaft

(E) Development intake Shatt

(F) ESF Production Shat/Repository Emplacement Intake Shatt

(G) ESF Service ShatuRepostory Emplacement Intake Shatt

Intake Airflow

- Exhaust Airtlow

- Delt Conveyor, Showing Direction of flow

Eridge, for Crossover Entry

D2] Ramp, Showing Downhill Direction

D Equipment/ventilation Door

- Equipment/ventilation Door with Regulator

= stopping

R Stopping with Regulator

DII Rigid Vent Tubing

Substantial Stopping

00 Overcas:

Dox Check (Stopping with Belt Passthrough)

- Fire Door
SHAFT PILLAR ARRANGEMENT (SHEET 2 OF 2) 
alternate emplacement intake Shaft $C$ will be located near the ESs (Shafts $F$ and G) which serve the emplacement ventilation system. M- ned-salt/exhaust Shaft D and service/intake Shaft $E$, which will serve the development ventilation system, will be located at a distance from the group of emplacement shafts.

ESF Isolation. To retain the option of isolating the ESF, all repository shafts will be located west of the ESF.

Shaft Pillar. Shafts $B, D$, and $E$ will be located on an east-west line parallel with the north boundary line of the property. Shaft A will be located to the north of this line of shafts to accommodate the emplacement exhaust system.

Shaft Location. The shafts will be updip from the emplacement areas. This concept will enhance water control in the emplacement horizon and shorten the length of the shafts.

\subsubsection{Underground Arrangement}

The underground arrangement shown in Figure $4.4-4$ has the shafts centrally located toward the north end of the property and at a surface elevation above the PMF. The main access entries will extend south from the shafts and bisect the emplacement area. Emplacement panels will be oriented in an east-west alignment, approximately on strike, along both sides of the main entries except for Panel 9 which is located west of the shaft area. The underground repository area will be centrally located between the east-west property boundaries, as defined in the environmental assessment (EA), to provide a buffer zone of approximately equal width along the east, west, and south property boundaries (DOE, 1986a).

The emplacement horizon dips $0.3^{\circ}$ on a due south bearing. Thus the underground arrangement is oriented so the shafts and shaft pillar will be located at the higher elevation at the north end of the site so water will drain away from them. This orientation will safeguard the shaft facilities 

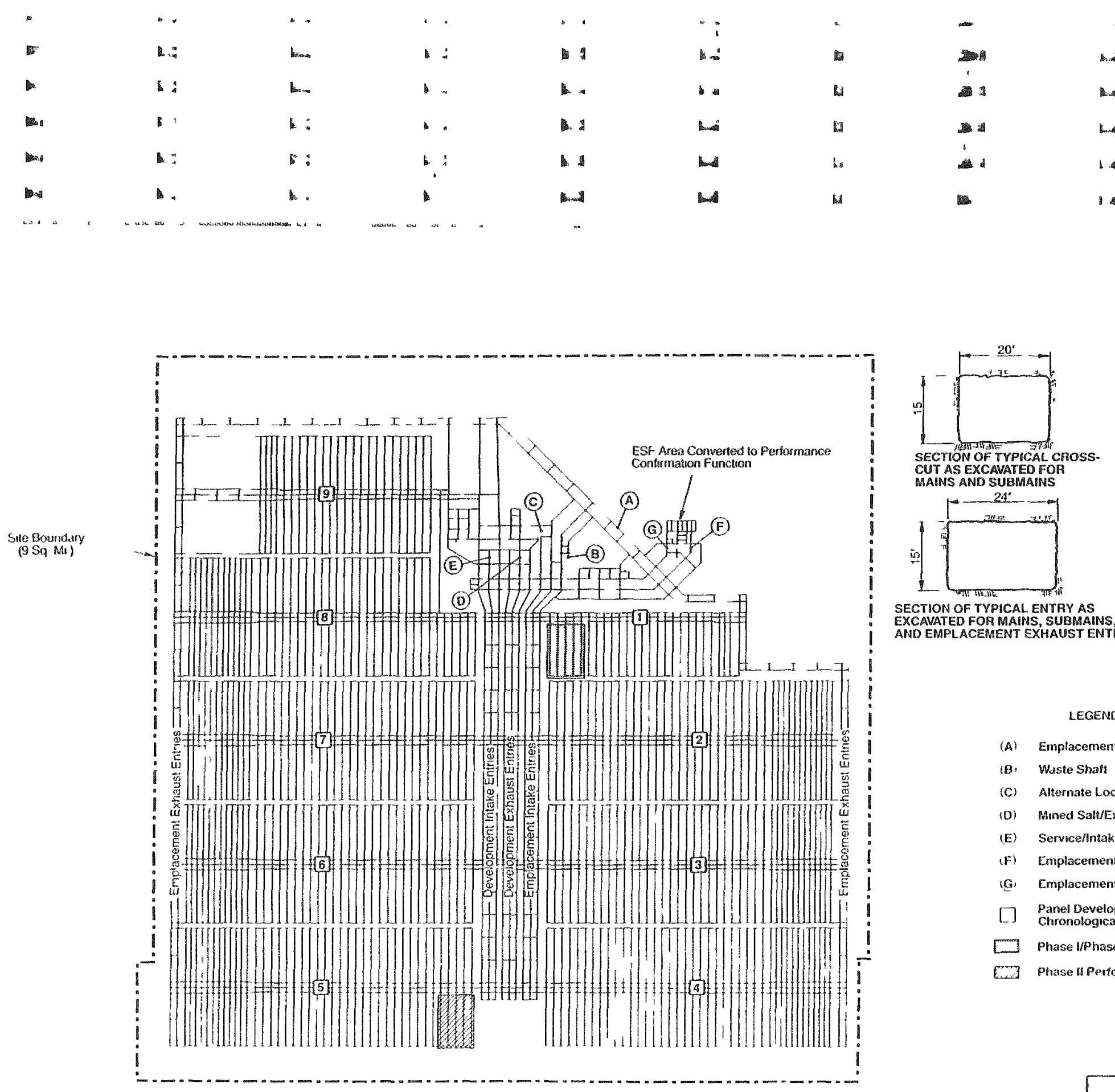

SECTION OF TYPICAL ENTRY AS

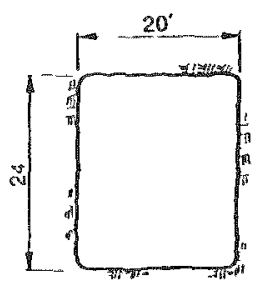

(A) Emplacement Exhaust Shaft

(B) Waste Shaff

(C) Alternate Location for Emplacement Intake Shaft

(D) Mined Salt/Exhaust Shaft

(E) Service/lntake Shaft

(F) Emplacement Intake Shaft

(G) Cmplacement Intake Shaft

$\square$ Panel Development Sequence, Numbers trdicate Chronological Order of Development

Phase l/Phase li Performance Confurmation Area Cury Phase If Performance Confurmation Area

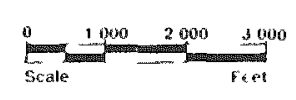

REPOSITOHY UNOERGHOUND I AYOUI 

during water inflow events. Small water inflows will be handled by the underground drainage system. Because water inflows would most likely be encountered during underground development excavation, development will advance in a downdip direction; thus, any water inflows will be confined to the downdip development face areas of the emplacement and main entries.

\subsubsection{Shaft Pillar}

The shaft pillar will be a low extraction area (extraction ratio less than $10 \%$ ) which surrounds and protects the shafts. Long-lived support facilities will be located within the shaft pillar for their protection during the time from initial construction through decommissioning. These facilities are listed in Section 4.4.2.1. To ensure shaft pillar stability, waste emplacement areas will be located outside the shaft pillar boundary.

The shaft pillar itself will be shaped like a cone with its apes located at the shaft collar. An engineering evaluation which was conducted to determine the shaft pillar size showed that it should have a 1,200-ft radius, based on a typical depth at 2,471 ft. See Section 7.1.3.7 Entries, Pillars and Ground Support Systems.

Entries within the shaft pillar area will be spaced further apart than those in other locations in order to leave pillars which are large and stable.

\subsubsection{Waste Emplacement Panels}

The waste emplacement panels will be rectangular, oriented in an east-west direction, and perpendicular to the main entries. Typical emplacement panels will have three submains located in the center of the panel to provide access to the emplacement entries. The emplacement entries will be located along both sides of the submains and oriented perpendicular to them. The typical emplacement panel layout yields an extraction ratio of $16 \%$.

Creep at elevated temperatures combined with retrieval considerations significantly impacts the panel design. Thermal loading and its effects on the salt medium are described in further detail in Section 6.4.4, Thermal Loads. 
The methodology and engineering analysis used to predict salt creep characteristics and the calculated amounts at ambient and elevated temperatures are discussed in Section 7.1.3, Shafts and Underground Elements. Retrieval procedures and anticipated conditions are described in Section 6.3 , Waste Retrieval.

The main and emplacement return entries may be used for a period of about 84 years. It will therefore be advantageous to minimize creep by minimizing temperatures. This will be done by maintaining wide abutment pillars immediately adjacent to these entries. Thermal loading will be controlled, hence peak temperatures and creep rates reduced to a minimum by selecting appropriate pillar widths. However, if retrieval is initiated after the repository operating period, it is expected that at some time remining of these entries will be required.

The submain panel entries may also be kept open to provide access for possible waste retrieval. To reduce creep closure rates in these entries, temperatures will be reduced by leaving a waste-free pillar area adjacent to the submains. However, following emplacement, considerable closure of these submains will be allowed. Therefore, enlargement of these entries may be required prior to retrieval.

Areal heat loading will be limited to a maximum of about $40 \mathrm{~kW} / \mathrm{Ac}$ to ensure that peak temperatures and creep closure are within acceptable limits to accommodate retrieval. To maintain this areal heat loading in entries which contain consolidated spent fuel, the centerline distance between disposal containers will be varied according to the heat output of each individual container.

For disposal containers of lower heat output, e.g., West Valley High-Level Waste (WVHLW), defense high-level waste (DHLW), and fuel assembly hardware (FAH), the design utilizes minimum spacing between containers and reduced spacing between entries. The resulting areal heat loading will be about $17.6 \mathrm{~kW} / \mathrm{Ac}$. Design details of waste emplacement entries are presented in Section 4.4.2.2. 
The emplacement entries are designed as long, single entries without crosscuts to enhance emplacement efficiency, geotechnical stability, and operational simplicity for retrieval. Entry length was evaluated to determine its relationship to creep closure in re-excavated entries and to the length of time required to retrieve packages from an entry. The retrieval scenario was based on the assumption that all packages within an entry would be retrieved, and that allowable entry creep closure would not exceed $10 \%$ within the time that retrieval took place.

Assuming an entry re-excavation rate of 150 tons per shift, a retrieval time of two days per package and a backfill rate of 400 tons per shift, it was determined that all packages in an entry could be retrieved before $10 \%$ closure occurred.

\subsubsection{Entries and Pillars}

The mains and submains will be designed with a rectangular section $15 \mathrm{ft}$ high by $24 \mathrm{ft}$ wide and crosscuts between the mains and submains will be $15 \mathrm{ft}$ high by $20 \mathrm{ft}$ wide. Waste emplacement entries will be $20 \mathrm{ft}$ wide and $24 \mathrm{ft}$ high. These dimensions will be adequate for movement of air, personnel, and equipment. The $15 \mathrm{ft}$ room height in mains, submains, and cross cuts was selected because it will permit excavation by single pass mining methods. Waste emplacement entries will be mined $24 \mathrm{ft}$ high to provide sufficient clearance for vertical emplacement equipment. The rationale for entry sizing is discussed in Section 7.1.3.7. The entries will be excavated with rounded corners to reduce stress concentrations at those locations. The entry dimensions include a $10 \%$ allowance for creep closure. Thus, the openings can close to $13.5 \mathrm{ft}$ high by $21.6 \mathrm{ft}$ wide for mains and submains, and $18 \mathrm{ft}$ wide by $21.6 \mathrm{ft}$ high for emplacement entries and still provide adequate clearance for equipment operation and adequate cross section for conducting ventilation air.

Remining during the operating life of the repository is not expected. Crosscuts will be driven between the mains and submains to improve face ventilation and shuttle car haulage efficiency. However, no crosscuts will be driven between the waste emplacement entries because no similar benefits would be realized. Rock support systems to be used are discussed in Section 3.3.5, 
Ground Support Methods. A detailed description of the methodology and rationale for entry and pillar design is included in Section 7.1.3.7, Entries, Pillars, and Ground Support Systems.

\subsubsection{Drainage System}

The drainage system design parameters will be determined in ACD. The design assumes that there will be no major water inflows into the underground workings. Thus, the drainage system will be designed to handle only minor water or brine inflows if they occur.

The drainage system will consist of an underground collection system, a dewatering pump station, and discharge piping. The underground collection system will include pumps at the bottoms of the shafts and a portable dewatering pump station located in the face area of the main entries. Pipelines will extend from these pumps to the main dewatering pump station. The portable dewatering pump station will be relocated periodically and the pipeline extended to maintain proximity to the advancing development faces. The location and arrangement of the underground drainage system is shown in Figure $4.4-5$.

The dewatering pump station will be located within the shaft pillar near Shaft $E$. This location places it updip from the repository development faces which will advance in a downdip direction. If a water inflow event should occur in the underground, this design would safeguard the dewatering pump station from flooding and provide storage in the mined areas. The discharge pipeline will extend trom the main dewatering pump to the service/intake shaft and up the shaft to the surface.

\subsubsection{Underground Layout}

Design concepts were utilized in an interactive design process to develop an integrated underground layout. These design results are presented in several figures which illustrate major components of the underground including 

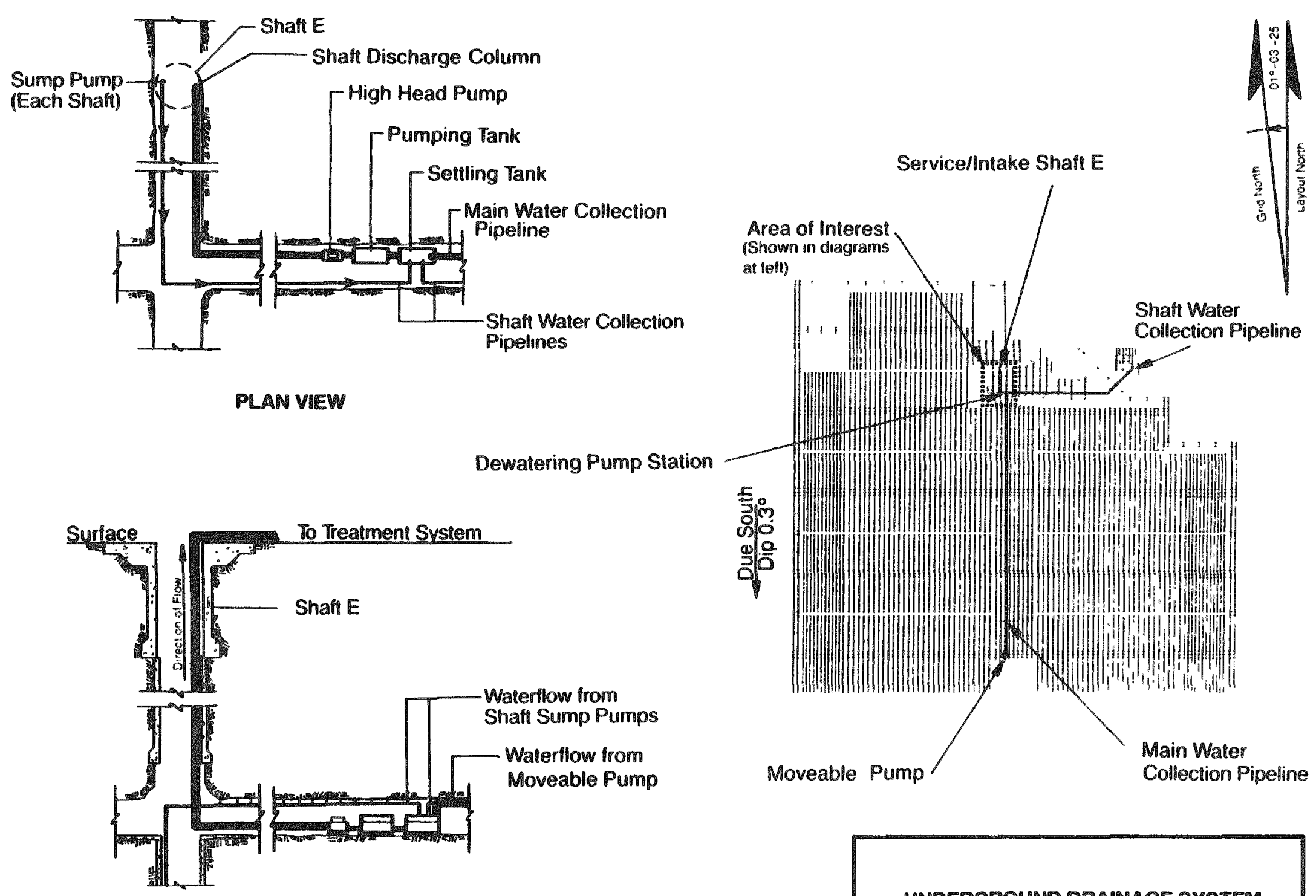

LONGITUDINAL SECTION 
the ESF, main entries, shaft pillar area, and emplacement areas and their aggregate repository arrangement.

\subsubsection{Shaft Pillar Layout and Facilities}

The shaft pillar layout shows the shafts centrally located within a grid of pillars and interconnecting entries. The arrangement of the shaft area is shown in Figure 4.4-3, and some of the major functions performed here are listed in Section 4.5. The descriptions in the following sections are referenced to the locations shown in Figure 4.4-3.

The underground is laid out in two functional areas extending in a northsouth direction, and separated by substantial stoppings located between minedsalt/exhaust Shaft $D$ and waste Shaft B. Development airflow paths are located on the west side of the substantial stoppings, and emplacement airflow paths are located on the east side. Access for transporting equipment between the development side and the emplacement side is provided through a substantial aix lock located in the entry immediately north of Shaft $\mathrm{C}$ location. A radiation check station will be located on the emplacement side of the air lock for checking equipment and personnel entering or leaving the emplacement side.

The repository development side will include service/intake shaft $\mathrm{E}$ and mined-salt/exhaust Shaft D. Shaft $E$ will provide intake air for development and provide access for personnel, supplies, and equipment between the surface and the underground. Shaft $D$ will return development exhaust air to the surface and hoist mined salt.

A set of three main entries, which extend south of Shaft $E$, will provide access and intake ventilation to the active development areas. The entry on the east side will contain the belt conveyor that transports mined salt from the development faces to the mined-salt storage bin. A development side refueling area will be located on the west side of these mains. The dewatering pump station will be located in the second crosscut south of the shaft.

A parallel set of entries, which will be located south of Shaft D, will conduct exhaust air from the development areas to the shaft for discharge. 
The development side support facilities will be located northwest of Shaft E. These facilities will include an office area, shop area, and warehouse. The shop area will consist of four bays for large equipment $(2,150 \mathrm{sq} \mathrm{ft}$ each) and 10 bays for small equipment (875 sq ft each). The warehouse will occupy $5,900 \mathrm{sq} \mathrm{ft}$, and $1,500 \mathrm{sq}$ ft of office space will be provided. The ambulance/fire truck station will be located in the shop complex area. Parking areas will also be provided.

Immediately north of the shop complex will be two future emplacement exhaust main entries. A temporary development belt conveyor will transport the mined salt from these entries to the mined-salt storage bin.

Facilities for handling mined salt will be located to the north of Shafts $D$ and $E$. A detailed description of these facilities is provided in Section 4.4 .2 .6

The emplacement operations side will include waste shaft B, emplacement exhaust Shaft $A$, and emplacement intake shafts $F$ and $G$.

The transfer cask handling area will be located immediately north of Shaft B. It will include two parallel entries, one aligned with the shaft and the other extending from the emplacement main access entry. The entry aligned with the shaft will provide access for the underground cage off/on loader. The entry extending from the emplacement main access entry will provide access for the underground waste transporter. These entries will be connected by two crosscuts. The crosscut nearest the shaft will provide maintenance access, and the crosscut furthest from the shaft will be used for transferring disposal containers from the shaft to the emplacement main entry.

A high-efficiency particulate air (HEPA) filter installation in the area of waste Shaft B will mitigate the escape of radioactive particulates should a release occur from the transfer cask area. An air lock will isolate the waste shaft area from emplacement intake access mains while allowing the waste transporter to shuttle between the transfer cask handling area and the emplacement panels. 
The main entry located on the west side will contain the backfill belt conveyor which will transport salt to the emplacement entry backfilling operation.

A set of two entries will carry the exhaust air from the emplacement operations areas in a northwesterly direction to exhaust shaft A. These same entries will overcast the emplacement intake air entries at a location south of Shafts $F$ and $G$.

The emplacement side support facilities will be located adjacent to the air overcasts and on the north side of the intake entries. These facilities will include a fuel station, an office area, a warehouse area, and a shop area. The shop area will consist of one bay for large equipment (1,500 sq ft) and five bays for small equipment ( $750 \mathrm{~s} \mathrm{ft}$ each). The warehouse will occupy $2,500 \mathrm{sq} f t$ and $1,000 \mathrm{sq}$ ft of office space will be provided. The ambulance/ fire truck station will be located within the shop complex area.

\subsubsection{Waste Emplacement Configuration}

The design for waste disposal container emplacement allows the flexibility to segregate waste by container type or heat output. Although not a requirement, segregation of waste will be helpful for purposes of accountability and retrieval. The containers will vary in length from $11.1 \mathrm{ft}$ to $15.9 \mathrm{ft}$ and in heat output from $0.0 \mathrm{~kW}$ to $6.6 \mathrm{~kW}$, depending on the type of container and its age. Section 2.1 provides more information on waste containers.

For emplacement purposes, the containers will be divided into two general categories: (1) spent fuel, and (2) DHLW, WVHLW, and FAH. Spent fuel, which is high-heat output waste, will be emplaced in entries dedicated to pressurized-water reactor (PWR) and boiling-water reactor (BWR) disposal containers.

The emplacement design is constrained by an areal heat loading limit not to exceed about $40 \mathrm{~kW} / \mathrm{Ac}$. To meet this constraint, spacing of PWR and BWR disposal containers will be varied in accordance with the heat output of each individual container. The average number of spent fuel containers emplaced in each entry will be 30.6 . Figure 4.4-6 illustrates waste emplacement design for 


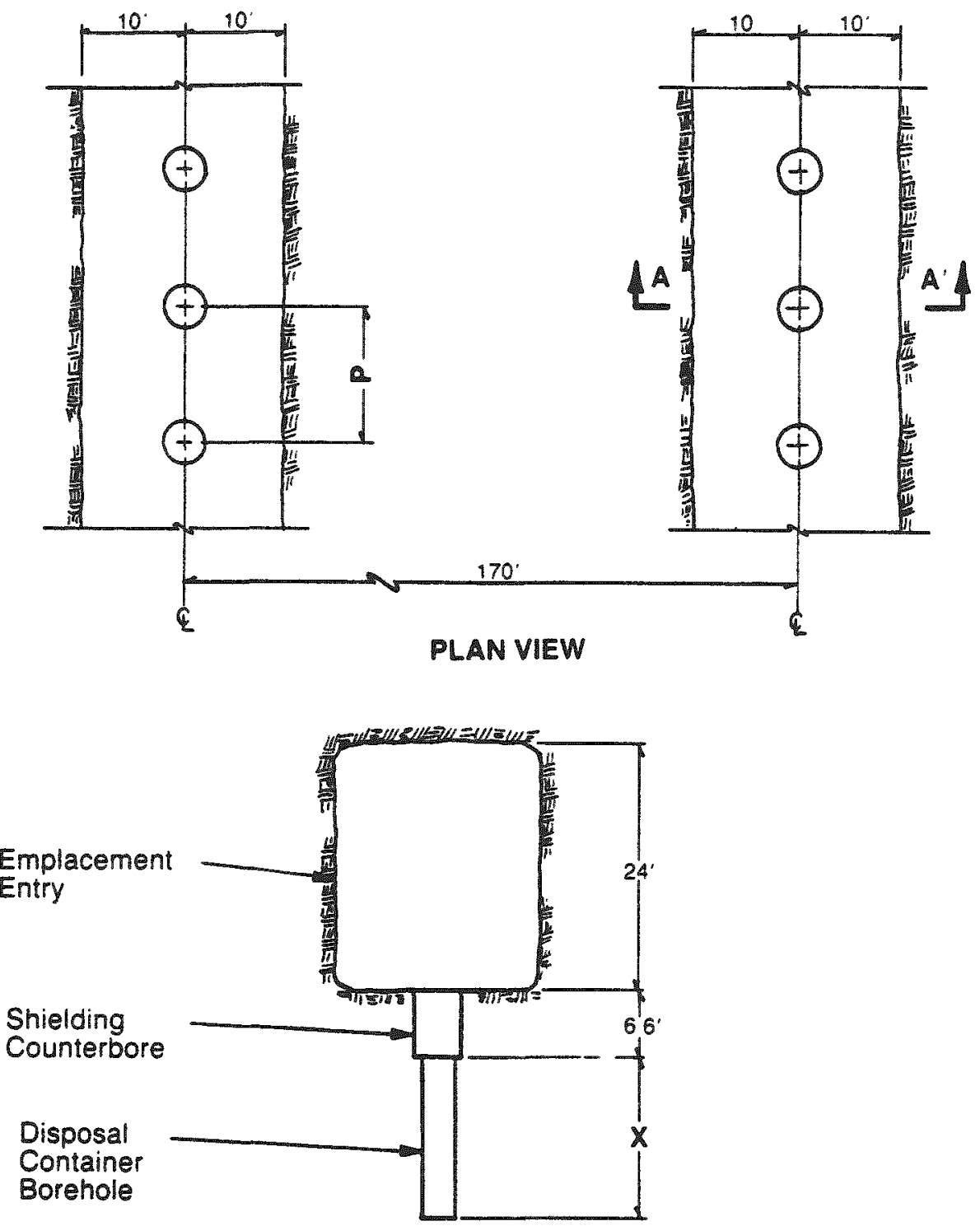

SECTION A-A'

Disposal Container Emplacement Borehole Dimensions

\begin{tabular}{ccccc}
\multicolumn{2}{c}{ Disposal Container } & & \multicolumn{2}{c}{ Borehole } \\
\cline { 5 - 6 } Type & Heat Output & & Length $X$ & Spacing P \\
PWR & $6.6 \mathrm{~kW}$ & & $14.9 \mathrm{ft}$ & $42.3 \mathrm{ft}$ \\
PWR/BWR & 1.62 to $5.4 \mathrm{~kW}$ & & $16.0 \mathrm{ft}$ & $10.41034 .6 \mathrm{ft}$
\end{tabular}

NOTE: 1) Container spacing shall not result in area heat loading in excess of $40 \mathrm{~kW} / \mathrm{AC}$.

2) Disposal containers are segregated by containers with PWR $6.6 \mathrm{~kW}$ containers emplaced in separate entries from PWR/BWR 1.6 kW to $5.4 \mathrm{~kW}$ containers.

\begin{tabular}{c} 
WASTE EMPLACEMENT ENTRY - \\
SPENT FUEL \\
FIGURE 4.46 \\
\hline
\end{tabular}


spent fuel. The waste emplacement entries will be initially excavated $24 \mathrm{ft}$ high by $20 \mathrm{ft}$ wide and spaced on $170 \mathrm{ft}$ centers. The PWR containers for consolidated spent fuel will be $14.8 \mathrm{ft}$ long, and their heat output will be $6.6 \mathrm{~kW}$. The PWR containers for intact spent fuel will be $15.9 \mathrm{ft}$ long with a heat output of $2.2 \mathrm{~kW}$ to $4.4 \mathrm{~kW}$. The spacing between containers will vary from $14.0 \mathrm{ft}$ to $42.3 \mathrm{ft}$, depending on the heat output of individual disposal containers.

The BWR disposal containers will be $15.9 \mathrm{ft}$ long with heat output ranging from $1.62 \mathrm{~kW}$ to $5.4 \mathrm{~kW}$. Spacing between containers will vary from $10.4 \mathrm{ft}$ to $34.6 \mathrm{ft}$, depending on the heat output of individual disposal containers.

Emplacement of low-heat waste will be constrained not by heat output but by the need to enhance the stability of the emplacement configuration by minimizing stress interactions between adjacent boreholes. The containers will be placed approximately $8.7 \mathrm{ft}$ apart, which is about twice the diameter of the counterbore (see Figure 4.5-3). This spacing will minimize superimposition of stresses between adjacent boreholes. Under retrieval conditions, temperature and closure rates will be lower and thus will compensate for the expected longer retrieval time, and allow total retrieval without the need to remine.

Figure 4.4-7 illustrates the emplacement design for the low-heat DHLW, WVHLW, and FAH containers. These waste emplacement entries will also be initially excavated $24 \mathrm{ft}$ high by $20 \mathrm{ft}$ wide and spaced on $120 \mathrm{ft}$ centers. The areal heat loading for this design will be about $17.6 \mathrm{~kW} / \mathrm{Ac}$. The disposal container for DHLW and WHLW will be $11.1 \mathrm{ft}$ long, and the heat output will be $0.42 \mathrm{~kW}$ and $0.23 \mathrm{~kW}$, respectively. The container length for FAH will be $14.8 \mathrm{ft}$ with a relatively low heat output. 

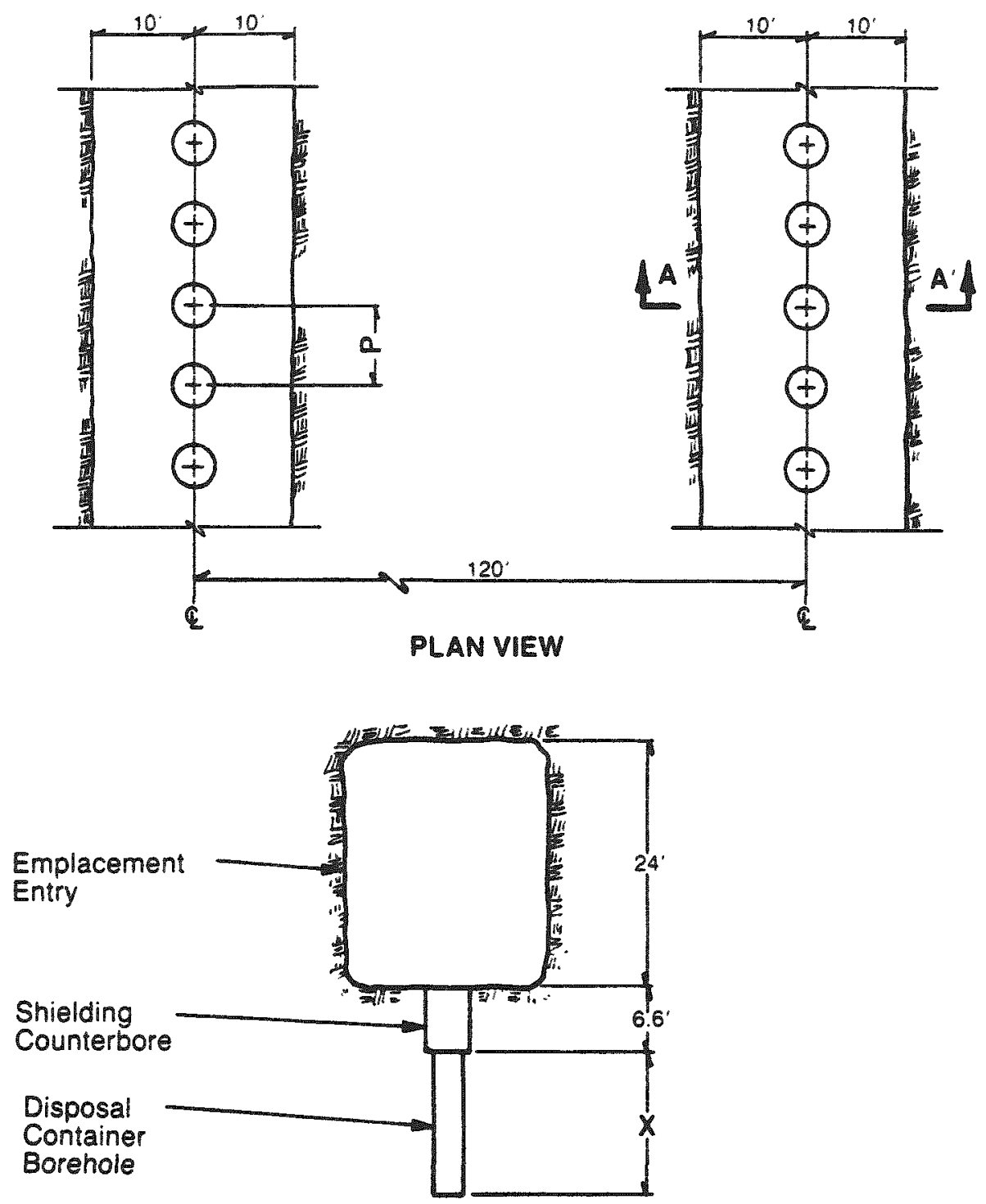

SECTION A-A'

Disposal Container Emplacement Borehole Dimensions

\section{Disposal Container}

Type

DHLW

WVHLW

FAH
Heat Output

$$
\begin{gathered}
0.42 \mathrm{~kW} \\
0.23 \mathrm{~kW} \\
0.0 \mathrm{~kW}
\end{gathered}
$$

\begin{tabular}{cc}
\multicolumn{2}{c}{ Borehole } \\
\hline Length $X$ & Spacing $P$ \\
$11.2 \mathrm{ft}$ & $8.7 \mathrm{Ht}$ \\
$11.2 \mathrm{ft}$ & $8.7 \mathrm{ft}$ \\
$14.9 \mathrm{ft}$ & $8.7 \mathrm{ft}$
\end{tabular}

WASTE EMPLACEMENT ENTRY DHLW, WVHLW, FAH

FIGURE 4.4 .7 


\subsubsection{Borehole Dimensions and Locations}

The waste emplacement boreholes will be cylindrical excavations extending vertically into the floor of the emplacement entries. Each borehole will consist of a smaller diameter section toward the bottom of the hole and a larger diameter section near the collar. The smaller diameter borehole will receive the disposal container and the larger diameter (counterbore) section will receive part of the transfer cask during emplacement and later will be backfilled with crushed salt. The design of the waste emplacement borehole is shown in Figure 4.4-8.

The centers of the boreholes will be located on the entry centerline. The entry centerline will be used as a reference point because it will provide consistent waste package locations with reference to surveyed baselines irrespective of salt creep. The depth of the counterbore section will be $6.6 \mathrm{ft}$ below the floor of the entry.

\subsubsection{Waste Emplacement Panels}

A typical waste emplacement panel and its dimensions are shown in Figure 4.4-9. Three submains will bisect the panel and provide access to the emplacement entries. The submains will be spaced on $100 \mathrm{ft}$ centers adjacent to the $170 \mathrm{ft}$ spaced entries, and on $120 \mathrm{ft}$ centers adjacent to $120 \mathrm{ft}$ spaced entries (see Figure 4.4-10). The emplacement entries will be oriented perpendicular to the submains and will be spaced symmetrically along both sides at intervals of either $120 \mathrm{ft}$ or $170 \mathrm{ft}$. The entries on $120 \mathrm{ft}$ spacing will be designed to receive low-heat waste and will be positioned at the rear of the panel. The low heat entries will be clustered at the rear of the panel to effect improvement in ventilation and backfilling. The entries on $170 \mathrm{ft}$ spacing will be designed to receive high-heat waste.

The emplacement entries will extend from the submains to an exhaust air entry located along the side of the panel. The entries spaced on $120 \mathrm{ft}$ centers will be 1,156 ft long and the entries spaced on $170 \mathrm{ft}$ centers will be 


\begin{tabular}{|c|c|c|c|c|}
\hline $\begin{array}{l}\text { Disposal Contaner } \\
\text { Type }\end{array}$ & PWR" FAH & BWP!" & PWR'2: \& BWR2 & $\begin{array}{l}\text { DHLW and } \\
\text { WVHLW }\end{array}$ \\
\hline$X(f)$ & 14.9 & 16.0 & 16.0 & 11.2 \\
\hline$Y(f)$ & 3.15 & 3.15 & 3.35 & 3.0 \\
\hline $\begin{array}{c}\text { Disposal Contaner } \\
\text { Lengin (if) }\end{array}$ & 148 & 15.9 & 15.9 & 11.1 \\
\hline $\begin{array}{l}\text { Disposal Contaner } \\
\text { Diameter }(f)\end{array}$ & 2.9 & 2.9 & 3.1 & 2.8 \\
\hline
\end{tabular}

": Consolidated Spent Fuel

a) Intact Spent Fuel

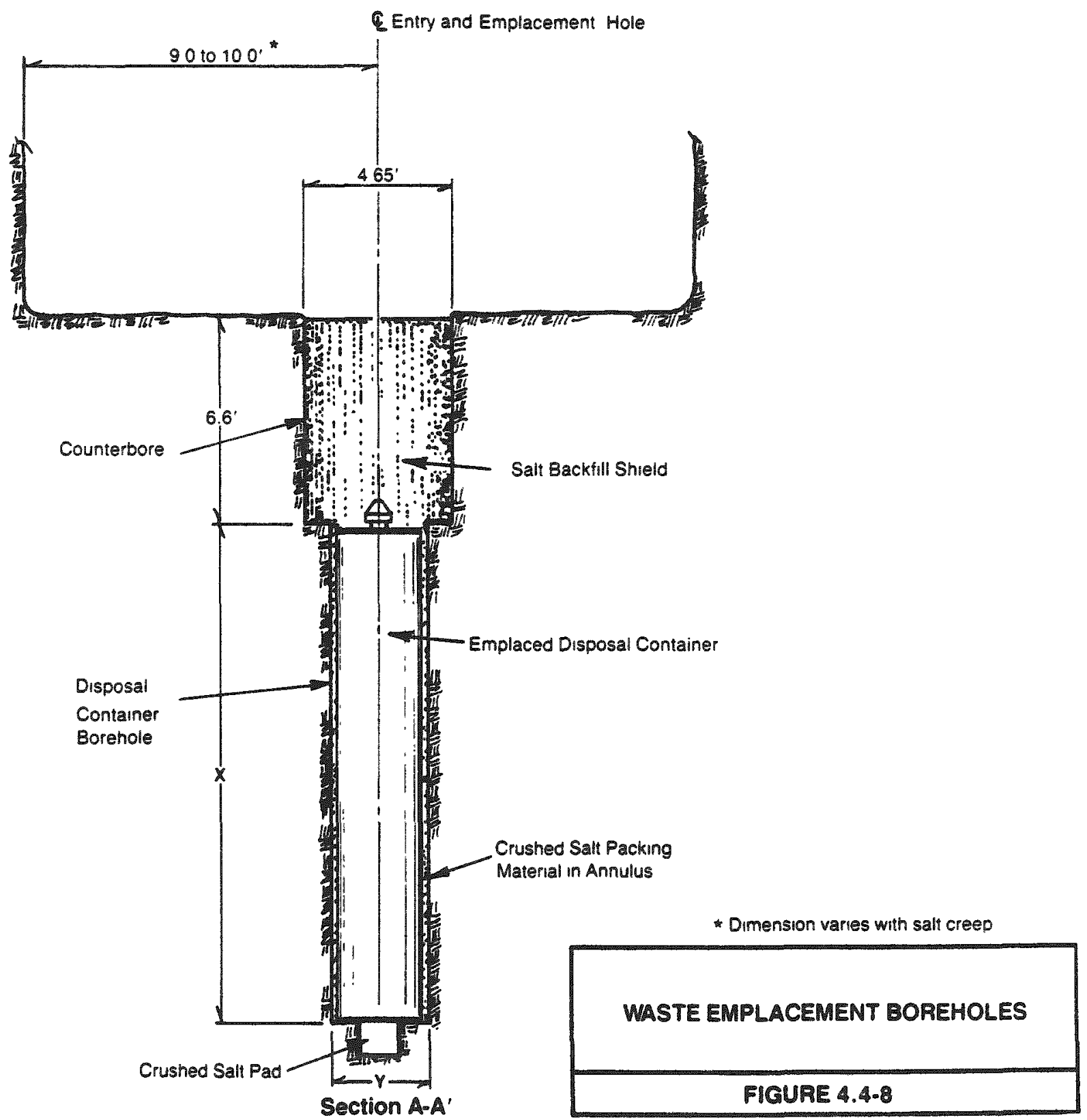



累

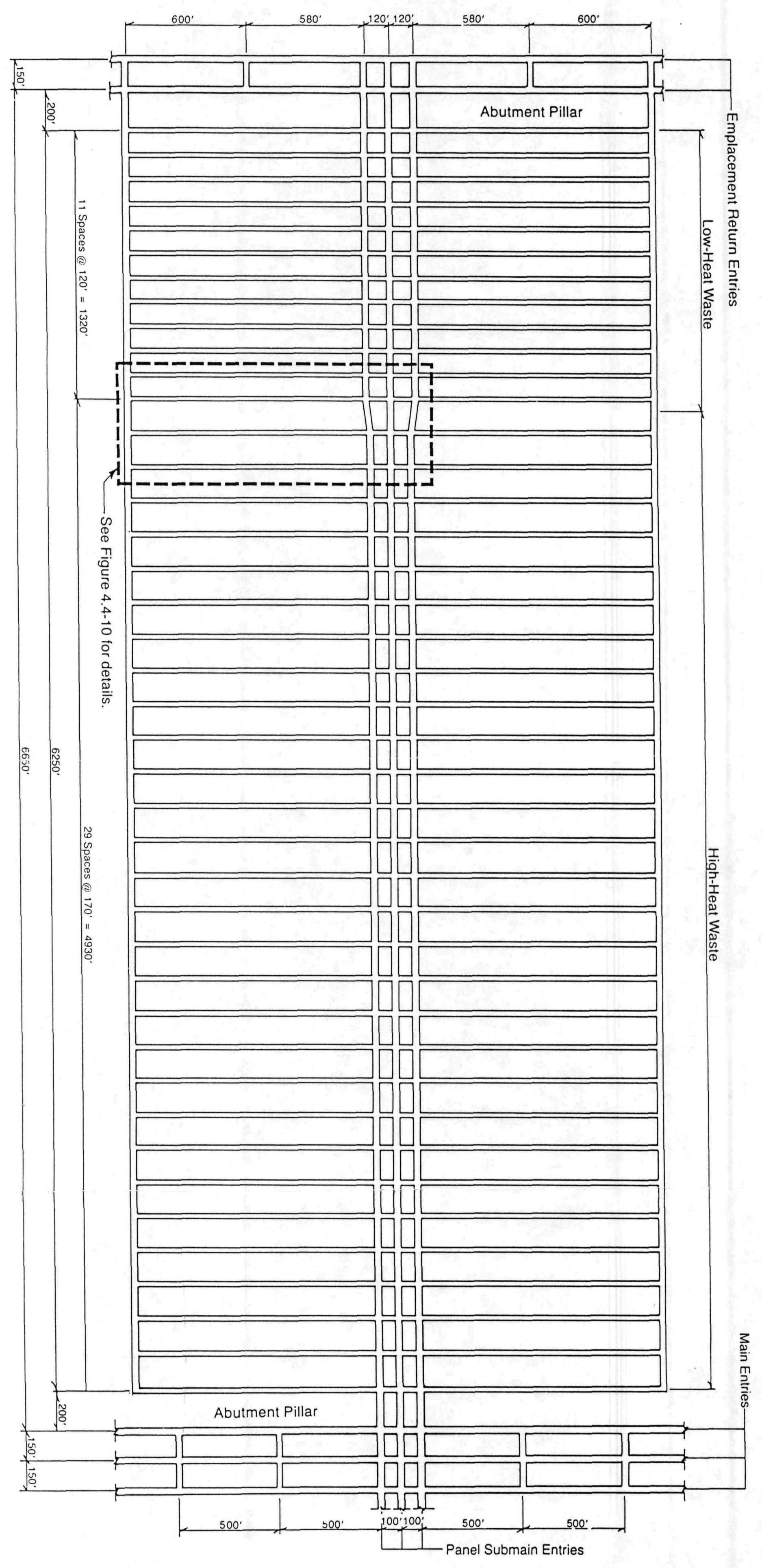




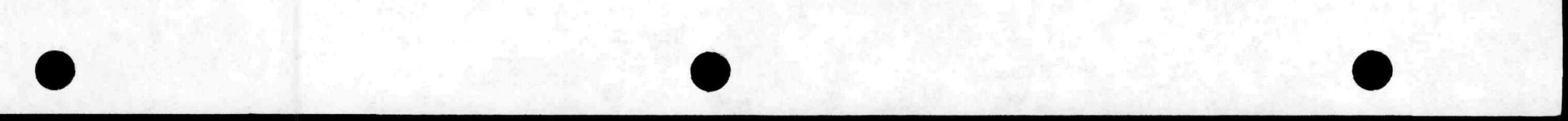




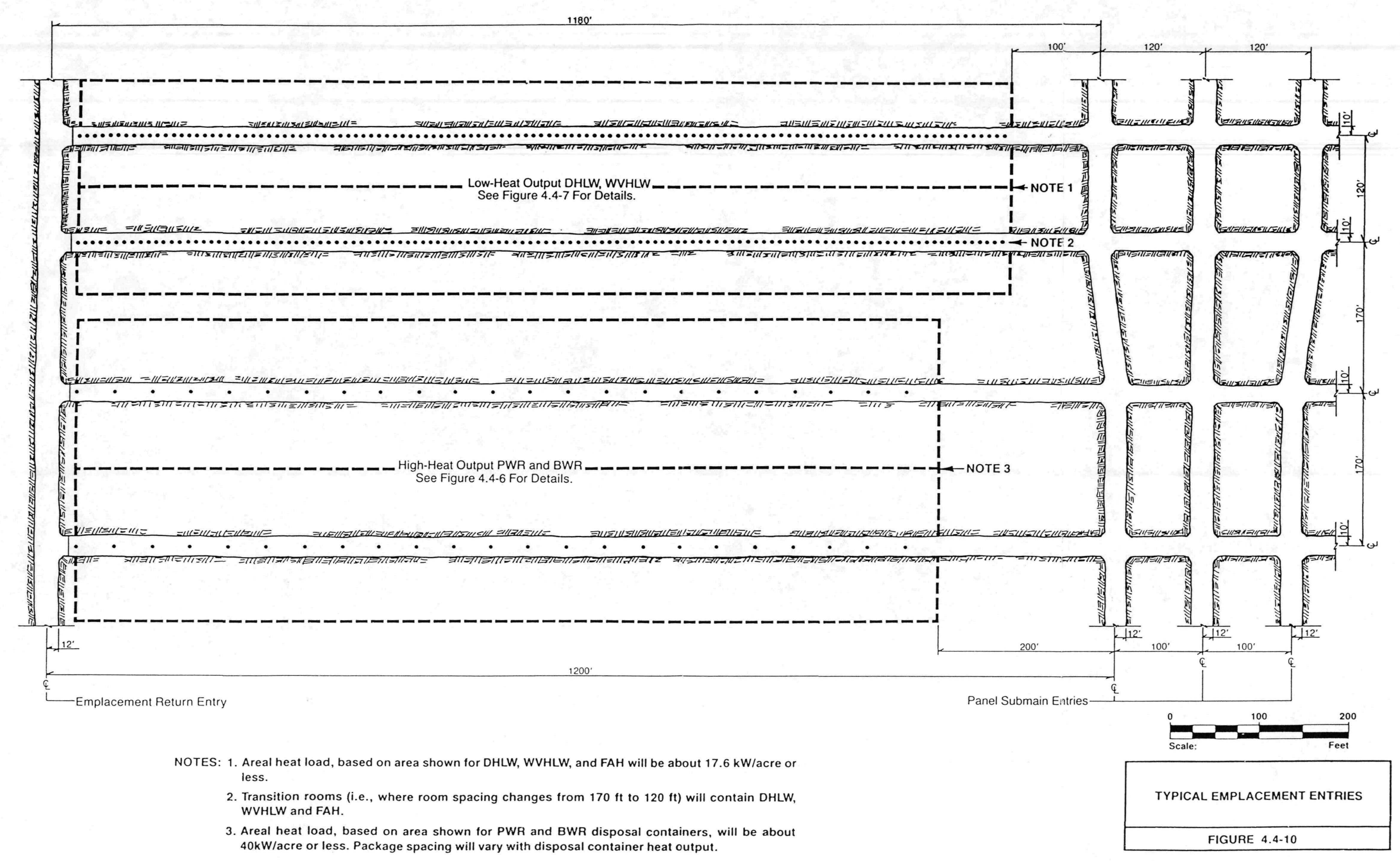


- 100 
1,176 ft long. Abutment pillars will be located at the front and rear of the panel. Narrower pillars will be located along both sides to separate adjacent panels.

Typical high-heat and low-heat entries are shown in Figure 4.4-10. The upper portion of the figure shows a typical DHLW, WVHLW, and FAH emplacement entry. The disposal containers will be emplaced vertically in the floor along the centerline of the entry at a spacing of approximately $8.7 \mathrm{ft}$. The area used for determining areal heat load will be bounded by the centerline of the pillars and an emplacement length of 1,048 ft. Entries located at the transition from low-heat to high-heat entries, i.e., where entry spacing changes from $120 \mathrm{ft}$ to $170 \mathrm{ft}$, will be used for emplacement of low-heat waste. Another option for storing $F A H$ would be to place the disposal containers between the high-heat packages.

The lower part of Figure 4.4-10 shows a typical BWR and PWR emplacement entry. Disposal containers here will also be placed in the floor along the centerline of the entry. The area used for determining areal heat load will be bounded by the pillar centerlines and an emplacement length of $968 \mathrm{ft}$.

Both the high-heat and low-heat emplacement configurations include a setback distance in the section of the pillar adjacent to the submain entries to reduce temperature levels in the nearby submains. Since these entries must remain open for a long service life, lower temperatures will reduce creep closure rates.

\subsubsection{Site Arrangement}

The repository underground layout and its relationship to the site boundaries as depicted in the EA are shown in Figure 4.4-4. The repository will be bisected by three sets of main access/ventilation entries oriented in a north-south direction. These entries will connect to the shaft pillar area located toward the north end of the property. The shaft pillar area will include facilities to support repository development and emplacement operations, the ESF area, and a group of six shafts connecting the underground repository with the surface. 
The repository emplacement area will consist of a number of panels arranged along both sides of the main entries and oriented perpendicular to them, and Panel 9 which will be located west of the thaft area. Three full panels (5 through 7) and parts of Panels 8 and 9 will be located on the west side of the mains, and three full panels (2 through 4) plus part of Panel 1 will be located on the east side of the mains. Panel 9 has unused space which could provide alternate capacity for approximately 2,200 MTU. The perimeter of the repository will be bounded on the north, east, and west sides by a pair of ventilation entries conducting exhaust air from the emplacement areas to the exhaust shaft.

Panels 1 and 5 will provide a special area dedicated to Phase I and II performance confirmation. For a further discussion of performance confirmation, see Section 6.5 .

\subsubsection{Mined-Salt Handling Facilities}

A process flow diagram showing the complete mined-salt handling system from face excavation through surface disposal is shown in Figure 4.4-11. The initial four blocks of this flow diagram are described in section 3.3 , Underground Development. The "hoist to surface" block of the diagram is described in Section 4.3, Shaft Facilities. The blocks downstream of the "hoist to surface" are surface salt handling functions which are described in Section 4.2, Surface Facilities. The remainder of this section describes the functions on the diagram which are performed by salt handling facilities located in the shaft pillar area.

The general location and arrangement of the mined-salt handling facilities is shown in Figure 4.4-3.

The mined salt will be transported from the repository development areas by belt conveyor. It will be transferred onto a shuttle conveyor which will load it into the storage bin. It will then be reclaimed from the bin by a reclaim belt conveyor and discharged into the distribution bin. 


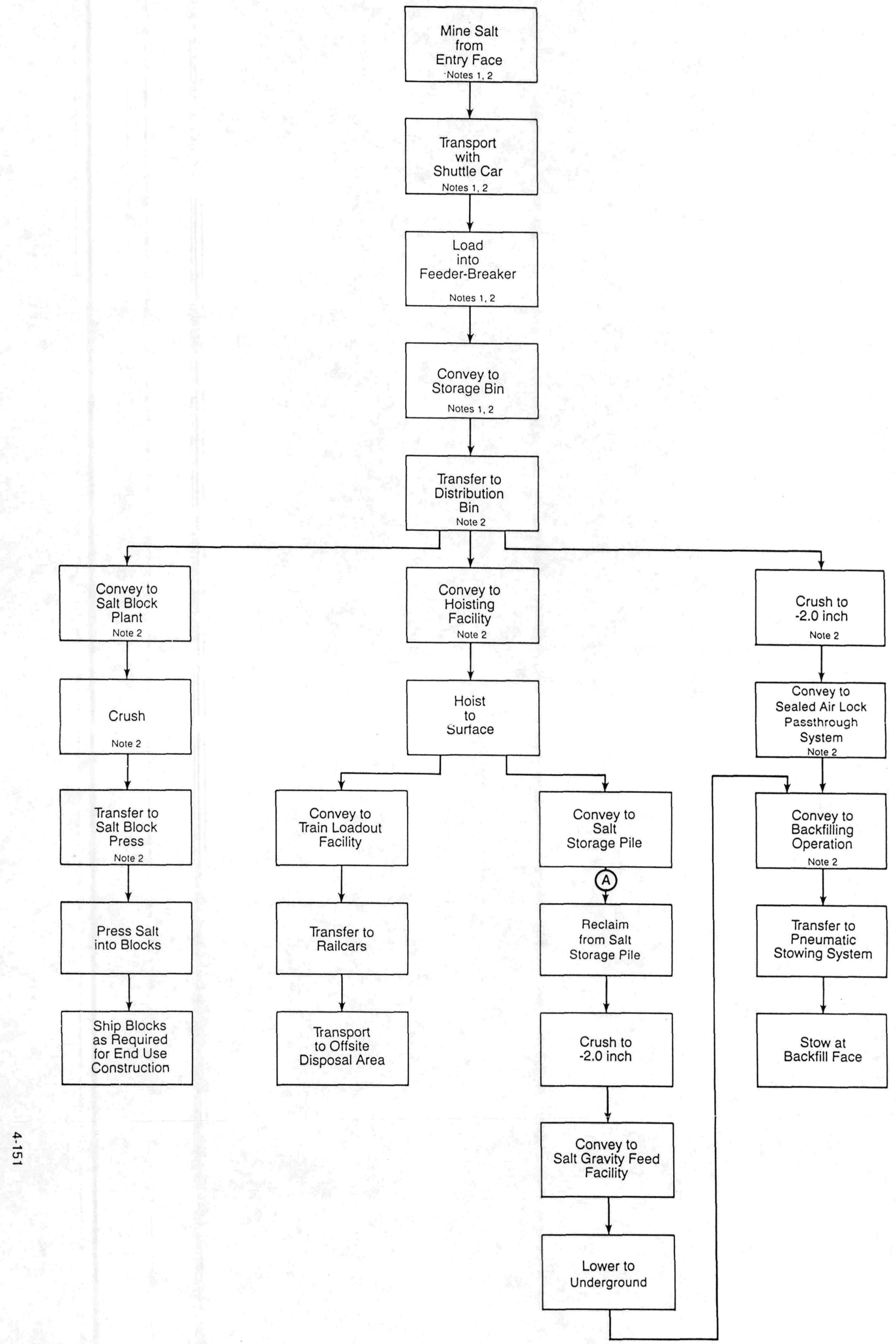

NOTES: 1. Reference Underground Development Conceptual Flow Diagram, Figure 3.3-3. 2. Reference Salt Handling Facilities, Figure 4.4-12 and 13.

(A) = Reclaim for backfill begins after completion of underground development excavation ( $\approx$ Yr 22 after initiation of emplacement). 
From the distribution bin the salt flow can be fed in three directions. To the north, a belt conveyor will carry it to the processing plant where the salt blocks will be manufactured. The blocks will be fabricated from crushed salt by compressing the grains together under high pressures. When the plant receives the salt from the distribution bin, it will first crush it. The crushed salt will then be fed between a set of dies and pressed into blocks by a large hydraulic press. These salt blocks will be used for constructing entry stoppings and portions of substantial stoppings. These stoppings are discussed in Section 4.5.5, Entry Backfilling and Entry Stopping. The blocks may also be used to add stability in excavations made during retrieval operations.

To the east, salt for the backfilling operation will be transported by the belt conveyor to screw conveyors which will pass the salt through the air lock and onto the backfill belt conveyor. Backfilling is discussed in section 4.5.5.1, Entry Backfilling.

To the south, the skip loading belt conveyor will transport the salt to a skip loading pocket at Shaft $D$. The underground skip loading station and hoisting function are discussed in Section 4.3, Shaft Facilities.

The salt handling facilities are described in greater detail below. The general axrangements of these facilities are shown in plan, Figure 4.4-12, and longitudinal section, Figure 4.4-13.

1. Shuttle Conveyor - 60 in. wide $\mathrm{x} 220 \mathrm{ft}$ long, $180 \mathrm{ft}$ travel, 1,600 tph.

2. Mined-Salt Storage Bin - 2,500-ton capacity, free-standing, $192 \mathrm{ft}$ long $\times 38 \mathrm{ft}$ high $\times 24 \mathrm{ft}$ wide, 8 vibrating reclaim feeders.

3. Salt Storage Reclaim Belt Conveyor - 36 in. Flexwall Steep Angle, $400 \mathrm{tph}$.

4. Salt Distribution Bin - 500-ton capacity, $24 \mathrm{ft}$ square $\mathrm{x} 48 \mathrm{ft}$ high. 




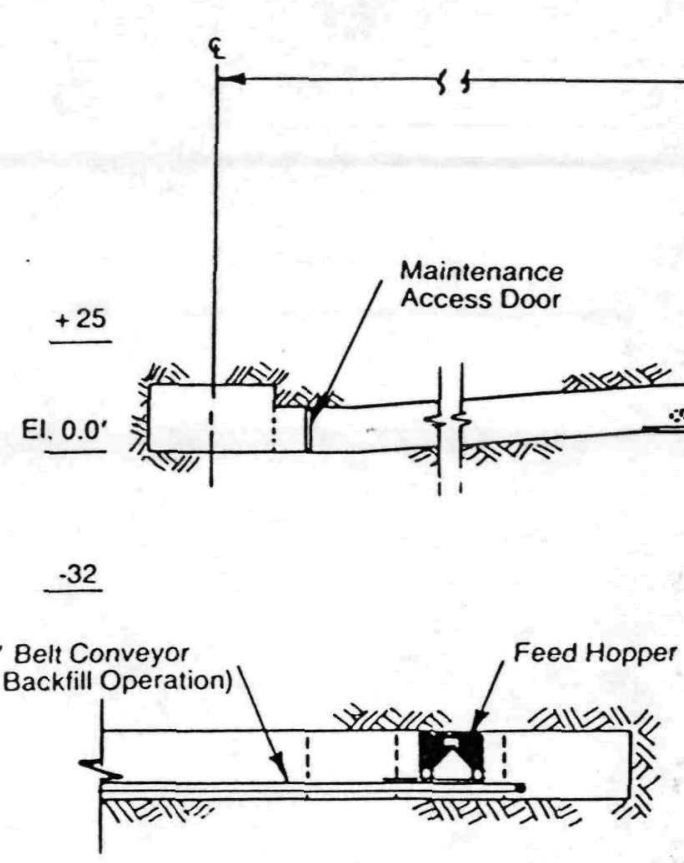

SECTION B-B'

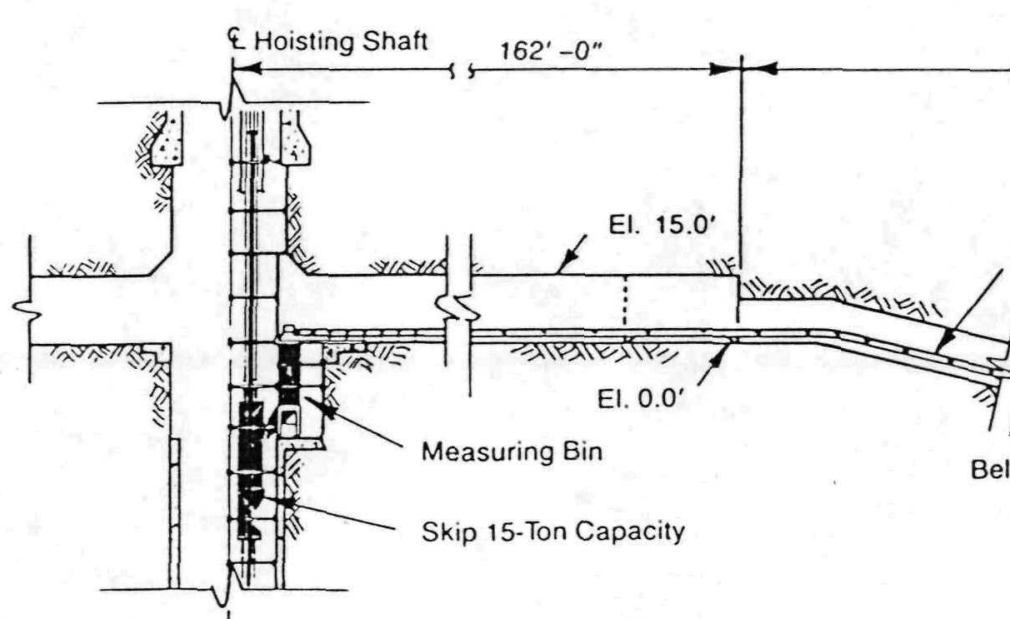

$$
300^{\prime}-0 \text { " }
$$
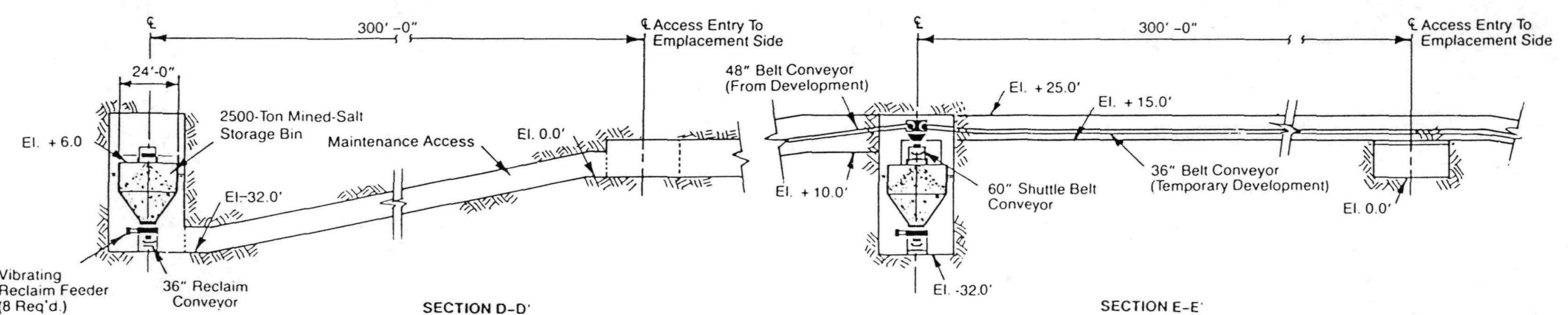

NOTE: See Figure 4.4-12 for plan view.

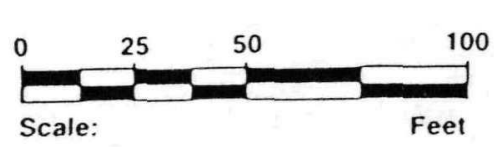

SALT HANDLING FACILITIES VERTICAL SECTIONS

FIGURE 4.4-13 
0 
5. Belt Conveyor to Salt Block Plant - vibrating feeder, 18 in belt conveyor, $15 \mathrm{tph}, 40$ ton surge hopper, hammer mill, screw conveyor, salt block press.

6. Backfill Conveyor - vibrating feeder, hammer mill, 24 in conveyor, $250 \mathrm{tph}$.

7. Screw Conveyor - Hopper, rotary air lock feeders (2), screw conveyors, $125 \mathrm{tph}(2)$.

8. Backfill Belt Conveyor -24 in wide, 250 tph.

9. Belt Conveyor to Salt Hoisting Facility - 36 in wide, $400 \mathrm{tph}$, skip loading bin. 


\subsection{SUBSURFACE REPOSITORY OPERATIONS}

Other sections of this report describe portions of the underground repository operations. Salt excavation and haulage are discussed in Section 3.3 and are shown in Figure 3.3-3; underground ventilation is discussed in Section 3.4.1.4; and waste retrieval is discussed in Section 6.3. Section 4.5 describes the underground operating functions not discussed elsewhere. These functions include support activities, emplacement scheduling, emplacement operations, entry backfilling, and entry stopping.

\subsubsection{Support Activities}

Support activities will include maintenance of all shaft and underground equipment, utilities, facilities, and other support services.

\subsubsection{Maintenance}

A substantial complement of equipment will be required to perform repository development and waste emplacement. Some equipment, such as personnel vehicles (jeeps) and trucks, are similar to current industrial units and will be readily available. Other equipment, such as transfer cask handling equipment, is very specialized and unlike any existing industrial equipment. This equipment will require significant development work to advance it from the current conceptual designs to an operating stage.

To ensure that adequate equipment will be available to support operations, the equipment fleet will be backed up by an appropriate number of spares. It is assumed that major components (e.g. engines, transmission, etc.) will be repaired by outside contractors. Tables 4.5-1, 4.5-2, and 4.5-3 show the types and quantities of equipment which will be required for operations and support functions. Quantities indicated include spare equipment. 
Table 4.5-1. Major Shaft Equipment List

Item

Hoist, Friction, Waste, 190-in dia., 1,250 HP

Hoist, Friction, Mined-Salt, 114-in dia., 2,000 HP

Hoist, Friction, Service, 163-in dia., 1,500 HP

Skip Loader, Salt, 15-ton capacity

Skips, Salt Hoisting, 15-ton capacity

Bin, Skip Unloading, 200-ton capacity

Cage, Service, 25-ton capacity

Cage, Waste, 48-ton capacity

Hoist, Single Drum, Service Emergency, 60-in dia., 150 HP

Hoist, Single Drum, Mined-Salt Emergency, 60-in dia., $150 \mathrm{HP}$

3-Hoists, Single Drum, Ventilation Inspection, 60-in dia., $150 \mathrm{HP}$

Cage, Service Emergency, 1-ton capacity

Cage, Mined-Salt Emergency, 1-ton capacity

3-Cages, Ventilation Inspection, 1-ton capacity

4-Winches, Ventilation Inspection

3-Decks, Maintenance

See paragraph 4.3.4 for further discussion of shaft equipment. 
Table 4.5-2. Major Development Equipment List

\begin{tabular}{|c|c|c|c|}
\hline Item & Operating & Spares & Total \\
\hline Continuous Miners (Roadheaders)(c) & 6 & 2 & 8 \\
\hline Electric Shuttle Cars(c) & 6 & 4 & 10 \\
\hline Load-Haul-Dump (LHD), 3 Cu Yd(b) & 3 & 1 & 4 \\
\hline Lube Truck(b) & 3 & - & 3 \\
\hline Maintenance Truck(b) & 4 & 1 & 5 \\
\hline Supply Truck(b) & 3 & - & 3 \\
\hline Roadgrader (b) & 1 & - & 1 \\
\hline Fire Truck(b) & 1 & - & 1 \\
\hline Ambulance (b) & 1 & - & 1 \\
\hline Tire Truck(b) & 1 & - & 1 \\
\hline Forklift(b) & 6 & 1 & 7 \\
\hline Elevating Basket, Personnel(b) & 3 & - & 3 \\
\hline Roof Bolter $(b)$ & 1 & - & 1 \\
\hline Personnel Carrier (Visitors)(b) & 1 & - & 1 \\
\hline Personnel Vehicles(b) & 32 & 8 & 40 \\
\hline Feeder-Breakers (c) & 6 & 2 & 8 \\
\hline Panel Belt Conveyors (36 in)(c) & $\begin{array}{l}14,000 \text { lineal feet } \\
\text { (1f) (max.) }\end{array}$ & - & - \\
\hline $\begin{array}{l}\text { Development Collection Belt (c) } \\
\text { Conveyors ( } 48 \text { in) }\end{array}$ & 12,000 If (max.) & - & - \\
\hline Shuttle Conveyor $(60 \mathrm{in})(\mathrm{c})$ & 1 & - & 1 \\
\hline $\begin{array}{l}\text { Salt Storage Reclaim Belt(c) } \\
\text { Conveyor ( } 36 \text { in) }\end{array}$ & 1 & - & 1 \\
\hline Production Hoist Conveyor (36 in)(c) & 1 & - & 1 \\
\hline Salt Block Plant Conveyor (18 in)(c) & 1 & - & 1 \\
\hline Salt Block Press(c) & 1 & - & 1 \\
\hline Fan, 96 in Axivane (a) & 2 & 1 & 3 \\
\hline Fan, 84 in Axivane (a) & - & 2 & 2 \\
\hline Cooling Plant(a) & 1 & - & 1 \\
\hline Heating Plant(a) & 1 & - & 1 \\
\hline Pump, Dewatering(c) & 1 & 1 & 2 \\
\hline
\end{tabular}

Notes:

(a) This equipment is located on the surface.

(b) Diesel powered equipment

(c) Electric powered equipment 
Table 4.5-3. Major Emplacement Equipment List

\begin{tabular}{|c|c|c|c|}
\hline Item & Operating & Spares & Total \\
\hline Underground Cage Off/On Loader(d) & 1 & 1 & 2 \\
\hline Underground Transfer Cart(d) & 2 & 1 & 3 \\
\hline Underground Waste Transporter(c) & 2 & 1 & 3 \\
\hline Load-Haul-Dump (LHD), $3 \mathrm{Cu} \mathrm{Yd}(\mathrm{C})$ & 1 & - & 1 \\
\hline Waste Emplacement Machine(c) & 2 & 1 & 3 \\
\hline Crushed Salt Emplacement Machine(c) & 2 & 1 & 3 \\
\hline Emplacement Leveling Platform & 4 & 2 & 6 \\
\hline Leveling Platform Transporter(c) & 4 & 2 & 6 \\
\hline Electric Compressors (Backfill)(d) & 2 & 1 & 3 \\
\hline Pneumatic Stowing Machine(d) & 2 & 2 & 4 \\
\hline Borehole Drilling Machine(c),(d) & 3 & 1 & 4 \\
\hline Mobile Surge Hopper (Backfill) & 1 & - & 1 \\
\hline Maintenance Truck(c) & 2 & - & 2 \\
\hline Pipe Truck (Backfill)(c) & 1 & - & 1 \\
\hline Fire Truck(c) & 1 & - & 1 \\
\hline Forklift(c) & 2 & - & 2 \\
\hline Ambulance (c) & 1 & - & 1 \\
\hline Elevating Basket, Personnel(c) & 1 & - & 1 \\
\hline Personnel Carrier (Visitors)(c) & 1 & - & 1 \\
\hline Personnel Vehicles (c) & 17 & 4 & 21 \\
\hline Load-Haul-Dump (LHD), $5 \mathrm{Cu} Y \mathrm{Yd}(\mathrm{c})$ & 1 & - & 1 \\
\hline Truck 15-Ton (Borehole)(c) & 1 & 1 & 2 \\
\hline Backfill Belt Conveyors ( 24 in) & 18,000 lineal feet & - & - \\
\hline Backfill Transfer Conveyor (24 in) (d) & 1 & $=$ & 1 \\
\hline Backfill Screw Conveyor(d) & 2 & - & 2 \\
\hline Fan, 96 in, Axivane(a) & 2 & 1 & 3 \\
\hline Cooling Plant(a) & 1 & - & 1 \\
\hline Heating Plant(a) & 1 & - & 1 \\
\hline Waste Shaft Area Emergency Eilter Unit & 1 & 1 & 2 \\
\hline Transfer Cask (b) & 8 & 2 & 10 \\
\hline
\end{tabular}

Notes:

(a) This equipment is located on the surface.

(b) This equipment will be maintained by surface maintenance personnel.

(c) Diesel powered equipment.

(d) Electric powered equipment 
Maintenance facilities will be provided in the shaft pillar area on both the development and emplacement sides. The location of these facilities is shown in the Figure 4.4-3. All routine and major maintenance work on development equipment will be performed in the development side shop. Likewise, routine maintenance on emplacement equipment will be performed in the emplacement side shop area. However, major maintenance on emplacement equipment will be performed in the development side shop area. The emplacement side shop area will also be used for performing decontamination work if required.

\subsubsection{Underground Utilities and Facilities and Other Support Services}

A number of other activities to be designed in ACD will also take place on a regular basis to support underground development and emplacement operations. These activities include delivery of supplies and fuel, and installation and maintenance of the following:

1. Ventilation (Check curtains, regulators, overcasts, stoppings, fans, and tubing)

2. Roadways

3. Pipelines

4. Dewatering Systems

5. Power, Lighting, Communication, and Monitoring Systems

6. Sanitary Facilities

7. Conveyors

8. Mined-Salt Handling Facilities

9. Backfill System 


\subsubsection{Repository Emplacement Sequence}

The sequence of waste emplacement will follow the sequence of repository panel development, proceeding in a clockwise direction. The development sequence is discussed in Section 3.3.3. Figure 4.5-1 illustrates this sequence with Panel 1 being emplaced first and Panel 9 last. This figure also uses letters to identify special emplacement areas. A and B designate areas which will be set aside for performance confirmation purposes during Phases I and II. These areas were selected because they have geologic conditions which may be representative of opposite ends of the underground repository horizon. $C$ and $D$ designate the respective areas in Panel 1 that will be emplaced during Phases I and II.

Figure 4.5-1 also illustrates the direction of waste emplacement within a panel under an advancing emplacement sequence. Under this sequence, the high heat and low heat emplacement entries nearest the front of the panel (closest to the mains) would receive waste first, and entries toward the rear of the panel would receive waste last. See Figure 4.5-2 for further details.

An alternative procedure, retreat emplacement, was also considered. In this procedure, emplacement entries near the back of the panel would receive waste first, and those nearest the front would receive it last. The retreat emplacement sequence presents additional concerns such as longer entry open times and backfilling the ventilation exhaust entries.

Panel development will be performed in a clockwise direction (west panels) or counterclockwise direction (east panels) as discussed in Section 3.3, Underground Development. In either case, the youngest and the oldest emplacement entries will be located nearest the main entries. Based on the amount of time required to develop a panel, the oldest emplacement entries will be $2-3 / 4$ years old when emplacement operations begin. Under an advancing emplacement sequence they will receive waste first and be backfilled. Under a retreat emplacement sequence these oldest emplacement entries would receive waste last. The retreat emplacement sequence would therefore increase the open time of the oldest emplacement entries by one year, allowing additional creep 




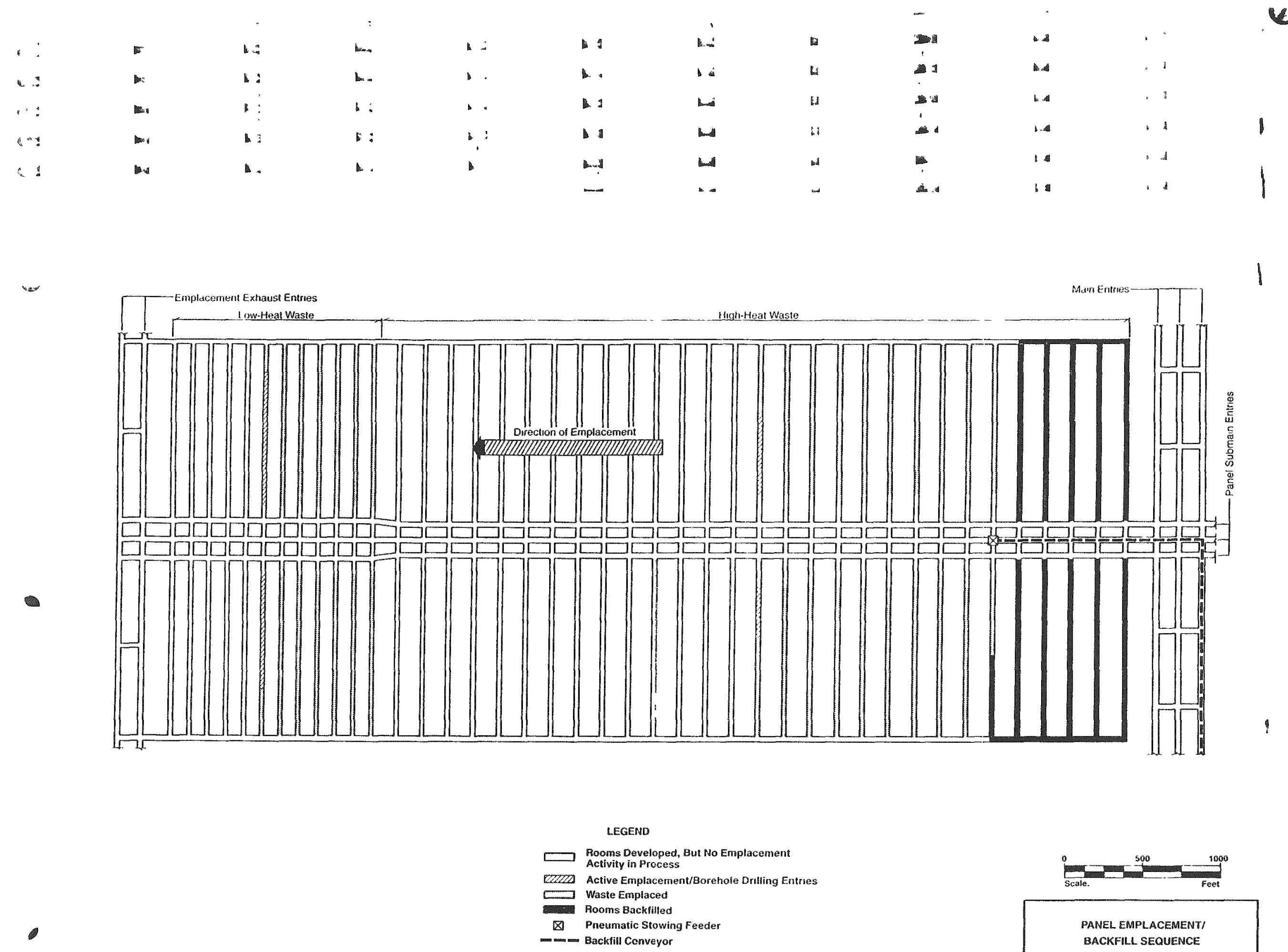

- Backfill Conveyor 

additional creep closure and increasing the potential for problems during emplacement operations.

The basic panel ventilation system will direct fresh air from the mains into the panel, then through the emplacement entries to an exhaust entry located along each side of the panel. The air will continue through the exhaust entry to the main exhaust entries. Under the advancing emplacement concept, the high-heat entries nearest the ventilation source would be emplaced first and backfilled. The adjoining segment of the exhaust entry would also be backfilled along with the entry. This backfill sequence will be followed through the entire panel. Thus, the low-heat entries would not be backfilled until all high heat entries were emplaced and backfilled.

Under the retreating emplacement concept, the two exhaust entries would be left open for the entire panel emplacement period. Thus, when panel emplacement is completed, two single entries would be open along the panel sides for the full length of the panel. Backfilling these entries could present significant problems since the length of the entries would exceed the capability of the pneumatic stowing equipment, and ventilation would require a complex multistage duct system.

\subsubsection{Panel Emplacement Sequence}

The panel emplacement function will include borehole drilling, emplacement of disposal containers, emplacement of crushed salt shielding, entry backfilling, and entry stopping. Each of these activities will be performed in sequence and in several entries within the panel concurrently, depending on the timing and rate of receipt of different types of disposal containers.

The initial activity, borehole drilling, will be complicated by several variables, the most important of which are:

1. Separate emplacement entries for: (a) consolidated (PWR) spent fuel, (b) consolidated (BWR) spent fuel, (c) intact PWR and BWR spent fuel and RCSF, (d) defense high-level waste (DHLW) and West Valley HighLevel Waste (WHLW), and (e) fuel assembly hardware (FAH). 
2. Variable borehole spacing for high-heat packages, depending on heat output.

3. Two different borehole sizes for high-heat packages.

4. Two different borehole sizes for low-heat packages.

Because of the numerous variables, careful planning will be required before each hole is drilled. Holes will not be drilled in advance of what prudent planning and borehole creep closure rates will allow.

Emplacement within individual emplacement entries will begin at the back of the entries and retreat toward the submains. Emplacement operations and backfilling operations will be performed on opposite sides of the panel to minimize interference between equipment and personnel. A typical panel emplacement and backfill sequence is shown in Figure 4.5-2. Backfilling will begin at the front of the panel and progress to the rear of the panel. The figure portrays each activity of the emplacement function and shows a typical lead/lag relationship between them for the high-heat waste. Emplaced low-heat waste entries will remain open and ventilated until completion of high-heat waste emplacement and extension of the backfill conveyor into the low-heat area.

\subsubsection{Emplacement Operations}

The disposal container emplacement function will include drilling the emplacement borehole; receiving, transporting, and emplacing the disposal container; and placing crushed salt into the counterbore section of the hole. An isometric view of a typical spent fuel waste emplacement entry with emplaced disposal containers is shown in Figure 4.5-3. The sequence of these activities is shown in Figures 3.1-4 through 3.1-6, Mechanical Flow Diagram, Waste Handling, and Emplacement.

\subsubsection{Borehole Drilling}

The waste emplacement holes will be excavated by a mobile borehole drilling machine. The machine will consist of an electrically powered rotary drilling 


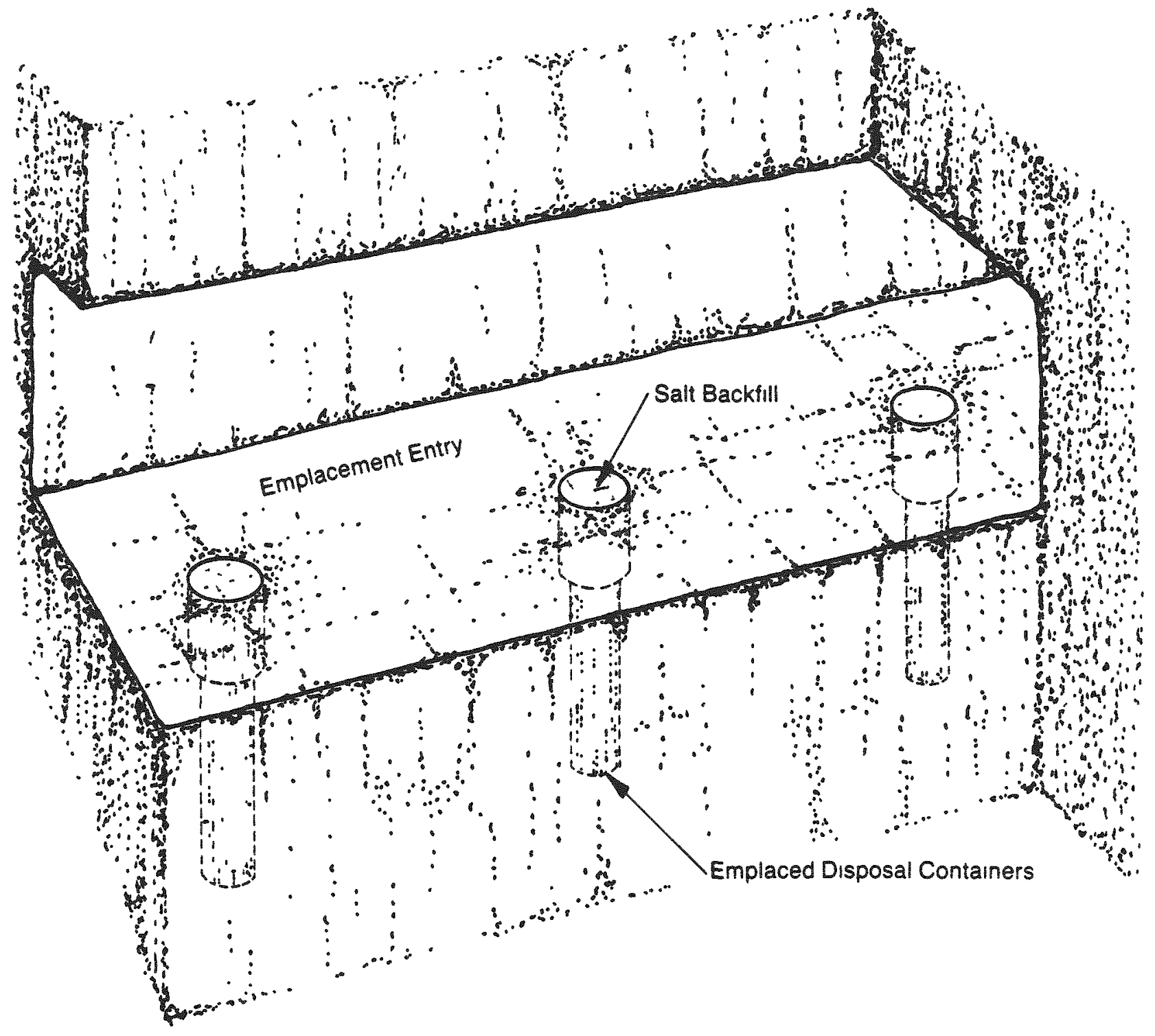

NOTE: Container spacing varies according to the heat output of the container. See Figures 4.4-6, 4.4.7 and 4.4.8 for borehole dimensions and spacing.

ISOMETRIC VIEW

VEATICAL EMPLACEMENT

FIGURE 4.5.3 
unit and feed mechanism mounted on a set of diesel powered crawlers. The feed mechanism will be positioned vertically and it will be possible to elevate, lower, or tilt this mechanism in order to accommodate a prescribed alignment. The rotary drive will travel either up or down on the feed mechanism frame. It will apply both thrust and torque to a stem-type drill rod with a drag bit mounted on the end. The drilling machine and the operational sequence for drilling a hole are shown in Figure 4.5-4.

Borehole drilling will be performed in the following sequence:

1. The drilling machine will be positioned in the center of the entry and in vertical alignment with the borehole centerline. The feed mechanism will be elevated and tilted as required to attain vertical alignment with the borehole.

2. The rotary drive unit will be activated and feed thrust applied to collar the hole and drill the first section of the hole.

3. The drill steel will be disconnected, the rotary drive retracted, and an extension steel added. The drive and feed will be reactivated to continue drilling the hole. Drilling will be stopped when the toe of the borehole reaches the predetermined depth.

4. The rotary drive will be retracted, the steel sections disconnected, and the bit removed. The drive will then be reconnected to the reaming bit and the counterbore section reamed to a depth of $6.6 \mathrm{ft}$ below floor level.

Water or an other drilling fluid is not expected to be used. Therefore, excavated material may be removed by a vacuum system and discharged into a hopper attached to the drilling machine. The hopper will discharge the cuttings into a truck which will transport them to the backfilling operations area. 

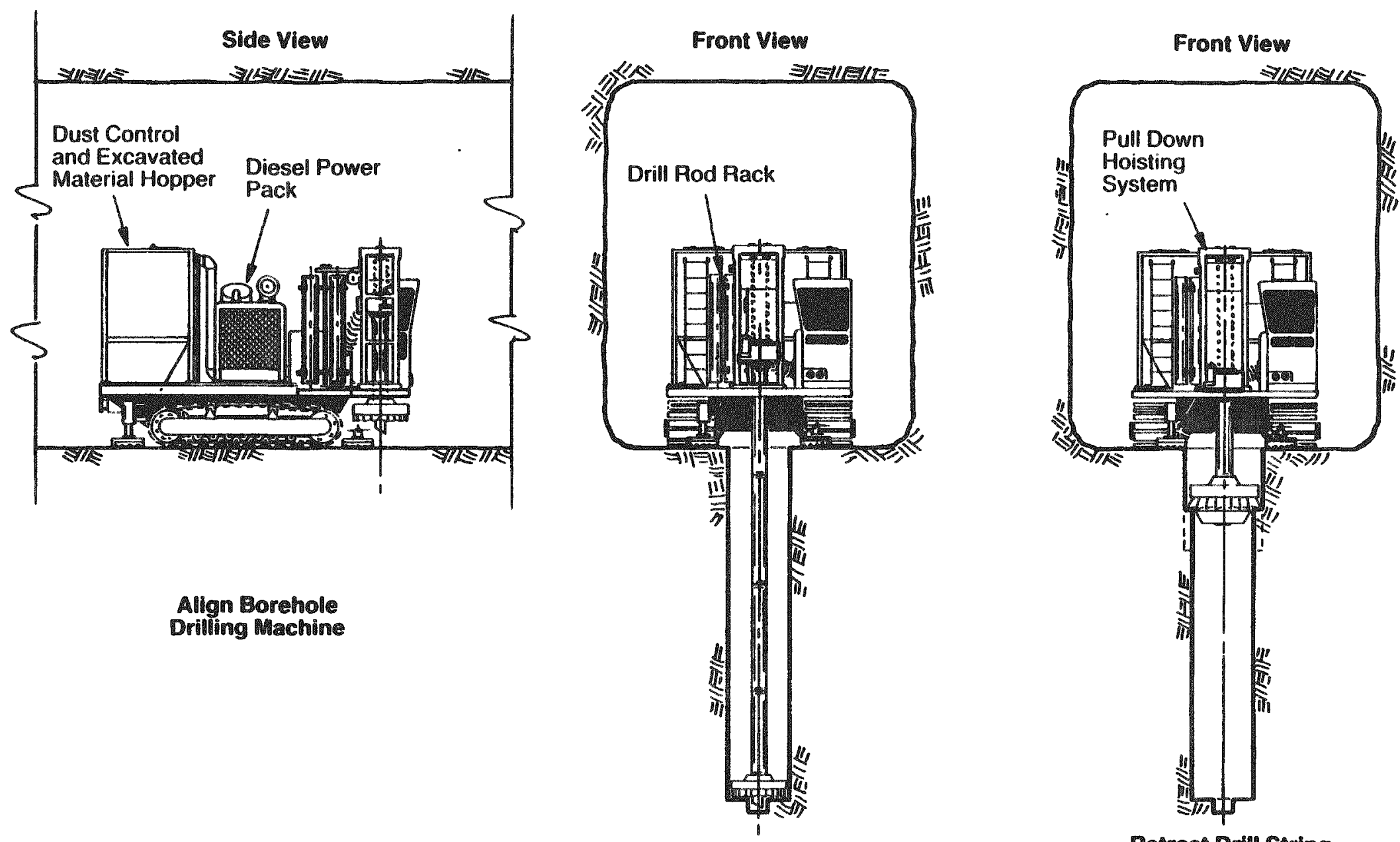

Allgn Borehole
Drilling Machine

Collar Drill Bit and Drill Borehole

Retract Drill String

Install Counterbore Cutter Ream Countebore

BOREHOLE DRILLING SEQUENCE

FIGURE 4.5-4 
After the cuttings have been cleared from the borehole, a cover plate will be placed over the collar of the hole to keep it clean and protect it.

\subsubsection{Shaft Station Handling}

Disposal containers will be enclosed in transfer casks when they are delivered to the transfer cask handling area located at Shaft $B$. The location of this area is shown in Figure 4.4-3 and its arrangement is shown in Figure $4.5-5$.

Transfer casks will be cylindrical steel vessels with a maximum length of $17 \mathrm{ft}$ and a $4.4 \mathrm{ft}$ maximum diameter. The maximum loaded weight (transfer cask plus disposal container) will be 48.3 tons. Each cask will have a removable cover at the bottom end and a pair of trunnions mounted near the top. A pintle device attached to the disposal container will project from the top of the cask. During hoisting operations in the waste shaft, the casks will be locked in a vertical position within the cage by two mechanical devices holding the base and the top. See Figure 4.3-5 for details.

The casks will be off-loaded from the waste cage by an underground cage off/on loader. The configuration of this machine is shown in Figure 4.5-6. It will be designed with a cantilevered set of lifting arms mounted overhead from a fixed pivot at the rear of the machine. A cradle near the end of each arm will engage the transfer cask trunnions. The arms will be raised or lowered by a hydraulic cylinder mounted at the front of the machine. The loader will be supported on flanged wheels traveling on a set of floor-mounted rails. The rails will be attached to a deck that can be adjusted to compensate for misalignment caused by salt creep. The loader will be electrically powered, utilizing an electrical cable supported in a fixed path cable carrier to prevent tangles and pinch points during forward and backward travel of the loader.

4.5.4.2.1 Unload Transfer Cask from Waste Cage. To unload the cask from the waste cage spotted at the repository horizon, the following sequence of activities will be performed: 


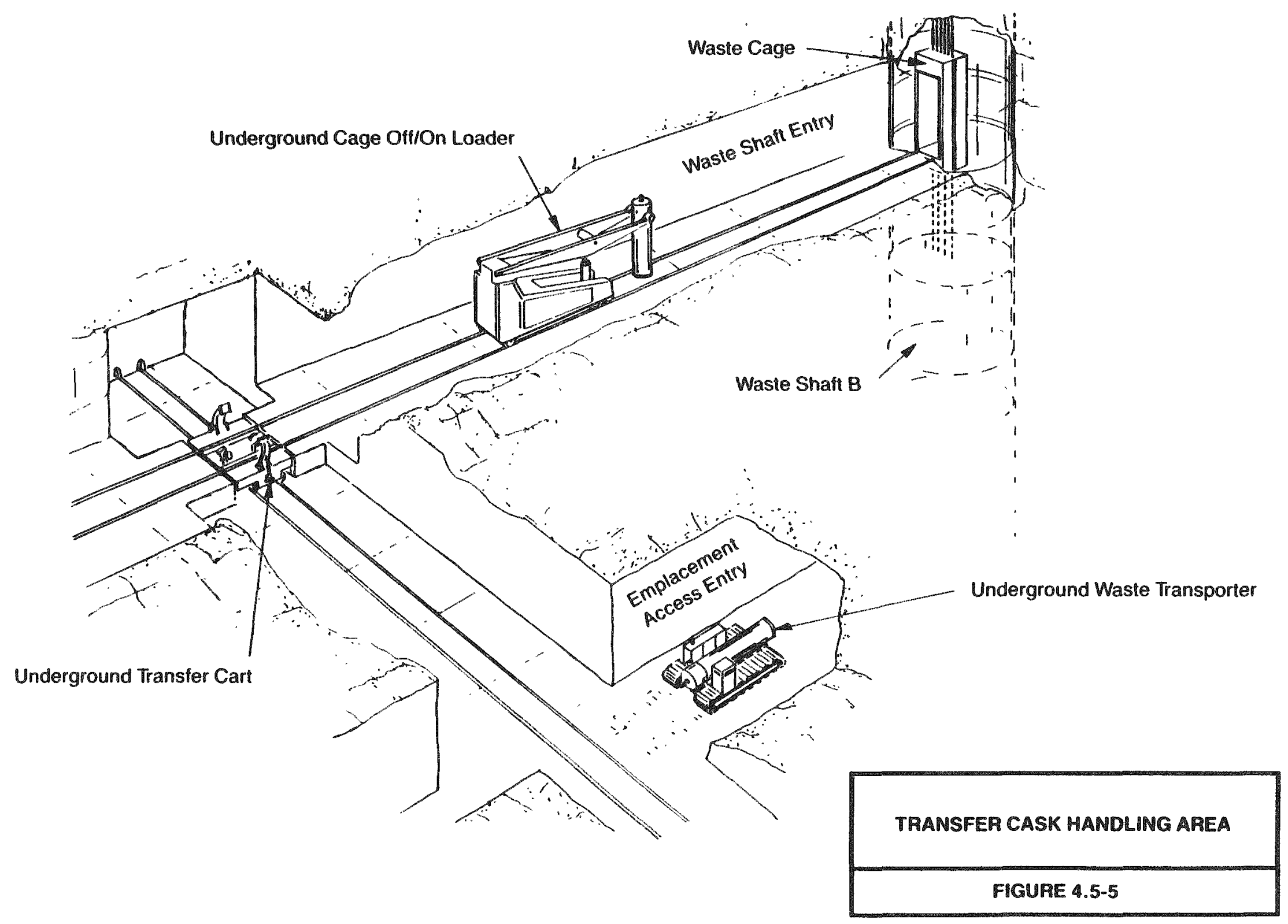




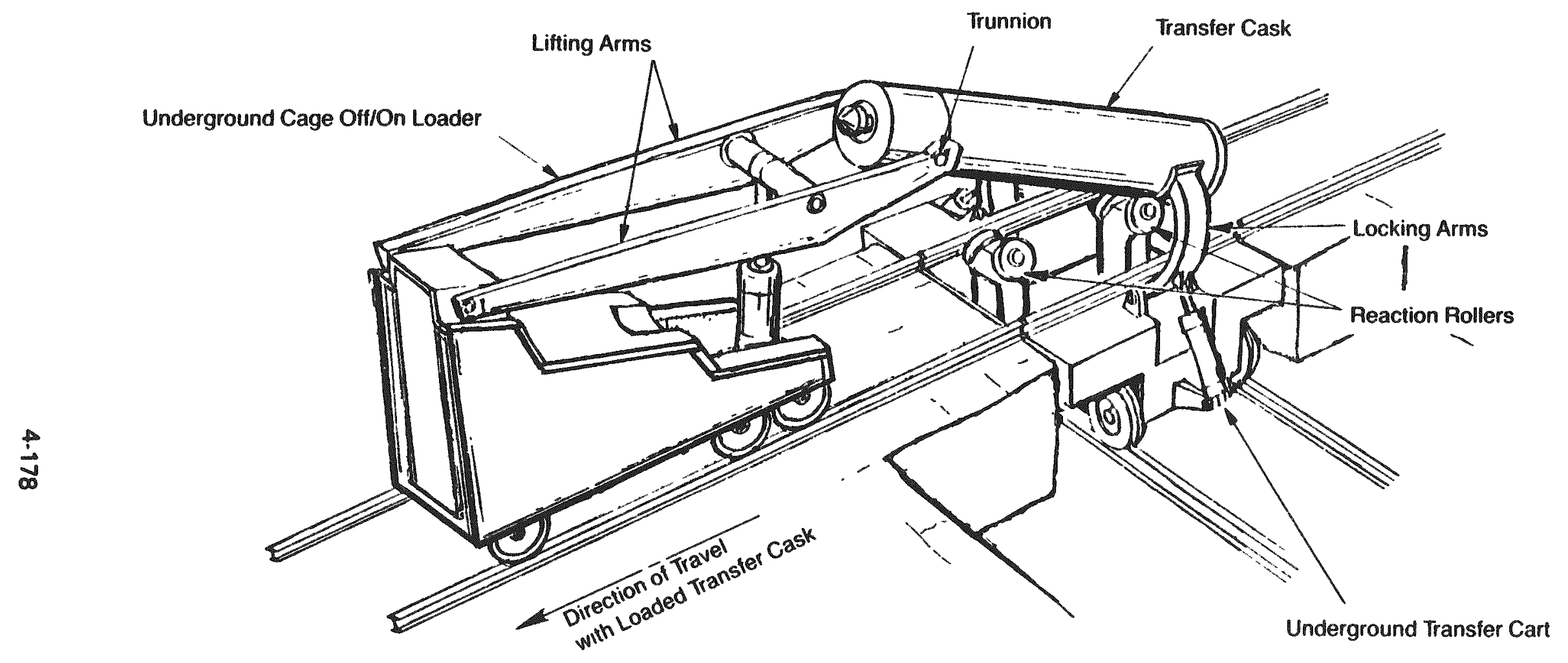

\section{LOAD TRANSFER CASK ONTO} TRANSFER CART

FIGURE 4.5-6 
1. The underground cage off/on loader will be advanced to a position where the cradles are centered beneath the trunnions on the transfer cask. The arms will be elevated to seat the trunnions in the cradles and the cask locking mechanisms will be retracted to free the transfer cask.

2. The lifting arms will be raised about 24 in to elevate the transfer cask above the waste cage floor. As the load transfers from the cage to the loader, the cage will rise approximately $18 \mathrm{in}$. because of elastic rebound in the cage support rope.

3. The loader will be backed away from the cage carrying the cask held in a vertical position $225 \mathrm{ft}$ to the transfer cart loading station.

\subsection{Transfer Cask To Emplacement Access Main Entry. Next, the} transfer cask will be loaded onto the transfer cart and moved from the waste shaft entry to the underground waste transporter off/on loading station in the emplacement access entry. The emplacement access entry will be located approximately $125 \mathrm{ft}$ west of the waste shaft entry. Its floor will be $4 \mathrm{ft}$ lower than that of the waste shaft entry. The two entries will be connected by a horizontal crosscut intersecting the emplacement access entry on grade and with a $4 \mathrm{ft}$ grade separation at the intersection with the waste shaft entry. This grade differential will facilitate the transfer function performed by the underground transfer cart as illustrated in Figure 4.5-6.

The underground transfer cart will be an electrically powered, wheelmounted, movable platform equipped with two sets of reaction rollers, a set of locking arms, and a short set of rails. The two sets of reaction rollers will be mounted on retractable pedestals and centered with the waste shaft entry rails. It will be possible to lock the reaction rollers in an elevated position to receive the transfer cask and to retract them below the platform to provide clearance for the passage of cage off/on loader. The two hydraulicallyactivated locking arms will be located opposite each other and pivot inward to hold the transfer cask in position. The rails on the transfer cart platform will match the elevation and alignment of the waste shaft entry rails. This will allow the transfer cart to be used as a bridge for the off/on loader when 
crossing the grade separation. The transfer cart will be supported on flanged wheels and will travel on a pair of rails located in the crosscut. This crosscut will connect the waste shaft entry with the emplacement access entry.

The transfer function will be performed in the following sequence:

1. The underground cage off/on loader will be spotted in a position where the transfer cask is suspended over the rear part of the transfer cart and behind the rear reaction roller.

2. The loader will be backed away from the transfer cart while lowering the top end of the cask. With the lower end of the cask supported on the rear reaction roller the cask will tip to a horizontal position, supported on the two reaction rollers. The locking arms will secure the transfer cask in position.

3. The loader will be disconnected from the cask.

4. The transfer cart holding mechanism (brake) will be released and the cask moved to the underground waste transporter off/on loading station.

5. A second transfer cart will be used to receive the empty cask carried on the waste transporter when it returns to the waste shaft entry. The empty casks will be moved through the crosscut to the waste emplacement entry transfer station. The cage off/on loader will then lift it from the transfer cart, move it to the waste shaft, and load it on the waste cage.

\subsubsection{Waste Transporting Function}

This function includes loading the transfer cask from the transfer cart onto the underground waste transporter and transporting it from the transfer cask handling area to the emplacement panel. This function will be performed by the underground waste transporter shown in Figure 4.5-7. 


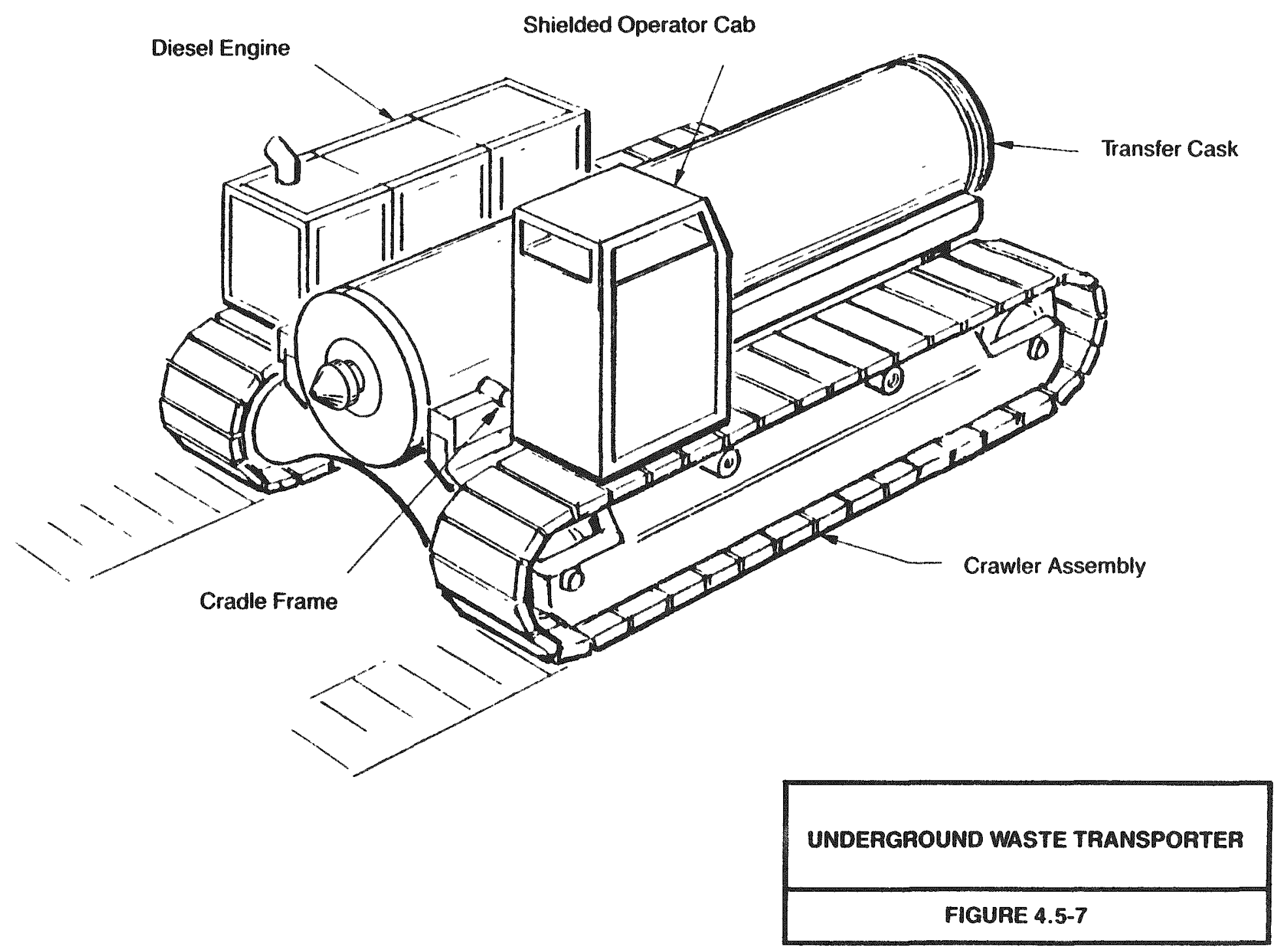


The underground waste transporter will be a manned, crawler-mounted, diesel-powered machine designed to carry the transfer cask on a horizontal support frame located between the crawlers and above the main frame of the machine. It will be possible to elevate, lower, or tilt the support frame. Also, the transporter will be equipped with a cradle assembly capable of traveling forward and backward on the support frame. This cradle assembly will be designed to load and unload the transfer cask.

The crawler-type suspension was compared to pneumatic tires, rail wheels, and other types of suspensions. The crawler has superior load carrying capacity and lower ground pressure as compared to pneumatic tires and provides much greater flexibility in vehicle routing as compared to rails. The diesel power plant was chosen because of its inherent flexibility for vehicle routing as compared to electric power which requires fixed overhead trolley wiring.

The transportation function will be performed in the following sequence:

1. The underground waste transporter will be positioned proximate to the transfer cart and aligned with the transfer cask. The cradle assembly will be positioned beneath the cask trunnions and elevated until the trunnions are seated in it.

2. The cradle assembly will be retracted to load the cask onto the waste transporter.

3. The waste transporter will be driven through the air lock system, which isolates the waste shaft, to the appropriate emplacement room entrance.

\subsubsection{Emplacement Function}

Waste emplacement will be a manned function consisting of set-up at the emplacement borehole, exchanging the transfer cask between the underground waste transporter and the waste emplacement machine, moving the cask to the emplacement hole, and emplacing the disposal container in the hole. 
To set-up at the emplacement borehole a special piece of equipment called a leveling platform will be used. This platform is shown in Figure 4.5-8. It will be positioned over the borehole to facilitate alignment of the transfer cask with the borehole. It will also be used to lower the disposal container into the borehole.

The waste emplacement machine will resemble the waste transporter in that it will be a crawler-mounted, diesel-powered vehicle with a shielded cab. It will also be equipped with a forward and backward traveling cradle assembly. However, it will differ from the waste transporter in that its cask support frame will be equipped to pivot and raise the transfer cask into a vertical position. The cradle assembly on the support frame will be designed to engage the trunnions on the transfer cask for loading and unloading. The waste emplacement machine will also be equipped with a mechanism for removing the bottom cover of the transfer cask.

Figure 4.5-9 shows the transfer cask being moved from the waste transporter to the waste emplacement machine. Figure 4.5-10 shows the transfer cask raised to the vertical position. The leveling platform is not shown in Figure 4.5-10, but it would be used during the emplacement operation, as shown in Figure 4.5-11.

The following steps will be performed during emplacement:

1. The protective cover plate will be removed from the borehole and the leveling platform moved into position over the hole. The deck of the leveling platform will then be jacked and shimned into a position normal to the borehole.

2. The waste transporter and waste emplacement machines will be positioned adjacent to one another with their transfer cask support frames in alignment. The transporter's cradle frame mechanism will move the transfer cask forward onto the emplacement machine until the transporter is disengaged from the transfer cask. 


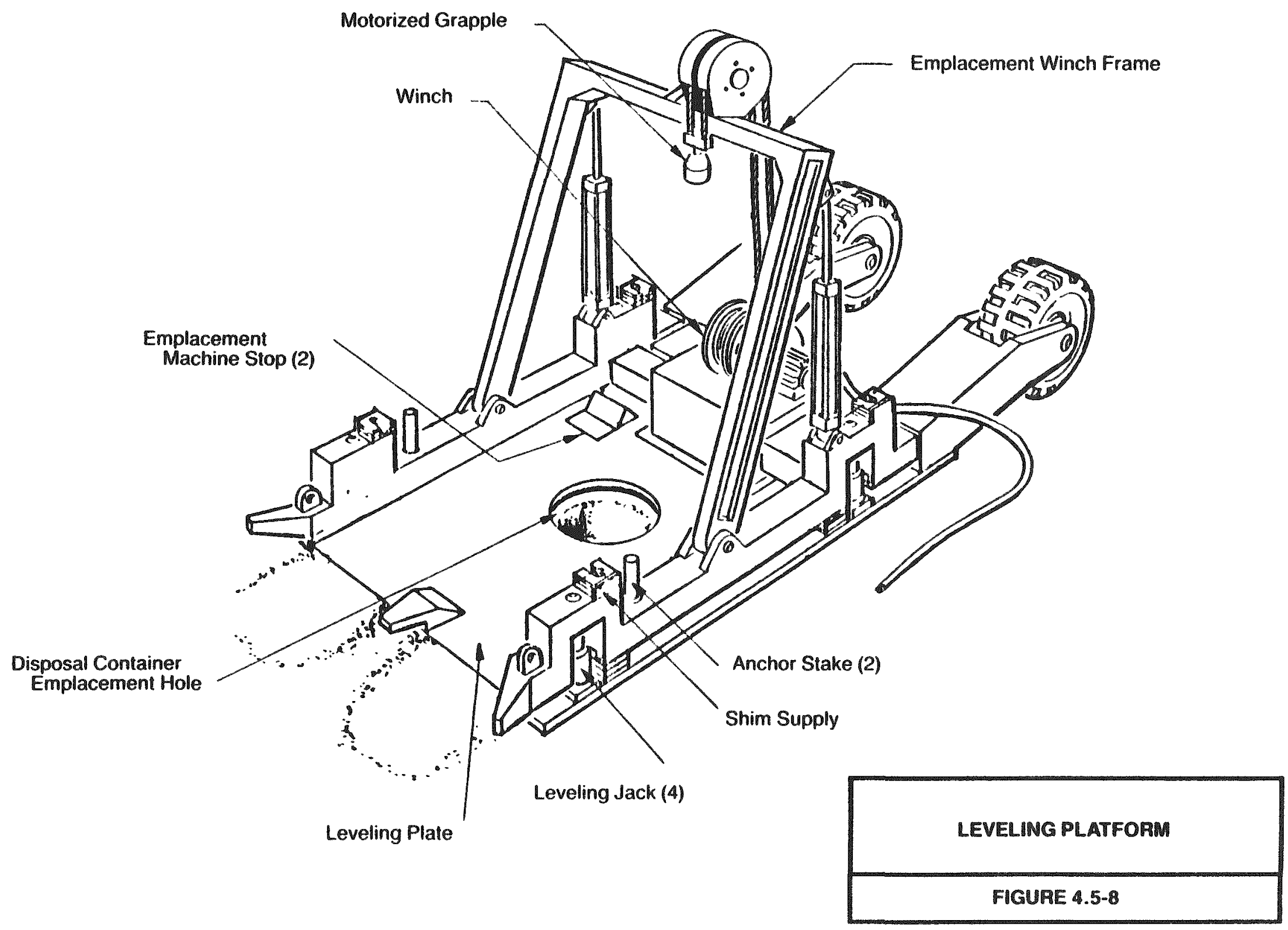




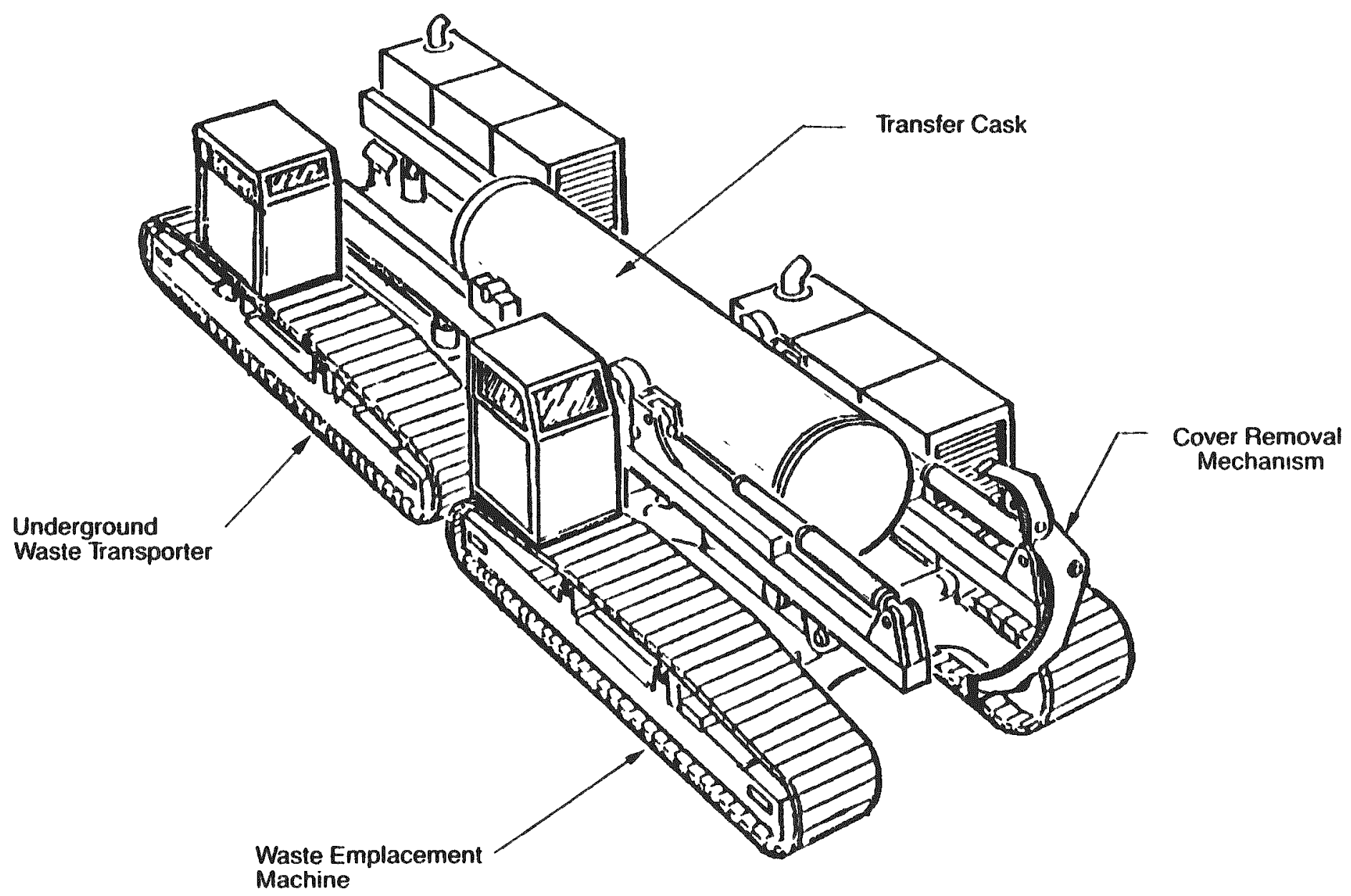

TRANSFER CASK MOVED FROM UNDERGROUND WASTE TRANSPORTEA TO WASTE EMPLACEMENT MACHINE

FIGURE 4.5-9 


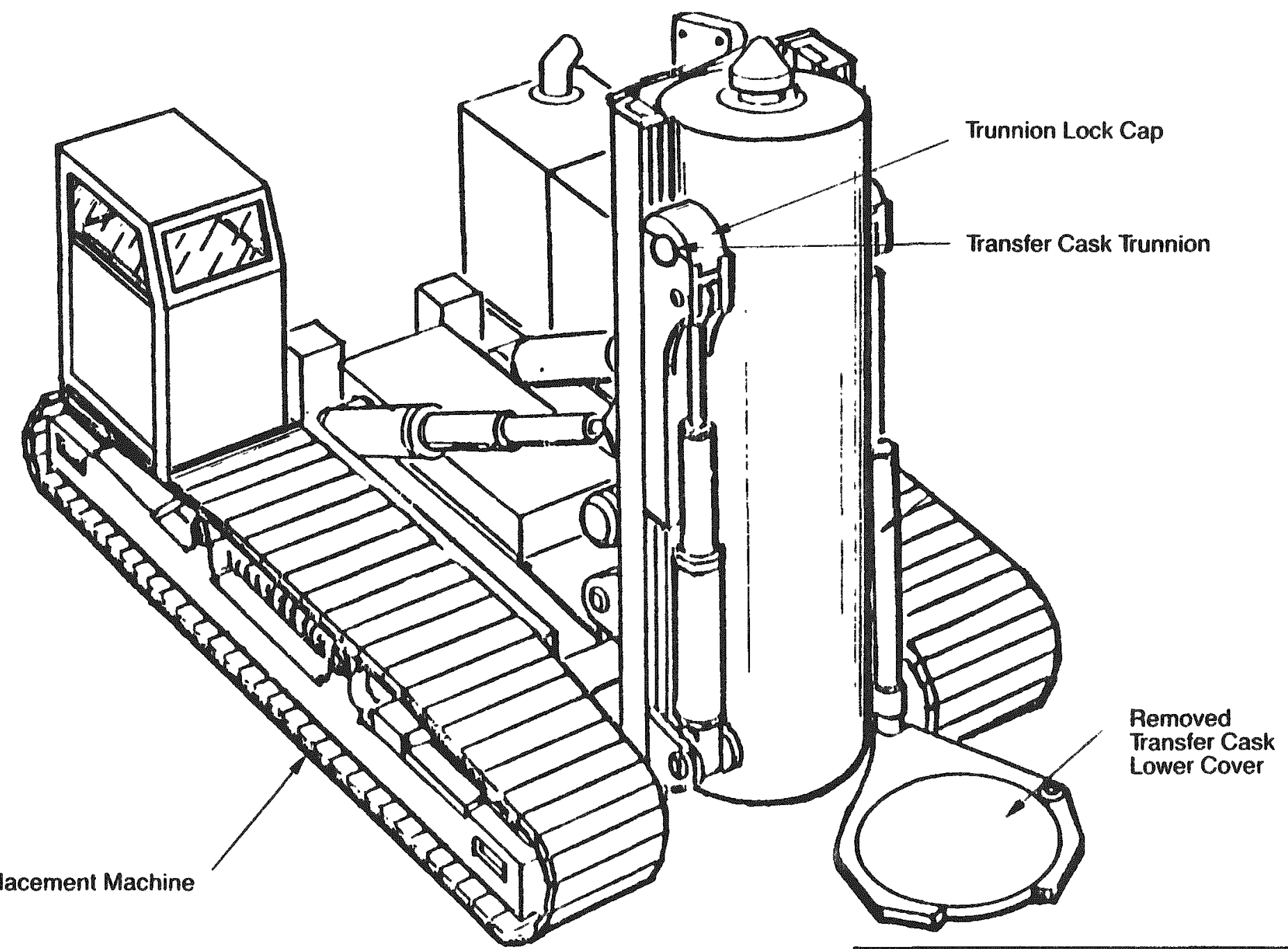

EMPLACEMENT MACHINE WITH

TRANSFER CASK IN

VERTICAL POSITION

FIGURE 4.5-10 


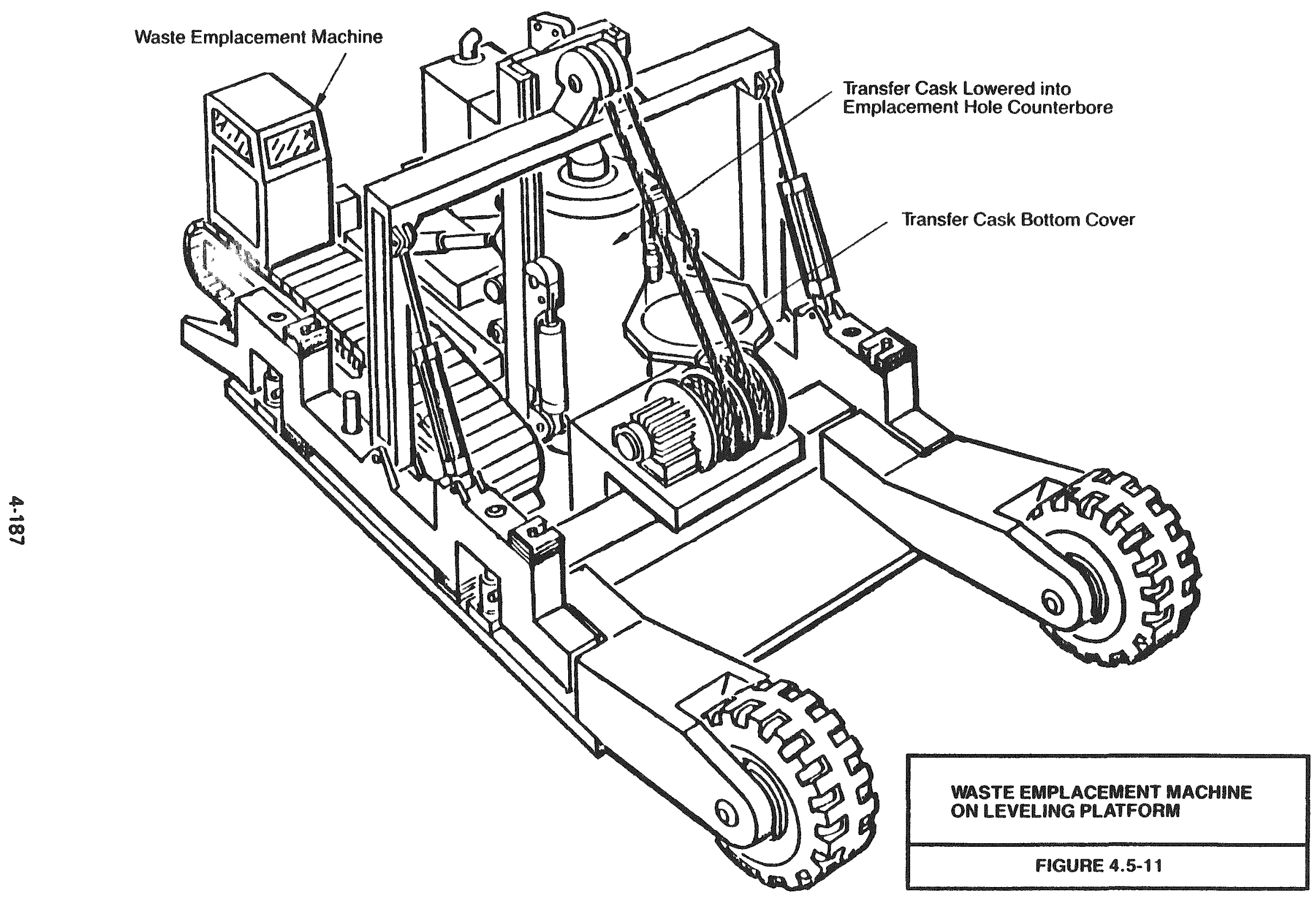


3. The emplacement machine's cradle frame will be positioned against the transfer cask trunnions and the cradle caps locked over the trunnions.

4. The emplacement machine will be driven down the emplacement entry and onto the leveling platform located at the prepared emplacement borehole. With the crawlers against the stops on the leveling platform, which will provide feedback of correct alignment of transfer cask with the emplacement hole, the transfer cask will be raised into a vertical position. The emplacement machine with the cask aligned with the borehole is shown in Figure 4.5-11.

5. The cover removal mechanism will grasp the transfer cask bottom cover and rotate it slightly to disengage its locks, lower the cover to clear the cask, and swing it sideways to clear the emplacement hole path, and then raise it to clear the leveling platform equipment.

6. The cradle frame mechanism will be activated and the transfer cask lowered into the counterbore of the emplacement hole.

7. The winch frame on the leveling platform will be raised until the motorized grapple is centered above the pintle projecting from the top cover of the transfer cask. The grapple will be lowered and locked onto the pintle and the winch activated until the weight of the disposal container is transferred from the transfer cask to the wire ropes and winch frame.

8. With the weight of the disposal container removed from the cask top cover plate, the locking wedges will be withdrawn from the disposal container thus freeing it to be lowered. The winch will then lower the disposal container into the hole as shown in Figure 4.5-12.

9. When the disposal container is in place at the bottom of the borehole, the motorized grapple will be activated to release the pintle. The grapple will be withdrawn until it clears the transfer cask. The winch frame will then be lowered. 


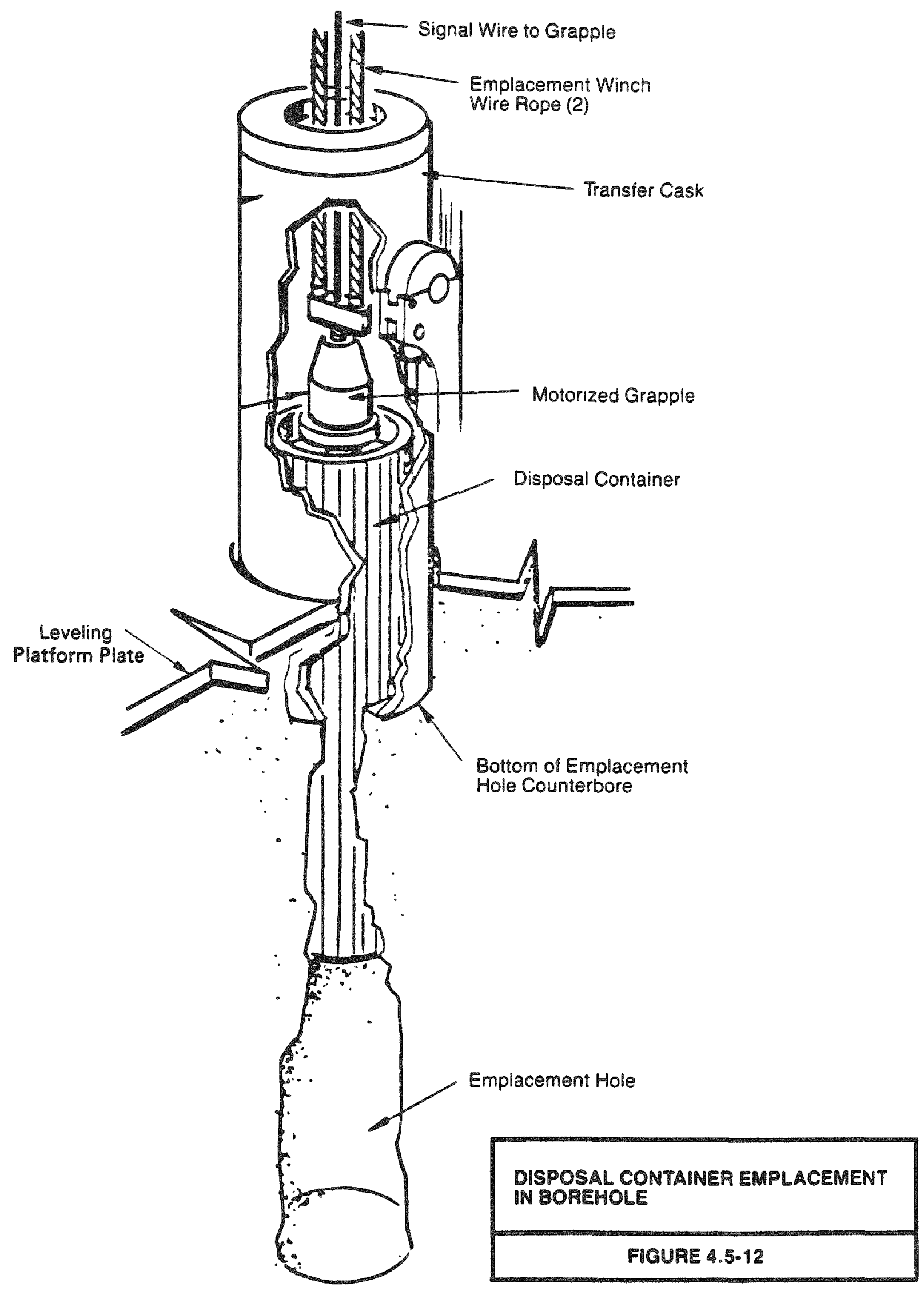


10. The cradle frame will withdraw the transfer cask from the borehole and the cover removal mechanism will then replace the bottom cover on the transfer cask.

11. The emplacement machine will pivot the empty transfer cask back to a horizontal position, then drive off the leveling platform and return to the underground waste transporter. The cask handling process will be reversed to return the cask back to the waste cage.

\subsubsection{Hole Shielding Function}

After each emplacement, shielding material will be deposited in the borehole over the diposal container to reduce radiation dose in the entry.

The hole shielding function will consist of placing crushed salt backfill into the counterbored portion of the emplacement hole. The crushed salt will be placed in layers with each layer being compacted before the next one is placed. The estimated radiation dose in the drift after emplacement of the backfill shielding will be less than 1 millirem per hour (Westinghouse Electric Corporation, 1986, p. 53).

Emplacement hole shielding material will be emplaced by the machine shown in Figure 4.5-13. The machine will be a Load-Haul-Dump (LHD) type which has been modified for this application by equipping it with a salt storage bin, an emplacement system, and a mechanical compactor. The operator will work in a shielded cab.

Hole shielding will be performed in the following sequence:

1. The operator will load the salt bin with crushed salt and transport it to the emplacement hole.

2. The operator will drive the machine onto the leveling platform and position the machine to align the salt dispensing nozzle above the emplacement hole. 


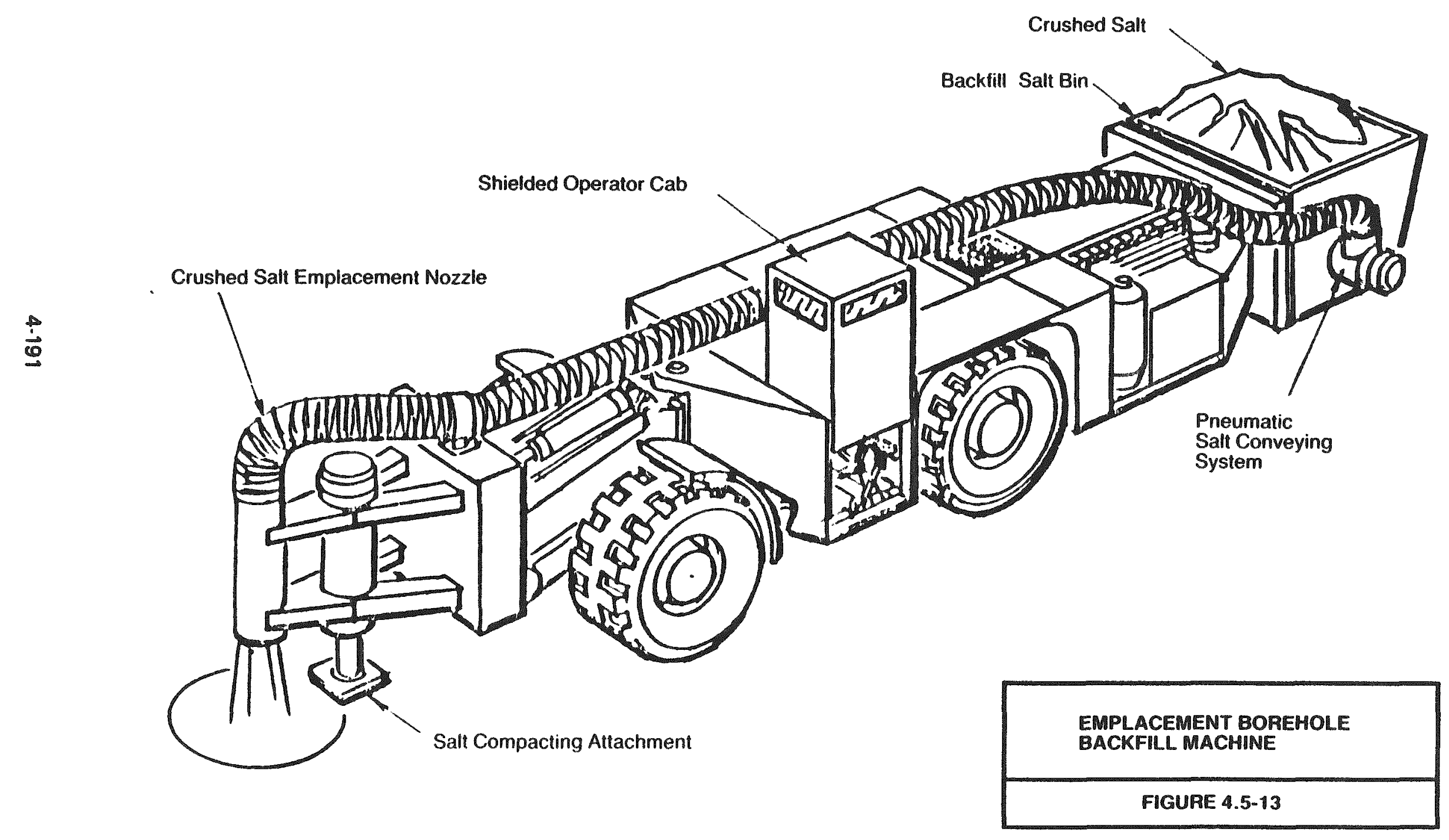


3. The operator will feed crushed salt into the borehole, filling the annulus between the disposal container and the borehole wall until a layer accumulates over the disposal container pintle. This layer will be compacted with the mechanical compactor. After that, successive layers will be placed and compacted until the borehole is filled.

\subsubsection{Entry Backfilling and Entry Stopping}

When each emplacement entry has been filled with waste to its design capacity, it will be backfilled and a stopping will be installed. Figure 4.5-14 portrays these activities.

\subsubsection{Entry Backfilling}

The backfill material will be crushed salt that has been excavated during repository development. Prior to the 22 nd year of operation, backfill salt will be obtained directly from development operations via the materials handling system. After Year 22, the salt will be reclaimed from the storage pile and brought underground. The backfill system will consist of a conveyor system for transporting salt to the backfilling operations area and a pneumatic stowing system.

The backfill conveying system will originate at the distribution bin of the material handling system in the shaft pillar area. A vibrating feeder will withdraw mined salt from the bin at a rate of 250 tons per hour. The salt will pass through a hammer mill which will reduce the product size to less than 2 in and load it onto a 24 in conveyor belt. The conveyor will discharge into a hopper equipped with two rotary lock feeders. Each rotary lock will feed a screw conveyor to transport the salt through a pillar. This system will provide positive sealing of air movement while transferring backfill salt from the development to the emplacement side.

The screw conveyors will discharge into a bin which will load a 24 in conveyor system located in the west main entry on the emplacement side. This system will transfer the salt onto a lateral conveyor which will carry it to the backfilling operation within the emplacement panel. 

A pneumatic stowing system will emplace the backfill in the entries. It will consist of an air compressor, receiving hopper, pneumatic stowing machine, rotary feeder, pipeline, and discharge nozzle.

The lateral conveyor will discharge the salt into the receiving hopper. A rotary feeder will then feed it into a pipeline where it will be mixed with compressed air. The compressed air will force it through a dual pipeline system to the discharge nozzles, which will direct it to the backfill face. Backfilling will begin at the rear of the entry and retreat toward the submains. As backfilling is completed sections of pipeline will be removed and the discharge nozzle retreated.

Dust generated by backfilling operations will be drawn into a ventilation tubing system with the intake located near the point of backfill impact. Dust-laden air will be carried through the duct and discharged directly into the exhaust ventilation system.

The pneumatic backfill method offers the potential for good compaction of emplaced material, plus the capability to carry the backfill up to the roofs of entries. The entry will be backfilled to the first submain intersection.

\subsubsection{Entry Stopping}

The final activity of the emplacement function will be the installation of a stopping across the entrance to the emplacement entry. This will be performed to satisfy federal gassy mine regulations. Once the stopping is installed, there will be no need to continue ventilating the entry.

Each stopping will be constructed of salt blocks and aligned parallel with the rib line of the submain. As construction of the stopping progresses upward, additional crushed salt will be placed behind the stopping to minimize voids. Sampling pipes with valves may be constructed through the stopping to allow for periodic collection of samples from behind the stopping for detection of mine gases should accumulation occur. If sampling pipes are installed, they will be removed at closure to avoid the possibility of creating a preferential pathway through the stopping. Alternate sampling methods will be sudied during ACD. 
4.6 STRUCTURES, SYSTEMS, AND COMPONENTS IMPORTANT TO SAFETY, AND IMPORTANT TO WASTE ISOLATION

\subsubsection{Introduction}

Three sections of the Statement of Work for this CDR require discussions of structures, systems, and components important to safety and important to waste isolation. These three sections $(2.7,4.6$, and 7.4$)$ are consolidated here. The purpose in consolidating the three sections into one is to allow the reader to obtain all information relating to Q-list development in one place. References are made to other sections of the CDR only to the extent necessary to clarify development of the list.

This section contains a description of the methodology for generating a Q-list for the salt repository. A preliminary Q-list, reflecting the current level of limited detail in the SCP conceptual design, is also provided in this section. No conclusions should be drawn at this time as a result of this Q-list presentation. The current material should be looked upon more as an example of what a $\mathrm{Q}-1$ ist is intended to provide. This preliminary Q-1ist will also be revised several times during Advanced Conceptual Design (ACD) and License Application Design (LAD). At that time more design detail will be available and more developmental work will have been done on the overall approach to Q-listing in preparation for application of the stringent QA requirements described below.

Subpart G, Quality Assurance, of 10CFR60 requires the DOE to apply a quality assurance (QA) program, based on the criteria of Appendix B of 10CFR50, to systems, structures, and components important to safety, to design and characterization of barriers important to waste isolation, and to activities related thereto. The SCP Q-1ist is a list of the structures, systems, and components (items) affected by this requirement. The Q-Iist is a convenient way to indicate items that are important to safety or to waste isolation, and it serves as a checklist to ensure that NRC QA criteria have been addressed for these items. It also facilitates interactions with the $\mathrm{NRC}$ in the prelicensing and licensing processes. Items not on the SCP Q-1ist, which include all other items, are subject to DOE self-imposed QA requirements but not NRC QA oversight. 
The Q-1ist in this CDR addresses the following categories of items which are descriptive of the repository physical system: surface and subsurface preclosure (important to safety) items, and subsurface postclosure (important to waste isolation) engineered barriers. Discussions under Section 4.6.2, Methodology Introduction, explain what methods were used to classify the items in these different categories.

Natural barriers consist of the host rock (except the disturbed zone) and surrounding geologic structures. They are not included on the Q-List since design criteria could not be effectively applied to them. However, they are important to waste isolation if their performance can impact the isolation function of the site. For this reason, activities performed on natural barriers (e.g., excavation) that could adversely affect their performance could be placed on a Quality Activity List. Activities on this list would be subject to compliance with QA Level 1 requirements.

The regulations which relate to developing a $\mathrm{Q}-1$ ist and which are pertinent to protecting the public health and safety with respect to the geologic repository are 10CFR60 and, by reference, 10CFR50 and 40CFR191. 10CFR60.2 defines the phase, "important to safety," as "those engineered structures, systems, and components essential to the prevention or mitigation of an accident that iuld result in a radiation dose to the whole body, or any organ, of 0.5 rem or greater at or beyond the nearest boundary of the unrestricted area at any time until the completion of permanent closure." Items important to waste isolation are those barriers (engineered or natural), structures, systems, and components that are relied on to meet 10CFR60 Subpart E postclosure performance objectives. These objectives are to inhibit the transport of radioactive material so that amounts and concentrations of this material entering the accessible environment will be kept within prescribed limits.

Items important to safety or engineered barriers important to waste isolation that have been placed on the Q-Iist will be subject to IOCFR50, Appendix B, (Level 1) QA requirements and will be designed to specific criteria consistent with 10CFR60 design requirements. These design requirements are described in 10CFR60.131(b), and 60.132 through 60.135. Graded QA measures wil1 be applied to Q-1isted items and will be based on a number of considerations. 
These include: the impact of failure of an item on safety or of failure of an engineered barrier on waste isolation, the complexity or uniqueness of an item, special controls required over an item, the degree to which functional compliance of an item can be demonstrated by inspection or test, and the quality history and degree of standardization of an item. A graded QA program, particularly for QA Level 1 items, will ensure that such considerations will be a part of the design and fabrication, procurement, or construction processes of a Q-1isted item. The result will be compliance with applicable provisions of $10 \mathrm{CFR} 50$, Appendix B, as well as a stipulation for the most logical, reasonable, and cost-effective means for providing an item. Additional information on the grading of quality assurance program elements is provided in Appendix $4 \mathrm{~A}-1$ of NQA-1 (ANSI/ASME, 1983) which meets the 10CFR50, Appendix B, criteria.

\subsubsection{Q-List Methodology}

The approaches to Q-1isting presented in this section are consistent with DOE guidance (DOE, 1986c) on this subject. The level of sophistication in applying the approaches was limited by availability of data, information, and design details at this time.

For the current CDR, with limited design information available, two different methods were used. Engineering judgement was applied to determine those repository surface facility preclosure items considered at this time to be potentially important to safety. Engineering judgment was also applied to determine those subsurface postclosure engineered barriers considered at this time to be potentially important to waste isolation. The engineering judgement methodology and its application are described in Section 4.6.2.1.

Based on current direction from DOE, a probabilistic risk assessment (PRA) methodology was used to classify subsurface preclosure items as potentially important to safety. This PRA approach was introduced at this time and a framework established for the required analyses even though many of the repository design details are not yet available. This methodology was applied to subsurface preclosure items only because their design is further advanced than the design of most surface structures, systems, and components. 
The PRA methodology and its application are described in Section 4.6.2.2.

As design progresses and more details become available, it is expected that PRA methods will be used to determine all items important to safety. At a later phase of design, performance assessment results will be used to determine all items important to isolation, and a retrieval compliance strategy will be used to address items relating to retrievability. These are not discussed in this CDR. These methods and analyses will apply particularly to the ACD and the LAD phases.

Prior to applying either classification methodology, a complete list of repository structures, systems, and components was developed consistent with the level of detail at this stage of design and as reflected by this CDR. Generally, this list identified only major systems and subsystems, since delineation of items at any greater level of detail was not possible at this point in the design process. This list of all repository items and site features considered for Q-1isting is presented in Table 4.6-1. The list includes, to the extent described above, all preclosure and postclosure items and features described in this CDR.

\subsubsection{Engineering Judgement Methodology}

This method was used to classify those repository surface preclosure structures, systems, and components considered at this time to be potentially important to safety, and those subsurface or subsurface-related postclosure engineered barriers considered potentially important to waste isolation.

Tables $6.2-1,6.2-2,6.2-3,6.2-4,6.2-5$, and $6.2-6$ contained in Sections $6.2 .1,6.2 .2$, and 6.2 .3 describe potential accident initiating events, accident scenarios, and estimated frequencies for such accidents, and identify potential preventive/mitigative design features for these accidents. The accident descriptions, their sequences, subsequent events, and related preventive/ mitigative design features together with the listing of preclosure and post- 
Table 4.6-1. List of Preclosure and Postclosure Structures, Systems, and Components (Sheet 1 of 6 )

Structure/System/Component

I. Waste Handling Buildings 1 and 2 (WHB 1 \& 2)

A. Waste Handing/Processing Areas

1. Waste Handling/Packaging Systems

a. Shipping Cask Receiving and off-Loading Area (WHB 1 \& 2)

(1) Cask Inspection Systems

(2) Cask Handing Systems

b. Shipping Cask. Preparation Station (WHB I \& 2)

(1) Cask Preparation System

(3) Gas Sampling System

(2) Contanination Inspection System

(3) Shipping Cask Closure Seal Inspection and Repair System

c. Shipping Cask Unloading Cell (WHB 1 \& 2)

(1) Cask Unloading System

(2) Cask Inter-Cell Carrier

(3) Spent Fuel Transfer Basket

d. Surge Storage Cell (WHB 2 only)

(I) Transfer Basket Handiing System

e. Disassembly Cell (WHB 2 only)

(1) Disassembly Cel1 Crane/Manipulator

(2) Disassembly Machine

(3) Hardware Compaction Machine

f. Canistering Cel1 (WHB $1 \& 2$ )

(1) Canister

(2) Canister and SFA/RCSF Handling System

(3) Canister Welding Robot

(4) Canister Weld Inspection Robot

g. Canister Decontamination Sub-Cel1 (WHB $1 \& 2$ )

(1) Canister Decontamination System

h. Overpacking Ce11 (WHB $1 \& 2$ )

(1) Container

(2) Container Handiing System

(3) Container Welding Robot

(4) Container We1d Inspection Robot

(5) Container Contamination Inspection Station

(6) Container Decontamination System

(7) Container Weld Repair Station

i. Disposal Container Storage and Loadout Cel1 (WHB 1 \& 2)

(I) Disposal Container Handling System

j. Special Function Cell (WHB 2 only)

(1) Canister Weld Repair Station

(2) Canister and SFA/RCSF Handing System

k. Performance Confirmation Ce11 (WHB 1 only)

(1) Performance Confirmation Package Inspection System

1. Other (WHB $1 \& 2$ )

(1) Remote Maintenance Equipment in all Areas (except Maintenance Cell and Manipulator Maintenance Area)

(2) Remote Maintenance Ce11 and Equipment

(3) Manipulator Maintenance Area and Equipment

B. Operating Support Systems

1. HVAC System (WHB 1)

a. Waste Receiving/Processing Areas (except Overpack \& Performance Confirmation Cel1s)

(1) Ventilation Supply Air Syster

(2) Exhaust and Filtration system

(3) Controls

b. Overpacking and Performance Confirmation Cells

(1) Ventilation Supply Air System

(2) Exhaust and Filtration System

(3) Controls

c. Maintenance Gallery

d. Other Operation Support Areas 
Structure/System/Component

2. HVAC System (WHB 2)

a. Waste Receiving Area

(1) Ventilation Supply Air System

(2) Exhaust and Filtration System

(3) Controls

b. Waste Processing Areas

(1) Ventilation Supply Air System

(2) Exhaust and Filtration System

(3) Controls

c. Overpacking Cell

(1) Ventilation Supply Air System

(2) Exhaust and Filtration System

(3) Controls

d. Maintenance Gallery

e. Radwaste Processing Areas

f. Other Operation Support Areas

3. Radwaste Handling Systems (WHB $1 \& 2$ )

a. Liquid Radwaste Handling System

b. Solid Radwaste Handling System

c. Gaseous Effluent Treatment System

4. Utilities and Miscellaneous Service Systems (WHB 1 \& 2)

a. Chemical Makeup System

b. Makeup Water System

c. Cooling Water Systen

d. Chilled Water systen

e. Steam and Condensate System

f. Liquid Non-Radwaste Handing System

g. Compressed Air System

h. Inert Gas System

i. Fuel System

j. Fire Protection System

k. Electrical System

(1) Electrical Power Emergency Distribution System

(2) Electrical Power Normal Distribution System

(3) Ups System

1. Security and Communications Systems

C. Operating Cells - Structural and Architectural Systems

1. Shipping Cask Unloading Cell (WHB 1 \& 2)

2. Surge Storage Cel1 (WHB 2 only - WHB 1 Surge Storage Contained in Shipping Cask Unloading Cel1)

3. Disassembly Cell (WHB 2 only)

4. Canistering Cel1 (WHB $1 \& 2$ )

5. Canister Decontamination Subcel1 (WHB $1 \& 2$ )

6. Overpacking Cell (WHB I\&2)

7. Disposal Container Storage and Loadout Ce11 (WHB I \& 2)

8. Special Function Cell (WHB 2 only)

9. Performance Confirmation Cell (WHB 1 only)

D. Transfer Corridors - Structural and Architectural Systems

1. SFA Transfer Corridor (WHB 1 \& 2)

2. Defective Canister and Failed Equipment Transfer Corridor (WHB $1 \& 2$ )

3. Empty Canister Delivery Corridor (WHB $1 \& 2$ )

4. Full Canister Transfer Corridor (WHB $1 \& 2$ )

E. Operating Support Areas - Structural and Architectural Systems

1. Shipping Cask Receiving And Off-Loading Areas

a. Truck Shipping Cask Preparation Bay

b. Truck Shipping Cask off-Loading Bay

c. Rail Shipping Cask Preparation Bay

d. Rail Shipping Cask Off-Loading Bay

e. Shipping Cask Transportation Control Center

2. Liquid Radwaste Handling/Solid Radwaste Handing/Radwaste Offgas Treating Areas

3. HVAC Equipment Areas

4. Control Room 
Table $4.6-1$ (Sheet 3 of 6 )

Structure/System/Component

5. Electrical Equipment Areas

6. Utility Rooms and Areas

7. Offices/Lunch Room/Health Physics

8. Container Storage/Inspection/Repair \& Transport Station

9. Empty Canister Weloing/Storage/Transport Center

10. Turntable Building

II. Subsurface Structures/Systems/Components

A. Surface Support

1. Surface Cage Off/on Loader

2. Office Building

3. Changehouse Building

4. Salt Material Handing System

5. Warehouse and Storage Yard

6. Emplacement Exhaust Shaft Fan and Filter Building

a. Normal Exhaust Fans

b. Emergency Exhaust Fans

c. Emergency Filtration (HEPA)

d. System Dampers and Ductwork

e. Controls

7. Development Intake Fan Building

a. Fans

b. Intake Air Cooling System

c. Intake Air Heating System

d. System Dampers and Ductwork

e. Controls

8. Emplacement Ventilation Heating/Cooling Buliding

a. Intake Air Cooling System

b. Intake Air Heating system

c. System Dampers and Ductwork

d. Controls

9. Waste Shaft Heating/Cooling Building

a. Intake Air Cooling System

b. Intake Air Heating System

c. System Dampers and Ductwork

d. Controls

10. Development Exhaust Fan Building

a. Emergency Reversal Fans

b. System Dampers and Ductwork

B. Shafts

c. Controls

1. Waste Shaft (Shaft B)

a. Headframe/Hoist House

b. Hoisting System

c. Shaft Collar and Station

d. Shaft Lining and Operational Seals

e. Shaft Decommissioning Seals

f. Freeze Hole Sealing

g. Conveyance Loading/Unloading System

h. Inspection Hoist System

2. Enplacement Intake Shafts (Shafts C, F, G)

a. Shaft Collar and Station

b. Shaft Iining and Operational Seals

c. Shaft Decomissioning Seals

d. Freeze Hole Sealing

e. Inspection Hoist System (Including Headframe and Hoisthouse)

f. Utility Systems

3. Service/Intake Shaft (Shaft E)

a. Headframe/Hoist House

b. Hoisting System

c. Shaft Collar and Station

d. Shaft Lining and Operational Seals 
Structure/System/Component

f. Freeze Hole Sealing

g. Inspection Hoist System

h. Utility Systems

4. Mined Salt/Developnent Exhaust Shaft (Shaft D)

a. Head frame/Hoist House

b. Hoisting System

c. Shaft Collar and Station

d. Shaft Lining and Operational Seals

e. Shaft Decommissioning Seals

f. Freeze Hole Sealing

5. Emplacement Ventilation Exhaust Shaft (Shaft A)

a. Shaft Collar and Station

b. Shaft Lining and Operational Seals

c. Shaft Decomissioning Seals

d. Freeze Hole Sealing

e. Inspection Hoist Systen (Including Headframe and Hoisthouse)

6. Miscellaneous Items Relating to Shafts

a. Shafts Geotechnical Instrumentation

b. Shaft Areas Disturbed Rock Zone (Near Field)

c. Shaft Areas Disturbed Rock Zone (Far Field)

7. Boreholes

a. Borehole Decomissioning Seals

C. Repository Horizon

1. Ventilation Control Devices (Stoppings, Overcasts, Substantial Barriers,

Check Curtains, Regulators, Ait Locks, Etc.)

2. Waste Package Position Monitoring System

3. Underground Waste Transporter

4. Transfer Cask

5. Underground Transfer Cart

6. Underground Cage off/on Loader

7. Waste Emplacement Machine

8. Emplacement Leveling Machine

9. Emplacement Hole Shield

10. Backfilling/Bulkhead/Decommissioning Systems (Including Emplacement

Entry Backfil1, Main Entry Backfil1/Bulkheads)

11. Underground Excavating System

12. Borehole Drilling Machine

13. Mined Salt Handling System

14. Ground Control System

15. Radiation Monitoring System

a. In Waste Shaft

b. Throughout Underground

16. Operational Monitoring and Control System

17. Ventilation Monitoring System

18. Geotechnical Monitoring System

19. Waste Package

a. Waste Form

b. Canister

c. Container

d. Packing Material

20. Disturbed Rock Zone Around Emplacement Holes (Very Near Field)

21. Disturbed Rock Zone Around Entries and Pillars (Near Field)

22. Disturbed Rock Zone Beyond Entries and Pillars (Far Field)

23. Operating Support Systems

a. Electrical Power Distribution System

b. Utility Systems

c. Security Systems

d. Communication Systems

e. Remote Maintenance Equipment

f. Dewatering System

g. Waste Shaft Pillar Area Exhaust HEPA Filters/Dampers/Controls

h. Fire Protection System 
Table 4.6-1 (Sheet 5 of 6 )

Structure/System/Component

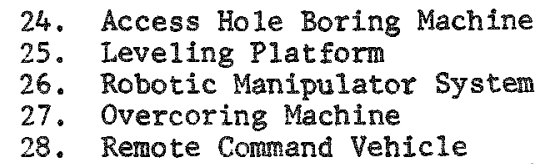

III. Balance of Plant Structures/Systems/Components

A. Administration

1. Visitor Center

2. Central Security Building

3. Administration Building with Cafeteria

4. Engineering Office Building

5. Instrument/Control Lab

6. Health Physics Lab

7. Training Center

8. Fire Station

9. Medical Facility

10. Security Guardhouses

B. Maintenance

1. Maintenance Shop

2. Fabrication Shop

3. Mobile Equipment Maintenance Shop

4. Motor Pool/Service Station

5. Cask Repair Building

6. Railroad Equipment and Truck Transporter Maintenance Building

C. Storage

1. Central Warehouse

2. Warehouse

3. Explosive and Cap Storage Buildings

4. Storage Yard

5. Storage Shed

6. Hazardous Materials Storage Building

D. Utilities (including Piping, Pumps, Valves, Fittings, and other Components as appropriate)

1. Drainage and Flood Control System

2. Reclaimed Water System

3. Boiler Feed Water Systen

4. Main Substation/Switchgear - Generator Building/Nomal Power Distribution System

5. Emergency Power Generating System

6. Raw Water and Potable Water System

7. Firewater System

8. Sewage Treatment (Sanitary Waste) System

9. Industrial and Waste Water Treatment System

10. Steam Generating System

11. Steam and Condensate System

12. Compressor/Chiller Bullding (for Surface Balance of Plant Facilities only)

13. Chilled Water System (Chillers, Chilled Water Circulation Punps)

14. Cooling Water System

15. Compressed Air System

16. Inert Gas Systems (Nitrogen, Argon)

17. Acid and Caustic Facilities

18. Diesel and Chemical Unloading Station

19. Fuel System (Gasoline, Diese1, Natural Gas)

20. Utility Control Bullding

21. Fuels and Chemical Storage Tank Area

E. Miscellaneous

I. Shipping Cask

2. Shipping Unit Washdown Building

a. Shipping Unit Washdown System

3. Radiation/Contamination Inspection Station

4. Shipping Cask Security Inspection Station

5. Interim Radwaste Storage Area

6. Excavated Shaft Materials Area 
Table 4.6-1 (Sheet 6 of 6 )

Structure/System/Component

7. Surface Mined Salt Handling/Storage Systems

8. Scalehouse

9. Radwaste Grout Feed Building

10. Salt Surge Building

11. Laundry Building

12. Radiation Monitoring Station

13. Railroad Control Tower

14. Housing Building

15. Salt Conveyor Transfer Tower

16. Salt Conveyor

17. Salt Loadout Structure

18. Truck Inspection Pit

19. Railcar Inspection Pit

20. Empty Salt Railcar Storage

21. Full Salt Railcar Storage

22. Shipping Unit Pacification Area

23. Meteorological Station with Tower

24. Stacks 
closure items in Table 4.6-1 were all considered and used as background information in the engineering judgement process.

The potential credible accidents from Table $6.2-5$ were reviewed. Information from Tables $6.2-4$ and $6.2-6$ was also used as background for the potential accidents, the related accident scenarios, and it was used to derive a primary safety function which required successful operation of one or more structures, systems, or components. Such items are in some cases implicitly described under Preliminary Preventive/Mitigative Design Features in Table 6.2-6. These features were then related back to the list of candidate preclosure items and postclosure engineered barriers (Table 4.6-1). Consequently, specific items relating to particular primary safety functions, which in turn related to potential and credible preclosure accident scenarios, were considered for placement on the Q-list.

A set of questions was also formulated to further guide determination, from an engineering judgement perspective, whether or not an item should be $\mathrm{Q}-1$ isted. The questions were based on the definition of importance to safety in 10CFR60.2. These questions are provided in the left half of Table 4.6-2. An affirmative answer to any of these questions, based on the evaluations discussed above, resulted in placement of the particular item on the Q-list.

Given that 10CFR60 uses performance objectives as the criteria for determining engineered barriers important to waste isolation, another set of questions was formulated. The questions relating to importance to waste isolation are provided in the right half of Table $4.6-2$ and directly relate to performance objectives stipulated in 10CFR60.112 and 60.113. An affirmative answer to any of these, based on the evaluations discussed above, also resulted in placement of the barrier on the Q-list. Natural barriers were not considered here.

The complete list of candidate items and engineered barriers (Table 4.6-1) was evaluated and the questions in Table 4.6-2 were addressed to determine whether to include or exclude any given item on the Q-list. The analyses and 
Table 4.6-2. Questions Relating to Engineering Judgement Methodology

Important to Safety
To select items for the preliminary 0 -list which are important to safety, the following questions were asked.

1. Can failure of the item initiate a credible accident, that if unmitigated could result in radiation exposure in the unrestricted area exceeding 0.5 rem?

2. Can the item be essential to the prevention of a postulated credible accident, that if unmitigated could result in radiation exposure in the unrestricted area exceeding $0.5 \mathrm{rem}$ ?

3. Can the item be essential to the mitigation of a postulated credible accident that could result in radiation exposure in the unrestricted area exceeding $0.5 \mathrm{rem}$ ?

4. Can failure of the item result in fallure of an

"important to safety" item under accident conditions when that "important to safety" item must function?

If the answer to any of the above questions was yes, the particular item was placed on the Q-1ist.
Important to Waste Isolation $(a)$ (a)

To select engineers barriers for the prelininary $0-1$ ist which are important to waste isolation, the following questions were asked.

1. Is the item essential for compliance with the 10 CFR60 postclosure performance objectives?

2. Does the item have a potential to compromise the site with regard to compliance with the $10 \mathrm{CFR} 60$ postelosure performance objectives?

3. Does the ttem have a potential to compromise the engineered barrier systen with regard to compliance with the 10CFR60 postclosure performance objectives?

the above questions was yes, the particular iten was placed on the Q-1ist. Note that site characterization activities were not addressed for the CDR Q-list.

(a) These questions were not applied to natural barriers, since only engineered barriers are candidates for the Q-List. 
evaluations performed for each of these Q-1isted items were based solely on engineering judgement, which was in turn based on the current understanding of the repository design, and supported in some cases by simplified scoping calculations.

The list of candidate items and engineered barriers from Table 4.6-1, along with the information from Section 6.2, was reviewed and evaluated in group discussions. The role of a candidate item in either preventing or mitigating a potential credible accident was discussed and then answers to the safety and isolation related questions were proposed for the item. Group concensus was then reached regarding which items would be appropriate for placement on the Q-Iist.

This preliminary Q-list, based on engineering judgement, is presented in Table 4.6-3. It is organized in a matrix format comprised of rows of item entries chosen from Table 4.6-1 and columns of answer entries relating to questions cited in Table 4.6-2. Two additional columns provide the following information: a credible accident (taken from Table 6.2-5) that could affect the item is noted in the first column, and the related primary safety function that could be violated if the item fails during the accident is noted in the next column. For example, the backfill engineered barrier (Table 4.6-3, Item II, C.10) is on the preliminary Q-List because of accident number 5, Natural Phenomena, from Table 6.2.-5, which is a design basis earthquake causing a disruption of the barrier. This accident is noted in the first column. The disruption could yield noncompliance with 10CFR60 performance objectives for repository isolation, as noted in the second column, by opening preferential pathways for nuclide migration to the shafts, which might also be disturbed. The last column on the table shows that isolation question number 1 (from Table 4.6-2) applies to this barrier since the item is essential for compliance with $10 \mathrm{CFR} 60$ postclosure performance objectives.

The classification of items using engineering judgement was done with the understanding that as the design progresses and more design details become available, currently listed items, or portions of currently listed items, may be removed from the 1 ist, and new items may be added to it. More developmental work is required relating to the entire process of Q-list classification, and this will occur in subsequent phases of the design. In particular, it is 
Table 4.6-3. Preliminary Q-list For SCP-CDR (Engineering Judgement) (Sheet 1 of 2)

(Based on Enginesring Judgenent and covers surface preclosure items potentially important postelosure engineered bariers potentially important to waste isolation)

reclosure or postclosure

Primary Safety

Prinction (derived

Important Safety

1. Waste Handing Buildings 1 \& 2 (with i \& 2 )

A. Waste Handing/processing Areas

$\therefore$ Shipping Unloading Cell

(1) Cask Unloading System

Surge Storage cell

(4aise 2 oniys

(1) Transfer Basket llandling

$$
\text { Transfer }
$$

e. Di

(1) Disassembly cell crane

f. Canistering cell

(2) Canistex and SFA/RCSF Handling system

B. Operating Support Systems

1. HVAC System (wiB 1)

a. Waste Receiv

Areas (except Overpack

Per forlance Confirsatio

(2) Exhaust and Filtration System

2. HWAC System (WHB 2 )

Waste Receiving Area

(2) Exhaust and Fitration

$$
\text { Syster }
$$

b. Waste Processing Areas

(2) Exhaust and Filtration

System

4. Utilities and Miscellaneous

Service Systems (WhB 1 \& 2

k. Flectrical System

(3) UPs System (that supports

items important to safety 15-0perationat

15-Operat ional

15-operational

15-Operational

2-Natural Phenonena

HVAC Isolation

Containment of

Radionuclides During

Containent of

Radionuclides During operations

Containment of

Radionuclides During

operations

Padionuclides During operations

1234 

Table 4.6-3 (Sheet 2 of 2 )

Preclosure or l'ostclosure

St ructure/System/Cumponem

C. Operating cells - St ructural dad

Architectural systems

- Shipping Gask Unloading leel

(Whis $1 \& 2$ )

Surge storage cell (wils 2 only

Whi 1 Surge Sturage Contained in

Shipping Cask Unloading Cell)

3. Disassembly cell (whib 2 only)

4. Canformance confirmation 2 II

(WHB 1 only)

C. Operating Support Areas - Structural

And Architectural System

3. AVAC Equipment Area

4. Control Roon

II. Sulsurface St ructures/Systems/

Component \&,

1. Watte Shaft (Shaft B)

e. Shaft Deconisissioning Seals

2. Timplacement Intake shafts (Shafts C, F, G)

c. Shaft Decomaissioning Seal

- Service/Intake Shaft (Shatt E)

e. Shatt lec conmissionng Seals

4. Mind Salt/lievelopment Exhaust Shaft (Shaft D

$\therefore$ Shaft Decommissioning Seals

Cmplacement lentilat ron Exhuast Shaft (Shatt A

- Shat teccomissioning Seals

. Marethaneous te eas Reliating to shat ts

. Mhat Ge

Bereho te Decomissioning Seds

1. Reposeltury Herizon

10. Batkilling/bukhead/broc ommissionng Syst tems

(Incluatiog Emplacement Entry Backfill, Main

knt ry Backtill/Bulkhedds)

19. Waste Package

- Contaner

5-Natural Phenomen.

$\cdot$

1 mary

Function (derived

ial Credible

ken trom Tahle $6.2-5$

Contanment in

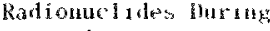
uperations

$" 1$
$"$
$"$
$"$

$\because::$

.

$\therefore$

Nim. Sep Table $4.6-2$ for wallanation of classification questions. 

expected that greater design detail will allow full application of PRA techniques to items considered to be important to safety.

\subsubsection{Probabilistic Risk Assessment Methodology}

The NRC staff and DOE require the use of PRA techniques to eventually support the identification of all repository structures, systems, and com ponents important to safety. For the current CDR Q-Iist, PRA analyses have been performed on a preliminary basis reflecting the current limited state of repository design. At this time, PRA analyses have been applied only to support identification of subsurface preclosure items relating to the emplace ment phase and considered to be potentially important to safety because it was judged that the subsurface design was relatively further advanced than the design of surface facilities. No postclosure engineered barriers were considered. As design progresses and more design details are developed, PRA analyses will be applied to support identification of all items important to safety, including surface structures, systems, and components.

Section 6.2 describes in detail the PRA analysis and consequence calculations performed for this CDR. A set of subsurface preclosure accident scenarios was identified along with corresponsing accident mitigation and prevention features for consideration in $Q$-list development.

The appropriate potential accidents applicable to the subsurface preclosure phase were described and from these, event-trees were developed. The event trees presented sequences from these accidents that would result in potential consequences with probabilities of greater than $10^{-5} / \mathrm{yr}$. Dose calculations identified event tree sequences with consequences greater than 0.5 rem. These critical sequences, in turn, highlighted functions or systems required to satisfy the important-to-safety objective of $10 \mathrm{CFR} 60$ of not exceeding a radiation dose of 0.5 rem to the public at or beyond the unrestricted area. The successful operation of these related systems is then necessary to prevent the undesirable sequences from occurring. Consequently, it is these systems and subsystems, related to the important-to-safety function and chosen from the candidate 1ist in Table 4.6-1, that have been placed on the preliminary Q-1ist. The results are shown on Table 4.6-4. 
Table 4.6-4. Preliminary Q-List for SCP-CDR (PRA Analys is)

(Based on a simplified PRA analys is and covers only subsurface preclosure items potentially important to safety)

\section{Structure/System/Component}

II. Subsurface Structures/Systems/Components

A. Surface Support

7. Emplacement Exhaust Shaft Fan and Filter Building

d. System Dampers and Ductwork

e. Controls

B. Shafts

1. Waste Shaft (Shaft B)

a. Hoisting System

C. Repository Horizon

15. Radiation Monitoring System

a. In Waste Shaft 
Application of PRA that resulted in the Q-listed items shown on Table $4.6-4$ is described below.

Four subsurface initiating events, waste transporter collision and fire, mine gas explosion, tornado affecting the waste shaft, and earthquake were selected from analyses in Section 6.2 for further evaluation on the basis of event frequency and potential consequences. Subsequent design evaluation eliminated the waste transporter collision and fire and the mine gas explosion for lack of a credible release mechanism. Certain event sequences from the tornado and earthquake event trees (Figures 6.2-4 and 6.2-5), involving freefall of a disposal container down the waste shaft, had probabilities of greater than $10^{-5} / \mathrm{yr}$ and yielded dose equivalents to the whole body or an organ in excess of the 0.5 rem limit. The specific sequences were $4 \mathrm{D}$ and $5 \mathrm{D}$ from Figure 6.2-4, Tornado Functional Event Tree and sequences $6 \mathrm{E}$ and $7 \mathrm{E}$ from Figure 6.2-5, Earthquake Functional Event Tree. These results show that one or more of the systems represented on the tornado and earthquake functional event trees involved in the worst-case sequences $4 D, 5 D$. $E$, and $7 E$ require consideration for $\mathrm{Q}$-listing. In following back through these sequences it appears that systems and subsystems related to the HVAC isolation function, radiation monitoring and control, and electrical power are likely candidates.

The next most severe sequence $7 \mathrm{D}$ from the tornado event tree and sequence $9 E$ from the earthquake event tree were then evaluated. The dose equivalent calculated for the whole body or an organ for these sequences was less than 0.5 rem. These results show that the electrical power function failure did not result in a dose greater than $0.5 \mathrm{rem}$. Consequently the el - rical power function did not require consideration for $\mathrm{Q}$-listing. Also these results substantiate that the other, less severe, event sequences will yield consequences less than $0.5 \mathrm{rem}$.

The end result was that those subsurface and subsurface- related preclosure systems which perform the subsurface HVAC isolation and radiation monitoring and control functions were to be considered as important to safety. Table 4.6-1 was examined to identify such items. The only items relating to these functions were the surface-support HVAC systems for the two shafts on the emplacement side of the repository, and the radiation monitoring system. 
To ensure successful HVAC isolation for the underground emplacement side, system dampers/ductwork and controls for the emplacement exhaust and waste shafts need to be Q-1isted. The radiation monitoring system for the waste shaft station in the repository horizon also needs to be Q-listed as this is the system that detects underground radiation. It has to operate successfully in order to properly react to a release situation so that the event will not result in a release sequence yielding 0.5 rem or more to the public.

Table 4.6-4 lists the above items chosen from Table 4.6-1. 


\section{CLOSURE AND DECOMMISSIONING}

Following the retrievability period, which may extend as long as 50 years after emplacement operations begin, the repository will be decontaminated and decommissioned. This assumes successful completion of the performance confirmation program. At that time, the U.S. Department of Energy (DOE) will apply for a license amendment for permanent closure of the underground facilities and shafts and decontamination and decommissioning (D\&D) of the surface facilities as stipulated in $10 \mathrm{CFR} 60.51$.

In the process of applying for the license amendment for permanent closure, the DOE will provide detailed D\&D plans. These plans will include DOE's final decommissioning concepts and commitments on disposition of the surface facilities. And they will specify the activities that are to occur during decommissioning. Since some decommissioning planning will occur after performance monitoring data become available, especially in regard to decommissioning design features, a detailed assessment of decommissioning factors cannot be performed at this time.

Although future $D \& D$ requirements may differ from current requirements, at this time the general DOE philosophy and approach will involve the following activities:

1. Backfill and seal all underground areas, shafts, and boreholes.

2. Decontaminate and dismantle all surface facilities. It is not expected that decontamination of the subsurface facilities will be necessary.

3. Stabilize or remove excess mined rock.

4. Restore the site to the extent feasible.

5. Install permanent markers.

6. Establish a postclosure monitoring system as necessary.

It should be noted that waste processing and emplacement operations will be completed in about 25 years. Therefore, D\&D operations can begin as soon thereafter as the facility license is amended. This will depend on the progress of the performance confirmation program and the length of the required 
retrievability period (up to an additional 25 years). If decommissioning begins soon after emplacement ends, then decommissioning operations can be carried out in conditions of minimum creep closure. This will also minimize the size of the stress disturbed rock zone around excavations. (See discussion in Section $7.3 .2 .2)$.

\subsection{CLOSURE OF THE UNDERGROUND FACILITY}

During decommissioning of the repository, the underground facility must be closed and sealed to prevent circulation of ground water into the waste emplacement areas and the transport of radionuclides out of the waste emplacement areas (NRC, 1986). This closure process will be accomplished by the application of short-term and long-term seals placed in the underground entries that will be constructed during repository development and waste emplacement operations. The process will involve removal of operating equipment and installation of engineered barriers.

This section describes the general concepts for closure of the underground facility. The major issues addressed are related to the layout of the repository, the necessary decommissioning facilities, and material requirements for sealing during postclosure. The qualitative design concepts presented are adapted from Kelsall, et al., (1985).

Short-term sealing will be provided by concrete bulkheads and engineered earthen backfills which are designed to prevent intrusion of ground water until long-term seals become effective. Long-term sealing will be provided primarily by the consolidation of the crushed salt backfill in each entry into a relatively impermeable mass with properties similar to the host rock. The required minimum design life for the short-term seals is based on the amount of time required for the crushed salt backfill seals to consolidate. The required minimum design life of the complete sealing system must span the full time required for isolation of the emplaced waste, pursuant to federal regulations. 
Long-term sealing will be provided by backfilling the entries with crushed salt and earthen materials. Crushed salt, when consolidated, has a low permeability similar to intact salt. Earthfill materials with clay additives will provide three types of sealing functions. Like salt, they will act as a hydraulic barrier of low porosity. They will retard movement of water by their water adsorbing properties. And they may retard outward migration of radionuclides by reacting chemically to adsorb waterborne radionuclides if chemical conditions are favorable.

\subsubsection{Major Elements Requiring Barriers}

The underground facility can be subdivided into four major components requiring sealing systems: main entries, submain entries, miscellaneous underground areas, and the exploratory shaft facility. The grouping is based on the relative importance of restricting ground water and radionuclide movements and the time at which these components can be closed. Figure 5.1-1 shows the general locations of these areas.

\subsubsection{Main Entries}

Main entry seals are located in entries leading from the bases of the shafts to the waste emplacement areas. These main entries (Figure 5.1-1) include ventilation intakes and exhausts for both development and emplacement facilities. The main entry seals will retard entry of ground water and the outward flow of radionuclides to the shaft areas.

Multiple-keyed bulkheads will be installed between the shafts and the edge of the waste emplacement area. These bulkheads will be designed to limit groundwater flow through the seal as well as along the seal/rock interface and through the mechanically disturbed rock zone created by excavating the host rock. The bulkheads will be constructed of concrete while the backfill will be earthen and/or crushed salt material. Items 3, 4, and 5 in Table 5.1-1 describe the main entries' components in greater detail. The relative locations of bulkheads with respect to the different backfills are shown in Figure 5.1-2. 



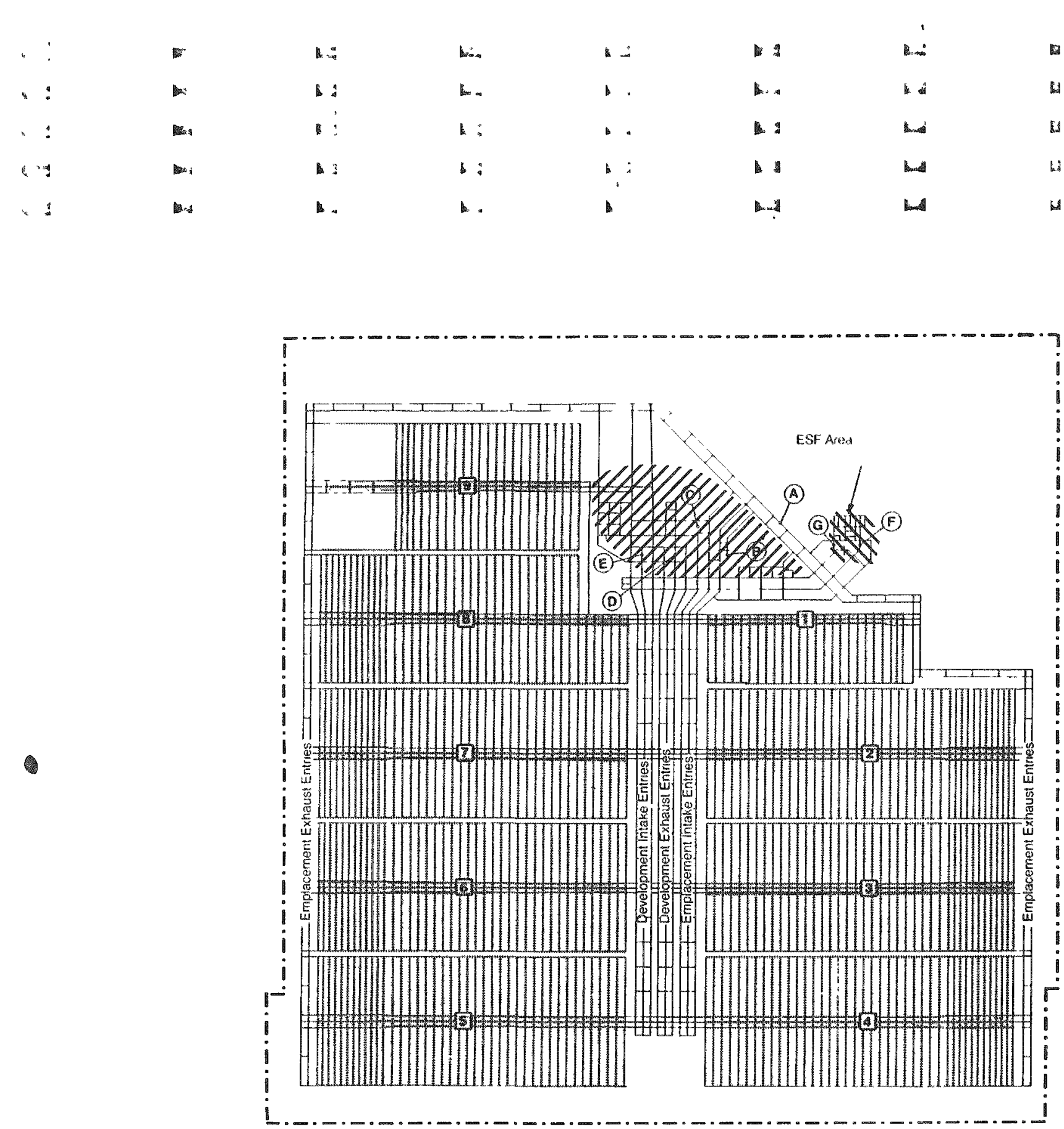

\begin{tabular}{|c|c|c|}
\hline and & $\because A$ & . \\
\hline 1 & ind & I \\
\hline all & L. & 1 \\
\hline 曾 & 1.4 & 11 \\
\hline 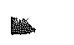 & 14 & , d \\
\hline
\end{tabular}

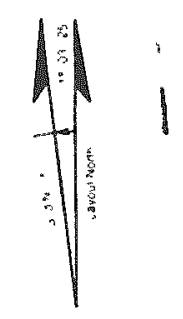

NOTES:

1. Each line represents the centerline of un entry.

2. For tricical bulkhead layout see Figures 5.12 and 5.13

LEGEND:

(A) Emplicesuent Exhaust Shaft

(B) Waste Shatt

(C) Alternate Location for Emplackment lntake Shaft

(b) Mined Salt/Exhaust Shoft

(E) Service/Intake Shatt

(E) Emplacement Intake Shaft

(G) Emplacement Intake Shafi

$\square$ Backfilled Emplacement Entries

Submin Entries

[_] Main Entres (Unshaded)

VIA Miscelldneous Underground Areas

MU Exploratory Shaft Facility

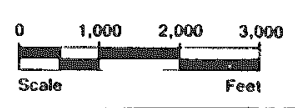

GENERAL SEALING AREAS ITHIN UNDERGROUND FACILITY

FIGURE 5.1-1 
Table 5.1-1. Basic Components in a Seal System for an Underground Facility (a)

\begin{tabular}{|c|c|c|c|c|}
\hline Item & Seal Component & Location & Principal Function(s) & Candidate Materials \\
\hline 1 & $\begin{array}{l}\text { Submain and } \\
\text { Emplacement } \\
\text { Entry Backfill }\end{array}$ & $\begin{array}{l}\text { Waste emplacement } \\
\text { entries, submains }\end{array}$ & $\begin{array}{l}\text { Low permeability; } \\
\text { prevents excessive } \\
\text { long-term rock mass } \\
\text { deformation }\end{array}$ & Crushed salt \\
\hline 2 & Panel Bulkheads & $\begin{array}{l}\text { Main/submain entry } \\
\text { intersections }\end{array}$ & $\begin{array}{l}\text { Low permeability } \\
\text { barrier isolating } \\
\text { individual waste } \\
\text { emplacement panel }\end{array}$ & $\begin{array}{l}\text { Salt blocks of highly } \\
\text { compacted crushed salt } \\
\text { or concrete }\end{array}$ \\
\hline 3 & $\begin{array}{l}\text { Waste Emplacement } \\
\text { Area Boundary } \\
\text { Bulkheads }\end{array}$ & $\begin{array}{l}\text { Main entries outside } \\
\text { waste emplacement } \\
\text { area limits }\end{array}$ & $\begin{array}{l}\text { Low permeability } \\
\text { barrier isolating } \\
\text { waste emplacement } \\
\text { area from shaft-main } \\
\text { entry system }\end{array}$ & Concrete \\
\hline 4 & $\begin{array}{l}\text { Main Entry } \\
\text { Backfill }\end{array}$ & $\begin{array}{l}\text { Mains within waste } \\
\text { emplacement areas } \\
\text { and connecting to } \\
\text { shafts }\end{array}$ & $\begin{array}{l}\text { Low permeability } \\
\text { and radionuclide } \\
\text { adsorbent; prevents } \\
\text { excessive long-term } \\
\text { rock mass deformation }\end{array}$ & $\begin{array}{l}\text { Crushed salt; earthfill } \\
\text { with clay additives } \\
\text { used in sections }\end{array}$ \\
\hline 5 & $\begin{array}{l}\text { Main Entry } \\
\text { Bulkheads }\end{array}$ & $\begin{array}{l}\text { Intervals in mains } \\
\text { joining shafts and } \\
\text { waste emplacement } \\
\text { areas }\end{array}$ & $\begin{array}{l}\text { Low permeability; } \\
\text { intersects interface } \\
\text { between entry and } \\
\text { host rock; removes } \\
\text { majority of mechanically } \\
\text { disturbed rock zone. }\end{array}$ & Concrete \\
\hline
\end{tabular}

(a) Modified from Kelsall, et a1., 1985. 


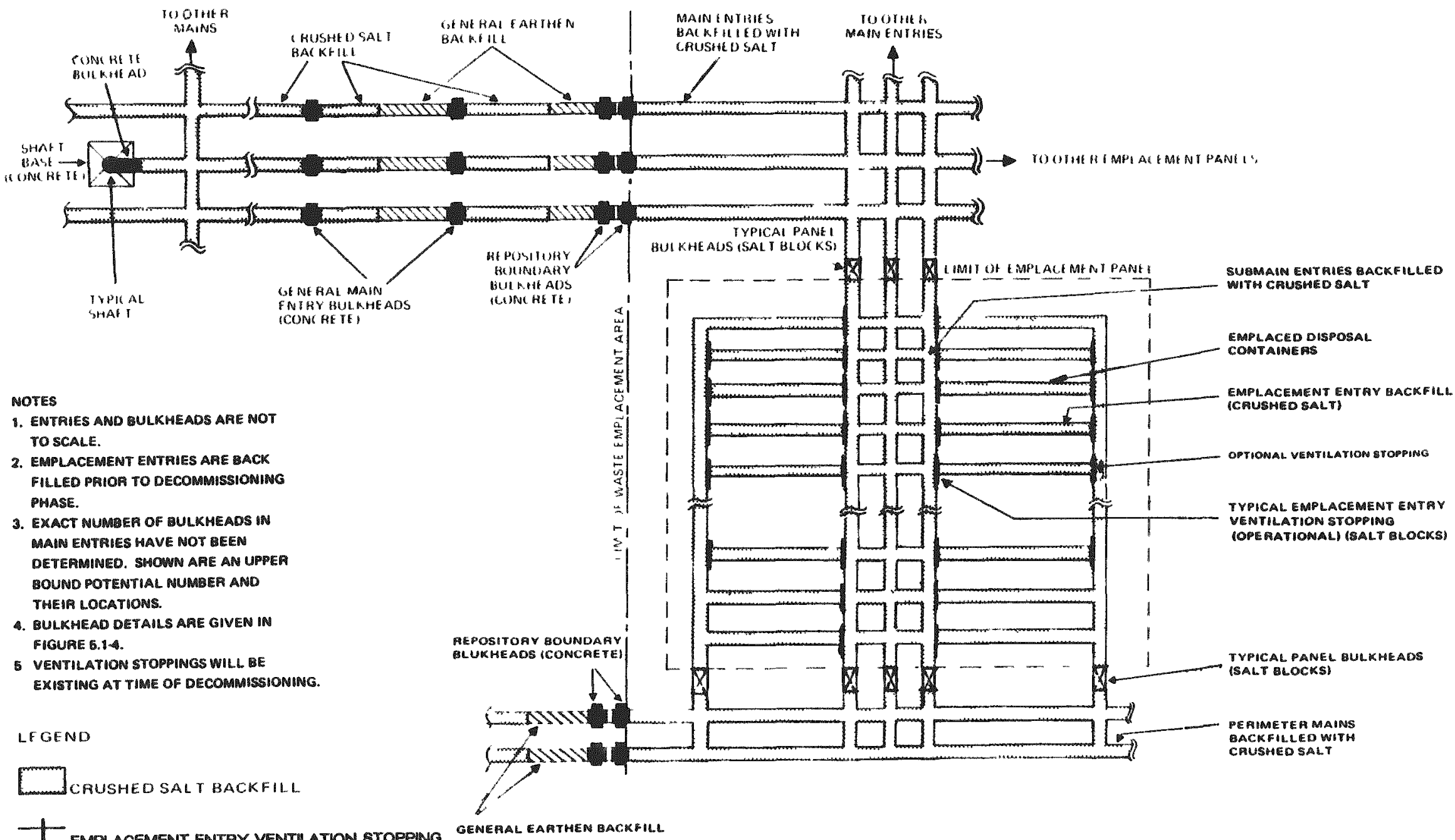

F emplacement entar venthation stopping

GENERAL SEALS SCHEMATIC FOR MAIN AND SUBMAIN ENTRIES

Eoncrete bullkhead

FIGURE 5.1-2 


\subsubsection{Submain Entries}

Submain entry seals will be located in submains joining waste emplacement panels to main entries. These entries (Figure 5.1-1) include waste emplacement entries and panel subentries. When decommissioning begins, the waste emplacement entries will already have been backfilled with pneumatically stowed crushed salt (see Section 4.5.5.1 and Figure 4.5-13). Pneumatic stowing will provide initial compaction of the crushed salt to a relative density of approximately 70 to 80 percent (Brezovec, 1983). The salt will have begun consolidating in response to thermal loading. At the ends of each waste emplacement entry, an operational ventilation bulkhead consisting of stacked salt blocks will have been installed. As illustrated in Figure 4.5-13, these ventilation bulkheads will help to impede any flow of ground water through the repository, but they will not be designed to be part of the decommissioning sealing system. Submain bulkheads will isolate emplacement panels from the main entries and provide short-term sealing while backfill consolidation occurs. Both ends of the mains will have such bulkheads consisting of stacked salt blocks. Items 1 and 2 in Table 5.1-1 describe the components of the waste emplacement panel seals.

\subsubsection{Miscellaneous Underground Areas}

Miscellaneous underground areas requiring closure will consist of facility areas located outside the waste emplacement areas, near the shafts. Such areas will include shops, offices, warehouses, refueling stations, salt storage, waste on/off loading, salt block plant areas, etc. Figure 5.1-1 indicates the general location of these areas. It has not been determined as to when and how each will be sealed. It is expected that the backfill material and its quality will be similar to that used in the main entries (i.e., crushed salt backfil1). Any necessary bulkheads will probably consist of stacked salt blocks.

\subsubsection{Exploratory Shaft Facility}

The ESF will be constructed prior to the development of the repository underground facilities. When or how this section of the underground facility 
facility will be sealed has not been determined. Figure 5.1-1 identifies its location.

The salt storage area within this section of the repository is expected to be sealed in a manner similar to that used for miscellaneous underground areas (see Section 5.1.1.3 above). Shaft access mains will probably be sealed the same way as main entries (see Section 5.1.1.1 above). Depending on the activities in the remainder of the ESF areas, the sealing methods will be similar to those used in main entries or miscellaneous underground areas.

\subsubsection{Removal of Operating Equipment}

During various phases of repository development and operation, equipment will be introduced to, and removed from, the underground facility as necessary. Upon closing, basically all major operating equipment will be removed prior to placing bulkheads and backfill. Four general types of equipment will require removal:

1. Mine development equipment: mining vehicles; conveyor system; ventilation system; and tools and equipment for maintenance, supply, and operations.

2. Waste emplacement equipment: transporting vehicles; ventilation system; and tools and equipment for maintenance, supply, and operations.

3. Performance confirmation and retrieval equipment: package removal vehicles, instrumentation, monitors, etc.

4. Facility closure equipment: backfill compaction vehicles, concrete batch plant, concrete and salt hauling vehicles, bulkhead construction tools and equipment, salt block plant, conveyor system, etc.

Refer to Tables 4.5-1, 4.5-2, and 4.5-3 for a complete list of equipment that will be used underground during the repository development and waste emplacement operations. 
The exact time of removal of each piece of equipment from the underground facility has not been determined. However, it is expected that associated equipment will be withdrawn in three phases: upon completion of mine development, upon completion of waste emplacement, and during closure operations.

\section{1 .3 Construction of Bulkheads}

Two main types of bulkheads will be constructed: those separating waste emplacement panels from main entries and those separating main entries from the shafts. Individual bulkheads must be constructed to strict specifications to ensure design performance as the bulkhead interfaces with the host rock. Specific designs will most likely be tested in situ at or near full scale.

The following subsections present the basic design concepts for the bulkheads. The discussion addresses the material composition of bulkheads, methods used for construction, and the physical response of the rock mass to the bulkhead system.

\subsubsection{Concepts and Rationale for Repository Bulkheads}

The schematic in Figure 5.1-2 illustrates the different types of bulkheading systems. Access entry bulkheads will be concrete plugs keyed into the entry wall. This design will create obstructions in potential flow paths and additional resistance against shearing deformation. The design objective is to reduce permeability at the concrete/salt interface. Removing part of the mechanically disturbed zone by replacing fractured rock with lower permeability bulkhead material will discourage groundwater flow.

The cross section in Figure 5.1-3 illustrates in greater detail a generalized main entry bulkhead system leading to the shafts, and Figure 5.1-4 is a schematic of a concrete bulkhead with approximate dimensions. Final design of these concrete bulkheads will require data from site characterization and performance monitoring of the host rock and seal material testing program. Items of concern include the amount of stress at the concrete/host-rock interface and the extent of the excavation disturbed zone. 


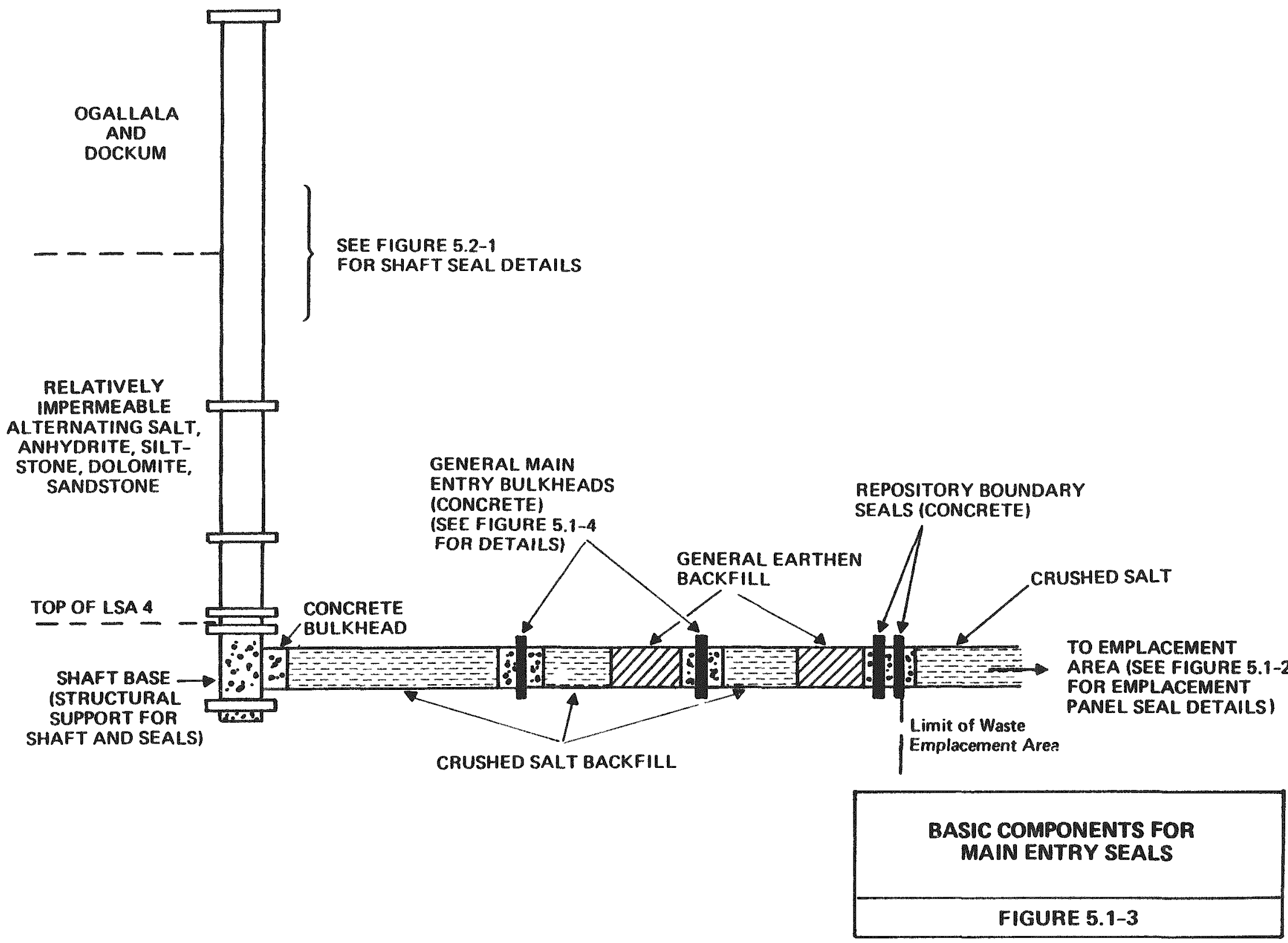




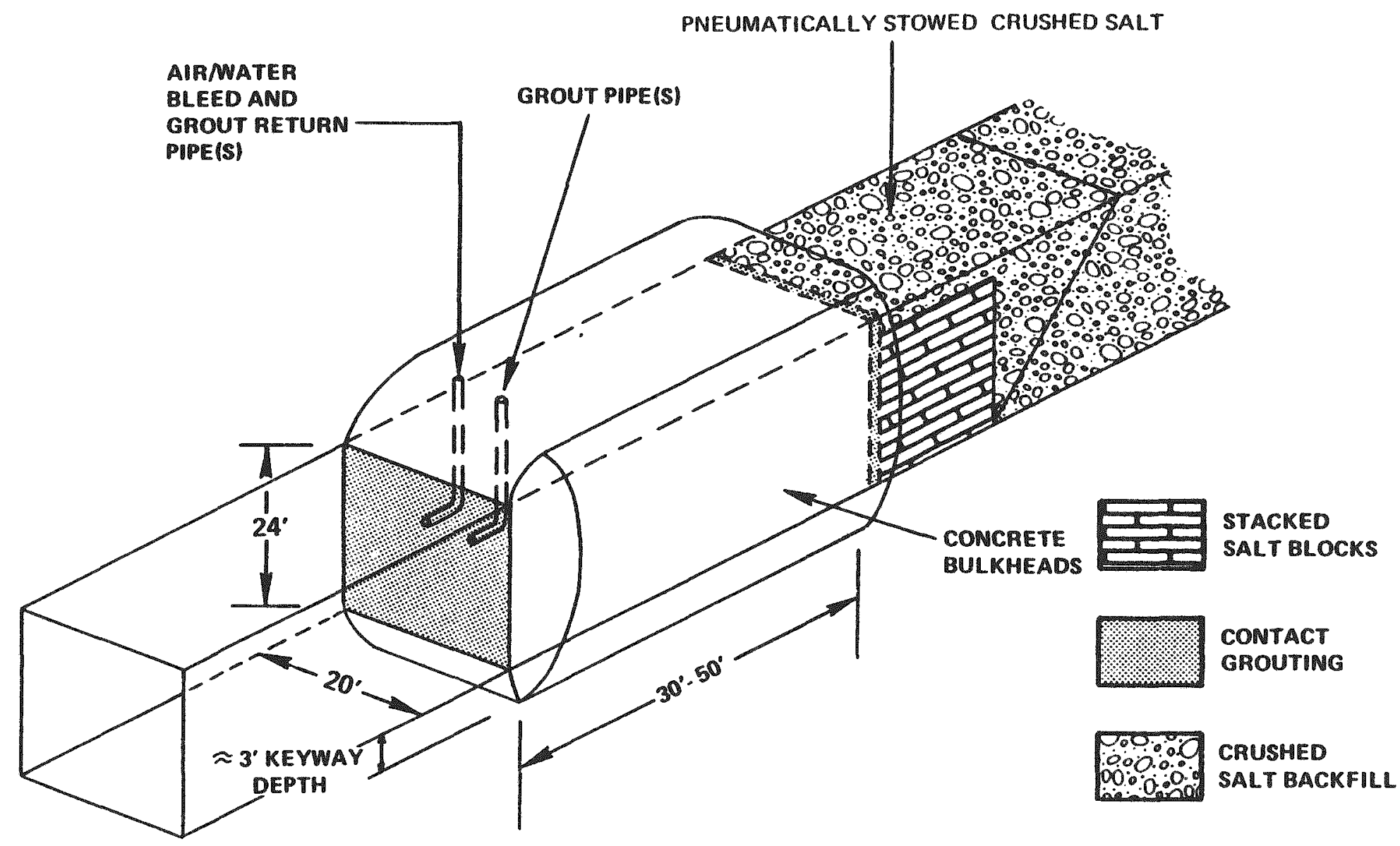

CONCEPT FOR TYPICAL MAIN ENTRY BULKHEAD 
Panel seals are bulkheads used to isolate completed and backfilled waste emplacement panels from the operational areas of the repository. They probably will be built from preformed salt blocks tightly stacked in a manner to mitigate groundwater flow through the bulkhead. Salt blocks are preferable to crushed salt because of their high initial density. The blocks will finish consolidation and heal into a relatively impermeable mass much faster than crushed salt will (Costin and Wawersik, 1980). An alternative to the stacked salt blocks is concrete bulkheads.

\subsubsection{Material Properties of Bulkheads}

At the present time, the primary candidate bulkhead seal materials are salt in block form and cementitious materials. Items 3 and 4 in Table $5.1-2$ present some of the requirements and specifications for materials used in the bulkhead sections.

Pressed salt blocks will have properties similar to consolidated crushed salt except at a higher density. Salt blocks are appropriate as bulkhead material since healing may produce a low permeability mass in a relatively short time (Relsall, et al., 1985). Since the blocks will be fabricated from the mined salt, they will be chemically compatible with the host rock, although crushing and classifying may be necessary prior to pressing the blocks. The elevated stresses, heat generated from the emplaced waste packages, and creep associated with room closure will aid in consolidating and crystallizing the salt blocks, thereby further reducing permeability and enhancing interblock healing. However, consolidation and healing data for salt blocks are very preliminary.

Cementitious materials, including grouts, mortars, and concretes, are a natural choice for the bulkheads in the main access entry areas. These materials are generally stiffer than the host rock, hence will deform less under loading, and because they are generally also more brittle, they will exhibit insignificant creep deformation. 
Table 5.1-2. Summary of Materials, Specifications and Construction Methods for Sealing the Underground Facility (a)

(Sheel 1 of 2 )

\begin{tabular}{|c|c|c|c|c|c|}
\hline Item & $\begin{array}{l}\text { Candidate } \\
\text { Material }\end{array}$ & Applications & $\begin{array}{l}\text { Performance } \\
\text { Requirements }\end{array}$ & Specification & $\begin{array}{l}\text { Construction/ } \\
\text { Installation }\end{array}$ \\
\hline 1 & $\begin{array}{l}\text { Crushed } \\
\text { Salt }\end{array}$ & $\begin{array}{l}\text { Backfill } \\
\text { emplacement } \\
\text { entries, } \\
\text { submains, and } \\
\text { mains }\end{array}$ & $\begin{array}{l}\text { Long-term } \\
\text { consolidation }\end{array}$ & $\begin{array}{l}\text { Crushed and graded to } \\
<2 \text { inches. Laboratory } \\
\text { testing required to } \\
\text { determine properties } \\
\text { (e.g., gradation) } \\
\text { required to promote } \\
\text { consolidation }\end{array}$ & $\begin{array}{l}\text { Installation by pneumatic } \\
\text { stowing. Compaction } \\
\text { not required in most } \\
\text { locations. }\end{array}$ \\
\hline
\end{tabular}

2 Crushed
Salt

Mains and
submain
backfill
(shaft pillars)

Long-term

consolidation

As above

(shaft pillars)

$3 \quad$ Salt

Blocks

Submain panel seals, main

entry seal, and possible waste emplacement area

boundary seals
Adequate fracture healing to form salt monolith in relatively short term
Salt bricks custom made at site to convenient size for handl ing
Pneumatic stowing and/or conventional bulldozers depending on degree of compaction necessary as determined by future testing and analysis.

Stacked with staggered joints. Space against tunnel walls and roof hand-packed with crushed salt. 
Table 5.1-2 (Sheet 2 of 2 )

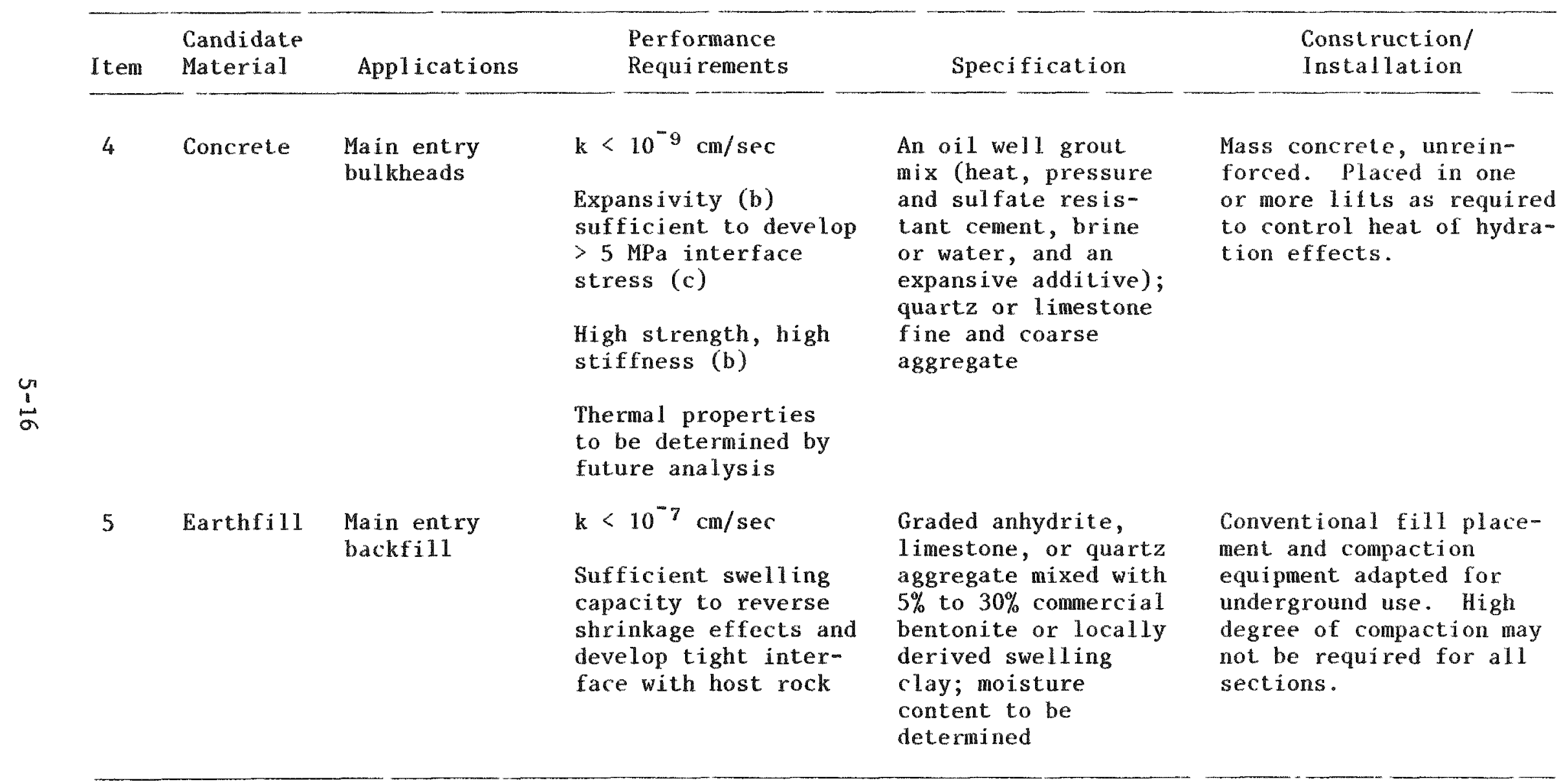

(a) Kelsal1, et al., 1985. Requirements for expansivity, strength, and modulus may be modified for future testing and modeling. Requirements may be different for placement in salt than for placement in non-salt rocks (as given).

(b) Modified from Kelsal1, et al., 1985. Requirements for expansivity, strength, and stiffness may be modified depending on future testing and modeling. Requirements may be different for placement in salt than for placement in nonsalt rocks (as given).

(c) $5 \mathrm{MPd}-725 \mathrm{psi}$. 
Cementitious materials are strong, relatively insoluble, relatively inexpensive, and easy to emplace. Extensive data is available on the chemistry, mineralogy, and engineering properties of these materials. The technological base for construction and placing concrete structures is extensive and well developed. However, their longevity in the salt repository environment is not well known.

A less stiff, fracture resistant concrete may be desirable for certain seal applications. An elastomeric polymer concrete and a concrete based on Portland cement mixed with a soft aggregate have been suggested for this purpose (Kelsall, et al., 1985). Although only limited research has been performed on these mixtures, the expansivity is known to be sufficient to develop enough stress to help close the seal/rock interface. The geochemical stability of the seal/rock interface is the topic of current research on concretes formulated with oil-well grout mixes.

\subsubsection{Bulkhead Construction Methods}

There are two important considerations in entry bulkhead construction: the design of support facilities must allow for straightforward construction using simple procedures and a salt block production plant must be operational before emplacement begins. These two factors will influence the layout of the underground facility.

The salt block plant will be used to fabricate pressed blocks of crushed salt for bulkheads. The plant will be located in the shaft pillar area and may require modification prior to decommissioning operations. The panel bulkhead fabrication sequence will proceed according to stages 1 through 3 in Figure $5.1-5$ as follows:

1. Prepare Bulkhead Location. The area that will be used for the bulkhead will be cleaned of salt debris. Blocks will be placed on a clean, smooth floor surface. No keyway is expected to be necessary since creep associated closure should form a tight seal in a short period and the need for shear interlocking is minimal. 

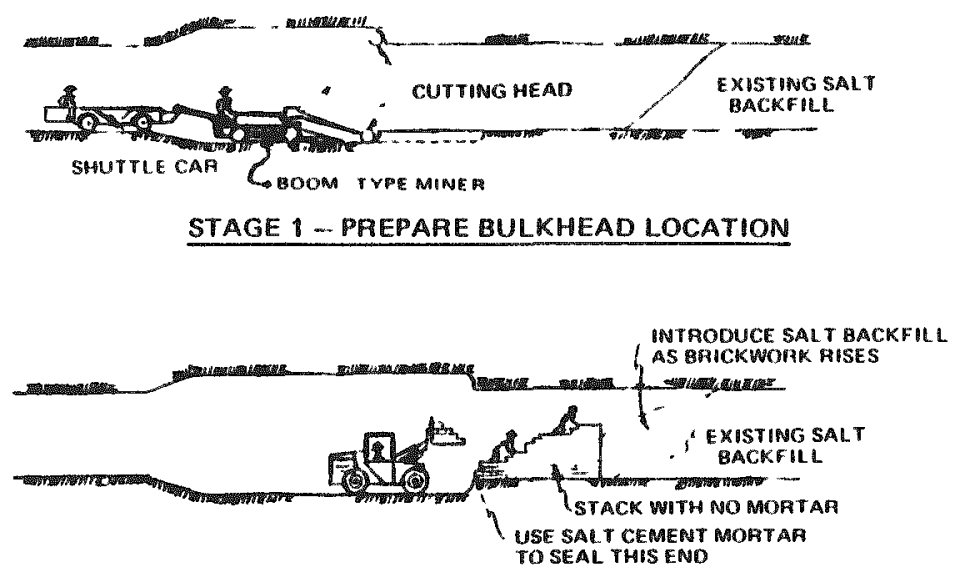

STAGE 2 - BUILD SALT BLOCK RETAINING WALL

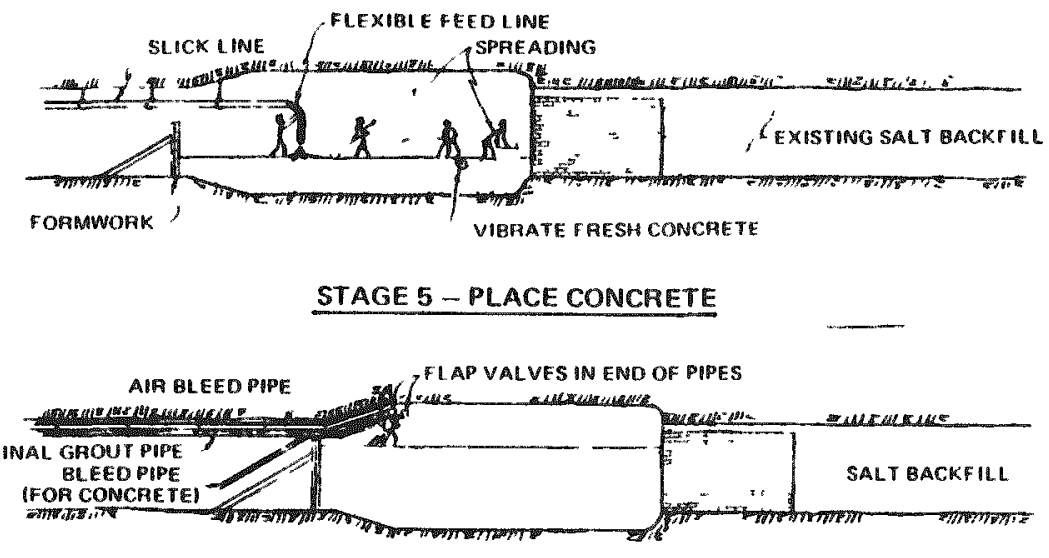

STAGE 6 - INSTALL FINAL GROUT PIPES

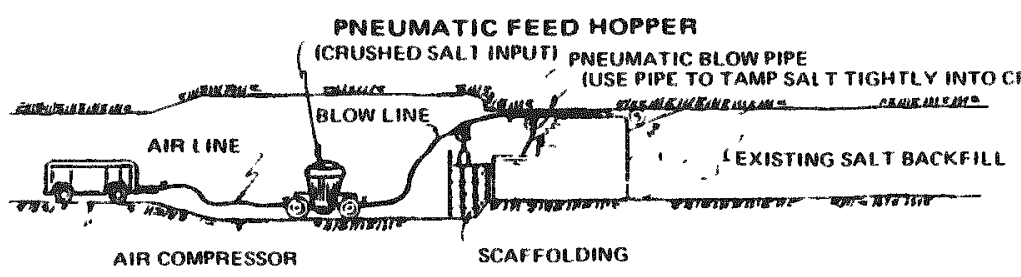

STAGE 3 - STOW CRUSHED SALT PNEUMATICALLY

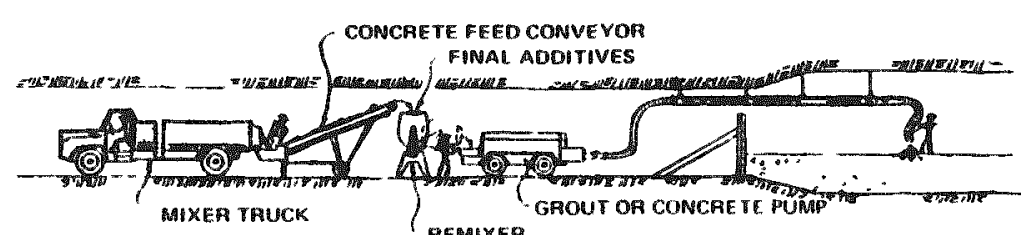

STAGE 4 - DELIVER CONCRETE

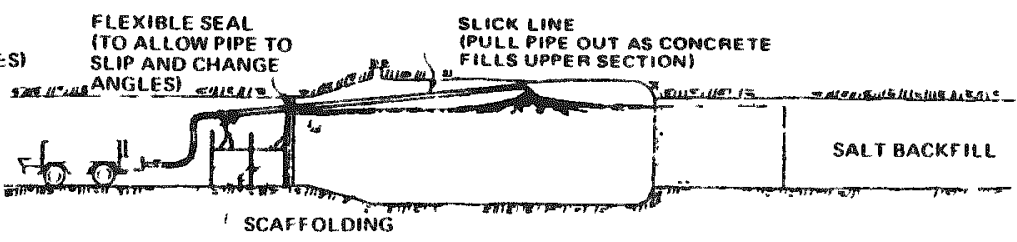

STAGE 7 - CONCRETE UPPER PART

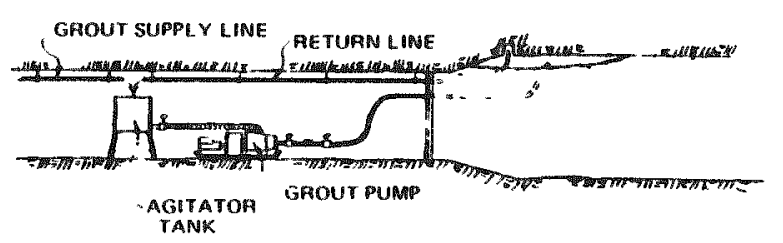

STAGE 8 - GROUT VOIDS ABOVE BULKHEAD

CONSTRUCTION SEQUENCE FOR MAIN ENTRY BULKHEAD

FIGURE 5.1-5 
2. Build Salt Block Bulkhead. Salt blocks will be stacked as high as possible with staggered joints so that potential flow channels will not form between blocks.

3. Stow Crushed Salt Pneumatically. Crushed salt will be pneumatically stowed into the space behind the bulkhead. If required, the salt can be compacted by is hand-held vibrator or impact-type compactor. No salt cement mortar will be necessary to seal ends since salt blocks and salt backfill are structurally and chemically compatible. The space around the perimeter of the stacked blocks wiIl be hand packed with crushed salt to ensure a tight seal. The gap between the entry wall and the top of the block structure will be filled with crushed salt using a small pipe to pneumatically stow it. Maximum salt particle size must be small enough to fit inside the pipe used to tamp the salt as it is introduced.

Constructing the concrete bulkheads will be a more complex task because more steps will be involved. Stages 1 through 8 in Figure 5.1-5 show a simplified construction scheme for building these bulkheads. It is assumed that a concrete batch plant will be erected near an intake/service shaft, but whether it will be located above or below ground has not yet been determined. The first three stages are similar to the construction sequence for salt block bulkheads. Work will progress as follows:

1. Prepare Bulkhead Location. The area to be used for the bulkhead will be prepared by cutting out the keyway using a continuous mining machine such as a boom type miner. All loose salt will be removed to ensure a good concrete/host-rock seal.

2. Build Salt Block Retaining Wall. The same sequence will be used as in construction of panel bulkheads (see discussion above). A saltcement mortar will be used to seal the end adjacent to the concrete bulkhead to prevent concrete flow into spaces between blocks.

3. Stow Crushed Salt Pneumatically. The same sequence will be used as in construction of panel bulkheads (see discussion above). 
4. Deliver Concrete. A truck equipped with an agitator will haul expansive concrete from a batch plant to the bulkhead locations. There a feed conveyor will load the mix into a remixer where final additives such as accelerators will be added.

5. Place Concrete. Final test samples will be taken before the concrete is pumped to the bulkhead locations. It will be tested for slump, expansivity, and other properties. The concrete will be pumped through a slick line, spread within previously prepared forms, and thoroughly vibrated.

6. Install Final Grout Pipes. Fill, return, and air bleed pipes used in placing grout will be installed with the ends of the pipes at the highest point in the roof. The fill and air bleed pipes will be equipped with flap valves to prevent concrete backflow yet permit air to bleed. The grout return line will not include a flap valve.

7. Finish Concrete Emplacement. Remaining formwork will be constructed and will include an access doorway. The slick line will protrude through a flexible seal in the formwork so the pipe can be rotated and withdrawn as concrete is pumped. A vibrator will be attached to the end of a pipe but is not shown in the figure.

8. Grout Voids above Bulkhead. The final step will be the grouting of voids above the bulkhead. High pressure grout will be pumped through the fill pipe until the return line flows with grout. Initially, the grout will be highly fluid, but it will be thickened as pumping continues. Grout pumping will be terminated when a predetermined pumping pressure is reached.

This construction procedure covers only the basic steps in fabricating a typical bulkhead. Further analysis will reveal whether additional components are necessary. Therefore, Figure 5.1-5 shows only a single construction joint, no cutoff grout curtain, and a limited amount of contact grouting between the concrete and salt. It has not been determined whether rock bolting, rebar, precooling the concrete, or other miscellaneous elements will be needed. 
More detailed calculations may indicate that concrete hydration thermal loads dictate the need for precooling concrete or installing construction joints. Horizontal joints can be easily utilized as long as they are discontinuous along the bulkhead length, thereby breaking up potential flow paths.

\subsubsection{Response of Host Rock to Bulkhead System}

The host rock will respond differently to the two different bulkheading systems because of differences in the material composition, stiffness properties, construction methods, and adjacent backfill response.

Consolidation of seals constructed of stacked salt blocks can be divided into two stages: primary and secondary consolidation. Primary consolidation will occur first in the form of closing and healing contacts between blocks. The rate of primary ble $k$ bulkhead consolidation is expected to be nearly the same as the entry closure rate at the time of decommissioning. This process will occur fast enough for the bulkhead to function as an efficient short-term seal. Depending on contact stresses, healing between block surfaces could occur in as short a time as several days (Costin and Wawersik, 1980). Secondary consolidation will be characterized by salt block consolidation until full lithostatic loading has been transferred to the bulkhead and no further consolidation occurs.

The long-term response of panel seals with respect to deformation behavior and ground water impedance is expected to be similar to the response of the host rock. In general, heat helps the consolidation and healing process. Elevated temperatures (caused by the emplaced waste packages) will increase the closure rate and accelerate consolidation.

Pure salt has very little capacity to retard radionuclide migration (Isherwood, 1981) via chemical adsorption behavior. The same is assumed to be true for stacked salt blocks.

Consolidation is not an important characteristic of the concrete bulkheads because they will be much stiffer than the host rock. As initial closure occurs around entries, the bulkhead/rock seal system will become effective almost 
immediately in response to load transfer. Since the concrete seals will be keyed into entry perimeters, and most of the disturbed rock will have been removed, they will become watertight more quickly than the panel seals.

Thermal creep response of the host rock will close the seal/rock interface and encourage concrete expansion although the host rock temperature near the seals will probably increase by no more than $1^{\circ} \mathrm{F}$ over the first 250 years (Section 7.2.2, Near Field Effects). However, more research is needed into the long-term temperature effects on stability of large concrete structures, especially in a brine environment.

\subsubsection{Installation of Backfill}

Two different systems will be used for backfilling the underground facility: crushed salt backfill in the repository areas and engineered backfill of earthen and/or crushed salt materials in areas outside the emplacement entries. The crushed salt backfill will function as a long-term seal through consolidation into an impermeable mass. It must be installed according to specifications necessary to ensure performance.

This section presents the basic design concepts for backfilling entries upon decommissioning of underground facilities. The discussion addresses backfill materials, methods of emplacement, and the physical responses of the rock mass to these backfill systems.

\subsubsection{Concepts and Rationale for Repository Backfill}

The layout of backfill areas in Figure 5.1-2 shows that all waste emplacement entries will be backfilled with crushed salt, which consolidates over time. This includes main entries and panel submain entries. Consolidated crushed salt will perform as a seal by retarding the flow of ground-water; however, it will not be effective in restricting radionuclide migration by chemical adsorption.

Backfill for main entries leading to shafts is shown in detail in Figure 5.1-3. It will be composed of alternating earthen and salt materials, 
thus creating a hydraulic barrier to retard the inflow of groundwater and prevent excessive entry deformation. Certain earthen backfill mixtures will be designed to adsorb radionuclides. Earthen backfills will be used where a relatively insoluble low permeability material is required. Alternating earthen backfills may be used to vary the adsorptive and permeability characteristics of the system in the main entry areas. Using the backfill to prevent excessive creep deformation will ensure that the local host rock remains intact and performs its function of inhibiting migration of groundwater and radionuclides.

\subsubsection{Material Properties of Backfills}

Currently, the primary candidate backfill materials are crushed salt left from the mine development operations and composite earthen material. These materials are specified as Items 1,2 , and 5 in Table 5.1-2.

The crushed salt will tend to consolidate and crystallize under the elevated stress and temperature in the waste emplacement areas, ultimately forming a nearly homogeneous, impermeable mass around the waste. Simple analytical models have been used to simulate the consolidation process for an idealized circular opening filled with crushed salt (IT Corporation, 1984; Kelsall, et al., 1985). These analyses indicate that consolidation to approximately the initial, intact porosity and permeability will require up to 100 to 200 years in main entries adjacent to waste emplacement panels and up to 500 to 700 years in entries near the shafts. These time periods will be controlled by salt creep rates and initial backfill density.

The above estimates assume that there will be no air gaps, water, or brine in backfilled entries. However, settling of backfill may induce air gaps in the roof area which must be accommodated by entry closure prior to consolidation of backfill. A gap of $1 \mathrm{ft}$ could add up to 60 years to the final consolidation time (Kelsall, et al., 1985). Furthermore, brine seeping from the interbeds of the salt may fill the residual porosity in the backfill. The impact of brine on the final degree of reconsolidation is unknown, although recent laboratory tests indicate that the presence of a small amount of brine will accelerate the consolidation process (IT Corporation, 1987). 
Earthen materials, including crushed rock, gravel, sand, and clays, may be used to partially backfill the main entries. These earthen materials can be engineered, by the addition of various clays, to have low hydraulic conductivity, high swelling capacity, high adsorption capacity and high compressibility relative to crushed salt backfill. Further analysis may indicate that earthen material of moderate hydraulic conductivity will enhance the adsorption ability of the compacted material. However, the lower the hydraulic conductivity, the better the backfill will minimize water flow. Earthen materials are known to be stable in many geological environments, and there is a large data base of engineering properties and a large technology base for emplacement and compaction techniques.

Swelling properties of clays are important because swelling will promote sealing by increasing the stress at interfaces where water is present. Additions of bentonite or other swelling clay mixtures on the order of $5 \%$ to $30 \%$ may produce an earthen material of high swelling capacity and low permeability if chemical conditions are favorable. Such clays have a large surface area capable of chemically adsorbing radionuclides, depending on mixing and compacting procedures.

The effects of direct radiation from the emplaced waste packages on the backfill material is expected to be negligible. Early studies of the effects of radiation on bedded salt concluded that gamma and neutron radiation are constrained to the area immediately around the waste. Because more than six feet of solid salt will remain between the waste packages and the backfilled entries, very little radiation is expected to reach the backfilled entries. It should not effect the sealing properties of the materials. Furthermore, studies of irradiated salt indicate that the mechanical properties and the stability of the salt are not significantly affected by radiation at the level expected in the underground. (McClain and Boch, 1974).

\subsubsection{Backfill Installation Methods}

Crushed salt backfill in the submain entries may not require compaction because consolidation could proceed relatively quickly due to the proximity to 
the thermal sources. The backfill can then be emplaced using the most economical and efficient method, probably pneumatic stowing.

The size of the crushed salt lumps is important since it may dictate the method of construction. Mined salt will consist of lumps with diameters that are predominantly less than 3 in if continuous mining machines are used. However, crushing and classifying may be required prior to placing.

Pneumatic stowing will be the primary technique for placing crushed salt backfill. Section 4.5 .5 describes this stowing operation. However, it may be feasible to supplement pneumatic stowing with bulk backfilling techniques.

This could be accomplished in two stages. First, the mined salt backfill would be dumped in piles in front of the area to be filled. A dozer or an articulated load-haul-dump machine with a flat blade replacing the bucket would distribute the salt into the fill area in specified lifts and compact it to the required density. Compaction would be accomplished by either rubber tire, smooth roller, or sheepsfoot type compaction equipment. In the second stage, the open space between the initial backfill and the roof would be filled by means of pneumatic stowing.

Installation techniques for backfilling earthen materials, including techniques of compact filling in horizontal entries, must be investigated. Control of placement of these materials will be critical in order to meet the specifications, especially with regard to water content. Water content will be important in controlling permeability, swelling, strength, and other related behaviors. To ensure control of water content, it may be feasible to use clay blocks, similar to salt blocks. These blocks could be prefabricated on the surface and tightly stacked into place. Conventional earthmoving equipment such as front-end loaders or load-haul-dump machines might be used to transport loose material to the backfill areas for bulk backfilling. Compaction can be achieved by using rubber-tired or crawler equipment, which will initially place the backfill material in the entries. The last few feet of backfill (near the roof of the entries) may require placement using pneumatic stowing, flinger, or elevating conveyor equipment. 


\subsubsection{Response of Host Rock to the Backfill System}

It is expected that salt creep will cause the backfill to consolidate at about the same rate as the entries close. This rate will initially be 1.6 percent per year volumetrically at ambient temperatures. This rate of closure will increase with time as the adjacent rock heats up, but it will decrease as consolidating backfill increases resistance. Consolidation will continue until host rock and backfill are in lithostatic equilibrium and the closure rate of the entries is reduced almost to zero. Deformation of the host rock will decrease with distance from the entries. Depending on the existence of local discontinuities in the host rock, the joints may initially relax due to this deformation, but eventually they will close and heal under lithostatic loading. Thermal effects are expected to encourage healing of any fractures that occur in the salt.

Further research is needed to investigate whether air or brine will become trapped during later stages of consolidation, thereby preventing void closure. If air or brine is confined in such voids, pressure in the voids will increase as entry closure continues until it approaches lithostatic pressure and closure stops. Any voids could become groundwater migration routes should void confinement break down and allow the pressurized gases or brine to escape. Also, further investigation will be necessary to determine what the actual settling rate and consolidation rate of crushed salt backfill will be. If the crushed salt is capable of settling under its own weight faster than creep can close the entries, large voids may form between the backfill and the roof or walls of the entry. These large voids could become groundwater migration paths.

The chemical nature of crushed salt backfill is the same as the host rock and should not be a factor in the control of groundwater or radionuclide migration. The earthen backfill, depending on how it is constructed, may contain clay that is capable of consolidating to a lower void ratio than the host rock, thus becoming less permeable. Chemically, the clay will be able to adsorb radionuclides, thus preventing their transport; however, the amount of adsorption will depend on such factors as the method of construction, water content, chemical compatibility with brine, and density. 
Further research must be conducted to determine the long-term stability of clay in a thermal environment. Of particular interest is the ability of clay to swell, to consolidate, to retard ground-water flow, and to adsorb radionuclides.

\subsubsection{Further Research Needs}

Future research on sealing the underground facilities includes the following:

1. Long-term temperature effects on stability of large concrete structures, especially in a brine environment.

2. Impact of brine on the final degree of crushed salt consolidation. Recent laboratory tests indicate that the presence of a small amount of brine will accelerate the consolidation process (IT Corporation, 1987).

3. Investigation of the extent to which air or brine may become trapped in voids during later stages of consolidation of crushed salt backfill. If air or brine is confined in such voids, pressure in the voids will increase as entry closure continues until it approaches lithostatic pressure and closure stops.

4. Long-term stability of clay in a thermal environment. Of particular interest is the ability of clay to swell, to consolidate, to retard ground-water flow, and to adsorb radionuclides. This would include the impact of brine on adsorption properties.

5. Expansivity of concrete placed in large pours. Current technology is proven in laboratory scale tests but is not well established in the field. The need for expansive concrete must also be addressed. 


\subsection{SEALING OF SHAFTS}

During decommissioning of the repository, the shafts will be closed and sealed to prevent the flow of ground water into, and transportation of radionuclides out of, the repository (NRC, 1986). This closure process will be accomplished by backfilling the shafts with earthen backfill sections and crushed salt backfill, and by installing large impermeable bulkheads in selected strata along the length of each shaft.

The shaft sealing system will require both short-term and long-term sealing. whort-term sealing will be provided by the concrete bulkheads which will be designed to prevent intrusion of ground water into the repository horizon. Eventually these bulkheads will be assisted by the long-term seals in restricting abnormal ground water movement. During this short-term period, the backfill in the shaft will be consolidating in response to overburden stresses. When consolidation is sufficiently complete, the backfill will begin to function as a long-term seal. This design philosophy is compatible with the short-term and long-term seals that will be used in the underground facilities discussed in Section 5.1. The long-term seals will prevent water flow downard into the repository horizon and also chemically adsorb radionuclides thus retarding their migration.

The design of the shaft seals may influence overall shaft design, construction, and sinking methods. The sinking methods and the treatment of the host rock for operational stability and ground water control are described in Section 4.3, Shaft Facilities. The factors discussed in this section pertain to those decommissioning sealing system components which may influence shaft liner design and host rock treatment.

\subsubsection{Shaft Sealing System Components}

The basic components of the shaft sealing system are concrete bulkheads, dense earthen backfill, structural backfill, general earthen backfill, the shaft base, and the shaft cap. Figure 5.2-1 presents site stratigraphy and a conceptual design for shaft seals. The locations of the basic seal components 


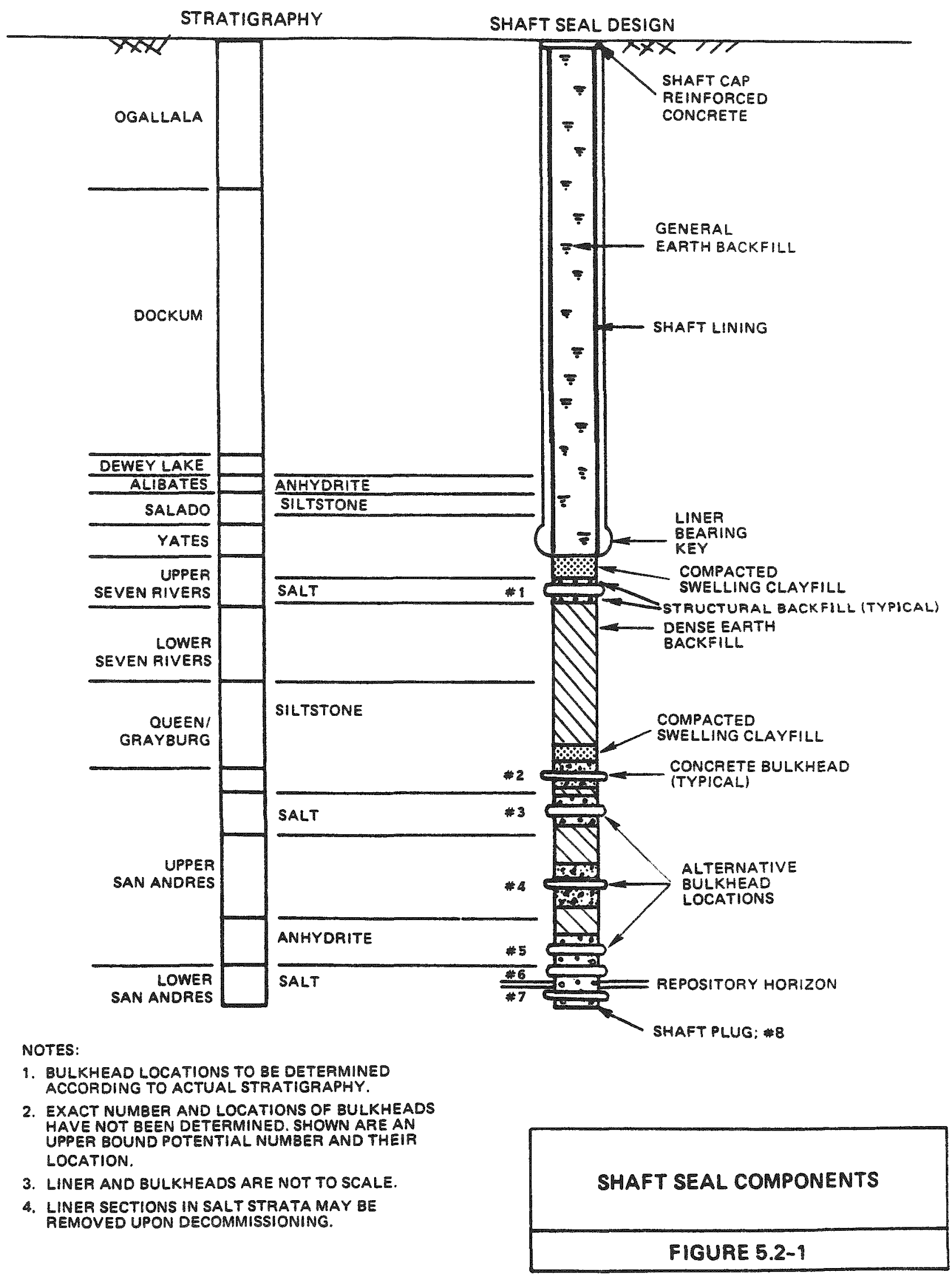


will be determined primarily by the locations of the stratigraphic units and hydrologic basins.

Concrete bulkheads will be the major components in the shaft sealing system. These bulkheads will be nearly impermeable structures that will inhibit the flow of fluid along the seal/host rock interface into the mechanically disturbed rock zones. Precise locations of bulkheads will depend on site-specific considerations, including the types of rock and the integrity

of the formations. The exact number of bulkheads that will be required (eight locations are shown in Figure 5.2-1) is uncertain for the same reason. Information obtained during shaft sinking will be vital to performing final design of the shaft sealing system.

The dimensions of the bulkheads will be determined as a function of the rock mass types and the character of the mechanically disturbed rock zone throughout the shaft length. The principal functions and the candidate materials of the bulkheads and other components of the shaft sealing system are summarized in Table 5.2-1.

\subsubsection{Concepts and Rationale for Shaft Bulkheads}

Concrete bulkheads will be keyed into the rock to intercept the seal/host rock interface and remove some of the mechanically disturbed rock zone surrounding the shaft. The keyways will provide obstructions in potential flow paths, thus reducing interfacial permeability to approximately that of the host rock. Additionally, the keyways will provide resistance against shear deformation.

The performance of bulkheads will be affected by the material properties of the host rock. For bulkheads in salt, closure of the shaft section surrounding the bulkheads will produce tight seals at the interfaces and in the short term, promote fracture healing in the salt. For bulkheads in nonsalt formations, time-dependent closure deformation will not increase stress around the bulkheads very rapidly. However, expansive concrete bulkheads in such strata would provide increased interface stress. 
Table 5.2-1. Basic Components in a Shaft Seal System (a)

\begin{tabular}{|c|c|c|c|c|}
\hline Item & Seal Component & Location & Principal Function(s) & Candidate Materials \\
\hline 1 & Shaft Base & Bases of shafts & Structural support & Concrete \\
\hline 2 & $\begin{array}{l}\text { Dense Earthen } \\
\text { Backfill }\end{array}$ & $\begin{array}{l}\text { Intervals in shaft } \\
\text { (excluding bulkheads } \\
\text { and structural back- } \\
\text { fill sections) }\end{array}$ & $\begin{array}{l}\text { Retards groundwater } \\
\text { flow and radionuclide } \\
\text { migration }\end{array}$ & $\begin{array}{l}\text { Gravel-sand-clay mix } \\
\text { highly compacted }\end{array}$ \\
\hline 3 & Structural Backfill & $\begin{array}{l}\text { Intervals in shaft } \\
\text { adjacent to bulkheads }\end{array}$ & $\begin{array}{l}\text { Low permeability, } \\
\text { structure support for } \\
\text { bulkheads }\end{array}$ & $\begin{array}{l}\text { Roller-compacted } \\
\text { concrete backfill }\end{array}$ \\
\hline 4 & Shaft Bulkhead & $\begin{array}{l}\text { Intervals in shaft } \\
\text { between base and } \\
\text { lower-most aquifer }\end{array}$ & $\begin{array}{l}\text { Prevents the shaft } \\
\text { and disturbed rock } \\
\text { zone from becoming } \\
\text { a flow path }\end{array}$ & $\begin{array}{l}\text { Expansive and/or } \\
\text { volume-stable } \\
\text { concrete }\end{array}$ \\
\hline 5 & $\begin{array}{l}\text { General Earthen } \\
\text { Backfill }\end{array}$ & $\begin{array}{l}\text { In Ogallala and } \\
\text { Dockum sections }\end{array}$ & $\begin{array}{l}\text { General fill, low } \\
\text { permeability }\end{array}$ & Gravel-sand-clay mix \\
\hline 6 & Shaft Cap & Tops of shafts & $\begin{array}{l}\text { Prevent human access } \\
\text { and surface water } \\
\text { infiltration }\end{array}$ & Concrete \\
\hline 7 & $\begin{array}{l}\text { Compacted Swelling } \\
\text { clayfill }\end{array}$ & $\begin{array}{l}\text { Below major and minor } \\
\text { aquifer sections }\end{array}$ & Very low permeability & Sand-silt-clay mix \\
\hline
\end{tabular}

(a) Modified from Kelsall, et al., 1985. 
Drilled cutoff curtains may be incorporated into bulkheads installed in nonsalt formations in order to ensure that long-term groundwater flow will be negligible in the disturbed rock zone. Figure 5.2-2 presents a schematic design for a concrete bulkhead with such a drilled cutoff curtain. The cutoff curtain would be constructed by drilling and grouting overlapping cores in the host rock until a complete curtain has been formed. This technique would produce minimal damage and minimal stress relief to the host rock. Much design work is needed to verify the complete feasibility of this or alternative cutoff curtains. The overlapping concrete core design scheme must demonstrate the ability to prevent leakage through cold construction joints between the overlapping cores.

Final design of each concrete bulkhead will require characterization of mechanically disturbed rock zones during shaft sinking. This information, along with a determination of the extent and frequency of cutoff curtains and an evaluation of construction and placement techniques, will be used to evaluate the mechanical response of drilled cutoff curtains in the thermomechanical environment of the expansive concrete.

Structural backfill will be located immediately above and below each bulkhead. The backfill will provide a load-bearing capability, as well as a low interface permeability. The structural backfill will be a high density, low permeability, volume-stable concrete. It must be volume stable in order to provide a seal that is independent of conditions during curing. Performance evaluation including tests of large or full scale backfills will be required to define the construction specifications and material requirements for this backfill.

Lower portions of the shaft where the liner will be removed will be filled with a dense, highly compacted earthen backfill. This type of backfill is relatively insoluble, and it can be flexibly engineered for low permeability, high swelling capacity, and high adsorption of radionuclides. Backfill specifications as well as emplacement and compaction techniques will be evaluated during future design efforts in order to optimize material properties and assess the potential for settlement. 


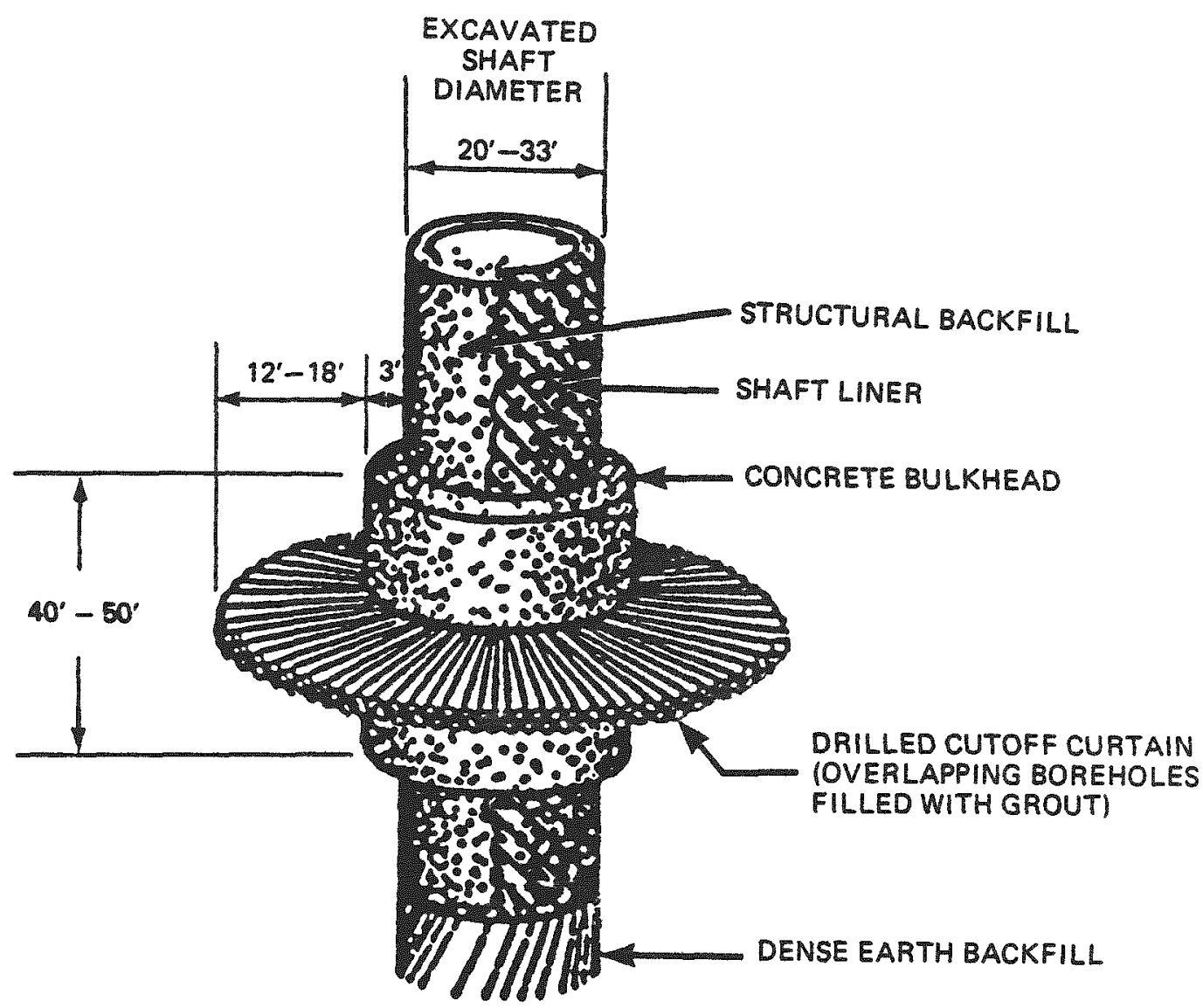

NOTES:

1. SIMILAR CONCEPT WITHOUT DRILLED CUTOFF USED FOR BULKHEADS IN SALT STRATA.

2. BULKHEAD WITH TWO VERTICALLY SEPARATED DRILLED CUTOFF CURTAINS MAY BE USED IF COMPETENT ANHYDRITE IS SUFFICIENTLY THICK.

3. SOURCE MODIFIED FROM (KELSALL, et. al., 1985)

\begin{tabular}{|c|}
\hline $\begin{array}{c}\text { CONCEPT FOR SHAFT } \\
\text { BULKHEAD }\end{array}$ \\
\hline FIGURE 5.2-2 \\
\hline
\end{tabular}


The dense earthen backfill materials will perform their sealing function best if they are chemically and structurally compatible with the host rock stratum. Materials excavated from the shaft during shaft sinking operations and stockpiled on the ground surface during repository operations will be used for this purpose. To meet decommissioning design specifications, it may be necessary to crush and/or introduce clay additives to these materials.

Compacted clay fill sections will be installed above bulkheads 1 and 2 (see Figure 5.2-1). Their purpose will be to seal minor aquifer and aquitard systems just above each bulkhead and to improve isolation of the Ogallala-Dockum aquifer from minor groundwater regimes near to and below bulkhead 1 .

The remainder of the upper portion of the shafts where the liners are not removed will be filled with a general, compacted earthen backfill. This backfill will require less stringent specifications for low permeability than the dense backfill further down.

\subsubsection{Materials Properties of Bulkheads}

At the present time, the primary candidate seal materials for the shaft system are cementitious and clay-bearing earthen materials. The performance requirements and specifications for these materials are presented in Table $5.2-2$.

Cementitious materials will be used for bulkheads and cutoffs in the shaft sealing system since these materials are strong, insoluble, relatively inexpensive, and easy to emplace. In addition, their behavior is well understood.

A less stiff, fracture-resistant concrete may be desirable for certain bulkhead seal applications. Compositions similar to those discussed in Section 5.1.3.2 can be used for expansive concrete. The expansivity if developed, will be sufficient to develop enough stress to help close the seal/ rock interface. 
Table 5.2-2. Summary of Materials, Specifications and Construction

Methods for Sealing Shafts (a) (Sheet 1 of 2)

\begin{tabular}{|c|c|c|c|c|c|}
\hline Item & $\begin{array}{l}\text { Candidate } \\
\text { Material }\end{array}$ & Applications & $\begin{array}{l}\text { Performance } \\
\text { Requirements }\end{array}$ & Specification & $\begin{array}{l}\text { Const ruction/ } \\
\text { Emplacement }\end{array}$ \\
\hline
\end{tabular}

1 Expansive Concrete

Shaft bulkheads shaft base

$\stackrel{\Pi}{\dot{\omega}}$

$\begin{array}{ll}\text { General } & \text { Upper portion } \\ \text { Earthen } & \text { of shaft } \\ \text { Backfill } & \end{array}$

$\begin{array}{ll}\text { Dense } & \text { Lower portion } \\ \text { Earthen } & \text { of shaft }\end{array}$

$k<10^{-9} \mathrm{~cm} / \mathrm{sec}$ swelling pressures $>5 \mathrm{MPa}$ at interface, high strength, high stiffness

$\mathrm{k}<10^{-7} \mathrm{~cm} / \mathrm{sec}$, (b) sufficient swelling capacity to reverse shrinkage effects and develop tight interface with lining

$\mathrm{k}<10^{-9} \mathrm{~cm} / \mathrm{sec}$, (b) low permeability, high swelling capacity, high radionuclide adsorption
An oil well grout mix

(heat, pressure and sulfate resistant

cement, brine, or

fresh water and an expansive additive); quartz or limestone fine and coarse aggregate

Graded anhydrite, limestone, or quartz aggregate mixed with $5 \%$ to $20 \%$ commercial bentonite or locally derived bentonite moisture content to be determined

Like Item 2 above, but like Item 2 above, but with $20 \%$ to $40 \%$ clay content, moisture content to be determined

Monolithic concrete placed in one or more lifts as required to control heat of hydration effects

Conventional fill placement and compaction equipment adapted for use in confined shaft envi ronment high compaction effort 
Table $5.2-2$ (Sheet 2 of 2 )

\begin{tabular}{|c|c|c|c|c|c|}
\hline Item & $\begin{array}{l}\text { Candidate } \\
\text { Material }\end{array}$ & Applications & $\begin{array}{l}\text { Performance } \\
\text { Requirements }\end{array}$ & Specification & $\begin{array}{l}\text { Const ruction/ } \\
\text { Fmp lacement }\end{array}$ \\
\hline 4 & $\begin{array}{l}\text { Structural } \\
\text { Backfil1 }\end{array}$ & $\begin{array}{l}\text { Above and below } \\
\text { each bulkhead }\end{array}$ & $\begin{array}{l}\mathrm{k}<10^{-9} \mathrm{~cm} / \mathrm{sec} \text {, (b) } \\
\text { low permeability, } \\
\text { high density, volume } \\
\text { stable }\end{array}$ & $\begin{array}{l}\text { Like Item } 1 \text { above, } \\
\text { without expansive } \\
\text { additives and at a } \\
\text { lower water content }\end{array}$ & $\begin{array}{l}\text { Conventional roller- } \\
\text { compacted concrete } \\
\text { placement and compaction } \\
\text { equipment adopted for } \\
\text { use in confined shaft } \\
\text { environment }\end{array}$ \\
\hline
\end{tabular}

(a) Modified from Kelsall, et a1., 1985.

(b) Final permeability is a function of clay content, water content, grain-size distribution, compactive effort, etc. 


\subsubsection{Material Properties of Backfills}

Earthen backfills will be composed of insoluble materials and clay mixtures that are highly impermeable and swell on contact with water. These earthen materials will be used to partially backfill the shafts where a relatively insoluble or swelling material is required. Earthen backfill with high swelling capacity can be obtained as necessary by adding bentonite or other swelling clay mixtures. Using expansive clay mixes with different percentages of clay may involve certain trade-offs between low permeability and high radionuclide adsorption beyond a certain compacted density. Such trade-offs will be examined as the design evolves further.

\subsubsection{Shaft Bulkhead Construction Methods}

Figure 5.2-3 presents a construction sequence for building a bulkhead and cutoff curtain in a shaft. The illustrated scheme is simplified and is intended for discussion and identification of key issues. For a typical bulkhead, construction progresses as follows:

1. Lower Concrete Plug. The lower concrete plug will be installed by completing earthen backfill to the required elevation and compaction. Test specimens of concrete will be prepared and tested at the batch plant. The concrete will then be lowered into the shaft using a system similar to that used for pouring the original shaft lining. A representative system is shown in Figure 5.2-3. Prior to placement, the concrete will be checked for specified properties and returned to the surface if rejected. Utilizing a multi-deck stage similar to that used during the original shaft sinking, the concrete will be placed and thoroughly vibrated.

2. Remove Lining. Removal of the lining sections will consist of constructing a temporary floor to protect the concrete surface of the previous placement. The multi-deck stage will be positioned for access to the liner at the top of the keyway location. Steel and concrete portions of the liner section will then be removed, using 

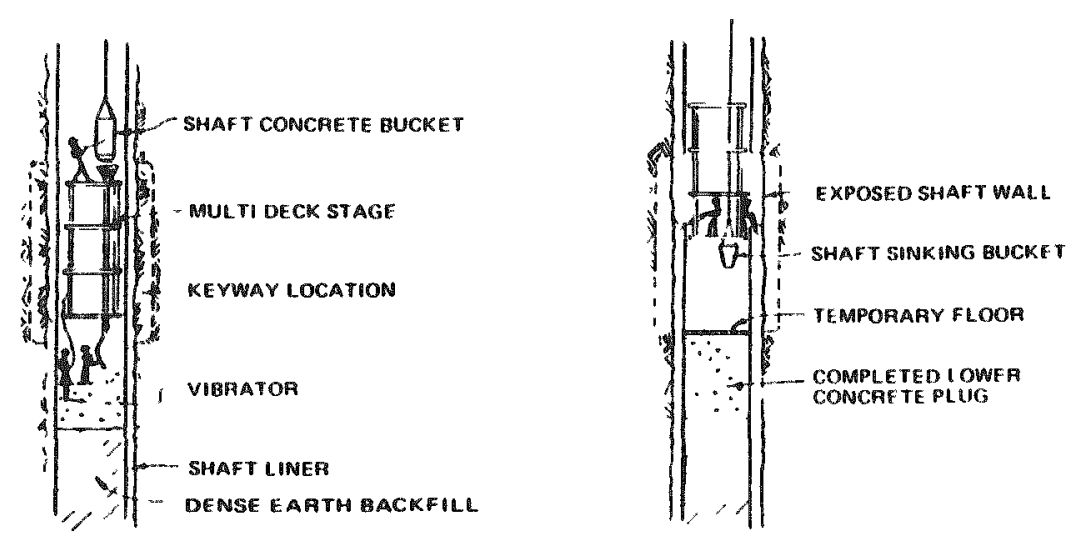

STAGE I. PLACE LOWEA CONCAETE PLUG
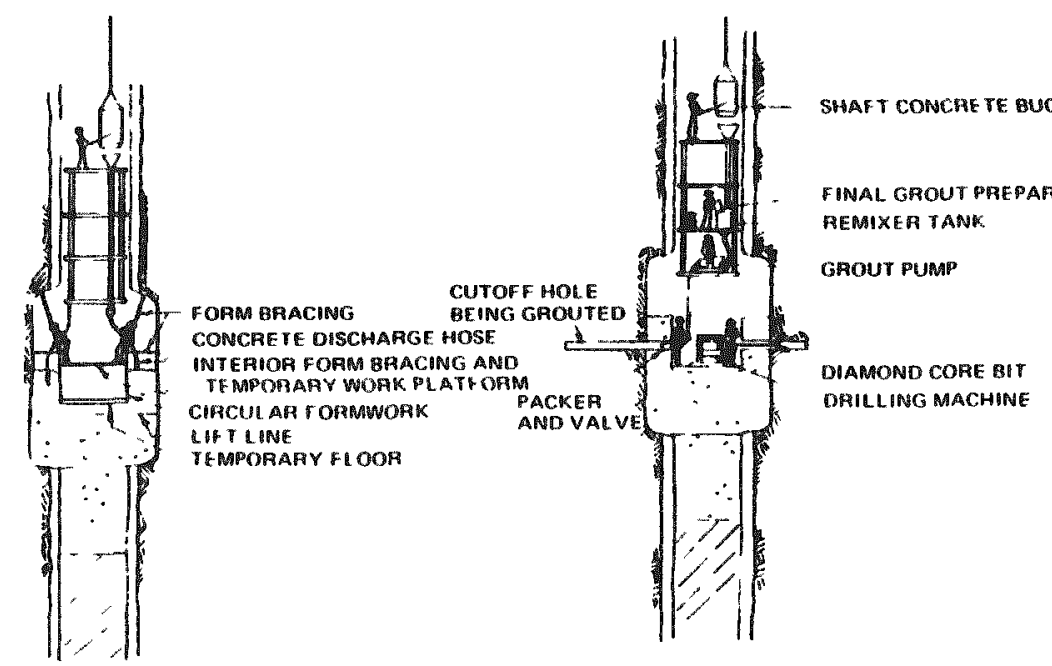

STAGE 5 - BUILD INNER FORM AND PLACE BúlkHé̃ó anNútus

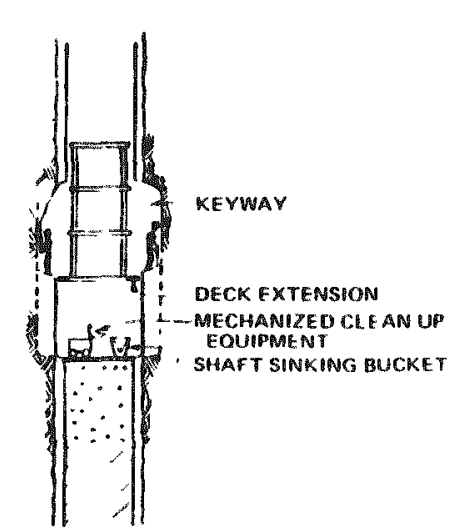

STAGE 3 - EXCAVATE KEYWAY

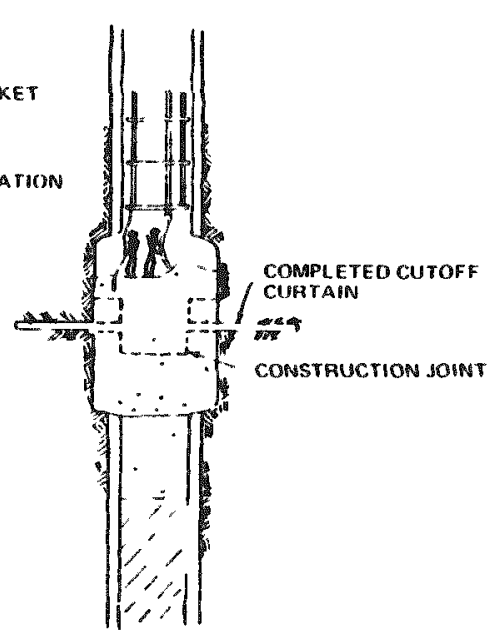

7 COMPLETE BULKHEAD POUR

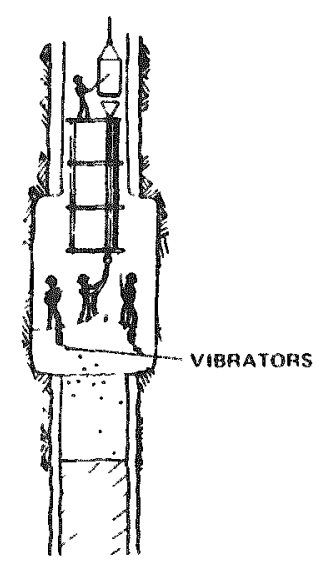

STAGE 4 - COMMENCE PLACING CONCRETE

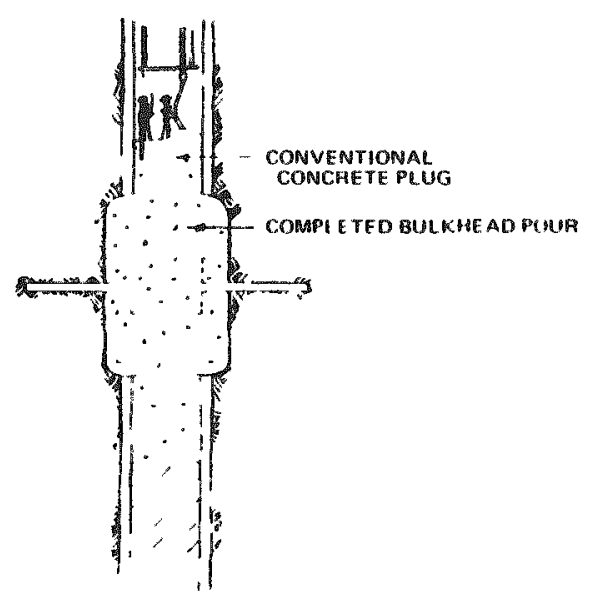

SIAGE 8 - PLACE UPPEA CONCAETE PLUG

NOTE. 1. DRAWINGS NOT TO SCALE.

2. PROCEDURE MAY VARY DEPENDING ON HOST ROCK STRATA.

\section{CONSTRUCTION SEQUENCE} FOR SHAFT BULKHEAD

FIGURE $5.2-3$ 
jackhammers, drills, and light explosives. The use of explosives will be minimized to avoid rock mass disturbance but may be necessary to loosen pieces of the lining. Steel rebar will be cut as necessary. The spoil material will be loaded into a shaft sinking bucket and hoisted to the surface. The work will proceed peripherally and in convenient increments. The multi-deck stage will be relocated when necessary. The exposed shaft wall will be scaled for removal of loose rock. It is assumed that no rock supports will be required.

3. Excavate Keyway. Excavation of the keyway will consist of raising the multi-deck stage to the top of the keyway location and extending the working deck to the shaft wall with removable or hinged platform sections. Excavation will be done by using hand tools or a mechanical excavation technique, and loading the excavated material into a shaft sinking bucket. Work will proceed peripherally and in convenient increments. The multi-deck stage will be relocated as required to perform the work. As necessary, the disturbed rock zone in nonsalt strata will be pressure grouted by injecting grout into drilled grout holes. The keyway will be scaled and carefully cleaned during excavation.

4. Commence Placing Concrete. The concrete will then be placed by removing the temporary floor and cleaning and preparing all surfaces. The concrete will be prepared and tested at the surface batch plant and tested again after it is lowered into the shaft. It will be thoroughly vibrated. The first lift will be completed to a depth that will permit construction of an inner form for cutoff installation.

5. Build Inner Form and Place Bulkhead Annulus. Building the inner form and placing the bulkhead annulus will begin by lowering the form components and assembling them in to proper position. The position will have to be accurately surveyed and the form top braced to the keyway wall. The concrete will be prepared, tested, and transported to the construction location. It will be thoroughly vibrated. 
6. Drill and Grout Cutoff curtain. The grout cutoff curtain will be installed by removing walls of the inner form, lowering and accurately installing the drilling machine, and installing grouting equipment on the multi-deck stage. The cutoff curtain will be developed as a series of drilled holes, close enough together and overlapping, to essentially create a flat disc around the shaft. The cutoff holes will be drilled radially without overlap initially, and the grouting process will begin. The drilling machine alignment will be rotated until enough overlapping holes have been drilled to create the continuous curtain. Upon completion, the drilling equipment will be removed, and grouting will be finished.

7. Complete Bulkhead Pour. The bottom floor of the form will be removed and the construction joint and keyway walls prepared. The concrete will then be mixed, tested, transported, placed, and vibrated.

8. Place Upper Concrete Plug. Placing of the upper concrete plug will consist of preparing, testing, and transporting the concrete to the desired location where it will be placed and vibrated to the correct elevation.

This construction procedure covers the basic steps in constructing a typical bulkhead. Further analysis will reveal whether additional components are necessary. Hence, the above assumes that no special effort will be necessary to seal the contact between the lining and the rock above and below the bulkhead area by grouting the lining contact or by any other means. Experience gained during shaft sinking should provide valuable information for constructing decommissioning bulkheads. Finally, these procedures assume that the rock behind the lining is competent and impermeable. Site characterization will verify this assumption. If these assumptions change, then the bulkhead construction procedure may also change.

\subsubsection{Response of Host Rock to Bulkhead System}

Concrete bulkheads in salt strata will undergo negligible deformation compared to the rock mass since concrete structures are much stiffer. As 
stress is transferred to the bulkheads, they will almost immediately become effective in retarding ground water migration due to the fracture, microfracture, and bulkhead interface closing. In nonsalt strata, the expansive properties of the concrete will ensure that these discontinuities close and seal upon expansion of the concrete. Enhancing this response is the fact that the bulkheads will be keyed into the shaft perimeter, and most of the disturbed rock will be removed.

The heat released by the emplaced waste will have minimal effect in elevating the temperature of the host rock around the shaft and the concrete bulkheads near the shaft base. The temperature increase due to heat of hydration of concrete will provide some thermal stresses to the host rock but will be much less than the effect of expansive concrete. The stresses that result from differential temperatures will aid in closing the concrete/rock interface.

The peak calculated temperature rise at the nearest shaft base will be less than $1^{\circ} \mathrm{F}$ in the first 250 years (Section 7.2.2, Near-Field Effects). The temperature will increase very slowly and should not influence thermal stresses within shaft, bulkheads, and backfill. Thus, improvement in seal performance due to thermal loading of the emplaced waste will be insignificant. However, the effects of disturbing the host rock's fracture system with respect to the decommissioned shaft is unclear and has not been modeled.

\subsubsection{Bulkhead Connection to Shaft Liner}

The current design of the shaft sealing bulkheads, described in Section 5.2.1, will require removal of a portion of each shaft liner. The specifics of the parts of liners to be removed have not been determined because the sealing system is only in schematic design. Shaft liner design is discussed in Section 4.3.2, Shaft Linings and Operational Seals. The liners incorporate a series of operational seals installed behind the watertight lining sections. Installing shaft bulkheads will involve removal of portions of the liner, so that the concrete directly contacts the host rock. 
The main purpose of the bulkheads is to retard ground-water flow down the shafts, both inside and outside the liners. Water flowing from outside the liners into the backfill above the bulkheads will not be a problem because the bulkheads will prevent the water from migrating down the shafts. Therefore, the connections of the bulkheads to the shaft liners need not be watertight. However, these connections must be designed to accommodate long-term differential settlements. Of more concern are the procedures necessary to remove the liners during decommissioning.

\subsubsection{Construction Considerations}

During the operational life of the repository, loads will have been transferred from the host rock to the liners. Removing sections of the liners at bulkhead locations will be a laborious and time consuming process. A traditional method of demolishing structures with components similar to the shaft liners is by blasting. However, blasting must be minimized at bulkhead locations to avoid disturbing the rock mass. Furthermore, if significant loads have been transferred to the liner prior to the time of decommissioning, Iiner removal may involve an appreciable amount of energy release in the form of spalling of liner fragments and underlying rocks.

Monitoring devices will be installed during liner construction to indicate water and ground pressures of the rock mass and stresses within the liner. The instruments will be monitored during the shaft's operational life and will provide vital data for determining final bulkhead design and performance. This will include determination of the adequacy of the selected locations for installing the bulkheads. Typical monitoring instruments have a life span of 10 to 40 years so the monitoring plan must include periodic maintenance and/or replacement of instruments.

\subsubsection{Alternative Concepts}

The current concept consists of installing a lithostatic bulkhead shell for bulkhead 1 and compressible zones behind the liner at bulkhead locations 2 through 7 during liner installation. At decommissioning, the liner will be cut and removed and a keyway will be excavated to remove disturbed rock. The 
concepts presented in this report make provisions for a decommissioning sealing system but do not design it. The alternatives are provided to emphasize the flexibility of the conceptual liner design in accommodating decommissioning bulkheads.

Figure 5.2-4 presents two alternative liner designs which may alleviate the problems associated with traditional liner removal. The first is designed to be easily removed while the other is designed to remain in the shaft and become an integral part of the seal system bulkhead. In either case, the liner would be supported by liner bearing keys and not by the bulkhead. Neither of these alternatives has been incorporated into current shaft liner concepts since further analysis is necessary to determine whether the traditional liner, a removable one, or a bulkhead/integrated liner is the most feasible.

Alternative 1 in Figure 5.2-4 will consist of a homogeneous concrete liner segment designed for removal during repository decommissioning. The liner segment would be constructed in an excavated shaft keyway and it would be structurally independent from the segments above and below. The larger size of this liner segment would permit structural design using concrete without steel. This might permit the use of mechanized removal equipment with low manpower requirements, such as a high-energy impact breaker, to break the liner segment into pieces. These pieces could then be loaded into a shaft sinking bucket with a clamshell mucking unit. Both pieces of equipment would be mounted below the multi-deck stage and would allow the operators to be above and away from the inherent dangers of liner removal.

Alternative 2 in Figure 5.2-4 shows a concrete liner bulkhead shell that is designed to remain in the shaft and become part of the final bulkhead seal. The liner segment would be constructed in a keyway that has been excavated during shaft sinking and whose thickness is a function of operational load imposed on the unreinforced bulkhead shell section. It would be constructed with an internal keyway designed to accept the concrete bulkhead during decommissioning. Since this liner segment would remain in the shaft, there would be no removal to cause additional ground disturbance, and the adequacy of the liner/rock interface could be monitored throughout the repository operating 


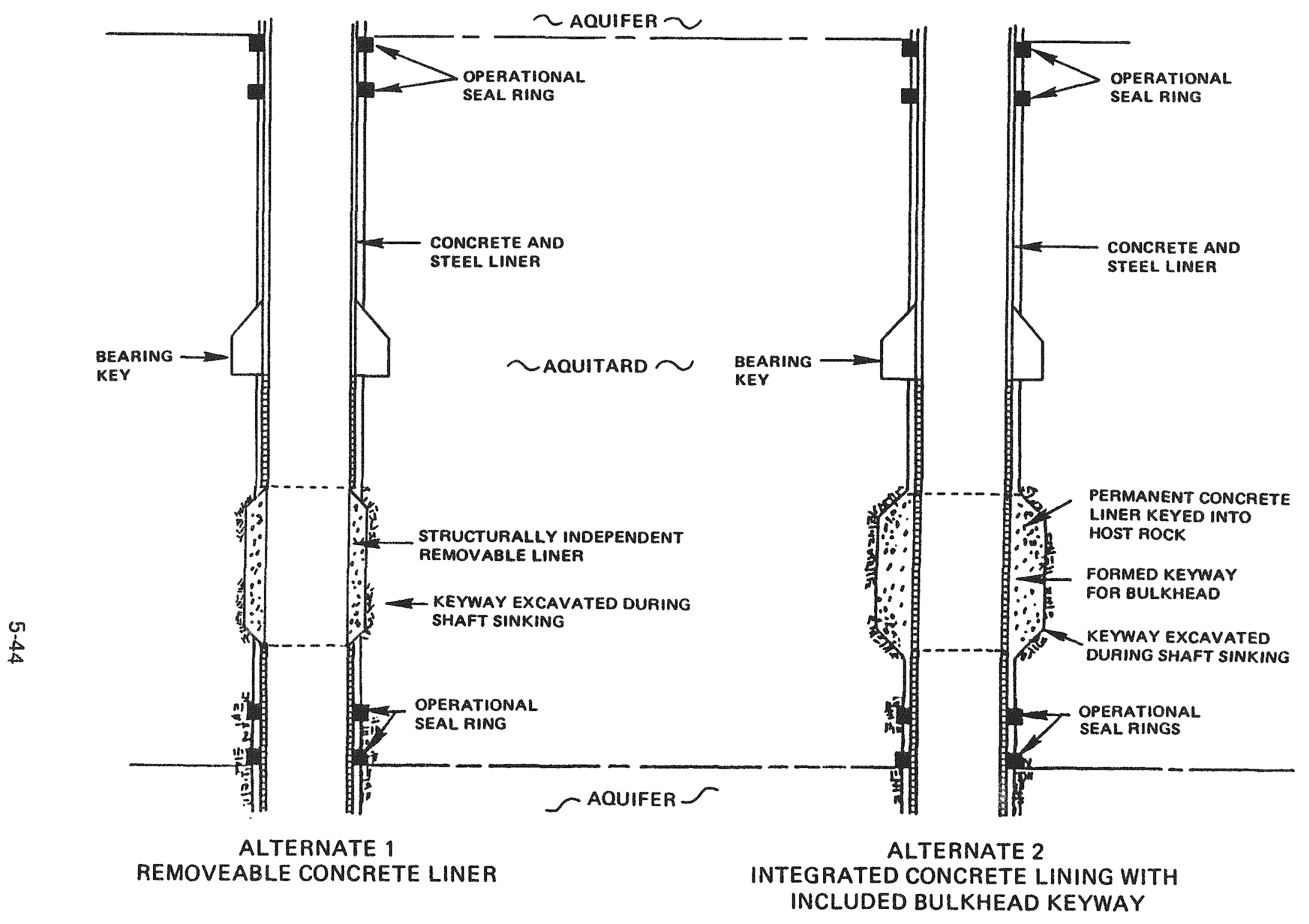

NOTES:

1. Figure modtried from Kelsall, et al., 1985.

2. Dimensions not to scale

3. For details on configuration see Figure 4.3.1

OPERATIONAL LINERS INTEGRATED WITH SHAFT KEYWAYS 
period. Liner construction would include the installation of monitoring equipment. The grout curtain can be installed during decommissioning operations if necessary.

Final shaft liner design should be optimized based on considerations for the installation of postclosure seals as determined by the most feasible alternative.

\subsubsection{Shaft Seal System Interaction with Aquifers}

Decommissioning bulkheads will be keyed into the mechanically disturbed rock zone, creating a discontinuity in the flow path along the shaft liner. The drilled cutoff curtains will extend radially beyond the bulkheads into the undisturbed rock mass so that groundwater migration through the disturbed rock will be retarded. The curtains will provide an added sealing redundancy. In addition, the bulkheads will be located in water retardant layers of rock. This will confine the ground water in its existing aquifers.

\subsubsection{Seals Below Aquifers}

The decommissioning sealing system for the shafts is not designed to rely on operational seals for postclosure performance. Operational seals will retard water migration behind the liner during the operational period only.

The backfill inside the shaft liners will not come into contact with water from the aquifers unless the liners degrade with time and become permeable. As part of the decommissioning seal system, this backfill is designed to have a lower permeability than the aquifer-bearing geologic units; therefore, the backfill should not become a preferential flow path. Even if water were to migrate through the degraded sections of a liner, the bulkhead system is designed to inhibit flow to lower sections of the shaft. The bulkhead, built without any steel components, will not be degraded over time by the corrosion processes which will affect portions of the shaft liner. 


\subsubsection{Seals Between Aquifers}

It is not expected that any permanent decommissioning bulkheads will be installed between aquifers. The only such planned seals are operational seals between the Ogallala and Dockum formations (see Section 4.3 .2 for details).

\subsubsection{Shaft Seal System Response to Seismic Load}

The Deaf Smith site is located in a region having low seismic activity. Although a full seismic analysis has not been performed to date for the conceptual design of the shaft sealing system, preliminary studies indicate that the greatest seismic concerns arise at depths of less than $300 \mathrm{ft}$. to $400 \mathrm{ft}$. (see Section 7.1.3.12). The major sealing components are located at depths greater than $1200 \mathrm{ft}$. It is expected that the cutoff curtains will behave like relatively thin discs having a brittle structural connection to the concrete bulkheads. Ground movement or cyclic vibration may cause a shearing action, creating the potential for cracks to propagate through the cutoff curtains at the seal/rock interfaces. During future design efforts, a complete analysis will be conducted to determine the magnitude of differential displacements (and associated stresses) between the cutoff curtains and the bulkheads. This should be followed by an assessment of the sealing integrity of the shaft seal system under these conditions.

\subsubsection{Further Research Needs}

Limited laboratory and field research has been done relative to sealing systems. Further research should be focused on the following areas:

1. Long-term $(10,000-\mathrm{yr})$ behavior and deterioration of sealing materials, such as concrete, clay, grout, and earthen backfill, especially nonsalt materials exposed to brine. Property changes of interest include swelling, consolidation, permeability, and adsorption of radionuclides. Small changes in such properties over geologic time might influence the sealing performance of the material. 
2. Long-term integrity of the liner and bearing keys. It may be desirable to design and install these operational elements in a manner that will allow them to become part of, or facilitate installation of, the decommissioning sealing system. This will be a subject of continued study and design.

3. Expansivity of concrete placed in large pours. Current technology is proven in laboratory scale tests but is not well established in the field. The need for expansive concrete must also be addressed.

4. Study of the entire cutoff curtain concept including installation, inspection, conformance with installation specifications, and alternative concepts. At this point, it is not clear whether such a curtain is even needed. This alternative should satisfy the quality control requirements of the sealing system (i.e., constructibility and structural integrity). Site characterization may indicate the curtain is not needed. Pressure grouting may provide an adequate alternative.

These research needs are discussed in greater detail in Section 8.7, Seal System for Permanent Closure. 


\subsection{SEALING OF BOREHOLES}

As part of the decommissioning of the repository facilities, all boreholes will be closed by installing sealing materials to prevent the intrusion of groundwater into, and migration of radionuclides out of, the repository to the accessible environment. Closure procedures will be accomplished by sealing the boreholes with suitable backfill material and low permeability concrete plugs. The seals will provide both short-term and long-term sealing.

The exact number, size, and locations of boreholes requiring sealing have not yet been determined. Figure 5.3-1 shows the approximate locations of the planned boreholes drilled from the surface. Table 5.3-1 describes the number, type, depth, and purpose of the boreholes. No estimates have been made for number, size, or locations of underground boreholes requiring sealing. In general, all boreholes will be backfilled and/or sealed according to one of the techniques to be specified.

\subsubsection{Sealing Criteria}

In general, the required standards for sealing of boreholes will depend on the location and depth of each borehole.

\subsubsection{Deep Boreholes}

Some boreholes will be sealed according to stringent repository decommissioning specifications developed by the repository sealing program to protect the integrity of the host rock and emplaced waste. Boreholes that extend into the control area and are capable of transmitting ground water into the repository area are considered to be deep boreholes (NRC, 1986). Such boreholes would connect the aquifers and the repository horizon by direct communication. The aquifers in question are considered to belong to the accessible environment. Candidate boreholes will be located within the repository boundary and several may extend locally outside the boundary depending on the transmissivity of the rock mass. 


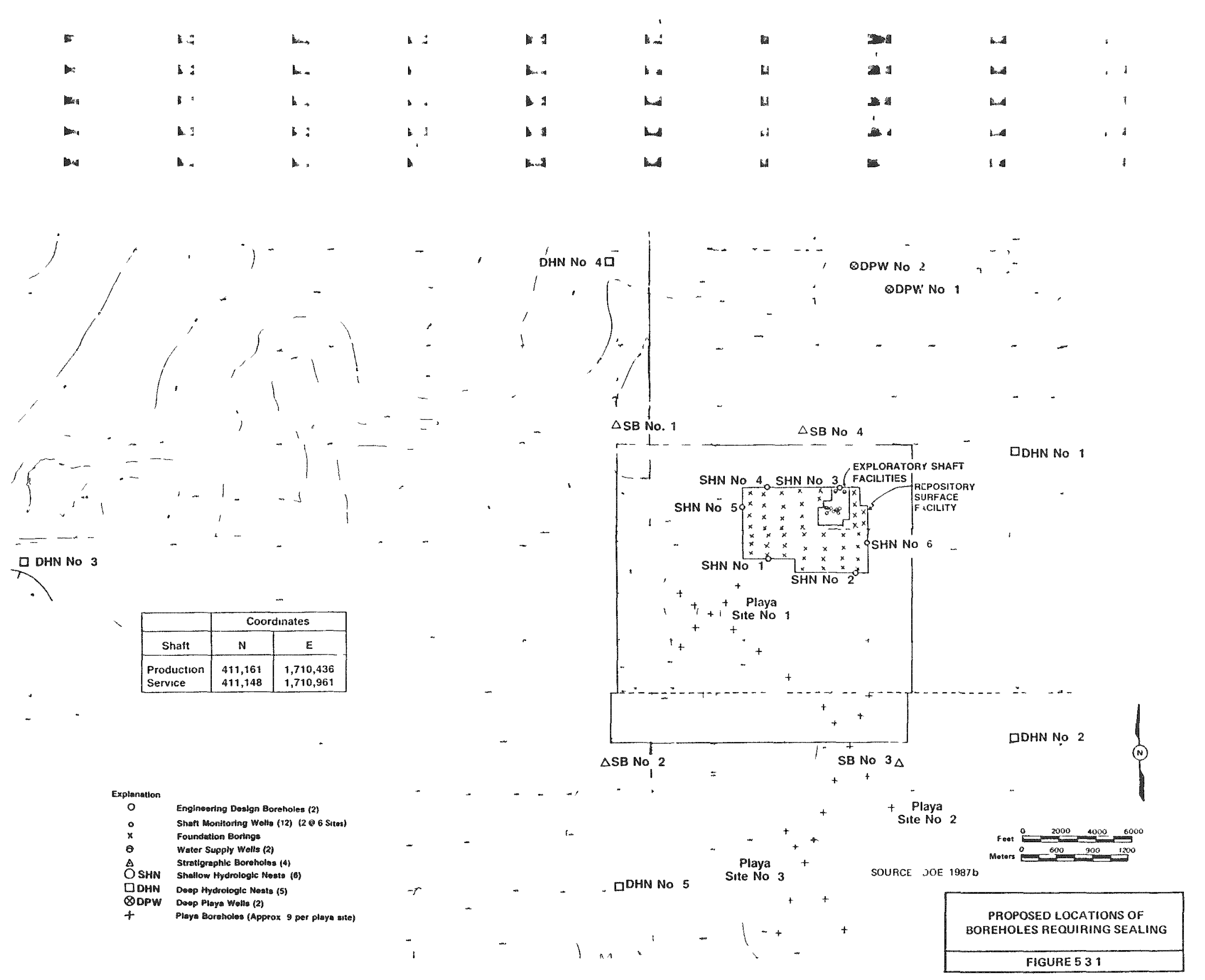


Table 5.3-1. Summary of Surface Borehole Characteristics

Pertaining to Sealing

\begin{tabular}{|c|c|c|c|c|}
\hline Activity & Scope & $\begin{array}{l}\text { Quantity } \\
\text { per S1te }\end{array}$ & $\begin{array}{l}\text { Total } \\
\text { Number of } \\
\text { Boreholes }\end{array}$ & $\begin{array}{l}\text { Estimated } \\
\text { Depth } \\
\text { (it) }\end{array}$ \\
\hline Sha1low Aquifer Hydronests & $\begin{array}{l}\text { Drilling, coring, logging, } \\
\text { testing, and monitoring }\end{array}$ & 3 wells & 15 & $<1300$ \\
\hline $\begin{array}{l}\text { Shallow Hydrological } \\
\text { Observation Well }\end{array}$ & $\begin{array}{l}\text { Drilling, coring, logging, } \\
\text { testing, and monitoring }\end{array}$ & 1 we 11 & 2 & $<1300$ \\
\hline Deep Aquifer Hydronests & $\begin{array}{l}\text { Drilling, some coring, } \\
\text { logging, testing, and } \\
\text { monitoring }\end{array}$ & 3 wells & 15 & 8500 \\
\hline Shaft Monitoring Wells & $\begin{array}{l}\text { Driling, some coring, } \\
\text { logging, testing, and } \\
\text { monitoring }\end{array}$ & 3 wel1s & 6 & $<1300$ \\
\hline Water Supply We1ls & $\begin{array}{l}\text { Drilling, casing, well } \\
\text { development, and production }\end{array}$ & 1 we11 & 2 & 800 \\
\hline $\begin{array}{l}\text { Exploratory Shaft } \\
\text { Facility Monitoring } \\
\text { Wells }\end{array}$ & $\begin{array}{l}\text { Driling, casing, some } \\
\text { coring, logging, and } \\
\text { monitoring }\end{array}$ & 1 wel1 & 30 & 360 \\
\hline $\begin{array}{l}\text { Repository and Surface } \\
\text { Facility Monitoring } \\
\text { Wells }\end{array}$ & $\begin{array}{l}\text { Drilling, casing, some } \\
\text { coring, logging, and } \\
\text { monitoring }\end{array}$ & 1 we11 & 100 & 360 \\
\hline Stratigraphic Boreholes & $\begin{array}{l}\text { Coring, logging, and } \\
\text { testing }\end{array}$ & 1 borehole & 4 & $<2800$ \\
\hline Deep Playa Wells & $\begin{array}{l}\text { Deep coring to investigate } \\
\text { potential for anomalous } \\
\text { fracture conditions }\end{array}$ & 1 borehole & 2 & 8500 \\
\hline Playa Boreholes & $\begin{array}{l}\text { Shallow borings, coring, } \\
\text { geophysical surveys, and } \\
\text { testing }\end{array}$ & 9 boreholes & 27 & $<1300$ \\
\hline $\begin{array}{l}\text { Engineering Design } \\
\text { Borehole (EDBH) }\end{array}$ & $\begin{array}{l}\text { Coring, logging, and } \\
\text { testing }\end{array}$ & 1 borehole & 2 & 2800 \\
\hline $\begin{array}{l}\text { Freeze-Wall Design } \\
\text { Boreholes }\end{array}$ & $\begin{array}{l}\text { Drilling, coring, logging, } \\
\text { testing, and monitoring }\end{array}$ & 5 boreholes & 10 & $<1300$ \\
\hline $\begin{array}{l}\text { Foundation Borings for } \\
\text { Shaft Design }\end{array}$ & $\begin{array}{l}\text { Sampling, coring, and } \\
\text { logging }\end{array}$ & 1 borehole & 50 & $<150$ \\
\hline $\begin{array}{l}\text { Foundation Borings for } \\
\text { Surface Facilities and } \\
\text { Access }\end{array}$ & $\begin{array}{l}\text { Drliling, test pits, and } \\
\text { sampling }\end{array}$ & 1 borehole & 400 & $<1.50$ \\
\hline Freeze-Wal1 Boreholes & $\begin{array}{l}\text { Construction of shaft } \\
\text { liner }\end{array}$ & $T B D$ & $T B D$ & 980 \\
\hline
\end{tabular}

TBD $=$ To be determined. 


\subsubsection{Shallow Boreholes}

Other boreholes will be sealed according to less stringent standards. State standards for sealing oil wells might be applied (with minor modifications) to those boreholes which do not pose a threat to repository integrity. For example, the standards would be used for sealing boreholes that do not penetrate below the water table. These state standards are intended to prevent contamination of clean aquifers. Boreholes may be evaluated on an individual basis according to their distance from the repository and the strata penetrated (especially aquifers), but in general would not extend deeper than the nearest interface with the accessible environment which is the bottom of the Dockum formation.

Two types of boreholes should be sealed according to repository decommissioning specifications. The first type includes horizontal or inclined boreholes drilled from the shaft bottom, test drifts, or the underground facilities. This type of borehole would be drilled, for example, to investigate the salt quality, to locate vertical features such as shear zones, or to install instrumentation. It includes boreholes that are part of the ESF program. At the present time, there is no demonstrated technology for sealing long horizontal boreholes, but this would not be of concern unless boreholes extend outside the proposed repository horizon salt unit, and it is not expected that any boreholes initiated at the repository level will do so. Boreholes that do not extend outside the salt will eventually seal through the natural salt creep process. They may be backfilled with crushed salt to accelerate sealing.

The second type of borehole requiring sealing to decommissioning specifications will be vertical holes drilled from the surface. For the most part, these will be boreholes used as part of the geologic site characterization program. It is expected that most of these will be sealed prior to decommissioning.

Freeze holes will be required during shaft excavation until the shaft liner has been installed. They will be sealed after liner construction is complete. They will extend to the bottom of the Dockum Formation, and will 
not penetrate the control area. They end at a shallower depth than the first shaft decommissioning bulkhead. They will therefore be sealed according to oil field standards. The engineering design boreholes (EDBH) will be obliterated during exploratory shaft sinking and therefore will not require sealing. The only anticipated deep boreholes remaining on site at decommissioning will be wells used for groundwater monitoring. It is assumed they will be sealed as part of the repository decommissioning program. Some of the deep stratigraphic and hydrologic boreholes, will be located off site and most likely will be sealed according to oil field standards since they will be a long distance away.

It is assumed that existing wells on the site that are not used as part of the repository program will be sealed prior to decomissioning activities. Existing wells will be used as much as possible to minimize the number of new wells drilled on site.

\subsubsection{Description of Sealing System for Deep Boreholes}

The sealing procedures for deep vertical boreholes may vary considerably from hole to hole depending on location, depth, and condition of the hole. However, a general conceptual design is outlined in the following subsections for typical boreholes which require sealing to decommissioning specifications.

\subsubsection{Concepts and Rationale for Sealing Deep Boreholes}

The major components of the borehole sealing system will include cement grout fill, clay backfill, cement grout bulkheads, and steel casing. These components are shown in Figure 5.3-2.

Cement grout will be used as general backfill material because it will accomplish what is required, and it is relatively easy to place. While. maintaining its quality, it is structurally monolithic when cured, and it has a high resistance to ground water flow. The grout will be squeezed into mechanically disturbed rock zones and/or permeable zones to retard inflow of water from water-bearing strata and to provide discontinuity in the flow path along the seal/rock interface. 
SEAL

DESIGN

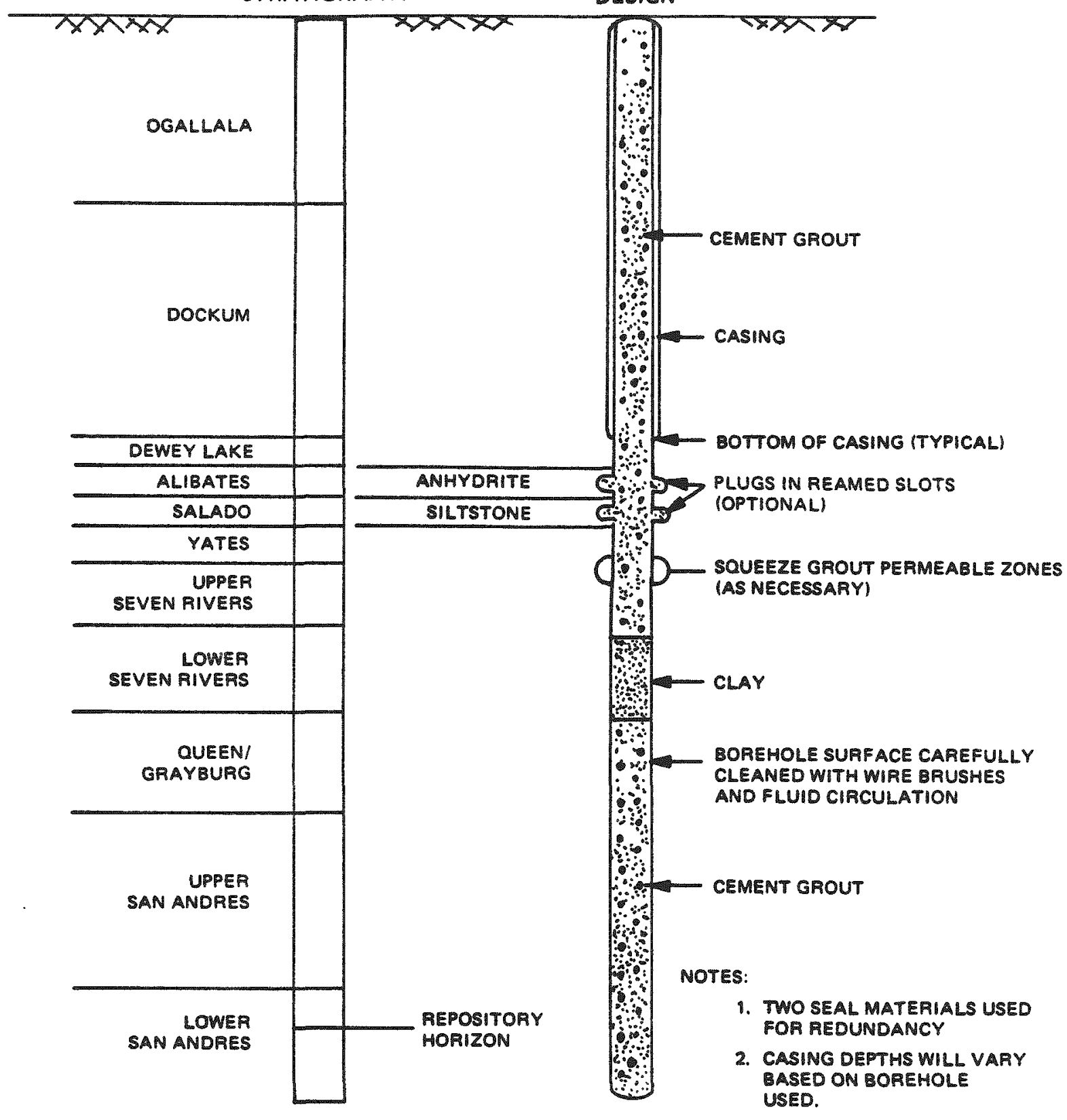

\section{DESIGN FOR A TYPICAL BOREHOLE SEAL}

FIGURE $5.3-2$ 
Clay material composed of fractional amounts of bentonite or other swelling clay mixtures will also be used in the backfilling of boreholes. Clay can be engineered to have a permeability lower than grout. It is more capable of accommodating differential displacements. And it has the capability of chemically adsorbing radionuclides depending on the placement method and the clay's chemical compatibility with the groundwater. In addition, certain clay materials respond to water by swelling. Swelling pressures will increase the stresses in the localized area, further reducing rock mass permeability.

Cement grout plugs, constructed in reamed slots, will be used to provide discontinuity in the flow paths along the interfaces between boreholes and the host rock. The main purpose of these plugs will be to retard water migration from aquifers down the borehole to the repository horizon. They will be located in competent strata, typically below the bottoms of the borehole casings. Strategically locating the plugs will help to prevent migration from the upper aquifers and the lower geologic units.

The boreholes will be cased to hold them open during initial drilling and extended periods of performance monitoring in weak strata near the ground surface. Typical casings will not reach the bottom of the Dockum Formation, but this will depend on borehole function. Casing will play no role in permanently sealing boreholes and will not be designed to perform a closure seal function. Casing will provide a minor degree of redundancy in the seal system during the short-term by retarding ground water movement into the backfilled borehole section. In the long-term, the seal components in the upper borehole including cement grout and reamed plugs will provide sealing. Potential flow through the degraded casing will be mitigated by the reamed bulkheads.

\subsubsection{Borehole Sealing Materials}

Two materials will be considered for sealing boreholes. The primary candidate will be cement grout composed of an oil-well grout mix. These slurry grouts can penetrate irregularities in the borehole walls as they are pumped into place and are preferred over materials requiring in-hole compaction. An 
alternative to oil-well grout mixtures might be a grout that offers greater deformability and resistance to cracking.

A second plugging material might be clay compacted in place, provided that adequate compaction procedures can be developed and demonstrated. Alternatively, crushed salt might be placed in the salt horizons of boreholes.

Expansive additives in aqueous grout will cause the grout to increase in volume as it cures. This will aid in providing a tight borehole/rock interface seal. Calcium sulfate is the most comnon of the many additives which can be mixed with grout to induce expansion.

\subsubsection{Installation Methods}

Because different types of borehole seals may be required, as discussed previously, several emplacement methods may be applicable. Described here is a typical method that may be used for sealing vertical boreholes drilled from the ground surface. These procedures would satisfy stringent specifications:

1. Characterize Borehole. The hole will be characterized by examining drilling records and, if necessary, by running additional geophysical logs. Particular attention will be paid to identifying permeable zones and to describing the hole geometry, using caliper logs and downhole television. Packer tests can be performed to locate and characterize permeable zones.

2. Clean Borehole. The hole will be flushed to remove debris, and the surface walls will be cleaned with brushes or reamers. The more permeable zones will be sealed by squeezing grout into appropriate zones. This will be done by using a packer arrangement to isolate the zone during the squeezing operation. To ensure adequate sealing, the hole will be drilled out, and packer tests will be repeated in permeable zones. The squeeze grouting will be repeated if necessary. As a final precaution the hole can be drilled out and grouted with 
bentonite or chemical grout (as necessary if cement grouting does not eliminate water losses).

3. Backfill Borehole. Backfilling the borehole will commence by drilling out the hole and partially filling it from the bottom with an expansive grout. Next, the section of hole above the first grout stage will be filled with clay, which will then be densely compacted in place.

4. Final Backfilling. Backfilling will continue by filling the hole with expansive grout to within a few feet below the bottom of the casing. A packer will be set in the bottom of the casing and pressurized grout will be introduced through the packer to ensure a tight seal at the casing/rock interface. Finally, the packer will be removed, and the remaining section of the hole will be filled to the ground surface with expansive grout.

Stages 1 through 4 are procedures that will apply in the open, uncased section of the borehole. Special considerations will be required for the cased section. Plugging a hole without removal of the casing would produce a double interface and a preferred flow path in the long-term as the casing deteriorates. Therefore, this procedure will be avoided.

Deterioration problems involving the casing need not be a concern if there is a large uncased portion of borehole above the repository. Preliminary estimates show that $330 \mathrm{ft}$ of uncased borehole should be sufficient for forming an adequate plug by grouting (Kelsall, et al., 1985). At shallower depths, it may be necessary to perforate the casing to grout sections where logging indicates the need for a good seal between waterbearing zones.

\subsubsection{Response of Host Rock to Borehole Seals}

The heat released from the emplaced waste packages is expected to have little or no effect on the borehole sealing systems since the temperature rise at these locations will be minimal. For the shaft pillar, the calculated temperature rise will be less than $1^{\circ} \mathrm{F}$ in 250 years after emplacement. The 
deep boreholes will be located at approximately the same distance from the emplacement area as the shafts, but the thermal impact will be less for the deep boreholes. This is because the average distance from the heat sources (i.e. waste packages) to the deep boreholes is less than the average distance from the heat sources to the shafts.

Cement grout is, in general, a stiffer material than the adjacent host rock layers. This is with respect to elastic deformation as compared to the viscoplastic deformation of salt. Thus grout is capable of transmitting lithostatic pressures without significant deformation. In slurry form, it has the ability to flow into the disturbed rock discontinuities while pressurized, thus decreasing the adjacent rock mass permeability and providing a stiffness transition to the solid grout material. Expansive additives mixed with the grout will help to ensure tight interface seals.

Clay backfill will consolidate as lithostatic pressure is transferred to the borehole. Consolidation will decrease the voids and therefore reduce the permeability. The cohesive, ductile behavior of the clay will permit it to perform satisfactorily under larger displacements and deformations than the grout backfill. Clay minerals are capable of chemically adsorbing radionuclides provided groundwater chemical conditions are compatible. Thus, in addition to their role as hydraulic barriers, they will perform a sealing function via chemical adsorption.

\subsubsection{Response to Seismic Loads}

The effects of postclosure seismic loads on seals are expected to be of little significance. The seal system can be considered a long cylindrical column buried in the ground, whose length is much longer than the expected amount of horizontal ground displacement due to seismic loading. As a result, it will exhibit flexibility during seismic loading. Therefore, small bending moments acting on the seals will not be significant enough to affect seal performance. If the borehole intersects geologic discontinuities, such as a shear zone, slip may occur. Clay may be a suitable sealing material for shear zones within the boreholes, since it will mitigate the effects of potential seismic related slip. Preliminary studies by the $\mathrm{A} / \mathrm{E}$ Contractor indicate that 
the only significant seismic activity at the site will occur well above the 1,200 ft elevation. Hence the performance of the decommissioned borehole below the reamed bulkheads should not be affected.

\subsubsection{Further Research Needs}

Future research on sealing boreholes should include the following:

1. Techniques should be developed for assessing the procedures for testing borehole seals and casings. This includes acquiring information on the techniques for detecting voids in the grout, remedial correction procedures, and quality control procedures.

2. The long-term geochemical behavior and geomechanical deterioration of the sealing materials must be better understood. Information is required on the possibility of cement grout and clay deterioration during the life of the repository.

3. The effects of brine and heat on the sealing materials in the salt horizons requires further study.

4. Theoretical analyses and analytical models based on valid data and expected conditions must be developed in order to accurately assess the overall seal system performance. This includes structural, hydrological, and geochemical responses with emphasis on stress redistributions, heating, and cooling.

These items are discussed in greater detail in Section 8.7, Seal System for Permanent Closure. 


\subsection{DECONTAMINATION AND DECOMMISSIONING OF SURFACE FACILITIES}

\subsubsection{Decommissioning Activities}

Decontamination and decommissioning (D\&D) activities will include decontamination of specific buildings on the site, dismantling of all surface structures and restoration and revegetation of the site. The process areas and the radwaste treatment areas of both waste handling buildings (WHB 1 and WHB 2) and support systems such as HVAC systems will require decontamination. The interim storage facility for onsite generated radwaste will also be decontaminated as necessary. Mechanical, chemical and electro-polishing methods will be used as appropriate to prevent contamination and to decontaminate facilities and equipment. The appropriate decontamination methods will be selected during planning for final decommissioning. Materials not capable of being decontaminated will be transferred offsite to low-level waste (LLW) storage sites. It is currently not expected that decommissioning LLW will be disposed of in the repository. Upon completion of decontamination, all surface facilities will be surveyed to determine if radiation levels are below the requirements for unrestricted access. This survey will also determine demolition needs.

Following the decontamination phase of $D \& D$, all surface facilities will be dismantled and demolished. Many methods currently exist for metal cutting and concrete demolition. Appropriate methods will be selected during final D\&D planning. Materials generated during dismantling will be disposed of offsite, as appropriate. Metals and structural steel will be handled as scrap materials.

The ponds used for control of surface water run-off and process water discharge will be inspected for contamination. If radionuclide levels exceed limits, appropriate clean up procedures will be followed. Otherwise, the ponds will be drained and backfilled consistent with plans for final site grading. The remainder of the site will be graded to approximate the original topography and revegetated. 


\subsubsection{Decommissioning Design Considerations}

In accordance with the NRC requirements for facilitating decommissioning through design (10 CFR $60.132(e)$ ), the SCP conceptual design includes decommissioning design features (DDFs) in appropriate detail for this level of design. The method used in evaluating DDFs is based on analyzing the effects they could have on improving occupational and public safety (i.e., reducing radiation exposure to $D \& D$ workers), reducing total decommissioning time, creating less radioactive waste, and simplifying performance of the activity. In evaluating new design features, an appropriate balance will be maintained between designs that meet these criteria and potential negative effects on plant construction and operating costs. However, most measures taken to reduce operating personnel exposure, simplify decommissioning activities, and reduce waste volumes are likely to have a favorable effect on decommissioning costs.

During conceptual design the DDFs were evaluated by investigating those provisions that are likely to yield significant parallel benefits. The areas in which DDFs could have these beneficial effects on other plant elements include:

1. Layout. Accessibility, equipment removal paths and transport distances, isolation of contaminated systems, and maintenance spaces.

2. Systems and equipment design. Material and equipment selection, decontamination provisions, replaceable radioactive components, and separation of systems required during decommissioning.

3. Structural design. Decontaminable surfaces, prefabricated structural units, and simplified designs for ease of assembly and disassembly.

Several DDFs were considered for the SCP conceptual design, essentially in the areas of design philosophy and design concepts. Consequently, no specific hardware items were listed. These DDF concepts are discussed below.

1. Remote maintenance. The repository design includes the capability to maintain and manipulate equipment within a highly radioactive hot 
cell without requiring entry of personnel into the cell. This capability is highly advantageous to decommissioning because early stages of D\&D can be conducted without personnel entering the cell. This remote capability also makes the functions of chemical and mechanical decontamination easier. It reduces costs of equipment removal, sectioning, and packaging, and it reduces the radiation exposure of $D \& D$ workers. It also reduces the requirements for decontamination before other activities are undertaken.

2. Compartmentalization of process functions. The repository design includes compartmentalization of process functions having comparable unit operations and comparable contamination levels (e.g., hot cells). This design feature is also desirable for decommissioning because it will keep contamination levels on one set of process equipment from affecting the decommissioning of equipment with lower contamination levels. As a result, D\&D of cleaner areas will be simplified.

Compartmentalization is expected to ease decommissioning efforts, reduce occupational exposure of $D \& D$ workers, and reduce $D \& D$ costs. However, there are also some disadvantages. More surface areas, e.g., walls, will be exposed to contamination. This will result in more $D \& D$ scrap material. Also more piping may be required, hence the amount of D\&D radwaste will be greater.

3. Hot cell liners. Liners on the walls of hot cells will be an aid to D\&D because they will minimize contamination of the concrete. Thin liners anchored to the concrete appear to have a net benefit to decommissioning as they can be decontaminated relatively effectively. This will reduce the decontamination effort required before personnel can enter a cell to complete the decommissioning. On the other hand, the many anchors securing the liner to the concrete will make the job of removing the liner difficult.

An alternative is to use free standing stainless steel liners that are connected with the concrete only at interface seals. This type of liner appears to offer more advantages to decommissioning than 
conventionally anchored liners. However, freestanding liners are more costly than anchored liners. These comments apply also to liners in waste storage vaults.

4. Protective coatings. Another alternative cell lining involves the use of coatings. Protective coatings on concrete cell walls and structures can reduce the amount of radioactive contamination absorbed by the concrete. Thus they can contribute to good chemical clean up of the cell concrete. However, to be fully effective, these protective coatings should maintain high integrity over the life of the facility, and they should resist deterioration caused by radiation and by decontamination chemicals. Because they lack this degree of durability, currently available coatings probably cannot achieve the desired degree of performance. On the other hand, recoating the exposed concrete surfaces periodically during the life of the repository may achieve the desired degree of performance. Use of protective coatings would be expected to ease decommissioning efforts, reduce D\&D worker radiation exposure, and reduce costs. Although coatings appear to be less effective than liners in hot cells, they may be more cost effective in low contamination areas.

5. Built-in provisions for chemical decontamination. The waste handling facility will have provisions for chemical decontamination within hot cells and waste receiving areas for standard operational purposes. However, additional decontamination capability in some areas may be desirable for decommissioning. This capability would allow for more effective chemical decontamination and consequently, lower D\&D worker exposure during decommissioning. An example of this design feature would be the capability to fill all vessels and their components with decontaminating chemicals, thus allowing some of the $D \& D$ to be conducted in a noncontact mode. Electropolishing the surfaces of all hot cell equipment before operation begins would also minimize the effort required to decontaminate that equipment.

6. Process equipment sizing. Certain equipment within the waste handling facility may be classified as radwaste at the time of 
decommissioning (e.g., disassembly machines) and may be disposed of in the repository. The sizing of the largest single component of any such system should be designed with consideration for its ultimate disposal. Disposing of highly contaminated components intact would reduce the risk of exposure during segmenting operations. If all such equipment is built using modular construction so that modules can fit into standard radwaste containers, D\&D of that equipment would be facilitated. Such a feature would also aid in maintenance and repair during repository operations.

7. Built-in capability for mechanical decontamination. Removal of contaminated concrete in hot cells could be one of the more time-consuming and labor intensive activities during decommissioning. Some of the following built-in features may be included in the design if their practicality is established. Methods such as drilling and blasting or rock splitting could be carried out much faster if holes were built into concrete surfaces. If heavy wall steel pipe was incorporated within reinforced concrete and kept sealed from waste materials, it could be used for placement of explosives, heater elements, etc. Built-in provisions for other methods, such as spalling of concrete by heat or electric current, might also be employed. Strategically located heater elements could be embedded in the concrete during construction for use during demolition. It may also be feasible to use rebar as the element in electric resistance heating. Concrete aggregates and reinforcing material should be selected to minimize radioactive activation products.

\subsubsection{Postclosure Activities}

The DOE is currently assuming that the D\&D period will last five years. Following this period, the repository will enter the postclosure phase. It is anticipated that the activities required during postclosure will be:

(1) active prevention of intrusion, (2) passive prevention of intrusion, and (3) active monitoring of site conditions. 